\title{
OAK RIDGE
}

NATIONAL LABORATORY

\section{SCALE 5.1 Predictions of PWR Spent Nuclear Fuel Isotopic Compositions}

March 2010

Prepared by

G. Radulescu

I. C. Gauld

G. Ilas

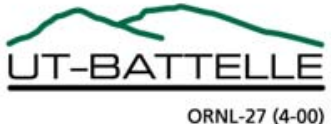




\title{
DOCUMENT AVAILABILITY
}

Reports produced after January 1, 1996, are generally available free via the U.S. Department of Energy (DOE) Information Bridge:

Web site: http://www.osti.gov/bridge

Reports produced before January 1, 1996, may be purchased by members of the public from the following source:

\author{
National Technical Information Service \\ 5285 Port Royal Road \\ Springfield, VA 22161 \\ Telephone: 703-605-6000 (1-800-553-6847) \\ TDD: $703-487-4639$ \\ Fax: 703-605-6900 \\ E-mail: info@ntis.fedworld.gov \\ Web site: http://www.ntis.gov/support/ordernowabout.htm
}

Reports are available to DOE employees, DOE contractors, Energy Technology Data Exchange (ETDE) representatives, and International Nuclear Information System (INIS) representatives from the following source:

Office of Scientific and Technical Information

P.O. Box 62

Oak Ridge, TN 37831

Telephone: 865-576-8401

Fax: 865-576-5728

E-mail: reports@adonis.osti.gov

Web site: http://www.osti.gov/contact.html

This report was prepared as an account of work sponsored by an agency of the United States Government. Neither the United States government nor any agency thereof, nor any of their employees, makes any warranty, express or implied, or assumes any legal liability or responsibility for the accuracy, completeness, or usefulness of any information, apparatus, product, or process disclosed, or represents that its use would not infringe privately owned rights. Reference herein to any specific commercial product, process, or service by trade name, trademark, manufacturer, or otherwise, does not necessarily constitute or imply its endorsement, recommendation, or favoring by the United States Government or any agency thereof. The views and opinions of authors expressed herein do not necessarily state or reflect those of the United States Government or any agency thereof. 
ORNL/TM-2010/44

Nuclear Science and Technology Division

\title{
SCALE 5.1 Predictions of PWR Spent Nuclear Fuel Isotopic Compositions
}

\author{
G. Radulescu \\ I. C. Gauld \\ G. Ilas
}

Date Published: March 2010

\author{
Prepared by \\ OAK RIDGE NATIONAL LABORATORY \\ P.O. Box 2008 \\ Oak Ridge, Tennessee 37831-6283 \\ managed by \\ UT-BATTELLE, LLC \\ for the \\ U.S. DEPARTMENT OF ENERGY \\ under contract DE-AC05-00OR22725
}





\section{CONTENTS}

$\underline{\text { Page }}$

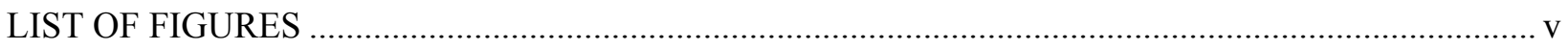

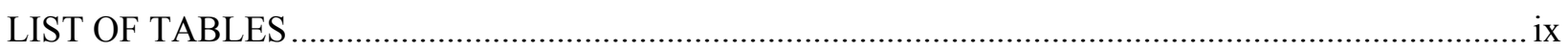

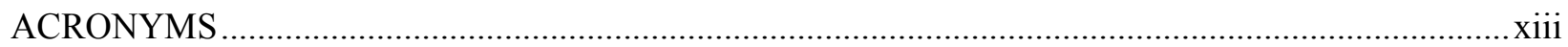

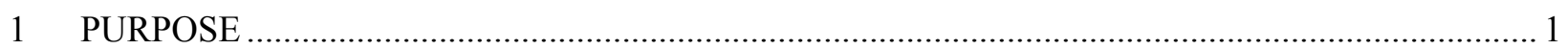

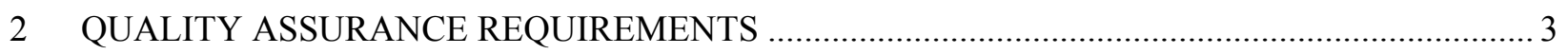

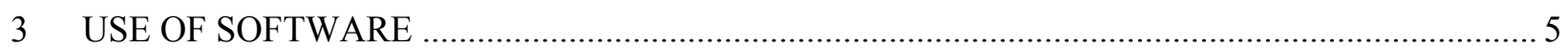

3.1 STANDARDIZED COMPUTER ANALYSIS FOR LICENSING EVALUATION

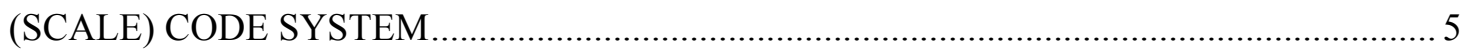

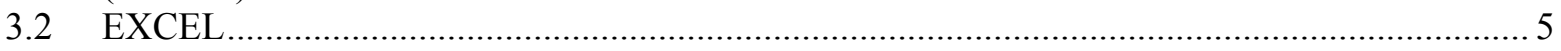

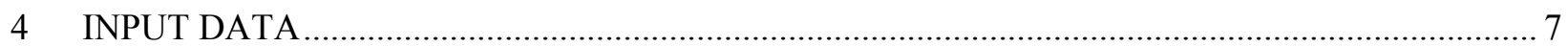

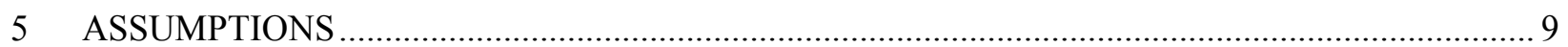

5.1 INITIAL URANIUM ISOTOPIC CONTENTS ….................................................... 9

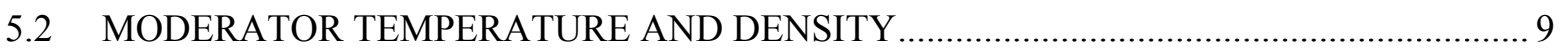

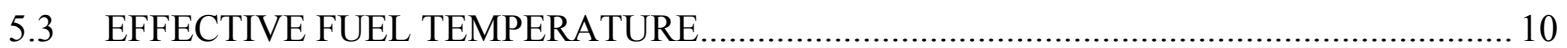

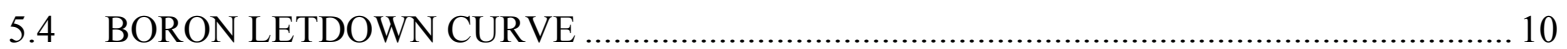

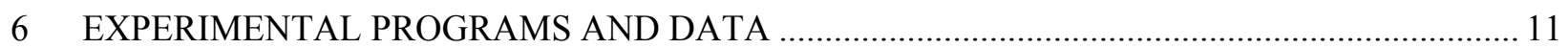

6.1 SELECTION OF SPENT FUEL ISOTOPIC COMPOSITION DATA .................................. 11

6.2 SUMMARY OF DATA USED IN PREVIOUS YMP ANALYSES ................................... 11

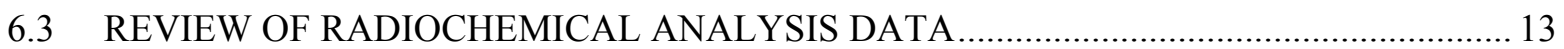

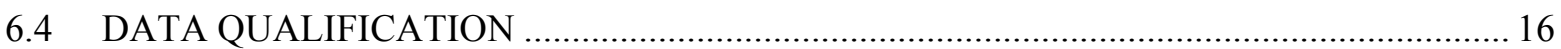

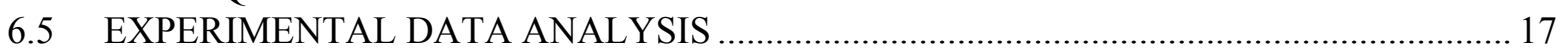

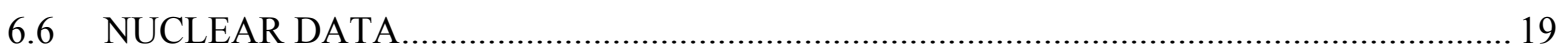

6.7 ANALYTICAL MEASUREMENT UNCERTAINTIES ............................................... 21

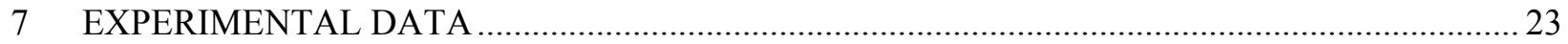

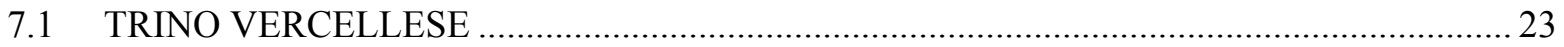

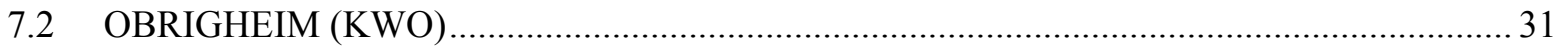

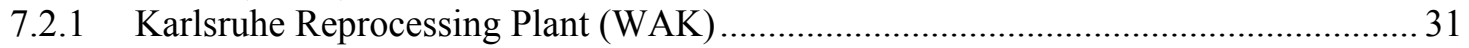

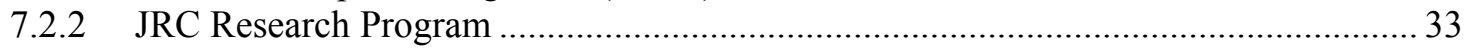

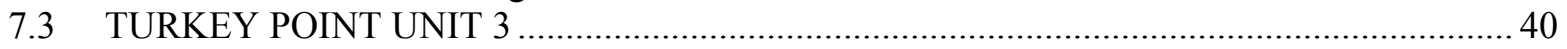

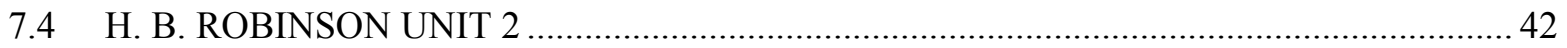

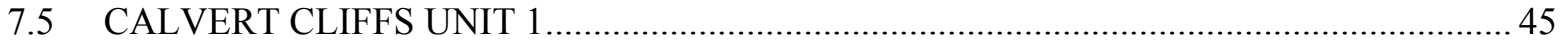

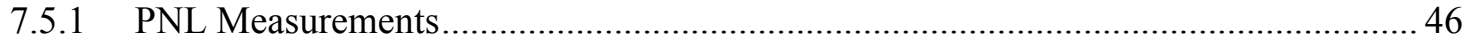

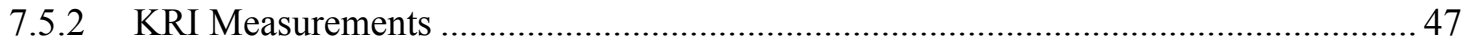

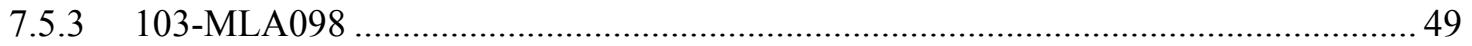

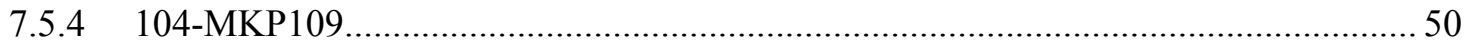

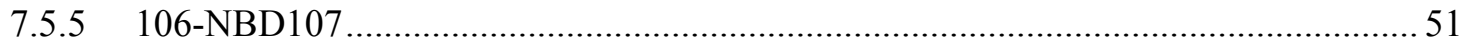

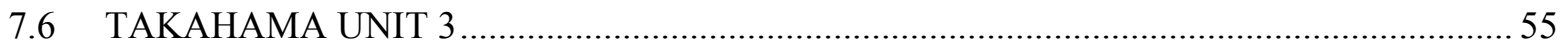

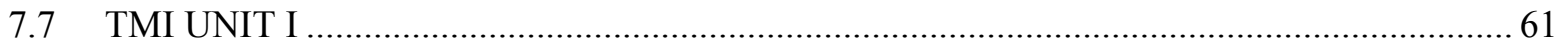

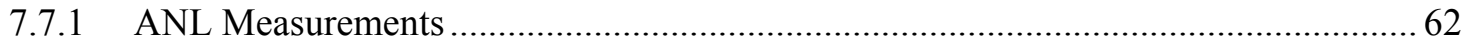

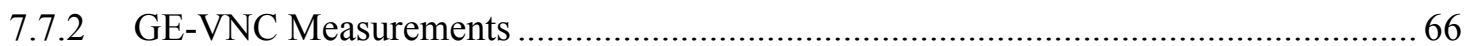

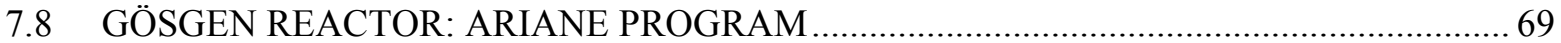

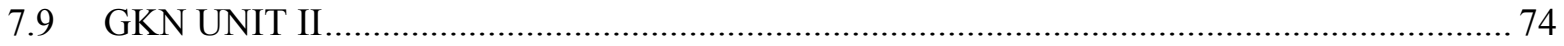

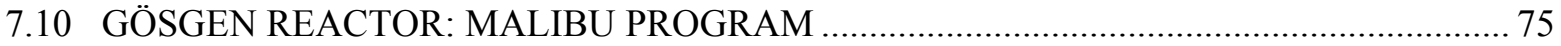




\section{CONTENTS (continued)}

$\underline{\text { Page }}$

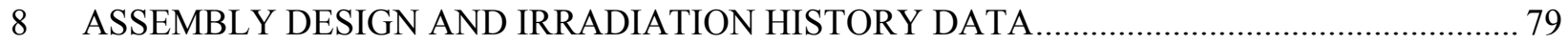

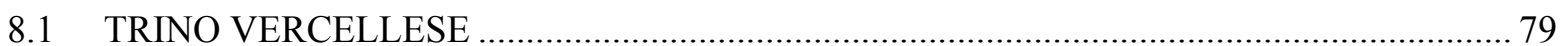

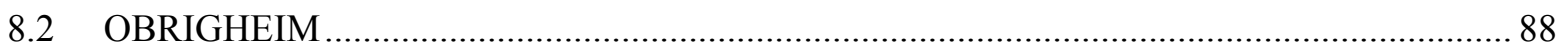

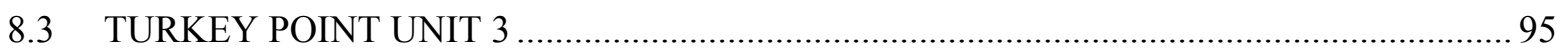

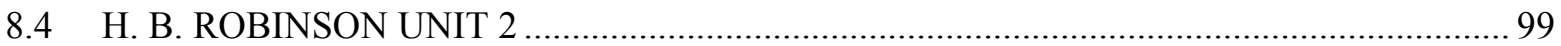

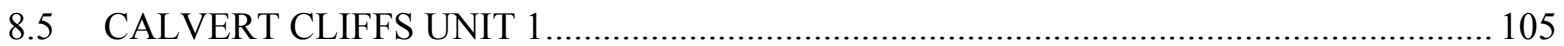

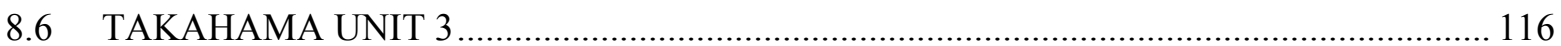

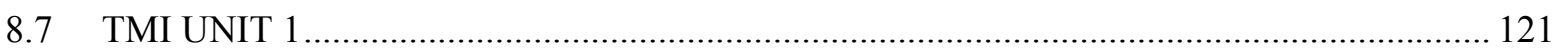

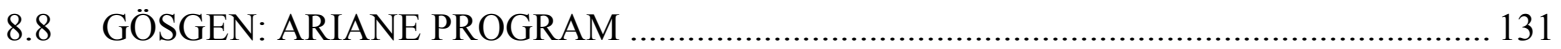

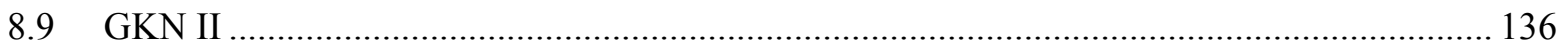

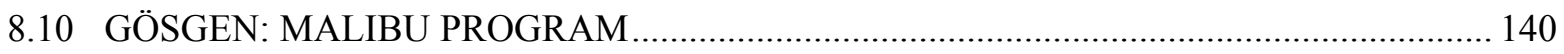

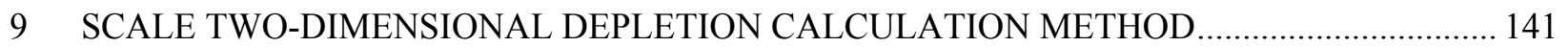

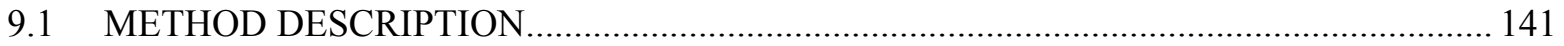

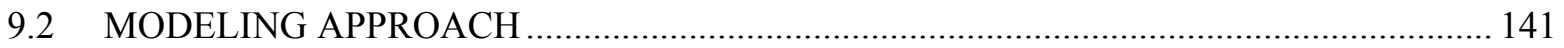

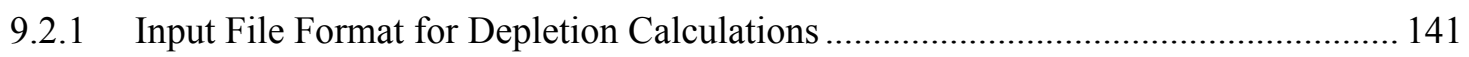

9.2.2 Fuel Mixture Modeling Simplifications...................................................................... 144

9.2.3 Modeling Approach for H. B. Robinson Assembly BO-5, Calvert Cliffs

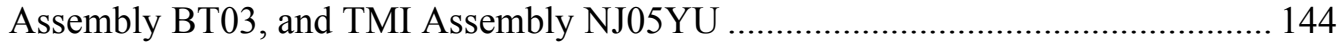

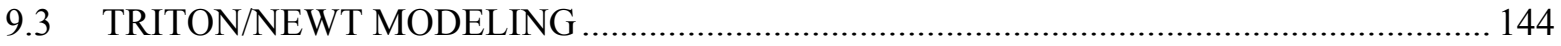

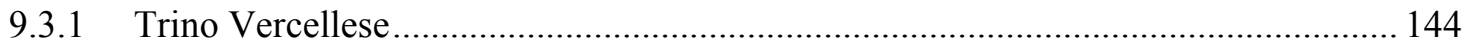

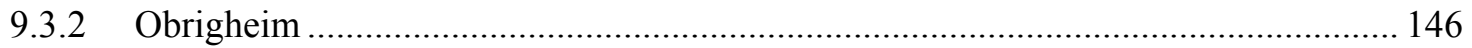

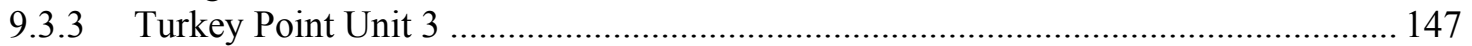

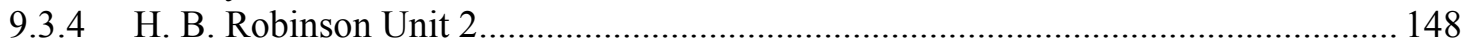

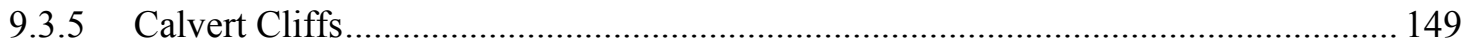

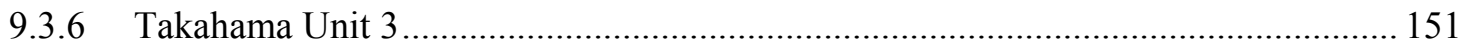

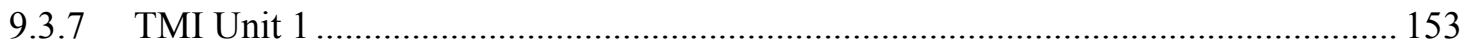

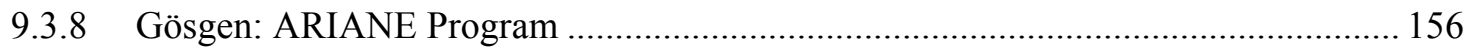

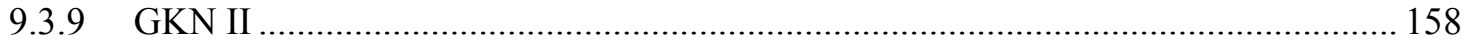

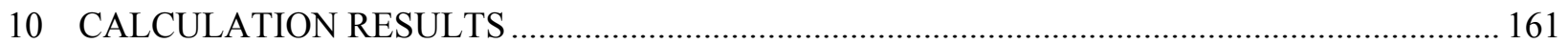

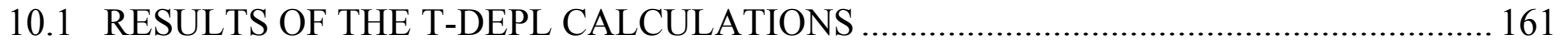

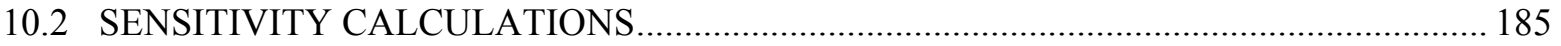

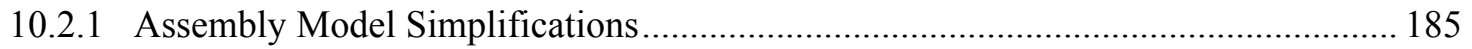

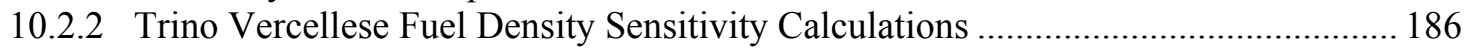

10.2.3 Trino Vercellese Fuel Temperature Sensitivity Calculations .................................... 187

10.3 GRAPHICAL REPRESENTATIONS OF E/C VALUES FOR THE BURNUP CREDIT

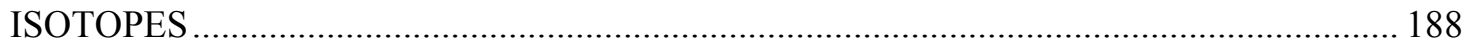

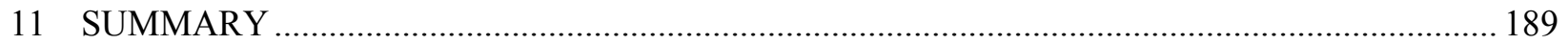

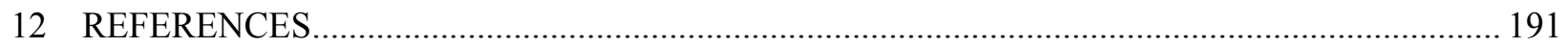

APPENDIX A: GRAPHICAL REPRESENTATIONS OF E/C VALUES FOR THE

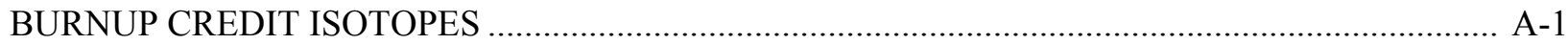

APPENDIX B: ELECTRONIC DATA SPECIFICATIONS ….......................................................... B-1 


\section{LIST OF FIGURES}

$\underline{\text { Page }}$

Fig. 1. Enrichment and burnup values of spent fuel samples used for validation compared to the actual and projected spent fuel assembly inventory and typical loading curve for PWR SNF assuming actinide and fission product burnup credit 15

Fig. 2. Schematic core map for the Trino Vercellese reactor showing the locations of the measured assemblies during cycle 1 and cycle 2 .

Fig. 3. (a) S-E quarter showing locations of cruciform assemblies containing control rods, fuel rods, and stainless steel fillers during cycle 1 ; (b) control group locations during cycle $2 \quad \ldots .82$

Fig. 4. Horizontal cross section of the Trino Vercellese square fuel assembly ................................ 83

Fig. 5. Location of Trino Vercellese measured fuel rods …........................................................... 83

Fig. 6. Layout of the KWO fuel assemblies showing the location of the guide tubes ..................... 90

Fig. 7. Core maps of the Obrigheim reactor during different irradiation cycles, showing the locations of control rods 91

Fig. 8. Location of measured fuel rods in Obrigheim assemblies BE124 and BE210_.................... 92

Fig. 9. Position of 21 guide tubes $(\times)$ and locations of measured fuel rods G9, G10, and H9 from Turkey Point assemblies D01 and D04. 98

Fig. 10. Core arrangement for H. B. Robinson Unit 2 reactor core ….............................................. 102

Fig. 11. Locations of fuel rod N-9, instrument tube, and guide tubes in assembly BO-5 .................. 103

Fig. 12. Axial burnup profiles for assembly exposures during cycles 1 and 2 ................................ 104

Fig. 13. Assembly layout for Calvert Cliffs samples from assemblies D047 and D101.................... 107

Fig. 14. Assembly layout for Calvert Cliffs samples from assembly BT03 ..................................... 108

Fig. 15. Assembly layout for Takahama-3 spent fuel samples. ........................................................ 116

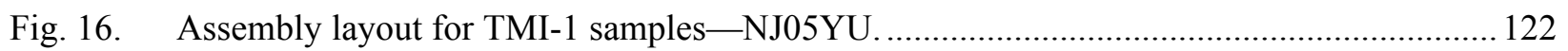

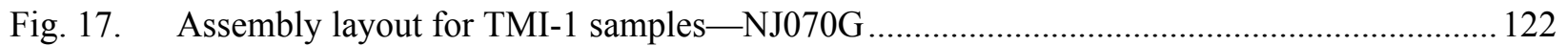

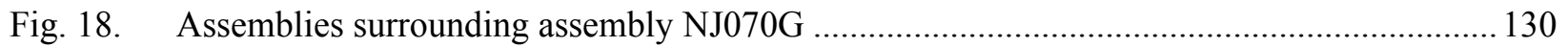

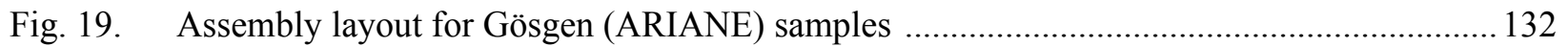

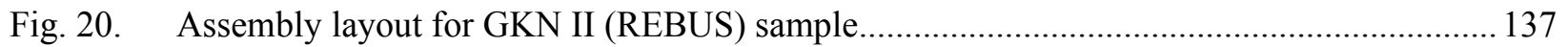

Fig. 21. TRITON/NEWT model for Trino Vercellese assembly 509-069, rod E11_......................... 145

Fig. 22. TRITON/NEWT model for Trino Vercellese assembly 509-104, rod M11........................ 146

Fig. 23. TRITON/NEWT model for KWO assembly BE124, fuel rod G7...................................... 147

Fig. 24. TRITON/NEWT model for Turkey Point Unit 3 assembly D01, rod G9............................ 148

Fig. 25. TRITON/NEWT model for H. B. Robinson Unit 2 assembly BO-5:

(a) for cycle 1 of irradiation; (b) for cycle 2 of irradiation. 149

Fig. 26. TRITON/NEWT model for Calvert Cliffs samples from assembly D047............................ 149

Fig. 27. TRITON/NEWT model for Calvert Cliffs samples from assembly D101 .......................... 150 


\section{LIST OF FIGURES (continued)}

$\underline{\text { Page }}$

Fig. 28. TRITON/NEWT model for Calvert Cliffs samples from assembly BT03, cycle 1............... 150

Fig. 29. TRITON/NEWT model for Calvert Cliffs samples from assembly BT03, cycles 2-4 .......... 151

Fig. 30. TRITON/NEWT model for Takahama-3 SF95 spent fuel samples...................................... 152

Fig. 31. TRITON/NEWT model for Takahama-3 SF96 spent fuel samples...................................... 152

Fig. 32. TRITON/NEWT model for Takahama-3 SF97 spent fuel samples..................................... 153

Fig. 33. TRITON/NEWT model for TMI-1 samples in assembly NJ05YU....................................... 154

Fig. 34. TRITON/NEWT model for TMI-1 samples in rod O12 of assembly NJ070G. .................... 155

Fig. 35. TRITON/NEWT model for TMI-1 samples in rod O1 of assembly NJ070G ...................... 155

Fig. 36. TRITON/NEWT assembly model for Gösgen (ARIANE) - sample GU1 .......................... 157

Fig. 37. TRITON/NEWT assembly model for Gösgen (ARIANE) - sample GU3/4, cycles 16 -17.157

Fig. 38. TRITON/NEWT assembly model for Gösgen (ARIANE) - sample GU3/4, cycle 18 .......... 158

Fig. 39. TRITON/NEWT assembly model for GKN II (REBUS) spent fuel sample........................ 159

Fig. A.1. Ratio of experimental-to-calculated (E/C) ${ }^{234} \mathrm{U}$ concentration versus sample burnup...........A-3

Fig. A.2. Ratio of experimental-to-calculated (E/C) ${ }^{235} \mathrm{U}$ concentration versus sample burnup............A-3

Fig. A.3. Ratio of experimental-to-calculated (E/C) ${ }^{236} \mathrm{U}$ concentration versus sample burnup............A-4

Fig. A.4. Ratio of experimental-to-calculated (E/C) ${ }^{238} \mathrm{U}$ concentration versus sample burnup............A-4

Fig. A.5. Ratio of experimental-to-calculated (E/C) ${ }^{238} \mathrm{Pu}$ concentration versus sample burnup ..........A-5

Fig. A.6. Ratio of experimental-to-calculated (E/C) ${ }^{239} \mathrm{Pu}$ concentration versus sample burnup .......... A-5

Fig. A.7. Ratio of experimental-to-calculated (E/C) ${ }^{240} \mathrm{Pu}$ concentration versus sample burnup .......... A-6

Fig. A.8. Ratio of experimental-to-calculated (E/C) ${ }^{241} \mathrm{Pu}$ concentration versus sample burnup ..........A-6

Fig. A.9. Ratio of experimental-to-calculated (E/C) ${ }^{242} \mathrm{Pu}$ concentration versus sample burnup ..........A-7

Fig. A.10. Ratio of experimental-to-calculated (E/C) ${ }^{237} \mathrm{~Np}$ concentration versus sample burnup..........A-7

Fig. A.11. Ratio of experimental-to-calculated (E/C) ${ }^{241}$ Am concentration versus sample burnup ........A-8

Fig. A.12. Ratio of experimental-to-calculated (E/C) ${ }^{242 \mathrm{~m}}$ Am concentration versus sample burnup ......A-8

Fig. A.13. Ratio of experimental-to-calculated (E/C) ${ }^{243}$ Am concentration versus sample burnup ........A-9

Fig. A.14. Ratio of experimental-to-calculated (E/C) ${ }^{95}$ Mo concentration versus sample burnup ..........A-9

Fig. A.15. Ratio of experimental-to-calculated (E/C) ${ }^{99} \mathrm{Tc}$ concentration versus sample burnup..........A-10

Fig. A.16. Ratio of experimental-to-calculated (E/C) ${ }^{101} \mathrm{Ru}$ concentration versus sample burnup........A-10

Fig. A.17. Ratio of experimental-to-calculated $(\mathrm{E} / \mathrm{C}){ }^{103} \mathrm{Rh}$ concentration versus sample burnup ........A-11

Fig. A.18. Ratio of experimental-to-calculated (E/C) ${ }^{109} \mathrm{Ag}$ concentration versus sample burnup........A-11

Fig. A.19. Ratio of experimental-to-calculated (E/C) ${ }^{143} \mathrm{Nd}$ concentration versus sample burnup........A-12 


\section{LIST OF FIGURES (continued)}

Page

Fig. A.20. Ratio of experimental-to-calculated (E/C) ${ }^{145} \mathrm{Nd}$ concentration versus sample burnup........A-12

Fig. A.21. Ratio of experimental-to-calculated (E/C) ${ }^{147} \mathrm{Sm}$ concentration versus sample burnup .......A-13

Fig. A.22. Ratio of experimental-to-calculated (E/C) ${ }^{149} \mathrm{Sm}$ concentration versus sample burnup ........A-13

Fig. A.23. Ratio of experimental-to-calculated (E/C) ${ }^{150} \mathrm{Sm}$ concentration versus sample burnup .......A-14

Fig. A.24. Ratio of experimental-to-calculated (E/C) ${ }^{151} \mathrm{Sm}$ concentration versus sample burnup .......A-14

Fig. A.25. Ratio of experimental-to-calculated (E/C) ${ }^{152} \mathrm{Sm}$ concentration versus sample burnup .......A-15

Fig. A.26. Ratio of experimental-to-calculated (E/C) ${ }^{151}$ Eu concentration versus sample burnup ........A-15

Fig. A.27. Ratio of experimental-to-calculated (E/C) ${ }^{153} \mathrm{Eu}$ concentration versus sample burnup........A-16

Fig. A.28. Ratio of experimental-to-calculated (E/C) ${ }^{155} \mathrm{Gd}$ concentration versus sample burnup........A-16 



\section{LIST OF TABLES}

$\underline{\text { Page }}$

Table 1. Summary of direct inputs for spent fuel sample modeling ................................................... 7

Table 2. Uranium isotope dependence on $X \mathrm{wt} \%{ }^{235} \mathrm{U}$ enrichment .................................................. 9

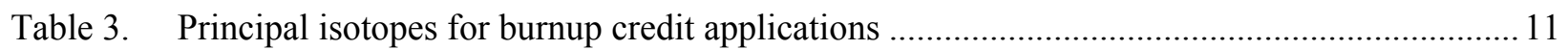

Table 4. Summary of experiments used for validation of spent fuel compositions............................... 14

Table 5. Nuclear data used for experiment data evaluation................................................................. 20

Table 6. Summary of the Trino Vercellese measured spent fuel ...........................................................2

Table 7. Experimental techniques and uncertainties for Trino Vercellese spent fuel samples.............. 25

Table 8. Burnup values derived from experimental measurements....................................................26

Table 9. Experimental results for Trino Vercellese fuel samples $\left(\mathrm{mg} / \mathrm{g} \mathrm{U}_{\text {initial }}\right)$..................................2 28

Table 10. Experimental techniques and uncertainties for Obrigheim measurements at WAK ............... 31

Table 11. Summary of measured Obrigheim assemblies reprocessed at WAK …................................. 32

Table 12. Measurement data for Obrigheim assemblies reprocessed at WAK (mg/g $\left.\mathrm{U}_{\text {initial }}\right)$.................. 33

Table 13. Summary of Obrigheim KWO fuel samples from assemblies BE124 and BE210_.................34

Table 14. Measurement methods and uncertainties in Obrigheim measurements at JRC ...................... 35

Table 15. Obrigheim sample burnup values from JRC measurements ................................................ 36

Table 16. Experimental results for Obrigheim JRC samples ${ }^{a}\left(\mathrm{mg} / \mathrm{g} \mathrm{U}_{\text {initial }}\right)$......................................... 38

Table 17. Summary of the Turkey Point Unit 3 spent fuel samples ….................................................. 40

Table 18. Experimental results $\left(\mathrm{mg} / \mathrm{g} \mathrm{U}_{\text {initial }}\right)$ for Turkey Point fuel samples ........................................ 41

Table 19. Experimental techniques and uncertainties for Turkey Point measurements ......................... 42

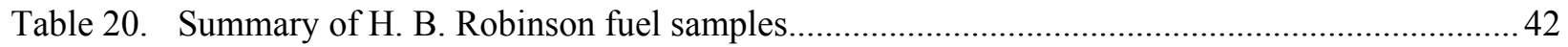

Table 21. Experimental results ( $\left.\mathrm{mg} / \mathrm{g} \mathrm{U}_{\text {initial }}\right)$ for $\mathrm{H}$. B. Robinson fuel samples ................................... 44

Table 22. Experimental techniques and uncertainties for H. B. Robinson measurements ...................... 44

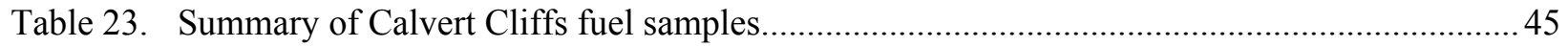

Table 24. Experimental techniques and uncertainties for Calvert Cliffs measurements at PNL ............. 47

Table 25. Experimental techniques and uncertainties for Calvert Cliffs measurements at KRI.............. 49

Table 26. Measurement results for Calvert Cliffs 103-MLA098 samples (mg/g U $\left.\mathrm{U}_{\text {initial }}\right)$........................50

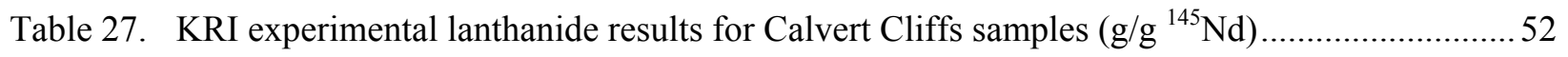

Table 28. Measurement results for Calvert Cliffs 104-MKP109 samples ( $\mathrm{mg} / \mathrm{g} \mathrm{U}$ initial $)$........................53

Table 29. Measurement results for Calvert Cliffs 106-NBD107 samples (mg/g U $\left.\mathrm{U}_{\text {initial }}\right)$........................54

Table 30. Summary of Takahama Unit 3 fuel samples from assemblies NT3G23 and NT3G24............55

Table 31. Experimental techniques and uncertainties for Takahama-3 samples ..................................57 


\section{LIST OF TABLES (continued)}

$\underline{\text { Page }}$

Table 32. Experimental results $\left(\mathrm{g} / \mathrm{g} \mathrm{U}_{\text {initial }}\right)$ for Takahama-3 samples from rod SF95 …........................58

Table 33. Experimental results $\left(\mathrm{g} / \mathrm{g} \mathrm{U}_{\text {initial }}\right)$ for Takahama-3 samples from rod SF96 …........................59

Table 34. Experimental results $\left(\mathrm{g} / \mathrm{g} \mathrm{U}_{\text {initial }}\right)$ for Takahama-3 samples from rod SF97 ............................60

Table 35. Summary of TMI Unit 1 fuel samples from assemblies NJ05YU and NJ070G...................... 61

Table 36. Experimental techniques and uncertainties for TMI-1 samples measurements at ANL...........63

Table 37. Experimental results $\left(\mathrm{g} / \mathrm{g} \mathrm{U}_{\text {initial }}\right)$ for TMI-1 samples measured at ANL ............................... 64

Table 38. Experimental techniques and uncertainties for TMI-1 samples measurements at GE-VNC .... 67

Table 39. Experimental results $\left(\mathrm{g} / \mathrm{g} \mathrm{U}_{\text {initial }}\right)$ for TMI-1 samples measured at GE-VNC ........................6 68

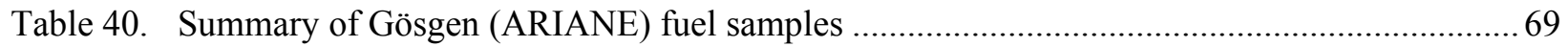

Table 41. Experimental techniques and uncertainties for ARIANE Program Gösgen samples ...............71

Table 42. Experimental results for ARIANE Program Gösgen samples …............................................ 72

Table 43. Decay time at the time of measurement for ARIANE Program Gösgen samples .................... 73

Table 44. Experimental techniques and uncertainties for REBUS Program GKN II sample.................. 76

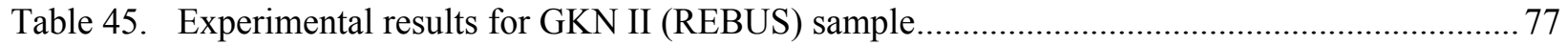

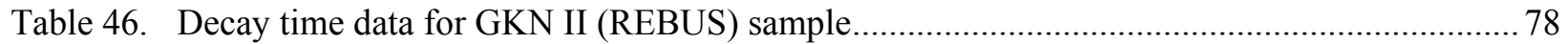

Table 47. Assembly design and operating data for Trino Vercellese …................................................ 84

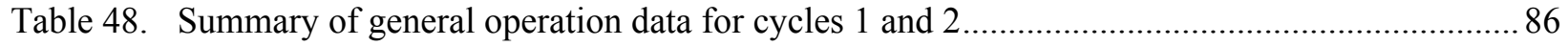

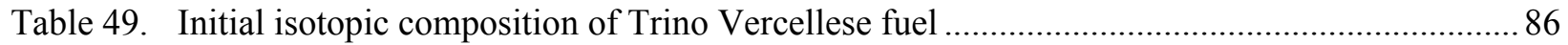

Table 50. Moderator temperature and density at sample locations for Trino Vercellese samples ........... 87

Table 51. Fuel burnup, operating power histories, and temperature for Trino Vercellese pellet

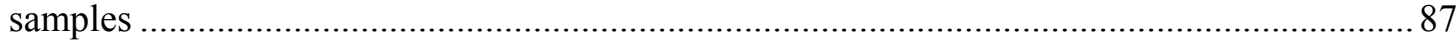

Table 52. Assembly design and operating data for Obrigheim measured spent fuel............................ 89

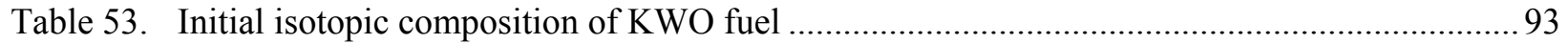

Table 54. Irradiation history of Obrigheim assemblies BE124 and BE210 .......................................93

Table 55. Specific power and final burnup data for KWO assemblies BE168, BE170, BE171,

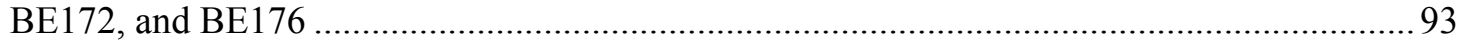

Table 56. Operating parameter values for KWO samples ................................................................... 94

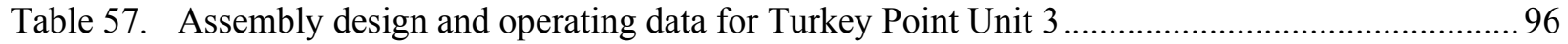

Table 58. Initial composition of Turkey Point fuel assemblies ............................................................ 97

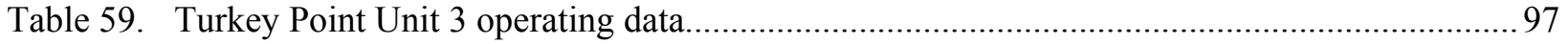

Table 60. Turkey Point sample specific powers and temperatures...................................................... 97

Table 61. Assembly design and operating data for H. B. Robinson ................................................. 100 


\section{LIST OF TABLES (continued)}

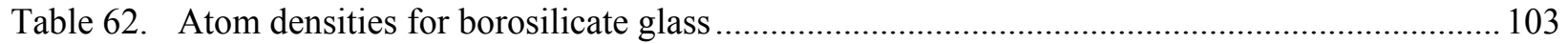

Table 63. Operating and fuel temperature data for H. B. Robinson spent fuel samples........................ 105

Table 64. Moderator conditions for H. B. Robinson spent fuel samples ............................................. 105

Table 65. Assembly design and operating data for Calvert Cliffs measured spent fuel ........................ 109

Table 66. Sample location data for Calvert Cliffs samples ................................................................ 110

Table 67. Moderator temperature and density data for Calvert Cliffs samples ................................... 110

Table 68. Concentration of soluble boron in moderator for Calvert Cliffs samples............................. 111

Table 69. Effective fuel temperature data for Calvert Cliffs samples ................................................ 111

Table 70. Burnup values for Calvert Cliffs spent fuel samples ......................................................... 112

Table 71. Linear heat generation data for fuel rod MKP109 ........................................................... 113

Table 72. Linear heat generation data for fuel rod MLA098 ............................................................ 114

Table 73. Linear heat generation data for fuel rod NBD107 ........................................................... 114

Table 74. Sample burnup at the end of each cycle for Calvert Cliffs samples ..................................... 115

Table 75. Decay time data for Calvert Cliffs samples ...................................................................... 115

Table 76. Assembly design data for Takahama-3 spent fuel samples ................................................ 118

Table 77. Burnup, power, sample location, and moderator data for Takahama-3 samples ................... 119

Table 78. Operation history data for Takahama-3 spent fuel samples................................................ 120

Table 79. Soluble boron concentration in moderator for Takahama-3 spent fuel samples.................... 120

Table 80. Sample burnup for Takahama-3 spent fuel samples ......................................................... 121

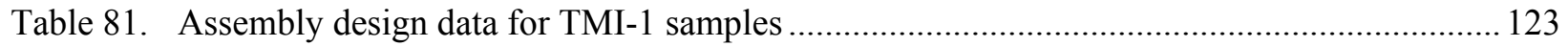

Table 82. Burnup and starting moderator density data for TMI-1 samples ......................................... 125

Table 83. Burnup as a function of time for TMI-1 samples from assembly NJ05YU.......................... 126

Table 84. Fuel temperature and concentration of soluble boron in moderator for TMI-1 samples

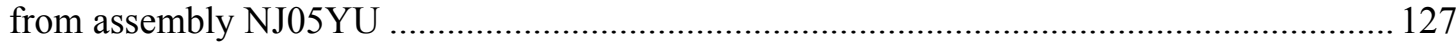

Table 85. Moderator density multiplication factors for TMI-1 samples from assembly NJ05YU ......... 128

Table 86. Burnup as a function of time for TMI-1 samples from assembly NJ070G ......................... 129

Table 87. Fuel temperature and concentration of soluble boron in moderator for TMI-1 samples

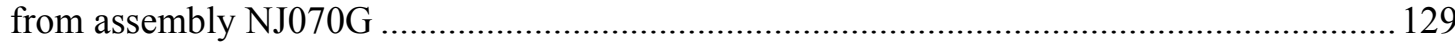

Table 88. Moderator density multiplication factors for TMI-1 samples from assembly NJ070G......... 129

Table 89. Modeling data for the assemblies adjoining the SW corner of assembly NJ070G................ 130

Table 90. Assembly design data for Gösgen (ARIANE) samples ..................................................... 133

Table 91. Operating history data for Gösgen (ARIANE) sample GU1 ............................................. 134 


\section{LIST OF TABLES (continued)}

$\underline{\text { Page }}$

Table 92. Operating history data for Gösgen (ARIANE) samples GU3 and GU4 ….......................... 135

Table 93. Assembly design data for GKN II (REBUS) sample ....................................................... 138

Table 94. Operating history data for GKN II (REBUS) sample ......................................................... 139

Table 95. Cycle average power data for GKN II (REBUS) sample …................................................ 140

Table 96. Cycle average moderator and fuel data for GKN II (REBUS) sample ................................. 140

Table 97. SCALE calculation results for Trino Vercellese spent fuel samples .................................... 162

Table 98. SCALE calculation results for Obrigheim spent fuel samples ........................................... 166

Table 99. SCALE calculation results for Turkey Point Unit 3 spent fuel samples............................... 170

Table 100. SCALE calculation results for H. B. Robinson Unit 2 spent fuel samples............................ 170

Table 101. SCALE calculation results for Calvert Cliffs Unit 1 spent fuel samples.............................. 171

Table 102. SCALE calculation results for the Takahama Unit 3 spent fuel samples ............................. 173

Table 103. SCALE calculation results for the TMI Unit 1 spent fuel samples ....................................... 177

Table 104. SCALE calculation results for Gösgen (ARIANE) spent fuel samples ................................. 181

Table 105. SCALE calculation results for GKN II (REBUS) spent fuel sample ................................... 183

Table 106. SCALE calculation results for Gösgen (MALIBU) spent fuel samples ................................ 184

Table 107. Comparison between isotopic compositions obtained with detailed and simplified

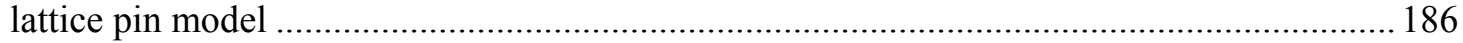

Table 108. Fuel density sensitivity calculation results for Trino Vercellese spent fuel samples.............. 187

Table 109. Fuel temperature sensitivity calculation results for Trino Vercellese spent fuel samples ...... 188 


\title{
ACRONYMS
}

\author{
ANL Argonne National Laboratory \\ ARIANE Actinide Research in a Nuclear Element \\ ASTM American Society for Testing and Materials \\ ATM Approved Testing Material \\ B\&W Babcock \& Wilcox \\ BPR burnable poison rod \\ BU burnup \\ $\mathrm{C} / \mathrm{E}$ ratio of calculated-to-measured isotopic concentration \\ CE Combustion Engineering \\ CEA Commissariat à l'Énergie Atomique (France) \\ CFR Code of Federal Regulations \\ CRG control rod group \\ CSNF commercial spent nuclear fuel \\ DOE (U.S.) Department of Energy \\ DTN data tracking number \\ DVD digital video disc \\ E/C experimental to calculated \\ EFPD effective full power days \\ ENDF Evaluated Nuclear Data File \\ EOC end of cycle \\ EPRI Electric Power Research Institute \\ FIMA fission per initial metal atom \\ FPD full power days \\ GE-VNC General Electric Vallecitos Nuclear Center \\ GKN II Gemeinschaftskernkraftwerk Unit II in Neckarwestheim/Neckar \\ GRS Gesellschaft für Reaktorsicherheit $\mathrm{mbH}$ \\ HEDL Hanford Engineering and Development Laboratory \\ IAEA International Atomic Energy Agency \\ ICP-MS inductively coupled plasma mass spectrometry \\ ID identifier \\ IDA isotope dilution analysis \\ IDMS isotope dilution mass spectrometry \\ IRCh Institute of Radiochemistry \\ ITU European Institute for Transuranium Elements \\ JAERI Japan Atomic Energy Research Institute \\ JRC Joint Research Center, European Commission \\ KRI Khlopin Radium Institute \\ KWO Kernkraftwerk Obrigheim \\ LA license application; luminescent analysis \\ LANL Los Alamos National Laboratory \\ LHGR linear heat generation rate \\ MALIBU Radiochemical analysis of MOX $\underline{A}$ nd UOX LWR fuels Irradiated to high Burnup \\ MCC Materials Characterization Center (PNL) \\ NEA Nuclear Energy Agency \\ NRC (U.S.) Nuclear Regulatory Commission \\ NSTD Nuclear Science and Technology Division \\ OECD Organization for Economic Cooperation and Development \\ OCRWM Office of Civilian Radioactive Waste (Management)
}


ORNL Oak Ridge National Laboratory

PNL Pacific Northwest National Laboratory

PSI Paul Scherrer Institute (Switzerland)

PWR pressurized water reactor

RCA radiochemical assay (data)

REBUS Reactivity Tests for a Direct Evaluation of the Burnup Credit on Selected Irradiated LWR Fuel Bundles

RSD relative standard deviation

SCALE Standardized Computer Analysis for Licensing Evaluation

SCK $\cdot$ CEN Studiecentrum voor Kernenergie - Centre d'étude de l'Energie Nucléaire (Belgium)

SIMS secondary ion mass spectrometry

TIMS thermal ionization mass spectrometry

TMI Three Mile Island

WAK Karlsruhe Reprocessing Plant

XRFA X-ray fluorescent analysis

YMP Yucca Mountain Project 


\section{PURPOSE}

The purpose of this calculation report is to document the comparison to measurement of the isotopic concentrations for pressurized water reactor (PWR) spent nuclear fuel determined with the Standardized Computer Analysis for Licensing Evaluation (SCALE) 5.1 (Ref. 1) depletion calculation method. Specifically, the depletion computer code and the cross-section library being evaluated are the twodimensional (2-D) transport and depletion module, TRITON/NEWT, ${ }^{2,3}$ and the 44GROUPNDF5 (Ref. 4) cross-section library, respectively, in the SCALE 5.1 code system.

This calculation report was developed in support of licensing activities for the proposed repository at Yucca Mountain, Nevada, and the development of the report is consistent with Test Plan for: Isotopic Validation for Postclosure Criticality of Commercial Spent Nuclear Fuel. ${ }^{5}$ The calculation report describes a comprehensive evaluation of radiochemical measurement, assembly design, and irradiation history data for 118 PWR spent fuel samples obtained from low-, moderate-, and high-burnup spent fuel assemblies from nine PWRs: Trino Vercellese, Kernkraftwerk Obrigheim (KWO), Turkey Point Unit 3, H. B. Robinson Unit 2, Calvert Cliffs Unit 1, Three Mile Island (TMI) Unit 1, Takahama Unit 3, Gösgen, and GKN II. The initial fuel enrichments and burnup values for the samples considered vary from 2.453 to $4.657 \mathrm{wt} \%{ }^{235} \mathrm{U}$ and from 7.2 to $70.4 \mathrm{GWd} / \mathrm{MTU}$, respectively. The majority of the spent fuel samples were obtained from $\mathrm{UO}_{2}$ rods in assemblies with no exposure to either burnable poison rods or control rods. However, the evaluated spent fuel samples also include samples from $\mathrm{UO}_{2}$ assemblies containing burnable poison rods and samples from gadolinia rods. The report also describes the TRITON/NEWT models developed and provides the values obtained for the ratio of experimental-to-calculated $(\mathrm{E} / \mathrm{C})$ isotopic concentrations. 



\section{QUALITY ASSURANCE REQUIREMENTS}

Development of this report has been determined to be subject to the Yucca Mountain Project quality assurance requirements as described in Test Plan for: Isotopic Validation for Postclosure Criticality of Commercial Spent Nuclear Fuel. ${ }^{5}$ The Test Plan identifies Oak Ridge National Laboratory (ORNL)Office of Civilian Radioactive Waste (OCRW) quality assurance procedures applicable to the development, documentation, and electronic management of the data for this report.

The development of the calculation and analysis documentation was performed in accordance with ORNL-OCRW-19.1, Calculation Packages. ${ }^{6}$ The Test Plan for the development of the report was prepared in accordance with ORNL-OCRW-21.0, Scientific Investigations. ${ }^{7}$ The control of electronic data was performed in accordance with ORNL-OCRW-23.0, Control of the Electronic Management of Data. ${ }^{8}$ The computer codes used in this calculation have been qualified per ORNL-OCRW-19.0, Software Control. $^{9}$ 



\section{USE OF SOFTWARE}

\subsection{STANDARDIZED COMPUTER ANALYSIS FOR LICENSING EVALUATION (SCALE) CODE SYSTEM}

The SCALE (Ref. 1) code system was used to perform transport and depletion calculations. ${ }^{2,3}$ The SCALE 5.1 code system used herein has been qualified per ORNL-OCRW-19.0, Software Control. ${ }^{9}$

- Software Title: SCALE

- Version/Revision Number: Version 5.1

- Status/Operating System: Qualified/Linux 2.6.9-42.0.2 ELsmp \#1, x86_64 GNU/Linux (Ref. 10)

- Computer Type: CPILE2 Linux cluster of the Nuclear Systems Analysis, Design, and Safety organization, Nuclear Science and Technology Division, ORNL

Rationale for Selection: SCALE is accepted by the U.S. Nuclear Regulatory Commission (NRC) for criticality safety applications. ${ }^{11}$ This computer code system has multiple unique capabilities relevant to this work including automated sequences to produce problem-dependent multigroup cross-section data and analysis sequences for transport and depletion calculations.

The input and output files for the SCALE depletion calculations are located on a DVD that accompanies this report (refer to Appendix B for the contents of the DVD), so that an independent repetition of the calculations may be performed.

\subsection{EXCEL}

The commercial off-the-shelf software Microsoft Office Excel (copyright Microsoft Corporation) was used in calculations to manipulate the inputs and to tabulate and chart results using standard mathematical expressions and operations. Microsoft Excel was used only as a worksheet and not as a software routine. Therefore, Excel is exempt from the requirements of ORNL-OCRW-19.0, Software Control. ${ }^{9}$ All necessary information for reproducing the operations performed is provided on the DVD that accompanies this report, so that an independent repetition of the operations may be performed. 



\section{INPUT DATA}

Direct inputs to the isotopic composition validation include measured isotopic concentrations and burnup of spent nuclear fuel samples, design and irradiation parameters for the analyzed spent fuel assemblies, material compositions and densities, nuclear data, etc., as detailed in the following sections.

Table 1 provides a summary of the direct inputs documented in the report, the sources of input data, and a justification for use as direct inputs. The direct inputs were obtained from primary reports published by radiochemical assay measurement programs, from industry handbooks, and from NRC- and industryapproved documents.

Table 1. Summary of direct inputs for spent fuel sample modeling

\begin{tabular}{|c|c|c|c|}
\hline Parameter & Value & Source & Justification \\
\hline Trino Vercellese data ${ }^{a}$ & See Sects. 7.1 and 8.1 & Refs. 12,13 , and 14 & $\begin{array}{l}\text { Primary experimental } \\
\text { reports }\end{array}$ \\
\hline $\mathrm{KWO}_{\text {data }}{ }^{a}$ & See Sects. 7.2 and 8.2 & $\begin{array}{l}\text { Refs. } 15,16,17,18,19 \text {, and } \\
20\end{array}$ & $\begin{array}{l}\text { Primary experimental } \\
\text { reports }\end{array}$ \\
\hline Turkey Point Unit 3 data $^{a}$ & See Sects. 7.3 and 8.3 & Refs. $21,22,23,24$, and 25 & $\begin{array}{l}\text { Primary experimental } \\
\text { reports }\end{array}$ \\
\hline H. B. Robinson Unit 2 data $^{a}$ & See Sects. 7.4 and 8.4 & Refs. $26,27,28$, and 29 & $\begin{array}{l}\text { Primary experimental } \\
\text { reports }\end{array}$ \\
\hline Calvert Cliffs Unit 1 data $^{a}$ & See Sects. 7.5 and 8.5 & $\begin{array}{l}\text { Refs. } 30,31,32,33,34,35 \text {, } \\
36,37,38,39 \text {, and } 40\end{array}$ & $\begin{array}{l}\text { Primary experimental } \\
\text { reports }\end{array}$ \\
\hline Takahama Unit 3 data $^{a}$ & See Sects. 7.6 and 8.6 & Refs. 41,42 , and 43 & $\begin{array}{l}\text { Primary experimental } \\
\text { reports }\end{array}$ \\
\hline TMI Unit 1 data $^{a}$ & See Sects. 7.7 and 8.7 & Refs. $44,45,46$, and 47 & $\begin{array}{l}\text { Primary experimental } \\
\text { reports }\end{array}$ \\
\hline $\begin{array}{l}\text { Gösgen: ARIANE Program } \\
\text { data }^{a}\end{array}$ & See Sects. 7.8 and 8.8 & Ref. 48 & $\begin{array}{l}\text { Primary experimental } \\
\text { reports }\end{array}$ \\
\hline GKN II data ${ }^{a}$ & See Sects. 7.9 and 8.9 & Refs. $49,50,51,52$, and 53 & $\begin{array}{l}\text { Primary experimental } \\
\text { reports }\end{array}$ \\
\hline $\begin{array}{l}\text { Gösgen: MALIBU Program } \\
\text { data }^{a}\end{array}$ & $\begin{array}{l}\text { See Sects. } 7.10 \text { and } \\
8.10\end{array}$ & Refs. 54 and 55 & $\begin{array}{l}\text { Primary experimental } \\
\text { reports }\end{array}$ \\
\hline General power plant data & & Refs. 56 and 57 & $\begin{array}{l}\text { Industry-approved } \\
\text { documents }\end{array}$ \\
\hline Steam tables & & Ref. 58 & NRC-approved document \\
\hline $\begin{array}{l}\text { Nuclear data and fundamental } \\
\text { general physics constants }\end{array}$ & & Refs. 59, 60, 61, 62, 63 & Industry handbooks \\
\hline
\end{tabular}





\section{ASSUMPTIONS}

Values for certain physical and operational parameters (e.g., moderator density and temperature at the sample location along the fuel rod length, or the concentrations of ${ }^{234} \mathrm{U}$ and ${ }^{236} \mathrm{U}$ in initial fuel compositions) required as input data for depletion calculations are not always available in the original documents that describe spent fuel isotopic composition data. The following assumptions were used in all the calculations documented in this report to determine unavailable data.

\subsection{INITIAL URANIUM ISOTOPIC CONTENTS}

The uranium minor isotopes ${ }^{234} U$ and ${ }^{236} U$ are usually measured in irradiated fuel, but their concentration in fresh fuel is not always available. Uranium-234 depletes through neutron capture to form additional

${ }^{235} \mathrm{U}$ and is a long-lived isotope unaffected by reactor downtime and discharge from the reactor. Over long periods, minute quantities of ${ }^{234} \mathrm{U}$ are produced through alpha emissions in ${ }^{238} \mathrm{Pu}\left(\mathrm{T}_{1 / 2}=87.7\right.$ years). Uranium-236 is a long-lived isotope that depletes through neutron capture to form additional ${ }^{237} \mathrm{U}$. However, the ${ }^{236} \mathrm{U}$ thermal capture cross section is small compared to that of ${ }^{235} \mathrm{U}$. As a result, more ${ }^{236} \mathrm{U}$ is produced than is lost during reactor operation.

The fresh fuel uranium isotopic concentrations are assumed to have the dependence on $X \mathrm{wt} \%{ }^{235} \mathrm{U}$ enrichment as shown in Table 2 (Ref. 64). The isotopic ratio factors shown in the table were derived from mass spectrometric analyses of initial fuel for the Yankee Reactor Core V. Therefore, these isotopic ratio factors are mostly applicable to all fresh $\mathrm{UO}_{2}$ fuel produced in the United States. However, the relationships shown in Table 2 were also used to determine the initial compositions of the evaluated spent fuel samples from the European reactors Trino Vercellese and Obrigheim because the applicable primary references do not provide the fuel ${ }^{234} \mathrm{U}$ and ${ }^{236} \mathrm{U}$ initial concentrations. As a result, the variability of the ${ }^{234} \mathrm{U}$ and ${ }^{236} \mathrm{U}$ validation results for the evaluated Trino Vercellese and Obrigheim samples may be large as compared to the variability obtained for the other spent fuel samples.

Table 2. Uranium isotope dependence on $X$ wt $\%{ }^{235} \mathrm{U}$ enrichment

\begin{tabular}{cl}
\hline Isotope & \multicolumn{1}{c}{ Assay, wt \% } \\
\hline${ }^{234} \mathrm{U}$ & $0.0089 \mathrm{X}$ \\
${ }^{235} \mathrm{U}$ & $1.0000 \mathrm{X}$ \\
${ }^{236} \mathrm{U}$ & $0.0046 \mathrm{X}$ \\
${ }^{238} \mathrm{U}$ & $100-1.0135 \mathrm{X}$ \\
\hline
\end{tabular}

\subsection{MODERATOR TEMPERATURE AND DENSITY}

The moderator temperature as a function of the distance from the bottom of the active fuel region of the fuel rod is calculated using the following equation that was derived in Ref. 65 . The equation is based on the assumption that the power density in the fuel rod varies approximately according to an idealized sinusoidal function that has the maximum value in the center of the fuel rod.

$$
T(z)=T_{\text {in }}+\frac{T_{\text {out }}-T_{\text {in }}}{2}\left(1-\cos \frac{\pi \cdot z}{H}\right)
$$


where

$$
\begin{aligned}
& T(z)=\text { temperature }(\mathrm{K}) \text { at height } z(\mathrm{~cm}) \text { with respect to the bottom of the fuel region, } \\
& T_{\text {in }}=\text { inlet temperature }(\mathrm{K}) \\
& T_{\text {out }}=\text { outlet temperature }(\mathrm{K}) \\
& H \quad=\text { total active fuel height }(\mathrm{cm})
\end{aligned}
$$

The moderator density depends on the coolant pressure and moderator temperature, which is determined as described by Eq. (1). The moderator density is taken directly from, or obtained by interpolating tabulated, compressed water density data available in Ref. 58 as a function of water pressure and temperature.

\subsection{EFFECTIVE FUEL TEMPERATURE}

Effective fuel temperature is an input parameter that is used to calculate resonance absorption in the fuel. For spent fuel samples with unavailable effective fuel temperature data, such as those from fuel assemblies irradiated in the Trino Vercellese and H. B. Robinson reactors, the temperature data for fuel assemblies with a similar design were used in the calculations. Thus, the effective fuel temperatures for the Trino Vercellese spent fuel samples were determined using data in Ref. 85, Table C-1, providing effective fuel temperature values versus specific power values for Yankee Rowe PWR fuel assemblies (see Sect. 8.1), whereas the effective fuel temperatures for the H. B. Robinson spent fuel samples were determined from the curve provided in Ref. 16, Fig. 2, showing effective fuel temperature versus rod linear power for Obrigheim fuel assemblies (see Sect. 8.4).

For spent fuel isotopic composition data sets for which fuel centerline and surface temperatures were available, the effective fuel temperature was assumed to be described by Eq. (2) (Ref. 66). This equation has been derived for an effective fuel temperature to be used for calculating resonance absorption in a ${ }^{238} \mathrm{UO}_{2}$ lump with a nonuniform temperature profile.

$$
T_{e f f}=T_{s}+\frac{4}{9}\left(T_{c}-T_{s}\right)
$$

In Eq. (2), $T_{\text {eff }}$ is the effective fuel temperature, and $T_{c}$ and $T_{s}$ are the temperatures at the center and surface of the fuel rod, respectively.

\subsection{BORON LETDOWN CURVE}

Cycle-averaged soluble boron concentrations were available for many of the spent fuel samples considered. For those samples, it is assumed that soluble boron concentration during an irradiation cycle decreases linearly. Adjustment factors for computing soluble boron concentrations at various time steps within a cycle were taken from the boron letdown curve available in Ref. 67. 


\section{EXPERIMENTAL PROGRAMS AND DATA}

\subsection{SELECTION OF SPENT FUEL ISOTOPIC COMPOSITION DATA}

Validation of the TRITON depletion analysis sequence is based on benchmarking code predictions against measured spent fuel isotopic concentrations. A total of 118 spent fuel samples selected from commercial PWR fuel assemblies were evaluated in this report. Most samples were obtained by sectioning individual fuel rods. Several samples were obtained from dissolved assemblies at a fuel reprocessing plant. Consistent with the Disposal Criticality Analysis Methodology Topical Report (Ref. 68), the evaluated spent fuel isotopic composition data sets provide measured isotopic concentrations for a set of 29 actinides and fission products, referred to as "principal isotopes" that are used in burnup-credit criticality calculations. The principal isotopes are listed in Table 3.

Table 3. Principal isotopes for burnup credit applications

\begin{tabular}{cc|cc}
\hline \multicolumn{2}{c|}{ Actinide isotopes } & \multicolumn{2}{|c}{ Fission product isotopes } \\
\hline${ }^{233} \mathrm{U}$ & ${ }^{239} \mathrm{Pu}$ & ${ }^{95} \mathrm{Mo}$ & ${ }^{149} \mathrm{Sm}$ \\
${ }^{234} \mathrm{U}$ & ${ }^{240} \mathrm{Pu}$ & ${ }^{99} \mathrm{Tc}$ & ${ }^{150} \mathrm{Sm}$ \\
${ }^{235} \mathrm{U}$ & ${ }^{241} \mathrm{Pu}$ & ${ }^{101} \mathrm{Ru}$ & ${ }^{151} \mathrm{Sm}$ \\
${ }^{236} \mathrm{U}$ & ${ }^{242} \mathrm{Pu}$ & ${ }^{103} \mathrm{Rh}$ & ${ }^{152} \mathrm{Sm}$ \\
${ }^{238} \mathrm{U}$ & ${ }^{241} \mathrm{Am}$ & ${ }^{109} \mathrm{Ag}$ & ${ }^{151} \mathrm{Eu}$ \\
${ }^{237} \mathrm{~Np}$ & ${ }^{242 \mathrm{~m}} \mathrm{Am}{ }^{a}$ & ${ }^{143} \mathrm{Nd}$ & ${ }^{153} \mathrm{Eu}$ \\
${ }^{238} \mathrm{Pu}$ & ${ }^{243} \mathrm{Am}$ & ${ }^{145} \mathrm{Nd}$ & ${ }^{155} \mathrm{Gd}$ \\
& & ${ }^{147} \mathrm{Sm}$ & \\
\hline
\end{tabular}

${ }^{a}$ The $m$ refers to a long-lived metastable state of ${ }^{242} \mathrm{Am}$.

Radiochemical analysis measurements are reported for all of the principal isotopes with the exception of

${ }^{233} \mathrm{U}$ for which the concentrations in spent fuel are lower than the detection limit at the time of measurement. At longer decay times, a significant amount of ${ }^{233} \mathrm{U}$ is generated by the alpha decay of ${ }^{237} \mathrm{~Np}\left(\mathrm{~T}^{1} 12>10^{6}\right.$ years $)$. The concentration of ${ }^{233} \mathrm{U}$ at long decay times can therefore be indirectly validated from ${ }^{237} \mathrm{~Np}$ measurements.

\subsection{SUMMARY OF DATA USED IN PREVIOUS YMP ANALYSES}

Isotopic analysis used to support the Yucca Mountain Project License Application (LA) submitted on June 3, 2008, included radiochemical assay for 74 samples for PWR fuel. The samples were obtained for the following reactors, as documented in the report titled Calculation of Isotopic Bias and Uncertainty for PWR Spent Nuclear Fuel. ${ }^{69}$

Trino Vercellese

Yankee Rowe

Turkey Point

Mihama

H. B. Robinson

Obrigheim

Calvert Cliffs

Three Mile Island
14 samples

8 samples

5 samples

9 samples

4 samples

6 samples

9 samples

19 samples 
Not all of the experimental data sets used in previous analyses to determine isotopic bias and uncertainty ${ }^{69}$ were included in the current report.

The data for Mihama were omitted due to incomplete documentation of design and reactor operating information and due to unusually large variations observed in measured results for samples with similar burnup. ${ }^{70}$ Future use of this set of data was not recommended because of the unexplained variation in the results, which may indicate problems related to the radiochemical analysis of samples or the incomplete documentation of operating data.

The Yankee Rowe (Yankee) reactor data were also omitted. The analyses performed for the Yankee data exhibit deviations of the measured data as compared with corresponding calculated data that were much larger than the deviations observed for other similar data sets considered. These deviations are thought to be due to samples located near the edge of the assembly that were exposed to control blades used in this reactor. The control blades perturb the neutronic environment of the fuel rods located at the periphery of the assembly. There was insufficient documented information on the blade insertion levels to enable the blades to be modeled. Evaluation of the Yankee data has also been hindered by the inability to access primary reference reports on the reactor operation for the irradiation cycles, referenced in earlier analyses as Safety Analysis Reports for the reactor. As it has not been possible to access the reports at this time, the reactor operating data could not be confirmed. For these reasons the Yankee data are not included in the current report.

The current report includes a total of 118 fuel samples and provides an analysis of additional data from several recent experimental programs (some proprietary) and from samples measured in previous experiments that have not been evaluated before (see Table 4).

The most significant differences compared to previously reported analyses are summarized below.

Trino Vercellese

All previously analyzed samples (14) are included in this report, and 17 previously unevaluated samples from the same experiment were added.

Obrigheim

Previous analyses of Obrigheim reactor fuel included data for six batch samples from five dissolved assemblies (each batch $=$ half assembly) obtained from the Karlsruhe reprocessing plant. In this report, all ten batches were evaluated, and the two batch results for each assembly were combined, providing full assembly average data for five assemblies. In addition, 22 Obrigheim fuel rods samples measured under a different European benchmark program were included in this study. The fuel rod samples were not previously evaluated in the LA.

\section{$\underline{\text { Calvert Cliffs }}$}

All Calvert Cliffs samples previously evaluated in the LA (nine samples) are included in this report. Additional measurements of lanthanide fission product isotopes for four of these samples made at the Khlopin Radium Institute (KRI) in Russia, measurements not previously used, are included in this report. The KRI data also include one measurement of ${ }^{103} \mathrm{Rh}$.

\section{Gösgen}

New measurement data for $\mathrm{UO}_{2}$ spent fuel from the Gösgen reactor, in Switzerland, are included in this report. The Gösgen data are obtained from the ARIANE and MALIBU international experimental programs ${ }^{71}$ coordinated by Belgonucleaire in Belgium. Measurements are reported for three samples in the ARIANE program and three samples in the MALIBU program. These data include extensive isotopic measurements that involve multiple laboratories for cross-check verification. Therefore, these data are 
considered to be of high quality and reliability. The isotopic measurement data include all nuclides of importance to burnup credit. The Belgonucleaire programs are commercial proprietary, although only the MALIBU data are considered restricted from public access at this time. ${ }^{71}$

\section{GKN II}

New measurement data for one $\mathrm{UO}_{2}$ fuel sample are available for the GKN II reactor in Neckarwestheim, Germany. The measurements are reported as part of the REBUS International Program, ${ }^{72}$ also coordinated by Belgonucleaire. These data include full isotopic measurements for nuclides of importance to burnup credit isotopic validation.

\subsection{REVIEW OF RADIOCHEMICAL ANALYSIS DATA}

The total number of measured spent fuel samples used in the isotopic composition validation is 118 . Their initial enrichment and burnup vary between 2.453 and $4.657 \mathrm{wt} \%{ }^{235} \mathrm{U}$ and between 7.2 and $70.4 \mathrm{GWd} / \mathrm{MTU}$, respectively. A summary of the experiments used to validate calculated spent fuel compositions is provided in Table 4. A comparison between sample burnup and enrichment values and the loading curve for the PWR SNF obtained from Ref. 73 is illustrated in Fig. 1. Physical parameters and irradiation conditions of the spent fuel samples are representative of the range of initial enrichment and burnup values for the inventory of commercial spent fuel assemblies in the United States. 
Table 4. Summary of experiments used for validation of spent fuel compositions

\begin{tabular}{|c|c|c|c|c|c|c|}
\hline Reactor & $\begin{array}{l}\text { Measurement } \\
\text { laboratory }^{a}\end{array}$ & $\begin{array}{l}\text { Experimental } \\
\text { program name }\end{array}$ & $\begin{array}{l}\text { Assembly } \\
\text { design }\end{array}$ & $\begin{array}{l}\text { Enrichment } \\
\left(\text { wt } \%{ }^{235} U\right)\end{array}$ & $\begin{array}{c}\text { No. of } \\
\text { samples/ } \\
\text { fuel rods }\end{array}$ & $\begin{array}{c}\text { Burnup } \\
\text { (GWd/MTU) }\end{array}$ \\
\hline \multirow[t]{2}{*}{ Trino Vercellese } & JRC Ispra, Karlsruhe & EUR & $15 \times 15$ & $2.719,3.13,3.897$ & $15 / 5$ & $7.2-17.5$ \\
\hline & JRC Ispra, Karlsruhe & EUR & $15 \times 15$ & 3.13 & $16 / 5$ & $12.8-25.3$ \\
\hline \multirow[t]{2}{*}{ Obrigheim } & JRC Ispra, Karlsruhe & EUR & $14 \times 14$ & $2.83,3.00$ & $22 / 6$ & $15.6-37.5$ \\
\hline & ITU, IRCh, WAK, IAEA & ICE & $14 \times 14$ & 3.13 & $5 / 5$ & $27.0-29.4$ \\
\hline Turkey Point-3 & Battelle-Columbus & NWTS (CLIMAX) & $15 \times 15$ & 2.556 & $5 / 2$ & $30.5-31.6$ \\
\hline H. B. Robinson-2 & PNL & ATM-101 ${ }^{b}$ & $15 \times 15$ & 2.561 & $4 / 1$ & $16.0-31.7$ \\
\hline \multirow[t]{3}{*}{ Calvert Cliffs-1 } & PNL, KRI & ATM-104 & $14 \times 14$ & 3.038 & $3 / 1$ & $27.4-44.3$ \\
\hline & PNL & ATM-103 & $14 \times 14$ & 2.72 & $3 / 1$ & $18.7-33.2$ \\
\hline & PNL, KRI & ATM-106 & $14 \times 14$ & 2.453 & $3 / 1$ & $31.4-46.5$ \\
\hline Takahama-3 & JAERI & JAERI & $17 \times 17$ & $2.63,4.11$ & $16 / 3$ & $7.8-47.3$ \\
\hline \multirow[t]{2}{*}{ TMI-1 } & ANL & $\mathrm{DOE} \mathrm{YMP}^{c}$ & $15 \times 15$ & 4.013 & $11 / 1$ & $44.8-55.7$ \\
\hline & GE-VNC & DOE YMP & $15 \times 15$ & 4.657 & $8 / 3$ & $22.8-29.9$ \\
\hline \multirow[t]{2}{*}{ Gösgen } & $\mathrm{SCK} \cdot \mathrm{CEN}, \mathrm{ITU}$ & ARIANE $^{d}$ & $15 \times 15$ & $3.5,4.1$ & $3 / 2$ & $29.1-59.7$ \\
\hline & $\mathrm{SCK} \cdot \mathrm{CEN}, \mathrm{PSI}, \mathrm{CEA}$ & MALIBU $^{d}$ & $15 \times 15$ & 4.3 & $3 / 1$ & $47.2-70.4$ \\
\hline GKN II & $\mathrm{SCK} \cdot \mathrm{CEN}$ & REBUS $^{d}$ & $18 \times 18$ & 3.8 & $1 / 1$ & 54.1 \\
\hline
\end{tabular}

Khlopin Radium Institute; JAERI = Japan Atomic Energy Research Institute (now Japan Atomic Energy Agency); JRC = Joint Research Center, European

Commission; ITU = European Institute for Transuranium Elements; IRCh = Institute for Radiochemistry at Karlsruhe; WAK = Karlsruhe Reprocessing Plant

IAEA = International Atomic Energy Agency; SCK $\cdot$ CEN $=$ Studiecentrum voor Kernenergie - Centre d'étude de l'Energie Nucléaire; PSI = Paul Scherrer Institute; $\mathrm{CEA}=$ Commissariat à l'Energie Atomique.

${ }^{b} \mathrm{ATM}=$ Approved Testing Material.

${ }^{c}$ DOE YMP $=$ U.S. Department of Energy Yucca Mountain Project.

${ }^{d}$ International Experimental Programs coordinated by Belgonucleaire, Belgium - currently managed by SCK $\cdot$ CEN Laboratory (Ref. 71 ). 

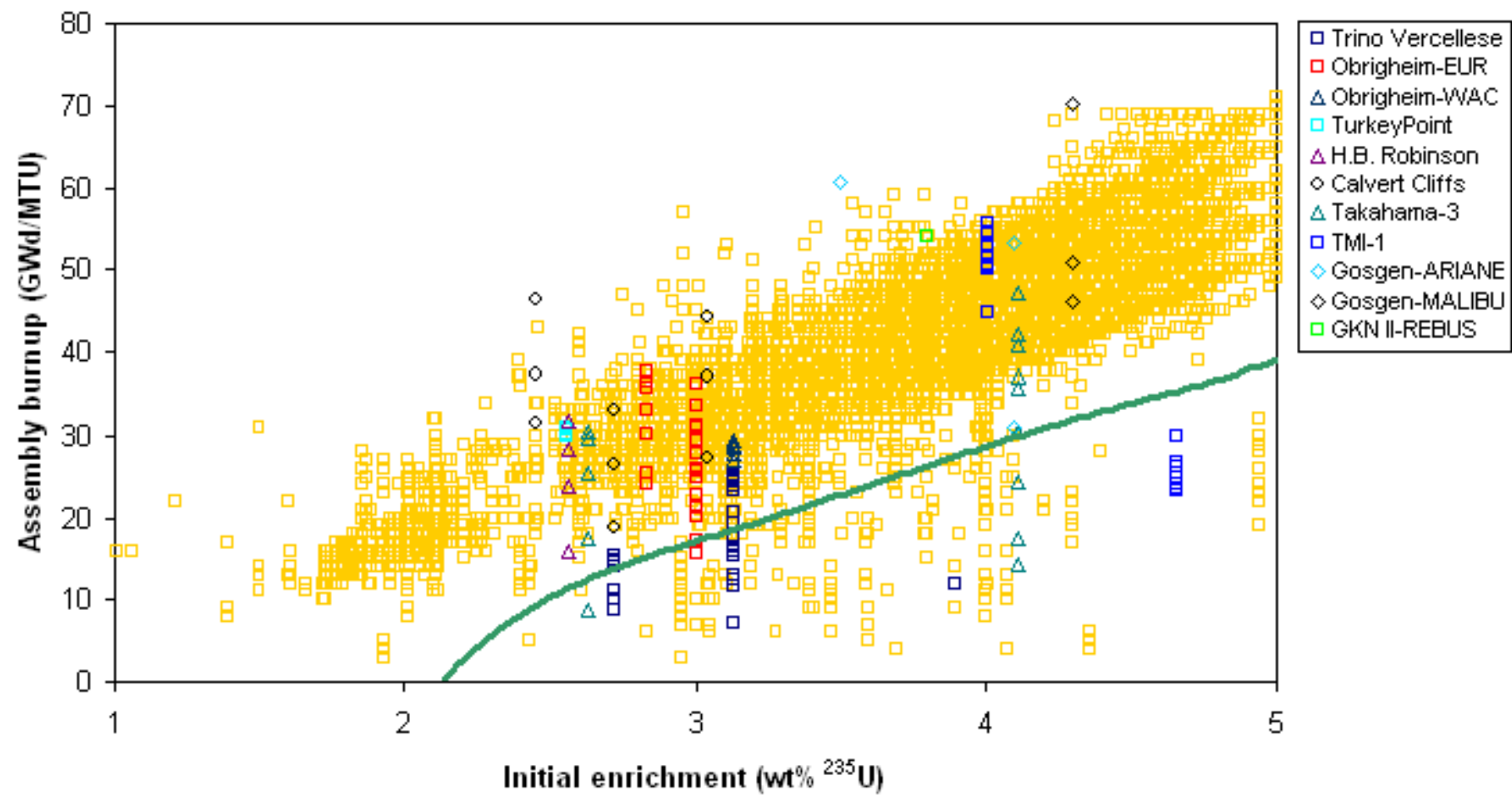

Fig. 1. Enrichment and burnup values of spent fuel samples used for validation compared to the actual and projected spent fuel assembly inventory and typical loading curve for PWR SNF assuming actinide and fission product burnup credit. (Note: Each point for the existing inventory represents multiple assemblies.) 
In this report, measured values for all isotopes were evaluated. Reported values of isotopic ratios, which could not be directly converted to absolute contents, were not included. The number of measured nuclides is substantially greater than the list of principal isotopes considered in burnup credit. The additional isotopes include many that are of radiological importance (neutron and gamma ray emitters, e.g., ${ }^{244} \mathrm{Cm}$ and ${ }^{137} \mathrm{Cs}$ ), are important to decay heat (e.g. ${ }^{134} \mathrm{Cs}$ ), and others that are important to longer term waste management safety analyses (e.g., ${ }^{79} \mathrm{Se},{ }^{135} \mathrm{Cs}$ ). It is the intent that this report will serve not only as a radiochemical analysis database for burnup credit isotopic validation, but also validation for many other safety- and design-related applications important to post-closure and pre-closure analyses.

The complete list of nuclides evaluated in this report is listed below. Nuclides identified as the principal isotopes for burnup credit are shown in italics.

Actinides

- ${ }^{234} U,{ }^{235} U,{ }^{236} U,{ }^{238} U$

- ${ }^{238} \mathrm{Pu},{ }^{239} \mathrm{Pu},{ }^{240} \mathrm{Pu},{ }^{241} \mathrm{Pu},{ }^{242} \mathrm{Pu}$

- $\quad{ }^{237} \mathrm{~Np},{ }^{241} \mathrm{Am},{ }^{242 \mathrm{~m}} \mathrm{Am},{ }^{243} \mathrm{Am}$

- ${ }^{242} \mathrm{Cm},{ }^{243} \mathrm{Cm},{ }^{244} \mathrm{Cm},{ }^{245} \mathrm{Cm},{ }^{246} \mathrm{Cm},{ }^{247} \mathrm{Cm}$

Lanthanides

- $\quad{ }^{143} \mathrm{Nd},{ }^{144} \mathrm{Nd},{ }^{145} \mathrm{Nd},{ }^{146} \mathrm{Nd},{ }^{148} \mathrm{Nd},{ }^{150} \mathrm{Nd}$

- ${ }^{144} \mathrm{Ce},{ }^{147} \mathrm{Pm}$

- ${ }^{147} \mathrm{Sm},{ }^{148} \mathrm{Sm},{ }^{149} \mathrm{Sm},{ }^{150} \mathrm{Sm},{ }^{151} \mathrm{Sm},{ }^{152} \mathrm{Sm},{ }^{154} \mathrm{Sm}$

- ${ }^{151} \mathrm{Eu},{ }^{152} \mathrm{Eu},{ }^{153} \mathrm{Eu},{ }^{154} \mathrm{Eu},{ }^{155} \mathrm{Eu}$

- ${ }^{154} \mathrm{Gd},{ }^{155} \mathrm{Gd},{ }^{156} \mathrm{Gd},{ }^{157} \mathrm{Gd},{ }^{158} \mathrm{Gd},{ }^{160} \mathrm{Gd}$

Volatile fission products

- $\quad{ }^{133} \mathrm{Cs},{ }^{134} \mathrm{Cs},{ }^{135} \mathrm{Cs},{ }^{137} \mathrm{Cs}$

Metallic and other fission products

- ${ }^{90} \mathrm{Sr},{ }^{95} \mathrm{Mo},{ }^{99} \mathrm{Tc},{ }^{101} \mathrm{Ru},{ }^{106} \mathrm{Ru},{ }^{103} \mathrm{Rh},{ }^{109} \mathrm{Ag}$

- ${ }^{79} \mathrm{Se},{ }^{105} \mathrm{Pd},{ }^{108} \mathrm{Pd},{ }^{126} \mathrm{Sn},{ }^{129} \mathrm{Sb}$

As noted previously, no measurements of ${ }^{233} \mathrm{U}$ are included because of the very low concentrations in commercial spent fuel at the time of the laboratory analyses.

\subsection{DATA QUALIFICATION}

Qualification of the experimental data is not addressed in this report. However, as part of this work, the original data were obtained from primary experimental reports, reviewed, and evaluated for consistency. In several cases, measured isotopes were removed from consideration due to measurement results that were grossly out of trend when compared to other measurements made at the same laboratory or other measurements on similar fuel measured at independent laboratories. In some cases it is likely that the observed discrepancies are due to typographical errors in the experimental reports, or random or systematic measurement problems related to one or more samples or isotopes. Removal of measured data is discussed in the sections describing each experimental data set. 
Many experimental programs described in this report used independent laboratory cross-check analyses. In some cases, samples from the same fuel assembly were measured at different laboratories. In other cases, laboratories performed independent radiochemical analysis on effectively the same sample, providing verification of measurements. The cross-check measurements provide a high degree of confidence to the radiochemical analysis results since in many cases the laboratories used different radiochemical techniques. Comparison of laboratory results also provides a reliable measure of experimental accuracy.

\subsection{EXPERIMENTAL DATA ANALYSIS}

Isotopic composition data were reported by laboratories in a number of different units. Isotopic data were converted in this report to a consistent basis of milligrams per gram of initial (unirradiated) uranium $(\mathrm{mg} / \mathrm{g} \mathrm{U})$. This facilitates comparison of measurement data from different experiments and provides a consistent basis for comparison of measured with calculated results. In all cases, the unit conversion was performed independently of the code calculations.

The conversion of data reported measurement in units of $g / g$ fuel to $m g / g U$ (initial) is done using Eq. (3).

$$
m(m g / g U)=m\left(g / g_{\text {fuel }}\right)(g \text { fuel } / g U) \cdot 10^{3} \mathrm{mg} / \mathrm{g} .
$$

The fraction of uranium mass with respect to the unirradiated fuel mass can be determined, if not provided, using Eq. (4), where $\bar{M}_{U}$ is the average uranium atomic weight corresponding to the initial fuel enrichment.

$$
g U / g \text { fuel }=\frac{U}{U O_{2}}=\frac{\overline{M_{U}}}{\left(\overline{M_{U}}+2 M_{O}\right)},
$$

and

$$
\overline{M_{U}}=1 / \sum_{i}^{w_{U_{i}}} \frac{M_{U_{i}}}{} \text {. }
$$

In Eq. (4), $M_{O}$ is the relative atomic mass for oxygen, $M_{U_{i}}$ is the relative atomic mass for uranium isotope $i$, and $w_{U_{i}}$ is the weight fraction of each uranium isotope. The weight fraction of uranium in fuel is about 0.8815 for the samples evaluated in this report.

In some cases, data reported as activity in disintegrations per second (dps), or curies (Ci), were converted to a mass basis. As an example, mass values $m$, in units of $m g / g U$, were calculated from reported activities in $\mathrm{dps} /(\mathrm{g}$ fuel) using Eq. (5):

$$
m\left(m g / g_{U}\right)=\frac{\Lambda}{\lambda} \frac{M}{\mathrm{~N}_{\mathrm{A}}} \frac{10^{3}}{0.8815},
$$


where

$$
\begin{array}{ll}
\Lambda & =\text { reported activity in units of dps } /(\mathrm{g} \text { fuel }) \\
\lambda & =\text { decay constant }\left(\mathrm{s}^{-1}\right) \\
M & =\text { relative atomic mass, } \\
\mathrm{N}_{\mathrm{A}} & =\text { Avogadro's constant }\left(\mathrm{mol}^{-1}\right) \\
0.8815 & =\text { weight fraction of uranium in fuel [Eq. (4)] }
\end{array}
$$

The radiochemical analysis results were in some cases reported with respect to the measured total uranium or ${ }^{238} \mathrm{U}$ content in the fuel after irradiation. In order to compare measured data obtained from the different experimental programs, the data were converted to units of $\mathrm{mg} / \mathrm{g} \mathrm{U}_{\text {initial }}$. The initial uranium in the measured sample was derived directly from the radiochemical analysis measurement data using the following procedures.

The initial concentration of heavy metal (uranium) atoms present in the fuel after irradiation is determined from the isotopic contents in the fuel sample according to:

$$
\sum_{N_{0}}=\sum_{N_{E}}+\sum_{\Delta N},
$$

where

$$
\begin{aligned}
& \sum N_{0}=\text { number of initial uranium atoms initially present, } \\
& \sum N_{E}=\text { number of heavy metal atoms after irradiation, } \\
& \sum \Delta N=\text { number of heavy metal atoms fissioned. }
\end{aligned}
$$

The sum is performed over all heavy metal nuclides ( $\mathrm{U}, \mathrm{Np}, \mathrm{Pu}, \mathrm{Am}, \mathrm{Cm})$. The integral number of fissions occurring in the fuel during irradiation can be determined by measurement of fission products with properties that make them reliable monitors of fission, i.e., their concentrations are proportional to the number of heavy element atoms fissioned. The isotope ${ }^{148} \mathrm{Nd}$ is a widely-used fission monitor that is used as a standard test method for atom fission ${ }^{74}$ in ASTM E 321. Cesium-137 can also be used, provided that the decay of ${ }^{137} \mathrm{Cs}$ during the irradiation period is taken into account. Other isotopes like ${ }^{150} \mathrm{Nd}$, ${ }^{143} \mathrm{Nd}+{ }^{144} \mathrm{Nd}$, and ${ }^{145} \mathrm{Nd}+{ }^{146} \mathrm{Nd}$ have also been used as reliable burnup monitors. ${ }^{75}$ The method used in the current report relies primarily on measurements of ${ }^{148} \mathrm{Nd}$ that are reported for most fuel samples.

The number of atoms fissioned is calculated from the measured ${ }^{148} \mathrm{Nd}$ atom concentration and the effective fission yield of ${ }^{148} \mathrm{Nd}$ according to the relationship:

$$
\sum \Delta N=\frac{N_{148} N d}{\bar{Y}^{148} N d}
$$

where

$$
\begin{aligned}
& N_{148}=\text { total number of atoms of }{ }^{148} \mathrm{Nd} \text { isotope measured, } \\
& \bar{Y}_{{ }^{148}{ }_{N d}}=\text { effective fission product yield for }{ }^{148} \mathrm{Nd} .
\end{aligned}
$$

Values for the ${ }^{148} \mathrm{Nd}$ fission yield exhibit only a small dependence of burnup, because the ${ }^{148} \mathrm{Nd}$ cumulative fission yields for ${ }^{235} \mathrm{U}$ and ${ }^{239} \mathrm{Pu}$ are similar. The effective ${ }^{148} \mathrm{Nd}$ yield values applied in this report were 0.0176 for the GKN II UO 2 fuel (Ref. 50) and 0.0170 for the other cases (e.g., TMI- $1 \mathrm{UO}_{2}$ 
fuel) (Ref. 76). The estimate of the initial heavy metal mass is not very sensitive to this parameter because the amount of heavy metal fissioned represents typically less than $5 \%$ of the initial fuel mass.

Expressing the data in terms of mass $m$, Eq. (6) can be written:

$$
\frac{m_{U_{0}}}{\bar{M}_{U}}=\sum \frac{m_{E}}{M_{E}}+\frac{1}{\bar{Y}_{n}} \frac{m_{n}}{M_{n}},
$$

where $m_{E}$ is the measured mass and $M_{E}$ is the relative atomic mass for each of the major heavy elements, and $m_{n}$ and $M_{n}$ are the measured mass and relative atomic mass of the of fission product burnup indicator (in this case ${ }^{148} \mathrm{Nd}$ ). To a good approximation,

$$
\bar{M}_{\mathrm{U}}=M_{E} \approx 238
$$

and therefore, the initial uranium mass in the unirradiated fuel, $m_{U_{0}}$, is calculated as

$$
m_{U_{0}} \approx \sum_{k} m_{U_{k}}+m_{{ }^{237} N p}+\sum_{l} m_{P u_{l}}+\sum_{m} m_{A m_{m}}+\sum_{n} m_{C m_{n}}+\frac{(238)}{(148)} \frac{\left.m_{148}\right)}{\bar{Y}_{148}{ }_{N d}}
$$

The majority of the heavy element mass in the irradiated fuel is associated with the uranium and plutonium isotopes. For samples that did not measure americium, and/or curium, their omission resulted in less than a $0.1 \%$ error in the estimated initial uranium content.

As an example of the procedure, measurement data $m_{i}$ in units of $\mathrm{mg} / \mathrm{g}{ }^{238} \mathrm{U}$ in the sample, were adjusted to a basis of $\mathrm{mg} / \mathrm{g} \mathrm{U}$ initial uranium as follows:

$$
m_{i}\left(m g / g U_{\text {initial }}\right)=\frac{m_{i}\left(m g / g^{238} U\right)}{\sum_{k} m_{U_{k}}+m_{237 N p}+\sum_{l} m_{P u_{l}}+\sum_{m} m_{A m_{m}}+\sum_{n} m_{C m_{n}}+\frac{(238)}{(148)} \frac{m_{148} \bar{Y}_{148}}{\bar{Y}_{N d}}},
$$

where the measured mass for each of the isotopes in the denominator has units of $\mathrm{mg} / \mathrm{g}{ }^{238} \mathrm{U}$.

\subsection{NUCLEAR DATA}

The nuclear data used to convert experimental measurements from reported units to mass units in this report was obtained from recent evaluations maintained by the National Nuclear Data Center (NNDC) at Brookhaven National Laboratory. These data included relative atomic mass values and radionuclide half-lives. The data are taken mostly from the adopted properties of the various nuclides as given in the Evaluated Nuclear Structure Data File (ENSDF). ${ }^{59}$ ENSDF data are based on experiments and are published in Nuclear Data Sheets ${ }^{60}$ for $\mathrm{A}>20$ and in Nuclear Physics ${ }^{61}$ for $\mathrm{A} \leq 20$. Atomic mass data, used to derive nuclide mass values from atomic ratio measurements reported for some experiments, is obtained from the 2003 Atomic Mass Evaluation. ${ }^{62}$ The nuclear data used in this report are listed in Table 5 .

The decay half-lives differ to some extent from the values used by the computer code calculations. The values used in this report were based on the latest evaluations available and were more recent than values used in the computer models, which are based on ENDF/B-VI Rel. 1. In general the half-life values 
agreed to better than $3 \%$. One exception is the half-life of ${ }^{126} \mathrm{Sn}$, which increased from $10^{5}$ in ENDF/B-VI to $2.30 \times 10^{5}$ years in ENSDF.

Other physical constants and unit conversion factors are: ${ }^{63}$

$$
\begin{aligned}
& \mathrm{N}_{\mathrm{A}}=\text { Avogadro's constant }=6.02241 \times 10^{23} \text { atoms } \cdot \mathrm{mol}^{-1} \\
& 1 \mathrm{Ci}=3.7 \times 10^{10} \mathrm{~Bq} \\
& 1 \mathrm{~Bq}=1 \text { disintegration } \cdot \mathrm{s}^{-1}
\end{aligned}
$$

\begin{tabular}{|c|c|c|c|c|c|}
\hline Nuclide & Mass number & $\begin{array}{c}\text { Relative } \\
\text { atomic }^{\text {mass }(u)}{ }^{a}\end{array}$ & \multicolumn{2}{|c|}{ Half-life ${ }^{b}$} & $\begin{array}{c}\text { Decay constant } \\
\left(\mathrm{s}^{-1}\right)\end{array}$ \\
\hline \multirow[t]{4}{*}{$\mathrm{U}$} & 234 & 234.041 & $2.455 \mathrm{E}+05$ & $\mathrm{Y}^{c}$ & $8.9468 \mathrm{E}-14$ \\
\hline & 235 & 235.044 & $7.04 \mathrm{E}+08$ & $\mathrm{Y}$ & $3.1200 \mathrm{E}-17$ \\
\hline & 236 & 236.046 & $2.342 \mathrm{E}+07$ & $\mathrm{Y}$ & $9.3785 \mathrm{E}-16$ \\
\hline & 238 & 238.051 & $4.468 \mathrm{E}+09$ & $\mathrm{Y}$ & $4.9160 \mathrm{E}-18$ \\
\hline \multirow[t]{6}{*}{$\mathrm{Pu}$} & 236 & 236.046 & 2.858 & $\mathrm{Y}$ & 7.6853E-09 \\
\hline & 238 & 238.050 & 87.7 & $\mathrm{Y}$ & $2.5045 \mathrm{E}-10$ \\
\hline & 239 & 239.052 & 24110 & $\mathrm{Y}$ & $9.1101 \mathrm{E}-13$ \\
\hline & 240 & 240.054 & 6561 & $\mathrm{Y}$ & $3.3477 \mathrm{E}-12$ \\
\hline & 241 & 241.057 & 14.29 & $\mathrm{Y}$ & $1.5371 \mathrm{E}-09$ \\
\hline & 242 & 242.059 & $3.75 \mathrm{E}+05$ & $\mathrm{Y}$ & $5.8572 \mathrm{E}-14$ \\
\hline \multirow[t]{3}{*}{ Am } & 241 & 241.057 & 432.2 & $\mathrm{Y}$ & $5.0820 \mathrm{E}-11$ \\
\hline & $242 \mathrm{~m}$ & 242.060 & 141 & $\mathrm{Y}$ & $1.5578 \mathrm{E}-10$ \\
\hline & 243 & 243.061 & 7370 & $\mathrm{Y}$ & $2.9803 \mathrm{E}-12$ \\
\hline \multirow[t]{2}{*}{$\mathrm{Cm}$} & 242 & 242.059 & 162.8 & $\mathrm{D}^{c}$ & 4.9278E-08 \\
\hline & 244 & 244.063 & 18.1 & $\mathrm{Y}$ & $1.2135 \mathrm{E}-09$ \\
\hline $\mathrm{Np}$ & 237 & 237.048 & $2.144 \mathrm{E}+06$ & $\mathrm{Y}$ & $1.0245 \mathrm{E}-14$ \\
\hline $\mathrm{Se}$ & 79 & 78.918 & $2.95 \mathrm{E}+05$ & $\mathrm{Y}$ & $7.4456 \mathrm{E}-14$ \\
\hline $\mathrm{Sr}$ & 90 & 89.908 & 28.9 & $\mathrm{Y}$ & $7.6002 \mathrm{E}-10$ \\
\hline $\mathrm{Tc}$ & 99 & 98.906 & $2.111 \mathrm{E}+05$ & $\mathrm{Y}$ & $1.0405 \mathrm{E}-13$ \\
\hline $\mathrm{Ru}$ & 106 & 105.907 & 373.59 & $\mathrm{D}$ & $2.1474 \mathrm{E}-08$ \\
\hline $\mathrm{Sn}$ & 126 & 125.908 & $2.30 \mathrm{E}+05$ & $\mathrm{Y}$ & $9.5498 \mathrm{E}-14$ \\
\hline \multirow[t]{3}{*}{$\mathrm{Cs}$} & 134 & 133.907 & 2.0652 & $\mathrm{Y}$ & $1.0636 \mathrm{E}-08$ \\
\hline & 135 & 134.906 & $2.30 \mathrm{E}+06$ & $\mathrm{Y}$ & $9.5498 \mathrm{E}-15$ \\
\hline & 137 & 136.907 & 30.08 & $\mathrm{Y}$ & $7.3020 \mathrm{E}-10$ \\
\hline \multirow[t]{6}{*}{$\mathrm{Nd}$} & 143 & 142.910 & Stable & & \\
\hline & 144 & 143.910 & Stable & & \\
\hline & 145 & 144.913 & Stable & & \\
\hline & 146 & 145.913 & Stable & & \\
\hline & 148 & 147.917 & Stable & & \\
\hline & 150 & 149.921 & Stable & & \\
\hline $\mathrm{Ce}$ & 144 & 143.914 & 284.91 & $\mathrm{D}$ & $2.8158 \mathrm{E}-08$ \\
\hline $\mathrm{Eu}$ & 154 & 153.923 & 8.590 & $\mathrm{Y}$ & $2.5570 \mathrm{E}-09$ \\
\hline
\end{tabular}

Table 5. Nuclear data used for experiment data evaluation 


\subsection{ANALYTICAL MEASUREMENT UNCERTAINTIES}

Measurement uncertainties as reported by the laboratories have been included in this report. For experiments where uncertainty values are not given, it has been possible in some cases to derive approximate values by comparing reported measurement results for different fuel samples with similar properties. In general, it is difficult to apply the experimental uncertainties in the analysis in a quantitative fashion because the significance and method of evaluation of these uncertainties vary from one laboratory to another. Some laboratories report uncertainty associated only with the reproducibility of mass spectrometry results. In other cases the reported uncertainty includes additional sources of error due to sample preparation, isotopic dilution techniques, or standards. Sometimes reported uncertainties were based on past experience of the laboratory, whereas in other cases they were based on direct comparison of multiple measurement results for the same sample obtained independently by different laboratories using different radiochemical techniques. The inconsistent basis of the reported uncertainties makes it unreliable to use the uncertainty to weight data from different laboratories.

Nevertheless, the measurement uncertainties are listed in this report as they provide some indication of estimated measurement accuracy. However, it is not recommended that they be used quantitatively without further analysis to confirm the reported values. Comparisons of calculations and measurements in the current report include the estimated error from the experiment only in the experiment-to-calculation $(\mathrm{E} / \mathrm{C})$ isotopic concentration ratio. Additional errors in $\mathrm{E} / \mathrm{C}$ values arise from calculational uncertainty related to the model input, nuclear cross section data, and reactor operating conditions. Uncertainty in the sample burnup, a value determined from the measurement data, can also have a significant effect on the level of agreement between calculations and measurements. Although error in the sample burnup manifests itself in the calculations, the error arises mainly from uncertainties and bias in the measurement. 



\section{EXPERIMENTAL DATA}

This section describes the postirradiation analysis programs, the measurement techniques, and the reported isotopic concentrations and uncertainties for the evaluated spent fuel samples, as provided by the primary references (see Sect.4). Summary tables containing sample characteristics and isotopic concentrations relative to the initial uranium mass, which were derived from the reported experimental data, are provided in this section.

\subsection{TRINO VERCELLESE}

Trino Vercellese was a PWR in Italy with a net generating capacity of $270 \mathrm{MWe}$, which was designed by Westinghouse Electric Corp. (West). First power was achieved in October 1964 with an initial core consisting of West $15 \times 15$ assemblies. ${ }^{57}$

As part of a joint European research program, the isotopic composition of fuel samples from eight rods selected from three assemblies identified as 509-104 (core location L-7), 509-032 (H-10), and 509-049 (G-7), which were irradiated in the reactor for one cycle, were measured using nondestructive and destructive methods. ${ }^{12}$ Sixteen fuel samples from six rods from assembly 509-069, which was irradiated for two reactor cycles, were also measured. ${ }^{13}$ A summary of the 31 evaluated fuel samples from this program are listed in Table 6 . The assembly configuration and the position of the measured fuel rods in each assembly are illustrated in Fig. 4 and Fig. 5, respectively (see Sect. 8.1). The samples are identified by the rod location followed by the axial sampling position, numbered 1 to 9 from the top of the rod. Additional samples from fuel rod locations identified in the experimental reports as residing in perturbed assembly periphery locations were not analyzed due to potential exposure to control rods used in the reactor for which documentation was not available.

Measurements were performed at laboratories of the European Ispra and Karlsruhe establishments of the Joint Research Centre. A total of 31 fuel samples with reported measurement data are evaluated in this report. Of these samples, eight samples were measured at both laboratories, providing an independent cross-check of the measurement accuracy. The measurements are described briefly.

Mass spectrometry with isotopic dilution was used to determine the isotopic compositions and concentrations of uranium, plutonium and neodymium isotopes, using calibrated spikes of ${ }^{233} \mathrm{U},{ }^{242} \mathrm{Pu}$, and ${ }^{150} \mathrm{Nd}$. Mass spectrometry without isotopic dilution was applied to measure americium. Alpha spectrometry was used for determination of some plutonium isotopes, ${ }^{241} \mathrm{Am},{ }^{242} \mathrm{Cm}$, and ${ }^{244} \mathrm{Cm}$, using measured activity ratios and mass spectrometry data. Atom and mass ratios were reported by the laboratories, as was the absolute isotopic mass with respect to initial mass of uranium in the sample.

Gamma-ray spectroscopy was used to measure the activities of radioactive fission products ${ }^{106} \mathrm{Ru},{ }^{134} \mathrm{Cs}$, ${ }^{137} \mathrm{Cs},{ }^{144} \mathrm{Ce}$, and ${ }^{154} \mathrm{Eu}$ for samples measured at Ispra. The fission product activities were reported with respect to the mass of final uranium in the samples. Activity results were converted to mass units in this report using Eq. (5), and normalized to a basis of initial uranium in the sample using the ratio of final-toinitial uranium determined from the measurements (see spreadsheet $D V D / x l s /$ Experimental_data.xls).

Measurements performed by the European Institute for Transuranium Elements (ITU) at Karlsruhe did not include fission products, except for ${ }^{148} \mathrm{Nd}$ and ${ }^{137} \mathrm{Cs}$ values used for burnup verification, but did include fission gas collection during dissolution and measurement of $\mathrm{Xe}$ and $\mathrm{Kr}$ isotopic ratios by mass spectrometry. The xenon and krypton measurements are not analyzed in this report. 
Table 6. Summary of the Trino Vercellese measured spent fuel

\begin{tabular}{|c|c|c|c|c|c|c|}
\hline Assembly & $\begin{array}{c}\text { Sample } \\
\text { No. }\end{array}$ & $\begin{array}{l}\text { Measurement } \\
\text { laboratory }\end{array}$ & Sample & $\begin{array}{c}\text { Initial } \\
\text { enrichment } \\
\left(w t \%{ }^{235} U\right)\end{array}$ & $\begin{array}{c}\text { Axial } \\
\text { location } \\
(\mathrm{cm})\end{array}$ & $\begin{array}{c}\text { Burnup }^{b} \\
(\mathrm{GWd} / \mathrm{MTU})\end{array}$ \\
\hline \multirow[t]{7}{*}{$509-032$} & 1 & Ispra & E11-1 & 3.13 & 246.7 & 7.243 \\
\hline & 2 & Ispra & E11-4 & 3.13 & 165.6 & 15.377 \\
\hline & 3 & Ispra & E11-7 & 3.13 & 81.4 & 15.898 \\
\hline & 4 & Ispra & E11-9 & 3.13 & 28.8 & 11.529 \\
\hline & 5 & Karlsruhe & H9-4 & 3.13 & 165.6 & 16.556 \\
\hline & 6 & Ispra & H9-7 & 3.13 & 81.4 & 17.450 \\
\hline & 7 & Ispra & H9-9 & 3.13 & 28.8 & 12.366 \\
\hline \multirow[t]{7}{*}{ 509-049 } & 8 & Ispra & L5-1 & 2.719 & 246.7 & $7.822^{c}$ \\
\hline & 9 & Ispra-Karlsruhe & L5-4 & 2.719 & 165.6 & 14.323 \\
\hline & 10 & Ispra-Karlsruhe & L5-9 & 2.719 & 28.8 & 10.187 \\
\hline & 11 & Ispra & J8-1 & 2.719 & 246.7 & 8.713 \\
\hline & 12 & Ispra & J8-4 & 2.719 & 165.6 & 14.770 \\
\hline & 13 & Karlsruhe & $\mathrm{J} 8-7$ & 2.719 & 81.4 & 15.193 \\
\hline & 14 & Karlsruhe & J8-9 & 2.719 & 28.8 & 11.127 \\
\hline $509-104$ & 15 & Ispra-Karlsruhe & M11-7 & 3.897 & 81.4 & 12.042 \\
\hline \multirow[t]{16}{*}{$509-069$} & 16 & Ispra & E11-1 & 3.13 & 246.7 & $12.859^{c}$ \\
\hline & 17 & Karlsruhe & E11-2 & 3.13 & 221.1 & 20.602 \\
\hline & 18 & Karlsruhe & E11-4 & 3.13 & 165.6 & 23.718 \\
\hline & 19 & Ispra & E11-5 & 3.13 & 137.1 & 24.518 \\
\hline & 20 & Karlsruhe & E11-7 & 3.13 & 81.4 & 24.304 \\
\hline & 21 & Karlsruhe & E11-8 & 3.13 & 55.4 & 23.406 \\
\hline & 22 & Karlsruhe & E11-9 & 3.13 & 28.8 & 19.250 \\
\hline & 23 & Ispra & E5-4 & 3.13 & 165.6 & 23.867 \\
\hline & 24 & Karlsruhe & E5-7 & 3.13 & 81.4 & 24.548 \\
\hline & 25 & Ispra & E5-9 & 3.13 & 28.8 & 19.208 \\
\hline & 26 & Ispra & J9-4 & 3.13 & 165.6 & $24.849^{c}$ \\
\hline & 27 & Karlsruhe & J9-7 & 3.13 & 81.4 & 25.258 \\
\hline & 28 & Ispra & L5-4 & 3.13 & 165.6 & 24.330 \\
\hline & 29 & Ispra & $\mathrm{L} 5-7$ & 3.13 & 81.4 & $24.313^{c}$ \\
\hline & 30 & Karlsruhe & L11-4 & 3.13 & 165.6 & 23.928 \\
\hline & 31 & Ispra-Karlsruhe & L11-7 & 3.13 & 81.4 & 24.362 \\
\hline
\end{tabular}

Measurement data was adjusted by the laboratories to the time corresponding to discharge for all isotopes except ${ }^{241} \mathrm{Am}$, which was reported near the actual time of measurement (about 3 years after discharge) to avoid introducing potentially large errors associated with the correction. ${ }^{12,13}$ Isotopic data for plutonium was corrected for ${ }^{238} \mathrm{Pu}$ formation from ${ }^{242} \mathrm{Cm}$ decay, and correction of ${ }^{236} \mathrm{Pu}$ and ${ }^{241} \mathrm{Pu}$ for decay. Note that ${ }^{239} \mathrm{Pu}$ includes the contribution from short-lived ${ }^{239} \mathrm{~Np}$ decay.

The reported measurement uncertainties are summarized in Table 7. Experimental uncertainties for uranium and plutonium were determined by comparison between the results for the nine replicate samples analyzed at both Ispra and Karlsruhe. The relative standard deviations were derived from the differences of the replicate samples. Note that the reported error of $4.3 \%$ for ${ }^{238} \mathrm{U}$ depletion reduces to about $0.1 \%$ in the final ${ }^{238} \mathrm{U}$ content due to the small amount of ${ }^{238} \mathrm{U}$ depleted during irradiation. Measurement uncertainties for americium and curium isotopes were similarly obtained from Ispra-Karlsruhe interlaboratory comparisons. Uncertainties for ${ }^{241} \mathrm{Am}$, measured only by Ispra, and ${ }^{148} \mathrm{Nd}$ were obtained 
from other reported intercomparison studies in Ref. 14. The relative error for the $\gamma$-spectroscopy measurements were reported by Ispra $\left({ }^{134} \mathrm{Cs},{ }^{137} \mathrm{Cs},{ }^{106} \mathrm{Ru},{ }^{144} \mathrm{Ce}\right.$, and $\left.{ }^{154} \mathrm{Eu}\right)$ and include statistical errors of the gamma measurements, errors due to calibration standards, and errors due to the determination of the amount of uranium in the measured solutions. Comparison of ${ }^{137} \mathrm{Cs}$ measurements made at Ispra and Karlsruhe confirmed the estimated measurement error.

Table 7. Experimental techniques and uncertainties for Trino Vercellese spent fuel samples

\begin{tabular}{|c|c|c|}
\hline Nuclide & Technique $^{a}$ & $\begin{array}{c}\text { RSD } \\
(\%)^{b}\end{array}$ \\
\hline U-235 depleted $^{c}$ & IDMS & $1.6 \%$ \\
\hline $\mathrm{U}-235$ & IDMS & $<2.5 \%$ \\
\hline $\mathrm{U}-236$ & IDMS & $2.4 \%$ \\
\hline U-238 depleted ${ }^{c}$ & IDMS & $4.3 \%$ \\
\hline $\mathrm{U}-238$ & IDMS & $<0.1 \%$ \\
\hline $\mathrm{Pu}-238$ & IDMS & $2.7 \%$ \\
\hline $\mathrm{Pu}-239$ & IDMS & $2.0 \%$ \\
\hline $\mathrm{Pu}-240$ & IDMS & $2.2 \%$ \\
\hline $\mathrm{Pu}-241$ & IDMS & $2.3 \%$ \\
\hline $\mathrm{Pu}-242$ & IDMS & $2.8 \%$ \\
\hline $\mathrm{Cm}-242$ & $\alpha$ spec & $2 \%$ \\
\hline $\mathrm{Cm}-244$ & $\alpha$ spec & $7 \%$ \\
\hline Am-241 & $\alpha$ spec & $20 \%$ \\
\hline Am-242 & $\alpha$ spec & $11 \%$ \\
\hline Am-243 & $\alpha$ spec & $8 \%$ \\
\hline Nd-148 & IDMS & $<1 \%$ \\
\hline $\mathrm{Ru}-106^{d}$ & $\gamma$ spec & $3 \%$ \\
\hline Cs-134 ${ }^{d}$ & $\gamma$ spec & $2.5 \%$ \\
\hline $\mathrm{Cs}-137^{d}$ & $\gamma$ spec & $1.5 \%$ \\
\hline $\mathrm{Ce}-144^{d}$ & $\gamma$ spec & $1.7 \%$ \\
\hline Eu-154 ${ }^{e}$ & $\gamma$ spec & $5 \%$ \\
\hline \multicolumn{3}{|c|}{$\begin{array}{l}{ }^{a} \text { Main technique is listed; some nuclides require multiple techniques to } \\
\text { eliminate interferences. } \\
{ }^{b} \text { Relative standard deviation (RSD) (see DVD/xls/Experimental_data.xls, } \\
\text { worksheet trinoII). } \\
{ }^{c 235} \mathrm{U} \text { and }{ }^{238} \mathrm{U} \text { contents and uncertainties reported as depleted content. } \\
{ }^{d} \text { Ref. } 12 \text {, pp. } 28 \text { and } 30 . \\
{ }^{e} \text { Ref. 13, p. } 23 .\end{array}$} \\
\hline
\end{tabular}

Americium results were only reported for samples of assembly 509-069, and Ispra was the only laboratory to measure ${ }^{241} \mathrm{Am}$. The error in the Am isotopes (20\%) is relatively large due to the measurement method by $\alpha$-spectrometry and data regression analysis that required using activity ratios of $\mathrm{Am}$ and mass spectrometry data. Error in the determination of ${ }^{236} \mathrm{Pu}$ by $\alpha$-spectrometry, reported for some samples measured at Ispra, is about $10 \%$ due to the very small concentration in the fuel and consequently low counting rates.

The total error in the determination of ${ }^{148} \mathrm{Nd}$, including the uncertainties due to the isotopic dilution procedures and standards, is reported to be about $1 \%$. The reported burnup values for each sample based on destructive ${ }^{148} \mathrm{Nd}$ and ${ }^{137} \mathrm{Cs}$ (corrected for decay during irradiation) and nondestructive ${ }^{137} \mathrm{Cs}$ data (measured only at Ispra) are listed in Table 8 . These values are derived by the laboratories from the 
experimental data. The error in the estimated burnup from destructive ${ }^{137} \mathrm{Cs}$ gamma measurements is $4 \%$, and the error using the ${ }^{148} \mathrm{Nd}$ method is $2 \%$ (Refs. 12 and 13). The ${ }^{148} \mathrm{Nd}$ and ${ }^{137} \mathrm{Cs}$ burnup values are seen to be in good agreement with an average difference of $1.6 \%$ and maximum difference of $4 \%$. The average difference in the burnup estimated by ${ }^{137} \mathrm{Cs}$ between the Ispra and Karlsruhe laboratories is about $2 \%$. The ${ }^{148} \mathrm{Nd}$ burnup has the smallest uncertainty and was used in this study when available. In cases where ${ }^{148} \mathrm{Nd}$ values were measured at both the Ispra and Karlsruhe, an average of the two burnup values was used. For samples without measured ${ }^{148} \mathrm{Nd}$ values (e.g., 509-069 E11-1, J9-4), burnup was based on the destructive ${ }^{137}$ Cs values.

Table 8. Burnup values derived from experimental measurements

\begin{tabular}{|c|c|c|c|c|c|c|}
\hline Assembly & Sample & Laboratory & $\begin{array}{c}\text { Burnup based } \\
\text { on }^{148} \text { Nd }^{a} \\
(\mathrm{MWd} / \mathrm{MTU})\end{array}$ & $\begin{array}{c}\text { Burnup based } \\
\text { on }{ }^{137} \text { Cs }^{a} \\
\text { (MWd/MTU) }\end{array}$ & $\begin{array}{c}\text { Burnup based } \\
\text { on }^{137} \text { Cs }^{b} \\
\text { (MWd/MTU) }\end{array}$ & $\begin{array}{c}\text { Recommended } \\
\text { burnup } \\
\text { (MWd/MTU) }\end{array}$ \\
\hline \multirow{7}{*}{$509-032$} & E11-1 & Ispra & 7,243 & 7,415 & 7,340 & 7,243 \\
\hline & E11-4 & Ispra & 15,377 & 15,156 & 14,697 & 15,377 \\
\hline & E11-7 & Ispra & 15,898 & 15,477 & 15,251 & 15,898 \\
\hline & E11-9 & Ispra & 11,529 & 11,226 & 12,119 & 11,529 \\
\hline & H9-4 & Karlsruhe & 16,556 & 16,400 & 16,719 & 16,556 \\
\hline & H9-7 & Ispra & 17,450 & 17,064 & 16,885 & 17,450 \\
\hline & H9-9 & Ispra & 12,366 & 12,219 & 12,415 & 12,366 \\
\hline \multirow[t]{9}{*}{$509-049$} & L5-1 & Ispra & & 7,822 & 7,987 & 7,822 \\
\hline & L5-4 & Ispra & 14,155 & 14,099 & \multirow[t]{2}{*}{14,645} & \multirow{2}{*}{14,323} \\
\hline & L5-4 & Karlsruhe & 14,490 & 13,883 & & \\
\hline & L5-9 & Ispra & & 10,478 & \multirow[t]{2}{*}{11,252} & \multirow{2}{*}{10,187} \\
\hline & L5-9 & Karlsruhe & 10,187 & 10,444 & & \\
\hline & $\mathrm{J} 8-1$ & Ispra & 8,713 & 8,307 & 8,584 & 8,713 \\
\hline & J8-4 & Ispra & 14,770 & 14,644 & 15,024 & 14,770 \\
\hline & $\mathrm{J} 8-7$ & Karlsruhe & 15,193 & 15,007 & 15,442 & 15,193 \\
\hline & J8-9 & Karlsruhe & 11,127 & 11,142 & 10,706 & 11,127 \\
\hline \multirow[t]{2}{*}{$509-104$} & M11-7 & Ispra & 11,912 & 12,035 & \multirow[t]{2}{*}{12,606} & \multirow[b]{2}{*}{12,042} \\
\hline & M11-7 & Karlsruhe & 12,172 & 12,242 & & \\
\hline \multirow[t]{21}{*}{$509-069$} & E11-1 & Ispra & & 12,859 & 15,030 & 12,859 \\
\hline & E11-2 & Ispra & & 20,628 & 21,200 & \\
\hline & E11-2 & Karlsruhe & 20,602 & 21,296 & & 20,602 \\
\hline & E11-4 & Ispra & & 23,557 & 23,990 & \\
\hline & E11-4 & Karlsruhe & 23,718 & 23,969 & & 23,718 \\
\hline & E11-5 & Ispra & 24,518 & 24,250 & \multirow{4}{*}{22,822} & 24,518 \\
\hline & E11-7 & Ispra & & 23,953 & & \multirow{2}{*}{24,304} \\
\hline & E11-7 & Karlsruhe & 24,304 & 25,095 & & \\
\hline & E11-8 & Karlsruhe & 23,406 & 23,818 & & 23,406 \\
\hline & E11-9 & Karlsruhe & 19,250 & 20,060 & 19,150 & 19,250 \\
\hline & E5-4 & Ispra & 23,867 & 23,715 & 22,640 & 23,867 \\
\hline & E5-7 & Ispra & & 24,693 & 23,380 & \multirow{2}{*}{24,548} \\
\hline & E5-7 & Karlsruhe & 24,548 & 24,683 & & \\
\hline & E5-9 & Ispra & 19,208 & 19,254 & 19,260 & 19,208 \\
\hline & J9-4 & Ispra & & 24,849 & 25,030 & 24,849 \\
\hline & J9-7 & Karlsruhe & 25,258 & 25,386 & 25,340 & 25,258 \\
\hline & L5-4 & Ispra & 24,330 & 23,988 & 24,070 & 24,330 \\
\hline & L5-7 & Ispra & & 24,313 & 24,230 & 24,313 \\
\hline & L11-4 & Karlsruhe & 23,928 & 24,050 & 25,770 & 23,928 \\
\hline & L11-7 & Ispra & 24,023 & 24,471 & 25,290 & \multirow{2}{*}{24,362} \\
\hline & L11-7 & Karlsruhe & 24,700 & 24,532 & & \\
\hline
\end{tabular}

\footnotetext{
${ }^{a}$ Based on destructive measurements. ${ }^{12,13}$
}

${ }^{b}$ Based on nondestructive measurements performed only at Ispra. ${ }^{12,13}$ 
The isotopic contents of the fuel samples are listed in Table 9. Results for samples measured at both Ispra and Karlsruhe were averaged. The data for americium and curium isotopes, reported as atom ratios to initial uranium atoms, were adjusted to mass ratios using the atomic weight for each isotope. The mass of depleted ${ }^{238} \mathrm{U}$ was only reported for samples from assembly 506-069. The ${ }^{238} \mathrm{U}$ content for other samples was calculated in this report using the measured ${ }^{235} \mathrm{U} /{ }^{238} \mathrm{U}$ atom ratio for each sample and the absolute ${ }^{235} \mathrm{U}$ content.

The measurements were evaluated by comparing the trends in the measured isotope concentrations as a function of burnup for samples with the same initial enrichment. In most cases the observed variance was consistent with the reported uncertainty. Analysis of the experimental data for ${ }^{242} \mathrm{Pu}$ indicates that the data for assembly 509-032 sample H9-9 is significantly out of trend with other data and this measurement point was rejected. It appears that the value is about an order of magnitude too large, and is most likely attributed to a reporting error. 
Table 9. Experimental results for Trino Vercellese fuel samples ( $\left.\mathrm{mg} / \mathrm{g} \mathbf{U}_{\text {initial }}\right)$

\begin{tabular}{|c|c|c|c|c|c|c|c|c|c|c|}
\hline Assembly & $509-049^{a}$ & $509-049^{a}$ & $509-049^{a}$ & $509-049^{a}$ & $509-049^{a}$ & $509-049^{a}$ & $509-049^{a}$ & $509-032^{a}$ & $509-032^{a}$ & $509-032^{a}$ \\
\hline Sample ID & L5-1 & L5-4 & L5-9 & J8-1 & J8-4 & J8-7 & J8-9 & E11-1 & E11-4 & E11-7 \\
\hline $\begin{array}{c}\text { Burnup } \\
\text { (MWd/MTU) }\end{array}$ & 7,822 & 14,323 & 10,187 & 8,713 & 14,770 & 15,193 & 11,127 & 7,243 & 15,377 & 15,898 \\
\hline U-234 & $1.291 \mathrm{E}-01$ & $1.435 \mathrm{E}-01$ & $1.545 \mathrm{E}-01$ & $1.367 \mathrm{E}-01$ & $1.312 \mathrm{E}-01$ & & & $2.110 \mathrm{E}-01$ & $2.312 \mathrm{E}-01$ & $1.410 \mathrm{E}-01$ \\
\hline $\begin{array}{l}\text { U-235 } \\
\text { U- } 236\end{array}$ & $1.972 \mathrm{E}+01$ & $1.503 \mathrm{E}+01$ & $1.745 \mathrm{E}+01$ & $1.854 \mathrm{E}+01$ & $1.390 \mathrm{E}+01$ & $1.386 \mathrm{E}+01$ & $1.663 \mathrm{E}+01$ & $2.329 \mathrm{E}+01$ & $1.728 \mathrm{E}+01$ & $1.661 \mathrm{E}+01$ \\
\hline $\begin{array}{l}\text { U-236 } \\
\text { U-238 }\end{array}$ & $9.658 \mathrm{E}+02$ & $9.601 \mathrm{E}+02$ & $9.639 \mathrm{E}+02$ & $9.654 \mathrm{E}+02$ & $9.603 \mathrm{E}+02$ & $9.595 \mathrm{E}+02$ & $9.635 \mathrm{E}+02$ & $9.624 \mathrm{E}+02$ & $9.558 \mathrm{E}+02$ & $9.558 \mathrm{E}+02$ \\
\hline $\begin{array}{l}\mathrm{Pu}-236 \\
\mathrm{Pu}-238\end{array}$ & & & & & & & & & & \\
\hline $\mathrm{Pu}-239$ & $3.608 \mathrm{E}+00$ & $5.016 \mathrm{E}+00$ & $4.116 \mathrm{E}+00$ & $3.606 \mathrm{E}+00$ & $4.769 \mathrm{E}+00$ & $4.926 \mathrm{E}+00$ & $4.134 \mathrm{E}+00$ & $3.483 \mathrm{E}+00$ & $5.266 \mathrm{E}+00$ & $5.234 \mathrm{E}+00$ \\
\hline $\mathrm{Pu}-240$ & $5.150 \mathrm{E}-01$ & $1.121 \mathrm{E}+00$ & $7.325 \mathrm{E}-01$ & $5.600 \mathrm{E}-01$ & $1.160 \mathrm{E}+00$ & $1.196 \mathrm{E}+00$ & $8.020 \mathrm{E}-01$ & $4.420 \mathrm{E}-01$ & $1.118 \mathrm{E}+00$ & $1.137 \mathrm{E}+00$ \\
\hline $\mathrm{Pu}-241$ & $2.040 \mathrm{E}-01$ & $6.025 \mathrm{E}-01$ & $3.375 \mathrm{E}-01$ & $2.280 \mathrm{E}-01$ & $6.150 \mathrm{E}-01$ & $6.370 \mathrm{E}-01$ & $3.710 \mathrm{E}-01$ & $1.710 \mathrm{E}-01$ & $6.140 \mathrm{E}-01$ & $6.180 \mathrm{E}-01$ \\
\hline $\mathrm{Pu}-242$ & $1.532 \mathrm{E}-02$ & $8.493 \mathrm{E}-02$ & $3.373 \mathrm{E}-02$ & $1.887 \mathrm{E}-02$ & $9.938 \mathrm{E}-02$ & $1.026 \mathrm{E}-01$ & $4.205 \mathrm{E}-02$ & $1.170 \mathrm{E}-02$ & $8.425 \mathrm{E}-02$ & $9.252 \mathrm{E}-02$ \\
\hline $\begin{array}{l}\text { Cm-242 } \\
\text { Cm-244 } \\
\text { Am-241 } \\
\text { Am-242m } \\
\text { Am-243 }\end{array}$ & & & & & & & & & & \\
\hline Ru-106 & $3.110 \mathrm{E}-02$ & $6.575 \mathrm{E}-02$ & 4.440E-02 & $3.345 \mathrm{E}-02$ & 7.013E-02 & & & $2.522 \mathrm{E}-02$ & $6.417 \mathrm{E}-02$ & $6.855 \mathrm{E}-02$ \\
\hline Nd-148 & & $1.601 \mathrm{E}-01$ & $1.141 \mathrm{E}-01$ & $9.778 \mathrm{E}-02$ & $1.649 \mathrm{E}-01$ & $1.695 \mathrm{E}-01$ & $1.245 \mathrm{E}-01$ & $8.135 \mathrm{E}-02$ & $1.718 \mathrm{E}-01$ & $1.776 \mathrm{E}-01$ \\
\hline Cs-134 & $1.046 \mathrm{E}-02$ & $3.229 \mathrm{E}-02$ & $1.757 \mathrm{E}-02$ & $1.205 \mathrm{E}-02$ & $3.467 \mathrm{E}-02$ & & & $9.394 \mathrm{E}-03$ & $3.601 \mathrm{E}-02$ & $3.809 \mathrm{E}-02$ \\
\hline Cs-137 & $2.911 \mathrm{E}-01$ & $5.269 \mathrm{E}-01$ & $3.908 \mathrm{E}-01$ & $3.100 \mathrm{E}-01$ & $5.467 \mathrm{E}-01$ & & & $2.764 \mathrm{E}-01$ & $5.700 \mathrm{E}-01$ & $5.773 \mathrm{E}-01$ \\
\hline $\begin{array}{l}\text { Ce-144 } \\
\text { Eu-154 }\end{array}$ & $1.330 \mathrm{E}-01$ & $2.053 \mathrm{E}-01$ & $1.640 \mathrm{E}-01$ & $1.411 \mathrm{E}-01$ & $2.113 \mathrm{E}-01$ & & & $1.358 \mathrm{E}-01$ & $2.249 \mathrm{E}-01$ & $2.201 \mathrm{E}-01$ \\
\hline
\end{tabular}


Table 9. Experimental results for Trino Vercellese fuel samples ( $\left.\mathrm{mg} / \mathrm{g} \mathbf{U}_{\text {initial }}\right)$ (continued)

\begin{tabular}{|c|c|c|c|c|c|c|c|c|c|c|}
\hline Assembly & $509-032^{a}$ & $509-032^{a}$ & $509-032^{a}$ & $509-032^{a}$ & $509-104^{a}$ & $509-069^{b}$ & $509-069^{b}$ & $509-069^{b}$ & $509-069^{b}$ & $509-069^{b}$ \\
\hline Sample ID & E11-9 & H9-4 & H9-7 & H9-9 & M11-7 & E5-4 & E5-7 & E5-9 & L5-4 & L5-7 \\
\hline $\begin{array}{c}\text { Burnup } \\
\text { (MWd/MTU) }\end{array}$ & 11,529 & 16,556 & 17,450 & 12,366 & 12,042 & 23,867 & 24,548 & 19,208 & 24,330 & 24,313 \\
\hline U-234 & & & $1.502 \mathrm{E}-01$ & $1.676 \mathrm{E}-01$ & & & & & & \\
\hline U-235 & $2.017 \mathrm{E}+01$ & $1.672 \mathrm{E}+01$ & $1.631 \mathrm{E}+01$ & $1.889 \mathrm{E}+01$ & $2.663 \mathrm{E}+01$ & $1.291 \mathrm{E}+01$ & $1.221 \mathrm{E}+01$ & $1.514 \mathrm{E}+01$ & $1.297 \mathrm{E}+01$ & $1.231 \mathrm{E}+01$ \\
\hline U-236 & & & & & & $3.530 \mathrm{E}+00$ & $3.545 \mathrm{E}+00$ & $3.270 \mathrm{E}+00$ & $3.480 \mathrm{E}+00$ & $3.570 \mathrm{E}+00$ \\
\hline U-238 & $9.595 \mathrm{E}+02$ & $9.551 \mathrm{E}+02$ & $9.548 \mathrm{E}+02$ & $9.471 \mathrm{E}+02$ & $9.513 \mathrm{E}+02$ & $9.496 \mathrm{E}+02$ & $9.487 \mathrm{E}+02$ & $9.536 \mathrm{E}+02$ & $9.491 \mathrm{E}+02$ & $9.476 \mathrm{E}+02$ \\
\hline $\mathrm{Pu}-236$ & & & & & & $6.560 \mathrm{E}-07$ & & $3.130 \mathrm{E}-07$ & $7.420 \mathrm{E}-07$ & $7.640 \mathrm{E}-07$ \\
\hline $\mathrm{Pu}-238$ & & & & & & $1.170 \mathrm{E}-01$ & $1.155 \mathrm{E}-01$ & $6.300 \mathrm{E}-02$ & $1.100 \mathrm{E}-01$ & $1.140 \mathrm{E}-01$ \\
\hline $\mathrm{Pu}-239$ & $4.418 \mathrm{E}+00$ & $5.172 \mathrm{E}+00$ & $5.234 \mathrm{E}+00$ & $4.446 \mathrm{E}+00$ & $4.586 \mathrm{E}+00$ & $5.950 \mathrm{E}+00$ & $5.980 \mathrm{E}+00$ & $5.270 \mathrm{E}+00$ & $6.060 \mathrm{E}+00$ & $5.970 \mathrm{E}+00$ \\
\hline $\mathrm{Pu}-240$ & $7.750 \mathrm{E}-01$ & $1.211 \mathrm{E}+00$ & $1.247 \mathrm{E}+00$ & $8.340 \mathrm{E}-01$ & $7.165 \mathrm{E}-01$ & $1.760 \mathrm{E}+00$ & $1.785 \mathrm{E}+00$ & $1.330 \mathrm{E}+00$ & $1.770 \mathrm{E}+00$ & $1.790 \mathrm{E}+00$ \\
\hline $\mathrm{Pu}-241$ & $3.690 \mathrm{E}-01$ & $6.760 \mathrm{E}-01$ & $6.940 \mathrm{E}-01$ & 4.090E-01 & $3.475 \mathrm{E}-01$ & $1.050 \mathrm{E}+00$ & $1.055 \mathrm{E}+00$ & $7.300 \mathrm{E}-01$ & $1.060 \mathrm{E}+00$ & $1.060 \mathrm{E}+00$ \\
\hline $\mathrm{Pu}-242$ & $3.709 \mathrm{E}-02$ & $1.047 \mathrm{E}-01$ & $1.080 \mathrm{E}-01$ & & $3.057 \mathrm{E}-02$ & $2.400 \mathrm{E}-01$ & $2.540 \mathrm{E}-01$ & $1.350 \mathrm{E}-01$ & $2.440 \mathrm{E}-01$ & $2.500 \mathrm{E}-01$ \\
\hline $\mathrm{Cm}-242$ & & & & & & $2.319 \mathrm{E}-02$ & $2.513 \mathrm{E}-02$ & 1.394E-02 & $2.523 \mathrm{E}-02$ & 2.482E-02 \\
\hline $\mathrm{Cm}-244$ & & & & & & 8.964E-03 & $9.426 \mathrm{E}-03$ & $2.544 \mathrm{E}-03$ & $9.528 \mathrm{E}-03$ & $8.790 \mathrm{E}-03$ \\
\hline Am-241 & & & & & & $2.223 \mathrm{E}-01$ & $2.444 \mathrm{E}-01$ & $1.526 \mathrm{E}-01$ & $2.432 \mathrm{E}-01$ & $2.989 \mathrm{E}-01$ \\
\hline Am-242m & & & & & & & $2.441 \mathrm{E}-03$ & & & \\
\hline Am-243 & & & & & & & 4.617E-02 & & & \\
\hline Ru-106 & 4.701E-02 & & 7.261E-02 & $5.047 \mathrm{E}-02$ & $4.248 \mathrm{E}-02$ & & & & & \\
\hline Nd-148 & $1.291 \mathrm{E}-01$ & $1.848 \mathrm{E}-01$ & $1.946 \mathrm{E}-01$ & $1.366 \mathrm{E}-01$ & $1.349 \mathrm{E}-01$ & $2.669 \mathrm{E}-01$ & $2.743 \mathrm{E}-01$ & $2.164 \mathrm{E}-01$ & $2.709 \mathrm{E}-01$ & \\
\hline Cs-134 & $2.096 \mathrm{E}-02$ & & 4.287E-02 & $2.285 \mathrm{E}-02$ & $2.108 \mathrm{E}-02$ & 5.914E-02 & $6.135 \mathrm{E}-02$ & $3.980 \mathrm{E}-02$ & $5.911 \mathrm{E}-02$ & $6.030 \mathrm{E}-02$ \\
\hline Cs-137 & $4.185 \mathrm{E}-01$ & & $6.373 \mathrm{E}-01$ & 4.495E-01 & 4.484E-01 & 8.354E-01 & 8.703E-01 & $6.780 \mathrm{E}-01$ & 8.449E-01 & $8.553 \mathrm{E}-01$ \\
\hline Ce-144 & $1.748 \mathrm{E}-01$ & & $2.407 \mathrm{E}-01$ & 1.952E-01 & $1.813 \mathrm{E}-01$ & & & & & \\
\hline Eu-154 & & & & & & $1.698 \mathrm{E}-02$ & $1.843 \mathrm{E}-02$ & $1.113 \mathrm{E}-02$ & $1.700 \mathrm{E}-02$ & $1.774 \mathrm{E}-02$ \\
\hline
\end{tabular}


Table 9. Experimental results for Trino Vercellese fuel samples ( $\left.\mathrm{mg} / \mathrm{g} \mathbf{U}_{\text {initial }}\right)$ (continued)

\begin{tabular}{|c|c|c|c|c|c|c|c|c|c|c|c|}
\hline Assembly & $509-069^{b}$ & $509-069^{b}$ & $509-069^{b}$ & $509-069^{b}$ & $509-069^{b}$ & $509-069^{b}$ & $509-069^{b}$ & $509-069^{b}$ & $509-069^{b}$ & $509-069^{b}$ & $509-069^{b}$ \\
\hline Sample ID & E11-1 & E11-2 & E11-4 & E11-5 & E11-7 & E11-8 & E11-9 & L11-4 & L11-7 & J9-4 & J9-7 \\
\hline $\begin{array}{c}\text { Burnup } \\
\text { (MWd/MTU) }\end{array}$ & 12,859 & 20,602 & 23,718 & 24,518 & 24,304 & 23,406 & 19,250 & 23,928 & 24,362 & 24,849 & 25,258 \\
\hline U-234 & & & & & & & & & & & \\
\hline U-235 & $1.946 \mathrm{E}+01$ & $1.436 \mathrm{E}+01$ & $1.248 \mathrm{E}+01$ & $1.227 \mathrm{E}+01$ & $1.235 \mathrm{E}+01$ & $1.262 \mathrm{E}+01$ & $1.497 \mathrm{E}+01$ & $1.282 \mathrm{E}+01$ & $1.225 \mathrm{E}+01$ & $1.201 \mathrm{E}+01$ & $1.175 \mathrm{E}+01$ \\
\hline U-236 & $2.450 \mathrm{E}+00$ & $3.315 \mathrm{E}+00$ & $3.615 \mathrm{E}+00$ & $3.620 \mathrm{E}+00$ & $3.640 \mathrm{E}+00$ & $3.590 \mathrm{E}+00$ & $3.240 \mathrm{E}+00$ & $3.760 \mathrm{E}+00$ & $3.465 \mathrm{E}+00$ & $3.640 \mathrm{E}+00$ & $3.690 \mathrm{E}+00$ \\
\hline U-238 & $9.591 \mathrm{E}+02$ & $9.522 \mathrm{E}+02$ & $9.498 \mathrm{E}+02$ & $9.491 \mathrm{E}+02$ & $9.496 \mathrm{E}+02$ & $9.502 \mathrm{E}+02$ & $9.542 \mathrm{E}+02$ & $9.489 \mathrm{E}+02$ & $9.486 \mathrm{E}+02$ & $9.483 \mathrm{E}+02$ & $9.489 \mathrm{E}+02$ \\
\hline $\mathrm{Pu}-236$ & & $3.740 \mathrm{E}-07$ & $7.190 \mathrm{E}-07$ & $6.560 \mathrm{E}-07$ & & & & & $6.860 \mathrm{E}-07$ & & \\
\hline $\mathrm{Pu}-238$ & $2.500 \mathrm{E}-02$ & $8.050 \mathrm{E}-02$ & $1.090 \mathrm{E}-01$ & $1.170 \mathrm{E}-01$ & $1.170 \mathrm{E}-01$ & $1.190 \mathrm{E}-01$ & $6.800 \mathrm{E}-02$ & $1.060 \mathrm{E}-01$ & $1.160 \mathrm{E}-01$ & $1.200 \mathrm{E}-01$ & $1.340 \mathrm{E}-01$ \\
\hline $\mathrm{Pu}-239$ & $4.580 \mathrm{E}+00$ & $5.755 \mathrm{E}+00$ & $5.895 \mathrm{E}+00$ & $6.010 \mathrm{E}+00$ & $6.070 \mathrm{E}+00$ & $5.910 \mathrm{E}+00$ & $5.630 \mathrm{E}+00$ & $6.060 \mathrm{E}+00$ & $5.995 \mathrm{E}+00$ & $5.820 \mathrm{E}+00$ & $5.830 \mathrm{E}+00$ \\
\hline $\mathrm{Pu}-240$ & $8.400 \mathrm{E}-01$ & $1.520 \mathrm{E}+00$ & $1.755 \mathrm{E}+00$ & $1.790 \mathrm{E}+00$ & $1.825 \mathrm{E}+00$ & $1.720 \mathrm{E}+00$ & $1.410 \mathrm{E}+00$ & $1.790 \mathrm{E}+00$ & $1.810 \mathrm{E}+00$ & $1.810 \mathrm{E}+00$ & $1.840 \mathrm{E}+00$ \\
\hline $\mathrm{Pu}-241$ & $4.000 \mathrm{E}-01$ & $8.850 \mathrm{E}-01$ & $1.030 \mathrm{E}+00$ & $1.040 \mathrm{E}+00$ & $1.060 \mathrm{E}+00$ & $1.030 \mathrm{E}+00$ & $7.800 \mathrm{E}-01$ & $1.050 \mathrm{E}+00$ & $1.055 \mathrm{E}+00$ & $1.070 \mathrm{E}+00$ & $1.080 \mathrm{E}+00$ \\
\hline $\mathrm{Pu}-242$ & 4.600E-02 & $1.720 \mathrm{E}-01$ & $2.435 \mathrm{E}-01$ & $2.400 \mathrm{E}-01$ & $2.575 \mathrm{E}-01$ & $2.320 \mathrm{E}-01$ & $1.470 \mathrm{E}-01$ & $2.470 \mathrm{E}-01$ & $2.590 \mathrm{E}-01$ & $2.700 \mathrm{E}-01$ & $2.820 \mathrm{E}-01$ \\
\hline $\mathrm{Cm}-242$ & $5.188 \mathrm{E}-03$ & $1.770 \mathrm{E}-02$ & $2.436 \mathrm{E}-02$ & $2.574 \mathrm{E}-02$ & $2.665 \mathrm{E}-02$ & $2.452 \mathrm{E}-02$ & $1.739 \mathrm{E}-02$ & $2.797 \mathrm{E}-02$ & $2.467 \mathrm{E}-02$ & $2.553 \mathrm{E}-02$ & $2.848 \mathrm{E}-02$ \\
\hline $\mathrm{Cm}-244$ & & 4.677E-03 & $9.021 \mathrm{E}-03$ & $9.918 \mathrm{E}-03$ & $9.908 \mathrm{E}-03$ & $7.590 \mathrm{E}-03$ & $3.641 \mathrm{E}-03$ & $9.159 \mathrm{E}-03$ & $9.739 \mathrm{E}-03$ & $1.070 \mathrm{E}-02$ & $9.672 \mathrm{E}-03$ \\
\hline Am-241 & $8.439 \mathrm{E}-02$ & $1.748 \mathrm{E}-01$ & $2.089 \mathrm{E}-01$ & $3.089 \mathrm{E}-01$ & $3.011 \mathrm{E}-01$ & & & & $2.033 \mathrm{E}-01$ & $2.120 \mathrm{E}-01$ & \\
\hline Am-242m & & $1.389 \mathrm{E}-03$ & $2.126 \mathrm{E}-03$ & $2.777 \mathrm{E}-03$ & $2.258 \mathrm{E}-03$ & $2.177 \mathrm{E}-03$ & $2.096 \mathrm{E}-03$ & $1.963 \mathrm{E}-03$ & $2.192 \mathrm{E}-03$ & & $2.085 \mathrm{E}-03$ \\
\hline Am-243 & & $2.395 \mathrm{E}-02$ & $4.535 \mathrm{E}-02$ & $5.495 \mathrm{E}-02$ & $4.586 \mathrm{E}-02$ & 4.372E-02 & $3.013 \mathrm{E}-02$ & 4.454E-02 & 4.249E-02 & & $5.015 \mathrm{E}-02$ \\
\hline \multicolumn{12}{|l|}{ Ru-106 } \\
\hline Nd-148 & & $2.309 \mathrm{E}-01$ & $2.657 \mathrm{E}-01$ & $2.803 \mathrm{E}-01$ & $2.722 \mathrm{E}-01$ & $2.623 \mathrm{E}-01$ & $2.159 \mathrm{E}-01$ & $2.679 \mathrm{E}-01$ & $2.725 \mathrm{E}-01$ & & $2.826 \mathrm{E}-01$ \\
\hline Cs-134 & $1.925 \mathrm{E}-02$ & 4.672E-02 & $5.862 \mathrm{E}-02$ & $6.090 \mathrm{E}-02$ & 6.007E-02 & & & & $6.123 \mathrm{E}-02$ & $6.288 \mathrm{E}-02$ & \\
\hline Cs-137 & $4.527 \mathrm{E}-01$ & $7.276 \mathrm{E}-01$ & $8.313 \mathrm{E}-01$ & $8.572 \mathrm{E}-01$ & 8.439E-01 & & & & $8.618 \mathrm{E}-01$ & $8.751 \mathrm{E}-01$ & \\
\hline Ce-144 & & & & & & & & & & & \\
\hline Eu-154 & $5.057 \mathrm{E}-03$ & $1.351 \mathrm{E}-02$ & $1.711 \mathrm{E}-02$ & $1.507 \mathrm{E}-02$ & $1.586 \mathrm{E}-02$ & & & & $1.650 \mathrm{E}-02$ & $1.618 \mathrm{E}-02$ & \\
\hline
\end{tabular}

${ }^{a}$ Measurements for 509-049, 509-032, and 509-104 reported at discharge date of 4/28/1967 (Ref. 12).

${ }^{b}$ Measurements for 509-069 reported at discharge date of 7/9/1971, except for ${ }^{241} \mathrm{Am}$, reported at 7/9/1974 (Ref. 13). 


\subsection{OBRIGHEIM (KWO)}

Obrigheim KWO was a PWR in Germany with a net generating capacity of $357 \mathrm{MWe}$, which was designed by Siemens AG. First power was achieved in October 1968 with an initial core consisting of Reaktor-Brennelement Union (RBU) $14 \times 14$ assemblies. $^{57}$

Fuel assemblies from the Obrigheim Kernkraftwerk Obrigheim GmbH (KWO) reactor were the subject of post-irradiation examination and isotopic measurements. Isotopic measurements were performed under two separate experimental programs of the

- European institutes in the framework of the Isotopic Correlation Experiment (ICE) that performed measurements on fuel assemblies reprocessed at the Karlsruhe reprocessing plant and

- European JRC Ispra and Karlsruhe Establishments in the framework of a European benchmarkexperiment activity.

\subsubsection{Karlsruhe Reprocessing Plant (WAK)}

Radiochemical analysis data for five KWO fuel assemblies, BE168, BE171, BE176, BE172, and BE170, reprocessed at the Karlsruhe Reprocessing Plant, were reported by Gesellschaft für Reaktorsicherheit $\mathrm{mbH}$ (GRS) in Germany. ${ }^{16}$ Independent measurements were performed at laboratories of the European Institute for Transuranium Elements (ITU), Institute for Radiochemistry at Karlsruhe (IRCh), Karlsruhe Reprocessing Plant (WAK), and International Atomic Energy Agency (IAEA). The experiments are unique in that full-length fuel assemblies were analyzed, instead of samples from individual fuel rods used in many experiments. The configuration of the Obrigheim KWO assembly is shown in Fig. 6 (see Sect. 8.2).

During reprocessing, each assembly was divided lengthwise and analyzed individually in two batches, each batch corresponding to a half assembly. In this report, the measurement data for the two batches were combined to obtain assembly-average isotopic concentrations. The main measurement techniques and experimental uncertainties are summarized in Table 10. The assemblies and batch numbers are summarized in Table 11. The burnup values for each batch, determined experimentally from ${ }^{148} \mathrm{Nd}$ measured at ITU had an estimated accuracy of about $4 \%$.

Table 10. Experimental techniques and uncertainties for Obrigheim measurements at WAK

\begin{tabular}{ccc}
\hline Assembly & Method & $\begin{array}{r}\mathbf{R}^{a} \\
\mathbf{( \% )}\end{array}$ \\
\hline $\mathrm{U}-238^{b}$ & & $<0.2$ \\
$\mathrm{U}-235$ & IDMS & 0.7 \\
$\mathrm{U}-236$ & IDMS & 0.9 \\
Pu-238 & IDMS & 6.3 \\
Pu-239 & IDMS & 2.4 \\
Pu-240 & IDMS & 2.7 \\
Pu-241 & IDMS & 2.5 \\
Pu-242 & IDMS & 3.6 \\
Am-241 & $\alpha$-spec & $<100$ \\
Am-243 & $\alpha$-spec & $<100$ \\
Cm-242 & $\alpha$-spec & $<100$ \\
Cm-244 & $\alpha-$-spec & 20 \\
\hline
\end{tabular}

${ }^{a}$ Relative standard deviation.

${ }^{b}$ Values for ${ }^{238} \mathrm{U}$ derived from other measurements. 
Table 11. Summary of measured Obrigheim assemblies reprocessed at WAK

\begin{tabular}{|c|c|c|c|c|}
\hline Assembly & $\begin{array}{c}\text { Initial enrichment } \\
\left(w t \%{ }^{235} U\right)\end{array}$ & Batch & $\begin{array}{c}\text { Batch burnup }^{a} \\
\text { (MWd/MTU) }\end{array}$ & $\begin{array}{c}\text { Assembly burnup }{ }^{b} \\
\text { (MWd/MTU) }\end{array}$ \\
\hline \multirow[t]{2}{*}{$\overline{B E} 168$} & 3.13 & 86 & 28,400 & 29,350 \\
\hline & & 87 & 30,300 & \\
\hline \multirow[t]{2}{*}{ BE 171} & 3.13 & 88 & 28,270 & 28,655 \\
\hline & & 89 & 29,040 & \\
\hline \multirow[t]{2}{*}{ BE 176} & 3.13 & 90 & 29,520 & 28,755 \\
\hline & & 91 & 27,990 & \\
\hline \multirow[t]{2}{*}{ BE 172} & 3.13 & 92 & 26,540 & 27,890 \\
\hline & & 93 & 29,240 & \\
\hline \multirow{2}{*}{ BE 170} & 3.13 & 94 & 25,930 & 27,005 \\
\hline & & 95 & 28,080 & \\
\hline
\end{tabular}

${ }^{a}$ Experimental value based on ${ }^{148} \mathrm{Nd}$ provided in Ref. 16, Table 4.

${ }^{b}$ Average of the two reprocessing batches for each assembly.

All four laboratories measured the uranium and plutonium isotopes. Tabulated data representing average batch results from all laboratories, in units of grams per ton initial uranium, were obtained from GRS report GRS-A-962 (Ref. 16). Isotopic ratios of fission products $\mathrm{Kr}, \mathrm{Xe}, \mathrm{Nd}$, and $\mathrm{Cs}$ (not evaluated in this report) and concentrations of americium and curium were measured only at ITU. The GRS data were independently verified by digitizing graphical measurement data available for each laboratory using figures published in Kernforschungszentrum Karlsruhe report KfK 3014 (Ref. 17). Measurements were performed three years after the fuel was discharged from the reactor and the data were adjusted to the time of discharge by each institute.

Measured isotope contents are listed in Table 12. The data for uranium and plutonium represent an average of the measurements from each of the four laboratories. In the case of ${ }^{238} \mathrm{Pu}$, the concentrations must be corrected for the contribution from ${ }^{242} \mathrm{Cm}$ decay. Since curium isotopes were only measured by ITU, only the ITU values for ${ }^{238} \mathrm{Pu}$ account for ${ }^{242} \mathrm{Cm}$ decay and therefore were the only data used for ${ }^{238} \mathrm{Pu}$. The ITU data were obtained from digitized plots of the results from each laboratory. ${ }^{17}$ The uncertainty in the measurements was estimated in the current report as the standard deviation of the difference in measured values from each of the four laboratories. Data for ${ }^{238} \mathrm{U}$ content was not reported by any laboratory but were derived in the current study using measurement data for the other heavy metal isotopes. Correction for the heavy metal mass loss from fission was estimated using the value of the fissions per initial metal atom (\% FIMA). The sample \% FIMA was determined from the sample burnup using a value of $9.6 \pm 0.3 \mathrm{GWd} / \mathrm{MTU}$ per $\%$ FIMA. $^{74}$ The mass of all heavy metal isotopes (including ${ }^{238} \mathrm{U}$ ) plus the heavy metal loss based on the \% FIMA value is the initial heavy metal content (known). Therefore, the residual obtained when ${ }^{238} \mathrm{U}$ is excluded effectively represents the ${ }^{238} \mathrm{U}$ content in the sample. The estimated uncertainty in the ${ }^{238} \mathrm{U}$ content includes the uncertainty in the measured heavy metal content, burnup, and uncertainty in the \% FIMA value.

Americium and curium data, reported only by ITU, were measured using $\alpha$-spectrometry and mass spectrometry. Large measurement uncertainties were associated with interferences in $\alpha$-spectrometry. In the case of ${ }^{241} \mathrm{Am}$, adjustment of the data to the time of discharge resulted in significant experimental uncertainties of sometimes up to $100 \%$ and erratic behavior of the results when trended as a function of burnup. The concentration of ${ }^{244} \mathrm{Cm}$ was measured with an estimated accuracy of $20 \%$. Due to the large uncertainty and variability in most of the curium and americium data, only the results for ${ }^{244} \mathrm{Cm}$ are considered acceptable for code validation in this report. For completeness, all measurement data are listed in Table 12. 
Table 12. Measurement data for Obrigheim assemblies reprocessed at WAK $\left(\mathrm{mg} / \mathrm{g} \mathbf{U}_{\text {initial }}\right)$

\begin{tabular}{c|c|c|c|c|c}
\hline Assembly & BE168 & BE171 & BE176 & BE172 & BE170 \\
\hline $\begin{array}{c}\text { Burnup } \\
\text { (MWd/MTU) }\end{array}$ & $\mathbf{2 9 , 3 5 0}$ & $\mathbf{2 8 , 6 5 5}$ & $\mathbf{2 8 , 7 5 5}$ & $\mathbf{2 7 , 8 9 0}$ & $\mathbf{2 7 , 0 0 5}$ \\
\hline $\mathrm{U}-238^{a}$ & $9.474 \mathrm{E}+02$ & $9.481 \mathrm{E}+02$ & $9.481 \mathrm{E}+02$ & $9.491 \mathrm{E}+02$ & $9.494 \mathrm{E}+02$ \\
$\mathrm{U}-235$ & $9.346 \mathrm{E}+00$ & $9.657 \mathrm{E}+00$ & $9.504 \mathrm{E}+00$ & $9.830 \mathrm{E}+00$ & $1.043 \mathrm{E}+01$ \\
$\mathrm{U}-236$ & $3.785 \mathrm{E}+00$ & $3.738 \mathrm{E}+00$ & $3.751 \mathrm{E}+00$ & $3.680 \mathrm{E}+00$ & $3.651 \mathrm{E}+00$ \\
\hline $\mathrm{Pu}-238^{b}$ & $1.192 \mathrm{E}-01$ & $1.028 \mathrm{E}-01$ & $1.069 \mathrm{E}-01$ & $9.392 \mathrm{E}-02$ & $8.875 \mathrm{E}-02$ \\
$\mathrm{Pu}-239$ & $5.008 \mathrm{E}+00$ & $4.923 \mathrm{E}+00$ & $4.928 \mathrm{E}+00$ & $4.793 \mathrm{E}+00$ & $4.876 \mathrm{E}+00$ \\
$\mathrm{Pu}-240$ & $2.046 \mathrm{E}+00$ & $1.961 \mathrm{E}+00$ & $1.982 \mathrm{E}+00$ & $1.895 \mathrm{E}+00$ & $1.881 \mathrm{E}+00$ \\
$\mathrm{Pu}-241$ & $1.123 \mathrm{E}+00$ & $1.076 \mathrm{E}+00$ & $1.093 \mathrm{E}+00$ & $1.031 \mathrm{E}+00$ & $1.026 \mathrm{E}+00$ \\
$\mathrm{Pu}-242$ & $4.290 \mathrm{E}-01$ & $3.880 \mathrm{E}-01$ & $4.035 \mathrm{E}-01$ & $3.720 \mathrm{E}-01$ & $3.445 \mathrm{E}-01$ \\
\hline $\mathrm{Am}-241$ & $6.550 \mathrm{E}-02$ & $1.095 \mathrm{E}-01$ & $1.140 \mathrm{E}-01$ & $1.100 \mathrm{E}-01$ & $1.125 \mathrm{E}-01$ \\
Am-243 & $2.585 \mathrm{E}-02$ & $4.120 \mathrm{E}-02$ & $4.415 \mathrm{E}-02$ & $3.805 \mathrm{E}-02$ & $2.710 \mathrm{E}-02$ \\
$\mathrm{Cm}-242$ & $2.135 \mathrm{E}-02$ & $2.010 \mathrm{E}-02$ & $2.020 \mathrm{E}-02$ & $2.180 \mathrm{E}-02$ & $1.880 \mathrm{E}-02$ \\
$\mathrm{Cm}-244$ & $1.755 \mathrm{E}-02$ & $1.590 \mathrm{E}-02$ & $1.675 \mathrm{E}-02$ & $1.420 \mathrm{E}-02$ & $1.245 \mathrm{E}-02$ \\
\hline${ }^{a}$ Values for ${ }^{238} \mathrm{U}$ are derived from other measurement data. \\
${ }^{b}$ Values for ${ }^{238}$ Pu are from ITU measurements only that were corrected for ${ }^{242} \mathrm{Cm}$ decay.
\end{tabular}

\subsubsection{JRC Research Program}

Measurements of spent fuel samples from the Obrigheim KWO reactor were also performed under a European JRC experimental program at laboratories of the Ispra and Karlsruhe establishments. ${ }^{15}$ These Obrigheim measurements have not been evaluated previously by the Yucca Mountain Project.

Fuel samples were obtained from six rods of two assemblies, BE124 and BE210. Positions of measured fuel rods in the assemblies are illustrated in Fig. 8 (see Sect. 8.2). Four of the six rods from which samples were selected were located at the outer edge of the assembly. A total of 23 samples were measured; 17 were measured at Ispra and 6 were measured at Karlsruhe (4 samples were measured at both laboratories for the purposes of cross-checking). One sample, D1-P1, did not report absolute heavy metal contents and was thus not used in the current study. A summary of the fuel samples evaluated in the current report is given in Table 13. The samples are identified by the rod location in the assembly and axial position identified in one of five uniform axial segments, P1 (lower) to P5 (upper).

Isotopic measurement techniques used at Ispra and Karlsruhe were similar to those used in other JRC experimental programs (e.g., Trino Vercellese). ${ }^{13}$ Measurements included the isotopes of uranium, plutonium, americium and curium, and fission products ${ }^{148} \mathrm{Nd},{ }^{134} \mathrm{Cs},{ }^{137} \mathrm{Cs}$, and ${ }^{154} \mathrm{Eu}$. Isotopic ratios of krypton and xenon noble gases were measured at Karlsruhe, but are not used in this report.

The main radiochemical analysis techniques included:

- IDMS for isotopes of $\mathrm{U}, \mathrm{Pu}, \mathrm{Am}$, and $\mathrm{Nd}$

- $\quad \gamma$-spectrometry for ${ }^{134} \mathrm{Cs},{ }^{137} \mathrm{Cs}$, and ${ }^{154} \mathrm{Eu}$

- $\alpha$-spectrometry for ${ }^{238} \mathrm{Pu},{ }^{241} \mathrm{Am},{ }^{242} \mathrm{Cm}$, and ${ }^{244} \mathrm{Cm}$

Results for ${ }^{134} \mathrm{Cs},{ }^{137} \mathrm{Cs}$, and ${ }^{154} \mathrm{Eu}$ were only reported for samples measured at Ispra. The gamma measurements applied in this work were those obtained for the dissolved fuel solutions and not from nondestructive analysis. Karlsruhe used $\alpha$-spectrometry only to measure ${ }^{241} \mathrm{Am}$. Ispra used $\alpha$-spectrometry for some samples, and higher-precision mass spectrometry with isotopic dilution for other samples. Mass 
spectrometry also provided data for ${ }^{242 \mathrm{~m}} \mathrm{Am}$ and ${ }^{243} \mathrm{Am}$ that were not available for the samples measured by $\alpha$-spectrometry.

Table 13. Summary of Obrigheim KWO fuel samples from assemblies BE124 and BE210

\begin{tabular}{|c|c|c|c|c|c|c|}
\hline Assembly & $\begin{array}{c}\text { Sample } \\
\text { No. }\end{array}$ & $\begin{array}{l}\text { Measurement } \\
\text { laboratory }\end{array}$ & $\begin{array}{c}\text { Fuel } \\
\text { sample }\end{array}$ & $\begin{array}{l}\text { Enrichment } \\
\left(\text { wt } \%{ }^{235} U\right)\end{array}$ & $\begin{array}{c}\text { Axial } \\
\text { location } \\
\text { (cm) }{ }^{a}\end{array}$ & $\underset{(\mathbf{G W d} / \mathbf{M T U})^{b}}{{ }^{b}}$ \\
\hline \multirow[t]{15}{*}{ BE124 } & 1 & Karlsruhe & D1-P1 & 3.00 & 15.0 & $21.17^{c}$ \\
\hline & 2 & Ispra & D1-P3 & 3.00 & 143.5 & 33.75 \\
\hline & 3 & Ispra & E3-P1 & 3.00 & 15.0 & 20.18 \\
\hline & 4 & Karlsruhe & E3-P2 & 3.00 & 31.5 & $29.35^{c}$ \\
\hline & 5 & Ispra & E3-P3 & 3.00 & 143.5 & 36.26 \\
\hline & 6 & Ispra / Karlsruhe & E3-P4 & 3.00 & 231.5 & 30.92 \\
\hline & 7 & Ispra & E3-P5 & 3.00 & 258.5 & 22.86 \\
\hline & 8 & Ispra / Karlsruhe ${ }^{d}$ & G7-P1 & 3.00 & 15.0 & 17.13 \\
\hline & 9 & Ispra & G7-P2 & 3.00 & 31.5 & 25.83 \\
\hline & 10 & Ispra / Karlsruhe & G7-P3 & 3.00 & 143.5 & 31.32 \\
\hline & 11 & Ispra & G7-P4 & 3.00 & 231.5 & 27.71 \\
\hline & 12 & Karlsruhe & G7-P5 & 3.00 & 258.5 & 25.81 \\
\hline & 13 & Karlsruhe & M14-P1 & 3.00 & 15.0 & 15.60 \\
\hline & 14 & Ispra & M14-P3 & 3.00 & 143.5 & 29.36 \\
\hline & 15 & Karlsruhe & M14-P4 & 3.00 & 231.5 & 24.90 \\
\hline \multirow[t]{7}{*}{ BE210 } & 16 & Ispra / Karlsruhe & G14-P3-1 & 2.83 & 132.8 & 37.49 \\
\hline & 17 & Ispra & G14-P4-1 & 2.83 & 220.6 & 35.64 \\
\hline & 18 & Ispra & G14-P5-1 & 2.83 & 242.6 & 30.16 \\
\hline & 19 & Ispra & G14-P5-2 & 2.83 & 254.7 & 24.22 \\
\hline & 20 & Ispra & K14-P1 & 2.83 & 15.0 & $22.90^{c}$ \\
\hline & 21 & Ispra & K14-P3-1 & 2.83 & 132.8 & 36.67 \\
\hline & 22 & Karlsruhe & K14-P4-1 & 2.83 & 220.6 & 32.90 \\
\hline
\end{tabular}

${ }^{a}$ Distance between sample axial location and the bottom of the active fuel.

${ }^{b}$ Burnup values determined by laboratories from measured ${ }^{148} \mathrm{Nd}$, except as noted.

${ }^{c}$ Burnup value determined by ${ }^{137} \mathrm{Cs}$ destructive gamma measurements.

${ }^{d}$ Only Ispra measurements used for sample G7-P1.

Source: Ref. 15, Fig. 2.

Experimental uncertainties were reported based on a comparison of different laboratory measurements for the cross-check samples. Results for one of these samples, G7-P1, exhibited consistent isotopic differences between the two cross-check samples. This discrepancy is likely due to an actual difference in the burnup of the cross-check samples due to the large burnup gradient near the bottom of the fuel rod (section P1) from where the samples were obtained. Therefore, the G7-P1 sample was not included as the cross-check evaluation, and only the Ispra measurement results were used for this sample. Measurement data for the other cross-check samples were combined in the current report. The measurement methods and relative standard deviation uncertainty based on three cross-check samples, E3-P4, G7-P3, and G14-P3, are summarized in Table 14. Uncertainties listed for ${ }^{134} \mathrm{Cs},{ }^{137} \mathrm{Cs}$, and ${ }^{154} \mathrm{Eu}$ isotopes, without reported laboratory cross-check data, are values reported by Ispra. Uncertainties for Am and Cm isotopes were not available but were obtained from other studies reported in Ref. 14. 
Table 14. Measurement methods and uncertainties in Obrigheim measurements at JRC

\begin{tabular}{|c|c|c|}
\hline Nuclide ID & Method & $\begin{array}{c}\text { RSD } \\
(\%)\end{array}$ \\
\hline $\mathrm{U}-235$ & IDMS & 3.8 \\
\hline U-236 & IDMS & 0.1 \\
\hline $\mathrm{U}-238$ & IDMS & $<0.1$ \\
\hline $\mathrm{Pu}-238$ & $\alpha$-spec & 14.3 \\
\hline Pu-239 & IDMS & 0.32 \\
\hline $\mathrm{Pu}-240$ & IDMS & 0.24 \\
\hline $\mathrm{Pu}-241$ & IDMS & 1.27 \\
\hline $\mathrm{Pu}-242$ & IDMS & 5.3 \\
\hline $\mathrm{Am}-241^{a}$ & $\alpha$-spec / IDMS & 20 \\
\hline $\mathrm{Am}-242 \mathrm{~m}^{a}$ & IDMS & N/A \\
\hline $\mathrm{Am}-243^{a}$ & IDMS & N/A \\
\hline $\mathrm{Cm}-242^{b}$ & $\alpha$-spec & 72 \\
\hline $\mathrm{Cm}-244^{b}$ & $\alpha$-spec & 28 \\
\hline Cs-134 & $\gamma$-spec & 1.5 \\
\hline Cs-137 & $\gamma$-spec & 1.5 \\
\hline Nd-148 & IDMS & 1.4 \\
\hline Eu-154 & $\gamma$-spec & 5.0 \\
\hline
\end{tabular}

Sample burnup values were determined by the laboratories using three independent methods: destructive analysis of ${ }^{148} \mathrm{Nd}$, destructive analysis of ${ }^{137} \mathrm{Cs}$, and nondestructive analysis of ${ }^{137} \mathrm{Cs}$. Destructive analysis of ${ }^{137} \mathrm{Cs}$ was reported only for samples measured at Ispra. Nondestructive ${ }^{137} \mathrm{Cs}$ measurements were made at both laboratories and were reported for most samples. The reported burnup values are listed in Table 15. The estimated accuracy of the burnup determined by destructive ${ }^{148} \mathrm{Nd},{ }^{137} \mathrm{Cs}$, and nondestructive ${ }^{137} \mathrm{Cs}$ measurements as reported by the laboratories ${ }^{13}$ is $1.5 \%, 2.5 \%$, and $5.0 \%$ (relative standard deviation), respectively. The average agreement between the two destructive analysis methods is within $1.2 \%$, with a relative standard deviation of $1.4 \%$, excluding sample K14-P1 for which an $11 \%$ difference was observed. Agreement between destructive and nondestructive ${ }^{137} \mathrm{Cs}$ values is also good, with an average difference of $0.7 \%$ and relative standard deviation of $4.3 \%$.

In the current study, the ${ }^{148} \mathrm{Nd}$ burnup values were used for all samples, except for E3-P2 and K14-P1, which exhibited large differences in the burnup based on the different burnup indicators, by about $16 \%$ and $11 \%$, respectively. The discrepancy was further evaluated by plotting the trends in the ${ }^{235} \mathrm{U}$ content as a function of the different burnup values for all five samples from rod E3 (see $D V D / x l s /$ Experimental data.xls). The results indicate significant out-of-trend behavior using the ${ }^{148} \mathrm{Nd}$ burnup value consistent with an overestimation of the burnup. The ${ }^{137} \mathrm{Cs}$ burnup value for E3-P2, available from nondestructive measurement only, was $16 \%$ lower than the ${ }^{148} \mathrm{Nd}$ burnup value, and resulted in consistent agreement with data for other rod E3 samples based on trending analysis. The analysis indicates a likely problem with the Karlsruhe ${ }^{148} \mathrm{Nd}$ measurement for this sample. A similar analysis of sample K14-P1 suggested a likely problem in the ${ }^{148} \mathrm{Nd}$ burnup measured at Ispra. In this case, 
the ${ }^{137} \mathrm{Cs}$ burnup value is also confirmed by both destructive and nondestructive measurements. The burnup values for all other samples were based on the ${ }^{148} \mathrm{Nd}$ method.

Table 15. Obrigheim sample burnup values from JRC measurements

\begin{tabular}{|c|c|c|c|c|c|c|}
\hline Assembly & $\begin{array}{c}\text { Fuel } \\
\text { sample }\end{array}$ & $\begin{array}{l}\text { Measurement } \\
\text { laboratory }\end{array}$ & $\begin{array}{c}{ }^{148} \mathrm{Nd} \\
\text { burnup } \\
(\mathrm{MWd} / \mathrm{MTU})\end{array}$ & $\begin{array}{l}\text { Destructive } \\
{ }_{137} \text { Cs burnup } \\
\text { (MWd/MTU) }\end{array}$ & $\begin{array}{c}\text { Non- } \\
\text { destructive } \\
{ }^{137} \text { Cs burnup } \\
\text { (MWd/MTU) }\end{array}$ & $\begin{array}{c}\text { Recommended } \\
\text { burnup } \\
\text { (MWd/MTU) }\end{array}$ \\
\hline \multirow[t]{18}{*}{ BE124 } & D1-P1 & Karlsruhe & 21,170 & \multirow{4}{*}{$\begin{array}{l}33,160 \\
19,540\end{array}$} & 19,520 & 21,170 \\
\hline & D1-P3 & Ispra & 33,750 & & 33,760 & 33,750 \\
\hline & E3-P1 & Ispra & 20,180 & & 19,420 & 20,180 \\
\hline & E3-P2 & Karlsruhe & 35,100 & & 29,350 & 29,350 \\
\hline & E3-P3 & Ispra & 36,260 & \multirow{3}{*}{$\begin{array}{l}35,220 \\
30,640\end{array}$} & 35,510 & 36,260 \\
\hline & E3-P4 & Ispra & 30,890 & & 28,140 & \multirow{2}{*}{30,920} \\
\hline & E3-P4 & Karlsruhe & 30,940 & & & \\
\hline & E3-P5 & Ispra & 22,860 & 22,570 & 22,920 & 22,860 \\
\hline & G7-P1 & Ispra & 17,130 & \multirow[t]{2}{*}{16,970} & 17,490 & \multirow[t]{2}{*}{17,130} \\
\hline & $\mathrm{G} 7-\mathrm{P} 1^{a}$ & Karlsruhe & 22,700 & & & \\
\hline & G7-P2 & Ispra & 25,830 & 24,880 & 26,240 & 25,830 \\
\hline & G7-P3 & Ispra & 31,500 & \multirow[t]{2}{*}{31,400} & 31,920 & \multirow{2}{*}{31,320} \\
\hline & G7-P3 & Karlsruhe & 31,140 & & & \\
\hline & G7-P4 & Ispra & 27,710 & \multirow[t]{3}{*}{27,420} & 29,460 & 27,710 \\
\hline & G7-P5 & Karlsruhe & 25,810 & & 28,830 & 25,810 \\
\hline & M14-P1 & Karlsruhe & 15,600 & & 15,790 & 15,600 \\
\hline & M14-P3 & Ispra & 29,360 & \multirow[t]{2}{*}{28,800} & 27,200 & 29,360 \\
\hline & M14-P4 & Karlsruhe & 24,900 & & 27,460 & 24,900 \\
\hline \multirow[t]{8}{*}{ BE210 } & G14-P3-1 & Ispra & 38,100 & \multirow[t]{2}{*}{37,720} & \multirow[t]{2}{*}{36,290} & \multirow{2}{*}{37,490} \\
\hline & G14-P3-1 & Karlsruhe & 36,880 & & & \\
\hline & G14-P4-1 & Ispra & 35,640 & 35,480 & 36,070 & 35,640 \\
\hline & G14-P5-1 & Ispra & 30,160 & 30,660 & 31,870 & 30,160 \\
\hline & G14-P5-2 & Ispra & 24,220 & 24,400 & 26,060 & 24,220 \\
\hline & K14-P1 & Ispra & 25,450 & 22,900 & 22,460 & 22,900 \\
\hline & K14-P3-1 & Ispra & 36,670 & 35,990 & 35,120 & 36,670 \\
\hline & K14-P4-1 & Karlsruhe & 32,900 & & 34,630 & 32,900 \\
\hline
\end{tabular}

${ }^{a}$ Karlsruhe cross-check sample G7-P1 was determined to have a significantly different burnup than the corresponding Ispra sample and was not analyzed.

All measurement data were adjusted by the laboratories to the time of discharge. The concentration of ${ }^{239} \mathrm{Pu}$ includes the contribution from ${ }^{239} \mathrm{~Np}$. The measurement data are listed in Table 16. Fission product measurements were reported using final uranium in the sample as a basis and were adjusted in this report to initial uranium using ratio of initial to final uranium in the sample as determined from the measured uranium isotopes ${ }^{235} \mathrm{U},{ }^{236} \mathrm{U}$, and ${ }^{238} \mathrm{U}$. Data unit conversion was performed according to procedures and data described in Sect. 6.5.

The procedure of back-calculating isotopic concentrations to the time of discharge resulted in large experimental uncertainties for measured ${ }^{241} \mathrm{Am}$. Because most of the ${ }^{241} \mathrm{Am}$ in the sample at the time of 
measurement is produced by ${ }^{241} \mathrm{Pu}$ decay, the correction involves subtracting the large ${ }^{241} \mathrm{Pu}$ contribution from the measured ${ }^{241} \mathrm{Am}$ content, resulting in small ${ }^{241} \mathrm{Am}$ concentrations and a large increase in the relative error. The Ispra ${ }^{241} \mathrm{Am}$ results obtained by $\alpha$-spectrometry exhibit erratic behavior with burnup and are inconsistent with results measured using mass spectrometry at Ispra and $\alpha$-spectrometry at Karlsruhe. ${ }^{15}$ Consequently, the Ispra $\alpha$-spectrometry data for ${ }^{241} \mathrm{Am}$ are not recommended for use. Experimental uncertainties were not reported and cross-check data were not available. Analysis of ${ }^{241} \mathrm{Am}$ data from similar JRC programs indicates the error is approximately $20 \%$ (Ref. 13, p. 58). Analysis of ${ }^{242 \mathrm{~m}} \mathrm{Am}$ and ${ }^{243} \mathrm{Am}$ data show erratic trends with burnup and errors that likely exceed $20 \%$. Therefore, these data are not considered acceptable for validation.

An analysis of the ${ }^{244} \mathrm{Cm}$ in the experimental report ${ }^{15}$ indicates that the Karlsruhe and Ispra results are generally compatible. The Karlsruhe measurement of sample E3-P2 was found to be out of trend with other data and is rejected. Evaluation of the ${ }^{242} \mathrm{Cm}$ measurement data in Ref. 13 found that the results reported by Karlsruhe are much higher than the results from Ispra, and that the Karlsruhe data do not agree with isotopic predictions or experience with other similar fuel measurements. Therefore, the ${ }^{242} \mathrm{Cm}$ results from Karlsruhe are not considered reliable for use as benchmark data and are similarly rejected. 
Table 16. Experimental results for Obrigheim JRC samples ${ }^{a}\left(\mathrm{mg} / \mathrm{g} \mathbf{U}_{\text {initial }}\right)$

\begin{tabular}{|c|c|c|c|c|c|c|c|c|c|c|c|}
\hline Assembly & BE124 & BE124 & BE124 & BE124 & BE124 & BE124 & BE124 & BE124 & BE124 & BE124 & BE124 \\
\hline Sample ID & D1-P1 & D1-P3 & E3-P1 & E3-P2 & E3-P3 & E3-P4 & E3-P5 & G7-P1 & G7-P2 & G7-P3 & G7-P4 \\
\hline $\begin{array}{c}\text { Burnup } \\
\text { (MWd/MTU) }\end{array}$ & 21,170 & 33,750 & 20,180 & 29,350 & 36,260 & 30,915 & 22,860 & 17,130 & 25,830 & 31,320 & 27,710 \\
\hline U-235 & $1.369 \mathrm{E}+01$ & $6.930 \mathrm{E}+00$ & $1.275 \mathrm{E}+01$ & $8.440 \mathrm{E}+00$ & $6.090 \mathrm{E}+00$ & $7.660 \mathrm{E}+00$ & $1.185 \mathrm{E}+01$ & $1.521 \mathrm{E}+01$ & $1.076 \mathrm{E}+01$ & $7.555 \mathrm{E}+00$ & $1.009 \mathrm{E}+01$ \\
\hline U-236 & $2.990 \mathrm{E}+00$ & $4.060 \mathrm{E}+00$ & $2.820 \mathrm{E}+00$ & $3.770 \mathrm{E}+00$ & $4.120 \mathrm{E}+00$ & $3.870 \mathrm{E}+00$ & $3.620 \mathrm{E}+00$ & $2.920 \mathrm{E}+00$ & $3.850 \mathrm{E}+00$ & $3.960 \mathrm{E}+00$ & $4.050 \mathrm{E}+00$ \\
\hline U-238 & $9.541 \mathrm{E}+02$ & $9.447 \mathrm{E}+02$ & $9.571 \mathrm{E}+02$ & $9.422 \mathrm{E}+02$ & $9.430 \mathrm{E}+02$ & $9.470 \mathrm{E}+02$ & $9.534 \mathrm{E}+02$ & $9.580 \mathrm{E}+02$ & $9.508 \mathrm{E}+02$ & $9.464 \mathrm{E}+02$ & $9.484 \mathrm{E}+02$ \\
\hline $\mathrm{Pu}-238$ & $3.600 \mathrm{E}-02$ & $1.560 \mathrm{E}-01$ & $4.100 \mathrm{E}-02$ & $1.040 \mathrm{E}-01$ & $1.650 \mathrm{E}-01$ & $1.140 \mathrm{E}-01$ & $6.200 \mathrm{E}-02$ & $3.100 \mathrm{E}-02$ & $7.900 \mathrm{E}-02$ & $1.415 \mathrm{E}-01$ & $1.060 \mathrm{E}-01$ \\
\hline $\mathrm{Pu}-239$ & $4.350 \mathrm{E}+00$ & $5.020 \mathrm{E}+00$ & $4.280 \mathrm{E}+00$ & $4.620 \mathrm{E}+00$ & $4.770 \mathrm{E}+00$ & $4.925 \mathrm{E}+00$ & $4.650 \mathrm{E}+00$ & $4.260 \mathrm{E}+00$ & $4.700 \mathrm{E}+00$ & $5.015 \mathrm{E}+00$ & $5.080 \mathrm{E}+00$ \\
\hline $\mathrm{Pu}-240$ & $1.320 \mathrm{E}+00$ & $2.360 \mathrm{E}+00$ & $1.360 \mathrm{E}+00$ & $1.990 \mathrm{E}+00$ & $2.410 \mathrm{E}+00$ & $2.230 \mathrm{E}+00$ & $1.620 \mathrm{E}+00$ & $1.160 \mathrm{E}+00$ & $1.810 \mathrm{E}+00$ & $2.280 \mathrm{E}+00$ & $2.040 \mathrm{E}+00$ \\
\hline $\mathrm{Pu}-241$ & $6.200 \mathrm{E}-01$ & $1.280 \mathrm{E}+00$ & $6.200 \mathrm{E}-01$ & $1.020 \mathrm{E}+00$ & $1.260 \mathrm{E}+00$ & $1.185 \mathrm{E}+00$ & $8.400 \mathrm{E}-01$ & $5.500 \mathrm{E}-01$ & $9.400 \mathrm{E}-01$ & $1.205 \mathrm{E}+00$ & $1.110 \mathrm{E}+00$ \\
\hline $\mathrm{Pu}-242$ & $1.280 \mathrm{E}-01$ & $5.640 \mathrm{E}-01$ & $1.390 \mathrm{E}-01$ & $3.800 \mathrm{E}-01$ & $6.290 \mathrm{E}-01$ & $4.760 \mathrm{E}-01$ & $2.110 \mathrm{E}-01$ & $9.900 \mathrm{E}-02$ & $2.790 \mathrm{E}-01$ & 4.890E-01 & $3.660 \mathrm{E}-01$ \\
\hline Am-241 & $2.190 \mathrm{E}-02$ & & & & & & & $1.400 \mathrm{E}-02$ & $2.480 \mathrm{E}-02$ & & \\
\hline Am- $242 m$ & & & & & & & & $2.880 \mathrm{E}-04$ & $4.940 \mathrm{E}-04$ & & \\
\hline Am-243 & & & & & & & & $8.600 \mathrm{E}-03$ & $3.900 \mathrm{E}-02$ & & \\
\hline $\mathrm{Cm}-242$ & & $1.565 \mathrm{E}-02$ & $4.500 \mathrm{E}-03$ & & $1.479 \mathrm{E}-02$ & $1.501 \mathrm{E}-02$ & $7.100 \mathrm{E}-03$ & $2.940 \mathrm{E}-03$ & $8.580 \mathrm{E}-03$ & $1.479 \mathrm{E}-02$ & $1.188 \mathrm{E}-02$ \\
\hline $\mathrm{Cm}-244$ & $2.220 \mathrm{E}-03$ & $3.397 \mathrm{E}-02$ & $2.040 \mathrm{E}-03$ & & 4.162E-02 & $2.349 \mathrm{E}-02$ & $5.130 \mathrm{E}-03$ & $1.040 \mathrm{E}-03$ & $9.490 \mathrm{E}-03$ & $2.823 \mathrm{E}-02$ & $1.652 \mathrm{E}-02$ \\
\hline Cs-134 & & $1.301 \mathrm{E}-01$ & $4.301 \mathrm{E}-02$ & & $1.380 \mathrm{E}-01$ & $1.116 \mathrm{E}-01$ & $6.247 \mathrm{E}-02$ & $3.498 \mathrm{E}-02$ & $7.567 \mathrm{E}-02$ & $1.190 \mathrm{E}-01$ & $9.562 \mathrm{E}-02$ \\
\hline Cs-137 & & $1.219 \mathrm{E}+00$ & $7.183 \mathrm{E}-01$ & & $1.294 \mathrm{E}+00$ & $1.127 \mathrm{E}+00$ & 8.298E-01 & $6.239 \mathrm{E}-01$ & $9.140 \mathrm{E}-01$ & $1.155 \mathrm{E}+00$ & $1.006 \mathrm{E}+00$ \\
\hline Nd-148 & $2.377 \mathrm{E}-01$ & $3.792 \mathrm{E}-01$ & $2.266 \mathrm{E}-01$ & & $4.078 \mathrm{E}-01$ & $3.472 \mathrm{E}-01$ & $2.571 \mathrm{E}-01$ & $1.923 \mathrm{E}-01$ & $2.901 \mathrm{E}-01$ & $3.519 \mathrm{E}-01$ & $3.117 \mathrm{E}-01$ \\
\hline Eu-154 & & $2.533 \mathrm{E}-02$ & 7.574E-03 & & $2.434 \mathrm{E}-02$ & $2.058 \mathrm{E}-02$ & $1.149 \mathrm{E}-02$ & $5.337 \mathrm{E}-03$ & $1.595 \mathrm{E}-02$ & $2.376 \mathrm{E}-02$ & $1.923 \mathrm{E}-02$ \\
\hline
\end{tabular}

${ }^{a}$ Measurements reported for reference date of $8 / 16 / 1974$ corresponding to time of discharge. 
Table 16. Experimental results for Obrigheim JRC samples ${ }^{a}$ (mg/g $\mathbf{U}_{\text {initial }}$ ) (continued)

\begin{tabular}{|c|c|c|c|c|c|c|c|c|c|c|c|}
\hline Assembly & BE124 & BE124 & BE124 & BE124 & BE210 & BE210 & BE210 & BE210 & BE210 & BE210 & BE210 \\
\hline Sample ID & G7-P5 & M14-P1 & M14-P3 & M14-P4 & G14-P3-1 & G14-P4-1 & G14-P5-1 & G14-P5-2 & K14-P1 & K14-P3-1 & K14-P4-1 \\
\hline $\begin{array}{c}\text { Burnup } \\
\text { (MWd/MTU) }\end{array}$ & 25,810 & 15,600 & 29,360 & 24,900 & 37,490 & 35,640 & 30,160 & 24,220 & 22,900 & 36,670 & 32,900 \\
\hline U-235 & $1.009 \mathrm{E}+01$ & $1.569 \mathrm{E}+01$ & $8.780 \mathrm{E}+00$ & $1.033 \mathrm{E}+01$ & $4.730 \mathrm{E}+00$ & $4.950 \mathrm{E}+00$ & $6.270 \mathrm{E}+00$ & $8.940 \mathrm{E}+00$ & $1.003 \mathrm{E}+01$ & $4.860 \mathrm{E}+00$ & $5.040 \mathrm{E}+00$ \\
\hline U-236 & $3.600 \mathrm{E}+00$ & $2.730 \mathrm{E}+00$ & $3.810 \mathrm{E}+00$ & $3.600 \mathrm{E}+00$ & $3.880 \mathrm{E}+00$ & $3.950 \mathrm{E}+00$ & $3.660 \mathrm{E}+00$ & $3.330 \mathrm{E}+00$ & $3.220 \mathrm{E}+00$ & $3.860 \mathrm{E}+00$ & $3.820 \mathrm{E}+00$ \\
\hline U-238 & $9.502 \mathrm{E}+02$ & $9.591 \mathrm{E}+02$ & $9.483 \mathrm{E}+02$ & $9.512 \mathrm{E}+02$ & $9.426 \mathrm{E}+02$ & $9.453 \mathrm{E}+02$ & $9.507 \mathrm{E}+02$ & $9.555 \mathrm{E}+02$ & $9.528 \mathrm{E}+02$ & $9.439 \mathrm{E}+02$ & $9.472 \mathrm{E}+02$ \\
\hline $\mathrm{Pu}-238$ & $7.900 \mathrm{E}-02$ & $2.500 \mathrm{E}-02$ & $1.070 \mathrm{E}-01$ & $7.600 \mathrm{E}-02$ & $1.645 \mathrm{E}-01$ & $1.590 \mathrm{E}-01$ & $1.140 \mathrm{E}-01$ & $6.500 \mathrm{E}-02$ & $6.500 \mathrm{E}-02$ & $1.690 \mathrm{E}-01$ & $1.260 \mathrm{E}-01$ \\
\hline $\mathrm{Pu}-239$ & $5.080 \mathrm{E}+00$ & $3.980 \mathrm{E}+00$ & $5.020 \mathrm{E}+00$ & $4.960 \mathrm{E}+00$ & $4.560 \mathrm{E}+00$ & $4.410 \mathrm{E}+00$ & $4.360 \mathrm{E}+00$ & $4.270 \mathrm{E}+00$ & $4.600 \mathrm{E}+00$ & $4.690 \mathrm{E}+00$ & $4.510 \mathrm{E}+00$ \\
\hline $\mathrm{Pu}-240$ & $1.950 \mathrm{E}+00$ & $1.040 \mathrm{E}+00$ & $2.080 \mathrm{E}+00$ & $1.860 \mathrm{E}+00$ & $2.495 \mathrm{E}+00$ & $2.380 \mathrm{E}+00$ & $2.110 \mathrm{E}+00$ & $1.720 \mathrm{E}+00$ & $1.740 \mathrm{E}+00$ & $2.470 \mathrm{E}+00$ & $2.370 \mathrm{E}+00$ \\
\hline $\mathrm{Pu}-241$ & $1.050 \mathrm{E}+00$ & $4.600 \mathrm{E}-01$ & $1.120 \mathrm{E}+00$ & $1.000 \mathrm{E}+00$ & $1.310 \mathrm{E}+00$ & $1.210 \mathrm{E}+00$ & $1.090 \mathrm{E}+00$ & $8.600 \mathrm{E}-01$ & $9.000 \mathrm{E}-01$ & $1.300 \mathrm{E}+00$ & $1.210 \mathrm{E}+00$ \\
\hline $\mathrm{Pu}-242$ & $3.200 \mathrm{E}-01$ & $7.500 \mathrm{E}-02$ & $3.840 \mathrm{E}-01$ & $2.990 \mathrm{E}-01$ & $7.800 \mathrm{E}-01$ & $6.800 \mathrm{E}-01$ & $4.940 \mathrm{E}-01$ & $2.850 \mathrm{E}-01$ & $2.640 \mathrm{E}-01$ & $7.350 \mathrm{E}-01$ & $6.580 \mathrm{E}-01$ \\
\hline Am-241 & & $6.700 \mathrm{E}-03$ & & & $4.100 \mathrm{E}-02$ & $4.030 \mathrm{E}-02$ & & $2.770 \mathrm{E}-02$ & $2.520 \mathrm{E}-02$ & & \\
\hline $\mathrm{Am}-242 \mathrm{~m}$ & & & & & $7.290 \mathrm{E}-04$ & $1.930 \mathrm{E}-03$ & $1.207 \mathrm{E}-03$ & $7.100 \mathrm{E}-04$ & & $7.570 \mathrm{E}-04$ & \\
\hline Am-243 & & & & & $1.540 \mathrm{E}-01$ & $1.380 \mathrm{E}-01$ & $4.200 \mathrm{E}-02$ & $3.600 \mathrm{E}-02$ & & $1.400 \mathrm{E}-01$ & \\
\hline $\mathrm{Cm}-242$ & & & $1.130 \mathrm{E}-02$ & & $1.454 \mathrm{E}-02$ & $1.436 \mathrm{E}-02$ & $1.170 \mathrm{E}-02$ & $7.560 \mathrm{E}-03$ & $8.130 \mathrm{E}-03$ & $1.775 \mathrm{E}-02$ & \\
\hline $\mathrm{Cm}-244$ & $1.068 \mathrm{E}-02$ & $1.040 \mathrm{E}-03$ & $1.799 \mathrm{E}-02$ & $8.910 \mathrm{E}-03$ & $5.288 \mathrm{E}-02$ & 4.715E-02 & $2.207 \mathrm{E}-02$ & $6.950 \mathrm{E}-03$ & $6.530 \mathrm{E}-03$ & $5.259 \mathrm{E}-02$ & $3.168 \mathrm{E}-02$ \\
\hline Cs- 134 & & & $1.018 \mathrm{E}-01$ & & $1.511 \mathrm{E}-01$ & $1.365 \mathrm{E}-01$ & $1.022 \mathrm{E}-01$ & $6.563 \mathrm{E}-02$ & $6.536 \mathrm{E}-02$ & $1.464 \mathrm{E}-01$ & \\
\hline Cs- 137 & & & $1.059 \mathrm{E}+00$ & & $1.382 \mathrm{E}+00$ & $1.300 \mathrm{E}+00$ & $1.124 \mathrm{E}+00$ & 8.942E-01 & 8.367E-01 & $1.316 \mathrm{E}+00$ & \\
\hline Nd-148 & $2.899 \mathrm{E}-01$ & $1.752 \mathrm{E}-01$ & $3.300 \mathrm{E}-01$ & $2.795 \mathrm{E}-01$ & $4.217 \mathrm{E}-01$ & $4.006 \mathrm{E}-01$ & $3.391 \mathrm{E}-01$ & $2.725 \mathrm{E}-01$ & $2.860 \mathrm{E}-01$ & $4.123 \mathrm{E}-01$ & $3.696 \mathrm{E}-01$ \\
\hline Eu-154 & & & $2.019 \mathrm{E}-02$ & & $2.608 \mathrm{E}-02$ & $2.488 \mathrm{E}-02$ & $1.996 \mathrm{E}-02$ & $1.294 \mathrm{E}-02$ & $1.317 \mathrm{E}-02$ & $2.770 \mathrm{E}-02$ & \\
\hline
\end{tabular}

${ }^{a}$ Measurements reported for reference date of $8 / 16 / 1974$ corresponding to time of discharge. 


\subsection{TURKEY POINT UNIT 3}

Turkey Point Unit 1 is a PWR in the United States with a net generating capacity of 699 MWe, which was designed by Westinghouse Electric Corp. (West). First power was achieved in November 1972 with an initial core consisting of West OFA/LOPAR $15 \times 15$ assemblies. $^{57}$

Radiochemical analysis of five fuel samples from two assemblies from the Turkey Point Unit 3 reactor was performed at the Battelle Columbus Laboratories. ${ }^{21}$ The samples were taken from five different fuel rods from sections located near the axial center of the assemblies, approximately $167 \mathrm{~cm}$ (66 in.) from the bottom of the fuel rod. Consequently, the samples had a very similar burnup and isotopic composition. Fuel rods G10, G9, and H9 were obtained from assembly D01. Fuel rods G10 and G9 were from assembly D04. The configuration of the Westinghouse $15 \times 15$ assembly showing the location of the measured fuel rods is illustrated in Fig. 9 (see Sect. 8.3). The characteristics of the measured samples are summarized in Table 17.

Table 17. Summary of the Turkey Point Unit 3 spent fuel samples

\begin{tabular}{cccccccc}
\hline Sample No. & Assembly & Rod ID & Sample ID & $\begin{array}{c}\text { Initial } \\
\text { enrichment } \\
\left(\mathbf{w t ~ \%}^{\mathbf{2 3 5}} \mathbf{U}\right)\end{array}$ & $\begin{array}{c}\text { Axial } \\
\text { location } \\
\text { (cm) }\end{array}$ & $\begin{array}{c}\text { Burnup } \\
\text { (GWd/MTU) }\end{array}$ & $\begin{array}{c}\text { Cooling } \\
\text { time } \\
\text { (days) }\end{array}$ \\
\hline 1 & D01 & G9 & D01-G9-15 & 2.556 & 167.6 & 30.72 & $927^{b}$ \\
2 & D01 & G10 & D01-G10-4 & 2.556 & 167.0 & 30.51 & 927 \\
3 & D01 & H9 & D01-H9-7 & 2.556 & 167.0 & 31.56 & 927 \\
4 & D04 & G9 & D04-G9-9 & 2.556 & 167.6 & 31.26 & 927 \\
5 & D04 & G10 & D04-G10-7 & 2.556 & 167.0 & 31.31 & 927 \\
\hline
\end{tabular}

${ }^{a}$ Height of sample location above bottom of fuel rod end plug.

${ }^{b}$ Value not reported. Obtained from Refs. 23 and 24.

${ }^{c}$ Last value designates the axial rod segment.

Source: Ref. 21, unless otherwise noted.

Isotopic measurements were reported for the uranium and plutonium isotopes and for ${ }^{148} \mathrm{Nd}$. Measured ${ }^{148} \mathrm{Nd}$ content was used to determine the sample burnup using the procedures of ASTM E 321 (Ref. 74) and E 267 (Ref. 78) standards. The ASTM procedures use isotopic dilution mass spectrometry to determine the concentrations of uranium, plutonium, and neodymium, with ${ }^{233} \mathrm{U},{ }^{242} \mathrm{Pu}$, and ${ }^{150} \mathrm{Nd}$ spikes. Measurement data were reported for isotopic abundances and atom ${ }^{148} \mathrm{Nd} /{ }^{238} \mathrm{U}$ and ${ }^{239} \mathrm{Pu} /{ }^{238} \mathrm{U}$ ratios in the samples. The relative isotopic distribution of the xenon and krypton in the fission gas was also measured by mass spectrometry but was not analyzed in the current report.

The isotopic concentrations with respect to initial uranium in the fuel were determined from the measured atom ratios using the following procedures. Isotopic mass ratios were first calculated from reported atom ratios and all isotopes were then calculated relative to final ${ }^{238} \mathrm{U}$ mass basis using the ${ }^{239} \mathrm{Pu} /{ }^{238} \mathrm{U}$ mass ratio. As an example of the procedure, the mass concentration of ${ }^{240} \mathrm{Pu}$ is calculated with respect to measured ${ }^{238} \mathrm{U}$ in the sample as

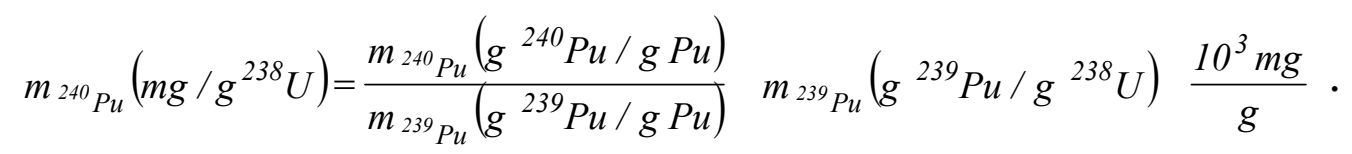

The initial heavy metal mass of the sample was calculated as the sum of the measured uranium and plutonium isotopes after irradiation plus the heavy metal mass reduction due to fission as derived from the ${ }^{148} \mathrm{Nd}$ concentration using procedures defined in Sect. 6.5. The isotopes not measured in these samples 
(Am, Cm) account for less than $0.1 \%$ of the heavy metal mass for these samples and negligible error in the procedure. The date of the measurements was not cited in the experimental report. An earlier evaluation $^{23}$ of the experimental data gives the time after discharge as 927 days, corresponding to a measurement date of June 3, 1980. This date was assumed in the current report. The long half-lives of most measured isotopes makes the results relatively insensitive to uncertainty in the measurement date. Only the value of ${ }^{241} \mathrm{Pu}\left(\mathrm{T}_{1 / 2}=14.4\right.$ years $)$ is influenced by the decay time.

Uncertainties in the measurements were not reported. The uncertainties were estimated in this report by evaluating the variance of the measurements with respect to a linear regression fit of the data as a function of sample burnup. The samples are sufficiently similar in burnup that the expected changes in the composition will be nearly linear with burnup over the range of data. The root mean square error was used to estimate the standard deviation of the random error from the residual of the data and linear regression fit. The relative error was calculated by dividing the root mean square error by the mean of all data points. The reported measurement data and the estimated uncertainties are given in Table 18 and Table 19, respectively. The error for ${ }^{148} \mathrm{Nd}$ was taken from ASTM E 321 (Ref. 74) based on typical laboratory experience.

Table 18. Experimental results ( $\left.\mathrm{mg} / \mathrm{g} \mathbf{U}_{\text {initial }}\right)$ for Turkey Point fuel samples

\begin{tabular}{|c|c|c|c|c|c|}
\hline Assembly & D01 & D01 & D01 & D04 & D04 \\
\hline Sample & G9-15 & G10-4 & H9-7 & G9-9 & G10-7 \\
\hline $\begin{array}{c}\text { Burnup } \\
\text { (MWd/MTU) }\end{array}$ & 30,720 & 30,510 & 31,560 & 31,260 & 31,310 \\
\hline U-234 & $1.299 \mathrm{E}-01$ & $1.299 \mathrm{E}-01$ & $1.205 \mathrm{E}-01$ & $1.113 \mathrm{E}-01$ & $1.298 \mathrm{E}-01$ \\
\hline U-235 & $5.793 \mathrm{E}+00$ & $5.607 \mathrm{E}+00$ & $5.515 \mathrm{E}+00$ & $5.442 \mathrm{E}+00$ & $5.593 \mathrm{E}+00$ \\
\hline U-236 & $3.228 \mathrm{E}+00$ & $3.229 \mathrm{E}+00$ & $3.149 \mathrm{E}+00$ & $3.131 \mathrm{E}+00$ & $3.226 \mathrm{E}+00$ \\
\hline U-238 & $9.506 \mathrm{E}+02$ & $9.510 \mathrm{E}+02$ & $9.499 \mathrm{E}+02$ & $9.503 \mathrm{E}+02$ & $9.502 \mathrm{E}+02$ \\
\hline $\mathrm{Pu}-238$ & $1.365 \mathrm{E}-01$ & $1.370 \mathrm{E}-01$ & $1.436 \mathrm{E}-01$ & $1.392 \mathrm{E}-01$ & $1.382 \mathrm{E}-01$ \\
\hline $\mathrm{Pu}-239$ & $4.860 \mathrm{E}+00$ & $4.875 \mathrm{E}+00$ & $4.966 \mathrm{E}+00$ & $4.977 \mathrm{E}+00$ & $4.823 \mathrm{E}+00$ \\
\hline $\mathrm{Pu}-240$ & $2.286 \mathrm{E}+00$ & $2.311 \mathrm{E}+00$ & $2.312 \mathrm{E}+00$ & $2.337 \mathrm{E}+00$ & $2.294 \mathrm{E}+00$ \\
\hline $\mathrm{Pu}-241$ & $1.075 \mathrm{E}+00$ & $1.076 \mathrm{E}+00$ & $1.113 \mathrm{E}+00$ & $1.132 \mathrm{E}+00$ & $1.080 \mathrm{E}+00$ \\
\hline $\mathrm{Pu}-242$ & $5.107 \mathrm{E}-01$ & $5.286 \mathrm{E}-01$ & $5.517 \mathrm{E}-01$ & $5.467 \mathrm{E}-01$ & $5.273 \mathrm{E}-01$ \\
\hline Nd-148 & 3.342E-01 & $3.319 \mathrm{E}-01$ & 3.434E-01 & $3.400 \mathrm{E}-01$ & $3.405 \mathrm{E}-01$ \\
\hline
\end{tabular}


Table 19. Experimental techniques and uncertainties for Turkey Point measurements

\begin{tabular}{lll}
\hline Nuclide & Method & $\begin{array}{c}\text { RSD }^{\boldsymbol{a}} \\
\mathbf{( \% )}\end{array}$ \\
\hline $\mathrm{U}-234$ & IDMS & 5.2 \\
$\mathrm{U}-235$ & IDMS & 2.1 \\
$\mathrm{U}-236$ & IDMS & 0.9 \\
$\mathrm{U}-238$ & IDMS & 0.01 \\
$\mathrm{Pu}-238$ & IDMS & 1.0 \\
$\mathrm{Pu}-239$ & IDMS & 0.9 \\
$\mathrm{Pu}-240$ & IDMS & 0.8 \\
$\mathrm{Pu}-241$ & IDMS & 1.6 \\
$\mathrm{Pu}-242$ & IDMS & 2.1 \\
\hline${ }^{a}$ The relative standard deviation (RSD) values associated with \\
the measurement techniques for the isotopes were determined in \\
DVD/xls/Experimantal_data.xls, worksheet turk.
\end{tabular}

\subsection{H. B. ROBINSON UNIT 2}

H. B. Robinson Unit 2 is a PWR in the United States with a net generating capacity of $769 \mathrm{MWe}$, which was designed by Westinghouse Electric Corp. (West). First power was achieved in September 1970 with an initial core consisting of West ANF Standard $15 \times 15$ assemblies. ${ }^{57}$

Radiochemical analyses of four fuel samples from H. B. Robinson Unit 2 were performed at the Materials Characterization Center (MCC) at Pacific Northwest Laboratory (PNL) as part of the Approved Testing Materials (ATM) program. ${ }^{26}$ The fuel sample material, designated ATM-101, was obtained from assembly BO-5 that was irradiated for the first two reactor operating cycles. The fuel rods were cut into segments at the Idaho Nuclear Engineering Laboratory and transported to the PNL hotcells at Hanford Engineering and Development Laboratory (HEDL) for destructive radiochemical analyses of the samples.

The burnup analyses were performed on four fuel samples obtained from rod N-9. The location of rod N-9 and the configuration of assembly BO-5 are shown in Fig. 11 (see Sect 8.4). The axial locations of the samples were selected to obtain a wide range of burnup values within the rod. The characteristics of the samples are listed in Table 20. The sample burnup was determined by the ${ }^{148} \mathrm{Nd}$ standard test method of the ASTM E 321 (Ref. 74). Note that the enrichment is given as $2.55 \mathrm{wt} \%{ }^{235} \mathrm{U}$ in the ATM-101 experimental report. ${ }^{26}$ However, the Department of Energy Information Administration database of spent fuel, RW-859 (Ref. 79), correspondence from the Electric Power Research Institute (EPRI), ${ }^{27}$ and Robinson 2 Plant Description ${ }^{29}$ indicate the actual enrichment was $2.561 \mathrm{wt} \%{ }^{235} \mathrm{U}$.

Table 20. Summary of H. B. Robinson fuel samples

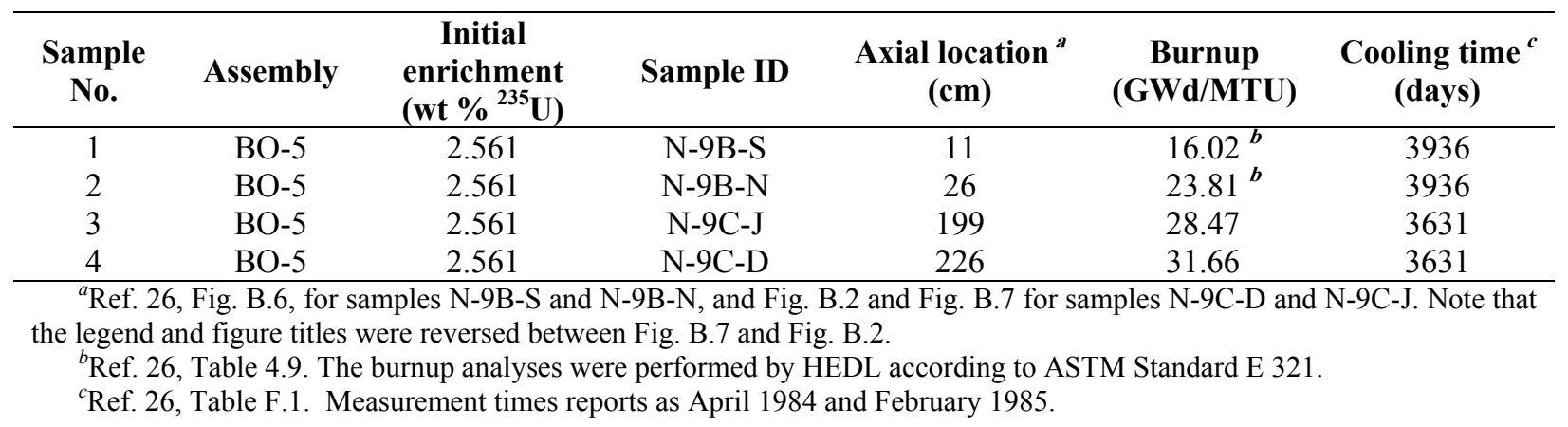


The radiochemical analysis of samples N-9C-D and N-9C-J were made in April 1984. Samples N-9B-N and N-9B-S were measured later in February 1985. The analysis dates were taken to be the middle of each month. Another fuel rod, P8, was also measured by Battelle Columbus laboratories, ${ }^{80,36}$ but the P8 rod data have not been evaluated in this work at this time.

The measurements include isotopes of uranium, plutonium, neodymium, ${ }^{237} \mathrm{~Np},{ }^{99} \mathrm{Tc}$, and ${ }^{137} \mathrm{Cs}$. The uranium and plutonium isotopes were determined as part of the burnup analyses using ASTM Standard Procedure E 321. The ASTM procedure uses isotopic dilution mass spectrometry with the spikes ${ }^{150} \mathrm{Nd}$, ${ }^{233} \mathrm{U}$, and ${ }^{242} \mathrm{Pu}$. Analyses for ${ }^{237} \mathrm{~Np}$ were made using a developmental procedure involving heavily spiking the samples with ${ }^{239} \mathrm{~Np}$ as a tracer and multiple neptunium separations. The ${ }^{99} \mathrm{Tc}$ was determined using a combination ion-exchange and solvent-extraction separation procedure and beta counting. The ${ }^{137} \mathrm{Cs}$ analyses were made by gamma spectral analysis using ASTM Standard Procedure E 692 (Ref. 81). Measurements of elemental uranium and plutonium were reported as $\mathrm{g} / \mathrm{g}$ fuel, and neodymium was reported as atoms/g fuel. Data for ${ }^{99} \mathrm{Tc}$ and ${ }^{137} \mathrm{Cs}$ were reported as activities and converted to mass contents in the current report using procedures described in Sect. 6.5.

Measurement uncertainties were not given in the experimental report. It was assumed that the procedures and uncertainties are similar to those reported in later ATM-series measurements, also performed at the PNL MCC laboratory. ${ }^{30}$ Neodymium uncertainty was reported separately ${ }^{34}$ as $<1 \%$ based on comparisons of the PNL data with independent measurements made at Los Alamos National Laboratory (LANL) and KRI for ${ }^{143} \mathrm{Nd}$ and ${ }^{145} \mathrm{Nd}$. Repeat analyses of ${ }^{148} \mathrm{Nd}$ for samples N-9C-D and N-9C-J resulted in relative differences of about $2 \%$ and $0.7 \%$, respectively. The estimated $\mathrm{Nd}$ isotope uncertainties were assumed to be about $1 \%$ based on these studies.

An independent verification of the burnup values in the current study using the reported ${ }^{148} \mathrm{Nd}$ measurements did not reproduce the burnup values cited by the laboratory. First, the exponent for the neodymium atom concentrations, listed as $10^{15}$ atoms per gram of fuel, is low by several orders of magnitude due to a reporting error. Furthermore, when atom \% fission (\% FIMA) is derived from the ${ }^{148} \mathrm{Nd}$ analysis results, the values are up to $14 \%$ larger than \% FIMA values cited in the experimental report (Ref. 26, Table 4.9). However, if the reported values of $\mathrm{Nd}$ atoms/g fuel are assumed to be actually ${ }^{148} \mathrm{Nd}$ atoms, the calculated \% FIMA values agree with values reported by the laboratory to within $1 \%$, with the exception of sample N-9C-D, for which it was $4 \%$ less than the reported value. Based on this observation, the reported $\mathrm{Nd}$ atom concentrations $\left(\times 10^{15}\right)$ were listed in this current report as ${ }^{148} \mathrm{Nd}$ atom concentrations $\left(\times 10^{18}\right)$. A second discrepancy in the plutonium isotopic vector for sample N-9B-N was identified in Table F.1 of Ref. 26. Using data from Table 4.1 of the same report, the error was traced to a reporting error for ${ }^{238} \mathrm{Pu}$ as the value is corrected in the current report. The measured isotopic compositions are listed in Table 21, and measurement methods and uncertainties are summarized in Table 22. 
Table 21. Experimental results ( $\left.\mathrm{mg} / \mathrm{g} \mathbf{U}_{\text {initial }}\right)$ for $\mathrm{H}$. B. Robinson fuel samples

\begin{tabular}{c|c|c|c|c}
\hline Assembly & BO-5 & BO-5 & BO-5 & BO-5 \\
\hline Sample & N-9C-D & N-9C-J & N-9B-N & N-9B-S \\
\hline Burnup & $\mathbf{3 1 , 6 6 0}$ & $\mathbf{2 8 , 4 7 0}$ & $\mathbf{2 3 , 8 1 0}$ & $\mathbf{1 6 , 0 2 0}$ \\
(MWd/MTU) & $1.253 \mathrm{E}-01$ & $1.339 \mathrm{E}-01$ & $1.556 \mathrm{E}-01$ & $1.755 \mathrm{E}-01$ \\
U-234 & $5.514 \mathrm{E}+00$ & $7.010 \mathrm{E}+00$ & $8.181 \mathrm{E}+00$ & $1.209 \mathrm{E}+01$ \\
U-235 & $3.403 \mathrm{E}+00$ & $3.204 \mathrm{E}+00$ & $3.103 \mathrm{E}+00$ & $2.487 \mathrm{E}+00$ \\
U-236 & $9.549 \mathrm{E}+02$ & $9.460 \mathrm{E}+02$ & $9.613 \mathrm{E}+02$ & $9.605 \mathrm{E}+02$ \\
U-238 & $1.479 \mathrm{E}-01$ & $1.293 \mathrm{E}-01$ & $7.894 \mathrm{E}-02$ & $3.208 \mathrm{E}-02$ \\
Pu-238 & $4.765 \mathrm{E}+00$ & $5.162 \mathrm{E}+00$ & $4.557 \mathrm{E}+00$ & $4.132 \mathrm{E}+00$ \\
Pu-239 & $2.404 \mathrm{E}+00$ & $2.236 \mathrm{E}+00$ & $1.890 \mathrm{E}+00$ & $1.241 \mathrm{E}+00$ \\
Pu-240 & $7.847 \mathrm{E}-01$ & $7.733 \mathrm{E}-01$ & $5.722 \mathrm{E}-01$ & $3.447 \mathrm{E}-01$ \\
Pu-241 & $6.001 \mathrm{E}-01$ & $4.682 \mathrm{E}-01$ & $3.208 \mathrm{E}-01$ & $1.155 \mathrm{E}-01$ \\
Pu-242 & $3.778 \mathrm{E}-01$ & $3.445 \mathrm{E}-01$ & $2.953 \mathrm{E}-01$ & $1.753 \mathrm{E}-01$ \\
Np-237 & $6.550 \mathrm{E}-01$ & $6.592 \mathrm{E}-01$ & $5.711 \mathrm{E}-01$ & $4.429 \mathrm{E}-01$ \\
Nd-143 & $1.162 \mathrm{E}+00$ & $1.051 \mathrm{E}+00$ & $8.794 \mathrm{E}-01$ & $5.756 \mathrm{E}-01$ \\
Nd-144 & $5.853 \mathrm{E}-01$ & $5.573 \mathrm{E}-01$ & $4.819 \mathrm{E}-01$ & $3.445 \mathrm{E}-01$ \\
Nd-145 & $5.998 \mathrm{E}-01$ & $5.575 \mathrm{E}-01$ & $4.631 \mathrm{E}-01$ & $3.071 \mathrm{E}-01$ \\
Nd-146 & $3.299 \mathrm{E}-01$ & $3.090 \mathrm{E}-01$ & $2.611 \mathrm{E}-01$ & $1.744 \mathrm{E}-01$ \\
Nd-148 & $1.628 \mathrm{E}-01$ & $1.519 \mathrm{E}-01$ & $1.249 \mathrm{E}-01$ & $8.044 \mathrm{E}-02$ \\
Nd-150 & $6.691 \mathrm{E}-01$ & $5.930 \mathrm{E}-01$ & $5.360 \mathrm{E}-01$ & $3.604 \mathrm{E}-01$ \\
Tc-99 & $9.317 \mathrm{E}-01$ & $8.193 \mathrm{E}-01$ & $7.043 \mathrm{E}-01$ & $4.691 \mathrm{E}-01$ \\
Cs-137 &
\end{tabular}

Source: Ref. 26, Table F.1, except for ${ }^{238} \mathrm{Pu}$ in sample N-9B-N which is from Table 4.12.

Table 22. Experimental techniques and uncertainties for H. B. Robinson measurements

\begin{tabular}{clc}
\hline Nuclide & Method & $\begin{array}{c}\text { RSD } \\
(\mathbf{\%})\end{array}$ \\
\hline $\mathrm{U}-234$ & IDMS & 1.6 \\
$\mathrm{U}-235$ & IDMS & 1.6 \\
$\mathrm{U}-236$ & IDMS & 1.6 \\
$\mathrm{U}-238$ & IDMS & 1.6 \\
$\mathrm{Pu}-238$ & IDMS & 1.6 \\
$\mathrm{Pu}-239$ & IDMS & 1.6 \\
$\mathrm{Pu}-240$ & IDMS & 1.6 \\
$\mathrm{Pu}-241$ & IDMS & 1.6 \\
$\mathrm{Pu}-242$ & IDMS & 1.6 \\
$\mathrm{~Np}-237$ & IDMS & 1.9 \\
$\mathrm{Nd}-143$ & IDMS & 1.0 \\
$\mathrm{Nd}-144$ & IDMS & 1.0 \\
$\mathrm{Nd}-145$ & IDMS & 1.0 \\
$\mathrm{Nd}-146$ & IDMS & 1.0 \\
Nd-148 & IDMS & 1.0 \\
Nd-150 & IDMS & 1.0 \\
Tc-99 & $\beta$-counting & 3.5 \\
$\mathrm{Cs}-137$ & $\gamma$-spec & 3.5 \\
\hline
\end{tabular}

${ }^{a}$ Relative standard deviation values from ATM-104 experiments, Ref. 31, Table 7.1. Neodymium uncertainties are based on reported data from Ref. 34 . 


\subsection{CALVERT CLIFFS UNIT 1}

Calvert Cliffs Unit 1 is a PWR in the United States with a generating capacity of $900 \mathrm{MWe}$, which was designed by Combustion Engineering Co. (CE). First power was achieved in December 1975 with an initial core consisting of CE $14 \times 14$ assemblies. ${ }^{57}$

Isotopic measurements for spent fuel samples from Calvert Cliffs Unit 1 reactor were performed at the PNL MCC for the ATM Program designed to characterize spent fuel in support of geological repository studies for the Office of Civilian Radioactive Waste Management (OCRWM). Three assemblies from the Calvert Cliffs reactor were analyzed as part of the ATM-103, ATM-104, and ATM-106 experiments. One fuel rod from each assembly was destructively analyzed to provide detailed isotopic characterization. Three fuel samples were analyzed from each fuel rod, providing data for nine samples.

The assembly design is a Combustion Engineering (CE) $14 \times 14$ lattice with 176 fuel rods and 5 large guide tubes for the assembly control cluster. The assembly configuration and location of ATM-103 fuel rod MLA098 and ATM-104 fuel rod MKP109 are illustrated in Fig. 13, whereas the assembly configuration and location of ATM-106 fuel rod NBD107 are illustrated in Fig. 14 (see Sect. 8.5). The fuel rods are representative of the different regions of the assembly that include the central asymptotic flux region, and perturbed regions next to the water guide tube, and at the edge of the assembly. The fuel samples were cut from different axial positions, providing data for a wide burnup range.

Radiochemical assay of the fuel samples performed initially at PNL included measurements of the major actinides, neodymium, and several radiological fission products. Measurements were later performed at PNL to provide additional data for fission products with large neutron cross sections important to nuclear criticality safety, including isotopes of cesium, and the lanthanides samarium, europium, and gadolinium. To obtain data for estimating the error associated with the lanthanide measurements, several ATM fuel samples were analyzed independently at LANL and the Khlopin Radium Institute (KRI) in St. Petersburg, Russia. Measurement data from PNL and KRI were combined in the current report. The Calvert Cliffs samples evaluated in this report are summarized in Table 23.

Table 23. Summary of Calvert Cliffs fuel samples

\begin{tabular}{|c|c|c|c|c|c|c|}
\hline $\begin{array}{l}\text { Sample } \\
\text { No. }\end{array}$ & Assembly & $\begin{array}{c}\text { PNL } \\
\text { sample ID }\end{array}$ & $\begin{array}{c}\text { KRI } \\
\text { sample ID }\end{array}$ & $\begin{array}{c}\text { Initial } \\
\text { enrichment } \\
\left(\text { wt } \%{ }^{c 35} \mathrm{U}\right)\end{array}$ & $\begin{array}{c}\text { Axial } \\
\text { location } \\
(\mathbf{c m})\end{array}$ & $\begin{array}{c}\text { Burnup }^{b, c} \\
(\text { GWd/MTU) }\end{array}$ \\
\hline 1 & D101 & 103-MLA098-JJ & & 2.72 & 361.7 & $18.68^{c}$ \\
\hline 2 & D101 & 103-MLA098-BB & & 2.72 & 346.3 & 26.62 \\
\hline 3 & D101 & 103-MLA098-P & & 2.72 & 208.9 & 33.17 \\
\hline 4 & D047 & 104-MKP109-LL & $87-81$ & 3.038 & 360.7 & 27.35 \\
\hline 5 & D047 & 104-MKP109-CC & $87-72$ & 3.038 & 346.0 & 37.12 \\
\hline 6 & D047 & 104-MKP109-P & $87-63$ & 3.038 & 209.3 & 44.34 \\
\hline 7 & ВТ03 & 106-NBD107-MM & & 2.453 & 359.3 & 31.40 \\
\hline 8 & BT03 & 106-NBD107-GG & $87-108$ & 2.453 & 350.7 & 37.27 \\
\hline 9 & ВT03 & 106-NBD107-Q & & 2.453 & 209.4 & 46.46 \\
\hline
\end{tabular}

${ }^{a}$ Ref. 30, Table D.1; Ref. 31, Table C.1; Ref. 32, Table D.1. Distance measured from the top of fuel rod.

${ }^{b}$ Burnup determinations were made by PNL using ${ }^{148} \mathrm{Nd}$ according to ASTM E 321.

${ }^{c}$ Burnup values are reported in Ref. 30, Table 4.13 with enrichment from Table 4.1; Ref. 31, Table 7.2 with enrichment from Table 3.1; and Ref. 32, Table 4.16 with enrichment from Table 4.1. 


\subsubsection{PNL Measurements}

The measurements at PNL were performed using the following main spectrometric methods: ${ }^{31}$

- $\quad$ isotope dilution mass spectrometry (IDMS) for $\mathrm{Nd}, \mathrm{U}$, and Pu nuclides, using a calibrated triple spike of ${ }^{150} \mathrm{Nd},{ }^{233} \mathrm{U}$, and ${ }^{242} \mathrm{Pu}$

- ICPMS measurements relative to ${ }^{143} \mathrm{Nd}$ and ${ }^{145} \mathrm{Nd}$ for the lanthanides $\mathrm{Sm}$, Eu, and Gd

- mass spectrometry (MS) for ${ }^{133} \mathrm{Cs}$ (Ref. 35 ) and ${ }^{135} \mathrm{Cs}$ after elemental separation of cesium

- $\quad \gamma$-spectrometry for ${ }^{137} \mathrm{Cs}$ and ${ }^{126} \mathrm{Sn}$

- $\quad \alpha$-spectrometry for ${ }^{241} \mathrm{Am}$ and ${ }^{237} \mathrm{~Np}$

- $\quad \beta$-spectrometry for ${ }^{99} \mathrm{Tc}$ and ${ }^{90} \mathrm{Sr}$

- liquid scintillation counting for ${ }^{79} \mathrm{Se}$

Isotopic measurements were reported in mass units of $\mathrm{g} / \mathrm{g}$ fuel or activity in units of $\mathrm{Ci} / \mathrm{g}$ gram fuel.

The lanthanide measurements were carried out using mass spectrometry without prior chemical separation into individual elements. This resulted in mass interference for nuclides with the same mass numbers 147 $(\mathrm{Pm}, \mathrm{Sm}), 150(\mathrm{Nd}, \mathrm{Sm}), 151(\mathrm{Sm}, \mathrm{Eu})$, and $155(\mathrm{Eu}, \mathrm{Gd})$, and measured data therefore included significant quantities of nuclides of more than one element. The measured data for these four mass numbers were adjusted by PNL using calculated isotopic ratios in order to infer information for individual isotopes. ${ }^{34}$ Consequently, the PNL lanthanide data for these isotopes were not considered in this report for validation studies to avoid introducing potential errors related to the calculated adjustments.

A summary of the measured nuclides, methods, and experimental uncertainties reported by the laboratory are provided in Table 24. Measurement uncertainties for most isotopes were reported by the laboratory. No uncertainties were reported for the ${ }^{133} \mathrm{Cs}$ results. Note that PNL reported curium data that combined ${ }^{242} \mathrm{Cm}$ and ${ }^{244} \mathrm{Cm}$. There values were not used in this study and results are not listed here. Experimental uncertainties for the lanthanides were evaluated by PNL using results of laboratory cross-check analyses performed for sample 87-81 measured at LANL and PNL using ICPMS, and at KRI using LA and IDMS measurement techniques. The burnup values used in the current study were the laboratory reported values based on measured ${ }^{148} \mathrm{Nd}$ using procedures of ASTM E 321 (Ref. 74). The relative standard error in the burnup is given as $2.5 \%$.

The PNL measurement data for the Calvert Cliffs samples are publicly available on the spent fuel isotopic composition database SFCOMPO, ${ }^{36}$ currently maintained and operated by the Organization for Economic Cooperation and Development (OECD)/ Nuclear Energy Agency (NEA) databank. The measurement data for ATM-104 served as the basis of an irradiated fuel benchmark for criticality calculations ${ }^{35}$ and was used for the OECD/NEA burnup credit criticality safety calculation benchmark Phase I-B. ${ }^{82}$ The SFCOMPO database currently does not include the lanthanide measurements made at PNL or KRI used in the current report. 
Table 24. Experimental techniques and uncertainties for Calvert Cliffs measurements at PNL

\begin{tabular}{|c|c|c|}
\hline Nuclide ID & Method $^{a}$ & $\begin{array}{c}\mathrm{RSD}^{b, c} \\
(\%)\end{array}$ \\
\hline U-234 & IDMS & 1.6 \\
\hline U-235 & IDMS & 1.6 \\
\hline U-236 & IDMS & 1.6 \\
\hline U-238 & IDMS & 1.6 \\
\hline $\mathrm{Pu}-238$ & IDMS & 1.6 \\
\hline $\mathrm{Pu}-239$ & IDMS & 1.6 \\
\hline $\mathrm{Pu}-240$ & IDMS & 1.6 \\
\hline $\mathrm{Pu}-241$ & IDMS & 1.6 \\
\hline $\mathrm{Pu}-242$ & IDMS & 1.6 \\
\hline $\mathrm{Np}-237$ & $\alpha$-spec & 1.9 \\
\hline Am-241 & $\alpha$-spec & 4.9 \\
\hline Cs-133 & IDMS & $\mathrm{N} / \mathrm{A}$ \\
\hline Cs-135 & IDMS & 14.0 \\
\hline Cs-137 & $\gamma$-spec & 3.5 \\
\hline Sr-90 & $\beta$-spec & 5.7 \\
\hline Tc-99 & $\beta$-spec & 3.5 \\
\hline Nd-143 & IDMS & $<1.0$ \\
\hline Nd-144 & IDMS & $\mathrm{N} / \mathrm{A}$ \\
\hline Nd-145 & IDMS & $<1.0$ \\
\hline Nd-146 & IDMS & N/A \\
\hline Nd-148 & IDMS & N/A \\
\hline Nd-150 & IDMS & N/A \\
\hline Sm-147 & $\mathrm{ICPMS}^{d}$ & 4.0 \\
\hline Sm-149 & ICPMS & 18.0 \\
\hline Sm-150 & ICPMS & 2.0 \\
\hline Sm-151 & ICPMS & 7.0 \\
\hline Sm-152 & ICPMS & 3.0 \\
\hline Eu-151 & ICPMS & $\mathrm{N} / \mathrm{A}$ \\
\hline Eu-153 & ICPMS & 2.0 \\
\hline Eu-155 & ICPMS & 29.0 \\
\hline Gd-155 & ICPMS & 29.0 \\
\hline $\begin{array}{l}{ }^{a} \text { Main techni } \\
\text { to eliminate inter } \\
{ }^{b} \text { Relative sta } \\
\text { Appendix B (lant } \\
{ }^{c} \text { N/A means } \\
{ }^{d} \text { Lanthanide } \\
\text { performed withou }\end{array}$ & $\begin{array}{l}\text {; some nuclic } \\
\text { tion reported } \\
\text { inties were no } \\
\text { d Gd) ICPMS } \\
\text { separation an }\end{array}$ & $\begin{array}{l}\text { iple techniques } \\
\text { Ref. } 33 \\
\text { hese isotopes. } \\
\text { were } \\
\text { in this work. }\end{array}$ \\
\hline
\end{tabular}

\subsubsection{KRI Measurements}

Additional lanthanide analyses were performed by KRI for Calvert Cliffs fuel samples from rod MKP109 and NBD107 at the request of PNL. ${ }^{37}$ KRI lanthanide measurements were reported for fuel samples identified as 87-81, 87-72, and 87-63, obtained from rod segments corresponding to PNL sections 
104-MKP109-LL, 104-MKP109-CC, and 104-MKP109-P, respectively. Lanthanide and rhodium $\left({ }^{103} \mathrm{Rh}\right)$ measurements are reported for sample 87-108 corresponding to the 106-NBD107-GG rod segment (see Table 23). The KRI measurements were reported in a series of technical reports ${ }^{37}$ and were reproduced in PNL-13677 (Ref. 33).

The KRI measurements involved the following radiochemical analysis techniques:

- Chemical separation of rare earth elements and transuranics followed by chemical separation of lanthanides into individual elements;

- IDMS for neodymium and gadolinium isotopes using spikes of ${ }^{142} \mathrm{Nd}$ and ${ }^{160} \mathrm{Gd}$;

- Luminescent analysis (LA) - laser-induced fluorometry for absolute measurement of europium and samarium content in the sample; the content was determined by comparison of the sample luminescence intensity with that of standard solutions containing known quantities of europium and samarium;

- MS for europium and samarium nuclides to determine relative isotope ratios;

- $\quad \mathrm{HPGe} \gamma$-spectrometry for ${ }^{154} \mathrm{Eu}$ and ${ }^{155} \mathrm{Eu}$;

- Quadrapole ICPMS for ${ }^{103} \mathrm{Rh}$ using an internal standard and a combined internal standard plus standard addition techniques.

Chemical separation of lanthanides performed at KRI prior to mass spectrometry measurements eliminated the element interferences present in the PNL lanthanide data. Absolute contents however were not reported by KRI. Isotopic compositions were generally reported as the ratio of nuclide mass to the ${ }^{145} \mathrm{Nd}$ mass. Isotopic abundance (wt \%) and relative element concentrations were also reported. For those nuclides not reported directly in $\mathrm{g} / \mathrm{g}{ }^{145} \mathrm{Nd}$ units, values were derived in this report using the relative isotopic mass abundance values and the total mass concentration of each element in the sample. For example, concentrations of ${ }^{156} \mathrm{Gd}$ relative to ${ }^{145} \mathrm{Nd}$ were calculated as

$$
{ }_{m^{156} G d}\left(g / g{ }^{145} N d\right)=\frac{m_{G d}(m g / \text { sample })}{m_{N d}(m g / \text { sample })} \frac{m_{156}{ }^{15 d}(g / g G d)}{m_{145}(g / g N d)}
$$

where $m_{G d}$ and $m_{N d}$ are the mass of elemental gadolinium and neodymium, respectively, in the sample. Uncertainties for the derived values were estimated using the same relative standard error as the values reported by KRI for sample 87-81 that included absolute error estimates for all measured isotopes.

The absolute lanthanide content for the KRI data was calculated in this report by normalizing the relative isotopic concentrations measured by KRI $\left(\mathrm{g} / \mathrm{g}{ }^{145} \mathrm{Nd}\right)$ using the absolute ${ }^{145} \mathrm{Nd}$ contents measured by PNL. The measured nuclides and experimental errors reported by KRI are listed in Table 25. Uncertainties in the KRI measurements were provided by the laboratory for most data used in this report. For data reported by KRI that did not explicitly provide uncertainty values, uncertainties were estimated using the relative error for other KRI samples. The measurements were obtained from Ref. 34, also data were reported in Ref. 37. However, reported values for ${ }^{152} \mathrm{Sm},{ }^{154} \mathrm{Gd},{ }^{155} \mathrm{Gd},{ }^{156} \mathrm{Gd}$, and ${ }^{158} \mathrm{Gd}$ for sample 87-81 are incorrect due to a transcription error in Table 2.5.2 of Ref. 37. 
Table 25. Experimental techniques and uncertainties for Calvert Cliffs measurements at KRI

\begin{tabular}{|c|c|c|}
\hline Nuclide ID & Method $^{a}$ & $\begin{array}{c}\text { RSD }^{b} \\
(\%)\end{array}$ \\
\hline Nd-143 & IDMS & $0.7-1.9$ \\
\hline Nd-145 & IDMS & $\mathrm{N} / \mathrm{A}$ \\
\hline Sm-147 & MS, LA & $2.5-3.3$ \\
\hline Sm-149 & MS, LA & $7.4-20.0$ \\
\hline $\mathrm{Sm}-150$ & MS, LA & $2.3-4.2$ \\
\hline Sm-151 & MS, LA & $3.2-4.7$ \\
\hline Sm-152 & MS, LA & $2.7-3.8$ \\
\hline Sm-154 & MS, LA & 5.7 \\
\hline Eu-151 & MS, LA & 9.7 \\
\hline Eu-154 & MS, LA, $\gamma$-spec & 8.6 \\
\hline Eu-155 & MS, LA, $\gamma$-spec & $2.7-16.7$ \\
\hline Gd-155 & IDMS & $3.0-3.7$ \\
\hline Rh-103 & ICPMS & 4.0 \\
\hline
\end{tabular}

The ${ }^{103} \mathrm{Rh}$ measurement was made using two techniques: $\mathrm{x}$-ray fluorescent analysis (xRFA) and ICPMS using several internal standard calibration techniques. In the current work only the ICPMS results were used because of large variability in the xRFA results. KRI also investigated use of several techniques including secondary ion mass spectrometry (SIMS) for some isotopes in sample 87-81. However, KRI reported that the samarium data measured by SIMS may not be reliable, and therefore, only the ICPMS results were used in the current work.

\subsubsection{3-MLA098}

Three fuel samples were analyzed from rod MLA098 located at the edge of assembly D101, designated ATM-103 test material. ${ }^{30}$ The samples were identified as 103-MLA098-P, 103-MLA098-BB, and 103-MLA098-JJ. Radiochemical analyses for these samples were performed only at PNL. The fuel is representative of average burnup fuel at that time.

The measured isotope concentrations are listed in Table 26. Burnup values were determined by the laboratory based on the ${ }^{148} \mathrm{Nd}$ content; however, neodymium isotopic data were not reported in the ATM-103 experimental report. The ATM-103 analysis date is reported as April 1987, with a cooling time of 6.5 years after discharge. A reference measurement date of April 15, 1987, was used for this study. This date gives a cooling time of 2374 days. Measurement uncertainties were not given in the ATM-103 experimental report. ${ }^{30}$ However, the measurement methods are consistent with subsequent ATM program measurements and the uncertainties are assumed to be the same as those cited in the ATM-104 report, listed in Table 24. 
Table 26. Measurement results for Calvert Cliffs 103-MLA098 samples (mg/g $\left.\mathbf{U}_{\text {initial }}\right)$

\begin{tabular}{lccccc}
\hline Nuclide & $\begin{array}{c}\text { Measurement } \\
\text { laboratory }\end{array}$ & $\begin{array}{c}\text { Measurement } \\
\text { date }^{\boldsymbol{a}}\end{array}$ & 103-MLA098-JJ & 103-MLA098-BB & 103-MLA098-P \\
\hline U-234 & PNL & $4 / 15 / 1987$ & $1.588 \mathrm{E}-01$ & $1.373 \mathrm{E}-01$ & $1.361 \mathrm{E}-01$ \\
U-235 & PNL & $4 / 15 / 1987$ & $1.163 \mathrm{E}+01$ & $7.873 \mathrm{E}+00$ & $5.423 \mathrm{E}+00$ \\
U-236 & PNL & $4 / 15 / 1987$ & $2.836 \mathrm{E}+00$ & $3.392 \mathrm{E}+00$ & $3.698 \mathrm{E}+00$ \\
U-238 & PNL & $4 / 15 / 1987$ & $9.700 \mathrm{E}+02$ & $9.686 \mathrm{E}+02$ & $9.554 \mathrm{E}+02$ \\
\hline Pu-238 & PNL & $4 / 15 / 1987$ & $5.502 \mathrm{E}-02$ & $1.099 \mathrm{E}-01$ & $1.682 \mathrm{E}-01$ \\
Pu-239 & PNL & $4 / 15 / 1987$ & $4.486 \mathrm{E}+00$ & $4.824 \mathrm{E}+00$ & $4.750 \mathrm{E}+00$ \\
Pu-240 & PNL & $4 / 15 / 1987$ & $1.410 \mathrm{E}+00$ & $2.003 \mathrm{E}+00$ & $2.395 \mathrm{E}+00$ \\
Pu-241 & PNL & $4 / 15 / 1987$ & $5.154 \mathrm{E}-01$ & $7.739 \mathrm{E}-01$ & $9.217 \mathrm{E}-01$ \\
Pu-242 & PNL & $4 / 15 / 1987$ & $1.581 \mathrm{E}-01$ & $3.745 \mathrm{E}-01$ & $6.210 \mathrm{E}-01$ \\
\hline Np-237 & PNL & $4 / 15 / 1987$ & $1.984 \mathrm{E}-01$ & $3.403 \mathrm{E}-01$ & $3.887 \mathrm{E}-01$ \\
Am-241 & PNL & $4 / 15 / 1987$ & $2.205 \mathrm{E}-01$ & $3.276 \mathrm{E}-01$ & $3.967 \mathrm{E}-01$ \\
\hline Se-79 & PNL & $4 / 15 / 1987$ & $2.534 \mathrm{E}-03$ & $3.391 \mathrm{E}-03$ & $4.093 \mathrm{E}-03$ \\
Sr-90 & PNL & $4 / 15 / 1987$ & $2.770 \mathrm{E}-01$ & $3.636 \mathrm{E}-01$ & $4.312 \mathrm{E}-01$ \\
Tc-99 & PNL & $4 / 15 / 1987$ & $4.684 \mathrm{E}-01$ & $6.208 \mathrm{E}-01$ & $7.486 \mathrm{E}-01$ \\
Sn-126 & PNL & $4 / 15 / 1987$ & $7.903 \mathrm{E}-03$ & $1.250 \mathrm{E}-02$ & $1.553 \mathrm{E}-02$ \\
\hline Cs-133 & PNL & $4 / 15 / 1987$ & & & \\
Cs-135 & PNL & $4 / 15 / 1987$ & $2.747 \mathrm{E}-01$ & $3.072 \mathrm{E}-01$ & $3.269 \mathrm{E}-01$ \\
Cs-137 & PNL & $4 / 15 / 1987$ & $5.998 \mathrm{E}-01$ & $8.533 \mathrm{E}-01$ & $1.053 \mathrm{E}+00$ \\
\hline
\end{tabular}

${ }^{a}$ Ref. 30. PNL measurements performed in April 1987 (6.5 years cooling time). A cooling time of 2374 days was used in this study.

\subsubsection{4-MKP109}

Three Calvert Cliffs fuel samples were measured from fuel rod MKP109 of assembly D047, designated as ATM-104 material. The rod is centrally located in the assembly, in an asymptotic flux region, and away from the guide tubes and periphery of the assembly. The three samples, identified as 104-MKP109-LL, 104-MKP109-CC, and 104-MKP109-P, were obtained from different axial locations of the rod.

The radiochemical analysis measurements were first performed at PNL in May $1987 .{ }^{31}$ Additional fission product measurements $\left({ }^{133} \mathrm{Cs}\right.$, isotopes of $\mathrm{Nd}, \mathrm{Sm}, \mathrm{Eu}$, and $\left.\mathrm{Gd}\right)$ were performed at PNL in October 1992, and the measured data were corrected for decay time to June 1987 (Ref. 34). These latter lanthanide measurements were performed without chemical separations and therefore included mass interference as discussed previously. In the current report the reference date for the PNL measurements was taken as May 31, 1987, corresponding to a cooling time of 1870 days, a value consistent with previous validation studies. ${ }^{38}$ The dates of the KRI measurements were inferred from information in the primary experimental reports $^{37}$ corresponding to cooling times of approximately 4171 and 4656 days. Sample 104-MKP109-LL (87-81) was measured September 17, 1993, and samples 104-MKP109-CC (87-72) and 104-MKP109-P (87-63) were measured in January 1995 (date of spike solution calibration).

The KRI lanthanide results, normalized to $\mathrm{g} / \mathrm{g}{ }^{145} \mathrm{Nd}$, are listed in Table 27. A comparison of the KRI and PNL neodymium isotopic results (with KRI values normalized to the ${ }^{145} \mathrm{Nd}$ concentration measurement by PNL) found that all isotopes agreed to within the estimated measurement uncertainty; better than $2 \%$. In the current report, the neodymium data measured by PNL were used for validation. Data for Sm, Eu, and Gd were based entirely on the KRI measurements because of the larger number of isotopes measured and the use of chemical separations. Cross-check evaluation of the KRI and PNL data for Sm, Eu, and Gd found that the results for most nuclides agreed to within about $10 \%$ after adjusting data for the difference in measurement dates. However, nuclides with very low concentrations, less than about $0.01 \mathrm{~g} / \mathrm{g}{ }^{145} \mathrm{Nd}$, were generally found to exhibit erratic behavior. Poor agreement was seen between the laboratories, and 
the measurement data did not trend reliably as a function of sample burnup. The results for ${ }^{149} \mathrm{Sm}$ showed large differences between laboratory measurements. The relative measurement accuracy for ${ }^{149} \mathrm{Sm}$ estimated by KRI and PNL was $20 \%$ and $18 \%$, respectively. The large error is likely associated with the low concentrations in the fuel, where the isotopic mass of ${ }^{149} \mathrm{Sm}$ is less than $0.5 \%$ of the elemental samarium mass. Large deviations were also observed for ${ }^{151} \mathrm{Eu}$ and ${ }^{152} \mathrm{Eu}$, which were present in the samples at concentrations close to the detection threshold. Therefore, the lanthanide data for the isotopes

${ }^{149} \mathrm{Sm},{ }^{151} \mathrm{Eu}$, and ${ }^{152} \mathrm{Eu}\left({ }^{152} \mathrm{Eu}\right.$ only reported by KRI) were rejected for use in validation in the current report.

Isotopic concentrations for the three 104-MKP109 samples are listed in Table 28. The data are compiled from three sources: the ATM-104 experimental report, ${ }^{31}$ subsequent fission product measurement performed at PNL, ${ }^{34}$ and independent measurements made at KRI. ${ }^{33}$ The KRI lanthanide data were measured in September 1993 and reported at the time of measurements. The KRI results were not adjusted to the time of the PNL measurements because some precursors were not measured. The KRI measurements method for ${ }^{154} \mathrm{Eu}$ included both mass and $\gamma$-spectrometry. The results obtained using the two methods are in good agreement and the recommended values are determined as a weighted average of the two results.

\subsubsection{6-NBD107}

Three fuel samples were analyzed from rod NBD107 of Calvert Cliffs Unit 1 assembly BT03 as part of the ATM-106 program. ${ }^{32}$ The fuel rod was located in a perturbed region at the edge of the center guide tube of the assembly. Rod NBD107 had a relatively high burnup for the enrichment. The samples were identified as 106-NBD107-MM, 106-NBD107-GG, and 106-NBD107-Q.

The measured isotopes are similar to those in the other ATM programs. One of the samples, section 106-NBD107-GG, had supplemental lanthanide measurements performed at KRI, ${ }^{37}$ thus providing more complete fission product data. In addition, KRI measured the concentration of ${ }^{103} \mathrm{Rh}$, an important fission product in spent fuel criticality safety analyses using burnup credit.

Lanthanide measurements for the NBD107 rod samples were not reported by PNL. Lanthanide data was measured at KRI on fuel material from sample 106-NBD107-GG, designated in the KRI measurements as sample 87-108. In addition, KRI performed ${ }^{103} \mathrm{Rh}$ measurements for this sample. The experimental data reported by PNL and KRI are listed as absolute contents in Table 29. The PNL measurements were reported for a reference measurement date given as June 1987, and a cooling time of 6.7 years after discharge. The effective date used in this work was July 1, 1987. The KRI rare earth measurements (Nd, $\mathrm{Eu}, \mathrm{Sm}, \mathrm{Gd}$ ) of sample 87-108 were performed in April 1996 and the rhodium measurement was performed in March 1996.

The PNL experimental report states that the ${ }^{234} U$ measurements may be suspect due to instrument drift. Although the results were corrected for drift, measurement error is likely larger than reported and these results are not recommended for use.

The ${ }^{103} \mathrm{Rh}$ concentration in the fuel was derived from separate analyzes of the rhodium and uranium content in the fuel sample. The mean value of the ICPMS rhodium measurement was $0.00676 \mathrm{mg} \pm 5 \%$ and the uranium content was $9.96 \mathrm{mg} \pm 6 \%$ in the sample (uncertainties represent the $p=95 \%$ confidence level). The ${ }^{103} \mathrm{Rh}$ mass content is calculated to be $0.068 \%$ with respect to the final uranium mass in the sample, with a $4 \%$ relative one standard deviation uncertainty. This value was adjusted to initial uranium in the sample using procedures described in Sect. 6.5 of this report. 
Table 27. KRI experimental lanthanide results for Calvert Cliffs samples (g/g $\left.{ }^{145} \mathrm{Nd}\right)$

\begin{tabular}{|c|c|c|c|c|c|c|c|c|c|c|c|c|}
\hline $\begin{array}{l}\text { KRI Sample ID } \\
\text { PNL Sample ID }\end{array}$ & \multicolumn{3}{|c|}{$87-81$} & \multicolumn{3}{|c|}{ 87-72 } & \multicolumn{3}{|c|}{$\begin{array}{c}87-63 \\
104-M K P 109-P\end{array}$} & \multicolumn{3}{|c|}{$\begin{array}{l}87-108 \\
\end{array}$} \\
\hline $\begin{array}{c}\text { Burnup }^{b} \\
\text { (GWd/MTU) }\end{array}$ & \multicolumn{3}{|c|}{27.35} & \multicolumn{3}{|c|}{37.12} & \multicolumn{3}{|c|}{44.34} & \multicolumn{3}{|c|}{37.27} \\
\hline Nuclide & $\begin{array}{c}\mathbf{g} / \mathbf{g} \\
\text { element } \\
(\%)\end{array}$ & $\mathrm{g} / \mathrm{g}{ }^{145} \mathrm{Nd}$ & $\sigma(\%)$ & $\begin{array}{c}\mathbf{g} / \mathbf{g} \\
\text { element } \\
(\%) \\
\end{array}$ & $\mathrm{g} / \mathrm{g}{ }^{145} \mathrm{Nd}$ & $\begin{array}{c}\sigma^{d} \\
(\%)\end{array}$ & $\begin{array}{c}\text { g/g element } \\
\text { (\%) }\end{array}$ & $\mathrm{g} / \mathrm{g}{ }^{145} \mathrm{Nd}$ & $\begin{array}{c}\sigma^{d} \\
(\%)\end{array}$ & $\begin{array}{c}\mathbf{g} / \mathbf{g} \\
\text { element } \\
(\%)\end{array}$ & $\mathrm{g} / \mathrm{g}{ }^{145} \mathrm{Nd}$ & $\begin{array}{l}\sigma^{d} \\
(\%)\end{array}$ \\
\hline ID-MS data & & & & & & & & & & & & \\
\hline Nd-142 & $0.65^{a}$ & 0.039 & 2.6 & 1.25 & 0.077 & 2.6 & 0.76 & 0.048 & 2.6 & 0.71 & 0.044 & 2.6 \\
\hline Nd-143 & 20.71 & 1.218 & 0.7 & 18.15 & 1.120 & 0.9 & 16.37 & 1.040 & 1.9 & 15.96 & 0.99 & 2.0 \\
\hline Nd-144 & 31.99 & 1.882 & 0.6 & 33.93 & 2.084 & 0.6 & 35.34 & 2.235 & 0.6 & 35.64 & 2.216 & 0.6 \\
\hline Nd-145 & 17.00 & 1.000 & & 16.28 & 1.000 & & 15.81 & 1.000 & & 16.08 & 1.000 & \\
\hline Nd-146 & 16.54 & 0.973 & 0.6 & 17.12 & 1.052 & 0.6 & 17.87 & 1.130 & 0.6 & 17.64 & 1.097 & 0.6 \\
\hline Nd-148 & 8.90 & 0.523 & 0.8 & 8.96 & 0.550 & 0.8 & 9.24 & 0.584 & 0.8 & 9.32 & 0.580 & 0.8 \\
\hline $\mathrm{Nd}-150$ & 4.21 & 0.248 & 8.1 & 4.32 & 0.265 & 8.1 & 4.59 & 0.290 & 8.1 & 4.65 & 0.289 & 8.1 \\
\hline Sm-147 & 34.40 & 0.398 & 3.3 & 30.57 & 0.365 & 2.5 & 28 & 0.365 & 3.3 & 29.14 & 0.367 & 2.5 \\
\hline Sm-148 & 14.92 & 0.173 & 1.7 & 18.3 & 0.218 & 1.7 & 20.39 & 0.226 & 1.7 & 18.78 & 0.236 & 1.7 \\
\hline Sm-149 & 0.40 & 0.005 & 20.0 & 0.22 & 0.0025 & 12.0 & 0.41 & 0.0054 & 7.4 & 0.22 & 0.0030 & 13.3 \\
\hline Sm-150 & 31.17 & 0.361 & 4.2 & 32.89 & 0.391 & 2.3 & 33.06 & 0.431 & 3.2 & 32.84 & 0.414 & 1.5 \\
\hline Sm-151 & 1.11 & 0.013 & 38.5 & 1.08 & 0.0127 & 3.1 & 0.97 & 0.0127 & 4.7 & 0.86 & 0.0110 & 4.6 \\
\hline Sm-152 & 13.41 & 0.155 & 3.2 & 12.56 & 0.148 & 2.7 & 12.05 & 0.157 & 3.8 & 13.26 & 0.167 & 2.4 \\
\hline Sm-154 & 4.54 & 0.053 & 5.7 & 4.32 & 0.051 & 5.7 & 5.12 & 0.067 & 5.7 & 4.9 & 0.062 & 5.7 \\
\hline Eu-151 & 1.88 & 0.0031 & 9.7 & 0.74 & 0.00140 & 9.7 & 1.91 & 0.00404 & 9.7 & 0.84 & 0.00183 & 9.7 \\
\hline $\mathrm{Eu}-152$ & 0.90 & 0.0002 & 100.0 & 0.04 & 0.00008 & 100.0 & 0.25 & 0.00053 & 100.0 & 0.08 & 0.00017 & 100.0 \\
\hline Eu-153 & 89.72 & 0.1472 & 1.8 & 91.98 & 0.17416 & 1.8 & 90.25 & 0.19201 & 1.8 & 93.9 & 0.2046 & 1.8 \\
\hline Eu-154 & 6.44 & 0.0105 & 8.6 & 6.26 & 0.01185 & 8.6 & 6.58 & 0.01393 & 8.6 & 4.48 & 0.00976 & 8.6 \\
\hline Eu-155 & 1.06 & 0.0018 & 16.7 & 0.98 & 0.00187 & 2.7 & 1.01 & 0.00215 & 2.8 & 0.71 & 0.00157 & 3.2 \\
\hline Gd-154 & 13.67 & 0.0236 & 2.1 & 13.28 & 0.0202 & 2.1 & 13.27 & 0.0237 & 2.1 & 11.46 & 0.0173 & 2.1 \\
\hline Gd-155 & 6.29 & 0.0108 & 3.7 & 6.58 & 0.0100 & 3.0 & 6.62 & 0.0118 & 3.4 & 6.35 & 0.0097 & 4.1 \\
\hline Gd-156 & 64.09 & 0.1100 & 1.8 & 65.10 & 0.0989 & 1.8 & 63.20 & 0.1129 & 1.8 & 66.26 & 0.1000 & 1.8 \\
\hline Gd-157 & 0.47 & $<0.00007$ & & 1.84 & 0.0028 & & 3.24 & 0.0058 & & 1.92 & 0.00290 & \\
\hline Gd-158 & 13.98 & 0.0241 & 2.1 & 13.20 & 0.0201 & 3.0 & 13.70 & 0.0245 & 2.1 & 13.56 & 0.0205 & 2.1 \\
\hline Gd-160 & 1.48 & 0.0025 & 12.0 & & & & & & & 0.46 & 0.00069 & 12.0 \\
\hline$\gamma$-spec data & & & & & & & & & & & & \\
\hline Eu-154 & & & & & 0.0117 & 5.1 & & 0.0119 & 5.9 & & & \\
\hline Eu-155 & & & & & 0.00182 & 4.9 & & 0.00209 & 5.7 & & & \\
\hline
\end{tabular}

${ }^{a}$ Values shown in italics are derived based on experimental data (see $D V D / x l s /$ Khlopin.xls). All other values are given in Ref. 33.

${ }^{b}$ As reported in Refs. 30 and 31 .

${ }^{c}$ Mass abundances for sample 87-81 are derived from measured isotopic mass data reported as nanograms per sample (see $D V D / x l s / K h l o p i n . x l s$ ).

${ }^{d}$ Relative uncertainties for derived concentrations assumed to be the same as sample 87-81. 
Table 28. Measurement results for Calvert Cliffs 104-MKP109 samples ( $\left.\mathrm{mg} / \mathbf{g} \mathbf{U}_{\text {initial }}\right)$

\begin{tabular}{|c|c|c|c|c|}
\hline Nuclide & $\begin{array}{c}\text { Measurement } \\
\text { laboratory }^{a}\end{array}$ & $\begin{array}{c}\text { 104-MKP109-LL } \\
(87-81)\end{array}$ & $\begin{array}{l}\text { 104-MKP109-CC } \\
(87-72)\end{array}$ & $\begin{array}{c}\text { 104-MKP109-P } \\
(87-63)\end{array}$ \\
\hline U-234 & PNL & $1.815 \mathrm{E}-01$ & $1.588 \mathrm{E}-01$ & $1.361 \mathrm{E}-01$ \\
\hline U-235 & PNL & $9.609 \mathrm{E}+00$ & $5.865 \mathrm{E}+00$ & $4.016 \mathrm{E}+00$ \\
\hline U-236 & PNL & $3.562 \mathrm{E}+00$ & $4.005 \mathrm{E}+00$ & $4.186 \mathrm{E}+00$ \\
\hline U-238 & PNL & $9.558 \mathrm{E}+02$ & $9.446 \mathrm{E}+02$ & $9.358 \mathrm{E}+02$ \\
\hline $\mathrm{Pu}-238$ & PNL & $1.146 \mathrm{E}-01$ & $2.147 \mathrm{E}-01$ & $3.049 \mathrm{E}-01$ \\
\hline $\mathrm{Pu}-239$ & PNL & $4.837 \mathrm{E}+00$ & $4.943 \mathrm{E}+00$ & $4.943 \mathrm{E}+00$ \\
\hline $\mathrm{Pu}-240$ & PNL & $1.950 \mathrm{E}+00$ & $2.540 \mathrm{E}+00$ & $2.885 \mathrm{E}+00$ \\
\hline $\mathrm{Pu}-241$ & PNL & $7.725 \mathrm{E}-01$ & $1.024 \mathrm{E}+00$ & $1.157 \mathrm{E}+00$ \\
\hline $\mathrm{Pu}-242$ & PNL & $3.279 \mathrm{E}-01$ & $6.535 \mathrm{E}-01$ & $9.530 \mathrm{E}-01$ \\
\hline Np-237 & PNL & $3.048 \mathrm{E}-01$ & $4.048 \mathrm{E}-01$ & $5.338 \mathrm{E}-01$ \\
\hline Am-241 & PNL & $2.830 \mathrm{E}-01$ & $3.901 \mathrm{E}-01$ & $4.331 \mathrm{E}-01$ \\
\hline Se-79 & PNL & $3.361 \mathrm{E}-03$ & $4.459 \mathrm{E}-03$ & 4.794E-03 \\
\hline Sr-90 & PNL & $3.784 \mathrm{E}-01$ & 4.864E-01 & $5.425 \mathrm{E}-01$ \\
\hline Tc-99 & PNL & $6.354 \mathrm{E}-01$ & $8.149 \mathrm{E}-01$ & $8.944 \mathrm{E}-01$ \\
\hline Sn-126 & PNL & $1.149 \mathrm{E}-02$ & $1.672 \mathrm{E}-02$ & $2.022 \mathrm{E}-02$ \\
\hline Cs-133 & PNL & $9.643 \mathrm{E}-01$ & $1.237 \mathrm{E}+00$ & $1.407 \mathrm{E}+00$ \\
\hline Cs-135 & PNL & $4.096 \mathrm{E}-01$ & $4.519 \mathrm{E}-01$ & 4.874E-01 \\
\hline Cs-137 & PNL & $8.768 \mathrm{E}-01$ & $1.177 \mathrm{E}+00$ & $1.424 \mathrm{E}+00$ \\
\hline Nd-143 & PNL & $6.954 \mathrm{E}-01$ & $8.123 \mathrm{E}-01$ & $8.656 \mathrm{E}-01$ \\
\hline Nd-144 & PNL & $1.070 \mathrm{E}+00$ & $1.518 \mathrm{E}+00$ & $1.864 \mathrm{E}+00$ \\
\hline Nd-145 & PNL & $5.786 \mathrm{E}-01$ & $7.408 \mathrm{E}-01$ & $8.440 \mathrm{E}-01$ \\
\hline Nd-146 & PNL & $5.559 \mathrm{E}-01$ & $7.737 \mathrm{E}-01$ & $9.416 \mathrm{E}-01$ \\
\hline Nd-148 & PNL & $3.006 \mathrm{E}-01$ & $4.073 \mathrm{E}-01$ & $4.855 \mathrm{E}-01$ \\
\hline $\mathrm{Nd}-150$ & PNL & $1.407 \mathrm{E}-01$ & $1.951 \mathrm{E}-01$ & $2.360 \mathrm{E}-01$ \\
\hline Sm-147 & KRI & $2.303 \mathrm{E}-01$ & $2.704 \mathrm{E}-01$ & $3.081 \mathrm{E}-01$ \\
\hline Sm-148 & KRI & $1.001 \mathrm{E}-01$ & $1.612 \mathrm{E}-01$ & $2.246 \mathrm{E}-01$ \\
\hline Sm-149 & $K R I$ & $2.893 E-03^{b}$ & $1.852 E-03$ & $4.558 E-03$ \\
\hline Sm-150 & KRI & $2.089 \mathrm{E}-01$ & $2.896 \mathrm{E}-01$ & $3.638 \mathrm{E}-01$ \\
\hline Sm-151 & KRI & $7.521 \mathrm{E}-03$ & $9.408 \mathrm{E}-03$ & $1.072 \mathrm{E}-02$ \\
\hline Sm-152 & KRI & $8.968 \mathrm{E}-02$ & $1.096 \mathrm{E}-01$ & $1.325 \mathrm{E}-01$ \\
\hline Sm-154 & KRI & $3.066 \mathrm{E}-02$ & $3.805 \mathrm{E}-02$ & $5.640 \mathrm{E}-02$ \\
\hline$E u-151$ & $K R I$ & $1.794 E-03$ & $1.045 E-03$ & $3.435 E-03$ \\
\hline$E u-152$ & $K R I$ & $1.157 E-04$ & $5.926 E-05$ & $4.473 E-04$ \\
\hline Eu-153 & KRI & $8.516 \mathrm{E}-02$ & $1.290 \mathrm{E}-01$ & $1.612 \mathrm{E}-01$ \\
\hline Eu-154 & KRI & $6.075 \mathrm{E}-03$ & $8.780 \mathrm{E}-03$ & $1.175 \mathrm{E}-02$ \\
\hline Eu-155 & KRI & $1.041 \mathrm{E}-03$ & $1.385 \mathrm{E}-03$ & $1.815 \mathrm{E}-03$ \\
\hline Gd-154 & KRI & $1.365 \mathrm{E}-02$ & $1.495 \mathrm{E}-02$ & $2.002 \mathrm{E}-02$ \\
\hline Gd-155 & KRI & $6.248 \mathrm{E}-03$ & $7.408 \mathrm{E}-03$ & $9.959 \mathrm{E}-03$ \\
\hline Gd-156 & KRI & $6.364 \mathrm{E}-02$ & 7.329E-02 & $9.533 \mathrm{E}-02$ \\
\hline Gd-157 & KRI & & $2.072 \mathrm{E}-03$ & $4.887 \mathrm{E}-03$ \\
\hline Gd-158 & KRI & $1.394 \mathrm{E}-02$ & $1.486 \mathrm{E}-02$ & $2.066 \mathrm{E}-02$ \\
\hline Gd-160 & KRI & $1.446 \mathrm{E}-03$ & & \\
\hline
\end{tabular}

${ }^{a}$ Ref. 31, Table 7.2. PNL burnup measurements performed in May 1987. Ref. 34, Table 3.2. PNL radiochemical analyses performed during June 1987, or corrected to this date. A reference date of 05/31/1987 was used in this work, yielding a cooling time of 1870 days. KRI lanthanide measurements for sample 87-81 performed 9/17/1993, and samples 87-63 and 87-72 performed $01 / 15 / 1995$, corresponding to decay times of 4171 and 4656 days, respectively.

${ }^{b}$ Values shown in italics are not recommended for use due to likely experimental errors. 
Table 29. Measurement results for Calvert Cliffs 106-NBD107 samples (mg/g $\left.\mathbf{U}_{\text {initial }}\right)$

\begin{tabular}{|c|c|c|c|c|}
\hline Nuclide & $\begin{array}{c}\text { Measurement } \\
\text { laboratory }{ }^{b}\end{array}$ & 106-NBD107-MM ${ }^{a}$ & $\begin{array}{c}\text { 106-NBD107-GG } \\
(87-108) \\
\end{array}$ & 106-NBD107-Q ${ }^{a}$ \\
\hline U-234 & PNL & $1.736 \mathrm{E}-01$ & $1.441 \mathrm{E}-01$ & $8.497 \mathrm{E}-02$ \\
\hline U-235 & PNL & $4.379 \mathrm{E}+00$ & $3.074 \mathrm{E}+00$ & $1.595 \mathrm{E}+00$ \\
\hline U-236 & PNL & $3.244 \mathrm{E}+00$ & $3.437 \mathrm{E}+00$ & $3.449 \mathrm{E}+00$ \\
\hline $\mathrm{U}-238$ & PNL & $9.581 \mathrm{E}+02$ & $9.572 \mathrm{E}+02$ & $9.384 \mathrm{E}+02$ \\
\hline $\mathrm{Pu}-238$ & PNL & $1.618 \mathrm{E}-01$ & $2.209 \mathrm{E}-01$ & $3.224 \mathrm{E}-01$ \\
\hline $\mathrm{Pu}-239$ & PNL & $4.327 \mathrm{E}+00$ & $4.351 \mathrm{E}+00$ & $4.272 \mathrm{E}+00$ \\
\hline $\mathrm{Pu}-240$ & PNL & $2.345 \mathrm{E}+00$ & $2.633 \mathrm{E}+00$ & $2.948 \mathrm{E}+00$ \\
\hline $\mathrm{Pu}-241$ & PNL & $8.236 \mathrm{E}-01$ & $9.223 \mathrm{E}-01$ & $1.005 \mathrm{E}+00$ \\
\hline $\mathrm{Pu}-242$ & PNL & $6.197 \mathrm{E}-01$ & $8.795 \mathrm{E}-01$ & $1.326 \mathrm{E}+00$ \\
\hline Np-237 & PNL & $2.967 \mathrm{E}-01$ & $3.645 \mathrm{E}-01$ & $4.290 \mathrm{E}-01$ \\
\hline Am-241 & PNL & $3.901 \mathrm{E}-01$ & $4.827 \mathrm{E}-01$ & 7.207E-01 \\
\hline Se-79 & PNL & $3.088 \mathrm{E}-03$ & $4.159 \mathrm{E}-03$ & $4.425 \mathrm{E}-03$ \\
\hline $\mathrm{Sr}-90$ & PNL & $3.826 \mathrm{E}-01$ & 4.271E-01 & $4.980 \mathrm{E}-01$ \\
\hline Тc-99 & PNL & $5.101 \mathrm{E}-01$ & $5.936 \mathrm{E}-01$ & $7.221 \mathrm{E}-01$ \\
\hline Rh-103 & KRI & & $6.542 \mathrm{E}-01$ & \\
\hline Sn-126 & PNL & $1.296 \mathrm{E}-02$ & $1.470 \mathrm{E}-02$ & $1.930 \mathrm{E}-02$ \\
\hline Cs-133 & PNL & & & \\
\hline Cs- 135 & PNL & $3.978 \mathrm{E}-01$ & $4.086 \mathrm{E}-01$ & $4.716 \mathrm{E}-01$ \\
\hline Cs- 137 & PNL & $9.761 \mathrm{E}-01$ & $1.119 \mathrm{E}+00$ & $1.464 \mathrm{E}+00$ \\
\hline Nd-143 & PNL & & 7.189E-01 & \\
\hline Nd-144 & PNL & & $1.603 \mathrm{E}+00$ & \\
\hline Nd-145 & PNL & & $7.246 \mathrm{E}-01$ & \\
\hline Nd-146 & PNL & & $7.805 \mathrm{E}-01$ & \\
\hline Nd-148 & PNL & & $4.124 \mathrm{E}-01$ & \\
\hline Nd-150 & PNL & & $\mathrm{N} / \mathrm{A}$ & \\
\hline Sm-147 & KRI & & $2.659 \mathrm{E}-01$ & \\
\hline Sm-148 & KRI & & $1.713 \mathrm{E}-01$ & \\
\hline$S m-149$ & $K R I^{c}$ & & $2.174 E-03$ & \\
\hline $\mathrm{Sm}-150$ & KRI & & $3.000 \mathrm{E}-01$ & \\
\hline $\mathrm{Sm}-151$ & KRI & & $7.970 \mathrm{E}-03$ & \\
\hline Sm-152 & KRI & & $1.210 \mathrm{E}-01$ & \\
\hline Sm-154 & KRI & & $4.470 \mathrm{E}-02$ & \\
\hline$E u-151$ & KRI & & $1.326 E-03$ & \\
\hline$E u-152$ & $K R I$ & & $1.263 E-04$ & \\
\hline Eu-153 & KRI & & $1.483 \mathrm{E}-01$ & \\
\hline Eu-154 & KRI & & $7.074 \mathrm{E}-03$ & \\
\hline Eu-155 & KRI & & $1.138 \mathrm{E}-03$ & \\
\hline Gd-154 & KRI & & $1.254 \mathrm{E}-02$ & \\
\hline Gd-155 & KRI & & $7.028 \mathrm{E}-03$ & \\
\hline Gd-156 & KRI & & $7.248 \mathrm{E}-02$ & \\
\hline Gd-157 & KRI & & $2.100 \mathrm{E}-03$ & \\
\hline Gd-158 & KRI & & $1.483 \mathrm{E}-02$ & \\
\hline Gd-160 & KRI & & $5.032 \mathrm{E}-04$ & \\
\hline
\end{tabular}

${ }^{a}$ Samples without reported lanthanide measurements by either PNL or KRI.

${ }^{b}$ Ref. 32. PNL Measurements performed in July 1987. KRI lanthanide measurements performed in April 1996, and rhodium measurements performed in March 1996 (Ref. 37). These dates yielded cooling times of 2447 for the PNNL measurements and 5658 and 5627 days for the KRI measurements (note that KRI measurements date of April can be used for all isotopes because rhodium is stable).

${ }^{c}$ Values shown in italics are not recommended for use due to likely experimental errors. 


\subsection{TAKAHAMA UNIT 3}

Takahama Unit 3 is a PWR in Japan with a net generating capacity of $870 \mathrm{MWe}$, which was designed by Mitsubishi Heavy Industries, Ltd. First power was achieved in May 1984 with an initial core consisting of Mitsubishi Nuclear Fuel (MNF)/Nuclear Fuel Industries (NFI) $15 \times 15$ assemblies. $^{57}$

From 1990 to 1999, Japan Atomic Energy Research Institute (JAERI) carried out a series of projects focused on obtaining high-quality experimental isotopic assay and criticality data to support the development of burnup credit for storage and transportation of spent fuel. The measurements included destructive radiochemical analyses of spent fuel samples, axial gamma scanning of spent fuel rods, and exponential experiments on spent fuel assemblies. The measured data were used by JAERI for evaluating the accuracy of depletion or criticality computer codes.

Sixteen samples selected from three fuel rods irradiated in assemblies NT3G23 and NT3G24 of the Takahama-3 reactor, which is operated in Japan, were included for destructive isotopic analyses. Five of these samples were from a $\mathrm{UO}_{2}-\mathrm{Gd}_{2} \mathrm{O}_{3}$ fuel rod (SF96), and 11 samples were from two $\mathrm{UO}_{2}$ fuel rods (SF96 and SF97). The reported burnup of these samples was between 8 and $47 \mathrm{GWd} / \mathrm{MTU}$. The Takahama Unit 3 samples evaluated in this report are summarized in Table 30.

Table 30. Summary of Takahama Unit 3 fuel samples from assemblies NT3G23 and NT3G24

\begin{tabular}{|c|c|c|c|c|c|c|}
\hline Assembly & $\begin{array}{l}\text { Rod } \\
\text { ID. }\end{array}$ & $\begin{array}{c}\text { Sample } \\
\text { No. }\end{array}$ & Sample ID & $\begin{array}{l}\text { Enrichment } \\
\left(\text { wt } \%{ }^{235} U\right)\end{array}$ & $\begin{array}{c}\text { Axial } \\
\text { location } \\
(\mathbf{c m})^{a}\end{array}$ & $\begin{array}{c}\text { Burnup } \\
\text { (GWd/MTU) }\end{array}$ \\
\hline \multirow[t]{10}{*}{ NT3G23 } & \multirow[t]{5}{*}{ SF95 } & 1 & SF95-1 & 4.11 & 20.1 & 14.30 \\
\hline & & 2 & SF95-2 & 4.11 & 36.1 & 24.35 \\
\hline & & 3 & SF95-3 & 4.11 & 88.1 & 35.42 \\
\hline & & 4 & SF95-4 & 4.11 & 216.1 & 36.69 \\
\hline & & 5 & SF95-5 & 4.11 & 356.1 & 30.40 \\
\hline & \multirow[t]{5}{*}{ SF96 } & 6 & SF96-1 & 2.63 & 17.6 & 7.79 \\
\hline & & 7 & SF96-2 & 2.63 & 33.6 & 16.44 \\
\hline & & 8 & SF96-3 & 2.63 & 85.6 & 28.20 \\
\hline & & 9 & SF96-4 & 2.63 & 213.6 & 28.91 \\
\hline & & 10 & SF96-5 & 2.63 & 353.6 & 24.19 \\
\hline \multirow[t]{6}{*}{ NT3G24G } & \multirow[t]{6}{*}{ SF97 } & 11 & SF97-1 & 4.11 & 16.3 & 17.69 \\
\hline & & 12 & SF97-2 & 4.11 & 35.0 & 30.73 \\
\hline & & 13 & SF97-3 & 4.11 & 62.7 & 42.16 \\
\hline & & 14 & SF97-4 & 4.11 & 183.9 & 47.03 \\
\hline & & 15 & SF97-5 & 4.11 & 292.6 & 47.25 \\
\hline & & 16 & SF97-6 & 4.11 & 355.6 & 40.79 \\
\hline
\end{tabular}

${ }^{a}$ Distance measured from top of fuel.

Source: Ref. 41.

The elements in each sample were separated by using exchange separation methods. The following experimental techniques were used to determine the nuclide concentrations: ${ }^{41}$

- ID-MS

- major actinides: $\mathrm{U}, \mathrm{Pu}$

- lanthanides: $\mathrm{Nd}, \mathrm{Sm}$

- $\alpha$-spectrometry plus MS

o Am, Cm

- $\gamma$-spectrometry 
o ${ }^{106} \mathrm{Ru},{ }^{134} \mathrm{Cs},{ }^{137} \mathrm{Cs},{ }^{144} \mathrm{Ce},{ }^{154} \mathrm{Eu},{ }^{125} \mathrm{Sb}$

- $\alpha$-spectrometry

o ${ }^{237} \mathrm{~Np}$

A summary of the nuclides measured, methods used, and corresponding experimental uncertainties are presented in Table 31. The reported experimental uncertainties were not specific for each sample measurement but were typical values based on previous measurement experience at JAERI. Not all nuclides shown in the table were measured in each of the samples. The reported experimental relative standard deviation is less than $0.5 \%$ for all measured $\mathrm{Pu}, \mathrm{Sm}$, and $\mathrm{Nd}$ isotopes, as well as for ${ }^{235} \mathrm{U}$ and ${ }^{238} \mathrm{U}$. For minor actinides measured by MS and $\alpha$-spectrometry the experimental errors are larger, in the 2 to $10 \%$ range. The nuclides determined through $\gamma$-spectrometry have measurement errors between 3 and $10 \%$.

The experimental results of the radiochemical analyses for the 16 samples from fuel rods SF95, SF96, and SF97 were reported as g/MTU initial. These data were reported at discharge time, except for samarium nuclides in samples from rod SF97 that were reported at 3.96 years after discharge. The measured data are presented in Table 32 through Table $34 \mathrm{in} \mathrm{g} / \mathrm{g} \mathrm{U}_{\text {initial. }}$. 
Table 31. Experimental techniques and uncertainties for Takahama-3 samples

\begin{tabular}{|c|c|c|}
\hline Nuclide ID & $\operatorname{Method~}^{a}$ & $\begin{array}{r}\text { RSD }^{b} \\
(\%)\end{array}$ \\
\hline U-234 & ID-MS & $<1.0$ \\
\hline U-235 & ID-MS & $<0.1$ \\
\hline U-236 & ID-MS & $<2.0$ \\
\hline U-238 & ID-MS & $<0.1$ \\
\hline $\mathrm{Pu}-238$ & ID-MS & $<0.5$ \\
\hline $\mathrm{Pu}-239$ & ID-MS & $<0.3$ \\
\hline $\mathrm{Pu}-240$ & ID-MS & $<0.3$ \\
\hline $\mathrm{Pu}-241$ & ID-MS & $<0.3$ \\
\hline $\mathrm{Pu}-242$ & ID-MS & $<0.3$ \\
\hline $\mathrm{Np}-237$ & $\alpha$-spec & $<10.0$ \\
\hline Am-241 & MS, $\alpha$-spec & $<2.0$ \\
\hline Am-242m & MS, $\alpha$-spec & $<10.0$ \\
\hline Am-243 & MS, $\alpha$-spec & $<5.0$ \\
\hline $\mathrm{Cm}-242$ & MS, $\alpha$-spec & $<10.0$ \\
\hline $\mathrm{Cm}-243$ & MS, $\alpha$-spec & $<2.0$ \\
\hline $\mathrm{Cm}-244$ & MS, $\alpha$-spec & $<2.0$ \\
\hline $\mathrm{Cm}-245$ & MS, $\alpha$-spec & $<2.0$ \\
\hline $\mathrm{Cm}-246$ & MS, $\alpha$-spec & $<5.0$ \\
\hline Cs-134 & $\gamma$-spec & $<3.0$ \\
\hline Cs-137 & $\gamma$-spec & $<3.0$ \\
\hline $\mathrm{Ce}-144$ & $\gamma$-spec & $<10.0$ \\
\hline Nd-142 & ID-MS & $<0.1$ \\
\hline Nd-143 & ID-MS & $<0.1$ \\
\hline Nd-144 & ID-MS & $<0.1$ \\
\hline Nd-145 & ID-MS & $<0.1$ \\
\hline $\mathrm{Nd}-146$ & ID-MS & $<0.1$ \\
\hline Nd-148 & ID-MS & $<0.1$ \\
\hline Nd-150 & ID-MS & $<0.1$ \\
\hline Sm-147 & ID-MS & $<0.1$ \\
\hline Sm-148 & ID-MS & $<0.1$ \\
\hline Sm-149 & ID-MS & $<0.1$ \\
\hline Sm-150 & ID-MS & $<0.1$ \\
\hline Sm-151 & ID-MS & $<0.1$ \\
\hline Sm-152 & ID-MS & $<0.1$ \\
\hline Sm-154 & ID-MS & $<0.1$ \\
\hline Eu-154 & $\gamma$-spec & $<3.0$ \\
\hline Ru-106 & $\gamma$-spec & $<5.0$ \\
\hline Sb-125 & $\gamma$-spec & $<10.0$ \\
\hline
\end{tabular}

${ }^{a}$ Main technique is listed; some nuclides require multiple techniques to eliminate interferences.

${ }^{b}$ Relative standard deviation.

Source: Ref. 41. 
Table 32. Experimental results ( $\left.\mathrm{g} / \mathrm{g} \mathbf{U}_{\text {initial }}\right)$ for Takahama-3 samples from rod SF95

\begin{tabular}{|c|c|c|c|c|c|}
\hline Assembly & NT3G23 & NT3G23 & NT3G23 & NT3G23 & NT3G23 \\
\hline Sample ID & SF95-1 & SF95-2 & SF95-3 & SF95-4 & SF95-5 \\
\hline $\begin{array}{c}\text { Burnup }^{a} \\
\text { (GWd/MTU) }\end{array}$ & 14.30 & 24.35 & 35.42 & 36.69 & 30.40 \\
\hline U-234 & $2.987 \mathrm{E}-04$ & $850 \mathrm{E}-04$ & 1.873E-04 & $1.870 \mathrm{E}-04$ & 2.829E-04 \\
\hline U-235 & $574 \mathrm{~B}$ & $927 \mathrm{E}-02$ & 1.326 & 1.23 & 02 \\
\hline U-236 & 572E-03 & 024E-03 & $4.911 \mathrm{E}-03$ & 4.999E-03 & 4.566 \\
\hline U-238 & 499E-01 & $9.424 \mathrm{E}-01$ & $9.338 \mathrm{E}-01$ & 9.335E-01 & 9.388E-01 \\
\hline $\mathrm{Pu}-238$ & $1.718 \mathrm{E}-05$ & 7.102E-05 & $1.539 \mathrm{E}-04$ & $1.588 \mathrm{E}-04$ & $1.020 \mathrm{E}-04$ \\
\hline $\mathrm{Pu}-23$ & $4.227 \mathrm{E}-03$ & $5.655 \mathrm{E}-03$ & 6.194E-03 & $6.005 \mathrm{E}-03$ & $5.635 \mathrm{E}-03$ \\
\hline $\mathrm{Pu}-2$ & $302 \mathrm{E}$ & $1.539 \mathrm{I}$ & 2.186 & 2.207E-03 & $1.821 \mathrm{E}-03$ \\
\hline $\mathrm{Pu}-$ & $3.690 \mathrm{E}-04$ & $9.578 \mathrm{E}-04$ & 1.4861 & $1.466 \mathrm{E}-03$ & $1.153 \mathrm{E}-03$ \\
\hline $\mathrm{Pu}-242$ & $3.790 \mathrm{E}-05$ & 1.844 & 4.516 & 4.803E-04 & $2.976 \mathrm{E}-04$ \\
\hline An & & 05 & 3.31 & 2.35 & -05 \\
\hline Am-2 & $1.840 \mathrm{E}$ & 5.201E-07 & 7.877 & 7.282E-07 & 5.687E-07 \\
\hline Am-243 & $2.682 \mathrm{E}-06$ & 2.289E-05 & $8.04^{\prime}$ & 8.47 & 4.40 \\
\hline & 1.510 & 7.672 & 1.96 & 2.32 & 1.00 \\
\hline $\mathrm{Cn}$ & 1.415 & 1.240 & 3.72 & 3.97 & 2.29 \\
\hline $\mathrm{Cm}$ & 2.712 & 5.042 & 2.56 & 2.83 & 1.06 \\
\hline & 5.519 & 1.96 & 1.39 & 1.58 & 4.839 \\
\hline $\mathrm{Cm}$ & 2.560 & $1.190 \mathrm{H}$ & $1.049 \mathrm{E}-07$ & $1.251 \mathrm{E}-07$ & $1.952 \mathrm{E}-08$ \\
\hline & & & & & \\
\hline $\mathrm{N}$ & 46 & 7.14 & 9.29 & 9.37 & 8.30 \\
\hline $\mathrm{Nc}$ & $3.276 \mathrm{E}-04$ & $6.046 \mathrm{H}$ & 9.347 & 1.02 & 7.928E-04 \\
\hline Nd-145 & $3.328 \mathrm{E}-04$ & 5.384E-04 & 7.392 & 7.598E-04 & $6.518 \mathrm{E}-04$ \\
\hline & 2.809 & 4.925 & 7.34 & 7.62 & 04 \\
\hline & 1.592 & 2.736 & 3.97 & 4.12 & 3.401 \\
\hline Nd-150 & 7.200E-05 & $1.258 \mathrm{E}-04$ & $1.895 \mathrm{E}-04$ & $1.959 \mathrm{E}-04$ & $1.572 \mathrm{E}-04$ \\
\hline & & & & & 1.0 \\
\hline Cs- 137 & 5.405E-04 & 9.336E-04 & $1.347 \mathrm{E}-03$ & $1.400 \mathrm{E}-03$ & $1.148 \mathrm{E}-03$ \\
\hline & & & & & \\
\hline Eu-154 & $4.093 \mathrm{E}-06$ & $1.306 \mathrm{E}-05$ & $2.525 \mathrm{E}-05$ & $2.657 \mathrm{E}-05$ & 1.817E-05 \\
\hline & & & 1.36 & 1.40 & 1.208 \\
\hline $\mathrm{Sb}-12$ & $1.471 \mathrm{E}-06$ & $2.900 \mathrm{E}-06$ & 3.733E-06 & $3.169 \mathrm{E}-06$ & $3.262 \mathrm{E}-06$ \\
\hline
\end{tabular}

${ }^{a}$ As reported in Ref. 41. Values correspond to discharge date of 6/19/1992.

${ }^{b} \mathrm{Pu}-239$ includes the amount of $\mathrm{Np}-239$. 
Table 33. Experimental results ( $\left.\mathrm{g} / \mathrm{g} \mathbf{U}_{\text {initial }}\right)$ for Takahama-3 samples from rod SF96

\begin{tabular}{|c|c|c|c|c|c|}
\hline Assembly & NT3G23 & NT3G23 & NT3G23 & NT3G23 & NT3G23 \\
\hline Sample ID & SF96-1 & SF96-2 & SF96-3 & SF96-4 & SF96-5 \\
\hline $\begin{array}{c}\text { Burnup }^{a} \\
(\text { GWd/MTU) }\end{array}$ & 7.79 & 16.44 & 28.20 & 28.91 & 24.19 \\
\hline U-234 & $1.805 \mathrm{E}-04$ & $1.522 \mathrm{E}-04$ & $1.251 \mathrm{E}-04$ & $1.250 \mathrm{E}-04$ & $1.354 \mathrm{E}-04$ \\
\hline U-235 & $1.944 \mathrm{E}-02$ & $1.408 \mathrm{E}-02$ & $8.638 \mathrm{E}-03$ & 8.064E-03 & $9.937 \mathrm{E}-03$ \\
\hline U-236 & $1.421 \mathrm{E}-03$ & $2.411 \mathrm{E}-03$ & $3.244 \mathrm{E}-03$ & $3.302 \mathrm{E}-03$ & $3.013 \mathrm{E}-03$ \\
\hline U-238 & $9.660 \mathrm{E}-01$ & $9.580 \mathrm{E}-01$ & $9.476 \mathrm{E}-01$ & $9.475 \mathrm{E}-01$ & $9.522 \mathrm{E}-01$ \\
\hline $\mathrm{Pu}-238$ & $8.536 \mathrm{E}-06$ & $4.172 \mathrm{E}-05$ & $1.206 \mathrm{E}-04$ & $1.248 \mathrm{E}-04$ & $7.978 \mathrm{E}-05$ \\
\hline $\mathrm{Pu}-239^{b}$ & $3.781 \mathrm{E}-03$ & $5.459 \mathrm{E}-03$ & $6.001 \mathrm{E}-03$ & $5.819 \mathrm{E}-03$ & $5.519 \mathrm{E}-03$ \\
\hline $\mathrm{Pu}-240$ & $6.764 \mathrm{E}-04$ & $1.494 \mathrm{E}-03$ & $2.303 \mathrm{E}-03$ & $2.327 \mathrm{E}-03$ & $1.964 \mathrm{E}-03$ \\
\hline $\mathrm{Pu}-241$ & $2.622 \mathrm{E}-04$ & $8.684 \mathrm{E}-04$ & $1.498 \mathrm{E}-03$ & $1.480 \mathrm{E}-03$ & $1.203 \mathrm{E}-03$ \\
\hline $\mathrm{Pu}-242$ & $2.440 \mathrm{E}-05$ & $1.615 \mathrm{E}-04$ & $5.103 \mathrm{E}-04$ & $5.411 \mathrm{E}-04$ & $3.551 \mathrm{E}-04$ \\
\hline Np-237 & $6.125 \mathrm{E}-05$ & $1.323 \mathrm{E}-04$ & $2.168 \mathrm{E}-04$ & $2.252 \mathrm{E}-04$ & $1.875 \mathrm{E}-04$ \\
\hline Am-241 & $5.985 \mathrm{E}-06$ & $1.735 \mathrm{E}-05$ & $2.845 \mathrm{E}-05$ & 3.094E-05 & $2.149 \mathrm{E}-05$ \\
\hline Am-242m & $1.218 \mathrm{E}-07$ & $4.579 \mathrm{E}-07$ & $6.413 \mathrm{E}-07$ & $6.793 \mathrm{E}-07$ & $5.647 \mathrm{E}-07$ \\
\hline Am-243 & $1.147 \mathrm{E}-06$ & $1.728 \mathrm{E}-05$ & $8.872 \mathrm{E}-05$ & $9.598 \mathrm{E}-05$ & $5.078 \mathrm{E}-05$ \\
\hline $\mathrm{Cm}-242$ & $8.502 \mathrm{E}-07$ & $5.781 \mathrm{E}-06$ & $1.628 \mathrm{E}-05$ & $1.679 \mathrm{E}-05$ & $1.115 \mathrm{E}-05$ \\
\hline $\mathrm{Cm}-244$ & $9.560 \mathrm{E}-08$ & $3.092 \mathrm{E}-06$ & $2.862 \mathrm{E}-05$ & $3.128 \mathrm{E}-05$ & $1.280 \mathrm{E}-05$ \\
\hline Nd-143 & $2.521 \mathrm{E}-04$ & $4.778 \mathrm{E}-04$ & $7.158 \mathrm{E}-04$ & $7.184 \mathrm{E}-04$ & $6.433 \mathrm{E}-04$ \\
\hline Nd-144 & $1.536 \mathrm{E}-04$ & $3.588 \mathrm{E}-04$ & $7.292 \mathrm{E}-04$ & $7.513 \mathrm{E}-04$ & $5.927 \mathrm{E}-04$ \\
\hline Nd-145 & $1.800 \mathrm{E}-04$ & $3.575 \mathrm{E}-04$ & $5.766 \mathrm{E}-04$ & $5.880 \mathrm{E}-04$ & $5.095 \mathrm{E}-04$ \\
\hline Nd-146 & $1.536 \mathrm{E}-04$ & $3.266 \mathrm{E}-04$ & $5.795 \mathrm{E}-04$ & $5.948 \mathrm{E}-04$ & $4.910 \mathrm{E}-04$ \\
\hline Nd-148 & $8.770 \mathrm{E}-05$ & $1.851 \mathrm{E}-04$ & $3.201 \mathrm{E}-04$ & $3.280 \mathrm{E}-04$ & $2.733 \mathrm{E}-04$ \\
\hline Nd-150 & $4.130 \mathrm{E}-05$ & 8.972E-05 & $1.591 \mathrm{E}-04$ & $1.628 \mathrm{E}-04$ & $1.331 \mathrm{E}-04$ \\
\hline Cs-134 & 8.609E-06 & $3.759 \mathrm{E}-05$ & $1.002 \mathrm{E}-04$ & $1.047 \mathrm{E}-04$ & $7.146 \mathrm{E}-05$ \\
\hline Cs-137 & $2.813 \mathrm{E}-04$ & $5.983 \mathrm{E}-04$ & $1.018 \mathrm{E}-03$ & $1.053 \mathrm{E}-03$ & $8.572 \mathrm{E}-04$ \\
\hline $\mathrm{Ce}-144$ & $1.179 \mathrm{E}-04$ & $2.250 \mathrm{E}-04$ & $3.362 \mathrm{E}-04$ & $3.453 \mathrm{E}-04$ & $3.145 \mathrm{E}-04$ \\
\hline Eu-154 & $2.309 \mathrm{E}-06$ & $8.538 \mathrm{E}-06$ & $1.973 \mathrm{E}-05$ & $1.992 \mathrm{E}-05$ & $1.423 \mathrm{E}-05$ \\
\hline $\mathrm{Ru}-106$ & $2.830 \mathrm{E}-05$ & $6.053 \mathrm{E}-05$ & $1.402 \mathrm{E}-04$ & $1.291 \mathrm{E}-04$ & $1.344 \mathrm{E}-04$ \\
\hline Sb-125 & $1.433 \mathrm{E}-06$ & $2.829 \mathrm{E}-06$ & $3.658 \mathrm{E}-06$ & $4.645 \mathrm{E}-06$ & $3.690 \mathrm{E}-06$ \\
\hline
\end{tabular}

${ }^{a}$ As reported in Ref. 41. Values correspond to discharge date of 6/19/1992.

${ }^{b} \mathrm{Pu}-239$ includes the amount of $\mathrm{Np}-239$. 
Table 34. Experimental results $\left(g / g U_{\text {initial }}\right)$ for Takahama-3 samples from rod SF97

\begin{tabular}{|c|c|c|c|c|c|c|}
\hline Assembly & NT3G24 & NT3G24 & NT3G24 & NT3G24 & NT3G24 & NT3G24 \\
\hline Sample ID & SF97-1 & SF97-2 & SF97-3 & SF97-4 & SF97-5 & SF97-6 \\
\hline $\begin{array}{c}\text { Burnup }^{a} \\
(\mathrm{GWd} / \mathrm{MTU})\end{array}$ & 17.69 & 30.73 & 42.16 & 47.03 & 47.25 & 40.79 \\
\hline U-234 & $2.939 \mathrm{E}-04$ & $2.348 \mathrm{E}-04$ & $2.010 \mathrm{E}-04$ & $1.872 \mathrm{E}-04$ & $1.865 \mathrm{E}-04$ & $2.057 \mathrm{E}-04$ \\
\hline U-235 & $2.347 \mathrm{E}-02$ & $1.571 \mathrm{E}-02$ & $1.030 \mathrm{E}-02$ & $8.179 \mathrm{E}-03$ & 7.932E-03 & $1.016 \mathrm{E}-02$ \\
\hline U-236 & $3.115 \mathrm{E}-03$ & $4.560 \mathrm{E}-03$ & $5.312 \mathrm{E}-03$ & $5.528 \mathrm{E}-03$ & $5.532 \mathrm{E}-03$ & $5.272 \mathrm{E}-03$ \\
\hline U-238 & $9.493 \mathrm{E}-01$ & $9.377 \mathrm{E}-01$ & $9.282 \mathrm{E}-01$ & $9.246 \mathrm{E}-01$ & $9.247 \mathrm{E}-01$ & $9.310 \mathrm{E}-01$ \\
\hline $\mathrm{Pu}-238$ & $2.370 \mathrm{E}-05$ & $1.250 \mathrm{E}-04$ & $2.581 \mathrm{E}-04$ & $3.199 \mathrm{E}-04$ & $3.188 \mathrm{E}-04$ & $2.175 \mathrm{E}-04$ \\
\hline $\mathrm{Pu}-239^{b}$ & $3.844 \mathrm{E}-03$ & $5.928 \mathrm{E}-03$ & $6.217 \mathrm{E}-03$ & $6.037 \mathrm{E}-03$ & $5.976 \mathrm{E}-03$ & $5.677 \mathrm{E}-03$ \\
\hline $\mathrm{Pu}-240$ & $9.347 \mathrm{E}-04$ & $1.871 \mathrm{E}-03$ & $2.471 \mathrm{E}-03$ & $2.668 \mathrm{E}-03$ & $2.648 \mathrm{E}-03$ & $2.326 \mathrm{E}-03$ \\
\hline $\mathrm{Pu}-241$ & $4.237 \mathrm{E}-04$ & $1.235 \mathrm{E}-03$ & $1.689 \mathrm{E}-03$ & $1.770 \mathrm{E}-03$ & $1.754 \mathrm{E}-03$ & $1.494 \mathrm{E}-03$ \\
\hline $\mathrm{Pu}-242$ & $6.185 \mathrm{E}-05$ & $3.152 \mathrm{E}-04$ & $6.517 \mathrm{E}-04$ & $8.246 \mathrm{E}-04$ & $8.341 \mathrm{E}-04$ & $5.977 \mathrm{E}-04$ \\
\hline Np-237 & $1.521 \mathrm{E}-04$ & 4.034E-04 & $5.845 \mathrm{E}-04$ & $6.604 \mathrm{E}-04$ & $6.701 \mathrm{E}-04$ & $5.570 \mathrm{E}-04$ \\
\hline Am-241 & $1.492 \mathrm{E}-05$ & 4.017E-05 & 4.909E-05 & $5.311 \mathrm{E}-05$ & $5.327 \mathrm{E}-05$ & 4.297E-05 \\
\hline Am-242m & $2.270 \mathrm{E}-07$ & $8.838 \mathrm{E}-07$ & $1.179 \mathrm{E}-06$ & $1.233 \mathrm{E}-06$ & $1.200 \mathrm{E}-06$ & $9.756 \mathrm{E}-07$ \\
\hline Am-243 & $4.448 \mathrm{E}-06$ & $5.132 \mathrm{E}-05$ & $1.410 \mathrm{E}-04$ & $1.924 \mathrm{E}-04$ & $1.935 \mathrm{E}-04$ & $1.170 \mathrm{E}-04$ \\
\hline $\mathrm{Cm}-242$ & $2.134 \mathrm{E}-06$ & $1.049 \mathrm{E}-05$ & $1.839 \mathrm{E}-05$ & $2.044 \mathrm{E}-05$ & $1.903 \mathrm{E}-05$ & $1.616 \mathrm{E}-05$ \\
\hline $\mathrm{Cm}-243$ & $2.483 \mathrm{E}-08$ & $2.773 \mathrm{E}-07$ & $6.921 \mathrm{E}-07$ & $8.721 \mathrm{E}-07$ & $8.670 \mathrm{E}-07$ & $5.600 \mathrm{E}-07$ \\
\hline $\mathrm{Cm}-244$ & $4.981 \mathrm{E}-07$ & $1.384 \mathrm{E}-05$ & $5.696 \mathrm{E}-05$ & $8.810 \mathrm{E}-05$ & $8.823 \mathrm{E}-05$ & $4.221 \mathrm{E}-05$ \\
\hline $\mathrm{Cm}-245$ & $1.087 \mathrm{E}-08$ & $6.848 \mathrm{E}-07$ & $3.735 \mathrm{E}-06$ & $6.042 \mathrm{E}-06$ & $5.915 \mathrm{E}-06$ & $2.363 \mathrm{E}-06$ \\
\hline $\mathrm{Cm}-246$ & $3.866 \mathrm{E}-10$ & $4.222 \mathrm{E}-08$ & $3.648 \mathrm{E}-07$ & $7.440 \mathrm{E}-07$ & $7.549 \mathrm{E}-07$ & $2.481 \mathrm{E}-07$ \\
\hline $\mathrm{Cm}-247$ & & $4.043 \mathrm{E}-10$ & 4.974E-09 & $1.098 \mathrm{E}-08$ & $1.075 \mathrm{E}-08$ & $3.139 \mathrm{E}-09$ \\
\hline Nd-143 & $5.450 \mathrm{E}-04$ & 8.307E-04 & $1.008 \mathrm{E}-03$ & $1.048 \mathrm{E}-03$ & $1.049 \mathrm{E}-03$ & $9.736 \mathrm{E}-04$ \\
\hline Nd-144 & 4.661E-04 & $8.843 \mathrm{E}-04$ & $1.331 \mathrm{E}-03$ & $1.567 \mathrm{E}-03$ & $1.599 \mathrm{E}-03$ & $1.311 \mathrm{E}-03$ \\
\hline Nd-145 & 4.045E-04 & $6.480 \mathrm{E}-04$ & $8.387 \mathrm{E}-04$ & $9.118 \mathrm{E}-04$ & $9.179 \mathrm{E}-04$ & $8.247 \mathrm{E}-04$ \\
\hline Nd-146 & $3.502 \mathrm{E}-04$ & $6.304 \mathrm{E}-04$ & $8.929 \mathrm{E}-04$ & $1.008 \mathrm{E}-03$ & $1.014 \mathrm{E}-03$ & $8.586 \mathrm{E}-04$ \\
\hline Nd-148 & $1.945 \mathrm{E}-04$ & $3.389 \mathrm{E}-04$ & $4.662 \mathrm{E}-04$ & $5.204 \mathrm{E}-04$ & $5.226 \mathrm{E}-04$ & 4.504E-04 \\
\hline Nd-150 & $8.570 \mathrm{E}-05$ & $1.582 \mathrm{E}-04$ & $2.234 \mathrm{E}-04$ & $2.516 \mathrm{E}-04$ & $2.518 \mathrm{E}-04$ & $2.130 \mathrm{E}-04$ \\
\hline Cs-134 & $2.983 \mathrm{E}-05$ & $1.030 \mathrm{E}-04$ & $1.829 \mathrm{E}-04$ & $2.139 \mathrm{E}-04$ & $2.144 \mathrm{E}-04$ & $1.632 \mathrm{E}-04$ \\
\hline Cs-137 & $6.617 \mathrm{E}-04$ & $1.151 \mathrm{E}-03$ & $1.582 \mathrm{E}-03$ & $1.749 \mathrm{E}-03$ & $1.761 \mathrm{E}-03$ & $1.531 \mathrm{E}-03$ \\
\hline Ce-144 & $2.026 \mathrm{E}-04$ & $3.061 \mathrm{E}-04$ & $3.720 \mathrm{E}-04$ & $3.756 \mathrm{E}-04$ & $3.750 \mathrm{E}-04$ & $3.714 \mathrm{E}-04$ \\
\hline Eu-154 & $5.253 \mathrm{E}-06$ & $1.973 \mathrm{E}-05$ & $3.293 \mathrm{E}-05$ & $3.739 \mathrm{E}-05$ & $3.707 \mathrm{E}-05$ & $2.859 \mathrm{E}-05$ \\
\hline Ru-106 & $5.163 \mathrm{E}-05$ & $1.162 \mathrm{E}-04$ & $1.829 \mathrm{E}-04$ & $1.936 \mathrm{E}-04$ & $1.162 \mathrm{E}-04$ & $1.959 \mathrm{E}-04$ \\
\hline Sb-125 & $2.462 \mathrm{E}-06$ & $5.118 \mathrm{E}-06$ & $4.966 \mathrm{E}-06$ & $6.090 \mathrm{E}-06$ & 7.507E-06 & $4.546 \mathrm{E}-06$ \\
\hline $\mathrm{Sm}-147^{c}$ & $1.529 \mathrm{E}-04$ & $2.050 \mathrm{E}-04$ & $2.355 \mathrm{E}-04$ & $2.468 \mathrm{E}-04$ & $2.479 \mathrm{E}-04$ & $2.371 \mathrm{E}-04$ \\
\hline Sm-148 & $4.092 \mathrm{E}-05$ & $1.194 \mathrm{E}-04$ & $1.978 \mathrm{E}-04$ & $2.338 \mathrm{E}-04$ & $2.357 \mathrm{E}-04$ & $1.809 \mathrm{E}-04$ \\
\hline Sm-149 & $2.935 \mathrm{E}-06$ & $3.976 \mathrm{E}-06$ & $4.259 \mathrm{E}-06$ & $3.943 \mathrm{E}-06$ & $3.799 \mathrm{E}-06$ & $3.843 \mathrm{E}-06$ \\
\hline Sm-150 & $1.323 \mathrm{E}-04$ & $2.499 \mathrm{E}-04$ & $3.599 \mathrm{E}-04$ & $4.074 \mathrm{E}-04$ & $4.113 \mathrm{E}-04$ & $3.409 \mathrm{E}-04$ \\
\hline Sm-151 & $9.324 \mathrm{E}-06$ & $1.351 \mathrm{E}-05$ & $1.503 \mathrm{E}-05$ & $1.491 \mathrm{E}-05$ & $1.465 \mathrm{E}-05$ & $1.294 \mathrm{E}-05$ \\
\hline Sm-152 & $6.526 \mathrm{E}-05$ & $9.546 \mathrm{E}-05$ & $1.191 \mathrm{E}-04$ & $1.298 \mathrm{E}-04$ & $1.319 \mathrm{E}-04$ & $1.207 \mathrm{E}-04$ \\
\hline Sm-154 & $1.425 \mathrm{E}-05$ & $2.977 \mathrm{E}-05$ & $4.536 \mathrm{E}-05$ & $5.252 \mathrm{E}-05$ & $5.298 \mathrm{E}-05$ & $4.231 \mathrm{E}-05$ \\
\hline
\end{tabular}

\footnotetext{
${ }^{a}$ As reported in Ref. $41 .{ }^{b} \mathrm{Pu}-239$ includes the amount of $\mathrm{Np}-239$.

${ }^{c}$ Measured data for Sm isotopes were reported at 3.96 years after discharge; at discharge time for all other isotopes $(9 / 30 / 1993)$.
} 


\subsection{TMI UNIT I}

TMI Unit 1 is a PWR in the United States with a net generating capacity of $871 \mathrm{MWe}$, which was designed by Babcock \& Wilcox Company (B\&W). First power was achieved in June 1974 with an initial core consisting of B\&W Mark B8 $15 \times 15$ assemblies. ${ }^{57}$

Measurements on 19 spent fuel samples from the TMI Unit 1 reactor were performed under the auspices of the DOE YMP. Fuel rods were obtained from two separate assemblies, identified as NJ05YU and NJ070G. Radiochemical analyses were performed at two independent experimental facilities: Argonne National Laboratory (ANL) and General Electric Vallecitos Nuclear Center (GE-VNC). Measurements on 11 of the samples from rod H6 of assembly NJ05YU were performed in 1998 and 2000 at ANL. ${ }^{44}$ The other eight samples, from rods O1, O12, and O13 of assembly NJ070G, were analyzed in 1999 at GE-VNC. ${ }^{45}$ The TMI Unit 1 samples evaluated in this report are summarized in Table 35.

Table 35. Summary of TMI Unit 1 fuel samples from assemblies NJ05YU and NJ070G

\begin{tabular}{l|c|l|l|c|c|c}
\hline Assembly & $\begin{array}{c}\text { Sample } \\
\text { No. }\end{array}$ & $\begin{array}{c}\text { Measurement } \\
\text { laboratory }\end{array}$ & Sample ID & $\begin{array}{c}\text { Enrichment } \\
\left(\mathbf{w t} \%{ }^{235} \mathbf{U}\right)\end{array}$ & $\begin{array}{c}\text { Axial } \\
\text { location } \\
(\mathbf{c m})^{a}\end{array}$ & $\begin{array}{c}\text { Burnup } \\
(\mathbf{G W d / M T U})^{b}\end{array}$ \\
\hline NJ05YU & 1 & ANL & A1B & 4.013 & 38.735 & 44.8 \\
& 2 & ANL & D2 & 4.013 & 322.072 & 44.8 \\
& 3 & ANL & B2 & 4.013 & 115.062 & 50.1 \\
& 4 & ANL & C1 & 4.013 & 235.458 & 50.2 \\
& 5 & ANL & D1A4 & 4.013 & 292.379 & 50.5 \\
& 6 & ANL & A2 & 4.013 & 74.676 & 50.6 \\
& 7 & ANL & C3 & 4.013 & 156.21 & 51.3 \\
& 8 & ANL & C2B & 4.013 & 194.615 & 52.6 \\
& 9 & ANL & B3J & 4.013 & 77.013 & 53.0 \\
& 10 & ANL & B1B & 4.013 & 155.956 & 54.5 \\
& 11 & ANL & D1A2 & 4.013 & 261.899 & 55.7 \\
\hline NJ070G & 12 & GE-VNC & O13S7 & 4.657 & 39.37 & 22.8 \\
& 13 & GE-VNC & O12S4 & 4.657 & 39.37 & 23.7 \\
& 14 & GE-VNC & O12S6 & 4.657 & 278.13 & 24.0 \\
& 15 & GE-VNC & O1S1 & 4.657 & 39.37 & 25.8 \\
& 16 & GE-VNC & O13S8 & 4.657 & 197.104 & 26.3 \\
& 17 & GE-VNC & O12S5 & 4.657 & 197.104 & 26.5 \\
& 18 & GE-VNC & O1S3 & 4.657 & 278.13 & 26.7 \\
& 19 & GE-VNC & O1S2 & 4.657 & 197.104 & 29.9 \\
\hline
\end{tabular}

${ }^{a}$ Distance between sample axial location and the tip of bottom end plug.

${ }^{b}$ Burnup values determined by laboratories from measured ${ }^{148} \mathrm{Nd}$.

Source: Refs. 44 and 45.

Both fuel assemblies were irradiated during cycle 10. Following indications of fuel leakage during cycle 10, EPRI examined the root causes of fuel rod failure. A detailed description of the investigations performed and the conclusions of the investigations have been made publicly available in the EPRI report TR-108784-V1 ${ }^{83}$ It was determined that the cause of fuel rod failure was localized cladding corrosion induced by crud that affected some of the fresh fuel assemblies during cycle 10. Crud accumulation appeared predominantly at the interface between neighboring fresh fuel assemblies and corner locations in fresh fuel assemblies, resulting in cladding and fuel temperatures well above normal operating temperatures. Assembly NJ070G was a fresh fuel assembly during cycle 10 with failed fuel. Rods O1, $\mathrm{O} 12$, and $\mathrm{O} 13$ of this assembly were intact but significantly affected by localized corrosion, as hot cell examination determined. Rod O1 was a corner rod with a higher average power than the other assembly 
rods, whereas rods $\mathrm{O} 12$ and $\mathrm{O} 13$ were in close proximity to a failed rod (O11). The fuel in assembly NJ05YU was adjacent to the failed fuel rods and was identified as having elevated levels of crud deposits on the fuel rods. Localized phenomena may have introduced additional uncertainties related to the actual irradiation conditions of the fuel that may affect the accuracy of code predictions. The type of uncertainties and their importance to the fuel simulations was not addressed in this validation.

\subsubsection{ANL Measurements}

The radiochemical analysis at ANL considered 11 samples from fuel rod $\mathrm{H} 6$ of assembly NJ05YU, cut from rod segments provided by GE-VNC. The samples for analysis were prepared by dissolution of an approximately $0.1-0.2 \mathrm{~g}$ aliquot of homogenized fuel sample powder. Analyses were carried out by using inductively coupled plasma mass spectrometry (ICPMS), $\gamma$-spectrometry, and $\alpha$-spectrometry to determine the isotopic mass of 31 nuclides. The use of isotopic dilution was limited to the uranium and plutonium isotopes, resulting in larger uncertainties for the other ICPMS results. The results were reported relative to the measured ${ }^{238} \mathrm{U}$ content in the sample, as $\mathrm{g} / \mathrm{g}{ }^{238} \mathrm{U}$. Two measures of the experimental uncertainty, a within-sample precision and a bias uncertainty, were provided by ANL. The within-sample precision was estimated by ANL as one standard deviation through repeated measurements of samples, whereas the bias uncertainty was estimated from deviations of quality control standard solutions measured in two separate phases of measurement performed at different times; the bias uncertainty included the propagation of error for normalization to ${ }^{238} \mathrm{U}$ (Ref. 44).

The main experimental techniques used for each nuclide and the reported corresponding experimental uncertainties $^{44}$ are presented in Table 36. In addition to the bias values shown in the table, a bias uncertainty of $3.8 \%$ was reported for ${ }^{238} \mathrm{U}$, but no explanation was provided on the significance of this value; it is assumed here that it refers to the absolute ${ }^{238} \mathrm{U}$ concentration measured directly. The withinsample precision shown in the table was calculated so that it accounted for error propagation due to normalization of the concentration to the ${ }^{238} \mathrm{U}$ content as

$$
\sigma_{i, \text { within-sample }}=\sqrt{\left(\sigma_{i, \text { within-sample }}^{\text {reported }}\right)^{2}+\left(\sigma_{238}^{\text {reported } \text {,within-sample }}\right)^{2}},
$$

where $i$ identifies the nuclide. The total uncertainty for the measured concentration of a nuclide $i$ expressed relative to the ${ }^{238} \mathrm{U}$ content is shown in the sixth column of Table 36 and was obtained by combining the within-sample uncertainty, calculated as in Eq. (13), and the reported bias, as

$$
\sigma_{i, \text { total }}=\sqrt{\left(\sigma_{i, \text { within-sample }}\right)^{2}+\left(\sigma_{i, \text { bias }}^{\text {reported }}\right)^{2}} \text {. }
$$

The total uncertainty is $3.7 \%$ for ${ }^{235} \mathrm{U}$, in the range $5-8 \%$ for plutonium nuclides, and about $5-7 \%$ for neodymium isotopes.

The measurement results for the samples analyzed at ANL (Ref. 44) are shown in Table 37. The data are obtained from the reported units of $\mathrm{g} / \mathrm{g}{ }^{238} \mathrm{U}$ using the procedures described in Sect. 6.5. 
Table 36. Experimental techniques and uncertainties for TMI-1 samples measurements at ANL

\begin{tabular}{|c|c|c|c|c|c|}
\hline Nuclide ID & Method $^{a}$ & $\begin{array}{c}\text { Reported } \\
\text { within-sample } \\
\text { precision } \\
(\%)\end{array}$ & $\begin{array}{c}\text { Reported } \\
\text { bias } \\
\text { uncertainty } \\
\quad(\%)\end{array}$ & $\begin{array}{c}\text { Within-sample } \\
\text { precision }{ }^{b} \\
\text { accounting for } \\
\text { normalization to }{ }^{238} \mathrm{U} \\
(\%) \\
\end{array}$ & $\begin{array}{c}\text { Total }^{c} \\
\text { uncertainty } \\
(\%)\end{array}$ \\
\hline U-234 & ICP-MS & 3.0 & 2.7 & 3.4 & 4.4 \\
\hline U-235 & ICP-MS & 1.5 & 2.9 & 2.3 & 3.7 \\
\hline U-236 & ICP-MS & 4.6 & 3.1 & 4.9 & 5.8 \\
\hline U-238 & ICP-MS & 1.7 & 3.8 & 2.4 & 4.5 \\
\hline Np-237 & ICP-MS & 4.1 & 3.4 & 4.4 & 5.6 \\
\hline $\mathrm{Pu}-238$ & $\alpha$-spec & 6.8 & 3.6 & 7.0 & 7.9 \\
\hline $\mathrm{Pu}-239$ & ICP-MS & 4.3 & 3.3 & 4.6 & 5.7 \\
\hline $\mathrm{Pu}-240$ & ICP-MS & 5.1 & 3.1 & 5.4 & 6.2 \\
\hline $\mathrm{Pu}-241$ & ICP-MS & 3.2 & 2.9 & 3.6 & 4.6 \\
\hline $\mathrm{Pu}-242$ & ICP-MS & 5.9 & 2.8 & 6.1 & 6.7 \\
\hline Am-241 & $\gamma$-spec & 6.1 & 3.1 & 6.3 & 7.1 \\
\hline Am-242m & ICP-MS & NA & 3.1 & & 3.1 \\
\hline Am-243 & ICP-MS & 4.2 & 3.8 & 4.5 & 5.9 \\
\hline Mo-95 & ICP-MS & 1.7 & 3.4 & 2.4 & 4.2 \\
\hline Tc-99 & ICP-MS & 2.7 & 7.3 & 3.2 & 8.0 \\
\hline Ru-101 & ICP-MS & 1.6 & 5.3 & 2.3 & 5.8 \\
\hline $\mathrm{Rh}-103$ & ICP-MS & 1.5 & 3.1 & 2.3 & 3.8 \\
\hline Ag-109 & ICP-MS & 4.7 & 3.1 & 5.0 & 5.9 \\
\hline Cs-137 & $\gamma$-spec & 3.6 & 2.7 & 4.0 & 4.8 \\
\hline Nd-143 & ICP-MS & 3.5 & 3.9 & 3.9 & 5.5 \\
\hline Nd-145 & ICP-MS & 4.8 & 3.5 & 5.1 & 6.2 \\
\hline Nd-148 & ICP-MS & 4.2 & 5.5 & 4.5 & 7.1 \\
\hline Sm-147 & ICP-MS & 3.3 & 9.4 & 3.7 & 10.1 \\
\hline Sm-149 & ICP-MS & 7.1 & 3.5 & 7.3 & 8.1 \\
\hline $\mathrm{Sm}-150$ & ICP-MS & 3.5 & 3.2 & 3.9 & 5.0 \\
\hline $\mathrm{Sm}-151$ & ICP-MS & 6.1 & 3.2 & 6.3 & 7.1 \\
\hline Sm-152 & ICP-MS & 2.7 & 3.2 & 3.2 & 4.5 \\
\hline $\mathrm{Eu}-151$ & ICP-MS & 12.0 & 2.9 & 12.1 & 12.5 \\
\hline Eu-153 & ICP-MS & 3.9 & 3.0 & 4.3 & 5.2 \\
\hline Eu-155 & $\gamma$-spec & 6.4 & 2.7 & 6.6 & 7.2 \\
\hline Gd-155 & ICP-MS & 6.8 & 3.8 & 7.0 & 8.0 \\
\hline
\end{tabular}


Table 37. Experimental results ( $\left.\mathrm{g} / \mathrm{g} \mathrm{U}_{\text {initial }}\right)$ for TMI-1 samples measured at ANL

\begin{tabular}{|c|c|c|c|c|c|c|c|c|c|c|c|}
\hline Assembly & NJ05YU & NJ05YU & NJ05YU & NJ05YU & NJ05YU & NJ05YU & NJ05YU & NJ05YU & NJ05YU & NJ05YU & NJ05YU \\
\hline Sample ID & $\mathrm{A1B}^{a}$ & D2 ${ }^{b}$ & $\mathrm{~B} 2^{b}$ & $C 1^{b}$ & $\mathrm{D1A4}^{a}$ & $A 2^{b}$ & $\mathrm{C3}^{b}$ & $\mathrm{C}^{2} \mathrm{~B}^{a}$ & $\mathrm{B3J}^{a}$ & $\mathrm{~B} \mathrm{~B}^{a}$ & D1A2 ${ }^{a}$ \\
\hline $\begin{array}{c}\text { Burnup } \\
\text { (GWd/MTU) }\end{array}$ & 44.8 & 44.8 & 50.1 & 50.2 & 50.5 & 50.6 & 51.3 & 52.6 & 53.0 & 54.5 & 55.7 \\
\hline U-234 & $2.054 \mathrm{E}-04$ & $1.923 \mathrm{E}-04$ & $1.868 \mathrm{E}-04$ & $1.977 \mathrm{E}-04$ & $1.975 \mathrm{E}-04$ & $1.912 \mathrm{E}-04$ & $1.847 \mathrm{E}-04$ & $1.808 \mathrm{E}-04$ & $1.834 \mathrm{E}-04$ & $1.877 \mathrm{E}-04$ & $1.927 \mathrm{E}-04$ \\
\hline U-235 & $8.605 \mathrm{E}-03$ & $7.378 \mathrm{E}-03$ & $6.205 \mathrm{E}-03$ & $6.588 \mathrm{E}-03$ & $7.485 \mathrm{E}-03$ & $6.319 \mathrm{E}-03$ & $6.251 \mathrm{E}-03$ & $6.228 \mathrm{E}-03$ & $6.111 \mathrm{E}-03$ & $6.386 \mathrm{E}-03$ & $6.966 \mathrm{E}-03$ \\
\hline U-236 & $5.111 \mathrm{E}-03$ & $5.334 \mathrm{E}-03$ & $5.400 \mathrm{E}-03$ & $5.470 \mathrm{E}-03$ & $5.362 \mathrm{E}-03$ & $5.497 \mathrm{E}-03$ & $5.327 \mathrm{E}-03$ & $5.185 \mathrm{E}-03$ & $5.456 \mathrm{E}-03$ & $5.402 \mathrm{E}-03$ & $5.452 \mathrm{E}-03$ \\
\hline $\mathrm{Pu}-238$ & $4.033 \mathrm{E}-04$ & $3.252 \mathrm{E}-04$ & $3.144 \mathrm{E}-04$ & $3.299 \mathrm{E}-04$ & $3.747 \mathrm{E}-04$ & $3.538 \mathrm{E}-04$ & $2.511 \mathrm{E}-04$ & $4.585 \mathrm{E}-04$ & $3.982 \mathrm{E}-04$ & $4.316 \mathrm{E}-04$ & $3.809 \mathrm{E}-04$ \\
\hline $\mathrm{Pu}-239$ & $5.064 \mathrm{E}-03$ & $5.427 \mathrm{E}-03$ & $5.289 \mathrm{E}-03$ & $5.405 \mathrm{E}-03$ & $5.399 \mathrm{E}-03$ & $5.340 \mathrm{E}-03$ & $5.512 \mathrm{E}-03$ & $4.991 \mathrm{E}-03$ & $5.088 \mathrm{E}-03$ & $5.107 \mathrm{E}-03$ & $5.452 \mathrm{E}-03$ \\
\hline $\mathrm{Pu}-240$ & $2.342 \mathrm{E}-03$ & $2.667 \mathrm{E}-03$ & $2.728 \mathrm{E}-03$ & $2.754 \mathrm{E}-03$ & $2.621 \mathrm{E}-03$ & $2.781 \mathrm{E}-03$ & $2.844 \mathrm{E}-03$ & $2.546 \mathrm{E}-03$ & $2.654 \mathrm{E}-03$ & $2.632 \mathrm{E}-03$ & $2.708 \mathrm{E}-03$ \\
\hline $\mathrm{Pu}-241$ & $1.208 \mathrm{E}-03$ & $1.366 \mathrm{E}-03$ & $1.387 \mathrm{E}-03$ & $1.423 \mathrm{E}-03$ & $1.430 \mathrm{E}-03$ & $1.358 \mathrm{E}-03$ & $1.403 \mathrm{E}-03$ & $1.329 \mathrm{E}-03$ & $1.364 \mathrm{E}-03$ & $1.362 \mathrm{E}-03$ & $1.469 \mathrm{E}-03$ \\
\hline $\mathrm{Pu}-242$ & $6.793 \mathrm{E}-04$ & $7.945 \mathrm{E}-04$ & $9.146 \mathrm{E}-04$ & $9.000 \mathrm{E}-04$ & $9.414 \mathrm{E}-04$ & $9.229 \mathrm{E}-04$ & $9.233 \mathrm{E}-04$ & $9.318 \mathrm{E}-04$ & $1.106 \mathrm{E}-03$ & $9.570 \mathrm{E}-04$ & $9.637 \mathrm{E}-04$ \\
\hline Np-237 & $6.040 \mathrm{E}-04$ & $6.755 \mathrm{E}-04$ & $6.917 \mathrm{E}-04$ & $7.041 \mathrm{E}-04$ & $6.848 \mathrm{E}-04$ & $6.938 \mathrm{E}-04$ & $6.823 \mathrm{E}-04$ & $6.864 \mathrm{E}-04$ & $7.060 \mathrm{E}-04$ & 7.012E-04 & $7.058 \mathrm{E}-04$ \\
\hline Am-241 & $3.466 \mathrm{E}-04$ & $3.457 \mathrm{E}-04$ & $3.412 \mathrm{E}-04$ & $3.770 \mathrm{E}-04$ & $5.261 \mathrm{E}-04$ & $3.021 \mathrm{E}-04$ & $3.028 \mathrm{E}-04$ & $5.074 \mathrm{E}-04$ & $5.060 \mathrm{E}-04$ & $2.880 \mathrm{E}-04$ & $3.350 \mathrm{E}-04$ \\
\hline Am-242m & -- & -- & - & - & $8.389 \mathrm{E}-07$ & -- & -- & $1.679 \mathrm{E}-06$ & $1.244 \mathrm{E}-06$ & $1.031 \mathrm{E}-06$ & $6.085 \mathrm{E}-07$ \\
\hline Am-243 & $1.245 \mathrm{E}-04$ & $1.923 \mathrm{E}-04$ & $2.552 \mathrm{E}-04$ & $2.458 \mathrm{E}-04$ & $1.846 \mathrm{E}-04$ & $2.541 \mathrm{E}-04$ & $2.465 \mathrm{E}-04$ & $1.956 \mathrm{E}-04$ & $2.111 \mathrm{E}-04$ & $2.043 \mathrm{E}-04$ & $2.056 \mathrm{E}-04$ \\
\hline Nd-143 & $9.850 \mathrm{E}-04$ & $9.134 \mathrm{E}-04$ & $9.987 \mathrm{E}-04$ & $9.794 \mathrm{E}-04$ & $1.080 \mathrm{E}-03$ & $9.516 \mathrm{E}-04$ & $9.510 \mathrm{E}-04$ & $1.033 \mathrm{E}-03$ & $1.060 \mathrm{E}-03$ & $1.086 \mathrm{E}-03$ & $1.111 \mathrm{E}-03$ \\
\hline Nd-145 & $8.521 \mathrm{E}-04$ & $8.289 \mathrm{E}-04$ & $9.062 \mathrm{E}-04$ & $8.972 \mathrm{E}-04$ & $9.598 \mathrm{E}-04$ & $8.777 \mathrm{E}-04$ & $8.965 \mathrm{E}-04$ & $9.411 \mathrm{E}-04$ & $9.770 \mathrm{E}-04$ & $9.847 \mathrm{E}-04$ & $1.000 \mathrm{E}-03$ \\
\hline Nd-148 & $4.869 \mathrm{E}-04$ & 4.869E-04 & $5.447 \mathrm{E}-04$ & $5.452 \mathrm{E}-04$ & $5.482 \mathrm{E}-04$ & $5.506 \mathrm{E}-04$ & $5.577 \mathrm{E}-04$ & $5.720 \mathrm{E}-04$ & $5.761 \mathrm{E}-04$ & $5.926 \mathrm{E}-04$ & $6.058 \mathrm{E}-04$ \\
\hline Cs-137 & $1.682 \mathrm{E}-03$ & $1.617 \mathrm{E}-03$ & $1.748 \mathrm{E}-03$ & $1.811 \mathrm{E}-03$ & $1.652 \mathrm{E}-03$ & $1.765 \mathrm{E}-03$ & $1.699 \mathrm{E}-03$ & $1.762 \mathrm{E}-03$ & $1.733 \mathrm{E}-03$ & $1.758 \mathrm{E}-03$ & $1.533 \mathrm{E}-03$ \\
\hline Sm-147 & $2.258 \mathrm{E}-04$ & $1.821 \mathrm{E}-04$ & $1.859 \mathrm{E}-04$ & $1.866 \mathrm{E}-04$ & $2.353 \mathrm{E}-04$ & $1.968 \mathrm{E}-04$ & $1.819 \mathrm{E}-04$ & $2.288 \mathrm{E}-04$ & $2.479 \mathrm{E}-04$ & $2.549 \mathrm{E}-04$ & $2.515 \mathrm{E}-04$ \\
\hline Sm-149 & 3.113E-06 & 3.094E-06 & $3.264 \mathrm{E}-06$ & $3.188 \mathrm{E}-06$ & $3.599 \mathrm{E}-06$ & $3.816 \mathrm{E}-06$ & $2.899 \mathrm{E}-06$ & $3.358 \mathrm{E}-06$ & $3.189 \mathrm{E}-06$ & 3.423E-06 & $3.855 \mathrm{E}-06$ \\
\hline Sm-150 & $3.577 \mathrm{E}-04$ & $3.485 \mathrm{E}-04$ & $3.754 \mathrm{E}-04$ & $3.835 \mathrm{E}-04$ & $4.125 \mathrm{E}-04$ & $3.742 \mathrm{E}-04$ & $3.619 \mathrm{E}-04$ & $4.189 \mathrm{E}-04$ & $4.525 \mathrm{E}-04$ & $4.675 \mathrm{E}-04$ & $4.525 \mathrm{E}-04$ \\
\hline Sm-151 & $1.292 \mathrm{E}-05$ & $1.264 \mathrm{E}-05$ & $1.341 \mathrm{E}-05$ & $1.247 \mathrm{E}-05$ & $1.412 \mathrm{E}-05$ & $1.256 \mathrm{E}-05$ & $1.256 \mathrm{E}-05$ & $1.329 \mathrm{E}-05$ & $1.475 \mathrm{E}-05$ & $1.500 \mathrm{E}-05$ & $1.551 \mathrm{E}-05$ \\
\hline Sm-152 & $1.217 \mathrm{E}-04$ & $1.208 \mathrm{E}-04$ & $1.295 \mathrm{E}-04$ & $1.266 \mathrm{E}-04$ & $1.338 \mathrm{E}-04$ & $1.321 \mathrm{E}-04$ & $1.256 \mathrm{E}-04$ & $1.301 \mathrm{E}-04$ & $1.419 \mathrm{E}-04$ & $1.436 \mathrm{E}-04$ & $1.423 \mathrm{E}-04$ \\
\hline Eu-151 & $6.579 \mathrm{E}-07$ & $7.034 \mathrm{E}-07$ & $7.934 \mathrm{E}-07$ & $6.856 \mathrm{E}-07$ & $6.673 \mathrm{E}-07$ & $8.832 \mathrm{E}-07$ & $8.476 \mathrm{E}-07$ & $7.030 \mathrm{E}-07$ & 7.475E-07 & $5.696 \mathrm{E}-07$ & $6.618 \mathrm{E}-07$ \\
\hline Eu-153 & $1.468 \mathrm{E}-04$ & $1.561 \mathrm{E}-04$ & $1.674 \mathrm{E}-04$ & $1.672 \mathrm{E}-04$ & $1.744 \mathrm{E}-04$ & $1.709 \mathrm{E}-04$ & $1.607 \mathrm{E}-04$ & $1.725 \mathrm{E}-04$ & $1.834 \mathrm{E}-04$ & $1.859 \mathrm{E}-04$ & $1.891 \mathrm{E}-04$ \\
\hline Eu-155 & $1.004 \mathrm{E}-05$ & $1.227 \mathrm{E}-05$ & $1.313 \mathrm{E}-05$ & $1.432 \mathrm{E}-05$ & $1.264 \mathrm{E}-05$ & $1.284 \mathrm{E}-05$ & $1.274 \mathrm{E}-05$ & $9.964 \mathrm{E}-06$ & $1.032 \mathrm{E}-05$ & $1.546 \mathrm{E}-05$ & $9.821 \mathrm{E}-06$ \\
\hline
\end{tabular}


Table 37. Experimental results ( $\mathrm{g} / \mathrm{g} \mathbf{U}_{\text {initial }}$ ) for TMI-1 samples measured at ANL (continued)

\begin{tabular}{|c|c|c|c|c|c|c|c|c|c|c|c|}
\hline Assembly & NJ05YU & NJ05YU & NJ05YU & NJ05YU & NJ05YU & NJ05YU & NJ05YU & NJ05YU & NJ05YU & NJ05YU & NJ05YU \\
\hline Sample ID & $\mathbf{A 1 B}^{a}$ & D2 ${ }^{b}$ & $B 2^{b}$ & $C 1^{b}$ & $\mathrm{D} 1 A 4^{a}$ & $\mathbf{A 2}{ }^{b}$ & $\mathrm{C3}^{b}$ & $\mathrm{C2B}^{a}$ & B3J $^{a}$ & $\mathrm{~B} 1 \mathrm{~B}^{a}$ & D1A2 $^{a}$ \\
\hline $\begin{array}{c}\text { Burnup } \\
\text { (GWd/MTU) }\end{array}$ & 44.8 & 44.8 & 50.1 & 50.2 & 50.5 & 50.6 & 51.3 & 52.6 & 53.0 & 54.5 & 55.7 \\
\hline Gd-155 & $8.224 \mathrm{E}-06$ & $5.594 \mathrm{E}-06$ & $6.547 \mathrm{E}-06$ & $6.357 \mathrm{E}-06$ & $1.394 \mathrm{E}-05$ & $5.220 \mathrm{E}-06$ & $6.666 \mathrm{E}-06$ & $9.411 \mathrm{E}-06$ & $1.041 \mathrm{E}-05$ & $1.003 \mathrm{E}-05$ & $1.019 \mathrm{E}-05$ \\
\hline Mo-95 & $1.041 \mathrm{E}-03$ & $9.199 \mathrm{E}-04$ & $1.128 \mathrm{E}-03$ & $1.100 \mathrm{E}-03$ & $1.089 \mathrm{E}-03$ & $1.118 \mathrm{E}-03$ & $1.006 \mathrm{E}-03$ & $1.098 \mathrm{E}-03$ & $1.124 \mathrm{E}-03$ & $1.150 \mathrm{E}-03$ & $1.111 \mathrm{E}-03$ \\
\hline Tc-99 & $1.422 \mathrm{E}-03$ & $9.757 \mathrm{E}-04$ & $1.091 \mathrm{E}-03$ & $1.081 \mathrm{E}-03$ & $1.191 \mathrm{E}-03$ & $1.081 \mathrm{E}-03$ & $1.034 \mathrm{E}-03$ & $1.356 \mathrm{E}-03$ & $1.244 \mathrm{E}-03$ & $1.316 \mathrm{E}-03$ & $1.138 \mathrm{E}-03$ \\
\hline Ru-101 & $1.115 \mathrm{E}-03$ & $9.478 \mathrm{E}-04$ & $1.202 \mathrm{E}-03$ & $1.164 \mathrm{E}-03$ & $1.098 \mathrm{E}-03$ & $1.155 \mathrm{E}-03$ & $1.025 \mathrm{E}-03$ & $1.172 \mathrm{E}-03$ & $1.171 \mathrm{E}-03$ & $1.187 \mathrm{E}-03$ & $1.129 \mathrm{E}-03$ \\
\hline Rh-103 & $5.956 \mathrm{E}-04$ & $5.157 \mathrm{E}-04$ & $6.288 \mathrm{E}-04$ & $6.182 \mathrm{E}-04$ & $6.027 \mathrm{E}-04$ & $6.190 \mathrm{E}-04$ & $5.475 \mathrm{E}-04$ & $6.145 \mathrm{E}-04$ & $6.203 \mathrm{E}-04$ & $6.267 \mathrm{E}-04$ & $6.168 \mathrm{E}-04$ \\
\hline Ag-109 & $5.111 \mathrm{E}-05$ & $4.655 \mathrm{E}-05$ & $5.280 \mathrm{E}-05$ & $5.359 \mathrm{E}-05$ & $8.463 \mathrm{E}-05$ & $5.968 \mathrm{E}-05$ & $9.233 \mathrm{E}-05$ & $6.532 \mathrm{E}-05$ & $7.788 \mathrm{E}-05$ & $4.399 \mathrm{E}-05$ & 4.607E-05 \\
\hline
\end{tabular}

${ }^{b}$ Cooling time for TMI-1 samples A2, B2, C1, C3, and D2 is 1103 days (Ref. 46, p.12). 


\subsubsection{GE-VNC Measurements}

The measurements performed at GE-VNC ${ }^{45}$ considered eight samples selected from three fuel rods from assembly NJ070G. Most of the 32 nuclides for which isotopic concentrations were measured at GE-VNC were determined by using thermal ionization mass spectrometry (TIMS) and some through $\gamma$ - or $\alpha$-spectrometry. The nuclide concentrations in the samples measured by TIMS were determined from measurements of spiked and unspiked samples. The nuclide content was reported as $\mathrm{g} / \mathrm{g}{ }^{238} \mathrm{U}$. The main experimental techniques used for each nuclide and the corresponding experimental uncertainty as reported are presented in Table 38. The experimental errors, reported by GE-VNC as relative uncertainty at a $95 \%$ confidence level, are shown in the table. The relative standard deviation (RSD) shown in the fourth column of the table was obtained as half of the reported uncertainty at a $95 \%$ confidence level. The RSD for the GE-VNC measurements is $0.6 \%$ for all plutonium nuclides except for ${ }^{238} \mathrm{Pu}, 0.5 \%$ for ${ }^{235} \mathrm{U}$, and $0.8 \%$ for neodymium isotopes.

The reported results of the radiochemical analyses for samples measured at GE-VNC ${ }^{45}$ are shown in Table 39. 
Table 38. Experimental techniques and uncertainties for TMI-1 samples measurements at GE-VNC

\begin{tabular}{|c|c|c|c|}
\hline Nuclide ID & Method $^{a}$ & $\begin{array}{l}\text { Reported uncertainty } \\
\text { at } 95 \% \text { confidence } \\
(\%)\end{array}$ & $\begin{array}{c}\text { RSD }^{b} \\
(\%)\end{array}$ \\
\hline U-234 & TIMS & 1.0 & 0.5 \\
\hline $\mathrm{U}-235$ & TIMS & 1.0 & 0.5 \\
\hline U-236 & TIMS & 1.0 & 0.5 \\
\hline U-238 & TIMS & 1.0 & 0.5 \\
\hline Np-237 & $\alpha$-spec & 5.8 & 2.9 \\
\hline $\mathrm{Pu}-238$ & $\alpha$-spec & 5.0 & 2.5 \\
\hline $\mathrm{Pu}-239$ & TIMS & 1.2 & 0.6 \\
\hline $\mathrm{Pu}-240$ & TIMS & 1.2 & 0.6 \\
\hline $\mathrm{Pu}-241$ & TIMS & 1.2 & 0.6 \\
\hline $\mathrm{Pu}-242$ & TIMS & 1.2 & 0.6 \\
\hline Am-241 & TIMS, $\alpha$-spec & 7.0 & 3.5 \\
\hline Am-242m & TIMS, $\alpha$-spec & 7.0 & 3.5 \\
\hline Am-243 & TIMS, $\alpha$-spec & 7.0 & 3.5 \\
\hline $\mathrm{Cm}-242$ & TIMS, $\alpha$-spec & 20.0 & 10.0 \\
\hline $\mathrm{Cm}-243$ & TIMS, $\alpha$-spec & 5.5 & 2.75 \\
\hline $\mathrm{Cm}-244$ & TIMS, $\alpha$-spec & 5.5 & 2.75 \\
\hline $\mathrm{Cm}-245$ & TIMS, $\alpha$-spec & 5.5 & 2.75 \\
\hline Cs-134 & $\gamma$-spec & 3.5 & 1.75 \\
\hline Cs-137 & $\gamma$-spec & 3.5 & 1.75 \\
\hline Nd-143 & TIMS & 1.5 & 0.75 \\
\hline Nd-145 & TIMS & 1.5 & 0.75 \\
\hline Nd-146 & TIMS & 1.5 & 0.75 \\
\hline Nd-148 & TIMS & 1.5 & 0.75 \\
\hline Nd-150 & TIMS & 1.5 & 0.75 \\
\hline Sm-147 & TIMS & 1.7 & 0.85 \\
\hline Sm-149 & TIMS & 1.8 & 0.9 \\
\hline Sm-150 & TIMS & 1.7 & 0.85 \\
\hline Sm-151 & TIMS & 1.7 & 0.85 \\
\hline Sm-152 & TIMS & 1.7 & 0.85 \\
\hline Eu-151 & TIMS & 1.7 & 0.85 \\
\hline Eu-153 & TIMS & 1.8 & 0.9 \\
\hline Gd-155 & TIMS & 2.7 & 1.35 \\
\hline
\end{tabular}


Table 39. Experimental results (g/g $\left.\mathrm{U}_{\text {initial }}\right)$ for TMI-1 samples measured at GE-VNC

\begin{tabular}{|c|c|c|c|c|c|c|c|c|}
\hline Assembly & NJ070G & NJ070G & NJ070G & NJ070G & NJ070G & NJ070G & NJ070G & NJ070G \\
\hline Sample ID & $013 S 7^{b}$ & $012 S 4^{a}$ & $\mathrm{O12S6}^{a}$ & O1S1 $^{a}$ & O13S8 $^{b}$ & $012 S 5^{b}$ & $\mathrm{O1S3}^{a}$ & O1S2 $^{b}$ \\
\hline $\begin{array}{c}\text { Burnup } \\
\text { (GWd/MTU) }\end{array}$ & 22.8 & 23.7 & 24.0 & 25.8 & 26.3 & 26.5 & 26.7 & 29.9 \\
\hline U-234 & $3.427 \mathrm{E}-04$ & $3.332 \mathrm{E}-04$ & $3.260 \mathrm{E}-04$ & $3.263 \mathrm{E}-04$ & $3.184 \mathrm{E}-04$ & $3.126 \mathrm{E}-04$ & $3.134 \mathrm{E}-04$ & $3.037 \mathrm{E}-04$ \\
\hline U-235 & $2.376 \mathrm{E}-02$ & $2.356 \mathrm{E}-02$ & $2.388 \mathrm{E}-02$ & $2.203 \mathrm{E}-02$ & $2.191 \mathrm{E}-02$ & $2.181 \mathrm{E}-02$ & $2.170 \mathrm{E}-02$ & $1.916 \mathrm{E}-02$ \\
\hline U-236 & $4.216 \mathrm{E}-03$ & $4.299 \mathrm{E}-03$ & $4.384 \mathrm{E}-03$ & $4.529 \mathrm{E}-03$ & $4.579 \mathrm{E}-03$ & $4.615 \mathrm{E}-03$ & $4.668 \mathrm{E}-03$ & $4.990 \mathrm{E}-03$ \\
\hline $\mathrm{Pu}-238$ & $6.019 \mathrm{E}-05$ & $6.270 \mathrm{E}-05$ & $7.765 \mathrm{E}-05$ & 7.192E-05 & $8.699 \mathrm{E}-05$ & $8.799 \mathrm{E}-05$ & $9.354 \mathrm{E}-05$ & $1.084 \mathrm{E}-04$ \\
\hline $\mathrm{Pu}-239$ & $5.418 \mathrm{E}-03$ & $5.435 \mathrm{E}-03$ & $6.182 \mathrm{E}-03$ & $5.448 \mathrm{E}-03$ & $5.880 \mathrm{E}-03$ & $6.000 \mathrm{E}-03$ & $6.024 \mathrm{E}-03$ & $5.588 \mathrm{E}-03$ \\
\hline $\mathrm{Pu}-240$ & $1.371 \mathrm{E}-03$ & $1.389 \mathrm{E}-03$ & $1.508 \mathrm{E}-03$ & $1.519 \mathrm{E}-03$ & $1.620 \mathrm{E}-03$ & $1.647 \mathrm{E}-03$ & $1.712 \mathrm{E}-03$ & $1.850 \mathrm{E}-03$ \\
\hline $\mathrm{Pu}-241$ & $6.610 \mathrm{E}-04$ & $6.890 \mathrm{E}-04$ & $7.999 \mathrm{E}-04$ & $7.539 \mathrm{E}-04$ & $8.230 \mathrm{E}-04$ & $8.397 \mathrm{E}-04$ & $8.942 \mathrm{E}-04$ & $9.149 \mathrm{E}-04$ \\
\hline $\mathrm{Pu}-242$ & $1.446 \mathrm{E}-04$ & $1.483 \mathrm{E}-04$ & $1.649 \mathrm{E}-04$ & $1.800 \mathrm{E}-04$ & $2.022 \mathrm{E}-04$ & $2.059 \mathrm{E}-04$ & $2.208 \mathrm{E}-04$ & $2.841 \mathrm{E}-04$ \\
\hline Np-237 & $2.826 \mathrm{E}-04$ & $3.032 \mathrm{E}-04$ & $3.278 \mathrm{E}-04$ & $3.038 \mathrm{E}-04$ & $3.474 \mathrm{E}-04$ & $3.482 \mathrm{E}-04$ & 3.639E-04 & $3.953 \mathrm{E}-04$ \\
\hline Am-241 & $1.624 \mathrm{E}-04$ & $1.521 \mathrm{E}-01$ & $1.377 \mathrm{E}-01$ & $1.144 \mathrm{E}-01$ & $2.022 \mathrm{E}-01$ & $2.078 \mathrm{E}-01$ & $1.712 \mathrm{E}-01$ & $1.981 \mathrm{E}-01$ \\
\hline$A m-242 m$ & $3.155 \mathrm{E}-04$ & $3.539 \mathrm{E}-04$ & $3.719 \mathrm{E}-04$ & $2.747 \mathrm{E}-04$ & $4.672 \mathrm{E}-04$ & $4.849 \mathrm{E}-04$ & 4.209E-04 & 4.233E-04 \\
\hline Am-243 & $1.606 \mathrm{E}-02$ & $1.690 \mathrm{E}-02$ & $1.649 \mathrm{E}-02$ & $1.500 \mathrm{E}-02$ & $2.669 \mathrm{E}-02$ & $2.771 \mathrm{E}-02$ & $2.563 \mathrm{E}-02$ & 3.504E-02 \\
\hline $\mathrm{Cm}-242^{c}$ & $6.995 \mathrm{E}-06$ & $2.159 \mathrm{E}-05$ & $1.873 \mathrm{E}-05$ & $1.772 \mathrm{E}-05$ & $1.170 \mathrm{E}-05$ & $1.123 \mathrm{E}-05$ & $2.713 \mathrm{E}-05$ & $1.635 \mathrm{E}-05$ \\
\hline $\mathrm{Cm}-243$ & $5.606 \mathrm{E}-05$ & $5.970 \mathrm{E}-05$ & $6.547 \mathrm{E}-05$ & $5.157 \mathrm{E}-05$ & $9.457 \mathrm{E}-05$ & $1.002 \mathrm{E}-04$ & $9.728 \mathrm{E}-05$ & $1.168 \mathrm{E}-04$ \\
\hline $\mathrm{Cm}-244$ & $2.460 \mathrm{E}-03$ & $2.713 \mathrm{E}-03$ & $3.016 \mathrm{E}-03$ & $2.494 \mathrm{E}-03$ & 4.897E-03 & $5.158 \mathrm{E}-03$ & $4.976 \mathrm{E}-03$ & 7.177E-03 \\
\hline $\mathrm{Cm}-245$ & $1.070 \mathrm{E}-04$ & $1.164 \mathrm{E}-04$ & $1.564 \mathrm{E}-04$ & $1.116 \mathrm{E}-04$ & $2.566 \mathrm{E}-04$ & $2.715 \mathrm{E}-04$ & $2.628 \mathrm{E}-04$ & 3.757E-04 \\
\hline Nd-143 & $6.958 \mathrm{E}-04$ & 7.049E-04 & $7.175 \mathrm{E}-04$ & $7.454 \mathrm{E}-04$ & 7.594E-04 & $7.638 \mathrm{E}-04$ & $7.745 \mathrm{E}-04$ & 8.336E-04 \\
\hline Nd-145 & $5.174 \mathrm{E}-04$ & $5.247 \mathrm{E}-04$ & $5.283 \mathrm{E}-04$ & $5.626 \mathrm{E}-04$ & $5.693 \mathrm{E}-04$ & 5.719E-04 & $5.809 \mathrm{E}-04$ & $6.420 \mathrm{E}-04$ \\
\hline Nd-146 & $4.732 \mathrm{E}-04$ & $4.806 \mathrm{E}-04$ & 4.927E-04 & $5.213 \mathrm{E}-04$ & $5.356 \mathrm{E}-04$ & $5.392 \mathrm{E}-04$ & $5.491 \mathrm{E}-04$ & $6.149 \mathrm{E}-04$ \\
\hline Nd-148 & $2.601 \mathrm{E}-04$ & $2.638 \mathrm{E}-04$ & $2.698 \mathrm{E}-04$ & $2.860 \mathrm{E}-04$ & $2.921 \mathrm{E}-04$ & $2.939 \mathrm{E}-04$ & $3.003 \mathrm{E}-04$ & $3.345 \mathrm{E}-04$ \\
\hline Nd-150 & $1.174 \mathrm{E}-04$ & $1.183 \mathrm{E}-04$ & $1.227 \mathrm{E}-04$ & $1.294 \mathrm{E}-04$ & $1.330 \mathrm{E}-04$ & $1.339 \mathrm{E}-04$ & $1.375 \mathrm{E}-04$ & $1.533 \mathrm{E}-04$ \\
\hline Cs-134 & $1.653 \mathrm{E}-05$ & $2.084 \mathrm{E}-05$ & $2.285 \mathrm{E}-05$ & $2.353 \mathrm{E}-05$ & $2.125 \mathrm{E}-05$ & $2.125 \mathrm{E}-05$ & $2.713 \mathrm{E}-05$ & $2.579 \mathrm{E}-05$ \\
\hline Cs-137 & $8.375 \mathrm{E}-04$ & $8.495 \mathrm{E}-04$ & $8.598 \mathrm{E}-04$ & $9.104 \mathrm{E}-04$ & $9.457 \mathrm{E}-04$ & $9.361 \mathrm{E}-04$ & $9.634 \mathrm{E}-04$ & $1.093 \mathrm{E}-03$ \\
\hline Sm-147 & $1.746 \mathrm{E}-04$ & $1.699 \mathrm{E}-04$ & $1.677 \mathrm{E}-04$ & $1.791 \mathrm{E}-04$ & $1.863 \mathrm{E}-04$ & $1.881 \mathrm{E}-04$ & $1.815 \mathrm{E}-04$ & $2.056 \mathrm{E}-04$ \\
\hline Sm-149 & $3.972 \mathrm{E}-06$ & $4.055 \mathrm{E}-06$ & $4.430 \mathrm{E}-06$ & 4.051E-06 & 4.139E-06 & $4.156 \mathrm{E}-06$ & $4.415 \mathrm{E}-06$ & 4.074E-06 \\
\hline Sm-150 & $1.934 \mathrm{E}-04$ & $1.981 \mathrm{E}-04$ & $2.033 \mathrm{E}-04$ & $2.157 \mathrm{E}-04$ & $2.228 \mathrm{E}-04$ & $2.256 \mathrm{E}-04$ & $2.310 \mathrm{E}-04$ & $2.598 \mathrm{E}-04$ \\
\hline Sm-151 & $1.268 \mathrm{E}-05$ & $1.295 \mathrm{E}-05$ & $1.480 \mathrm{E}-05$ & $1.275 \mathrm{E}-05$ & $1.414 \mathrm{E}-05$ & $1.413 \mathrm{E}-05$ & $1.431 \mathrm{E}-05$ & $1.374 \mathrm{E}-05$ \\
\hline Sm-152 & $7.953 \mathrm{E}-05$ & $8.091 \mathrm{E}-05$ & $7.877 \mathrm{E}-05$ & $8.654 \mathrm{E}-05$ & $8.605 \mathrm{E}-05$ & $8.677 \mathrm{E}-05$ & $8.924 \mathrm{E}-05$ & $9.999 \mathrm{E}-05$ \\
\hline Eu-151 & $4.206 \mathrm{E}-07$ & $4.027 \mathrm{E}-07$ & $4.580 \mathrm{E}-07$ & $3.891 \mathrm{E}-07$ & $4.672 \mathrm{E}-07$ & 4.699E-07 & $4.312 \mathrm{E}-07$ & $4.430 \mathrm{E}-07$ \\
\hline Eu-153 & $6.695 \mathrm{E}-05$ & $6.918 \mathrm{E}-05$ & $7.203 \mathrm{E}-05$ & $7.548 \mathrm{E}-05$ & $8.062 \mathrm{E}-05$ & $8.097 \mathrm{E}-05$ & $8.231 \mathrm{E}-05$ & $9.438 \mathrm{E}-05$ \\
\hline Gd-155 & $1.972 \mathrm{E}-06$ & $1.905 \mathrm{E}-06$ & $2.182 \mathrm{E}-06$ & $2.307 \mathrm{E}-06$ & $2.528 \mathrm{E}-06$ & $2.509 \mathrm{E}-06$ & $2.638 \mathrm{E}-06$ & $2.888 \mathrm{E}-06$ \\
\hline
\end{tabular}

${ }^{a}$ Cooling time for TMI-1 samples O1S1, O1S3, O12S4, and O12S6 is 1298 days (Ref. 46, p.12).

${ }^{b}$ Cooling time for TMI-1 samples O1S2, O12S5, O13S7, and O13S8 is 1529 days (Ref. 46, p.12).

${ }^{c}$ Average of the two values measured by TIMS and $\gamma$-spectrometry. 


\subsection{GÖSGEN REACTOR: ARIANE PROGRAM}

Gösgen is a PWR in Switzerland with a net generating capacity of 1020 MWe, which was designed by German Kraftwerk Union AG (KWU). First power was achieved in February 1979 with an initial core consisting of RBU $15 \times 15$ assemblies. ${ }^{57}$

ARIANE, an international program designed to improve the database of isotopic measurements for spent fuel source term and isotopic inventory validation, was coordinated by Belgonucleaire and completed in March 2001. ${ }^{48}$ This collaborative project involved participants from laboratories and utilities from seven countries: Belgium, Germany, Japan, Netherlands, Switzerland, the United Kingdom, and the United States.

A key feature of the ARIANE program was that two cross-checking laboratories participated in radiochemical assay measurements to reduce the experimental uncertainties and improve confidence in the measured data: Studiecentrum voor Kernenergie-Centre d'Étude de l'Énergie Nucléaire (SCK-CEN) in Belgium and Institute for Transuranium Elements (ITU) in Germany. Measurements were carried out on both uranium dioxide $\left(\mathrm{UO}_{2}\right)$ and mixed oxide (MOX) fuels between 1996 and 1999. Only the $\mathrm{UO}_{2}$ samples are analyzed in this report.

The three $\mathrm{UO}_{2}$ samples considered were selected from fuel rods irradiated in the Gösgen reactor operated in Switzerland. One of these samples was obtained from an assembly with an initial enrichment of $3.5 \mathrm{wt} \%{ }^{235} \mathrm{U}$ that was irradiated for four consecutive cycles. The other two samples, irradiated for three cycles, were taken from a rebuilt assembly with initial fuel enrichment of $4.1 \mathrm{wt} \%{ }^{235} \mathrm{U}$. The main characteristics of the three samples analyzed are summarized in Table 40.

Three $\mathrm{UO}_{2}$ samples, identified as GU1, GU3, and GU4, were measured in the ARIANE program. Duplicate measurements for sample GU3 were carried out at two different facilities, SCK-CEN in Belgium and ITU in Germany, and the results of these two measurements were combined. Measurements for sample GU1 were performed at SCK-CEN, and measurements for sample GU4 were carried out at ITU only.

Table 40. Summary of Gösgen (ARIANE) fuel samples

\begin{tabular}{|c|c|c|c|c|c|c|}
\hline Assembly & $\begin{array}{c}\text { Sample } \\
\text { No. }\end{array}$ & $\begin{array}{l}\text { Measurement } \\
\text { laboratory }\end{array}$ & $\begin{array}{c}\text { Fuel } \\
\text { Sample ID }\end{array}$ & $\begin{array}{l}\text { Enrichment } \\
\left(w \%^{235} U\right)\end{array}$ & $\begin{array}{c}\text { Axial } \\
\text { location } \\
(\mathbf{c m})^{a}\end{array}$ & $\underset{(\mathbf{G W d} / \mathbf{t})^{b}}{\text { Burnup }}$ \\
\hline $12-40$ & 1 & SCK-CEN & GU1 & 3.5 & 97.7 & 59.7 \\
\hline $16-01,17-01$ & 2 & SCK-CEN, ITU & GU3 & 4.1 & 127.42 & 52.5 \\
\hline $16-01,17-01$ & 3 & ITU & GU4 & 4.1 & 7.42 & 29.1 \\
\hline
\end{tabular}

${ }^{a}$ With respect to the bottom of the active fuel region.

The following main experimental techniques have been applied for measurements performed at SCK-CEN:

- Thermal ionization mass spectrometry (TIMS)

o major ( $\mathrm{U}, \mathrm{Pu}$ ) and minor (Am and ${ }^{245,246} \mathrm{Cm}$ ) actinides

o lanthanides: $\mathrm{Nd}, \mathrm{Sm},{ }^{144} \mathrm{Ce},{ }^{155} \mathrm{Gd},{ }^{151} \mathrm{Eu},{ }^{153} \mathrm{Eu}$

o cesium nuclides: ${ }^{133-135} \mathrm{Cs}$

- Inductively coupled plasma mass spectrometry (ICP-MS) with external calibration

- Metallics: ${ }^{95} \mathrm{Mo},{ }^{99} \mathrm{Tc},{ }^{101} \mathrm{Ru},{ }^{103} \mathrm{Rh},{ }^{109} \mathrm{Ag}$ 
- $\quad{ }^{237} \mathrm{~Np}$

- $\gamma$-spectrometry

o ${ }^{106} \mathrm{Ru},{ }^{137} \mathrm{Cs},{ }^{144} \mathrm{Ce},{ }^{154} \mathrm{Eu},{ }^{155} \mathrm{Eu},{ }^{243} \mathrm{Cm},{ }^{125} \mathrm{Sb}$

- $\quad \alpha$-spectrometry

o ${ }^{242} \mathrm{Cm},{ }^{244} \mathrm{Cm}$

- $\beta$-spectrometry

o ${ }^{90} \mathrm{Sr}$

The following two main experimental techniques have been used for measurements performed at ITU:

- $\quad$ TIMS

o major actinides (uranium, plutonium)

- ICP-MS with IDA (isotope dilution analysis)

- all other measured nuclides

Because of the variety of the analysis techniques, the varying properties of the nuclides being analyzed, and their differing concentrations, uncertainties in the measured concentrations can vary considerably. Table 41 lists the measurement method used and the experimental uncertainty, expressed both as the reported ${ }^{48}$ uncertainty at $95 \%$ confidence level and as relative standard deviation, which was calculated as half of the $95 \%$ confidence level uncertainty reported. Only the maximum uncertainty corresponding to the measurements at each laboratory is shown in Table 41.

The nuclide concentrations in $\mathrm{mg} / \mathrm{g} \mathrm{U}$ initial in the measured samples are provided in Table 42 . For metallic fission products, the values represent a combination of the separate measurements done on the main solution and undissolved residue. For samples GU1 and GU4, the data shown in the table correspond to measurement dates shown in Table 43, except for ${ }^{106} \mathrm{Ru},{ }^{125} \mathrm{Sb}$, and ${ }^{147} \mathrm{Pm}$, for which they correspond to discharge. For sample GU3, most of the isotopes considered by the program were measured at both SCK-CEN and ITU. For the isotopes with two independent measurements, the recommended values were established by consensus of experts participating in the program, based on a detailed crosscheck analysis of the measurements. The cross-check was based on a comparison of the $95 \%$ confidence intervals associated to the measured values. If there was an intersection zone between the two $95 \%$ confidence intervals, the concentration results were combined in a weighted average. If the two concentration values were outside this intersection zone, either only one of the two values was recommended based on a detailed analysis of the measurement process or both values were maintained without recommendation. The isotope concentration values shown in Table 42 for sample GU3 correspond to the discharge date for the following isotopes: ${ }^{241} \mathrm{Pu},{ }^{242 \mathrm{~m}} \mathrm{Am},{ }^{242,243,244} \mathrm{Cm},{ }^{90} \mathrm{Sr},{ }^{106} \mathrm{Ru},{ }^{125} \mathrm{Sb}$, ${ }^{134,137} \mathrm{Cs},{ }^{144} \mathrm{Ce},{ }^{147} \mathrm{Pm},{ }^{151} \mathrm{Sm},{ }^{154,155} \mathrm{Eu}$; for the other considered isotopes, the data correspond to the measurement dates at which measurements were performed at the two laboratories presented in Table 43. There were four nuclides $\left({ }^{244,245} \mathrm{Cm},{ }^{133} \mathrm{Cs}\right.$, and $\left.{ }^{155} \mathrm{Gd}\right)$ measured in sample GU3 for which no recommended values were provided because of disagreement between the measurement values reported by SCK-CEN and ITU. For these four nuclides, the data shown in Table 42 were calculated as weighted averages of the two results provided by the program as given in Eq. (15):

$$
c_{\text {avg }}=\left(\frac{c_{1}}{\sigma_{1}^{2}}+\frac{c_{2}}{\sigma_{2}^{2}}\right) /\left(\frac{1}{\sigma_{1}^{2}}+\frac{1}{\sigma_{2}^{2}}\right) \text {, }
$$

where $c_{1}$ and $c_{2}$ are the reported concentration values and $\sigma_{1}$ and $\sigma_{2}$ the corresponding relative experimental errors. Note that the two reported concentrations for these four nuclides differed by about $6 \%$ for ${ }^{133} \mathrm{Cs}, 14 \%$ for ${ }^{155} \mathrm{Gd}$, and $20 \%$ for ${ }^{244,245} \mathrm{Cm}$. 
Table 41. Experimental techniques and uncertainties for ARIANE Program Gösgen samples

\begin{tabular}{|c|c|c|c|c|c|c|}
\hline \multirow[b]{2}{*}{ Nuclide ID } & \multicolumn{3}{|c|}{ Measurements at SCK/CEN } & \multicolumn{3}{|c|}{ Measurements at ITU } \\
\hline & Method $^{a}$ & $\begin{array}{c}\text { Uncertainty }^{b} \\
95 \% \text { confidence } \\
(\%)\end{array}$ & $\begin{array}{c}\text { RSD }^{c} \\
(\%)\end{array}$ & Method & $\begin{array}{c}\text { Uncertainty }^{b} \\
95 \% \text { confidence } \\
(\%)\end{array}$ & $\begin{array}{c}\text { RSD }^{c} \\
(\%)\end{array}$ \\
\hline U-234 & TIMS & 5.02 & 2.51 & TIMS & 0.02 & 0.01 \\
\hline U-235 & TIMS & 2.05 & 1.03 & TIMS & 2.40 & 1.20 \\
\hline U-236 & TIMS & 0.67 & 0.34 & TIMS & 1.57 & 0.79 \\
\hline U-238 & TIMS & 0.45 & 0.23 & TIMS & 0.02 & 0.01 \\
\hline $\mathrm{Pu}-238$ & TIMS & 3.05 & 1.53 & TIMS & 2.15 & 1.08 \\
\hline $\mathrm{Pu}-239$ & TIMS & 0.57 & 0.29 & TIMS & 0.51 & 0.26 \\
\hline $\mathrm{Pu}-240$ & TIMS & 0.57 & 0.29 & TIMS & 0.51 & 0.26 \\
\hline $\mathrm{Pu}-241$ & TIMS & 0.57 & 0.29 & TIMS & 3.40 & 1.70 \\
\hline $\mathrm{Pu}-242$ & TIMS & 0.59 & 0.29 & TIMS & 0.55 & 0.28 \\
\hline $\mathrm{Np}-237$ & ICP-MS & 20.60 & 10.30 & ICP-MS & 9.61 & 4.81 \\
\hline Am-241 & TIMS & 3.56 & 1.78 & ICP-MS & 11.87 & 5.94 \\
\hline Am-242m & TIMS & 10.60 & 5.30 & & & \\
\hline Am-243 & TIMS & 3.56 & 1.78 & ICP-MS & 13.29 & 6.65 \\
\hline $\mathrm{Cm}-242$ & $\alpha$-spec & 7.22 & 3.61 & & & \\
\hline $\mathrm{Cm}-243$ & $\gamma$-spec & 73.49 & 36.75 & & & \\
\hline $\mathrm{Cm}-244$ & $\alpha$-spec & 3.24 & 1.62 & ICP-MS & 12.85 & 6.43 \\
\hline $\mathrm{Cm}-245$ & TIMS & 5.89 & 2.95 & ICP-MS & 20.29 & 10.15 \\
\hline $\mathrm{Cm}-246$ & TIMS & 20.24 & 10.12 & & & \\
\hline Cs-133 & TIMS & 4.91 & 2.46 & ICP-MS & 3.27 & 1.64 \\
\hline Cs-134 & TIMS & 4.94 & 2.46 & ICP-MS & 8.20 & 4.10 \\
\hline Cs-135 & TIMS & 4.91 & 2.46 & ICP-MS & 3.29 & 1.65 \\
\hline Cs-137 & $\gamma$-spec & 4.90 & 2.45 & ICP-MS & 3.00 & 1.50 \\
\hline Ce-144 & $\gamma$-spec & 7.84 & 3.92 & ICP-MS & 7.49 & 3.75 \\
\hline Nd-142 & TIMS & 10.01 & 5.01 & ICP-MS & 10.18 & 5.09 \\
\hline Nd-143 & TIMS & 0.57 & 0.29 & ICP-MS & 12.32 & 6.16 \\
\hline Nd-144 & TIMS & 0.57 & 0.29 & ICP-MS & 11.89 & 5.95 \\
\hline Nd-145 & TIMS & 0.57 & 0.29 & ICP-MS & 11.78 & 5.89 \\
\hline Nd-146 & TIMS & 0.57 & 0.29 & ICP-MS & 14.73 & 7.37 \\
\hline Nd-148 & TIMS & 0.59 & 0.30 & ICP-MS & 13.4 & 6.70 \\
\hline Nd-150 & TIMS & 0.59 & 0.30 & ICP-MS & 13.55 & 6.78 \\
\hline Pm-147 & $\beta$-spec & 18.01 & 9.00 & ICP-MS & 13.51 & 6.76 \\
\hline Sm-147 & TIMS & 0.64 & 0.32 & ICP-MS & 21.14 & 10.57 \\
\hline Sm-148 & TIMS & 0.64 & 0.32 & ICP-MS & 8.01 & 4.01 \\
\hline Sm-149 & TIMS & 2.09 & 1.05 & ICP-MS & 42.83 & 21.42 \\
\hline Sm-150 & TIMS & 0.64 & 0.32 & ICP-MS & 6.87 & 3.44 \\
\hline Sm-151 & TIMS & 0.79 & 0.40 & ICP-MS & 67.63 & 33.82 \\
\hline Sm-152 & TIMS & 0.64 & 0.32 & ICP-MS & 6.41 & 3.21 \\
\hline Sm-154 & TIMS & 0.66 & 0.33 & ICP-MS & 11.3 & 5.65 \\
\hline Eu-151 & TIMS & 2.10 & 1.05 & & & \\
\hline Eu-153 & TIMS & 0.67 & 0.34 & ICP-MS & 10.97 & 5.49 \\
\hline Eu-154 & $\gamma$-spec & 5.29 & 2.65 & ICP-MS & 23.73 & 11.87 \\
\hline Eu-155 & $\gamma$-spec & 9.83 & 4.92 & ICP-MS & 32.13 & 16.07 \\
\hline Gd-155 & TIMS & 5.00 & 2.50 & ICP-MS & 13.72 & 6.86 \\
\hline Sr-90 & $\beta$-spec & 16.01 & 8.01 & ICP-MS & 0.77 & 0.39 \\
\hline Mo-95 & ICP-MS & 9.14 & 4.57 & ICP-MS & 2.20 & 1.10 \\
\hline Tc-99 & ICP-MS & 17.7 & 8.85 & ICP-MS & 1.78 & 0.89 \\
\hline $\mathrm{Ru}-101$ & ICP-MS & 24.42 & 12.21 & ICP-MS & 1.88 & 0.94 \\
\hline Ru-106 & $\gamma$-spec & 28.41 & 14.21 & ICP-MS & 8.18 & 4.09 \\
\hline Rh-103 & ICP-MS & 9.77 & 4.89 & ICP-MS & 6.53 & 3.27 \\
\hline Ag-109 & ICP-MS & 18.12 & 9.06 & & & \\
\hline Sb-125 & $\gamma$-spec & 18.85 & 9.43 & & & \\
\hline
\end{tabular}


Table 42. Experimental results for ARIANE Program Gösgen samples

\begin{tabular}{|c|c|c|c|c|c|c|}
\hline Sample ID & \multicolumn{2}{|c|}{ GU1 } & \multicolumn{2}{|c|}{ GU3 } & \multicolumn{2}{|c|}{ GU4 } \\
\hline Burnup $^{a}$ & \multicolumn{2}{|c|}{59.7} & \multicolumn{2}{|c|}{52.5} & \multicolumn{2}{|c|}{29.1} \\
\hline Enrichment (wt \% ${ }^{235} \mathrm{U}$ ) & \multicolumn{2}{|c|}{3.5} & \multicolumn{2}{|c|}{4.1} & \multicolumn{2}{|c|}{4.1} \\
\hline Measuring laboratory & \multicolumn{2}{|c|}{ SCK/CEN } & \multicolumn{2}{|c|}{ SCK/CEN \& ITU } & \multicolumn{2}{|c|}{ ITU } \\
\hline Nuclide ID & $\mathbf{g} / \mathbf{g} \mathbf{U}_{\text {initial }}$ & $\begin{array}{c}\text { RSD }^{b} \\
(\%)\end{array}$ & $g / g U_{\text {initial }}$ & $\begin{array}{c}\text { RSD } \\
(\%)\end{array}$ & $\mathbf{g} / \mathbf{g} \mathbf{U}_{\text {initial }}$ & $\begin{array}{c}\text { RSD } \\
(\%)\end{array}$ \\
\hline U-234 & $1.20 \mathrm{E}-04$ & 2.51 & $1.43 \mathrm{E}-04$ & 0.01 & $1.95 \mathrm{E}-04$ & 0.01 \\
\hline U-235 & $2.11 \mathrm{E}-03$ & 1.03 & $6.05 \mathrm{E}-03$ & 0.32 & $1.45 \mathrm{E}-02$ & 0.45 \\
\hline U-236 & $4.83 \mathrm{E}-03$ & 0.34 & $5.65 \mathrm{E}-03$ & 0.31 & $4.59 \mathrm{E}-03$ & 0.45 \\
\hline U-238 & $9.20 \mathrm{E}-01$ & 0.23 & $9.27 \mathrm{E}-01$ & 0.01 & $9.44 \mathrm{E}-01$ & 0.01 \\
\hline $\mathrm{Pu}-238$ & $4.54 \mathrm{E}-04$ & 1.53 & $3.72 \mathrm{E}-04$ & 0.28 & $1.11 \mathrm{E}-04$ & 1.08 \\
\hline $\mathrm{Pu}-239$ & $4.89 \mathrm{E}-03$ & 0.29 & $5.81 \mathrm{E}-03$ & 0.19 & $5.16 \mathrm{E}-03$ & 0.24 \\
\hline $\mathrm{Pu}-240$ & $3.18 \mathrm{E}-03$ & 0.29 & $2.84 \mathrm{E}-03$ & 0.15 & $1.84 \mathrm{E}-03$ & 0.26 \\
\hline $\mathrm{Pu}-241$ & $1.44 \mathrm{E}-03$ & 0.29 & $1.82 E-03^{c}$ & 0.28 & $9.87 \mathrm{E}-04$ & 1.70 \\
\hline $\mathrm{Pu}-242$ & $1.55 \mathrm{E}-03$ & 0.29 & $1.02 \mathrm{E}-03$ & 0.02 & $3.10 \mathrm{E}-04$ & 0.28 \\
\hline $\mathrm{Np}-237$ & & & $8.11 \mathrm{E}-04$ & 3.00 & $5.25 \mathrm{E}-04$ & 2.41 \\
\hline Am-241 & $2.48 \mathrm{E}-04$ & 1.78 & $2.28 \mathrm{E}-04$ & 0.79 & $1.47 \mathrm{E}-04$ & 5.94 \\
\hline Am-242m & $6.85 \mathrm{E}-07$ & 5.30 & $9.30 E-07$ & 5.29 & & \\
\hline Am-243 & 4.03E-04 & 1.78 & $2.38 \mathrm{E}-04$ & 1.74 & $4.38 \mathrm{E}-05$ & 6.65 \\
\hline $\mathrm{Cm}-242$ & 3.09E-07 & 3.61 & $2.76 E-05$ & 2.02 & & \\
\hline $\mathrm{Cm}-243$ & $3.38 \mathrm{E}-07$ & 36.75 & $6.24 E-07$ & 9.61 & & \\
\hline $\mathrm{Cm}-244$ & $2.44 \mathrm{E}-04$ & 1.51 & $1.41 E-04$ & 1.57 & $1.24 \mathrm{E}-05$ & 1.57 \\
\hline $\mathrm{Cm}-245$ & $1.75 \mathrm{E}-05$ & 2.95 & $1.10 \mathrm{E}-05$ & 1.43 & $5.74 \mathrm{E}-07$ & 10.15 \\
\hline $\mathrm{Cm}-246$ & $5.29 \mathrm{E}-06$ & 10.12 & $1.44 \mathrm{E}-06$ & 5.26 & & \\
\hline Cs-133 & $1.72 \mathrm{E}-03$ & 2.46 & $1.63 \mathrm{E}-03$ & 0.94 & $1.08 \mathrm{E}-03$ & 1.64 \\
\hline Cs-134 & $1.08 \mathrm{E}-04$ & 2.47 & $2.51 E-04$ & 1.44 & $4.14 \mathrm{E}-05$ & 1.27 \\
\hline Cs- 135 & $5.16 \mathrm{E}-04$ & 2.46 & $4.69 \mathrm{E}-04$ & 1.12 & $3.73 \mathrm{E}-04$ & 1.21 \\
\hline Cs-137 & $2.03 \mathrm{E}-03$ & 2.45 & $1.87 E-03$ & 0.52 & $9.95 \mathrm{E}-04$ & 1.50 \\
\hline $\mathrm{Ce}-144$ & $3.37 \mathrm{E}-05$ & 3.92 & $4.41 E-04$ & 1.01 & $3.63 \mathrm{E}-05$ & 2.75 \\
\hline Nd-142 & $6.77 \mathrm{E}-05$ & 5.01 & $4.23 \mathrm{E}-05$ & 5.01 & $1.20 \mathrm{E}-05$ & 5.09 \\
\hline Nd-143 & $9.33 \mathrm{E}-04$ & 0.29 & $1.07 \mathrm{E}-03$ & 0.28 & $8.62 \mathrm{E}-04$ & 6.16 \\
\hline Nd-144 & $2.63 \mathrm{E}-03$ & 0.29 & $2.14 \mathrm{E}-03$ & 0.28 & $1.23 \mathrm{E}-03$ & 5.95 \\
\hline Nd-145 & $1.04 \mathrm{E}-03$ & 0.29 & $9.89 \mathrm{E}-04$ & 0.28 & $6.76 \mathrm{E}-04$ & 6.89 \\
\hline Nd-146 & $1.33 \mathrm{E}-03$ & 0.29 & $1.15 \mathrm{E}-03$ & 0.28 & $6.50 \mathrm{E}-04$ & 7.37 \\
\hline Nd-148 & $6.66 \mathrm{E}-04$ & 0.30 & $5.87 \mathrm{E}-04$ & 0.29 & $3.47 \mathrm{E}-04$ & 6.70 \\
\hline Nd- 150 & 3.39E-04 & 0.30 & $2.86 \mathrm{E}-04$ & 0.29 & $1.58 \mathrm{E}-04$ & 6.78 \\
\hline Pm-147 & $1.37 E-04$ & 5.13 & $1.93 E-04$ & 9.01 & $2.02 E-04$ & \\
\hline Sm-147 & $2.22 \mathrm{E}-04$ & 0.32 & $1.96 \mathrm{E}-04$ & 0.32 & $1.61 \mathrm{E}-04$ & 10.57 \\
\hline Sm-148 & $3.24 \mathrm{E}-04$ & 0.32 & $2.54 \mathrm{E}-04$ & 0.32 & $1.11 \mathrm{E}-04$ & 4.01 \\
\hline Sm-149 & $3.28 \mathrm{E}-06$ & 1.05 & $3.36 \mathrm{E}-06$ & 1.05 & $3.02 \mathrm{E}-06$ & 5.88 \\
\hline Sm-150 & $5.08 \mathrm{E}-04$ & 0.32 & $4.46 \mathrm{E}-04$ & 0.32 & $2.43 \mathrm{E}-04$ & 3.44 \\
\hline Sm-151 & $1.30 \mathrm{E}-05$ & 0.40 & $1.47 E-05$ & 0.41 & $1.13 \mathrm{E}-05$ & 2.21 \\
\hline Sm-152 & $1.66 \mathrm{E}-04$ & 0.32 & $1.34 \mathrm{E}-04$ & 0.32 & $9.46 \mathrm{E}-05$ & 3.21 \\
\hline Sm-154 & 8.04E-05 & 0.33 & $5.73 \mathrm{E}-05$ & 0.33 & $2.64 \mathrm{E}-05$ & 5.65 \\
\hline Eu-151 & $7.18 \mathrm{E}-07$ & 1.05 & $4.20 \mathrm{E}-07$ & 1.05 & & \\
\hline Eu-153 & $2.10 \mathrm{E}-04$ & 0.34 & $1.84 \mathrm{E}-04$ & 0.33 & $9.39 \mathrm{E}-05$ & 5.49 \\
\hline Eu-154 & $3.22 \mathrm{E}-05$ & 1.95 & $4.30 E-05$ & 0.77 & $1.38 \mathrm{E}-05$ & 11.87 \\
\hline Eu-155 & $1.13 \mathrm{E}-05$ & 2.64 & $1.53 E-05$ & 4.72 & $4.40 \mathrm{E}-06$ & 4.64 \\
\hline Gd-155 & $5.63 \mathrm{E}-06$ & 2.50 & $3.93 \mathrm{E}-06$ & 1.00 & $2.64 \mathrm{E}-06$ & 6.81 \\
\hline Sr-90 & $9.72 \mathrm{E}-04$ & 7.50 & $7.75 E-04$ & 0.32 & $5.05 \mathrm{E}-04$ & \\
\hline Mo-95 & $1.23 \mathrm{E}-03$ & 3.87 & $1.18 \mathrm{E}-03$ & 1.47 & $7.58 \mathrm{E}-04$ & 1.56 \\
\hline Tc-99 & $1.25 \mathrm{E}-03$ & 6.30 & $1.12 \mathrm{E}-03$ & 1.94 & 5.99E-04 & 1.18 \\
\hline $\mathrm{Ru}-101$ & $1.29 \mathrm{E}-03$ & 4.58 & $1.21 \mathrm{E}-03$ & 1.75 & 7.49E-04 & 2.00 \\
\hline $\mathrm{Ru}-106$ & $2.56 E-04$ & 2.82 & $2.90 E-04$ & 14.21 & $1.29 E-04$ & 2.69 \\
\hline $\mathrm{Rh}-103$ & $6.13 \mathrm{E}-04$ & 4.49 & $5.40 \mathrm{E}-04$ & 2.44 & $4.54 \mathrm{E}-04$ & 2.36 \\
\hline Ag-109 & $7.51 \mathrm{E}-05$ & 5.18 & $1.19 \mathrm{E}-04$ & 9.06 & & \\
\hline Sb-125 & $9.29 E-06$ & 5.07 & $7.50 E-06$ & 9.43 & & \\
\hline
\end{tabular}

${ }^{a}$ In MWd/MTU; as reported in Ref. 48 .

${ }^{b}$ Relative standard deviation.

${ }^{c}$ Values shown in italics are reported at the time of discharge; all other values correspond to the time of measurement listed in Table 43. 
Table 43. Decay time at the time of measurement for ARIANE Program Gösgen samples

\begin{tabular}{|c|c|c|c|c|c|c|}
\hline \multirow{3}{*}{$\begin{array}{c}\text { Sample ID } \\
\text { Experimental facility } \\
\text { Nuclides }\end{array}$} & \multirow{2}{*}{\multicolumn{2}{|c|}{$\begin{array}{c}\text { GU1 } \\
\text { SCK/CEN }\end{array}$}} & \multirow{2}{*}{\multicolumn{2}{|c|}{$\begin{array}{c}\text { GU3 } \\
\text { SCK/CEN \& ITU }\end{array}$}} & \multirow{2}{*}{\multicolumn{2}{|c|}{$\begin{array}{c}\text { GU4 } \\
\text { ITU } \\
\end{array}$}} \\
\hline & & & & & & \\
\hline & $\begin{array}{c}\text { Measurement } \\
\text { date }^{a} \\
\text { (month/day/year) }\end{array}$ & $\begin{array}{l}\text { Decay } \\
\text { time } \\
\text { (days) }\end{array}$ & $\begin{array}{c}\text { Measurement } \\
\text { date }^{a} \\
\text { (month/day/year) }\end{array}$ & $\begin{array}{l}\text { Decay } \\
\text { time } \\
\text { (days) }\end{array}$ & $\begin{array}{c}\text { Measurement } \\
\text { date }^{a} \\
\text { (month/day/year) }\end{array}$ & $\begin{array}{l}\text { Decay } \\
\text { time }^{b} \\
\text { (days) }\end{array}$ \\
\hline Uranium & $4 / 9 / 97$ & 1040 & $10 / 12 / 99$ & 857 & $5 / 20 / 99$ & 712 \\
\hline Plutonium & $4 / 22 / 97$ & 1053 & $10 / 11 / 99$ & 856 & 8/17/99 & 801 \\
\hline Neptunium & & & $12 / 22 / 99$ & 928 & $6 / 16 / 99$ & 739 \\
\hline Americium & $4 / 9 / 97$ & 1040 & $12 / 21 / 99$ & 927 & $6 / 16 / 99$ & 739 \\
\hline Curium & $6 / 4 / 97$ & 1096 & 7/1/99 & 754 & $6 / 16 / 99$ & 739 \\
\hline Neodymium & $4 / 9 / 97$ & 1040 & $11 / 24 / 99$ & 900 & 9/30/99 & 845 \\
\hline Cesium & $5 / 30 / 97$ & 1091 & $7 / 1 / 99$ & 754 & $10 / 6 / 99$ & 851 \\
\hline Cerium & $2 / 28 / 97$ & 1000 & 7/1/99 & 754 & 9/30/99 & 845 \\
\hline Samarium & $4 / 23 / 97$ & 1054 & $12 / 13 / 99$ & 919 & $10 / 1 / 99$ & 846 \\
\hline Europium & $4 / 23 / 97$ & 1054 & $7 / 1 / 99$ & 754 & $10 / 4 / 99$ & 849 \\
\hline Gadolinium & & & $12 / 1 / 99$ & 907 & $10 / 4 / 99$ & 849 \\
\hline Strontium & $6 / 24 / 97$ & 1116 & $5 / 16 / 00$ & 1074 & $11 / 15 / 99$ & 891 \\
\hline${ }^{95} \mathrm{Mo},{ }^{99} \mathrm{Tc},{ }^{101} \mathrm{Ru}$ & $4 / 10 / 00$ & 2137 & $4 / 10 / 00$ & 1038 & $11 / 15 / 99$ & 891 \\
\hline${ }^{103} \mathrm{Rh},{ }^{109} \mathrm{Ag}$ & $4 / 10 / 00$ & 2137 & $4 / 10 / 00$ & 1038 & $11 / 15 / 99$ & 891 \\
\hline${ }^{106} \mathrm{Ru},{ }^{125} \mathrm{Sb}$ & $2 / 28 / 97$ & 1000 & $10 / 7 / 99$ & 852 & $11 / 15 / 99$ & 891 \\
\hline
\end{tabular}

${ }^{a}$ Measurement dates from DTN: MO0808ARIANEIP.000, Tables 3.2-CEN results.xls and Tables 3.2-ITU results.xls

${ }^{b}$ Decay time calculated based on cycle end dates of 6/4/1994 for sample GU1 (DTN: MO0808ARIANEIP.000, ARIANE Final Report.pdf, p.

106) and 6/7/1997 for samples GU3 and GU4 (DTN: MO0808ARIANEIP.000, ARIANE Final Report.pdf, p. 134). 
A material balance for the ARIANE Gösgen samples was performed ${ }^{48}$ using two independent measures to verify the consistency of the experimental data. The material balance ratio was calculated as

$$
M B=\frac{1.1345 \times\left(W_{U}+W_{P u}+W_{M A}+\Delta W\right)}{W_{\text {sample }}^{\text {total }}},
$$

where $W_{U}, W_{P u}$, and $W_{M A}$ are the weights of the uranium, plutonium, and minor actinides (americium and curium) measured in the dissolved solution, $\Delta W$ is the loss on the initial uranium mass due to fission, and $W_{\text {sample }}^{\text {total }}$ is the actual mass of the fuel sample as measured on the mass balance. The coefficient 1.1345 represents the approximate ratio of the fuel weight to uranium weight. The loss due to fission, $\Delta W$, was determined using the measured concentrations of the burnup indicator fission product ${ }^{148} \mathrm{Nd}$. The fuel mass ratio obtained for samples GU3 and GU4 (all laboratories) was 1.00; however, the ratio obtained for sample GU1 was 1.12, indicating that the mass derived from the sum of measured actinides was about $12 \%$ greater than the actual measured fuel sample mass. The experimental data was therefore adjusted to the initial fuel mass as derived from the heavy metal isotopic measurements. The only plausible source of such significant error in the isotopic data would be the absolute measured mass of uranium in the solution.

\subsection{GKN UNIT II}

The REBUS (Reactivity Tests for a Direct Evaluation of the Burnup Credit on Selected Irradiated LWR Fuel Bundles) International Program ${ }^{49}$ coordinated by Belgonucleaire was dedicated to the validation of computer codes for criticality calculations that take into account the reduction of reactivity of spent fuel as a result of burnup credit. Participants in REBUS included institutes from Belgium, France, Germany, Japan, and the United States. ORNL was a participant in the early stages of the program under support from the U.S. Nuclear Regulatory Commission (NRC) and negotiated access to the data from this program. The REBUS program was completed in December 2005.

REBUS involved critical measurements in the VENUS critical facility at SCK-CEN in Belgium using spent fuel rod segments. One of the segments was assayed to experimentally determine the isotopic content of the fuel. The results for this sample, measured by the SCK-CEN radiochemical laboratory, were reported. The sample was obtained from a fuel rod of an $18 \times 18$ PWR assembly operated in the German reactor Gemeinschaftskernkraftwerk Unit II (GKN II) in Neckarwestheim/Neckar. GKN is a PWR in Germany with a net generating capacity of 1400 MWe, which was designed by German Kraftwerk Union AG (KWU). First power was achieved in January 1989 with an initial core consisting of KWU $18 \times 18$ assemblies. ${ }^{57}$ Although this reactor currently operates with a MOX core, the assembly was obtained from the reactor during a period when it operated with only $\mathrm{UO}_{2}$ fuel. The measured sample had an initial enrichment of $3.8 \mathrm{wt} \%{ }^{235} \mathrm{U}$. The sample consisted of about three fuel pellets cut from the fuel rod identified as M11. The reported sample burnup was about $54 \mathrm{GWd} / \mathrm{MTHM}$.

The selected sample was subjected to a two-step dissolution process followed by sample preparation for the various analytical techniques employed. The radiochemical analysis techniques included $\alpha$ - and $\gamma$-spectrometry, ICP-MS, and TIMS. For the actinides, the analysis was performed for isotopes of uranium, neptunium, plutonium, americium, and curium. The fission products analyzed were of two types: burnup indicators, consisting of neodymium isotopes as well as ${ }^{137} \mathrm{Cs}$ and ${ }^{144} \mathrm{Ce}$; and absorbing fission products, consisting of metallic species $\left({ }^{95} \mathrm{Mo},{ }^{99} \mathrm{Tc},{ }^{101} \mathrm{Ru},{ }^{103} \mathrm{Rh},{ }^{105} \mathrm{Pd},{ }^{108} \mathrm{Pd}\right.$, and $\left.{ }^{109} \mathrm{Ag}\right),{ }^{133} \mathrm{Cs}$, and isotopes of $\mathrm{Sm}, \mathrm{Eu}$, and $\mathrm{Gd}$. The metallic species were difficult to dissolve completely, and as a result, the dissolution residue had to be analyzed separately. 
Because of the variety of the analysis techniques, the varying properties of the nuclides being analyzed, and their differing concentrations, uncertainties in the measured concentrations vary greatly. Table 44 lists the measurement method and, for each of the measured nuclides, the reported experimental uncertainty at $95 \%$ confidence level, corresponding to the experimental results reported in $\mathrm{mg} / \mathrm{g}{ }^{238} \mathrm{U}$ (Ref. 50). Also shown in Table 44 is the relative standard deviation calculated as half of the reported $95 \%$ confidence level uncertainty.

Nuclide concentrations were reported both in $\mathrm{mg} / \mathrm{g}$ fuel and $\mathrm{mg} / \mathrm{g}{ }^{238} \mathrm{U}$ in the sample at the measurement date. ${ }^{51}$ For the purpose of comparison to measured data from other programs, the experimental data for the GKN II sample are presented in $\mathrm{g} / \mathrm{g} \mathrm{U}_{\text {initial }}$ units in Table 45. The unit conversion was done using Eq. (9) (see Sect. 6.5).

The measurement date and the time duration from discharge to the measurement date for each of the analyzed nuclides is provided in Table 46 (Ref. 50).

\subsection{GÖSGEN REACTOR: MALIBU PROGRAM}

A description of radiochemical analysis data produced by the MALIBU program and used in this validation study is available in DTN: MO1003MALIBUIP.001. 
Table 44. Experimental techniques and uncertainties for REBUS Program GKN II sample

\begin{tabular}{|c|c|c|c|}
\hline $\begin{array}{c}\text { Nuclide } \\
\text { ID }\end{array}$ & $\operatorname{Method}^{a}$ & $\begin{array}{c}\text { Uncertainty }^{b} \text { at } 95 \% \\
\text { confidence level } \\
(\%)\end{array}$ & $\begin{array}{r}\text { RSD }^{c} \\
(\%)\end{array}$ \\
\hline U-234 & TIMS & 5.0 & 2.5 \\
\hline $\mathrm{U}-235$ & TIMS & 0.73 & 0.37 \\
\hline $\mathrm{U}-236$ & TIMS & 0.73 & 0.37 \\
\hline $\mathrm{U}-238$ & TIMS & 0.57 & 0.29 \\
\hline Total U & & 0.53 & 0.22 \\
\hline $\mathrm{Np}-237$ & ICP-MS & 20.0 & 10.0 \\
\hline $\mathrm{Pu}-238$ & TIMS, $\alpha$-spec & 3.1 & 1.6 \\
\hline $\mathrm{Pu}-239$ & TIMS & 0.59 & 0.30 \\
\hline $\mathrm{Pu}-240$ & TIMS & 0.59 & 0.30 \\
\hline $\mathrm{Pu}-241$ & TIMS & 0.59 & 0.30 \\
\hline $\mathrm{Pu}-242$ & TIMS & 0.61 & 0.31 \\
\hline Am-241 & TIMS & 3.5 & 1.8 \\
\hline $\mathrm{Am}-242 \mathrm{~m}$ & TIMS & 11.0 & 5.5 \\
\hline $\mathrm{Am}-243$ & TIMS & 3.5 & 1.8 \\
\hline $\mathrm{Cm}-242$ & $\alpha$-spec & 32.0 & 16.0 \\
\hline $\mathrm{Cm}-243$ & $\gamma$-spec & 20.0 & 10.0 \\
\hline $\mathrm{Cm}-244$ & $\alpha$-spec & 2.5 & 1.3 \\
\hline $\mathrm{Cm}-245$ & TIMS & 5.6 & 2.8 \\
\hline Mo-95 & ICP-MS & 9.9 & 5.0 \\
\hline Tc-99 & ICP-MS & 10.0 & 5.0 \\
\hline Ru-101 & ICP-MS & 9.9 & 5.0 \\
\hline Rh-103 & ICP-MS & 10.0 & 5.0 \\
\hline Pd-105 & ICP-MS & 9.8 & 4.9 \\
\hline Pd-108 & ICP-MS & 9.8 & 4.9 \\
\hline Ag-109 & ICP-MS & 10.0 & 5.0 \\
\hline Cs-133 & TIMS & 2.6 & 1.3 \\
\hline Cs- 135 & $\gamma$-spec & 2.6 & 1.3 \\
\hline Cs-137 & $\gamma$-spec & 2.6 & 1.3 \\
\hline Nd-142 & TIMS & 0.78 & 0.39 \\
\hline Nd-143 & TIMS & 0.64 & 0.32 \\
\hline Nd-144 & TIMS & 0.64 & 0.32 \\
\hline Nd-145 & TIMS & 0.64 & 0.32 \\
\hline Nd-146 & TIMS & 0.64 & 0.32 \\
\hline Nd-148 & TIMS & 0.65 & 0.32 \\
\hline Nd-150 & TIMS & 0.65 & 0.33 \\
\hline $\mathrm{Ce}-144$ & $\gamma$-spec & 10.0 & 5.0 \\
\hline Sm-147 & TIMS & 0.75 & 0.38 \\
\hline $\mathrm{Sm}-148^{d}$ & TIMS & 0.75 & 0.38 \\
\hline Sm-149 & TIMS & 2.13 & 1.07 \\
\hline Sm-150 & TIMS & 0.75 & 0.38 \\
\hline Sm-151 & TIMS & 0.88 & 0.44 \\
\hline Sm-152 & TIMS & 0.75 & 0.38 \\
\hline Sm-154 ${ }^{d}$ & TIMS & 0.76 & 0.38 \\
\hline Eu-153 & TIMS & 0.9 & 0.5 \\
\hline Eu-154 & $\gamma$-spec & 3.4 & 1.7 \\
\hline Eu-155 & $\gamma$-spec & 6.0 & 3.0 \\
\hline Gd-155 & TIMS & 5.0 & 2.5 \\
\hline
\end{tabular}

${ }^{a}$ Main technique is listed; some nuclides may require multiple techniques to eliminate interferences.

${ }^{b}$ As reported for the measured data expressed in $\mathrm{mg} / \mathrm{g}{ }^{238} \mathrm{U}$ in Ref. 50.

${ }^{c}$ Relative standard deviation.

${ }^{d}$ The use of TIMS for these Sm isotopes was inferred from Ref. 50. The reference does not include these isotopes in the list of isotopes analyzed by TIMS. However, the reference indicates that TIMS was used to determine isotopic compositions and concentrations of elemental Sm. 
Table 45. Experimental results for GKN II (REBUS) sample

\begin{tabular}{|c|c|c|c|c|c|}
\hline Nuclide & $\begin{array}{c}\text { Concentration }^{a} \\
\left(\mathrm{~g} / \mathrm{g} \mathrm{U}_{\text {initial }}\right)\end{array}$ & $\begin{array}{c}\text { RSD }^{b} \\
(\%)\end{array}$ & Nuclide & $\begin{array}{c}\text { Concentration }^{a} \\
\left(\mathrm{~g} / \mathrm{g} \mathrm{U}_{\text {initial }}\right)\end{array}$ & $\begin{array}{l}\text { RSD }^{b} \\
(\%)\end{array}$ \\
\hline U-234 & $1.49 \mathrm{E}-04$ & 2.52 & Ag-109 & $1.07 \mathrm{E}-04$ & 5.01 \\
\hline U-235 & $5.12 \mathrm{E}-03$ & 0.46 & Cs-133 & $1.60 \mathrm{E}-03$ & 1.33 \\
\hline U-236 & $5.35 \mathrm{E}-03$ & 0.46 & Cs-135 & $5.76 \mathrm{E}-04$ & 1.33 \\
\hline $\mathrm{U}-238$ & $9.21 \mathrm{E}-01$ & 2.52 & Cs-137 & $1.68 \mathrm{E}-03$ & 1.33 \\
\hline Np-237 & $6.08 \mathrm{E}-04$ & 10.0 & $\mathrm{Ce}-144$ & $4.88 \mathrm{E}-07$ & 5.01 \\
\hline $\mathrm{Pu}-238$ & $4.28 \mathrm{E}-04$ & 1.58 & Nd-142 & $5.22 \mathrm{E}-05$ & 0.48 \\
\hline $\mathrm{Pu}-239$ & $5.77 \mathrm{E}-03$ & 0.41 & Nd-143 & $1.07 \mathrm{E}-03$ & 0.43 \\
\hline $\mathrm{Pu}-240$ & $3.22 \mathrm{E}-03$ & 0.41 & Nd-144 & $2.26 \mathrm{E}-03$ & 0.43 \\
\hline $\mathrm{Pu}-241$ & $1.30 \mathrm{E}-03$ & 0.41 & Nd-145 & $9.96 \mathrm{E}-04$ & 0.43 \\
\hline $\mathrm{Pu}-242$ & $1.17 \mathrm{E}-03$ & 0.42 & Nd-146 & $1.18 \mathrm{E}-03$ & 0.43 \\
\hline Am-241 & $5.25 \mathrm{E}-04$ & 1.77 & Nd-148 & $5.96 \mathrm{E}-04$ & 0.43 \\
\hline$A m-242 m$ & $1.57 \mathrm{E}-06$ & 5.51 & Nd-150 & $2.95 \mathrm{E}-04$ & 0.43 \\
\hline Am-243 & 2.49E-04 & 1.77 & Sm-147 & 2.99E-04 & 0.47 \\
\hline $\mathrm{Cm}-242$ & 4.33E-09 & 16.00 & Sm-148 & $2.88 \mathrm{E}-04$ & 0.47 \\
\hline $\mathrm{Cm}-243$ & $7.75 \mathrm{E}-07$ & 10.00 & Sm-149 & 2.39E-06 & 1.10 \\
\hline $\mathrm{Cm}-244$ & $1.33 \mathrm{E}-04$ & 1.28 & Sm-150 & 4.77E-04 & 0.47 \\
\hline $\mathrm{Cm}-245$ & $1.33 \mathrm{E}-05$ & 2.81 & Sm-151 & $1.43 \mathrm{E}-05$ & 0.52 \\
\hline Mo-95 & $1.04 \mathrm{E}-03$ & 5.01 & Sm-152 & $1.47 \mathrm{E}-04$ & 0.47 \\
\hline Tc-99 & $1.25 \mathrm{E}-03$ & 5.01 & Sm-154 & $6.70 \mathrm{E}-05$ & 0.48 \\
\hline $\mathrm{Ru}-101$ & $9.68 \mathrm{E}-04$ & 5.01 & Eu-153 & $1.92 \mathrm{E}-04$ & 0.53 \\
\hline Rh-103 & $5.81 \mathrm{E}-04$ & 5.01 & Eu-154 & $2.30 \mathrm{E}-05$ & 1.72 \\
\hline Pd-105 & $4.52 \mathrm{E}-04$ & 5.01 & Eu-155 & $6.17 \mathrm{E}-06$ & 3.01 \\
\hline Pd-108 & $1.77 \mathrm{E}-04$ & 5.01 & Gd-155 & $1.01 \mathrm{E}-05$ & 2.52 \\
\hline
\end{tabular}

${ }^{a}$ Calculated using Eq. (10) and the isotopic concentration values, in $\mathrm{mg} / \mathrm{g}{ }^{238} \mathrm{U}$, reported in Ref. 50 (see DVD/xls/Experimental_data.xls).

${ }^{b}$ Accounts for reported error in measured ${ }^{238} \mathrm{U}$. 
Table 46. Decay time data for GKN II (REBUS) sample

\begin{tabular}{ccl}
\hline $\begin{array}{c}\text { Measurement date } \\
\text { (month/day/year) }\end{array}$ & $\begin{array}{c}\text { Decay time } \\
\text { (days) }\end{array}$ & \multicolumn{1}{c}{ Measured nuclides } \\
\hline $9 / 28 / 2004$ & 2600 & ${ }^{144} \mathrm{Ce},{ }^{154} \mathrm{Eu},{ }^{155} \mathrm{Eu},{ }^{137} \mathrm{Cs}$ \\
$9 / 29 / 2004$ & 2601 & ${ }^{242} \mathrm{Cm},{ }^{244} \mathrm{Cm}$ \\
$11 / 02 / 2004$ & 2635 & ${ }^{238} \mathrm{Pu},{ }^{239} \mathrm{Pu},{ }^{240} \mathrm{Pu},{ }^{241} \mathrm{Pu},{ }^{242} \mathrm{Pu}$ \\
$11 / 15 / 2004$ & 2648 & ${ }^{133} \mathrm{Cs},{ }^{135} \mathrm{Cs}$ \\
$12 / 09 / 2004$ & 2672 & ${ }^{234} \mathrm{U},{ }^{235} \mathrm{U},{ }^{236} \mathrm{U},{ }^{238} \mathrm{U}$ \\
$2 / 10 / 2005$ & 2735 & ${ }^{147} \mathrm{Sm},{ }^{148} \mathrm{Sm},{ }^{149} \mathrm{Sm},{ }^{150} \mathrm{Sm},{ }^{151} \mathrm{Sm},{ }^{152} \mathrm{Sm},{ }^{154} \mathrm{Sm},{ }^{153} \mathrm{Eu},{ }^{155} \mathrm{Gd}$ \\
$2 / 28 / 2005$ & 2753 & ${ }^{142} \mathrm{Nd},{ }^{143} \mathrm{Nd},{ }^{144} \mathrm{Nd},{ }^{145} \mathrm{Nd},{ }^{146} \mathrm{Nd},{ }^{148} \mathrm{Nd},{ }^{150} \mathrm{Nd}$ \\
$3 / 07 / 2005$ & 2760 & ${ }^{243} \mathrm{Cm},{ }^{241} \mathrm{Am},{ }^{242 \mathrm{~m}} \mathrm{Am},{ }^{243} \mathrm{Am}$ \\
$4 / 29 / 2005$ & 2813 & ${ }^{237} \mathrm{~Np},{ }^{95} \mathrm{Mo},{ }^{99} \mathrm{Tc},{ }^{101} \mathrm{Ru},{ }^{103} \mathrm{Rh},{ }^{105} \mathrm{Pd},{ }^{108} \mathrm{Pd},{ }^{109} \mathrm{Ag}$ \\
$6 / 01 / 2005$ & 2846 & ${ }^{245} \mathrm{Cm}$ \\
\hline
\end{tabular}

Source: Ref. 50. 


\section{ASSEMBLY DESIGN AND IRRADIATION HISTORY DATA}

This section describes assembly design and irradiation history data that are relevant to 2-D transport and depletion calculations for the evaluated spent fuel samples.

\subsection{TRINO VERCELLESE}

The Trino Vercellese Nuclear Power Plant was an 825-MW PWR located in Italy. The power plant has been permanently shut down and is being decommissioned. The steam generation plant and fuel were designed by Westinghouse Electric Corp. The reactor core was composed of square and cruciform assemblies. Details related to the geometry, material composition, and irradiation history were obtained from Refs. 12, 13, and 14. The assembly locations in the reactor core are illustrated in Fig. 2. During the first cycle, the reactor core was composed of 120 square fuel assemblies, which were organized into three radial zones of initial enrichments of $2.719,3.13$, and $3.897 \mathrm{wt} \%{ }^{235} \mathrm{U}$, and 52 cruciform assemblies of initial enrichment of $2.72 \mathrm{wt} \%{ }^{235} \mathrm{U}$. Of the 52 cruciform assemblies, 24 were permanently inserted in the core and 28 were connected to 28 cruciform control rods as "fuel bearing followers" so that if a cruciform control rod were removed, a cruciform fuel assembly would raise into the fuel. Ten cruciform control rods acted as a control group during power operation, and the remaining 18 cruciform rods acted as shut-down rods. The cruciform control rods were composed of 32 absorber rods containing $\mathrm{Ag}$, In, and $\mathrm{Cd}$ in the ratio 80:15:5. A cross section showing the locations of the cruciform assemblies in the S-E quarter of the core during cycle 1 is presented in Fig. 3(a) and a cross section of the reactor core showing the locations of the cruciform assemblies during cycle 2, as provided in Ref. 84, Fig. 3.1, is shown in Fig. 3(b).

All square assemblies contain fuel and are based on a $15 \times 15$ lattice of fuel pins, with 16 of the outer pins excluded to accommodate cruciform assemblies or control rods, as illustrated in Fig. 4 (Ref. 14). The assemblies are surrounded by a 0.6-mm-thick stainless steel channel tube (see Fig. 4). The center position in each assembly was used for instrumentation and was represented as vacant for the depletion calculations in the current report. The cruciform fuel pins are always $2.72 \mathrm{wt} \%{ }^{235} \mathrm{U}$, even though the fuel assembly in which they are placed may have a higher enrichment. For the 28 lattice positions of the cruciform assembly, there are only 26 fuel pins (Ref. 12). Reactor core characteristics and design data for square fuel assemblies and cruciform fuel and absorber rods are based on the values reported in Refs. 12 and 13 and are given in Table 47. The numbers in parentheses are for the second cycle, which are mainly taken from Ref. 12. The data in both references are consistent, with the exception of the core equivalent diameter, which was listed as $240 \mathrm{~cm}$ in Ref. 13. Operational parameters for cycles 1 and 2 and for subcycle periods I, II, and III of cycle 1 are given in Table 48. During cycle 1, two downtime intervals occurred prior to the end of the cycle, and cycle 2 was completed with no downtime. The control rods have been inserted 30\% during the first part of the first cycle in the core locations identified in Fig. 3 (Ref. 12), and they were completely withdrawn during cycle 2 (Ref. 24).

At the end of the first cycle, the 40 assemblies of the inner core (enrichment $2.719 \mathrm{wt} \%{ }^{235} \mathrm{U}$ ) and some assemblies of the intermediate and outer regions (enrichments 3.13 and $3.897 \mathrm{wt} \%{ }^{235} \mathrm{U}$ ) were unloaded from the reactor for reprocessing. The reactor core for cycle 2 was reduced by replacing eight fuel assemblies with eight dummy assemblies. ${ }^{14}$ Radiochemical assay data exist for four square fuel assemblies. Three of the assemblies, referred to as 509-032, 509-049, and 509-104, were irradiated in the core during the first cycle only. The remaining assembly, identified as 509-069, was irradiated during both first and second fuel cycles. This validation study considers 31 different Trino Vercellese fuel samples that were cut from fuel rods E11 and H9 in assembly 509-032; fuel rods J8 and L5 in assembly 509-049; fuel rods E5, E11, J9, L5, and L11 in assembly 509-069; and fuel rod M11 in assembly 509-104, with the pin locations illustrated in Fig. 5. All the mentioned fuel rods were assembly inner rods. 
Note that the spent fuel samples obtained from assembly peripheral fuel rods were not selected for evaluation in this validation report because the enrichment and burnup of the adjoining square assembly were not provided in the reference documents and the use of a simplified 2-D assembly model that neglects the characteristics of the adjoining assemblies may increase the uncertainty in the calculated isotopic compositions. The measured spent fuel samples were obtained from a variety of axial locations along the fuel rods. The sample heights were not explicitly provided in Refs. 12 and 13. Rather, the sample pellet locations were identified by level number, 1 to 9 , and were illustrated in relation to the positions of the assembly grids (Ref. 12, Fig. 3). Sample axial positions were determined in Ref. 14 based on the gamma-activity plots shown in Figs. 19 through 26 in Ref. 12 and Figs. 21 through 27 in Ref. 13. The sample identification and general characteristics are presented in Table 6 (see Sect. 7.1). Note that some of the gamma-activity plots show small variations $(< \pm 2 \mathrm{~cm})$ from the values provided in Ref. 14 . The variation occurs because the sampled fuel rods had slightly different lengths; however, neglecting those variations should have insignificant effects on the values of the calculated moderator temperature and density based on Eq. (1) (see Sect. 5.2). Note that all the considered sampled rods occupied inner assembly positions that were separated from control rods by at least four rods. In addition, samples taken from elevations 4 through 9 were clearly positioned below the control rods. Therefore, it was determined that the control rod influence is negligible on the results of the isotopic calculations.

Data for a series of input parameters were not available in the published reports. The input parameters, which include initial fuel compositions, moderator temperatures and densities, fuel and clad temperatures, operating power histories, and soluble boron content in cycle 2 for the Trino Vercellese assemblies, were determined using the methods described in Sect. 5 and additional assumptions as described below.

The calculated fuel initial isotopic compositions and mass densities are listed in Table 49. The isotopic composition values were calculated using the empirical relation described in Table 2 and the fuel initial enrichments provided in Refs. 12 and 13.

Moderator temperatures and densities at sample axial locations are listed in Table 50. The moderator temperatures were calculated using Eq. (1) and sample axial locations listed in Table 6 and the inlet and outlet temperatures listed in Table 48. The moderator densities were determined by interpolating density data for the coolant pressure of $140 \mathrm{~kg} / \mathrm{cm}^{2}$, as described in Sect. 5.2.

Assembly-specific burnup values for the irradiation periods and cycles were supplied for assembly 509-069 only (see Table 48). Power histories and effective fuel temperatures for each sample are listed in Table 51. The specific power for each individual sample in a given assembly was determined from the final sample burnup (see Table 6), the specified uptimes (see Table 48), and the burnup distribution for assembly 509-069 (see Table 48) assuming that the relative burnup per depletion step is the same for assembly 509-069 and the sample. The effective fuel temperatures were computed from resonanceeffective temperatures given in operating data for the similarly designed Yankee Rowe PWR (Ref. 85, Table C-1). To evaluate the magnitude of the uncertainty in the calculated isotopic concentrations due to the uncertainty associated with the effective fuel temperature values used, sensitivity calculations were performed for two Trino Vercellese samples in which the applicable Yankee Rowe effective fuel temperature values were increased by $10 \%$. The relative percent differences between the isotopic concentrations obtained with the Yankee Rowe temperature values and the isotopic concentrations obtained with the perturbed temperature values were less than $1.2 \%$ for all isotopes of interest (see Sect. 10.2.3, Table 109). Therefore, although the uncertainty in the effective fuel temperature cannot be evaluated, the effect of the fuel temperature uncertainty on the calculated isotopic concentrations is expected to be significantly small. 


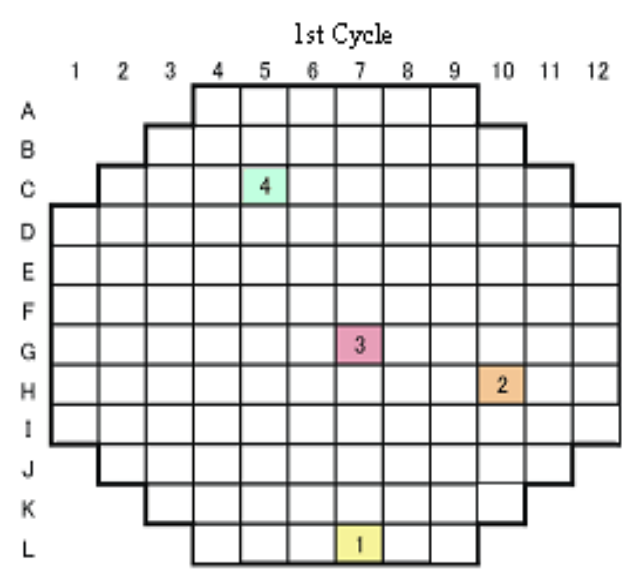

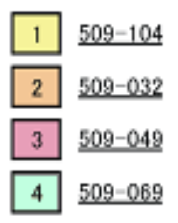

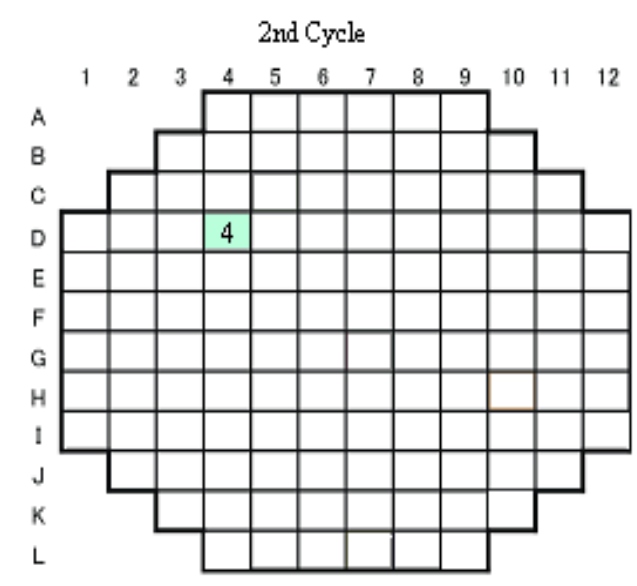

$4 \sqrt[509-069]{2}$

Fig. 2. Schematic core map for the Trino Vercellese reactor showing the locations of the measured assemblies during cycle 1 and cycle 2. (Source: Ref. 14, Fig. I.8.) 


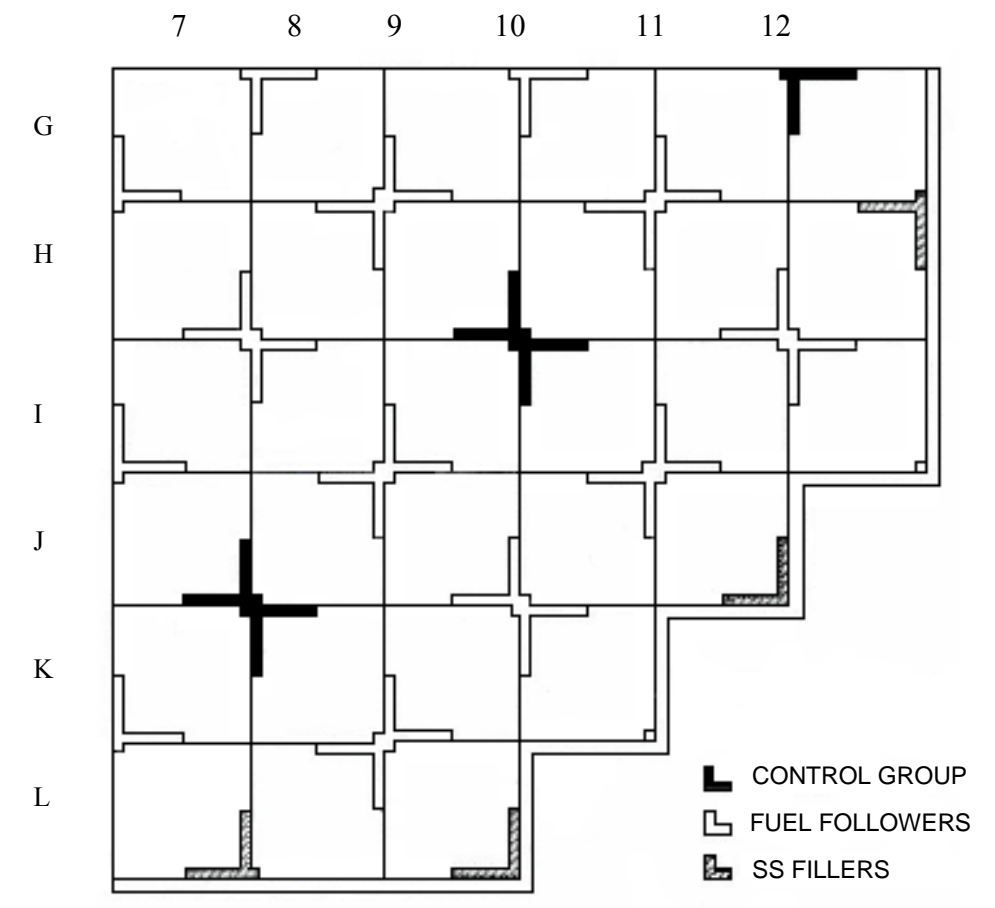

(Source: Ref. 12, Fig. 1.)

(a)

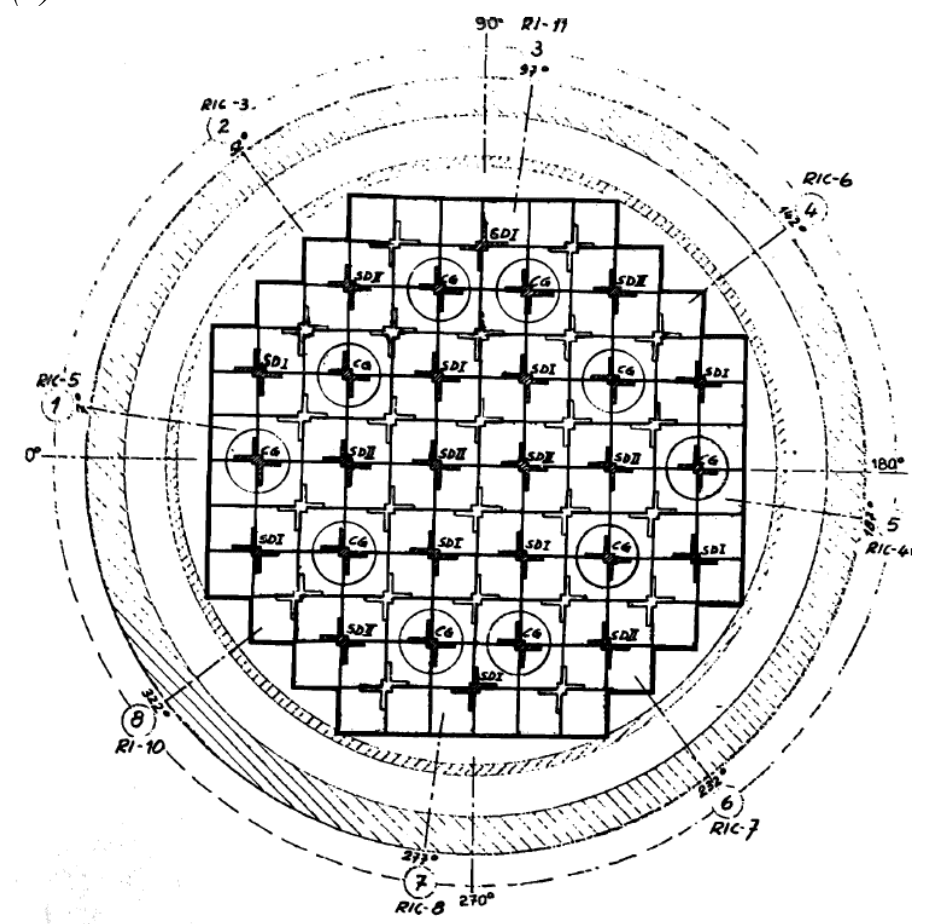

Note: $\mathrm{CG}=$ control group; $\mathrm{SDI}=$ shut down group $1 ; \mathrm{SDII}=$ shut down group 2

(b)

Fig. 3. (a) S-E quarter showing locations of cruciform assemblies containing control rods, fuel rods, and stainless steel fillers during cycle 1; (b) control group locations during cycle 2. (Source: Ref. 84, Fig. 3.1.) 


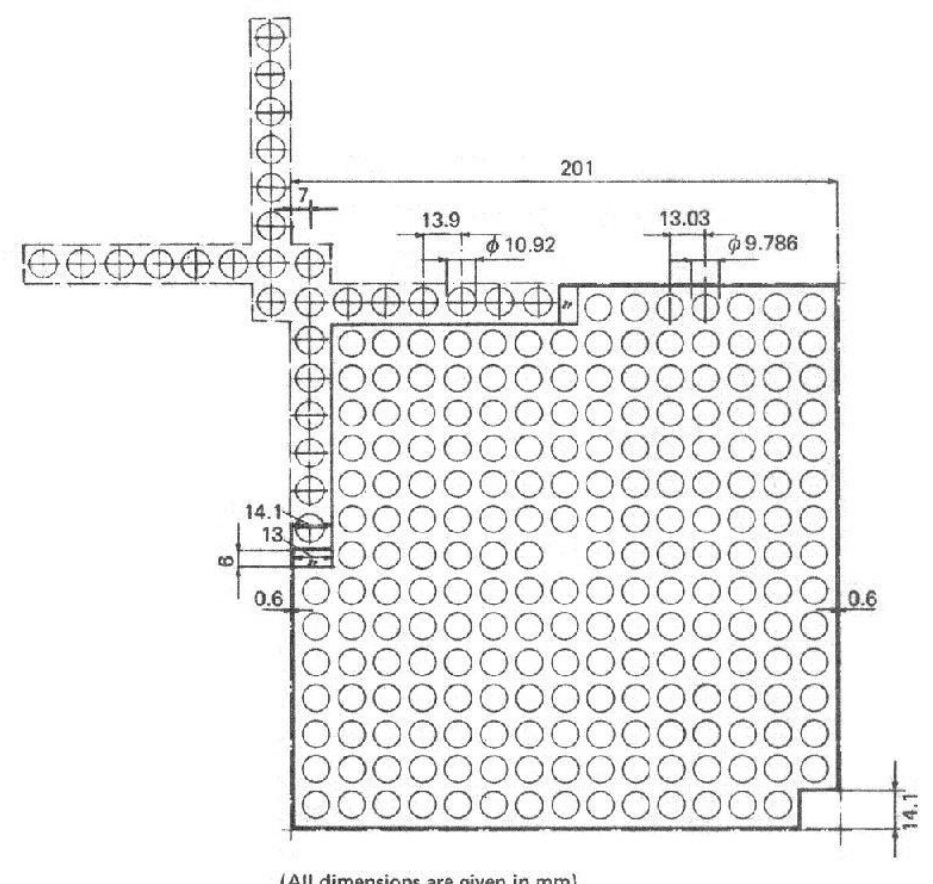

Fig. 4. Horizontal cross section of the Trino Vercellese square fuel assembly. (Source: Ref. 14, Fig. I.10.)
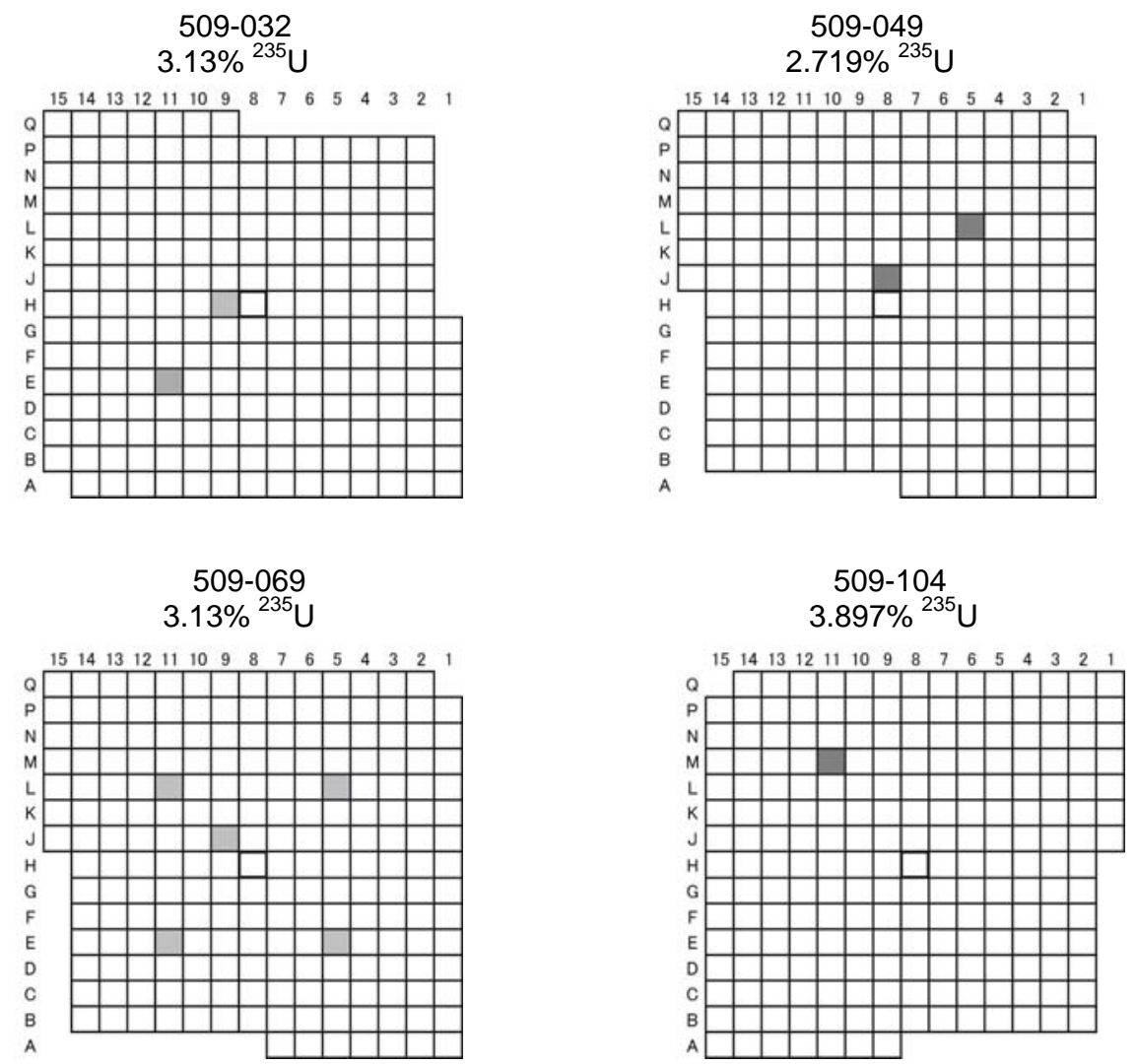

Fig. 5. Location of Trino Vercellese measured fuel rods. (Source: Ref. 13, Table 5, and Ref. 14, Fig. I.9.) 
Table 47. Assembly design and operating data for Trino Vercellese

\begin{tabular}{|c|c|}
\hline Parameter & Data \\
\hline \multicolumn{2}{|l|}{ Core mechanical characteristics } \\
\hline Design & Westinghouse, PWR \\
\hline Number of square fuel assemblies, cycle 1 (cycle 2) & $120(112)$ \\
\hline Number of cruciform fuel assemblies & 52 \\
\hline Number of control rods & 28 \\
\hline Number of enrichment regions in the core & 3 \\
\hline Initial enrichments (square assemblies) & $2.719-3.13-3.897 \%$ \\
\hline Initial enrichment (cruciform assemblies) & $2.719 \%$ \\
\hline $\mathrm{UO}_{2}$ in square fuel assemblies, cycle 1 (cycle 2$), \mathrm{kg}$ & $42,321(39,626)$ \\
\hline $\mathrm{UO}_{2}$ in cruciform fuel assemblies, $\mathrm{kg}$ & 2,313 \\
\hline Total U weight, cycle 1 (cycle 2 ), kg & $39,873(36,968)$ \\
\hline Assembly layout & See Fig. 4 \\
\hline \multicolumn{2}{|l|}{ Core thermohydraulic characteristics } \\
\hline Power output, MW(th) & 825 \\
\hline Coolant pressure, $\mathrm{kg} / \mathrm{cm}^{2}$ & 140 \\
\hline Coolant inlet temperature, cycle $1,{ }^{\circ} \mathrm{C}$ & 266.5 \\
\hline Coolant average temperature, cycle 1 (cycle 2$),{ }^{\circ} \mathrm{C}$ & $282(269)$ \\
\hline Coolant outlet temperature, cycle $1,{ }^{\circ} \mathrm{C}$ & 297.5 \\
\hline Max. rod surface temperature, ${ }^{\circ} \mathrm{C}$ & 340 \\
\hline Core average power density, cycle 1 (cycle 2$), \mathrm{kW} / \mathrm{l}$ & $64.4(69.9)$ \\
\hline Max. design linear power density, cycle 1 (cycle 2$), \mathrm{kW} / \mathrm{ft}$ & $12.4(11.4)$ \\
\hline $\begin{array}{l}\text { Locations of cruciform assemblies containing control rods, } \\
\text { fuel rods, and stainless steel fillers }\end{array}$ & See Fig. 3 \\
\hline General operations of cycles 1 and 2 & See Table 48 \\
\hline \multicolumn{2}{|l|}{ Square fuel assembly } \\
\hline Rod array & $15 \times 15$ \\
\hline Number of fuel rods & 208 \\
\hline Side of square cross section, $\mathrm{cm}$ & 20 \\
\hline Total length, $\mathrm{cm}$ & 320.88 \\
\hline $\mathrm{UO}_{2}$ weight, $\mathrm{kg}$ & 353.81 \\
\hline Initial weight of one rod in Assembly No. 509-069, ${ }^{a} \mathrm{~g} \mathrm{U}$ & $1,511.3$ \\
\hline Pellet stack density (\% TD) ${ }^{b} \mathrm{~g} / \mathrm{cm}^{3}$ & $96.5 \%$ of $\mathrm{TD}$ \\
\hline Pellet diameter, cm & 0.89 \\
\hline Pellet length, cm & 1.53 \\
\hline Pellet dishing depth, mm & 0.33 \\
\hline Number of pellets per rod (approx.) & 173 \\
\hline Length of pellet stack in fuel rod, $\mathrm{cm}$ & 264.1 \\
\hline Clad-pellet clearance, $\mathrm{mm}$ & 0.114 \\
\hline Clad inside diameter, $\mathrm{cm}$ & 0.902 \\
\hline Clad wall thickness, mm & 0.383 \\
\hline Clad material & SS $304^{c}$ \\
\hline \multicolumn{2}{|l|}{ Cruciform fuel assembly } \\
\hline Number of fuel rods & 26 \\
\hline Fuel length, cm & 240.3 \\
\hline Rod outer diameter, $\mathrm{cm}$ & 1.092 \\
\hline $\mathrm{UO}_{2}$ weight, $\mathrm{kg}$ & 44 \\
\hline Pellet diameter (assumes same clad thickness as control rod and no gap) & 1.0056 \\
\hline
\end{tabular}


Table 47. Assembly design and operating data for Trino Vercellese (continued)

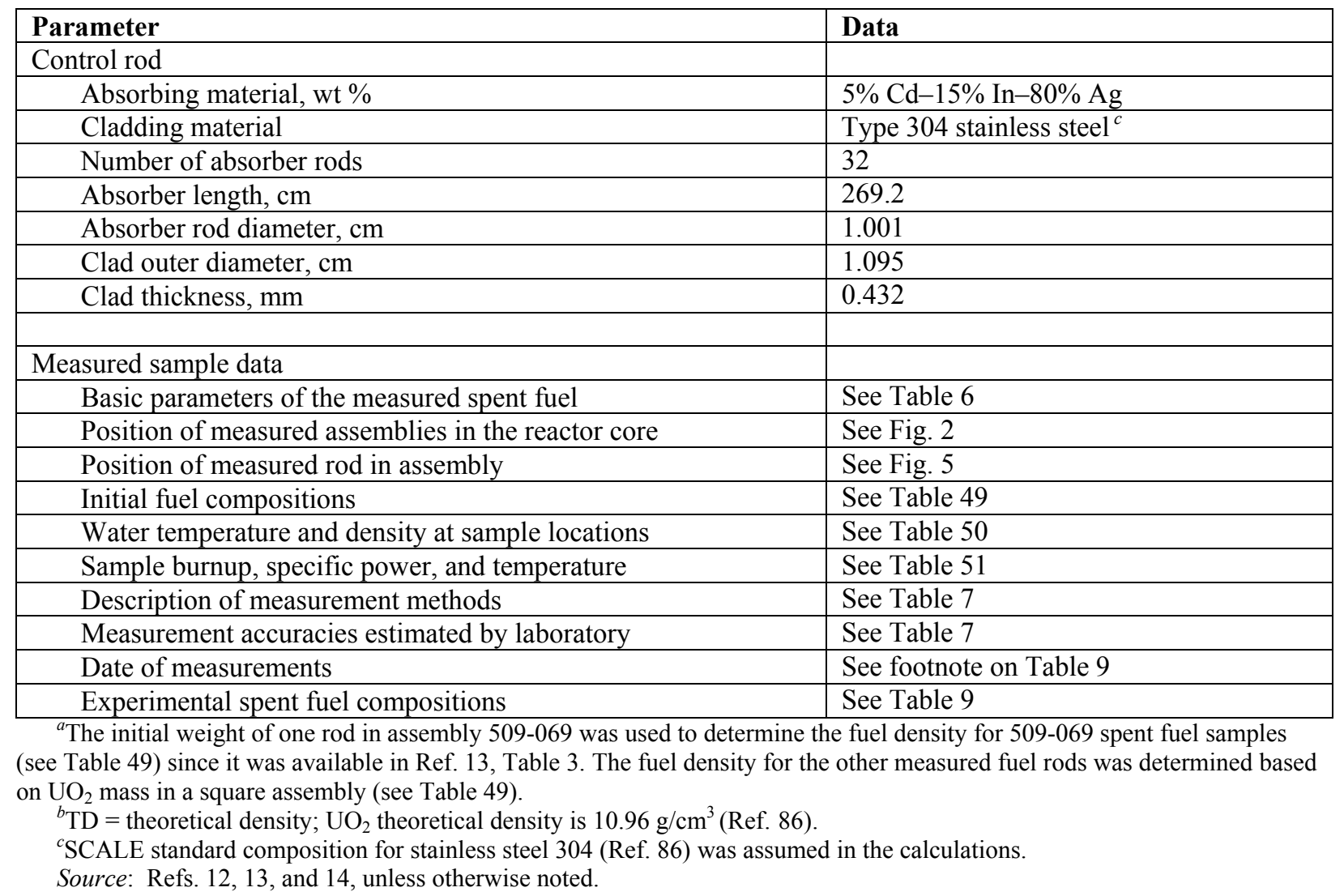


Table 48. Summary of general operation data for cycles 1 and 2

\begin{tabular}{|c|c|c|c|c|}
\hline Parameter & \multicolumn{4}{|c|}{ Cycle/period data } \\
\hline Cycle & 1 & 1 & 1 & 2 \\
\hline Period $^{a}$ & $\mathrm{I}$ & II & III & All of cycle \\
\hline Starting date & $10 / 23 / 64$ & $8 / 31 / 65$ & $7 / 11 / 66$ & $5 / 20 / 70$ \\
\hline Uptime, $\mathrm{d}$ & 226 & 263 & 292 & 416 \\
\hline Downtime, $\mathrm{d}$ & 86 & 51 & 1117 & 0 \\
\hline Coolant inlet temperature, ${ }^{b}{ }^{o} \mathrm{C}$ & 266.5 & 255.3 & 255.3 & 255.3 \\
\hline Coolant outlet temperature, ${ }^{b}{ }^{\circ} \mathrm{C}$ & 297.5 & 288.7 & 288.7 & 288.7 \\
\hline Control rod insertion, $\%$ & 30 & 4 & 4 & $0^{d}$ \\
\hline Boron concentrations, $\mathrm{ppm}^{c}$ & 1300 to 1050 & 1150 to 650 & 650 to 0 & 1300 to $0^{e}$ \\
\hline Assembly 509-069 burnup ${ }^{f}$ GWd/MTU & 2.726 & 4.927 & 6.327 & 7.720 \\
\hline
\end{tabular}

${ }^{a}$ At the end of period I, power was increased from 615 to $825 \mathrm{MW}(\mathrm{h})$.

${ }^{b}$ Coolant inlet and outlet temperatures for cycle 1, Periods II and III, and cycle 2 were taken from Ref. 56.

${ }^{c}$ Average boron concentrations for the operation periods were used in the calculations.

${ }^{d}$ Not given. This value was assumed because the analyzed measured fuel rods were unaffected. This assumption was also used in previous validation studies. ${ }^{24}$

${ }^{e}$ Not given, assumed similar to cycle 1 boron concentration range, consistently with previous validation studies. ${ }^{24}$

${ }^{f}$ Applied to the cycle 1 burnup for Assemblies 509-032, 509-049, and 509-104 to obtain the values shown in Table 51.

Source: Ref. 12, Tables 1 and 3, and Ref. 13, Table 4, unless otherwise noted.

Table 49. Initial isotopic composition of Trino Vercellese fuel

\begin{tabular}{|c|c|c|c|c|c|}
\hline \multirow[b]{2}{*}{ Assembly ID } & \multicolumn{4}{|c|}{ Isotopic composition (wt \%) } & \multirow{2}{*}{$\begin{array}{c}\mathrm{UO}_{2} \text { density } \\
\left(\mathrm{g} / \mathrm{cm}^{3}\right)\end{array}$} \\
\hline & ${ }^{235} \mathbf{U}^{b}$ & ${ }^{234} \mathbf{U}$ & ${ }^{236} \mathbf{U}$ & ${ }^{238} \mathbf{U}$ & \\
\hline $509-049$ & 2.719 & 0.024 & 0.013 & 97.244 & $10.3530^{d}$ \\
\hline Cruciform & 2.719 & 0.024 & 0.013 & 97.244 & 8.8672 \\
\hline $509-032$ & 3.13 & 0.028 & 0.014 & 96.828 & $10.3530^{d}$ \\
\hline $509-069$ & 3.13 & 0.028 & 0.014 & 96.828 & $10.4354^{e}$ \\
\hline $509-104$ & 3.897 & 0.035 & 0.018 & 96.050 & $10.3530^{d}$ \\
\hline
\end{tabular}

${ }^{a}$ Calculations performed in DVD/xls/input_data.xls, worksheet trino.

${ }^{b}$ Ref. 13, Section 2, for Assembly 509-069 and Ref. 12, Table 4, for the other assemblies.

${ }^{c}$ Fuel mass was homogenized within the volume delimited by the active fuel height and fuel radius for the square assemblies and within the volume delimited by the active fuel height and clad inner radius for the cruciform assembly. In the calculations, it was assumed that the clad thicknesses for the fuel rods and control rods in the cruciform assembly were identical $(0.432 \mathrm{~mm})$ since the two types of rods had approximately the same outer diameter.

${ }^{d}$ This fuel density was obtained by averaging $10.3529 \mathrm{~g} / \mathrm{cm}^{3}$, which is the fuel density based on the $\mathrm{UO}_{2}$ mass in a square assembly $(353.81 \mathrm{~kg})$ in Ref. 12, Table 2, and $10.3531 \mathrm{~g} / \mathrm{cm}^{3}$, which is the fuel density based on the $\mathrm{UO}_{2}$ mass in all $112 \mathrm{square}$ assemblies for Cycle $2(39,626 \mathrm{~kg})$ in Ref. 13, Table 2. Note that the fuel density based on the total $\mathrm{UO}_{2} \operatorname{mass}(42,321 \mathrm{~kg})$ in 120 square fuel assemblies for Cycle 1 provided in Ref. 12, Table 2, is $10.3198 \mathrm{~g} / \mathrm{cm}^{3}$. Sensitivity calculations performed using a fuel mass density of $10.3198 \mathrm{~g} / \mathrm{cm}^{3}$ for a few samples irradiated during cycle 1 (see Sect.10.2.2) showed a difference in the calculated isotopic concentrations of maximum $0.5 \%$ (i.e., negligible) as compared with the results obtained using a fuel mass density of $10.3530 \mathrm{~g} / \mathrm{cm}^{3}$.

${ }^{e}$ This value is based on the initial weight of one rod in assembly 509-069 (Ref. 13, Table 3). 
Table 50. Moderator temperature and density at sample locations for Trino Vercellese samples

\begin{tabular}{|c|c|c|c|c|c|}
\hline \multirow[b]{2}{*}{$\begin{array}{c}\text { Sample } \\
\text { axial level }\end{array}$} & \multicolumn{2}{|c|}{ Cycle 1, period I } & \multicolumn{3}{|c|}{ Cycle 1, periods II and III, and cycle 2} \\
\hline & $\begin{array}{c}\text { Temperature }^{a} \\
\text { (K) }\end{array}$ & $\begin{array}{c}\text { Density }^{a} \\
\left(\mathrm{~g} / \mathrm{cm}^{3}\right)\end{array}$ & $\begin{array}{c}\text { Temperature }^{a} \\
\text { (K) }\end{array}$ & $\begin{array}{c}\text { Density }^{a} \\
\left(\mathrm{~g} / \mathrm{cm}^{3}\right)\end{array}$ & $\begin{array}{l}\text { Fraction of density } \\
\text { in cycle } 1 \text {, period I }\end{array}$ \\
\hline 1 & 570.3 & 0.7297 & 561.5 & 0.7471 & 1.024 \\
\hline 2 & 568.7 & 0.7331 & 559.7 & 0.7505 & 1.024 \\
\hline 4 & 561.2 & 0.7477 & 551.6 & 0.7650 & 1.023 \\
\hline 5 & 556.1 & 0.7571 & 546.2 & 0.7744 & 1.023 \\
\hline 7 & 546.4 & 0.7741 & 535.7 & 0.7911 & 1.022 \\
\hline 8 & 542.9 & 0.7798 & 531.9 & 0.7971 & 1.022 \\
\hline 9 & 540.6 & 0.7834 & 529.4 & 0.8009 & 1.022 \\
\hline
\end{tabular}

${ }^{a}$ Calculations performed in $D V D /$ xls/input_data.xls, worksheet trino.

Table 51. Fuel burnup, operating power histories, and temperature for Trino Vercellese pellet samples

\begin{tabular}{|c|c|c|c|c|c|c|c|c|c|c|c|}
\hline \multirow{3}{*}{ Assembly } & \multirow{3}{*}{ Rod } & \multirow{3}{*}{ Level } & \multirow{3}{*}{$\begin{array}{c}\text { Burnup } \\
\text { (GWd/MTU) }\end{array}$} & \multicolumn{3}{|c|}{ Cycle 1} & Cycle 2 & \multicolumn{3}{|c|}{ Cycle 1} & \multirow[t]{2}{*}{ Cycle 2} \\
\hline & & & & I & II & III & & $\mathbf{I}$ & II & III & \\
\hline & & & & \multicolumn{4}{|c|}{ Power $(\mathrm{MW} / \mathrm{MTU})^{a}$} & \multicolumn{4}{|c|}{ Fuel temperature $(\mathrm{K})^{b}$} \\
\hline \multirow[t]{7}{*}{$509-032$} & E11 & 1 & 7.243 & 6.249 & 9.706 & 11.226 & & 703 & 740 & 757 & \\
\hline & & 4 & 15.377 & 13.267 & 20.606 & 23.833 & & 779 & 859 & 894 & \\
\hline & & 7 & 15.898 & 13.717 & 21.304 & 24.641 & & 784 & 867 & 903 & \\
\hline & & 9 & 11.529 & 9.947 & 15.449 & 17.869 & & 743 & 803 & 829 & \\
\hline & H9 & 4 & 16.556 & 14.285 & 22.186 & 25.660 & & 790 & 876 & 914 & \\
\hline & & 7 & 17.450 & 15.056 & 23.384 & 27.046 & & 799 & 889 & 929 & \\
\hline & & 9 & 12.366 & 10.669 & 16.571 & 19.166 & & 751 & 815 & 843 & \\
\hline \multirow[t]{7}{*}{ 509-049 } & L5 & 1 & 7.822 & 6.749 & 10.482 & 12.123 & & 708 & 749 & 767 & \\
\hline & & 4 & 14.323 & 12.358 & 19.193 & 22.199 & & 769 & 844 & 876 & \\
\hline & & 9 & 10.187 & 8.789 & 13.651 & 15.789 & & 730 & 783 & 807 & \\
\hline & J8 & 1 & 8.713 & 7.518 & 11.676 & 13.504 & & 717 & 762 & 782 & \\
\hline & & 4 & 14.770 & 12.744 & 19.792 & 22.892 & & 774 & 850 & 884 & \\
\hline & & 7 & 15.193 & 13.109 & 20.359 & 23.548 & & 778 & 856 & 891 & \\
\hline & & 9 & 11.127 & 9.600 & 14.911 & 17.246 & & 739 & 797 & 823 & \\
\hline $509-104$ & M11 & 7 & 12.042 & 10.390 & 16.137 & 18.664 & & 748 & 810 & 838 & \\
\hline \multirow[t]{16}{*}{ 509-069 } & E5 & 4 & 23.867 & 13.266 & 20.605 & 23.832 & 20.411 & 779 & 859 & 894 & 857 \\
\hline & & 7 & 24.548 & 13.645 & 21.193 & 24.512 & 20.993 & 783 & 866 & 902 & 863 \\
\hline & & 9 & 19.208 & 10.677 & 16.582 & 19.180 & 16.427 & 751 & 815 & 844 & 814 \\
\hline & E11 & 1 & 12.859 & 7.148 & 11.101 & 12.840 & 10.997 & 713 & 756 & 775 & 755 \\
\hline & & 2 & 20.602 & 11.452 & 17.786 & 20.571 & 17.619 & 759 & 828 & 859 & 827 \\
\hline & & 4 & 23.718 & 13.184 & 20.476 & 23.683 & 20.283 & 778 & 858 & 893 & 856 \\
\hline & & 5 & 24.518 & 13.628 & 21.167 & 24.482 & 20.968 & 783 & 865 & 901 & 863 \\
\hline & & 7 & 24.304 & 13.509 & 20.982 & 24.268 & 20.785 & 782 & 863 & 899 & 861 \\
\hline & & 8 & 23.406 & 13.010 & 20.207 & 23.371 & 20.017 & 776 & 855 & 889 & 853 \\
\hline & & 9 & 19.250 & 10.700 & 16.619 & 19.221 & 16.462 & 751 & 816 & 844 & 814 \\
\hline & L5 & 4 & 24.330 & 13.524 & 21.004 & 24.294 & 20.807 & 782 & 863 & 899 & 861 \\
\hline & & 7 & 24.313 & 13.514 & 20.990 & 24.277 & 20.792 & 782 & 863 & 899 & 861 \\
\hline & L11 & 4 & 23.928 & 13.300 & 20.657 & 23.893 & 20.463 & 780 & 860 & 895 & 858 \\
\hline & & 7 & 24.362 & 13.542 & 21.032 & 24.326 & 20.834 & 782 & 864 & 900 & 862 \\
\hline & J9 & 4 & 24.849 & 13.812 & 21.452 & 24.812 & 21.251 & 785 & 868 & 905 & 866 \\
\hline & & 7 & 25.258 & 14.040 & 21.805 & 25.221 & 21.600 & 788 & 872 & 909 & 870 \\
\hline
\end{tabular}

${ }^{a}$ Specific powers determined from the above burnups and the specified uptimes and burnup distributions for assembly 509-069 in Table 48 (see DVD/xls/input_data.xls, worksheet trino).

${ }^{b}$ Effective fuel temperatures computed from resonance-effective temperatures given in operating data for the similar-design Yankee Rowe PWR (Ref. 85, Table C-1) (see DVD/xls/input_data.xls, worksheet trino). The clad temperature used in calculations is $570 \mathrm{~K}$ based on the clad temperature data for a Yankee Rowe PWR assembly with a specific power of approximately $20 \mathrm{MW} / \mathrm{MTU}$. Note that the calculated moderator temperature for sample axial level 1 was higher than the clad temperature by $0.3 \mathrm{~K}$ (see Table 50); this temperature difference is considered negligible and does not affect the accuracy of the results. 


\subsection{OBRIGHEIM}

KWO was the first PWR in Germany built by Siemens-Schuekertwerke as a demonstration plant as part of the German Atomic Program. The reactor operated from 1968 to 2005.

This validation study considers 22 different Obrigheim rod spent fuel samples ${ }^{15}$ and five different whole spent fuel assembly compositions from assemblies BE168, BE170, BE171, BE172, and BE176 (Ref. 16) for which experimental data exists (see Sect. 7.2). The rod spent fuel samples were cut from fuel rods D1, E3, G7, and M14 of assembly BE124, and from fuel rods G14 and K14 of assembly BE210. Assembly design and operating data for the Obrigheim spent fuel samples with measured isotopic compositions are summarized in Table 52. The layout of the Obrigheim fuel assemblies showing dimensions and location of the guide tubes is illustrated in Fig. 6. The core locations for assemblies BE124 and BE210 in each irradiation cycle and the position of control rod clusters provided in Ref. 15 and Ref. 18, respectively, are shown in Fig. 7. The locations of the measured rods from assemblies BE124 and BE210 and the axial locations of the measured spent fuel samples from those assemblies are shown in Fig. 8. The samples were cut from five positions and were identified as P1, P2, P3, P4, and P5 from the bottom to the top of the rod for the assembly BE124. The sample cutting positions were identified as P1, P3(1), P4(1), P5(1), and P5(2) for the assembly BE210. In Fig. 8, the cutting positions for BE124 are shown on the left, and for BE2 10 are shown on the right.

Note that 13 of the evaluated Obrigheim rod samples were obtained from assembly peripheral rods and five of the evaluated rod samples were obtained from a rod adjacent to a guide tube. However, the technical information required to accurately simulate the perturbed irradiation environment of those samples was not available. Therefore, although evaluated in this report, these samples may be inadequate for use in isotopic composition bias determination due to the significant uncertainty associated with the following parameters:

1. Fuel type, initial enrichment, and burnup for the assemblies adjacent to assemblies BE124 and BE210 during irradiation cycles 2 through 5. The KWO first charge core consisted of $\mathrm{UO}_{2}$ fuel assemblies of 2.5, 2.8, and $3.1 \mathrm{wt} \%{ }^{235} \mathrm{U}$ initial enrichments and the KWO core contained mixed oxide (MOX) fuel assemblies starting with the third core refueling. ${ }^{18}$ One MOX assembly and eight MOX fuel assemblies were loaded into the core during the 1972 and 1973 September refueling processes, respectively. This study assumes that the characteristics of adjacent assemblies do not differ from those of the measured assembly. Hence, assembly reflective boundary conditions were used in calculations. This assumption may impact the calculation results for rods D1 and M14 of assembly BE124 and for rods G14 and K14 of assembly BE210, which were located in the assembly periphery.

2. Exposure to control rods. This study assumes that control rods were not inserted at the core locations used for assemblies BE124 and BE210. This assumption is based on a table note provided in Ref. 15, Table II, which describes fuel rod E3 of assembly BE124 as being near a water hole and its neutron spectrum as being intermediate. Note that this assumption may impact the results for the spent fuel samples from the top of rod E3 of assembly BE124, which was adjacent to a control rod location. 
Table 52. Assembly design and operating data for Obrigheim measured spent fuel

\begin{tabular}{|c|c|}
\hline Parameter & Data \\
\hline \multicolumn{2}{|l|}{ Assembly and core data } \\
\hline Design & Siemens, $14 \times 14$ PWR \\
\hline Number of fuel assemblies & 121 \\
\hline Number of control rod clusters & 32 \\
\hline First charge enrichment, wt $\%{ }^{235} \mathrm{U}$ & $2.5-2.8-3.1$ \\
\hline Number of guide tubes & 16 \\
\hline Assembly pitch, ${ }^{a} \mathrm{~cm}$ & 20.03 \\
\hline Total $\mathrm{UO}_{2}$ weight, $\mathrm{kg}$ & 39,930 \\
\hline Assembly layout & See Fig. 6 \\
\hline \multicolumn{2}{|l|}{ Fuel rod data } \\
\hline Rod pitch, cm & 1.43 \\
\hline Active fuel length, ${ }^{b} \mathrm{~cm}$ & 275 \\
\hline Fuel pellet diameter (cold), ${ }^{c} \mathrm{~cm}$ & 0.913 \\
\hline \multicolumn{2}{|l|}{ Fuel pellet linear density, $\mathrm{g} / \mathrm{cm}$} \\
\hline Fuel assembly BE124 & 6.68 \\
\hline Fuel assembly BE210 & 6.52 \\
\hline $\begin{array}{l}\text { Fuel pellet density for assemblies BE168, BE170, BE171, BE172, and } \\
\text { BE176 (cold, with dishing), }{ }^{e} \mathrm{~g} / \mathrm{cm}^{3}\end{array}$ & 10.05 \\
\hline Clad inner diameter, $\mathrm{cm}$ & 0.9318 \\
\hline Clad outer diameter, $\mathrm{cm}$ & 1.074 \\
\hline Clad material & Zircaloy-4 \\
\hline Clad temperature, ${ }^{f \circ} \mathrm{C}$ & 332 \\
\hline \multicolumn{2}{|l|}{ Guide tube } \\
\hline Inner diameter, ${ }^{d} \mathrm{~cm}$ & 1.292 \\
\hline Outer diameter, ${ }^{d} \mathrm{~cm}$ & 1.372 \\
\hline \multicolumn{2}{|l|}{ Control Rod } \\
\hline Absorbing material & $\mathrm{Ag} 15-\operatorname{In} 5-\mathrm{Cd}$ \\
\hline Canning material & Stainless steel \\
\hline \multicolumn{2}{|l|}{ Moderator data } \\
\hline Nominal pressure, ${ }^{g}$ atm & 148 \\
\hline Inlet temperature, ${ }^{g}{ }^{\circ} \mathrm{C}$ & 283 \\
\hline Outlet temperature,${ }^{g}{ }^{\circ} \mathrm{C}$ & 312.4 \\
\hline Average moderator temperature, ${ }^{h} \mathrm{~K}$ & 571 \\
\hline Average moderator density, ${ }^{i} \mathrm{~g} / \mathrm{cm}^{3}$ & 0.7299 \\
\hline Soluble boron in moderator - average value, $\mathrm{ppm}$ & 450 \\
\hline
\end{tabular}


Table 52. Assembly design and operating data for Obrigheim measured spent fuel (continued)

\begin{tabular}{|l|l|}
\hline \multicolumn{1}{|c|}{ Parameter } & \multicolumn{1}{c|}{ Data } \\
\hline Measured sample data & \multicolumn{1}{c|}{} \\
\hline Basic parameters of the measured spent fuel & See Table 11 and Table 13 \\
\hline Position of measured assemblies in the reactor core & See Fig. 7 \\
\hline Position of measured rod in assembly & See Fig. 8 \\
\hline Initial fuel compositions used & See Table 53 \\
\hline Water temperature and density at sample locations & See Table 56 \\
\hline Sample burnup, specific power, and temperature & See Table 56 \\
\hline Description of measurement methods & See Table 14 \\
\hline Measurement accuracies estimated by laboratory & See Table 10 and Table 14 \\
\hline Date of measurements & Fuel discharge \\
\hline Experimental spent fuel compositions & See Table 12 and Table 16 \\
\hline
\end{tabular}

${ }^{a}$ Assembly pitch value assumed in this validation study. The values for assembly pitch provided in Refs. 18 and 19 are 20 and $20.03 \mathrm{~cm}$, respectively.

${ }^{b}$ The active fuel length of $295.6 \mathrm{~cm}$ provided in Ref. 15 seems to be incorrect. Refs. 18 and 19 show fuel pin length and the active fuel length as being $295.6 \mathrm{~cm}$ and $275 \mathrm{~cm}$ respectively.

${ }^{c}$ Value obtained from Ref. 16. The pellet diameter provided in Ref. 15 is 0.904 .

${ }^{d}$ Ref. 20

${ }^{e}$ Fuel density with a dishing volume of $1.5 \%$ provided in Ref. 16 . The density provided in Ref. 16 for cold fuel without dishing is $10.2 \mathrm{~g} / \mathrm{cm}^{3}$. Note that this value is equivalent to the pellet linear density for assembly BE124 $(6.68 \mathrm{~g} / \mathrm{cm})$ given in Ref. 15.

Ref. 17, p. 66.

${ }^{g}$ Ref. 18.

${ }^{h}$ Derived from moderator inlet and outlet temperatures.

${ }^{i}$ Moderator density corresponding to the moderator average temperature (Ref. 58).

Source: Refs. 15 and 16, unless otherwise noted.

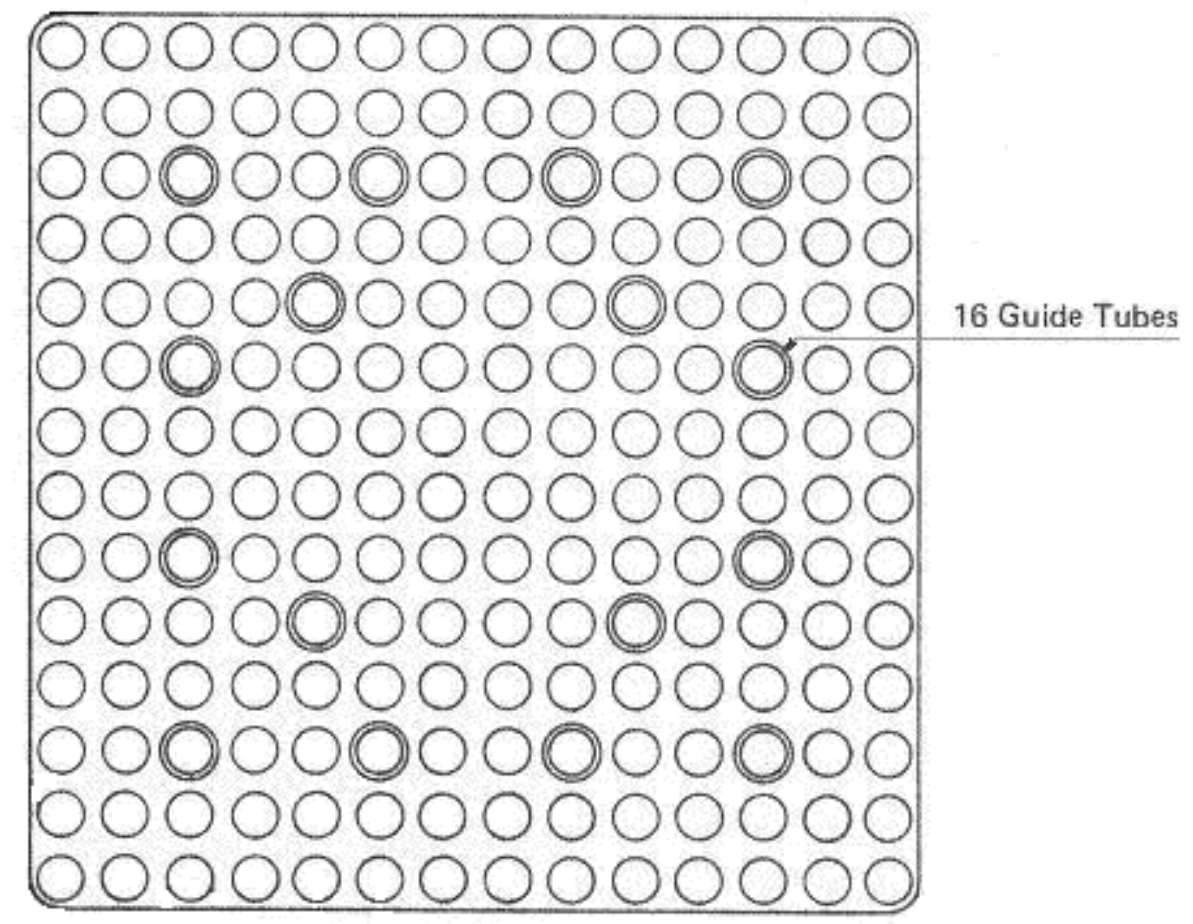

Fig. 6. Layout of the KWO fuel assemblies showing the location of the guide tubes. (Source: Ref. 18.) 


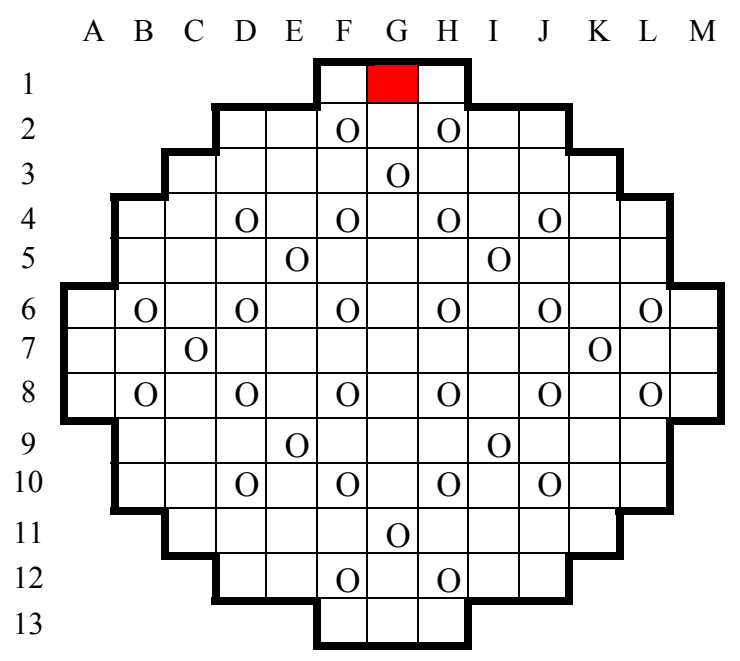

FOURTH IRRADIATION CYCLE

A $\begin{array}{lllllllllllllllllllllll} & \text { C } & \text { D } & \text { E } & \text { F } & \text { G } & \text { H } & \text { I } & \text { J } & \text { K } & \text { L } & \text { M }\end{array}$

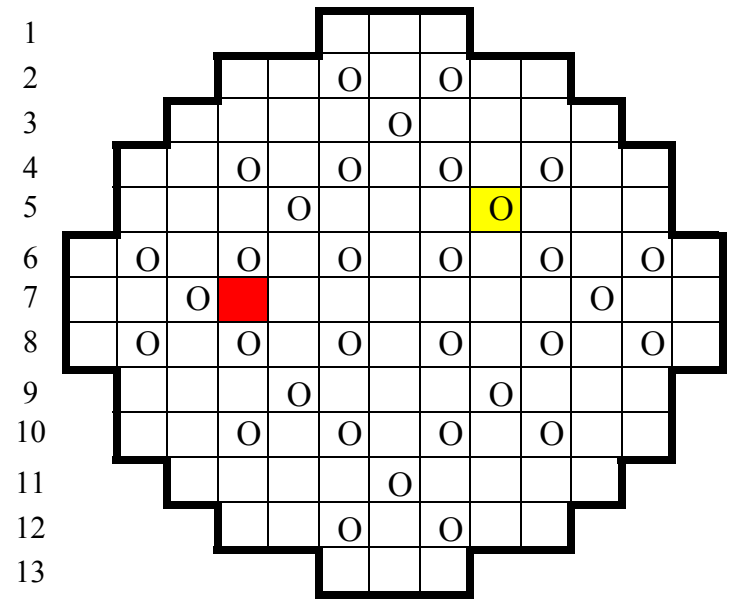

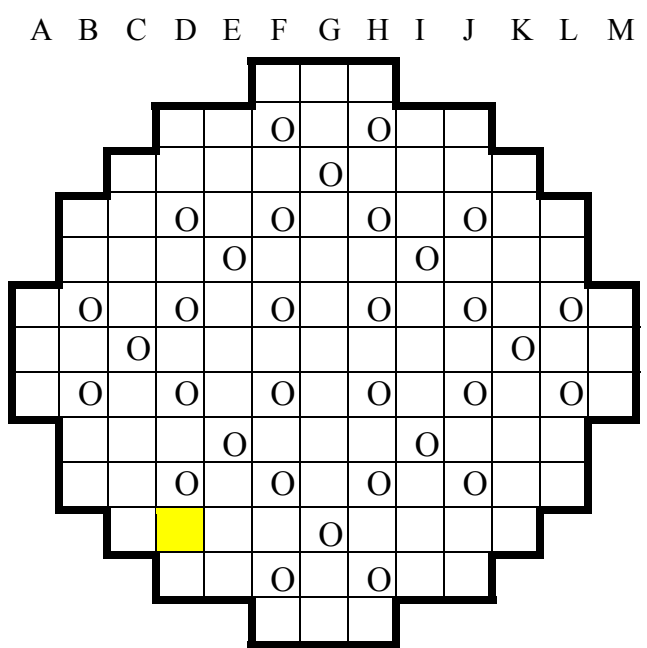

FIFTH IRRADIATION CYCLE

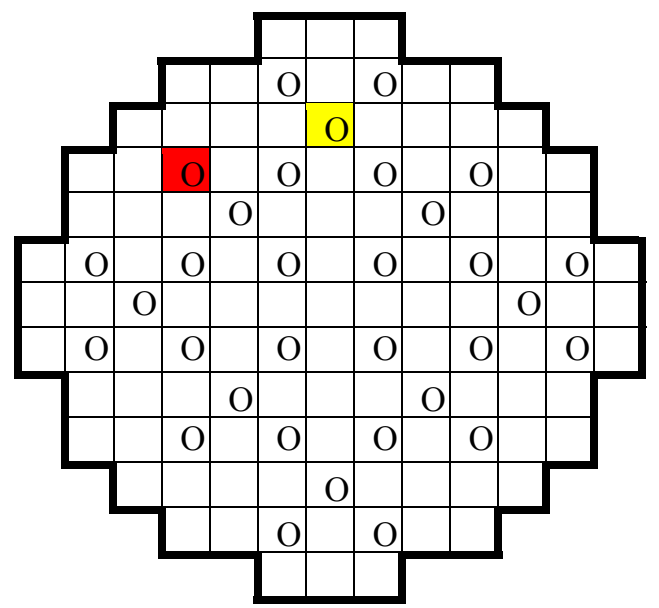

FUEL ASSEMBLY BE124 POSITIONS G1, D7, D4

FUEL ASSEMBLY BE210 POSITIONS D11, J5,

CONTROL ROD

Fig. 7. Core maps of the Obrigheim reactor during different irradiation cycles, showing the locations of control rods. (Note: Assembly locations during different irradiation cycles were provided in Ref. 15, whereas control rod bank locations were provided in Ref. 18.) 

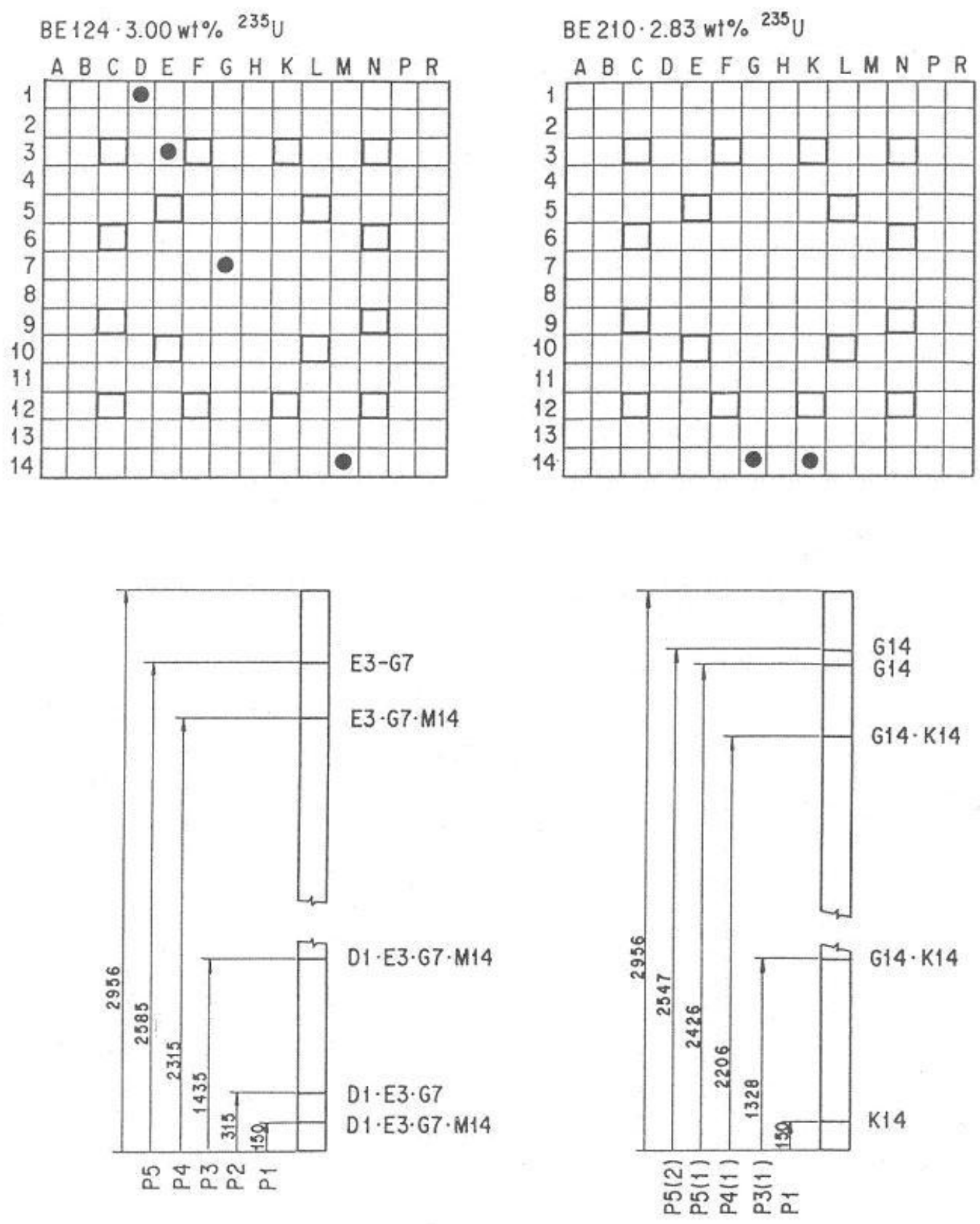

Fig. 8. Location of measured fuel rods in Obrigheim assemblies BE124 and BE210.

The irradiation histories for assemblies BE124 and BE210 are given in Table 54 (Ref. 15), and the assembly specific power and burnup according to operator data for assemblies BE168, BE170, BE171, BE172, and BE176 are given in Table 55 (Ref. 16). The derived cycle specific power values for the KWO samples are given in Table 56. 
Table 53. Initial isotopic composition of KWO fuel

\begin{tabular}{|c|c|c|c|c|c|}
\hline \multirow[b]{2}{*}{ Assembly ID } & \multicolumn{4}{|c|}{ Isotopic composition (wt \%) ${ }^{a}$} & \multirow{2}{*}{$\begin{array}{c}\mathrm{UO}_{2} \text { density } \\
\left(\mathrm{g} / \mathrm{cm}^{3}\right)\end{array}$} \\
\hline & ${ }^{235} \mathbf{U}$ & ${ }^{234} \mathbf{U}$ & ${ }^{236} \mathbf{U}$ & ${ }^{238} \mathbf{U}$ & \\
\hline BE210 & 2.83 & 0.025 & 0.013 & 97.132 & $9.8096^{c}$ \\
\hline BE124 & 3.00 & 0.027 & 0.014 & 96.960 & $10.0504^{c}$ \\
\hline $\begin{array}{l}\text { BE168, BE170, BE171, } \\
\text { BE172, BE176 }\end{array}$ & 3.13 & $0.028^{d}$ & 0.014 & 96.828 & 10.05 \\
\hline
\end{tabular}

${ }^{a}$ Calculated in spreadsheet input_data.xls, sheet $K W O$ using the equations provided in Table 2.

${ }^{b}$ Density for cold fuel with dishing.

${ }^{c}$ Based on linear density values shown in Table $52 .{ }^{d}$ Given as 0.03 in Ref. 16.

Table 54. Irradiation history of Obrigheim assemblies BE124 and BE210

\begin{tabular}{lcccccc}
\hline \multirow{2}{*}{$\begin{array}{c}\text { Cycle of } \\
\text { operation }\end{array}$} & $\begin{array}{c}\text { Periods } \\
(\mathbf{m m} / \mathbf{d d} / \mathbf{y r})\end{array}$ & Days ${ }^{\boldsymbol{a}}$ & $\begin{array}{c}\text { Position in } \\
\text { core }\end{array}$ & BE124 & $\begin{array}{c}\text { Position in } \\
\text { core }\end{array}$ & BE210 \\
\hline Second & 09.30 .70 & 258 & G-1 & 6,600 & & \\
Shut-down & 08.12 .71 & & & & & \\
& 08.13 .71 & 48 & & & D-11 & 9,900 \\
Third & 09.29 .71 & & & & & \\
Shut-down & 09.30 .71 & 295 & & & & \\
Fourth & 09.07 .72 & & & & & \\
& 09.08 .72 & 27 & & & & \\
Shut-down & 10.04 .72 & & & & & \\
Fifth & 10.05 .72 & 283 & D-7 & & & \\
& 09.01 .73 & & & & & \\
\hline
\end{tabular}

${ }^{a}$ Full power days (FPD) only.

Source: Ref. 15. Cycle assembly burnup values were used to determine the sample specific power values for each cycle shown in Table 56 (see DVD/xls/input_data.xls, worksheet $K W O$ ).

Table 55. Specific power and final burnup data for KWO assemblies BE168, BE170, BE171, BE172, and BE176

\begin{tabular}{|c|c|c|c|c|c|c|}
\hline $\begin{array}{l}\text { Cycle of } \\
\text { operation }\end{array}$ & FPD & $\begin{array}{c}\text { BE168 } \\
(30.018 \\
\text { GWd/MTU) }\end{array}$ & $\begin{array}{c}\text { BE170 } \\
(27.764 \\
\text { GWd/MTU) }\end{array}$ & $\begin{array}{c}\text { BE171 } \\
(30.052 \\
\text { GWd/MTU) }\end{array}$ & $\begin{array}{c}\text { BE172 } \\
(26.980 \\
\text { GWd/MTU) }\end{array}$ & $\begin{array}{c}\text { BE176 } \\
(29.647 \\
\text { GWd/MTU) }\end{array}$ \\
\hline & & \multicolumn{5}{|c|}{ Assembly specific power ${ }^{a}$ (MW/MTU) } \\
\hline Third & 288 & 29.95 & 22.41 & 30.14 & 35.41 & 32.26 \\
\hline $\begin{array}{l}\text { Shut- } \\
\text { down }\end{array}$ & 81 & & & & & \\
\hline Fourth & 309 & 40.17 & 40.12 & 40.31 & 25.45 & 36.96 \\
\hline $\begin{array}{l}\text { Shut- } \\
\text { down }\end{array}$ & 19 & & & & & \\
\hline Fifth $^{b}$ & 377 & 0 & 0 & 0 & 0 & 0 \\
\hline Sixth & 248 & 36.20 & 35.94 & 35.96 & 35.96 & 36.03 \\
\hline
\end{tabular}


Table 56. Operating parameter values for KWO samples

\begin{tabular}{|c|c|c|c|c|c|c|c|c|c|c|c|c|}
\hline \multirow{3}{*}{ Sample ID } & \multicolumn{5}{|c|}{ Sample specific power ${ }^{a}$ (MW/MTU) } & \multicolumn{5}{|c|}{ Sample temperature $^{b}(\mathrm{~K})$} & \multirow{2}{*}{\multicolumn{2}{|c|}{ Moderator $^{c}$}} \\
\hline & \multicolumn{5}{|c|}{ Cycle } & \multicolumn{5}{|c|}{ Cycle } & & \\
\hline & 2 & 3 & 4 & 5 & 6 & 2 & 3 & 4 & 5 & 6 & Temperature (K) & Density $\left(\mathrm{g} / \mathrm{cm}^{3}\right)$ \\
\hline BE124.D1P1 & 18.674 & & 30.954 & 33.153 & & 720 & & 833 & 855 & & 556 & 0.7585 \\
\hline BE124.D1P3 & 29.771 & & 49.348 & 52.853 & & 822 & & 1030 & 1072 & & 572 & 0.7279 \\
\hline BE124.E3P1 & 17.801 & & 29.507 & 31.602 & & 713 & & 819 & 840 & & 556 & 0.7585 \\
\hline BE124.E3P2 & 25.890 & & 42.915 & 45.963 & & 785 & & 957 & 991 & & 557 & 0.7567 \\
\hline BE124.E3P3 & 31.986 & & 53.018 & 56.784 & & 843 & & 1074 & 1122 & & 572 & 0.7279 \\
\hline BE124.E3P4 & 27.275 & & 45.210 & 48.422 & & 798 & & 982 & 1019 & & 584 & 0.7015 \\
\hline BE124.E3P5 & 20.165 & & 33.425 & 35.799 & & 733 & & 858 & 882 & & 585 & 0.6991 \\
\hline BE124.G7P1 & 15.111 & & 25.047 & 26.826 & & 689 & & 777 & 794 & & 556 & 0.7585 \\
\hline BE124.G7P2 & 22.785 & & 37.768 & 40.451 & & 757 & & 902 & 930 & & 557 & 0.7567 \\
\hline BE124.G7P3 & 27.628 & & 45.795 & 49.048 & & 801 & & 989 & 1027 & & 572 & 0.7279 \\
\hline BE124.G7P4 & 24.443 & & 40.517 & 43.395 & & 772 & & 931 & 962 & & 584 & 0.7015 \\
\hline BE124.G7P5 & 22.767 & & 37.739 & 40.419 & & 757 & & 902 & 930 & & 585 & 0.6991 \\
\hline BE124.M14P1 & 13.761 & & 22.810 & 24.430 & & 678 & & 757 & 772 & & 556 & 0.7585 \\
\hline BE124.M14P3 & 25.899 & & & 45.979 & & 785 & & 957 & 991 & & 572 & 0.7279 \\
\hline BE124.M14P4 & 21.965 & & & 38.994 & & 749 & & 888 & 915 & & 584 & 0.7015 \\
\hline BE210.G14P31 & & 41.799 & & 47.863 & & & 934 & 1026 & 1000 & & 570 & 0.7299 \\
\hline BE210.G14P41 & & 39.736 & & 45.501 & & & 913 & 998 & 974 & & 583 & 0.7039 \\
\hline BE210.G14P51 & & 33.626 & & 38.505 & & & 852 & 919 & 900 & & 584 & 0.7015 \\
\hline BE210.G14P52 & & 27.004 & 34.876 & 30.921 & & & 790 & 840 & 826 & & 585 & 0.6991 \\
\hline BE210.K14P1 & & 25.532 & 30.058 & 29.236 & & & 776 & 823 & 810 & & 556 & 0.7585 \\
\hline BE210.K14P31 & & 40.884 & 47.001 & 46.816 & & & 924 & 1013 & 988 & & 570 & 0.7299 \\
\hline BE210.K14P41 & & 38.610 & 46.345 & 42.003 & & & 882 & 958 & 936 & & 583 & 0.7039 \\
\hline BE168 & & 29.284 & 39.276 & & 35.404 & & 817 & 918 & & 878 & 571 & 0.7299 \\
\hline BE170 & & 21.797 & 39.023 & & 34.957 & & 748 & 915 & & 873 & 571 & 0.7299 \\
\hline BE171 & & 28.739 & 38.436 & & 34.279 & & 812 & 909 & & 866 & 571 & 0.7299 \\
\hline BE172 & & 36.606 & 26.309 & & 37.174 & & 890 & 789 & & 896 & 571 & 0.7299 \\
\hline BE176 & & 31.289 & 35.848 & & 34.946 & & 837 & 882 & & 873 & 571 & 0.7299 \\
\hline
\end{tabular}

${ }^{a}$ Specific power values were determined from the sample burnups (Table 16) and the specified uptimes and burnup distributions for assemblies shown in Table 54 and Table 55 (see

DVD/xls/input_data.xls, worksheet $K W O$ ).

${ }^{b}$ Effective fuel temperature was calculated using an equation based on the coordinates of datapoints from the graph showing $\mathrm{UO}_{2}$ temperature as a function of rod power in $\mathrm{W} / \mathrm{cm}$ provided in Fig. 2 of Ref. 16 (see $D V D / x l s /$ input data.xls, worksheet $K W O$ ).

Moderator temperature and density were calculated using Eq. (1) and tabulated steam data (see Sect. 5.2). 


\subsection{TURKEY POINT UNIT 3}

The Turkey Point Unit 3 PWR, operated by Florida Power and Light Co., was designed by Westinghouse Electric Corp. The fuel assembly design is based on a $15 \times 15$ square lattice, with 21 positions containing control rod and instrumentation guide tubes. Fuel design and operating parameters were taken from Refs. 21 and 22 and are given in Table 57. It should be noted that some of the input data for 2-D depletion calculations were not available in the aforementioned primary references, including control rod insertion data for the measured assemblies, soluble boron content, and sample specific powers. Therefore, assumptions were made consistently with the isotopic evaluations previously published. ${ }^{23,24}$

The current study considers five different Turkey Point Unit 3 fuel samples, with burnups ranging from 30.51 to $31.56 \mathrm{GWd} / \mathrm{MTU}$, that were taken from fuel rods $\mathrm{G} 9$, G10, and H9 in assembly D01, and from rods G9 and G10 in assembly D04. Radiochemical isotopic analyses of the five samples were analyzed by Battelle Columbus Laboratories for the Climax Spent Fuel Test and the results of the analyses are documented in Ref. 21. Assemblies D01 and D04 were irradiated in the reactor during cycles of operation 2, 3, and 4. Fig. 9 shows the configuration of the Westinghouse $15 \times 15$ assembly design and illustrates the position of each of the measured fuel rods within the assembly. Basic parameters for the measured samples, such as assembly and rod identification and burnup and axial location for each sample, are provided in Table 17 (see Sect. 7.3). A single sample was taken from each of the five different rods; the samples were taken from a location of either 167.0 or $167.6 \mathrm{~cm}$ above bottom of the fuel. It should be noted that fuel rod $\mathrm{H} 9$ was adjacent to the instrument tube and none of the measured fuel rods occupied an assembly location adjacent to a guide tube. As previously mentioned, information concerning control rod insertions for assemblies D01 and D04 is not available. Therefore, it is assumed that the guide tubes in assemblies D01 and D04 were vacant during cycles of operation 2, 3, and 4. This modeling assumption is based on engineering judgment and is considered to have either no effect or a small effect on the results of the calculations since the measured fuel rods were not adjacent to guide tubes and the samples were cut from the bottom half of the fuel rods. The sample cooling times between discharge and measurement date were not reported in Ref. 21.

Initial ${ }^{235} \mathrm{U}$ enrichment was given in Ref. 21; initial ${ }^{234} \mathrm{U},{ }^{236} \mathrm{U}$, and ${ }^{238} \mathrm{U}$ concentrations were estimated using empirical relationships (see Sect. 5.1, Table 2) and are given in Table 58.

Burnup values for the Turkey Point fuel samples were determined based on measured ${ }^{148} \mathrm{Nd}$ concentrations. $^{21}$ No data were available to indicate the operating power for the assemblies or core on a cycle-by-cycle basis. However, for other fuel assemblies for which power histories were available during cycles 2 through 4 , the assembly power varied by less than $10 \%$ from the average power. As an example, the group of assemblies from Region 4 of the reactor, with an average burnup of $28.430 \mathrm{GWd} / \mathrm{MTU}$, includes assemblies D01, D04, and D15 (Ref. 25). The burnup values for assembly D15 for cycles 2 though 4, which were obtained from reactor analyses and provided by Florida Power and Light Co., were 9.480, 9.752, and 8.920 GWd/MTU, respectively (Ref. 64). Hence, it was assumed that the reactor was operated at a constant power over all three cycles; average specific power was then computed for each sample based on the total length of the three cycles and the final burnup of the sample. These average specific power values are given in Table 60. 
Table 57. Assembly design and operating data for Turkey Point Unit 3

\begin{tabular}{|c|c|}
\hline Parameters & Data \\
\hline \multicolumn{2}{|l|}{ Assembly general data } \\
\hline Design & Westinghouse \\
\hline Lattice & $15 \times 15$ \\
\hline Assembly pitch, cm (in.) & $21.5036(8.466)$ \\
\hline Number of fuel rods & 204 \\
\hline Number of guide tubes & 20 \\
\hline Number of instrument tubes & 1 \\
\hline \multicolumn{2}{|l|}{ Fuel rod data } \\
\hline Type fuel pellet & $\mathrm{UO}_{2}$ \\
\hline Enrichment, wt $\%{ }^{235} \mathrm{U}$ & 2.556 \\
\hline Stack density with gap, dish smeared in, \% TD & $89.72^{a}$ \\
\hline Rod pitch, cm (in.) & $1.4300(0.563)$ \\
\hline Clad outer diameter, cm (in.) & $1.0719(0.422)$ \\
\hline Clad inner diameter, cm (in.) & $0.9484(0.3734)$ \\
\hline Pellet outer diameter, $\mathrm{cm}$ (in.) & $0.9294(0.3659)$ \\
\hline Clad material & Zircaloy-4 \\
\hline Clad temperature, $\mathrm{K}$ & $595^{b}$ \\
\hline Active fuel length, cm (in.) & $365.76(144)$ \\
\hline \multicolumn{2}{|l|}{ Guide and instrument tube data } \\
\hline Inner radius, $\mathrm{cm}$ (inner diameter as in.) & $0.6502(0.512)$ \\
\hline Outer radius, $\mathrm{cm}$ (outer diameter as in.) & $0.6934(0.546)$ \\
\hline Tube material & Zircaloy-4 \\
\hline General operation data for cycles 2,3 , and 4 & See Table 59 \\
\hline \multicolumn{2}{|l|}{ Measured sample data } \\
\hline Basic parameters of the measured spent fuel & See Table 17 \\
\hline Position of measured rod in assembly & See Fig. 9 \\
\hline Initial fuel compositions & See Table 58 \\
\hline Irradiation data & See Table 59 \\
\hline Sample specific power and effective fuel temperature & See Table 60 \\
\hline Water temperature at sample axial location, $\mathrm{K}$ & $579^{c}$ \\
\hline Water density at sample axial location, $\mathrm{g} / \mathrm{cm}^{3}$ & $0.7246^{d}$ \\
\hline Description of measurement methods & See Sect. 7.3 \\
\hline Measurement accuracies estimated by laboratory & See Table 19 \\
\hline Date of measurements & 927 days (see Sect. 7.3) \\
\hline Experimental spent fuel compositions & See Table 18 \\
\hline $\begin{array}{l}{ }^{a} \text { Based on Ref. } 22 \text {. The density of stack with gap is } 0.8972 \\
10.235 \mathrm{~g} / \mathrm{cm}^{3} \text { for fuel mass homogenized within the volum } \\
\text { DVD/xls } / \text { input_data.xls). } \\
\text { bef. } 23 \text {. } \\
{ }^{c} \text { Moderator temperature is the average of the values determin } \\
\text { in Table } 59 \text {, and sample axial locations in Table } 17 \text { (see } D V D / x \\
\text { cycles is justified since all calculated cycle moderator temperatur } \\
{ }^{d} \text { Based on steam tables in Ref. } 58 \text {. }\end{array}$ & $\begin{array}{l}\text { sity) }=9.8333 \mathrm{~g} / \mathrm{cm}^{3} \text {. Fuel density is } \\
\text { ve fuel height and fuel radius (see } \\
\text { 5.2), the inlet and outlet temperatures } \\
\text { at use of a single value for the three }\end{array}$ \\
\hline
\end{tabular}


Table 58. Initial composition of Turkey Point fuel assemblies

\begin{tabular}{ccc}
\hline Uranium isotope & Assembly D01 & Assembly D04 \\
\hline wt $\%{ }^{235} \mathrm{U}^{a}$ & 2.556 & 2.556 \\
wt $\%{ }^{234} \mathrm{U}^{b}$ & 0.023 & 0.023 \\
wt $\%{ }^{236} \mathrm{U}^{b}$ & 0.012 & 0.012 \\
wt $\%{ }^{238} \mathrm{U}^{b}$ & 97.409 & 97.409 \\
\hline
\end{tabular}

${ }^{a}$ Ref. 22.

${ }^{b}$ Values determined using the equations provided in Table 2 (see Sect. 5.1).

Table 59. Turkey Point Unit 3 operating data

\begin{tabular}{|c|c|c|c|c|c|c|c|c|}
\hline Cycle & $\begin{array}{l}\text { Cycle } \\
\text { start }^{a}\end{array}$ & $\begin{array}{l}\text { Cycle } \\
\text { end }\end{array}$ & $\begin{array}{l}\text { Uptime } \\
\text { (days) }^{a}\end{array}$ & $\begin{array}{l}\text { Downtime } \\
\text { (days) }^{a}\end{array}$ & $\begin{array}{c}\text { System } \\
\text { pressure } \\
\text { (psia) }\end{array}$ & $\begin{array}{c}\text { Inlet water } \\
\text { temperature } \\
\left({ }^{\circ} \mathbf{F}\right)\end{array}$ & $\begin{array}{c}\text { Outlet } \\
\text { water } \\
\text { temperature } \\
\left({ }^{\circ} \mathrm{C}\right)\end{array}$ & $\begin{array}{c}\text { Soluble boron } \\
\text { average } \\
\text { concentration } \\
(\mathrm{ppm})^{e}\end{array}$ \\
\hline 2 & $12 / 16 / 74$ & $10 / 26 / 75$ & 314 & 58 & 1900 & 538.6 & - & 450 \\
\hline 3 & $12 / 23 / 75$ & $11 / 15 / 76$ & 327 & 62 & 2100 & 539.0 & - & 450 \\
\hline 4 & $1 / 16 / 77$ & $11 / 24 / 77$ & 312 & $927^{b}$ & $2250^{c}$ & $546.2^{c}$ & $338^{d}$ & 450 \\
\hline
\end{tabular}

${ }^{a}$ Ref. 24 (based on personal communication with E. R. Knuckles - Florida Power and Light Co.). Residence time in reactor is 1073 days, consistent with the value for this parameter provided in Ref. 25. Note that total irradiation time in reactor, in effective full power days (EFPD), provided in Ref. 21 is 851 EFPD.

${ }^{b}$ Cooling time from shutdown to date of radiochemical analyses.

${ }^{c}$ Consistent with operation parameters in Ref. 56.

${ }^{d}$ Ref. 56.

${ }^{e}$ Refs. 23 and 24.

Source: Ref. 21, unless otherwise noted.

Table 60. Turkey Point sample specific powers and temperatures

\begin{tabular}{ccccccc}
\hline Sample No. & Assembly & Rod ID & $\begin{array}{c}\text { Burnup } \\
\text { (GWd/MTU) }\end{array}$ & $\begin{array}{c}\text { Specific power }^{\boldsymbol{a}} \\
\text { (MW/MTU) }\end{array}$ & $\begin{array}{c}\text { Effective fuel }_{\text {temperature }^{\boldsymbol{b}}} \\
\text { (K) }\end{array}$ & $\begin{array}{c}\text { Clad }^{\text {(MWperature }}{ }^{\boldsymbol{b}} \\
\text { (K) }\end{array}$ \\
\hline 1 & D01 & G9 & 30.720 & 32.235 & 922 & 595 \\
2 & D01 & G10 & 30.510 & 32.015 & 922 & \\
3 & D01 & H9 & 31.560 & 33.116 & 922 & \\
4 & D04 & G9 & 31.260 & 32.802 & 922 & \\
5 & D04 & G10 & 31.310 & 32.854 & 922 & \\
\hline
\end{tabular}

${ }^{a}$ Based on burnup values reported in Ref. 21 and sum of uptime values listed in Table 59.

${ }^{b}$ Refs. 23 and 24. 


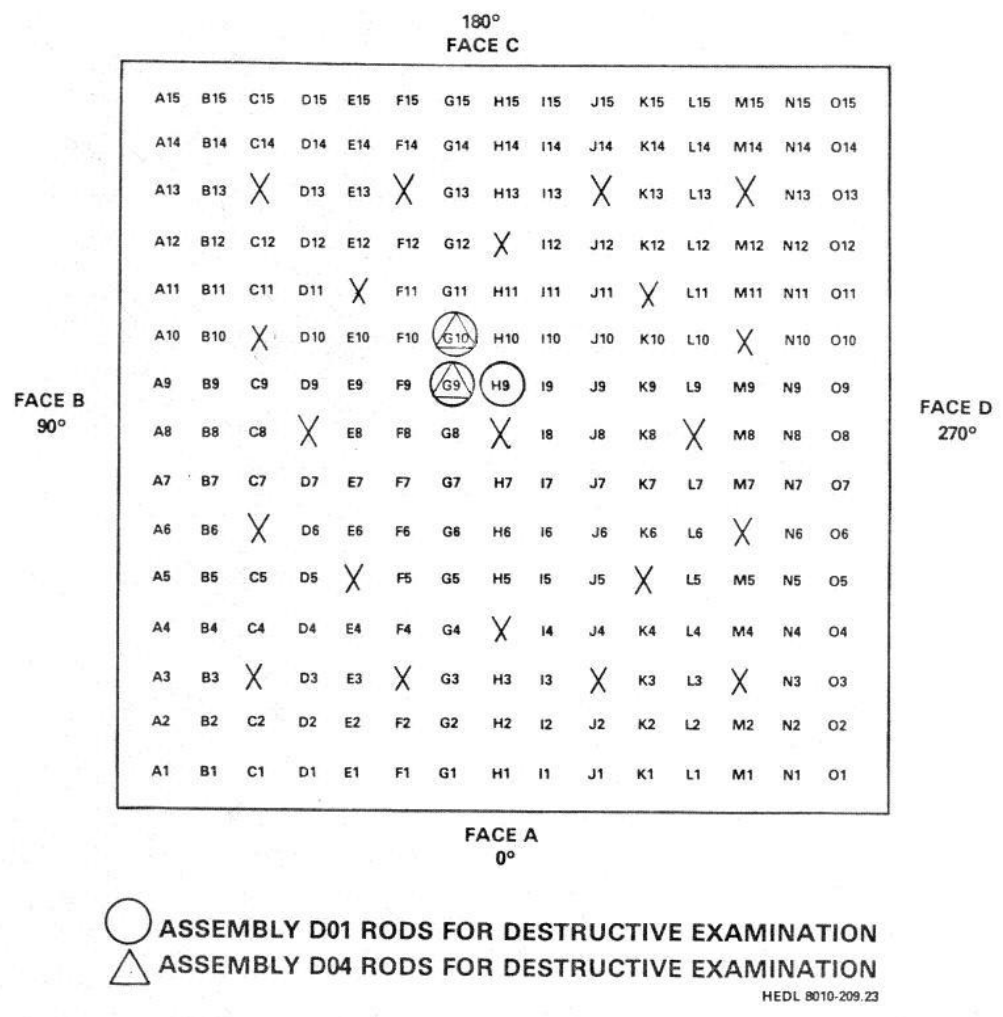

Fig. 9. Position of 21 guide tubes $(\times)$ and locations of measured fuel rods G9, G10, and $\mathrm{H} 9$ from Turkey Point assemblies D01 and D04. (Source: Ref. 21.) 


\subsection{H. B. ROBINSON UNIT 2}

ATM-101 consisted of 27 fuel rod segments from nine fuel rods H. B. Robinson in assembly BO-5. ${ }^{26}$ Four samples, denoted as N-9B-S, N-9B-N, N-9C-J, and N-9C-D from fuel rod N-9 of Assembly BO-5, are evaluated in the current study. Assembly BO-5 was irradiated during cycles 1 and 2 for a total of 799 effective full power days (EFPD), and then removed from the reactor on May 6, 1974. The postirradiation examinations of the four samples were carried out in April 1984 (N-9C-D and N-9C-J) and February 1985 (N-9B-S and N-9B-N). Table 20 (see Sect. 7.4) summarizes sample general characteristics. Table 21 (see Sect. 7.4) presents the experimental results, in $\mathrm{mg} / \mathrm{g} \mathrm{U}_{\text {initial }}$, at the cooling time shown in Table 20 for the four samples considered.

The H. B. Robinson Unit 2 PWR uses Westinghouse fuel assemblies with a $15 \times 15$ pin lattice. A standard Westinghouse burnable poison fixture was inserted into assembly BO-5 for the first cycle. ${ }^{27}$ Descriptions of the design characteristics of assembly BO-5 and the burnable poison rod (BPR) present in the assembly during cycle 1 are presented in Table 61. Note that Refs. 26 (ATM-101) and 27 provide different initial fuel enrichment values and assembly descriptions for assembly BO-5. The depletion calculations in the current report use design data from Ref. 27, consistent with the input data used in previously published evaluations and calculations. ${ }^{87,38}$ The location within the BO-5 lattice of rod N-9 is shown in Fig. 11.

Power histories are based on axial flux measurement data available in Ref. 28 for the assembly BO-5 at approximately beginning-of-life, $25 \%, 50 \%, 75 \%$, and end-of-life (100\%) exposures and on the sample total burnups. Fig. 12 shows the axial factors for 57 equal-length rod segments along with the corresponding assembly average burnups (see figure legend). Samples N-9B-S, N-9B-N, N-9C-J, and N-9C-D correspond to segments 2, 4, 31, and 35, respectively. The sample average power and effective fuel temperature values are given in the Table 63. Reference 29 describes outage and refueling durations in terms of approximate time. Outage durations for various repair work were approximately 2 months (starting in March of 1971), 2.5 months (starting in June of 1971), 1 month (starting in May of 1972), and 12 days in November of 1973. The first refueling outage was started in mid-March and lasted for approximately 2 months. The differences between the estimated and detailed power histories should not cause a significant change in the isotopic compositions calculated at the cooling times ( $\sim 10$ years) of the radiochemical analyses. Moderator temperature and density values are listed in Table 64 . The moderator temperatures were calculated using Eq. (1) and the inlet and outlet temperatures of $546.5^{\circ} \mathrm{F}$ and $600.6^{\circ} \mathrm{F}$, respectively. ${ }^{29}$ The moderator densities were determined by interpolating data on a temperature-pressuredensity table at a pressure of 2250 psia (Ref. 29). Average soluble boron concentration for each irradiation interval was determined assuming the boron adjustment factors of 1.45 and 0.55 applied to the cycle average soluble concentration, as shown in the boron letdown example for SAS2H calculations (Ref. 67). The effective fuel temperatures were determined from the fuel temperature versus rod linear power curve in Ref. 16, Fig. 2. Although the curve was developed for the Obrigheim PWR, the rod dimensions, rod lattice pitch, and operating conditions of the H. B. Robinson and Obrigheim fuel assemblies are similar. 
Table 61. Assembly design and operating data for H. B. Robinson

\begin{tabular}{|c|c|}
\hline Parameters & Data \\
\hline \multicolumn{2}{|l|}{ Reactor core } \\
\hline Design & Westinghouse, PWR $15 \times 15$ \\
\hline Lattice pitch, cm (in.) & $21.50364(8.466)$ \\
\hline Initial enrichment, ${ }^{235} \mathrm{U}$ wt $\%$ & $1.85 / 2.56 / 3.10^{a}$ \\
\hline Inlet coolant temperature, ${ }^{\circ} \mathrm{F}$ & $546.5^{a}$ \\
\hline Outlet coolant temperature, ${ }^{\circ} \mathrm{F}$ & $600.6^{a}$ \\
\hline Reactivity control & Soluble boron, burnable poison rods, and control rods \\
\hline Average boron concentration & $450 \mathrm{ppm}^{b}$ \\
\hline Operating pressure, psia & 2250 \\
\hline \multicolumn{2}{|l|}{ Fuel assembly } \\
\hline Lattice & $15 \times 15$ (see Fig. 11$)$ \\
\hline Number of fuel rods & 204 \\
\hline Uranium weight, kg & 443.7 \\
\hline Number of guide tubes & 20 \\
\hline Number of instrument tubes & 1 \\
\hline \multicolumn{2}{|l|}{ Fuel rod } \\
\hline Type fuel pellet & $\mathrm{UO}_{2}$ \\
\hline Pellet stack density (\% TD), $\mathrm{g} / \mathrm{cm}^{3}$ & $9.944(90.73)^{c}$ \\
\hline \multicolumn{2}{|l|}{ Initial fuel composition, ${ }^{d}$ wt $\%$ in $U$ total } \\
\hline${ }^{235} \mathrm{U}$ & 2.561 \\
\hline${ }^{234} \mathrm{U}$ & 0.023 \\
\hline${ }^{236} \mathrm{U}$ & 0.012 \\
\hline${ }^{238} \mathrm{U}$ & 97.404 \\
\hline Rod pitch, cm (in.) & $1.4300(0.563)$ \\
\hline Rod outer diameter, cm (in.) & $1.0719(0.422)$ \\
\hline Rod inner diameter, cm (in.) & $0.9484(0.3734)$ \\
\hline Pellet diameter, $\mathrm{cm}$ (in.) & $0.9294(0.3659)$ \\
\hline Active fuel length, cm (in.) & $365.76(144)$ \\
\hline Clad material & Zircaloy-4 \\
\hline Clad temperature, $\mathrm{K}$ & 595 \\
\hline \multicolumn{2}{|l|}{ Guide tube } \\
\hline Material & Zircaloy-4 \\
\hline Inner radius, $\mathrm{cm}$ (in.) & $0.6502(0.256)$ \\
\hline Outer radius, cm (in.) & $0.6934(0.273)$ \\
\hline BPR insertions ${ }^{e}$ & $\begin{array}{l}12 \text { during cycle } 1 \\
0 \text { during cycle } 2 \text { (see Fig. } 11 \text { ) }\end{array}$ \\
\hline Number of guide tubes with water & $\begin{array}{l}8 \text { during cycle } 1 \\
20 \text { during cycle } 2 \text { (see Fig. } 11)\end{array}$ \\
\hline \multicolumn{2}{|l|}{ Instrument tube } \\
\hline Material & Zircaloy-4 \\
\hline Inner radius, $\mathrm{cm}$ (in.) & $0.6502(0.256)$ \\
\hline Outer radius, cm (in.) & $0.6934(0.273)$ \\
\hline
\end{tabular}


Table 61. Assembly design and operating data for H. B. Robinson (continued)

\begin{tabular}{|l|l|}
\hline Parameters & Data \\
\hline Burnable poison rod & \\
\hline Air outer diameter, cm (in.) & $0.5677(0.2235)$ \\
\hline SS304 outer diameter, ${ }^{\dagger}$ cm (in.) & $0.6007(0.2365)$ \\
\hline Air outer diameter, cm (in.) & $0.6172(0.2430)$ \\
\hline Pyrex glass outer diameter, cm (in.) & $1.0058(0.3960)$ \\
\hline Air outer diameter, cm (in.) & $1.0173(0.4005)$ \\
\hline SS304 outer diameter, cm (in.) & $1.1151(0.4390)$ \\
\hline B $_{2} \mathrm{O}_{3}$, wt $\%$ & 12.5 \\
\hline Borated glass chemical composition and density & see Table 62 \\
\hline & \\
\hline Measured sample data & \\
\hline Basic parameters of the measured spent fuel & See Table 20 \\
\hline Position of measured assembly in the reactor core & See Fig. 10 \\
\hline Position of measured rod in assembly & See Fig. 11 \\
\hline Water temperature and density at sample locations & See Table 64 \\
\hline Sample burnup, specific power, and temperature & See Table 63 \\
\hline Description of measurement methods & See Sect. 7.4 \\
\hline Measurement accuracies estimated by laboratory & See Table 22 \\
\hline Date of measurements & See Table 20 \\
\hline Experimental spent fuel compositions & See Table 21 \\
\hline
\end{tabular}

${ }^{a}$ Ref. 29. Fuel initial enrichment for Region 2 is consistent with the design data provided in Refs. 27 and 88 . Note that ATM-101 (Ref. 26) provides a value of $2.55 \mathrm{wt} \%{ }^{235} \mathrm{U}$ for the parameter.

${ }^{b}$ Assumption in Ref. 27.

${ }^{c}$ Mass density based on homogenized $\mathrm{UO}_{2}$ within the fuel rod volume.

${ }^{d}$ Fuel enrichment for sampled rod was taken from Ref. 29. Initial uranium composition was calculated using the empirical relationship equations provided in Table 2, Sect. 5.1.

${ }^{e}$ The burnable poison was removed when the average assembly burnup had reached 18,000 MWd/MTU (Ref. 27). The burnup of assembly BO-5 at the end of cycle 1 was 18,613 MWd/MTU (Ref. 28).

${ }^{f}$ SCALE standard composition for SS304 was used in the calculations. ${ }^{86}$

Source: Ref. 27, unless otherwise noted. 


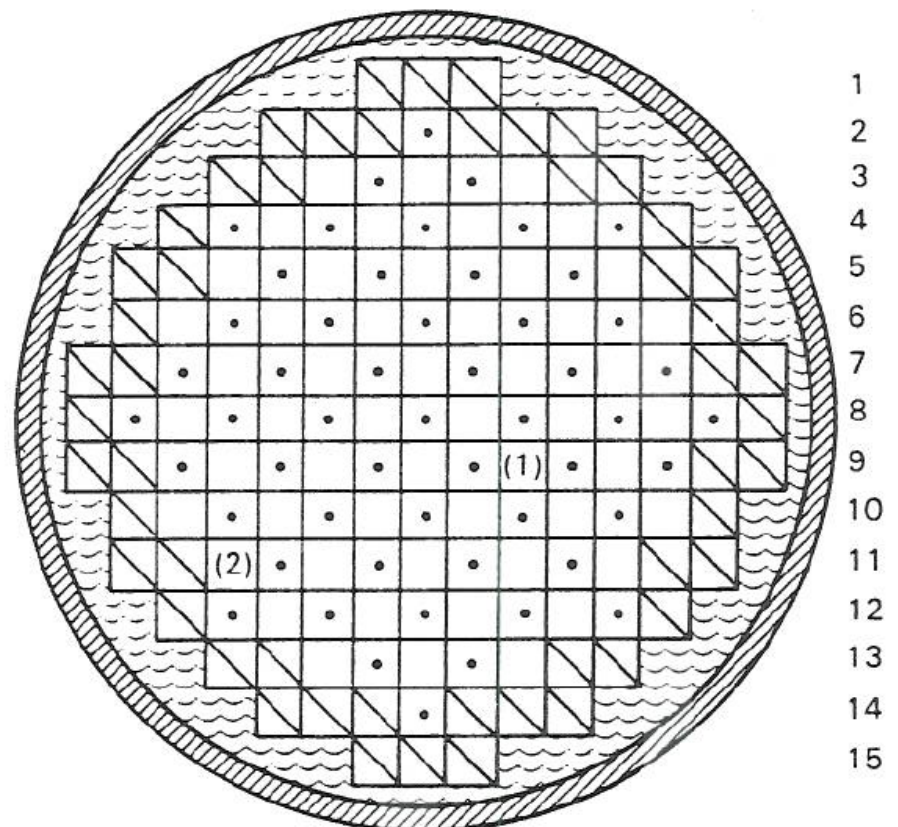

R P N M L K J H G F E D C B A

Core Arrangement - H.B. Robinson Reactor

Showing Location of Assembly $\mathrm{BO}-5$

During First (1) and Second (2) Cycles

- Region 1 (Enrichment 1.85\%) 53 Assemblies

Region 2 (Enrichment 2.55\%) 52 Assemblies

$\triangle$ Region 3 (Enrichment 3.10\%) 52 Assemblies

Fig. 10. Core arrangement for H. B. Robinson Unit 2 reactor core. (Source: Ref. 26, Fig. 4.1.) 


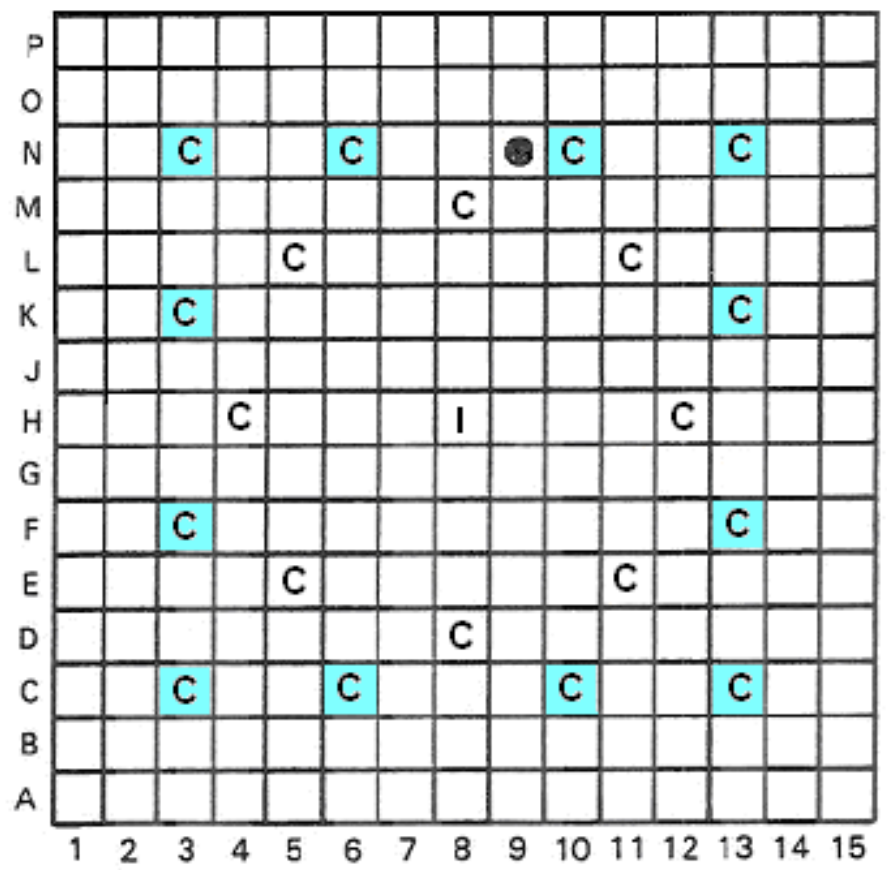

$$
\begin{aligned}
& \mathrm{C}]=\text { Control Rod Guide Tube } \\
& \mathrm{C} \text { = Burnable Poison Rod } \\
& \mathrm{D}=\text { Instrument Tube } \\
& \mathrm{C}=\text { ATM-101 Fuel Rod }
\end{aligned}
$$

Fig. 11. Locations of fuel rod N-9, instrument tube, and guide tubes in assembly BO-5. (Source: Ref. 26, Fig. 4.2, and Ref. 27, Fig. 3.2.3-8.) Note: During cycle 1 of irradiation, 12 guide tubes contained BPR insertions, as shown in this figure. No BPR insertion was present during cycle 2 of irradiation.)

Table 62. Atom densities for borosilicate glass

\begin{tabular}{ccccc}
\hline Compound & Weight fraction & Element/isotope & Weight percent $^{\boldsymbol{b}}$ & $\begin{array}{c}\text { Atom density } \\
\text { (atoms/cm/barn) }\end{array}$ \\
\hline $\mathrm{SiO}_{2}$ & 0.875 & $\mathrm{Si}$ & 40.9067 & $1.9560 \mathrm{E}-02$ \\
$\mathrm{~B}_{2} \mathrm{O}_{3}$ & $0.125^{a}$ & $\mathrm{O}$ & 55.2092 & $4.6341 \mathrm{E}-02$ \\
& & ${ }^{10} \mathrm{~B}$ & 0.6976 & $9.3562 \mathrm{E}-04$ \\
& & ${ }^{11} \mathrm{~B}$ & 3.1866 & $3.8871 \mathrm{E}-03$ \\
\hline
\end{tabular}

${ }^{a}$ Ref. 27.

${ }^{b}$ Ref. 89 .

${ }^{c}$ Calculated in $\mathrm{DVD} / \mathrm{xl}$ /sinput data.xls using element/isotope weight fractions, the borosilicate glass density of $2.23 \mathrm{~g} / \mathrm{cm}^{3}$ (Ref. 86), and relative atomic masses from Ref. 63. 

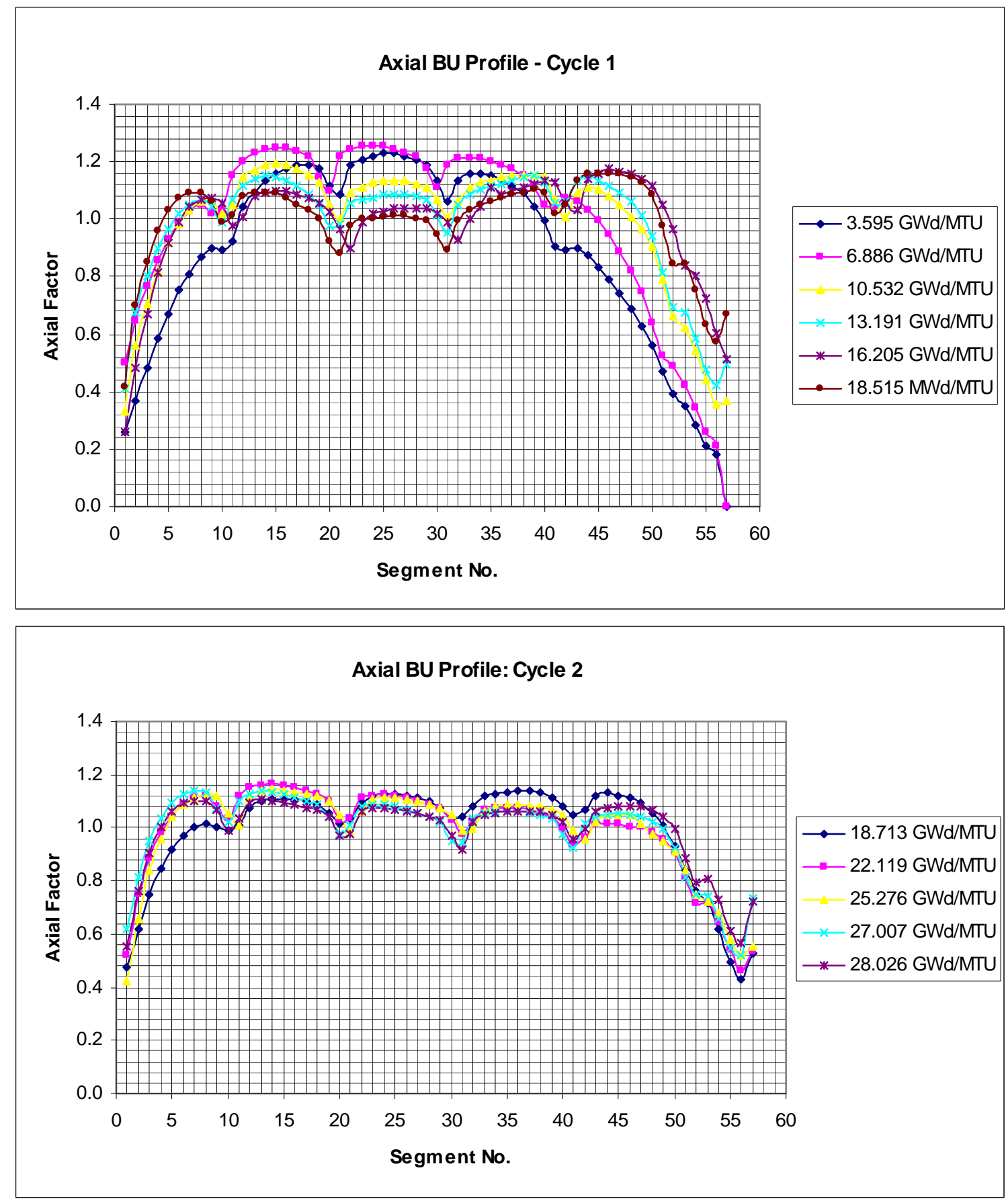

Fig. 12. Axial burnup profiles for assembly exposures during cycles 1 and 2. (Note: Samples N-9B-S, N9B-N, N-9C-J, and N-9C-D correspond to segments 2, 4, 31, and 35, respectively. A grid plate was adjacent to sample N-9C-J.) 
Table 63. Operating and fuel temperature data for H. B. Robinson spent fuel samples

\begin{tabular}{|c|c|c|c|c|c|c|c|c|c|}
\hline \multirow{2}{*}{$\begin{array}{c}\text { Irradiation } \\
\text { time } \\
\text { (days) }\end{array}$} & \multirow{2}{*}{$\begin{array}{c}\text { Downtime } \\
\text { following } \\
\text { interval }^{a} \\
\text { (days) }\end{array}$} & N-9B-S & N-9B-N & N-9C-D & N-9C-J & N-9B-S & N-9B-N & N-9C-D & N-9C-J \\
\hline & & \multicolumn{4}{|c|}{ Power (MW/MTU) ${ }^{b}$} & \multicolumn{4}{|c|}{ Effective fuel temperature (K) ${ }^{c}$} \\
\hline \multicolumn{10}{|c|}{ Cycle 1} \\
\hline 92.35 & 0 & 13.47 & 22.73 & 46.56 & 42.38 & 676.65 & 758.00 & 954.91 & 1002.28 \\
\hline 83.06 & 0 & 24.52 & 34.31 & 49.87 & 48.73 & 774.48 & 869.43 & 1027.74 & 1041.27 \\
\hline 92.57 & 30 & 20.23 & 31.10 & 44.70 & 39.08 & 735.37 & 837.28 & 919.06 & 980.95 \\
\hline 70.58 & 0 & 23.32 & 32.82 & 42.26 & 35.67 & 763.40 & 854.41 & 883.33 & 953.61 \\
\hline 83.51 & 0 & 15.91 & 28.56 & 39.05 & 35.43 & 697.38 & 812.61 & 880.84 & 918.80 \\
\hline 65.09 & 61 & 22.46 & 32.48 & 36.96 & 32.88 & 755.48 & 850.93 & 854.98 & 896.69 \\
\hline \multicolumn{10}{|c|}{ Cycle 2} \\
\hline 6.38 & 0 & 19.44 & 28.15 & 39.19 & 35.58 & 728.40 & 808.66 & 882.40 & 920.21 \\
\hline 109.91 & 0 & 21.37 & 29.60 & 33.72 & 30.19 & 745.65 & 822.64 & 828.41 & 863.40 \\
\hline 52.33 & 12 & 18.59 & 28.48 & 33.53 & 30.17 & 720.83 & 811.78 & 828.20 & 861.53 \\
\hline 52.33 & 0 & 18.59 & 28.48 & 33.53 & 30.17 & 720.83 & 811.78 & 828.20 & 861.53 \\
\hline 57.12 & 0 & 22.71 & 30.75 & 32.67 & 28.58 & 757.85 & 833.82 & 812.76 & 852.86 \\
\hline 33.68 & See Table 20 & 21.22 & 29.57 & 32.61 & 27.86 & 744.28 & 822.29 & 805.86 & 852.25 \\
\hline
\end{tabular}

${ }^{a}$ Ref. 29 describes outage and refueling durations in terms of approximate time. The impact on the fuel concentrations and neutron spectrum should be negligible due to the relatively short down times allowing short lived fission products to decay and due to the fact that the reactor operated for a significant time after shutdown.

${ }^{b}$ Values calculated in DVD/xls/input_data.xls using sample total burnup, the sample axial burnup profile (see Fig. 12), and the assembly average burnup of $28.03 \mathrm{GWd} / \mathrm{MTU}$ given in Ref. 26.

${ }^{c}$ Estimated from the curve of effective fuel temperature as function of linear power for reactor rod data (Ref. 16) of similar dimensions and pitch (DVD/xls/input_data.xls).

Table 64. Moderator conditions for H. B. Robinson spent fuel samples

\begin{tabular}{|c|c|c|c|c|}
\hline Sample ID & $\begin{array}{c}\text { Axial location } \\
(\mathbf{c m})\end{array}$ & $\begin{array}{l}\text { Total burnup } \\
\text { (GWd/MTU) }\end{array}$ & $\begin{array}{c}\text { Moderator } \\
\text { temperature }^{a}(\mathrm{~K}) \\
\end{array}$ & $\begin{array}{c}\text { Moderator density }^{b} \\
\left(\mathrm{~g} / \mathrm{cm}^{3}\right)\end{array}$ \\
\hline N-9B-S & 11 & 16.02 & 559 & 0.7540 \\
\hline N-9B-N & 26 & 23.81 & 559 & 0.7535 \\
\hline N-9C-J & 199 & 28.47 & 576 & 0.7206 \\
\hline N-9C-D & 226 & 31.66 & 579 & 0.7135 \\
\hline
\end{tabular}

${ }^{a}$ Derived using the method described in Sect. 5.2 and $546.5^{\circ} \mathrm{F}$ and $600.6^{\circ} \mathrm{F}$ for inlet and outlet temperatures, respectively (Ref. 29).

${ }^{b}$ Determined from the moderator temperature and the nominal pressure of 2250 psia (Ref. 29).

Source: Ref. 26, unless otherwise noted.

\subsection{CALVERT CLIFFS UNIT 1}

The isotopic measurements in the ATM-103 $\operatorname{program}^{30}$ were carried out on three samples from the fuel rod MLA098 belonging to fuel assembly D101, which was irradiated for three consecutive cycles, from cycle 2 to cycle 4. The samples are identified as MLA098-JJ, MLA098-BB, and MLA098-C. The measurements in the ATM-104 program ${ }^{30}$ were performed on three samples from the fuel rod MKP109 belonging to assembly D047, irradiated for four cycles, from cycle 2 to 5 . The samples are identified in this report as MKP109-LL, MKP109-CC, and MKP109-P. The measurements in the ATM-106 program $^{32}$ were performed on three samples from the fuel rod NBD107 belonging to assembly BT03. The samples are identified as NBD107-MM, NBD107-GG, and NBD107-Q. The NBD107 rod was irradiated for four consecutive cycles, from cycle 1 to cycle 4.

Each of the assemblies D101, D047, and BT03 had a CE $14 \times 14$ design and contained 176 rods and 5 guide tubes. There were no burnable absorber rods or gadolinia-bearing rods in the assembly during 
any of the irradiation cycles for assemblies D101 and D047. The layout of the assembly and the location of the rod from which the samples were selected are illustrated in Fig. 13 for assemblies D101 and D047. In the case of assembly BT03, there were 12 burnable absorber rods during cycle 1, and 4 test (non-fuel) rods during all irradiation time, as illustrated in Fig. 14.

The geometry data are presented in Table 65 and the sample location data in Table 66. The temperature of the moderator at the sample axial location was calculated using Eq. (1) (see Sect. 5.2). Based on the temperature values, the corresponding moderator densities (see Table 67) were calculated by using temperature vs. pressure tabulated data ${ }^{58}$ corresponding to the operating system pressure.

The concentration of the soluble boron in moderator was available ${ }^{35}$ for cycles 2 to 5 , as listed in Table 68. The soluble boron concentration at the beginning of cycle shown in Table 68 was not provided and was obtained by extrapolation of the available data. As no data was available for cycle 1, an average concentration of $330 \mathrm{ppm}$ as calculated for cycle 2 was used in the computational model. The effective fuel temperatures were available ${ }^{35}$ only for samples in fuel rod MKP109 that was irradiated during cycles 2 to 5. Lacking more detailed fuel temperature information, the data available for this fuel rod were applied to the other two measured fuel rods too, as listed in Table 69.

Data was available ${ }^{30,31,32}$ for the sample burnups determined based on the measured content of ${ }^{148} \mathrm{Nd}$, as listed in Table 70. Linear heat generation rates (LHGRs) data at the axial locations of samples, listed in Table 71, were available in detail ${ }^{34,38}$ for the three samples from rod MKP109 in assembly D047. At each axial location, the linear burnups of time intervals, calculated ${ }^{38}$ as the product of interval size and LHGR, were summed for each cycle. The calculated linear burnups per cycle were then normalized to the total burnups of the three D047 samples to produce the sample burnups presented in Table 70. The fuel rod burnup data for rods MLA098 and NBD107 were determined based on the available linear heat generation data for these two fuel rods, which are presented in Table 72 and Table 73 for fuel rods MLA098 and NBD107, respectively. For these two rods, no detailed LHGR data were available at the sample axial location, but only as rod-averaged data. In this case, the cumulative burnup at the end of cycle $k$ for a sample $s$ from fuel $\operatorname{rod} r, B_{s, r}^{k}$, was calculated based on the available sample total burnup $B_{s, r}^{\text {tot }}$, the fuel rod cumulative burnup at the end of each cycle $B_{r}^{k}$, and the fuel rod total burnup $B_{r}^{\text {tot }}$, as shown in Eq. (17). The data obtained for the sample cumulative burnup at the end of each cycle are listed in Table 74. The average cycle power for each sample can easily be obtained by dividing the sample burnup accumulated in a cycle by the time duration of that cycle provided in Table 74 . The cooling time for each of the samples is shown in Table 75.

$$
B_{s, r}^{k}=B_{s, r}^{t o t} \frac{B_{r}^{k}}{B_{r}^{t o t}} .
$$




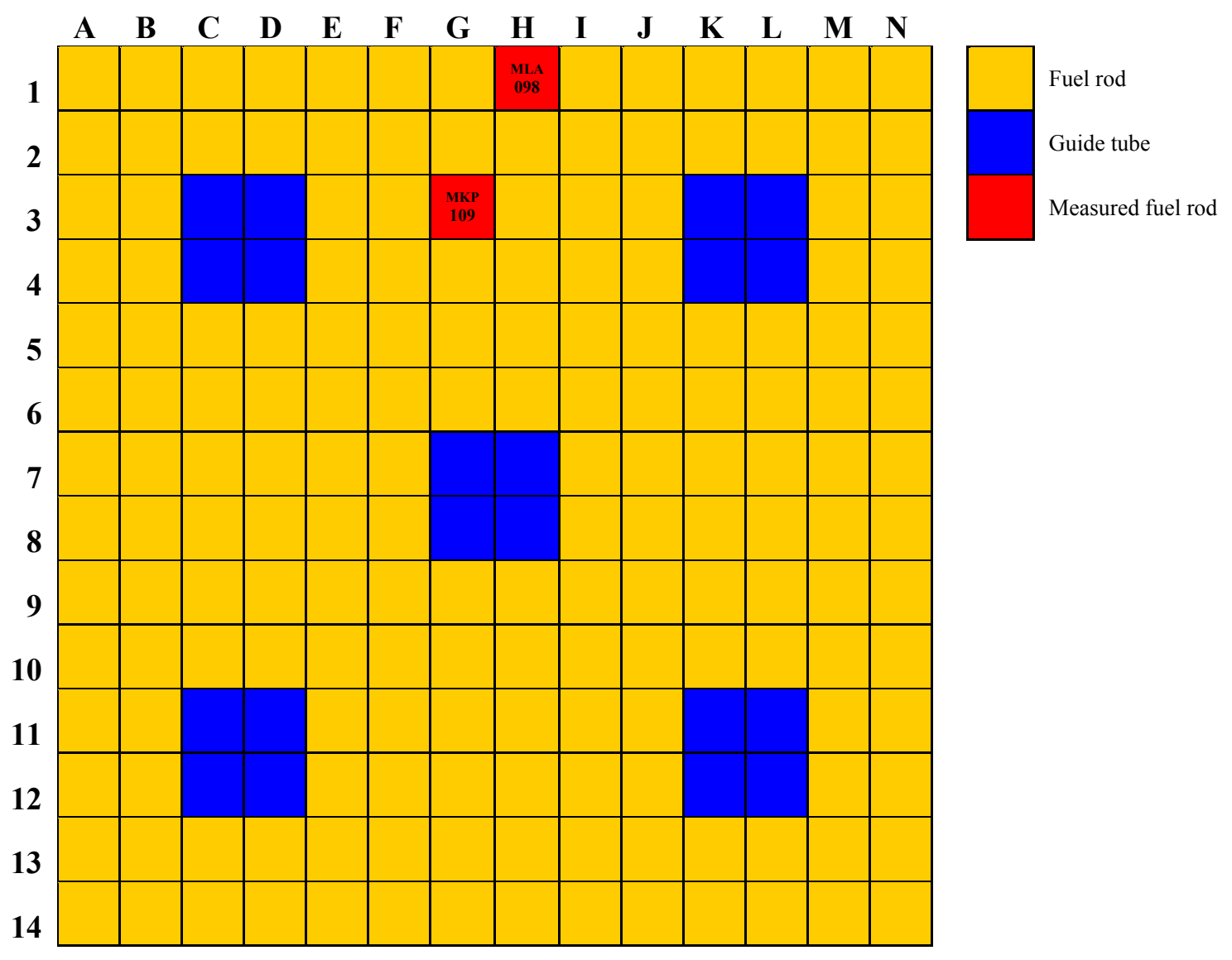

Fig. 13. Assembly layout for Calvert Cliffs samples from assemblies D047 and D101. (Source: Ref. 30, Fig. 4.3; Ref. 31, Fig. 3.3.) 


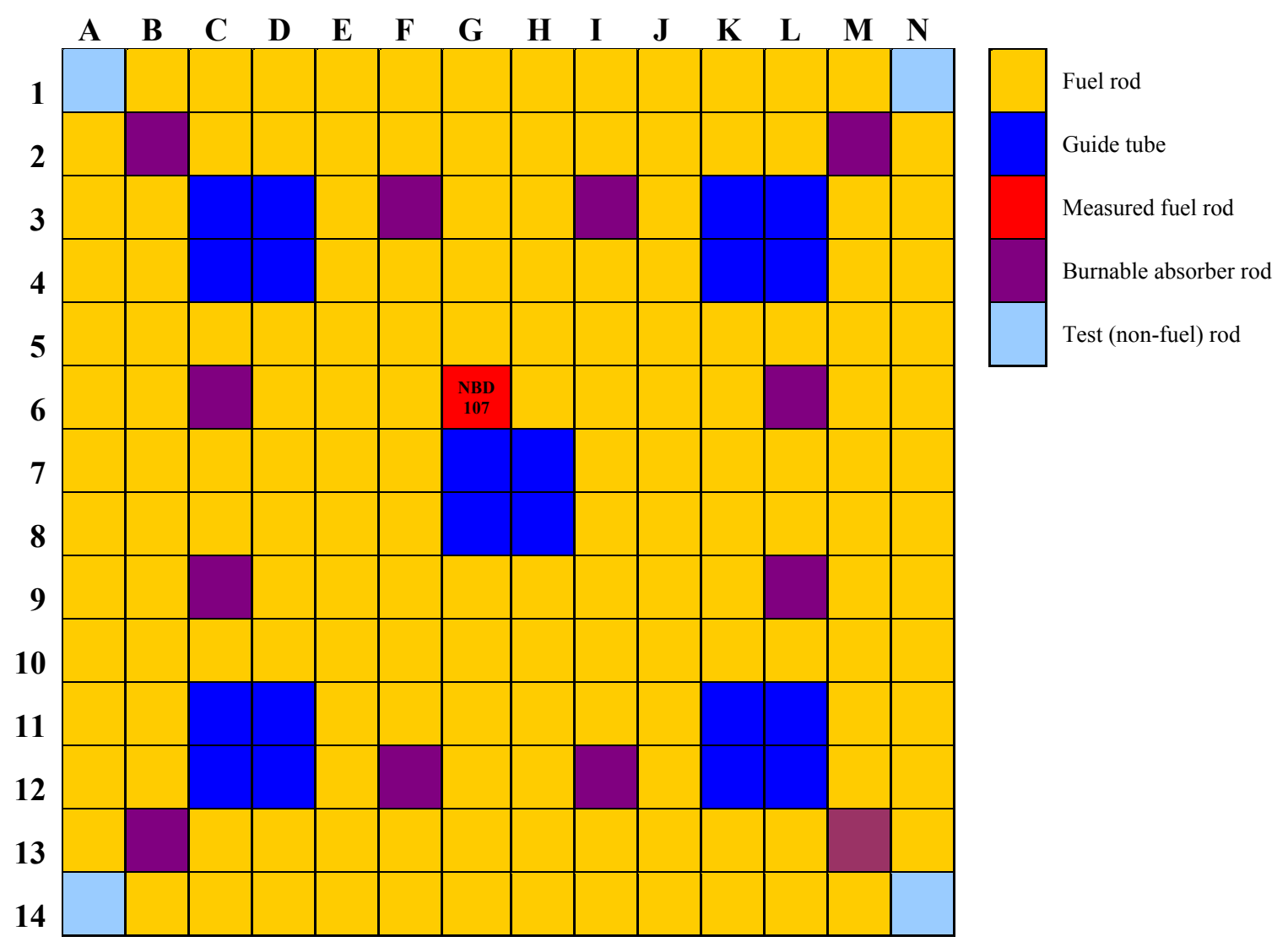

Fig. 14. Assembly layout for Calvert Cliffs samples from assembly BT03. (Source: Ref. 32, Fig. 4.3.) 
Table 65. Assembly design and operating data for Calvert Cliffs measured spent fuel

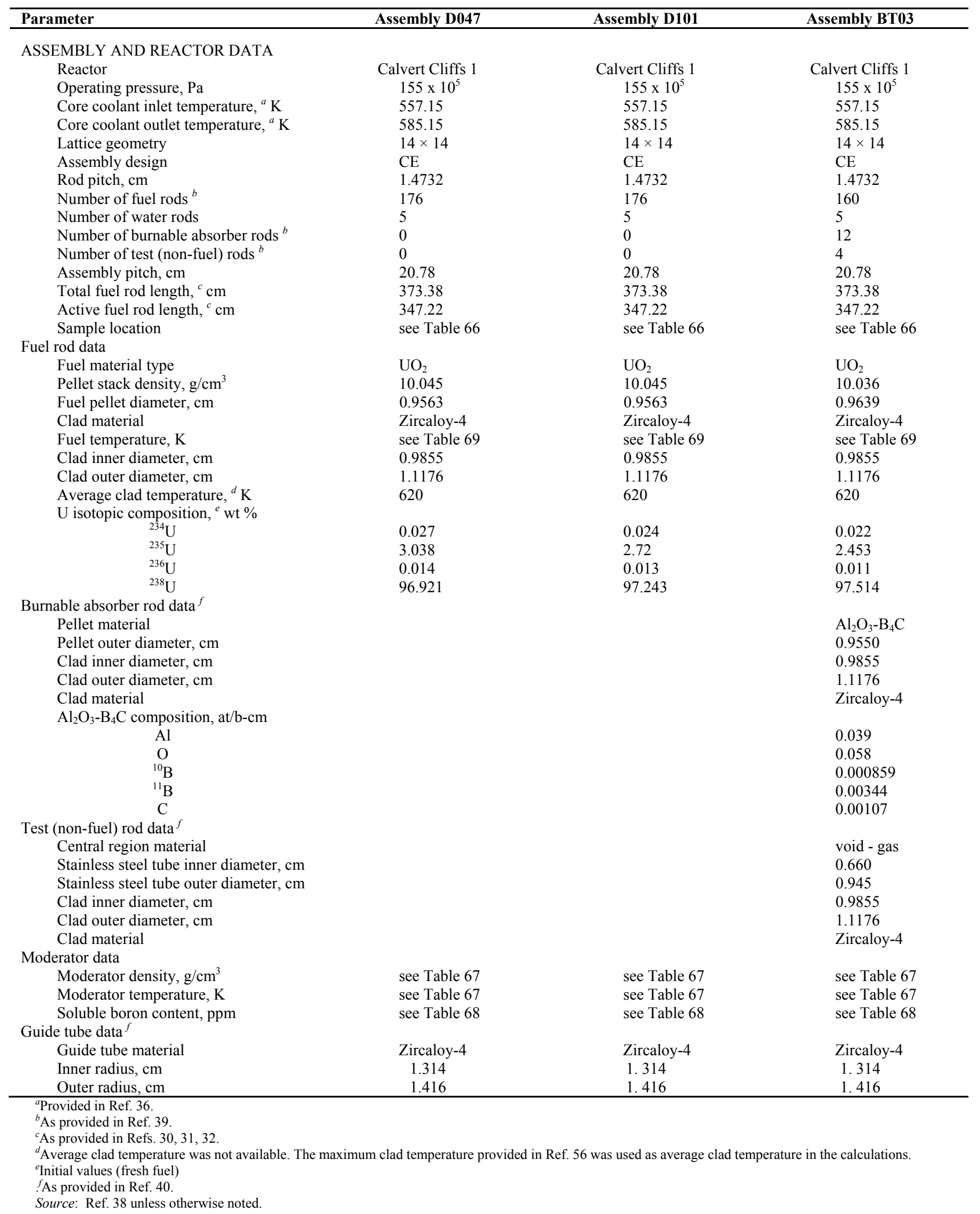


Table 66. Sample location data for Calvert Cliffs samples

\begin{tabular}{llccc}
\hline Assembly ID & Sample ID & $\begin{array}{c}\text { Distance from } \\
\text { top of fuel rod }^{a} \\
\text { (cm) }\end{array}$ & $\begin{array}{c}\text { Average distance } \\
\text { from top of fuel } \\
\text { rod } \\
\text { (cm) }\end{array}$ & $\begin{array}{c}\text { Distance from } \\
\text { bottom of active } \\
\text { fuel region } \\
\text { (cm) }\end{array}$ \\
\hline \multirow{2}{*}{ D047 } & MKP109-P & $208.656-209.926$ & 209.291 & 164.09 \\
& MKP109-CC & $345.331-346.619$ & 345.975 & 27.41 \\
& MKP109-LL & $360.032-361.320$ & 360.676 & 12.70 \\
\hline \multirow{2}{*}{ D101 } & MLA098-JJ & $361.013-362.379$ & 361.696 & 11.68 \\
& MLA098-BB & $345.603-346.969$ & 346.286 & 27.09 \\
& MLA098-P & $208.204-209.499$ & 208.852 & 164.53 \\
\hline \multirow{2}{*}{ BT03 } & NBD107-Q & $208.768-210.022$ & 209.495 & 163.89 \\
& NBD107-GG & $350.050-351.320$ & 350.685 & 22.70 \\
& NBD107-MM & $358.686-359.956$ & 359.321 & 14.06 \\
\hline
\end{tabular}

${ }^{a}$ As provided in Refs. 30, 31, and 32 for samples in assembly D047, D101, and BT03, respectively.

${ }^{b}$ The middle of the region from which the sample was cut.

Table 67. Moderator temperature and density data for Calvert Cliffs samples

\begin{tabular}{|c|c|c|c|}
\hline Assembly ID & Sample ID & $\begin{array}{c}\text { Temperature }^{a} \\
(\mathrm{~K})\end{array}$ & $\begin{array}{c}\text { Density }^{b} \\
\left(\mathrm{~g} / \mathrm{cm}^{3}\right) \\
\end{array}$ \\
\hline \multirow{3}{*}{ D047 } & MKP109-P & 569.9 & 0.7307 \\
\hline & MKP109-CC & 557.6 & 0.7569 \\
\hline & MKP109-LL & 557.2 & 0.7575 \\
\hline \multirow{3}{*}{ D101 } & MLA098-JJ & 557.2 & 0.7576 \\
\hline & MLA098-BB & 557.6 & 0.7570 \\
\hline & MLA098-P & 570.0 & 0.7305 \\
\hline \multirow{3}{*}{ BT03 } & NBD107-Q & 569.9 & 0.7308 \\
\hline & NBD107-GG & 557.4 & 0.7572 \\
\hline & NBD107-MM & 557.3 & 0.7575 \\
\hline
\end{tabular}

${ }^{a}$ The temperature of the moderator at the sample axial location was calculated using Eq. (1) (see Sect. 5.2).

${ }^{b}$ Based on the temperature values, the corresponding moderator densities were calculated by using temperature vs. pressure tabulated data ${ }^{58}$ corresponding to the operating system pressure given in Table 65 . 
Table 68. Concentration of soluble boron in moderator for Calvert Cliffs samples

\begin{tabular}{|c|c|c|c|c|c|c|c|}
\hline \multicolumn{2}{|c|}{ Cycle 2} & \multicolumn{2}{|c|}{ Cycle 3} & \multicolumn{2}{|c|}{ Cycle 4} & \multicolumn{2}{|c|}{ Cycle 5} \\
\hline $\begin{array}{c}\text { Time } \\
\text { interval } \\
\text { (days) }\end{array}$ & $\begin{array}{c}\begin{array}{c}\text { Soluble } \\
\text { boron }^{a} \\
\text { (ppm) }\end{array} \\
\end{array}$ & $\begin{array}{c}\text { Time } \\
\text { interval } \\
\text { (days) }\end{array}$ & $\begin{array}{c}\text { Soluble } \\
\text { boron }^{a} \\
(\mathrm{ppm})\end{array}$ & $\begin{array}{c}\text { Time } \\
\text { interval } \\
\text { (days) }\end{array}$ & $\begin{array}{c}\begin{array}{c}\text { Soluble } \\
\text { boron }^{a} \\
(\mathrm{ppm})\end{array} \\
\end{array}$ & $\begin{array}{c}\text { Time } \\
\text { interval } \\
\text { (days) }\end{array}$ & $\begin{array}{c}\begin{array}{c}\text { Soluble } \\
\text { boron }^{a} \\
(\mathrm{ppm})\end{array} \\
\end{array}$ \\
\hline $0.0^{b}$ & 663 & $0.0^{b}$ & 910 & $0.0^{b}$ & 1033 & $0.0^{b}$ & 1045 \\
\hline 7.0 & 654 & 7.9 & 883 & 46.1 & 960 & 65.0 & 919 \\
\hline 30.8 & 614 & 14.4 & 862 & 24.0 & 889 & 5.5 & 911 \\
\hline 16.3 & 563 & 19.7 & 837 & 22.6 & 827 & 6.6 & 896 \\
\hline 11.4 & 533 & 16.8 & 808 & 25.7 & 759 & 28.6 & 854 \\
\hline 12.5 & 507 & 16.3 & 775 & 30.2 & 706 & 31.2 & 784 \\
\hline 23.7 & 468 & 15.4 & 741 & 41.2 & 788 & 27.0 & 715 \\
\hline 22.8 & 418 & 39.1 & 684 & 50.3 & 720 & 22.7 & 655 \\
\hline 23.2 & 368 & 31.2 & 611 & 11.0 & 673 & 27.1 & 603 \\
\hline 8.1 & 333 & 31.8 & 545 & 32.8 & 527 & 55.2 & 521 \\
\hline 31.4 & 290 & 31.8 & 478 & 23.5 & 460 & 20.9 & 434 \\
\hline 34.3 & 218 & 44.3 & 368 & 29.4 & 370 & 41.9 & 356 \\
\hline 16.4 & 162 & 25 & 291 & 28.1 & 301 & 21.6 & 281 \\
\hline 19.2 & 122 & 59.1 & 224 & 65.4 & 191 & 27.6 & 226 \\
\hline 12.8 & 86 & 28.9 & 120 & 35.7 & 73 & 19.0 & 173 \\
\hline 34.2 & 36 & 81 & 83 & 85.0 & 31 & 61.2 & 79 \\
\hline 1.9 & 0 & & & & & & \\
\hline 71.0 & 0 & & & & & & \\
\hline
\end{tabular}

${ }^{a}$ The value given for each time interval is the arithmetic mean of the boron concentration at the beginning and end of the time interval (Ref. 35).

${ }^{b}$ Value at beginning of cycle ( 0.0 days) obtained by extrapolation of the available data.

Source: Ref. 35, Table II, unless otherwise noted.

Table 69. Effective fuel temperature data for Calvert Cliffs samples

\begin{tabular}{clccccc}
\hline \multirow{2}{*}{ Assembly ID } & Sample ID & $\begin{array}{c}\text { Temperature } \\
\text { cycle 1 } \\
(\mathbf{K})\end{array}$ & $\begin{array}{c}\text { Temperature } \\
\text { cycle 2 } \\
(\mathbf{K})\end{array}$ & $\begin{array}{c}\text { Temperature } \\
\text { cycle 3 } \\
(\mathbf{K})\end{array}$ & $\begin{array}{c}\text { Temperature } \\
\text { cycle 4 } \\
(\mathbf{K})\end{array}$ & $\begin{array}{c}\text { Temperature } \\
\text { cycle 5 } \\
(\mathbf{K})\end{array}$ \\
\hline \multirow{3}{*}{ D047 $^{a}{ }^{a}$} & MKP109-LL & & 829 & 850 & 775 & 709 \\
& MKP109-CC & & 940 & 927 & 793 & 712 \\
& MKP109-P & & 997 & 958 & 794 & 747 \\
\hline \multirow{2}{*}{ D101 $^{b}{ }^{b}$} & MLA098-JJ & & 829 & 850 & 775 & \\
& MLA098-BB & & 940 & 927 & 793 & \\
& MLA098-P & & 997 & 958 & 794 & \\
\hline \multirow{2}{*}{ BT03 $^{b}{ }^{b}$} & NBD107-MM & 829 & 829 & 850 & 775 \\
& NBD107-GG & 940 & 940 & 927 & 793 & \\
& NBD107-Q & 997 & 997 & 958 & 794 & \\
\hline
\end{tabular}

${ }^{a}$ Effective fuel temperatures available from Ref. 35 .

${ }^{b}$ Assumed temperature values based on available data for assembly D047. 
Table 70. Burnup values for Calvert Cliffs spent fuel samples

\begin{tabular}{llc}
\hline Assembly ID & \multicolumn{1}{c}{ Sample ID } & $\begin{array}{c}\text { Burnup }^{a} \\
\text { (GWd/MTU) }^{(\text {MWd }}\end{array}$ \\
\hline \multirow{2}{*}{ D047 } & MKP109- LL & 27.35 \\
& MKP109-CC & 37.12 \\
& MKP109- P & 44.34 \\
\hline \multirow{2}{*}{ D101 } & MLA098-JJ & 18.68 \\
& MLA098-BB & 26.62 \\
& MLA098-P & 33.17 \\
BT03 & NBD107- MM & 31.40 \\
& NBD107-GG & 37.27 \\
& NBD107- Q & 46.46 \\
\hline
\end{tabular}

${ }^{a}$ As reported in Refs. 30, 31, and 32 for samples in assembly D101, D047, and BT03, respectively. 
Table 71. Linear heat generation data for fuel rod MKP109

\begin{tabular}{|c|c|c|c|c|c|c|c|c|c|c|c|c|c|c|c|}
\hline \multicolumn{4}{|c|}{ Cycle \#2 } & \multicolumn{4}{|c|}{ Cycle \#3 } & \multicolumn{4}{|c|}{ Cycle \#4 } & \multicolumn{4}{|c|}{ Cycle \#5 } \\
\hline \multirow{2}{*}{$\begin{array}{c}\text { Interval } \\
\text { (days) }\end{array}$} & \multicolumn{3}{|c|}{$\begin{array}{c}\text { LGHR }^{a} \\
(\mathrm{~kW} / \mathbf{f t})\end{array}$} & \multirow{2}{*}{$\begin{array}{c}\text { Interval } \\
\text { (days) }\end{array}$} & \multicolumn{3}{|c|}{$\begin{array}{l}\text { LGHR } \\
(\mathrm{kW} / \mathrm{ft})\end{array}$} & \multirow{2}{*}{$\begin{array}{c}\text { Interval } \\
\text { (days) }\end{array}$} & \multicolumn{3}{|c|}{$\begin{array}{c}\text { LGHR } \\
(\mathrm{kW} / \mathrm{ft})\end{array}$} & \multirow{2}{*}{$\begin{array}{c}\text { Interval } \\
\text { (days) }\end{array}$} & \multicolumn{3}{|c|}{$\begin{array}{l}\text { LGHR } \\
(\mathrm{kW} / \mathrm{ft})\end{array}$} \\
\hline & $13.2 \mathrm{~cm}^{b}$ & $27.70 \mathrm{~cm}$ & $165.22 \mathrm{~cm}$ & & $13.2 \mathrm{~cm}$ & $27.70 \mathrm{~cm}$ & $165.22 \mathrm{~cm}$ & & $13.2 \mathrm{~cm}$ & $27.70 \mathrm{~cm}$ & $165.22 \mathrm{~cm}$ & & $13.2 \mathrm{~cm}$ & $27.70 \mathrm{~cm}$ & $165.22 \mathrm{~cm}$ \\
\hline 7.0 & 2.00 & 3.04 & 5.42 & 7.9 & 2.63 & 3.85 & 7.47 & 46.1 & 2.79 & 3.97 & 6.59 & 65.0 & 1.98 & 2.67 & 4.55 \\
\hline 30.8 & 2.73 & 4.08 & 6.64 & 14.4 & 2.71 & 3.95 & 7.20 & 24.0 & 2.91 & 4.11 & 6.54 & 5.5 & 2.15 & 2.91 & 4.80 \\
\hline 16.3 & 2.80 & 4.18 & 6.60 & 19.7 & 2.14 & 3.11 & 5.04 & 22.6 & 3.07 & 4.29 & 6.43 & 6.6 & 2.20 & 2.98 & 4.80 \\
\hline 11.4 & 2.86 & 4.26 & 6.60 & 16.8 & 3.18 & 4.58 & 7.79 & 25.7 & 3.29 & 4.56 & 6.33 & 28.6 & 2.36 & 3.15 & 4.79 \\
\hline 12.5 & 2.94 & 4.34 & 6.56 & 16.3 & 3.35 & 4.81 & 7.78 & 30.2 & 1.57 & 2.17 & 3.05 & 31.2 & 2.54 & 3.36 & 4.72 \\
\hline 23.7 & 3.01 & 4.43 & 6.41 & 15.4 & 3.74 & 5.33 & 8.16 & 41.2 & 1.79 & 2.46 & 3.18 & 27.0 & 2.66 & 3.52 & 4.73 \\
\hline 22.8 & 3.16 & 4.61 & 6.44 & 39.1 & 3.71 & 5.23 & 7.45 & 50.3 & 1.72 & 2.35 & 3.00 & 22.7 & 2.77 & 3.63 & 4.71 \\
\hline 23.2 & 3.27 & 4.73 & 6.37 & 31.2 & 3.95 & 5.50 & 7.37 & 11.0 & 3.18 & 4.33 & 5.23 & 27.1 & 2.46 & 3.22 & 4.05 \\
\hline 8.1 & 3.30 & 4.75 & 6.34 & 31.8 & 4.08 & 5.64 & 7.20 & 32.8 & 3.93 & 5.31 & 6.17 & 55.2 & 2.81 & 3.64 & 4.34 \\
\hline 31.4 & 3.48 & 4.95 & 6.34 & 31.8 & 4.20 & 5.75 & 7.02 & 23.5 & 4.07 & 5.42 & 6.12 & 20.9 & 3.17 & 4.08 & 4.75 \\
\hline 34.3 & 3.59 & 5.05 & 6.53 & 44.3 & 4.38 & 5.93 & 6.93 & 29.4 & 4.05 & 5.35 & 5.95 & 41.9 & 3.32 & 4.24 & 4.79 \\
\hline 16.4 & 3.75 & 5.25 & 6.38 & 25.0 & 0.00 & 0.00 & 0.00 & 28.1 & 4.25 & 5.56 & 6.07 & 21.6 & 3.38 & 4.30 & 4.80 \\
\hline 19.2 & 3.75 & 5.21 & 6.26 & 59.1 & 4.67 & 6.20 & 6.89 & 65.4 & 4.42 & 5.67 & 5.98 & 27.6 & 3.21 & 4.04 & 4.49 \\
\hline 12.8 & 3.81 & 5.28 & 6.30 & 28.9 & 4.95 & 6.52 & 7.12 & 35.7 & 4.62 & 5.87 & 6.02 & 19.0 & 3.57 & 4.49 & 4.87 \\
\hline 34.2 & 3.63 & 4.98 & 5.95 & & & & & & & & & 61.2 & 3.05 & 3.79 & 4.00 \\
\hline 1.9 & 3.64 & 4.98 & 5.96 & & & & & & & & & & & & \\
\hline
\end{tabular}

${ }^{a}$ Linear heat generation rate.

${ }^{b}$ Axial location of each of the three samples.

Source: Ref. 31, Table II. 
Table 72. Linear heat generation data for fuel rod MLA098

\begin{tabular}{cccccc}
\hline \multicolumn{2}{c}{ Cycle 2 } & \multicolumn{2}{c}{ Cycle 3 } & \multicolumn{2}{c}{ Cycle 4 } \\
\hline $\begin{array}{c}\text { Interval } \\
\text { (days) }\end{array}$ & $\begin{array}{c}\text { LHGR }^{\boldsymbol{a}} \\
\text { (kW/ft) }\end{array}$ & $\begin{array}{c}\text { Interval } \\
\text { (days) }\end{array}$ & $\begin{array}{c}\text { LHGR } \\
\text { (kW/ft) }\end{array}$ & $\begin{array}{c}\text { Interval } \\
\text { (days) }\end{array}$ & $\begin{array}{c}\text { LHGR } \\
\text { (kW/ft) }\end{array}$ \\
\hline 7.1 & 19.1 & 6.8 & 19.1 & 47.0 & 17.4 \\
30.8 & 23.5 & 14.3 & 18.6 & 24.1 & 17.2 \\
16.4 & 23.5 & 19.5 & 13.1 & 22.5 & 17.3 \\
11.4 & 23.5 & 16.5 & 20.7 & 25.5 & 17.3 \\
12.5 & 23.5 & 16.1 & 21.2 & 30.7 & 8.4 \\
23.4 & 23.5 & 15.1 & 22.4 & 41.0 & 8.6 \\
22.8 & 23.4 & 38.8 & 21.2 & 50.1 & 8.6 \\
22.9 & 23.3 & 31.0 & 21.3 & 10.9 & 14.9 \\
8.5 & 23.3 & 31.6 & 21.2 & 10.7 & 17.7 \\
31.4 & 23.5 & 31.6 & 20.9 & 45.1 & 17.9 \\
34.2 & 23.3 & 43.9 & 20.9 & 29.3 & 17.6 \\
16.6 & 23.7 & 61.7 & 21.2 & 28.0 & 18.1 \\
19.1 & 23.3 & 30.2 & 22.0 & 65.1 & 18.0 \\
12.8 & 23.5 & & & 35.7 & 18.2 \\
34.3 & 22.2 & & & & \\
1.9 & 22.2 & & & & \\
\hline${ }^{a}$ Linear heat generation rate. & & & & \\
Source: & Ref. 30, Table A.1 & & &
\end{tabular}

Table 73. Linear heat generation data for fuel rod NBD107

\begin{tabular}{|c|c|c|c|c|c|c|c|}
\hline \multicolumn{2}{|c|}{ Cycle 1} & \multicolumn{2}{|c|}{ Cycle 2} & \multicolumn{2}{|c|}{ Cycle 3} & \multicolumn{2}{|c|}{ Cycle 4} \\
\hline $\begin{array}{c}\text { Interval } \\
\text { (days) }\end{array}$ & $\begin{array}{c}\text { LHGR } \\
(\mathrm{kW} / \mathrm{ft})\end{array}$ & $\begin{array}{c}\text { Interval } \\
\text { (days) }\end{array}$ & $\begin{array}{c}\text { LHGR } \\
(\mathrm{kW} / \mathrm{ft})\end{array}$ & $\begin{array}{c}\text { Interval } \\
\text { (days) }\end{array}$ & $\begin{array}{c}\text { LHGR } \\
(\mathrm{kW} / \mathbf{f t})\end{array}$ & $\begin{array}{c}\text { Interval } \\
\text { (days) }\end{array}$ & $\begin{array}{c}\text { LHGR } \\
(\mathrm{kW} / \mathrm{ft})\end{array}$ \\
\hline 24.2 & 19.2 & 7.2 & 13.3 & 10.9 & 12.6 & 45.0 & 13.8 \\
\hline 19.6 & 24.1 & 31.0 & 17.1 & 14.1 & 12.4 & 24.1 & 13.8 \\
\hline 39.7 & 24.1 & 16.4 & 19.0 & 25.3 & 6.7 & 22.4 & 13.9 \\
\hline 39.7 & 23.9 & 11.4 & 18.9 & 12.2 & 14.0 & 25.2 & 14.1 \\
\hline 39.4 & 23.7 & 12.6 & 18.9 & 16.3 & 14.2 & 31.0 & 6.7 \\
\hline 39.3 & 23.6 & 23.2 & 18.9 & 15.1 & 15.2 & 44.8 & 6.3 \\
\hline 39.1 & 23.5 & 22.7 & 18.9 & 38.1 & 14.3 & 48.1 & 7.0 \\
\hline 38.9 & 23.6 & 23.0 & 18.9 & 30.9 & 14.6 & 10.9 & 12.4 \\
\hline 39.0 & 23.6 & 8.2 & 18.8 & 31.4 & 14.6 & 10.6 & 14.9 \\
\hline 39.1 & 23.5 & 31.0 & 19.3 & 31.5 & 14.6 & 45.3 & 15.2 \\
\hline 39.1 & 23.3 & 33.8 & 19.4 & 43.2 & 14.8 & 28.7 & 15.1 \\
\hline 39.4 & 23.1 & 16.5 & 19.8 & 60.0 & 14.9 & 27.9 & 15.6 \\
\hline 39.3 & 22.9 & 19.1 & 19.6 & 28.0 & 16.1 & 65.9 & 15.5 \\
\hline 39.3 & 22.6 & 12.8 & 19.8 & & & 36.1 & 15.7 \\
\hline 39.3 & 22.4 & 35.2 & 18.4 & & & & \\
\hline 39.3 & 22.2 & 1.9 & 18.3 & & & & \\
\hline 19.6 & 22.0 & & & & & & \\
\hline 20.4 & 21.1 & & & & & & \\
\hline 30.8 & 14.9 & & & & & & \\
\hline 32.8 & 12.3 & & & & & & \\
\hline
\end{tabular}


Table 74. Sample burnup at the end of each cycle for Calvert Cliffs samples

\begin{tabular}{|c|c|c|c|c|c|c|c|c|c|c|c|}
\hline \multirow[t]{2}{*}{$\begin{array}{c}\text { Cycle } \\
\#\end{array}$} & \multirow[t]{2}{*}{$\begin{array}{c}\begin{array}{c}\text { Duration } \\
\text { (days) }\end{array} \\
\end{array}$} & \multirow[t]{2}{*}{$\begin{array}{c}\begin{array}{c}\text { Downtime } \\
\text { (days) }\end{array} \\
\end{array}$} & \multicolumn{9}{|c|}{$\begin{array}{l}\text { Sample cumulative burnup } \\
\text { (GWd/MTU) }\end{array}$} \\
\hline & & & MKP109- LL & MKP109-CC & MKP109- P & MLA098-JJ & MLA098-BB & MLA098-P & NBD107- MM & NBD107-GG & NBD107- Q \\
\hline 1 & 730 & 81 & & & & & & & 14.59 & 17.32 & 21.59 \\
\hline 2 & 306 & 71 & 6.33 & 8.59 & 10.26 & 6.16 & 8.77 & 10.93 & 20.31 & 24.10 & 30.05 \\
\hline 3 & 382 & 81 & 14.20 & 19.27 & 23.01 & 12.36 & 17.61 & 21.94 & 25.29 & 30.02 & 37.42 \\
\hline 4 & 466 & 85 & 21.13 & 28.68 & 34.26 & 18.68 & 26.62 & 33.17 & 31.40 & 37.27 & 46.46 \\
\hline 5 & 461 & & 27.35 & 37.12 & 44.34 & & & & & & \\
\hline
\end{tabular}

Table 75. Decay time data for Calvert Cliffs samples

\begin{tabular}{|c|c|c|}
\hline Assembly ID & Sample ID & Decay time (days) \\
\hline \multirow{3}{*}{ D047 } & MKP109- LL & $1870^{a} \quad 4171^{b}$ \\
\hline & MKP109-CC & $1870^{a} \quad 4656^{b}$ \\
\hline & MKP109- P & $1870^{a} 4656^{b}$ \\
\hline \multirow{3}{*}{ D101 } & MLA098-JJ & 2374 \\
\hline & MLA098-BB & 2374 \\
\hline & MLA098-P & 2374 \\
\hline \multirow{3}{*}{ BT03 } & NBD107-MM & 2447 \\
\hline & NBD107-GG & $24475658^{c}$ \\
\hline & NBD107-Q & 2447 \\
\hline $\begin{array}{r}{ }^{a} \text { Values corres } \\
{ }^{b} \text { Values for lan } \\
\text { measurement dates } \\
{ }^{c} \text { Values for }{ }^{103} \mathrm{I} \\
\text { correspond to KRI }\end{array}$ & $\begin{array}{l}\text { nd to PNL measuren } \\
\text { anides except for nec } \\
\text { ef. 38). See also Sec } \\
\text { and lanthanides exc } \\
\text { casurement dates (Re }\end{array}$ & $\begin{array}{l}\text { Ref. 34). } \\
\text { otopes correspond to KRI } \\
\text { dymium isotopes } \\
\text { also Sect. } 7.5 \text {. }\end{array}$ \\
\hline
\end{tabular}




\subsection{TAKAHAMA UNIT 3}

Radiochemical analyses were performed at JAERI on 16 samples from three fuel rods identified as SF95, SF96, and SF97. ${ }^{41}$ Rods SF95 and SF97 were standard fuel rods with $4.11 \mathrm{wt} \%{ }^{235} \mathrm{U}$ initial enrichment; whereas SF96 was a fuel rod with gadolinia poison that had a fuel initial enrichment of $2.6 \mathrm{wt} \%{ }^{235} \mathrm{U}$ and a $\mathrm{Gd}_{2} \mathrm{O}_{3}$ content of $6 \%$. Rods SF95 and SF96 were from assembly NT3G23 and rod SF97 was from assembly NT3G24. Each of these two assemblies had a $17 \times 17$ configuration, with 264 fuel rods (16 of these containing gadolinia $)^{42}$ and 25 water-filled guide tubes. They resided in the reactor core for two (assembly NT3G23) or three (assembly NT3G24) consecutive cycles, starting from cycle 5. The configuration of the assembly, including the location of the measured rods, is illustrated in Fig. 15.

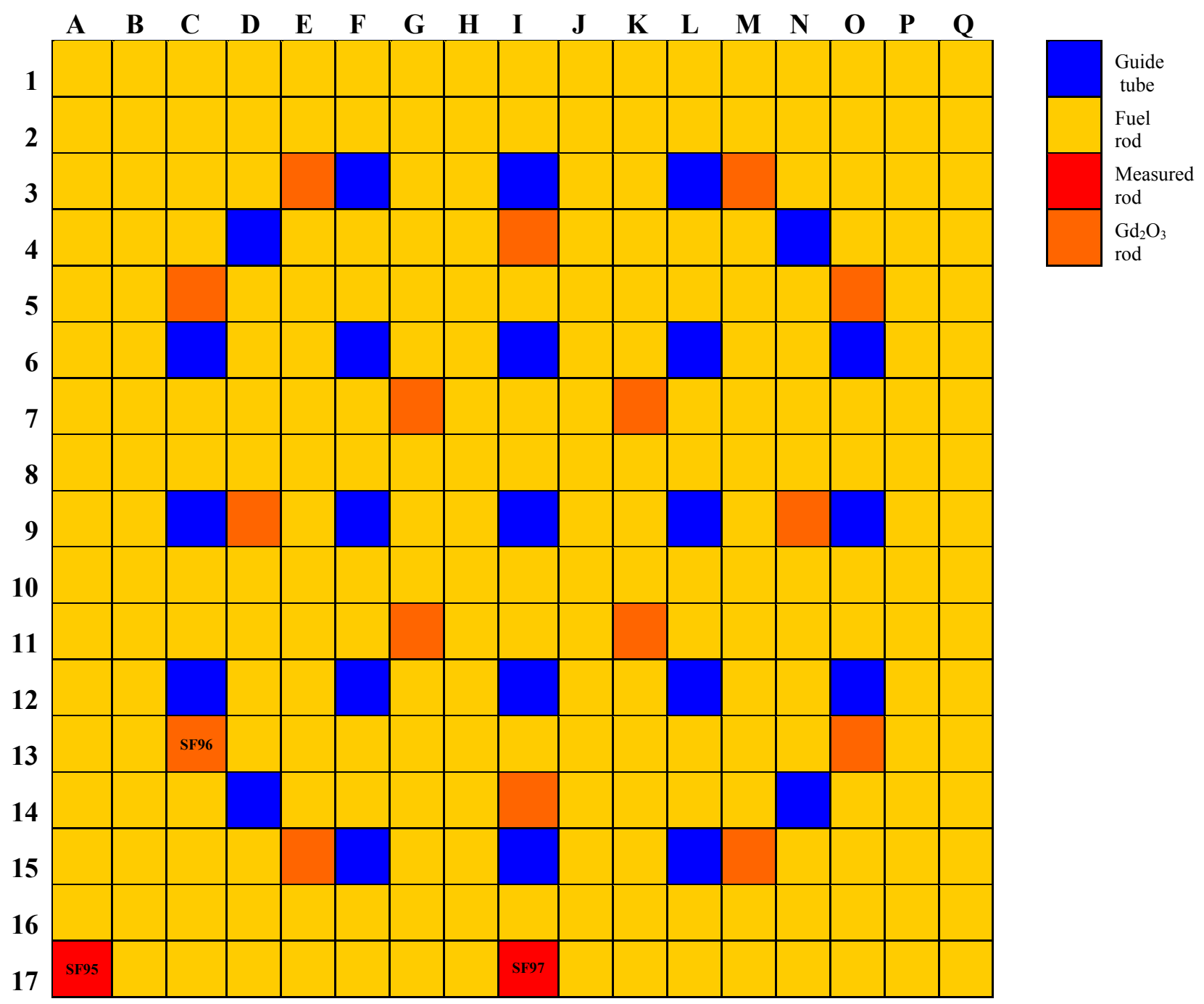

Fig. 15. Assembly layout for Takahama-3 spent fuel samples.

Assembly design data are listed in Table 76. Burnup values, sample axial location along the fuel rod, moderator density and temperature, and cycle power for each sample are shown in Table 77. Operation 
history data and soluble boron concentration are presented in Table 78 and Table 79 , respectively. The temperature of the moderator at the sample axial location with respect to the bottom of the active fuel region was calculated using Eq. (1) described in Section 5.2. The moderator density was determined by using temperature vs. pressure tabulated data ${ }^{58}$ corresponding to operating pressure value ${ }^{57}$ of $157 \mathrm{~kg} / \mathrm{cm}^{2}$. The cycle power for each sample as shown in Table 77 was obtained by averaging the power data given in Ref. 41. As the actual sample burnup was calculated to correspond to the measured ${ }^{148} \mathrm{Nd}$ content in each sample, the power used in the calculation was obtained by dividing the power data in Table 77 by the ratio of the reported burnup and actual burnup for each sample, as shown in Table 80. 
Table 76. Assembly design data for Takahama-3 spent fuel samples

\begin{tabular}{|c|c|}
\hline Parameter & Data \\
\hline \multicolumn{2}{|l|}{ Assembly and reactor data } \\
\hline Lattice geometry & $17 \times 17$ \\
\hline Operating pressure, ${ }^{a} \mathrm{~kg} / \mathrm{cm}^{2}$ & 157 \\
\hline Rod pitch, ${ }^{b} \mathrm{~cm}$ & 1.26 \\
\hline Number of fuel rods & 264 \\
\hline Number of guide tubes & 25 \\
\hline Assembly pitch, $\mathrm{cm}$ & 21.4 \\
\hline \multicolumn{2}{|l|}{ Fuel rod data } \\
\hline Fuel material type & $\mathrm{UO}_{2}$ \\
\hline Fuel pellet density (\% TD) & 95 \\
\hline Enrichment, wt $\%{ }^{235} \mathrm{U}$ & $4.11(2.63)$ \\
\hline Fuel pellet diameter, $\mathrm{cm}$ & 0.805 \\
\hline Active fuel rod length, $\mathrm{cm}$ & 366 \\
\hline Sample location, $\mathrm{cm}$ & See Table 77 \\
\hline Average fuel temperature, ${ }^{c} \mathrm{~K}$ & 900 \\
\hline Clad material & Zircaloy-4 \\
\hline Clad inner diameter, $\mathrm{cm}$ & 0.822 \\
\hline Clad outer diameter, $\mathrm{cm}$ & 0.95 \\
\hline Average clad temperature, ${ }^{c} \mathrm{~K}$ & 600 \\
\hline Number of rods with $\mathrm{Gd}_{2} \mathrm{O}_{3}$ & 16 \\
\hline $\begin{array}{l}\mathrm{Gd}_{2} \mathrm{O}_{3} \text { content, wt } \% \\
\mathrm{U} \text { isotopic composition, }{ }^{d} \text { wt } \%\end{array}$ & 6.0 \\
\hline${ }^{234} \mathrm{U}$ & $0.04(0.02)^{e}$ \\
\hline${ }^{235} \mathrm{U}$ & $4.11(2.63)$ \\
\hline${ }^{238} \mathrm{U}$ & $95.85(97.35)$ \\
\hline \multicolumn{2}{|l|}{ Moderator data } \\
\hline Density, $\mathrm{g} / \mathrm{cm}^{3}$ & See Table 77 \\
\hline Temperature, $\mathrm{K}$ & See Table 77 \\
\hline Soluble boron, ppm & See Table 79 \\
\hline Inlet temperature, $\mathrm{K}$ & 557 \\
\hline Outlet temperature, $\mathrm{K}$ & 594 \\
\hline \multicolumn{2}{|l|}{ Guide tube data ${ }^{f}$} \\
\hline Guide tube material & Zircaloy-4 \\
\hline Inner radius, $\mathrm{cm}$ & 0.5715 \\
\hline Outer radius, $\mathrm{cm}$ & 0.6121 \\
\hline
\end{tabular}

${ }^{a}$ Ref. 57. ${ }^{b}$ Given as an approximate value in Ref. $43 .{ }^{c}$ Values were assumed in Ref. 42.

${ }^{d}$ At beginning of life. Values in parentheses correspond to gadolinia-bearing fuel rods.

${ }^{e}$ Values assumed in Ref. 90.

${ }^{f}$ Guide tube data unavailable. Dimensions for a Westinghouse $17 \times 17$ assembly were assumed, similarly to Ref. 90 .

Source: Ref. 41 unless otherwise noted. 
Table 77. Burnup, power, sample location, and moderator data for Takahama-3 samples

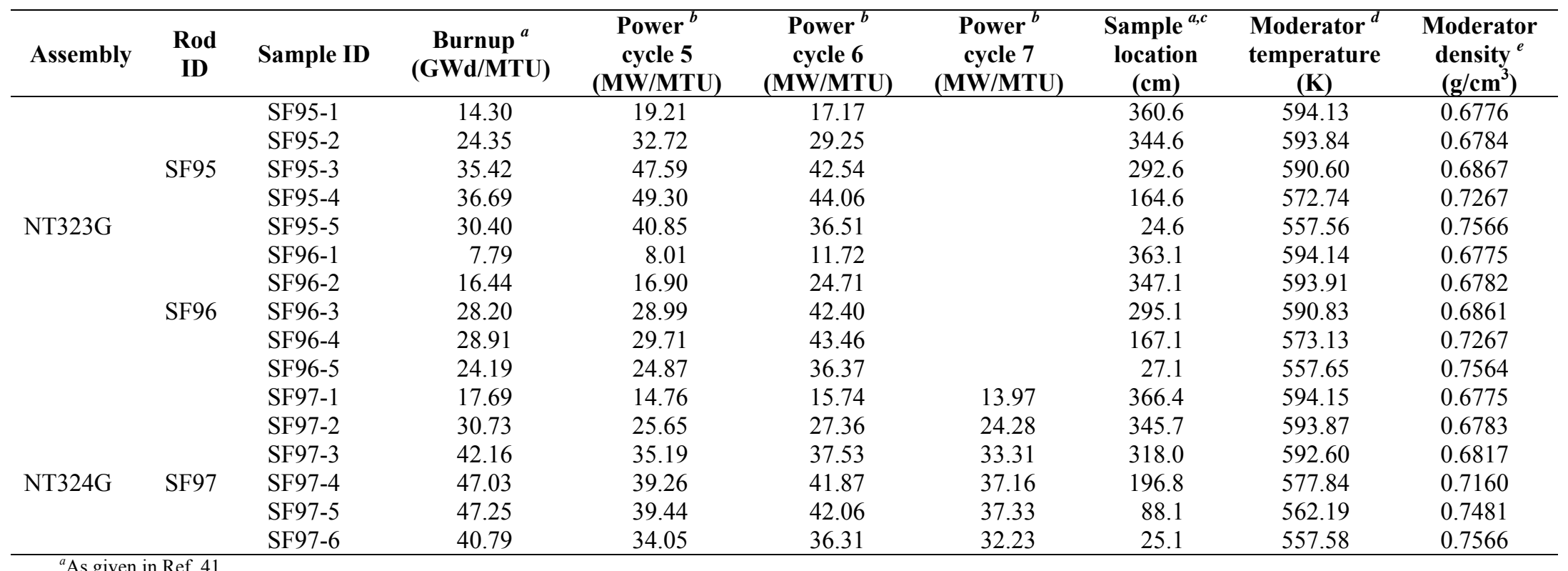

\footnotetext{
As given in Ref. 41.
}

${ }^{b}$ Cycle-averaged power calculated based on data provided in Ref. 41 . Cycle-averaged values were used because the time dependent specific power values were very similar. Distance measured from bottom of fuel.

"Calculated based on sample location, moderator inlet and outlet temperatures, and operating pressure, as expressed by Eq. (1) in Sect. 5.2.

${ }^{\mathrm{e}}$ Calculated by linear interpolation in temperature vs. pressure tabulated data. Note that use of spreadsheets for processing input parameters and unit conversions for input specifications lead to some roundoff error in last significant digit. 
Table 78. Operation history data for Takahama-3 spent fuel samples

\begin{tabular}{ccccc}
\hline $\begin{array}{c}\text { Cycle } \\
\text { No. }\end{array}$ & $\begin{array}{c}\text { Start } \\
\text { date }\end{array}$ & $\begin{array}{c}\text { End } \\
\text { date }\end{array}$ & $\begin{array}{c}\text { Duration } \\
\text { (days) }\end{array}$ & $\begin{array}{c}\text { Down } \\
\text { (days) }\end{array}$ \\
\hline 5 & $1990 / 01 / 26$ & $1991 / 02 / 15$ & 385 & 88 \\
6 & $1991 / 05 / 14$ & $1992 / 06 / 19$ & 402 & 62 \\
7 & $1992 / 08 / 20$ & $1993 / 09 / 30$ & 406 & \\
\hline Source: Ref. 41. & & &
\end{tabular}

Table 79. Soluble boron concentration in moderator for Takahama-3 spent fuel samples

\begin{tabular}{ccc}
\hline Cycle No. & $\begin{array}{c}\text { Cumulative } \\
\text { time }^{\boldsymbol{a}} \\
\text { (days) }^{\text {day }}\end{array}$ & $\begin{array}{c}\text { Boron content } \\
\text { (ppm) }\end{array}$ \\
\hline & 0 & 1154 \\
5 & 106 & 894 \\
& 205 & 651 \\
& 306 & 404 \\
& 385 & 210 \\
6 & 473 & 1132 \\
& 592 & 864 \\
& 704 & 613 \\
& 817 & 358 \\
& 875 & 228 \\
& 937 & 1154 \\
7 & 996 & 1001 \\
& 1048 & 867 \\
& 1100 & 732 \\
& 1152 & 598 \\
& 1204 & 463 \\
& 1256 & 329 \\
& 1308 & 195 \\
& 1342 & 104 \\
\hline
\end{tabular}

${ }^{a}$ Measured from beginning of cycle 5 .

Source: Ref. 43. 
Table 80. Sample burnup for Takahama-3

spent fuel samples

\begin{tabular}{ccc}
\hline Sample ID & $\begin{array}{c}\text { Reported }^{\boldsymbol{a}} \\
\text { sample burnup } \\
\text { (GWd/MTU) }\end{array}$ & $\begin{array}{c}\text { Actual }^{\boldsymbol{b}} \\
\text { sample burnup } \\
\text { (GWd/MTU) }\end{array}$ \\
\hline SF95-1 & 14.30 & 14.18 \\
SF95-2 & 24.35 & 24.46 \\
SF95-3 & 35.42 & 35.68 \\
SF95-4 & 36.69 & 37.01 \\
SF95-5 & 30.40 & 30.45 \\
SF96-1 & 7.79 & 8.63 \\
SF96-2 & 16.44 & 17.43 \\
SF96-3 & 28.20 & 29.69 \\
SF96-4 & 28.91 & 30.41 \\
SF96-5 & 24.19 & 25.42 \\
SF97-1 & 17.69 & 17.39 \\
SF97-2 & 30.73 & 30.48 \\
SF97-3 & 42.16 & 42.10 \\
SF97-4 & 47.03 & 47.07 \\
SF97-5 & 47.25 & 47.26 \\
SF97-6 & 40.79 & 40.85 \\
\hline${ }^{a}$ As given in Ref. 41. \\
${ }^{b}$ Calculated to correspond to the measured ${ }^{148}$ Nd.
\end{tabular}

\subsection{TMI UNIT 1}

The samples considered were selected from two different fuel assemblies, identified as NJ05YU and NJ070G, irradiated in the TMI-1 reactor. Details related to the geometry, material composition, and irradiation history were taken from Refs. 46 and 47. Both assemblies are a $15 \times 15$ design, with 208 fuel rods, 16 guide tubes, and one instrument tube, as illustrated in Fig. 16 and Fig. 17.

The fuel assembly geometry and material information for the two assemblies are presented in Table 81 . Assembly NJ05YU was irradiated in the reactor for two consecutive cycles, cycle 9 and cycle 10. It contained 16 burnable poison rods with $\mathrm{Al}_{2} \mathrm{O}_{3}-\mathrm{B}_{4} \mathrm{C}$ absorber, which were removed at the end of cycle 9 . All the fuel rods in this assembly had an initial fuel enrichment of $4.013 \mathrm{wt} \%{ }^{235} \mathrm{U}$. Assembly NJ070G was present in the reactor during cycles 10 and 11. At the end of cycle 10, some of the fuel rods, were removed and replaced with stainless steel rods. However, this rod replacement is of no consequence to the analysis in this report, as the fuel rods that were measured were present in the assembly during cycle 10 only. Assembly NJ070G contained 16 BPRs during cycle 10. Four of its fuel rods had $2.0 \mathrm{wt} \% \mathrm{Gd}_{2} \mathrm{O}_{3}$ poison, and their initial fuel enrichment was $4.19 \mathrm{wt} \%{ }^{235} \mathrm{U}$. The other 204 regular fuel rods in assembly NJ070G had an initial enrichment of $4.657 \mathrm{wt} \%{ }^{235} \mathrm{U}$. Guide and instrument tube data and the locations of the $\mathrm{Gd}_{2} \mathrm{O}_{3}$ poison rods in the assembly were used as given in Ref. 46 .

Eleven of the 19 TMI-1 samples, those measured at ANL, were selected from a fuel rod identified as H6, located in assembly NJ05YU. The other eight TMI-1 samples, analyzed at GE-VNC, were selected from the rods identified as $\mathrm{O} 1, \mathrm{O} 12$, and $\mathrm{O} 13$, located in assembly NJ070G. The location of the measured fuel rods in the assembly is illustrated in Fig. 16 and Fig. 17. Note that all three measured fuel rods from assembly NJ070G were located at the edge of the assembly; the rod identified as O1 was located at the corner of the assembly. As noted in Section 7.7, the measured fuel rods experienced crud-induced localized corrosion. 


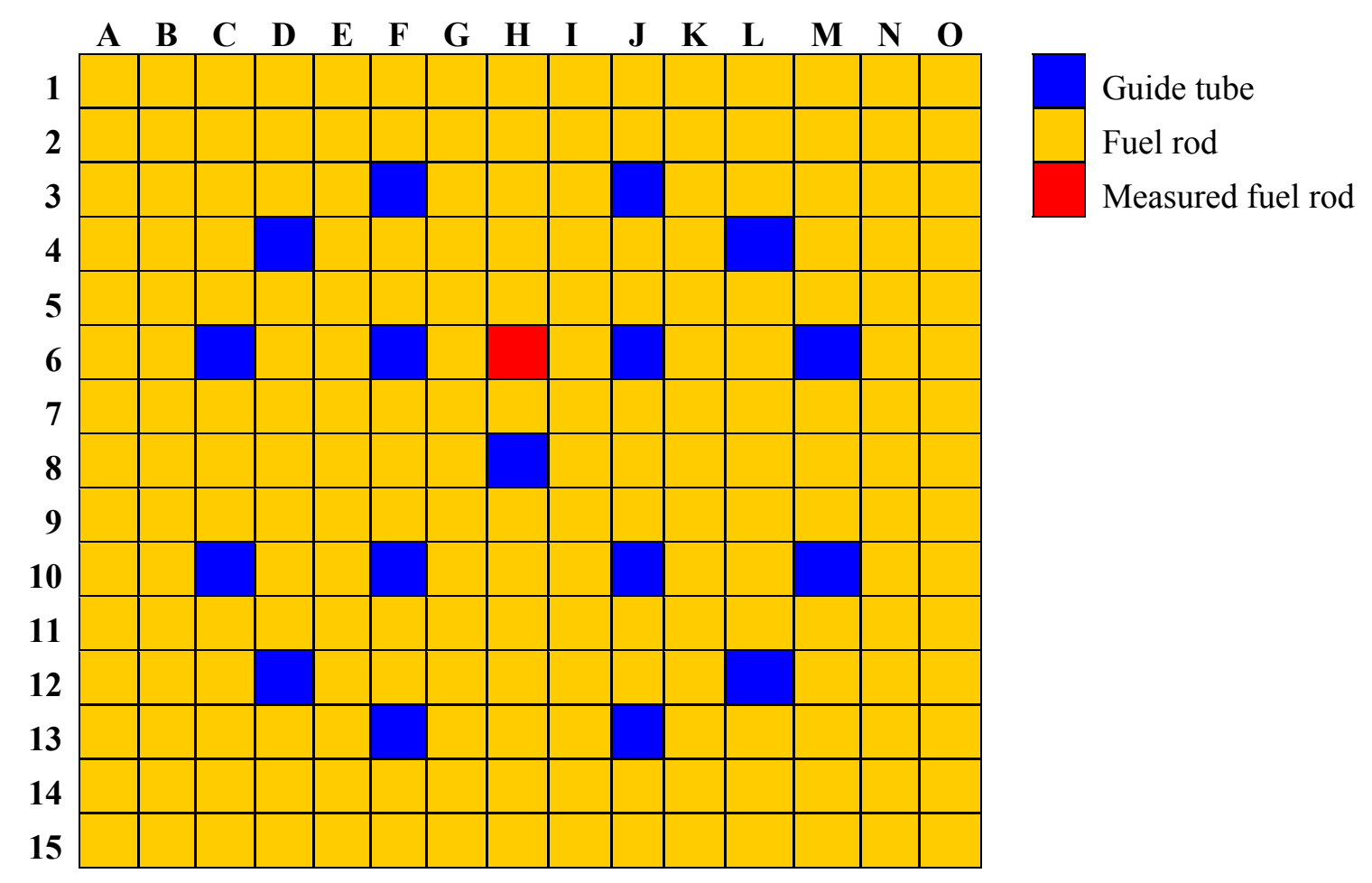

Fig. 16. Assembly layout for TMI-1 samples-NJ05YU.

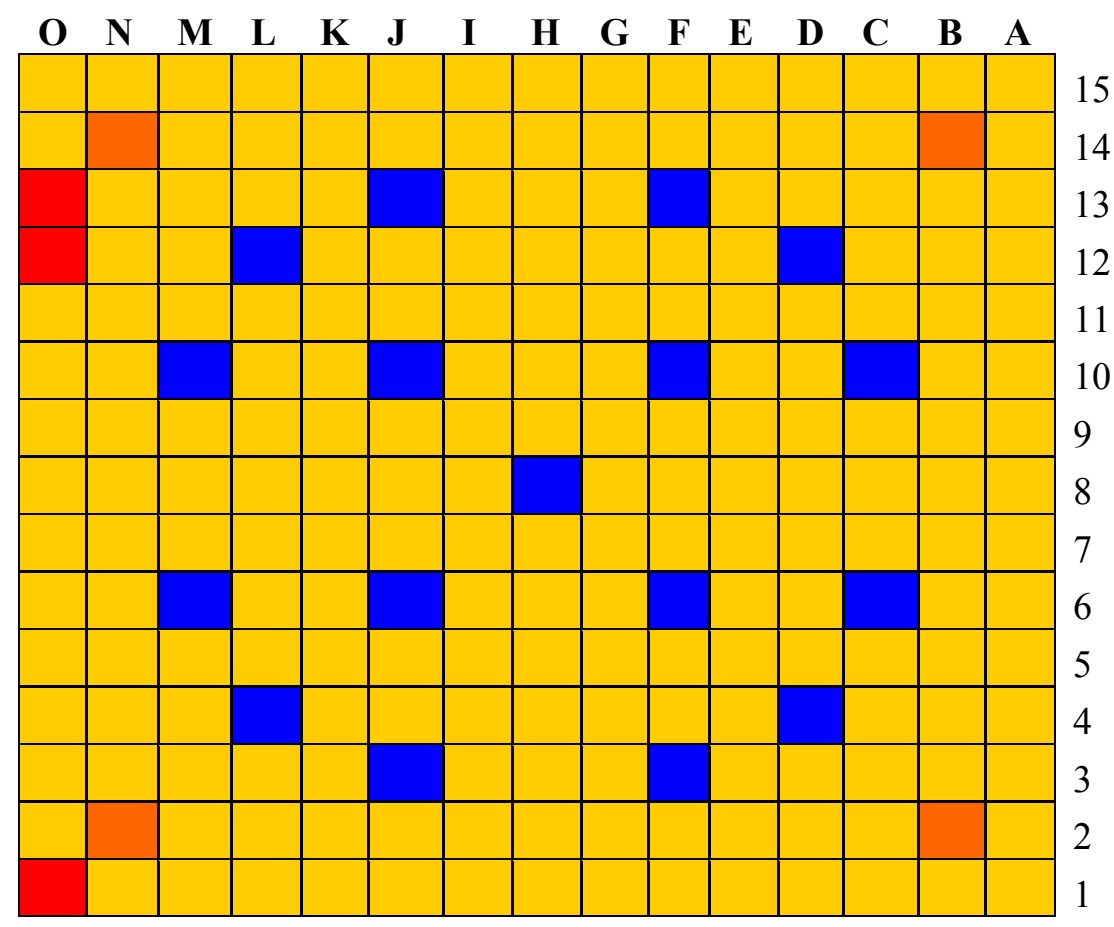

Fig. 17. Assembly layout for TMI-1 samples-NJ070G. (Note: The characteristics of the assemblies adjoining the measured fuel rods are provided in Fig. 18 and Table 89.) 
Table 81. Assembly design data for TMI-1 samples

\begin{tabular}{|c|c|c|}
\hline Parameter & $\begin{array}{c}\text { Data for assembly } \\
\text { NJ05YU }\end{array}$ & $\begin{array}{c}\text { Data for assembly } \\
\text { NJ070G }\end{array}$ \\
\hline \multicolumn{3}{|l|}{ Assembly and reactor data } \\
\hline Reactor & TMI-1 & TMI-1 \\
\hline Design & B\&W PWR & B\&W PWR \\
\hline Lattice geometry & $15 \times 15$ & $15 \times 15$ \\
\hline Rod pitch, cm & 1.44272 & 1.44272 \\
\hline Number of fuel rods & 208 & 208 \\
\hline Number of guide tubes & 16 & 16 \\
\hline Number of instrument tubes & 1 & 1 \\
\hline Assembly pitch, cm & 21.81098 & 21.81098 \\
\hline \multicolumn{3}{|l|}{ Fuel rod data } \\
\hline Fuel material type & $\mathrm{UO}_{2}$ & $\mathrm{UO}_{2}$ \\
\hline Fuel pellet density, $\mathrm{g} / \mathrm{cm}^{3}$ & 10.196 & 10.217 \\
\hline Fuel pellet diameter, $\mathrm{cm}$ & 0.9362 & 0.9398 \\
\hline Fuel temperature, $\mathrm{K}$ & See Table 84 & See Table 87 \\
\hline Enrichment, wt $\%{ }^{235} \mathrm{U}$ & 4.013 & 4.657 \\
\hline Clad material & Zircaloy-4 & Zircaloy-4 \\
\hline Clad inner diameter, $\mathrm{cm}$ & 0.95758 & 0.95758 \\
\hline Clad outer diameter, $\mathrm{cm}$ & 1.0922 & 1.0922 \\
\hline Clad temperature, ${ }^{a} \mathrm{~K}$ & 619 & 619 \\
\hline Number of rods with $\mathrm{Gd}_{2} \mathrm{O}_{3}$ & 0 & 4 \\
\hline $\mathrm{Gd}_{2} \mathrm{O}_{3}$ content, wt $\%$ & NA & 2.0 \\
\hline \multicolumn{3}{|l|}{ Initial fuel composition, wt $\%$} \\
\hline${ }^{234} \mathrm{U}$ & 0.040 & $0.045(0.0)^{b}$ \\
\hline${ }^{235} \mathrm{U}$ & 4.013 & $4.657(4.19)^{b}$ \\
\hline${ }^{238} \mathrm{U}$ & 95.947 & $95.298(95.981)^{b}$ \\
\hline \multicolumn{3}{|l|}{ Moderator data } \\
\hline Moderator density at sample location, $\mathrm{g} / \mathrm{cm}^{3}$ & See Table 82 and Table 85 & See Table 82 and Table 88 \\
\hline Soluble boron in moderator, ppm & See Table 84 & See Table 87 \\
\hline \multicolumn{3}{|l|}{ Burnable poison rod (BPR) data } \\
\hline Absorber diameter, $\mathrm{cm}$ & 0.8636 & 0.8636 \\
\hline Clad inner diameter, $\mathrm{cm}$ & 0.9144 & 0.9144 \\
\hline Clad outer diameter, $\mathrm{cm}$ & 1.0922 & 1.0922 \\
\hline Absorber material & $\mathrm{Al}_{2} \mathrm{O}_{3}-\mathrm{B}_{4} \mathrm{C}$ & $\mathrm{Al}_{2} \mathrm{O}_{3}-\mathrm{B}_{4} \mathrm{C}$ \\
\hline Absorber material density, $\mathrm{g} / \mathrm{cm}^{3}$ & 3.7 & 3.7 \\
\hline $\mathrm{B}_{4} \mathrm{C}$ content, wt $\%$ & 1.7 & 2.1 \\
\hline Cladding material & Zircaloy-4 & Zircaloy-4 \\
\hline \multicolumn{3}{|l|}{ Guide/instrument tube data ${ }^{c}$} \\
\hline Guide/instrument tube material & Zircaloy-4 & Zircaloy-4 \\
\hline Guide tube inner diameter, $\mathrm{cm}$ & 1.26492 & 1.26492 \\
\hline Guide tube outer diameter, $\mathrm{cm}$ & 1.3462 & 1.3462 \\
\hline Instrument tube inner diameter, $\mathrm{cm}$ & 1.12014 & 1.12014 \\
\hline Instrument tube outer diameter, $\mathrm{cm}$ & 1.25222 & 1.25222 \\
\hline
\end{tabular}


Two sets of burnup values were specified in Ref. 47 for each sample: cumulative burnup based on operational data at 20 and 10 statepoints for the samples from assembly NJ05YU and for the samples from assembly NJ070G, respectively, which include the end of cycle (EOC) for cycles 9 and 10, and the total measured burnup determined from radiochemical isotopic measurements corresponding to EOC-10. The effective full power days (EFPD) for cycle 9 and 10 are 639.4 days and 660.3 days, respectively. The down time between cycles 9 and 10 was 35 days (Ref. 46). The sample EOC burnup values from reactor operational data and the reported measured sample burnup values are presented in Table 82 . The sample burnup values at the various statepoints are provided in Table 83 and Table 86 for the samples from assemblies NJ05YU and for the samples from assemblies NJ070G, respectively. Sample specific average power for each irradiation interval, $\mathrm{P}_{\mathrm{i}}$, was determined as follows:

$$
P_{i}=\frac{\left(B_{i}-B_{i-1}\right)}{\left(t_{i}-t_{i-1}\right)} \times \frac{B_{\text {meas }}}{B_{10}}, i=1, \ldots, 20 \text { for } N J 05 Y U \text { samples and } i=1, \ldots, 10 \text { for NJ070G samples }
$$

where $B_{i}$ and $B_{i-1}$ are the sample burnup values for the two consecutive statepoints defining the irradiation interval $i, B_{\text {meas }}$ and $B_{10}$ are the sample measured burnup and the sample burnup based on operational data at EOC-10, respectively, and $t_{i}-t_{i-1}$ is the time interval between the two consecutive statepoints.

Moderator density values obtained at the sample axial position and at the beginning of cycle (BOC) 9 for the samples in assembly NJ05YU and at BOC 10 for the samples from assembly NJ070G are tabulated in Table 82. Moderator density variation with time for the samples from assemblies NJ05YU and NJ070G are shown in Table 85 and Table 88, respectively. The values in those two tables are multiplication factors to be applied to the moderator density values tabulated in Table 82 in order to obtain the moderator density averaged over a time interval between two consecutive statepoints.

The variations with time of the soluble boron concentration in moderator and of the fuel temperature for assemblies NJ05YU and NJ070G are shown in Table 84 and Table 87, respectively.

Data available $^{46}$ on the assemblies surrounding assembly NJ070G are illustrated in Fig. 18 and presented in Table 89. As the samples from this assembly are expected to be subjected to edge effects given their location at the periphery of the assembly, this information may be important for modeling purposes. The measured fuel rods were located at the west edge of assembly NJ070G that neighbored an assembly from batch $12 \mathrm{~A}$ with an initial fuel enrichment of $4 \mathrm{wt} \%{ }^{235} \mathrm{U}$. Assemblies in batch 12 were first irradiated in the core during cycle 10. Assemblies in batch 11 were present in the core since cycle 9. 
Table 82. Burnup and starting moderator density data for TMI-1 samples

\begin{tabular}{|c|c|c|c|c|c|c|}
\hline $\begin{array}{l}\text { Assembly } \\
\text { ID }\end{array}$ & $\begin{array}{c}\text { Rod } \\
\text { ID }\end{array}$ & Sample ID & $\begin{array}{c}\text { Burnup }^{a} \\
\text { EOC-9 } \\
\text { (GWd/MTU) }\end{array}$ & $\begin{array}{c}\text { Burnup }^{a} \\
\text { EOC-10 } \\
\text { (GWd/MTU) }\end{array}$ & $\begin{array}{c}\text { Measured }^{b} \\
\text { burnup } \\
\text { (GWd/MTU) }\end{array}$ & $\begin{array}{c}\text { Moderator } \\
\text { density }^{c} \\
\left(\mathrm{~g} / \mathrm{cm}^{3}\right)\end{array}$ \\
\hline \multirow{10}{*}{ NJ05YU } & \multirow{10}{*}{ H6 } & A2 & 28.338 & 51.861 & 50.6 & 0.7314 \\
\hline & & $\mathrm{B} 2$ & 28.444 & 52.089 & 50.1 & 0.7248 \\
\hline & & $\mathrm{C} 1$ & 28.132 & 51.545 & 50.2 & 0.6965 \\
\hline & & C3 & 28.230 & 51.696 & 51.3 & 0.7151 \\
\hline & & D2 & 26.366 & 48.569 & 44.8 & 0.6787 \\
\hline & & A1B & 24.767 & 45.687 & 44.8 & 0.7382 \\
\hline & & B1B & 28.230 & 51.696 & 54.5 & 0.7151 \\
\hline & & B3J & 28.338 & 51.861 & 53.0 & 0.7314 \\
\hline & & $\mathrm{C} 2 \mathrm{~B}$ & 28.155 & 51.563 & 52.6 & 0.7057 \\
\hline & & D1A2 & 28.115 & 51.530 & 55.7 & 0.6934 \\
\hline \multirow{9}{*}{ NJ070G } & \multirow{4}{*}{$\mathrm{O} 1$} & D1A4 & 28.034 & 50.810 & 50.5 & 0.6875 \\
\hline & & O1 S1 & & 27.498 & 25.8 & 0.7382 \\
\hline & & $\mathrm{O} 1 \mathrm{~S} 2$ & & 31.377 & 29.9 & 0.7057 \\
\hline & & $\mathrm{O} 1 \mathrm{~S} 3$ & & 30.848 & 26.7 & 0.6875 \\
\hline & \multirow{4}{*}{$\mathrm{O} 12$} & O12 S4 & & 25.592 & 23.7 & 0.7382 \\
\hline & & O12 S5 & & 29.271 & 26.5 & 0.7057 \\
\hline & & O12 S6 & & 28.760 & 24.0 & 0.6875 \\
\hline & & O13 S7 & & 25.331 & 22.8 & 0.7382 \\
\hline & $\mathrm{O} 13$ & O13 S8 & & 29.020 & 26.3 & 0.7057 \\
\hline
\end{tabular}

${ }^{a}$ End of cycle (EOC) burnup values derived in Ref. 47 from the detailed fuel assembly operating history in Appendix A of Ref. 46. ${ }^{b}$ Refs. 44 and 45 .

${ }^{c}$ Moderator densities in $\mathrm{ft}^{3} / \mathrm{lbm}$ are provided in Ref. 46 at the beginning of cycle (BOC) 9 for the samples from assembly NJ05YU and at BOC 10 for the samples from assembly NJ070G. The calculations documented in Ref. 47 performed conversion to $\mathrm{g} / \mathrm{cm}^{3}$ units. Source: Ref. 47 unless otherwise noted. 
Table 83. Burnup as a function of time for TMI-1 samples from assembly NJ05YU

\begin{tabular}{|c|c|c|c|c|c|c|c|c|c|c|c|c|}
\hline \multirow{2}{*}{$\begin{array}{l}\text { Cycle } \\
\text { No. }\end{array}$} & \multirow{2}{*}{$\begin{array}{c}\text { Sample } \\
\text { ID } \\
\text { Time } \\
\text { (days) }\end{array}$} & A2 & B2 & C1 & C3 & D2 & A1B & B1B & B3J & C2B & D1A2 & D1A4 \\
\hline & & \multicolumn{11}{|c|}{$\begin{array}{c}\text { Burnup } \\
\text { (GWd/MTU) }\end{array}$} \\
\hline \multirow{11}{*}{9} & 0.0 & & & & & & & & & & & \\
\hline & 74.2 & 3.184 & 3.456 & 3.543 & 3.551 & 2.839 & 2.450 & 3.551 & 3.184 & 3.588 & 3.476 & 3.365 \\
\hline & 141.1 & 6.269 & 6.701 & 6.805 & 6.819 & 5.639 & 4.907 & 6.819 & 6.269 & 6.866 & 6.709 & 6.540 \\
\hline & 214.0 & 9.446 & 9.953 & 10.004 & 10.045 & 8.474 & 7.521 & 10.045 & 9.446 & 10.077 & 9.892 & 9.687 \\
\hline & 283.9 & 12.660 & 13.178 & 13.142 & 13.213 & 11.359 & 10.245 & 13.213 & 12.660 & 13.218 & 13.030 & 12.813 \\
\hline & 349.7 & 15.690 & 16.158 & 16.021 & 16.119 & 14.123 & 12.900 & 16.119 & 15.690 & 16.092 & 15.922 & 15.715 \\
\hline & 425.0 & 19.139 & 19.505 & 19.237 & 19.370 & 17.275 & 16.023 & 19.370 & 19.139 & 19.305 & 19.155 & 18.971 \\
\hline & 483.9 & 21.785 & 22.055 & 21.703 & 21.854 & 19.756 & 18.484 & 21.854 & 21.785 & 21.764 & 21.639 & 21.483 \\
\hline & 549.2 & 24.662 & 24.819 & 24.376 & 24.550 & 22.490 & 21.227 & 24.550 & 24.662 & 24.433 & 24.331 & 24.208 \\
\hline & 608.0 & 27.148 & 27.240 & 26.788 & 26.966 & 24.933 & 23.628 & 26.966 & 27.148 & 26.846 & 26.750 & 26.645 \\
\hline & 639.4 & 28.338 & 28.444 & 28.132 & 28.230 & 26.366 & 24.767 & 28.230 & 28.338 & 28.155 & 28.115 & 28.034 \\
\hline \multirow{11}{*}{10} & 0.0 & & & & & & & & & & & \\
\hline & 68.0 & 30.741 & 31.040 & 30.743 & 30.883 & 28.260 & 26.617 & 30.883 & 30.741 & 30.817 & 30.667 & 29.947 \\
\hline & 131.8 & 32.991 & 33.423 & 33.131 & 33.294 & 30.302 & 28.445 & 33.294 & 32.991 & 33.232 & 33.022 & 32.156 \\
\hline & 209.0 & 35.730 & 36.253 & 35.944 & 36.121 & 32.841 & 30.742 & 36.121 & 35.730 & 36.053 & 35.820 & 34.852 \\
\hline & 272.1 & 37.994 & 38.541 & 38.205 & 38.384 & 34.970 & 32.698 & 38.384 & 37.994 & 38.309 & 38.084 & 37.080 \\
\hline & 347.4 & 40.714 & 41.249 & 40.867 & 41.047 & 37.561 & 35.112 & 41.047 & 40.714 & 40.958 & 40.759 & 39.756 \\
\hline & 416.4 & 43.209 & 43.701 & 43.276 & 43.451 & 39.971 & 37.386 & 43.451 & 43.209 & 43.350 & 43.186 & 42.215 \\
\hline & 486.4 & 45.728 & 46.153 & 45.689 & 45.856 & 42.435 & 39.740 & 45.856 & 45.728 & 45.744 & 45.621 & 44.706 \\
\hline & 556.3 & 48.220 & 48.568 & 48.065 & 48.227 & 44.900 & 42.123 & 48.227 & 48.220 & 48.104 & 48.020 & 47.174 \\
\hline & 626.1 & 50.674 & 50.941 & 50.407 & 50.563 & 47.363 & 44.515 & 50.563 & 50.674 & 50.432 & 50.383 & 49.620 \\
\hline & 660.3 & 51.861 & 52.089 & 51.545 & 51.696 & 48.569 & 45.687 & 51.696 & 51.861 & 51.563 & 51.530 & 50.810 \\
\hline
\end{tabular}

Source: Ref. 47. 
Table 84. Fuel temperature and concentration of soluble boron in moderator for TMI-1 samples from assembly NJ05YU

\begin{tabular}{|c|c|c|c|c|c|c|c|c|c|c|c|c|c|}
\hline \multirow{2}{*}{$\begin{array}{l}\text { Cycle } \\
\text { No. }\end{array}$} & \multirow{2}{*}{$\begin{array}{c}\text { Sample } \\
\text { ID } \\
\text { Time } \\
\text { (days) }\end{array}$} & A2 & B2 & C1 & C3 & D2 & A1B & B1B & B3J & C2B & D1A2 & D1A4 & \multirow{2}{*}{$\begin{array}{l}\text { Boron } \\
(\mathrm{ppm})\end{array}$} \\
\hline & & \multicolumn{11}{|c|}{$\begin{array}{c}\text { Temperature }^{a} \\
\text { (K) }\end{array}$} & \\
\hline \multirow{11}{*}{9} & 0.0 & & & & & & & & & & & & 1670 \\
\hline & 74.2 & 1051.15 & 1085.37 & 1105.65 & 1098.34 & 1029.01 & 948.65 & 1098.34 & 1051.15 & 1106.12 & 1100.73 & 1091.18 & 1481 \\
\hline & 141.1 & 1040.93 & 1058.79 & 1069.12 & 1062.90 & 1025.21 & 957.48 & 1062.90 & 1040.39 & 1066.84 & 1068.40 & 1065.04 & 1342 \\
\hline & 214.0 & 1023.32 & 1030.34 & 1034.43 & 1029.37 & 1009.34 & 959.34 & 1029.37 & 1023.32 & 1031.18 & 1035.79 & 1035.82 & 1175 \\
\hline & 283.9 & 1002.04 & 1001.96 & 1003.15 & 998.18 & 995.65 & 953.48 & 998.18 & 1002.04 & 998.93 & 1006.15 & 1008.98 & 990 \\
\hline & 349.7 & 982.09 & 976.62 & 976.01 & 971.18 & 982.57 & 947.65 & 971.18 & 982.09 & 971.23 & 980.18 & 985.07 & 772 \\
\hline & 425.0 & 959.40 & 950.04 & 948.93 & 944.23 & 963.71 & 940.48 & 944.23 & 959.40 & 944.23 & 963.43 & 959.34 & 545 \\
\hline & 483.9 & 936.51 & 925.90 & 925.46 & 920.59 & 945.73 & 927.57 & 920.59 & 936.51 & 920.98 & 929.87 & 936.23 & 352 \\
\hline & 549.2 & 918.46 & 907.79 & 907.79 & 903.40 & 929.26 & 913.93 & 903.40 & 918.46 & 904.04 & 911.73 & 917.79 & 134 \\
\hline & 608.0 & 888.21 & 884.01 & 900.23 & 889.62 & 924.34 & 886.48 & 889.62 & 888.21 & 895.07 & 904.15 & 909.82 & 13 \\
\hline & 639.4 & 772.90 & 777.37 & 810.43 & 790.98 & 837.01 & 771.65 & 790.98 & 772.90 & 801.65 & 815.26 & 821.01 & 2 \\
\hline \multirow{11}{*}{10} & 0.0 & & & & & & & & & & & & 1800 \\
\hline & 68.0 & 835.54 & 861.01 & 871.01 & 871.32 & 825.07 & 787.87 & 871.32 & 835.54 & 874.84 & 865.43 & 843.34 & 1649 \\
\hline & 131.8 & 828.59 & 846.96 & 856.62 & 853.46 & 825.54 & 785.79 & 853.46 & 828.59 & 856.84 & 854.23 & 840.48 & 1521 \\
\hline & 209.0 & 824.51 & 835.65 & 844.68 & 838.76 & 829.98 & 786.23 & 838.76 & 824.51 & 841.84 & 845.32 & 840.87 & 1322 \\
\hline & 272.1 & 823.76 & 828.87 & 835.79 & 829.29 & 831.73 & 791.43 & 829.29 & 823.76 & 831.71 & 838.01 & 838.93 & 1140 \\
\hline & 347.4 & 822.12 & 823.12 & 828.46 & 822.09 & 832.12 & 796.54 & 822.09 & 822.12 & 823.98 & 831.46 & 836.07 & 918 \\
\hline & 416.4 & 818.71 & 816.71 & 821.65 & 815.18 & 831.46 & 799.84 & 815.18 & 818.71 & 816.96 & 825.09 & 832.48 & 718 \\
\hline & 486.4 & 813.82 & 809.93 & 815.29 & 808.54 & 829.93 & 801.23 & 808.54 & 813.82 & 810.51 & 818.96 & 828.43 & 506 \\
\hline & 556.3 & 807.62 & 802.59 & 808.43 & 801.59 & 827.37 & 800.98 & 801.59 & 807.62 & 803.76 & 812.15 & 823.34 & 298 \\
\hline & 626.1 & 801.96 & 796.93 & 802.65 & 796.15 & 823.76 & 799.18 & 796.15 & 801.96 & 798.34 & 806.21 & 817.73 & 103 \\
\hline & 660.3 & 799.90 & 795.18 & 799.87 & 794.37 & 819.26 & 797.96 & 794.37 & 799.90 & 796.26 & 803.01 & 813.51 & 1.8 \\
\hline
\end{tabular}

${ }^{a}$ Fuel temperature values averaged over the time intervals between two consecutive statepoints.

Source: Ref. 46. 
Table 85. Moderator density multiplication factors for TMI-1 samples from assembly NJ05YU

\begin{tabular}{|c|c|c|c|c|c|c|c|c|c|c|c|c|}
\hline $\begin{array}{c}\text { Cycle } \\
\text { No. }\end{array}$ & $\begin{array}{c}\text { Sample } \\
\text { ID } \\
\text { Time } \\
\text { (days) } \\
\end{array}$ & $\mathbf{A 2}$ & B2 & C1 & $\mathrm{C3}$ & ator der & y multipl & ion factor & B3J & C2B & D1A2 & D1A4 \\
\hline \multirow{11}{*}{9} & 0.0 & & & & & & & & & & & \\
\hline & 74.2 & 1.0000 & 0.9995 & 1.0000 & 1.0000 & 1.0000 & 1.0000 & 1.0000 & 1.0000 & 1.0000 & 1.0000 & 1.0000 \\
\hline & 141.1 & 1.0000 & 0.9995 & 1.0000 & 1.0000 & 1.0000 & 1.0000 & 1.0000 & 1.0000 & 1.0000 & 0.9957 & 1.0000 \\
\hline & 214.0 & 0.9955 & 0.9995 & 1.0000 & 0.9956 & 1.0000 & 1.0000 & 0.9956 & 0.9955 & 1.0000 & 0.9957 & 1.0000 \\
\hline & 283.9 & 0.9955 & 0.9995 & 1.0000 & 0.9956 & 1.0000 & 1.0000 & 0.9956 & 0.9955 & 1.0000 & 0.9957 & 1.0000 \\
\hline & 349.7 & 0.9955 & 0.9995 & 1.0000 & 0.9956 & 1.0000 & 1.0000 & 0.9956 & 0.9955 & 1.0000 & 1.0000 & 1.0000 \\
\hline & 425.0 & 0.9955 & 0.9995 & 1.0000 & 0.9956 & 1.0000 & 1.0000 & 0.9956 & 0.9955 & 1.0000 & 1.0000 & 1.0000 \\
\hline & 483.9 & 0.9955 & 0.9995 & 1.0000 & 0.9956 & 1.0043 & 1.0000 & 0.9956 & 0.9955 & 1.0000 & 1.0000 & 1.0043 \\
\hline & 549.2 & 0.9955 & 0.9995 & 1.0044 & 1.0000 & 1.0043 & 1.0000 & 1.0000 & 0.9955 & 1.0000 & 1.0000 & 1.0043 \\
\hline & 608.0 & 1.0046 & 1.0045 & 1.0132 & 1.0090 & 1.0172 & 1.0046 & 1.0090 & 1.0046 & 1.0134 & 1.0132 & 1.0130 \\
\hline & 639.4 & 0.9910 & 0.9995 & 1.0222 & 1.0045 & 1.0351 & 0.9864 & 1.0045 & 0.9910 & 1.0134 & 1.0221 & 1.0310 \\
\hline \multirow{11}{*}{10} & 0.0 & & & & & & & & & & & \\
\hline & 68.0 & 1.0000 & 1.0000 & 1.0088 & 1.0045 & 1.0172 & 1.0000 & 1.0045 & 1.0000 & 1.0089 & 1.0087 & 1.0087 \\
\hline & 131.8 & 1.0000 & 1.0000 & 1.0132 & 1.0045 & 1.0172 & 1.0000 & 1.0045 & 1.0000 & 1.0089 & 1.0132 & 1.0087 \\
\hline & 209.0 & 1.0000 & 1.0000 & 1.0132 & 1.0045 & 1.0172 & 1.0000 & 1.0045 & 1.0000 & 1.0089 & 1.0132 & 1.0087 \\
\hline & 272.1 & 1.0000 & 1.0000 & 1.0132 & 1.0045 & 1.0172 & 1.0000 & 1.0045 & 1.0000 & 1.0089 & 1.0132 & 1.0087 \\
\hline & 347.4 & 1.0000 & 1.0000 & 1.0132 & 1.0045 & 1.0172 & 1.0000 & 1.0045 & 1.0000 & 1.0089 & 1.0132 & 1.0087 \\
\hline & 416.4 & 1.0000 & 1.0000 & 1.0132 & 1.0045 & 1.0172 & 1.0000 & 1.0045 & 1.0000 & 1.0089 & 1.0132 & 1.0130 \\
\hline & 486.4 & 1.0000 & 1.0000 & 1.0132 & 1.0045 & 1.0172 & 1.0000 & 1.0045 & 1.0000 & 1.0089 & 1.0132 & 1.0130 \\
\hline & 556.3 & 1.0000 & 1.0000 & 1.0132 & 1.0045 & 1.0126 & 1.0000 & 1.0045 & 1.0000 & 1.0089 & 1.0132 & 1.0130 \\
\hline & 626.1 & 1.0000 & 1.0000 & 1.0132 & 1.0045 & 1.0126 & 1.0000 & 1.0045 & 1.0000 & 1.0089 & 1.0132 & 1.0130 \\
\hline & 660.3 & 1.0000 & 1.0000 & 1.0132 & 1.0045 & 1.0126 & 1.0000 & 1.0045 & 1.0000 & 1.0089 & 1.0132 & 1.0130 \\
\hline
\end{tabular}

${ }^{a}$ Average values for time intervals between two consecutive statepoints. The sample average moderator density for the time interval between two consecutive statepoints is the product of sample moderator density provided in Table 82 and the sample moderator density multiplication factor for that time interval.

Source: Ref. 47. 
Table 86. Burnup as a function of time for TMI-1 samples from assembly NJ070G

\begin{tabular}{|c|c|c|c|c|c|c|c|c|c|}
\hline \multirow{2}{*}{$\begin{array}{c}\text { Cycle } \\
\text { No. }\end{array}$} & \multirow{2}{*}{$\begin{array}{c}\text { Sample ID } \\
\text { time } \\
\text { (days) }\end{array}$} & 01S1 & O1S2 & O1S3 & O12S4 & O12S5 & O12S6 & O13S7 & O13S8 \\
\hline & & \multicolumn{8}{|c|}{ Burnup (GWd/MTU) } \\
\hline \multirow{10}{*}{10} & 68.0 & 2.488 & 3.676 & 3.312 & 2.384 & 3.532 & 3.184 & 2.323 & 3.455 \\
\hline & 131.8 & 4.955 & 7.107 & 6.485 & 4.693 & 6.718 & 6.143 & 4.586 & 6.604 \\
\hline & 209.0 & 8.108 & 11.106 & 10.328 & 7.583 & 10.368 & 9.659 & 7.443 & 10.234 \\
\hline & 272.1 & 10.769 & 14.205 & 13.397 & 10.004 & 13.201 & 12.462 & 9.849 & 13.053 \\
\hline & 347.4 & 13.976 & 17.742 & 16.954 & 12.937 & 16.453 & 15.729 & 12.764 & 16.288 \\
\hline & 416.4 & 16.936 & 20.865 & 20.127 & 15.663 & 19.350 & 18.666 & 15.472 & 19.164 \\
\hline & 486.4 & 19.951 & 23.950 & 23.274 & 18.468 & 22.234 & 21.603 & 18.257 & 22.028 \\
\hline & 556.3 & 22.982 & 26.970 & 26.355 & 21.311 & 25.081 & 24.499 & 21.079 & 24.856 \\
\hline & 626.1 & 26.015 & 29.938 & 29.382 & 24.179 & 27.898 & 27.365 & 23.927 & 27.655 \\
\hline & 660.3 & 27.498 & 31.377 & 30.848 & 25.592 & 29.271 & 28.760 & 25.331 & 29.020 \\
\hline
\end{tabular}

Table 87. Fuel temperature and concentration of soluble boron in moderator for TMI-1 samples from assembly NJ070G

\begin{tabular}{|c|c|c|c|c|c|c|c|c|c|c|}
\hline \multirow[b]{2}{*}{$\begin{array}{l}\text { Cycle } \\
\text { No. }\end{array}$} & \multirow{2}{*}{$\begin{array}{c}\text { Sample ID } \\
\text { Time } \\
\text { (days) }\end{array}$} & O1S1 & O1S2 & O1S3 & O12S4 & O12S5 & O12S6 & O13S7 & O13S8 & \multirow[b]{2}{*}{$\begin{array}{l}\text { Boron } \\
\text { (ppm) }\end{array}$} \\
\hline & & \multicolumn{8}{|c|}{$\begin{array}{c}\text { Temperature } \\
\text { (K) }\end{array}$} & \\
\hline \multirow{11}{*}{10} & 0.0 & & & & & & & & & 1800 \\
\hline & 68.0 & 960.29 & 1119.51 & 1083.65 & 960.29 & 1119.51 & 1083.65 & 960.29 & 1119.51 & 1649 \\
\hline & 131.8 & 960.71 & 1084.79 & 1067.32 & 960.71 & 1084.79 & 1067.32 & 960.71 & 1084.79 & 1521 \\
\hline & 209.0 & 958.68 & 1043.23 & 1043.46 & 958.68 & 1043.23 & 1043.46 & 958.68 & 1043.23 & 1322 \\
\hline & 272.1 & 954.18 & 1007.09 & 1016.43 & 954.18 & 1007.09 & 1016.43 & 954.18 & 1007.09 & 1140 \\
\hline & 347.4 & 946.12 & 978.57 & 991.65 & 946.12 & 978.57 & 991.65 & 946.12 & 978.57 & 918 \\
\hline & 416.4 & 937.15 & 951.57 & 967.21 & 937.15 & 951.57 & 967.21 & 937.15 & 951.57 & 718 \\
\hline & 486.4 & 926.04 & 929.82 & 945.98 & 926.04 & 929.82 & 945.98 & 926.04 & 929.82 & 506 \\
\hline & 556.3 & 914.37 & 912.15 & 928.04 & 914.37 & 912.15 & 928.04 & 914.37 & 912.15 & 298 \\
\hline & 626.1 & 904.09 & 896.84 & 912.12 & 904.09 & 896.84 & 912.12 & 904.09 & 896.84 & 103 \\
\hline & 660.3 & 897.82 & 886.54 & 899.73 & 897.82 & 886.54 & 899.73 & 897.82 & 886.54 & 1.8 \\
\hline
\end{tabular}

Table 88. Moderator density multiplication factors for TMI-1 samples from assembly NJ070G

\begin{tabular}{cccccccccc}
\hline \multirow{2}{*}{$\begin{array}{c}\text { Cycle } \\
\text { No. }\end{array}$} & $\begin{array}{c}\text { Sample ID } \\
\text { Time (days) }\end{array}$ & O1S1 & O1S2 & O1S3 & O12S4 & O12S5 & O12S6 & O13S7 & O13S8 \\
\cline { 5 - 9 } & & \multicolumn{7}{c}{ Moderator density $^{\text {multiplication factor }}{ }^{\boldsymbol{a}}$} \\
& 0.0 & & & & & & & \\
& 68.0 & 1.0000 & 0.9956 & 0.9957 & 1.0000 & 0.9956 & 0.9957 & 1.0000 & 0.9956 \\
& 131.8 & 1.0000 & 0.9956 & 0.9957 & 1.0000 & 0.9956 & 0.9957 & 1.0000 & 0.9956 \\
& 209.0 & 1.0000 & 0.9956 & 1.0000 & 1.0000 & 0.9956 & 1.0000 & 1.0000 & 0.9956 \\
& 272.1 & 1.0000 & 1.0000 & 1.0000 & 1.0000 & 1.0000 & 1.0000 & 1.0000 & 1.0000 \\
& 347.4 & 1.0000 & 1.0000 & 1.0000 & 1.0000 & 1.0000 & 1.0000 & 1.0000 & 1.0000 \\
& 416.4 & 1.0000 & 1.0000 & 1.0000 & 1.0000 & 1.0000 & 1.0000 & 1.0000 & 1.0000 \\
& 486.4 & 1.0000 & 1.0000 & 1.0000 & 1.0000 & 1.0000 & 1.0000 & 1.0000 & 1.0000 \\
& 556.3 & 1.0000 & 1.0000 & 1.0000 & 1.0000 & 1.0000 & 1.0000 & 1.0000 & 1.0000 \\
& 626.1 & 1.0000 & 1.0000 & 1.0043 & 1.0000 & 1.0000 & 1.0043 & 1.0000 & 1.0000 \\
& 660.3 & 1.0000 & 1.0000 & 1.0043 & 1.0000 & 1.0000 & 1.0043 & 1.0000 & 1.0000 \\
\hline
\end{tabular}

${ }^{a}$ Average values for time intervals between two consecutive statepoints. The sample average moderator density for the time interval between two consecutive statepoints is the product of sample moderator density provided in Table 82 and the sample moderator density multiplication factor for that time interval.

Source: Ref. 47. 


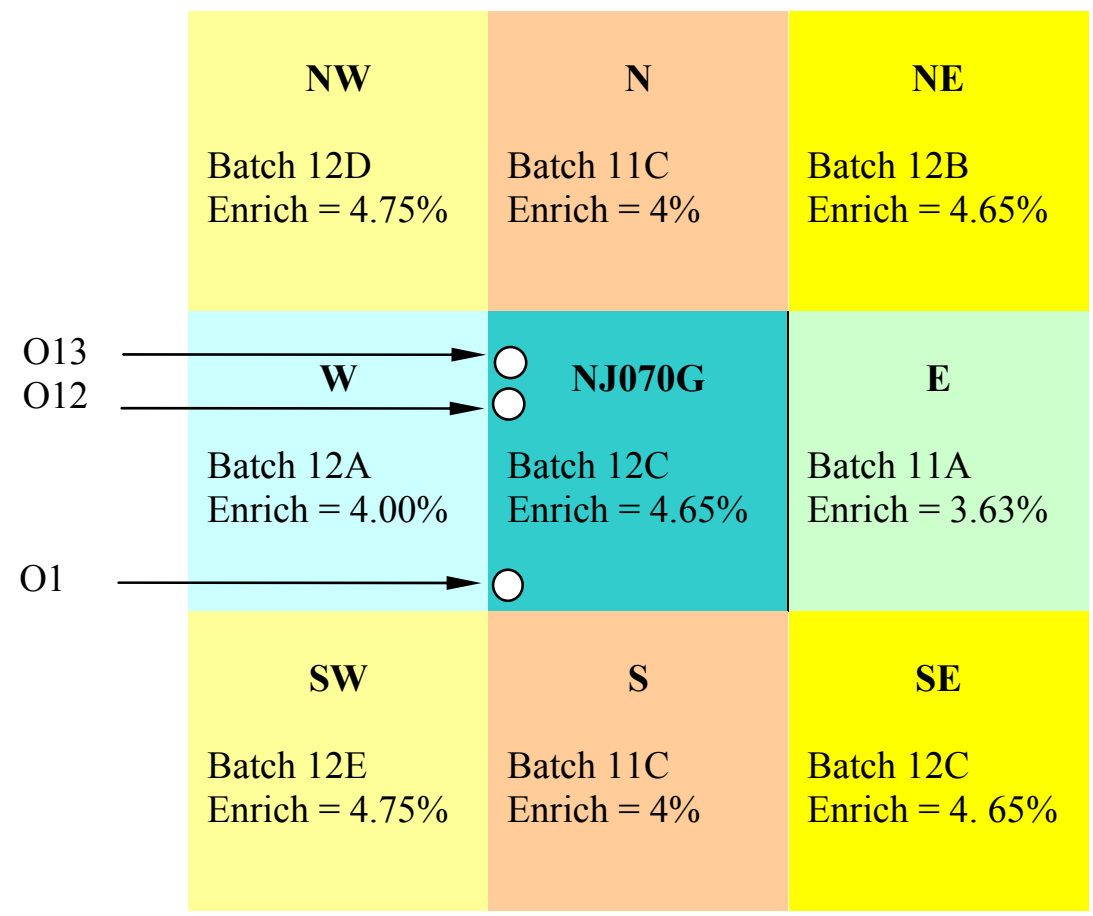

Fig. 18. Assemblies surrounding assembly NJ070G. (Source: Ref. 46, Figures 3-11, A-2, and A-4.)

Table 89. Modeling data for the assemblies adjoining the SW corner of assembly NJ070G

\begin{tabular}{|c|c|c|c|c|c|c|c|}
\hline $\begin{array}{c}\text { Cycle } \\
\text { No. }\end{array}$ & $\begin{array}{c}\text { Fresh fuel } \\
\text { batch }\end{array}$ & $\begin{array}{c}\text { wt \% } \\
{ }^{235} \mathbf{U}\end{array}$ & $\begin{array}{l}\text { Fuel pellet } \\
\text { diameter }^{a} \\
\text { (cm) }\end{array}$ & $\begin{array}{c}\text { BU }^{b} \\
(G W d / M T U)\end{array}$ & $\begin{array}{c}\text { Average power } \\
\text { (MW/MTU) }\end{array}$ & $\begin{array}{c}\text { Average } \\
\text { temperature } \\
\text { (K) }\end{array}$ & $\begin{array}{c}\mathrm{BPRA}^{d} \\
\text { wt } \% \mathrm{~B}_{4} \mathrm{C}\end{array}$ \\
\hline \multirow[t]{3}{*}{9} & $11 \mathrm{C}^{e}$ & 4.0 & 0.936244 & $19.352^{f}$ & $30.266^{f}$ & $874^{f}$ & 0.8 \\
\hline & & & & $22.522^{g}$ & $35.224^{g}$ & $938^{g}$ & 0.8 \\
\hline & & & & $22.042^{h}$ & $34.473^{h}$ & $936^{h}$ & 0.8 \\
\hline \multirow[t]{2}{*}{10} & $12 \mathrm{~A}^{i}$ & 4.00 & 0.936244 & - & - & - & - \\
\hline & $12 \mathrm{E}^{j}$ & 4.75 & 0.939800 & - & - & - & 0.2 \\
\hline
\end{tabular}

${ }^{a}$ All fuel rods have clad inner and outer diameters of 0.95758 and $1.0922 \mathrm{~cm}$, respectively (Ref. 46, Table 2-2).

${ }^{b}$ Burnup at the end of cycle 9 and cycle-averaged fuel temperature for the batch $11 \mathrm{C}$ assembly adjoining the south side of assembly NJ070G from Ref. 46, Table 4-82.

${ }^{c}$ Burnup divided by 639.4 days, the length of cycle 9.

${ }^{d}$ Burnable poison rod assembly (BPRA). The number of burnable poison rods per BPRA assembly is 16 (Ref. 46, p. 2-49).

${ }^{e}$ Ref. 46, Fig. 3-11, describes this assembly as being exposed to control rod group (CRG) \#5 and containing no burnable poison rods during cycle 10. However, CRG \#5 was withdrawn during cycle 10 (Ref. 46, Table 4-148).

${ }^{f}$ Values for the assembly axial node corresponding to the axial location of sample O1S1.

${ }^{g}$ Values for the assembly axial node corresponding to the axial location of sample O1S2.

${ }^{h}$ Values for the assembly axial node corresponding to the axial location of sample O1S3.

${ }^{i}$ Ref. 46, Fig. 3-11, indicates that this assembly was exposed to CRG \#1 and that CRG \#1 had a safety function only. This assembly did not contain burnable poison rods in cycle 10 .

${ }^{j}$ This fuel assembly had 4 gadolinia rods with $2.0 \mathrm{wt} \% \mathrm{Gd}_{2} \mathrm{O}_{3}$ and $4.19 \mathrm{wt} \%{ }^{235} \mathrm{U}$ and contained burnable poison rods with $0.2 \mathrm{wt} \% \mathrm{~B}_{4} \mathrm{C}$. The assembly locations of the gadolinia rods for assemblies in batches $12 \mathrm{C}$ and $12 \mathrm{E}$ are identical (Ref. 83, Fig. 7-8).

Source: Ref. 46, Table 3-1 and Figs. 3-10 and 3-11, unless otherwise noted. 


\subsection{GÖSGEN: ARIANE PROGRAM}

Three $\mathrm{UO}_{2}$ samples were measured for the ARIANE program. The samples were identified as GU1, GU3, and GU4. Samples GU3 and GU4 were from the same fuel rod. The layout of the assembly, showing the location of the measured rod at the beginning of cycles 12 and 16 for samples GU1 and GU3 (GU4), respectively, is illustrated in Fig. 19. Assembly geometry and fuel data are presented in Table 90. Table 91 shows the operating history data for sample GU1 as provided: ${ }^{48}$ irradiation cycle start and end dates, actual cycle duration and down days, effective full power days and down days, core load factor, concentration of soluble boron in the moderator, operator estimated sample burnup, and sample fuel temperature. The same type of information is presented in Table 92 for samples GU3 and GU4.

Sample GU1 was selected from a fuel rod with $3.5 \mathrm{wt} \%{ }^{235} \mathrm{U}$ initial enrichment of assembly 12-40, which was irradiated in the reactor for four consecutive cycles, from cycle 12 to cycle 15 . The 3.3 -cm sample was cut from an axial location centered at $97.7 \mathrm{~cm}$ from the bottom of the active region of the fuel rod. There were several changes in the fuel rod configuration of assembly 12-40 during cycles 14 and 15: in each of these cycles, three fuel rods were replaced by irradiated fuel rods from other assemblies, as specified in Ref. 48. At the start of cycle 14, three fuel rods corresponding to assembly 12-40 positions L12, M12, and N12, which were adjacent to the GU1 rod position M13 (see Fig. 19), were replaced. After cycle 14, the rods at positions N12, M14, and L14 were also replaced. The reconfiguration of the rods is potentially of consequence to the analysis because of the close proximity of the replacement rods to the measured rod, and the potential influence on the local neutronic environment of the measured sample. Further review found that the replacement rods, in general, had a burnup similar to that of the original rods for the nearest neighbors (rods located at M12 and M14) of the M13 rod. Based on diagrams provided in Ref. 48, the burnup of these above mentioned neighboring rods did not differ by more than 3-4\% from the burnup of rods placed in symmetric locations, with respect to the location of the rod from which sample GU1 was cut. Because additional details were not available (e.g., location of replacement rods from the donor assemblies), reconfiguration of the rods was not simulated in the computational analysis in the current report.

Samples GU3 and GU4 were selected from different axial locations of a single fuel rod irradiated in the Gösgen reactor for three consecutive cycles: cycle 16 to cycle 18. During cycles 16 and 17, this rod belonged to assembly 16-01 with an initial fuel enrichment of $4.1 \mathrm{wt} \%{ }^{235} \mathrm{U}$, whereas during last cycle 18, it was part of a different assembly identified as 17-01 with an initial fuel enrichment of $4.3 \mathrm{wt} \%$ ${ }^{235} \mathrm{U}$. The assemblies had a $15 \times 15$ configuration, with 205 fuel rods and 20 guide tubes. The estimated axial locations for samples GU3 and GU4 are centered at $127.42 \mathrm{~cm}$ and $7.42 \mathrm{~cm}$, respectively, from the bottom of the active fuel region.

Four rods from assembly 16-01, including the rod from which samples were selected, were taken out of the assembly after cycle 17 and inserted into assembly 17-01. The rod from which samples GU3 and GU4 were selected at the end of cycle 18 was reconstituted in a different assembly lattice location, with respect to the layout shown in Fig. 19. The lattice location changed from P7 in assembly 16-01 to R11 in assembly 17-01. The other three replacement rods in assembly 17-01 that were transferred from assembly 16-01 into assembly 17-01 at the end of cycle 17 were located at N9, N12, and S13 in assembly 17-01. At the beginning of cycle 18, assembly 17-01 is known to have had an average burnup of about $20 \mathrm{GWd} / \mathrm{MTU}$, whereas its burnup values at sample axial locations were 20.0 and $9.71 \mathrm{GWd} / \mathrm{MTU}$ for samples GU3 and GU4, respectively (Ref. 48, Table 3.b).

The temperature of the moderator at the sample axial location with respect to the bottom of the active fuel region was calculated using Eq. (1) provided in Sect. 5.2. 
Based on the moderator temperature value for each sample, the corresponding moderator density was calculated by using tabulated temperature vs. pressure data ${ }^{58}$ corresponding to a $154 \times 10^{5}$ Pa operating system pressure.

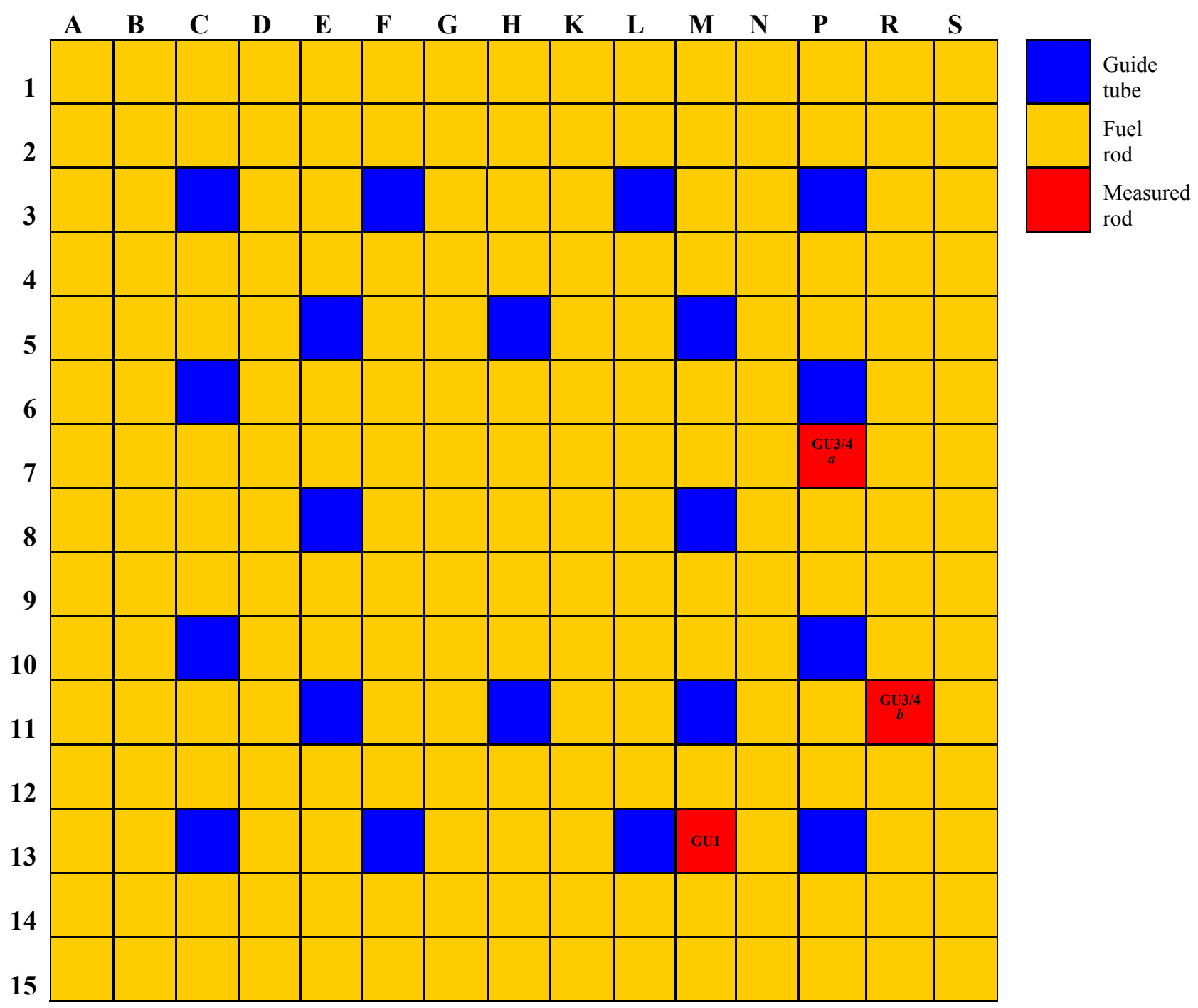

${ }^{a}$ Measured rod location in assembly 16-01 during cycles 16 and 17.

${ }^{b}$ Measured rod location in assembly 17-01 during cycle 18 .

Fig. 19. Assembly layout for Gösgen (ARIANE) samples. (Source: Ref. 48, pp. 110 and 140.) 
Table 90. Assembly design data for Gösgen (ARIANE) samples

\begin{tabular}{|c|c|c|}
\hline Parameter & Data for GU1 & Data for GU3/4 \\
\hline \multicolumn{3}{|l|}{ Assembly and reactor data } \\
\hline Reactor & Gösgen & Gösgen \\
\hline Operating pressure, $\mathrm{Pa}$ & $150 \times 10^{5}$ & $150 \times 10^{5}$ \\
\hline Lattice geometry & $15 \times 15$ & $15 \times 15$ \\
\hline Rod pitch, cm & 1.43 & 1.43 \\
\hline Number of fuel rods & 205 & 205 \\
\hline Number of guide tubes & 20 & 20 \\
\hline Active fuel rod length, $\mathrm{cm}$ & 340 & 355 \\
\hline Assembly pitch, cm & 21.56 & 21.56 \\
\hline \multicolumn{3}{|l|}{ Fuel rod data } \\
\hline Fuel material type & $\mathrm{UO}_{2}$ & $\mathrm{UO}_{2}$ \\
\hline Fuel pellet density, $\mathrm{g} / \mathrm{cm}^{3}$ & 10.4 & 10.4 \\
\hline Fuel pellet diameter, $\mathrm{cm}$ & 0.913 & 0.911 \\
\hline Sample axial location, ${ }^{a} \mathrm{~cm}$ & 97.7 & $127.42 / 7.42$ \\
\hline Fuel temperature, $\mathrm{K}$ & See Table 91 & See Table 92 \\
\hline \multicolumn{3}{|l|}{$\mathrm{U}$ isotopic composition, wt \% } \\
\hline${ }^{234} \mathrm{U}$ & 0.036 & 0.042 \\
\hline${ }^{235} \mathrm{U}$ & 3.5 & 4.1 \\
\hline${ }^{236} \mathrm{U}^{\mathrm{b}}$ & 0.0 & 0.0 \\
\hline${ }^{238} \mathrm{U}$ & 96.464 & 95.858 \\
\hline Clad material & Zircaloy-4 & Zircaloy-4 \\
\hline Clad inner diameter, $\mathrm{cm}$ & 0.93 & 0.93 \\
\hline Clad outer diameter, $\mathrm{cm}$ & 1.075 & 1.075 \\
\hline Average clad temperature, ${ }^{c} \mathrm{~K}$ & 619 & 619 \\
\hline \multicolumn{3}{|l|}{ Moderator data } \\
\hline Inlet temperature, $\mathrm{K}$ & 565 & 565 \\
\hline Outlet temperature, $\mathrm{K}$ & 599 & 599 \\
\hline Moderator density, ${ }^{d} \mathrm{~g} / \mathrm{cm}^{3}$ & 0.7299 & $0.722 / 0.7425$ \\
\hline Moderator temperature, ${ }^{d} \mathrm{~K}$ & 572 & $575 / 565$ \\
\hline Soluble boron content, ppm & See Table 91 & See Table 92 \\
\hline \multicolumn{3}{|l|}{ Guide tube data } \\
\hline Guide tube material & Zircaloy-4 & Zircaloy-4 \\
\hline Inner diameter, $\mathrm{cm}$ & 1.24 & 1.24 \\
\hline Outer diameter, $\mathrm{cm}$ & 1.38 & 1.38 \\
\hline
\end{tabular}

${ }^{a}$ With respect to the bottom of the active fuel region.

${ }^{b}$ Value not provided; assumed value 0 .

${ }^{c}$ Assumed value; maximum clad temperature as given in Ref. 56.

${ }^{d}$ Corresponding to sample axial location.

Source: Ref. 48. 
Table 91. Operating history data for Gösgen (ARIANE) sample GU1

\begin{tabular}{|c|c|c|c|c|c|c|c|c|c|c|}
\hline \multirow[b]{2}{*}{$\begin{array}{l}\text { Cycle } \\
\text { No. }\end{array}$} & \multirow[b]{2}{*}{$\begin{array}{l}\text { Start } \\
\text { date }\end{array}$} & \multirow[b]{2}{*}{$\begin{array}{l}\text { End } \\
\text { date }\end{array}$} & \multirow[b]{2}{*}{$\begin{array}{l}\text { Duration } \\
\text { (days) }\end{array}$} & \multirow[b]{2}{*}{$\begin{array}{l}\text { Down } \\
\text { (days) }\end{array}$} & \multirow[b]{2}{*}{$\begin{array}{c}\text { Effective } \\
\text { full } \\
\text { power } \\
\text { days }\end{array}$} & \multirow[b]{2}{*}{$\begin{array}{l}\text { Effective }^{a} \\
\text { down days }\end{array}$} & \multirow[b]{2}{*}{$\begin{array}{c}\text { Load } \\
\text { factor } \\
(\%)\end{array}$} & \multirow[b]{2}{*}{$\begin{array}{c}\text { Soluble } \\
\text { boron } \\
\text { in coolant } \\
(\mathrm{ppm})\end{array}$} & \multicolumn{2}{|c|}{ Sample GU1 } \\
\hline & & & & & & & & & $\begin{array}{c}\begin{array}{c}\text { Nominal } \\
\text { burnup }\end{array} \\
\text { (GWd/MTU) }\end{array}$ & $\begin{array}{c}\text { Fuel } \\
\text { temperature } \\
(\mathrm{K})\end{array}$ \\
\hline \multirow{5}{*}{12} & \multirow{5}{*}{$07 / 06 / 90$} & \multirow{5}{*}{$06 / 01 / 91$} & \multirow{5}{*}{330} & \multirow{5}{*}{32} & 0 & & & 1511 & & 1151.3 \\
\hline & & & & & 6 & & 100 & 1179 & & 1171.5 \\
\hline & & & & & 150 & 45 & 100 & 565 & & 1136.0 \\
\hline & & & & & 294.9 & & 100 & 8 & & 1078.3 \\
\hline & & & & & 317 & & 90.4 & 8 & 18.649 & 1046.7 \\
\hline \multirow{5}{*}{13} & \multirow{5}{*}{ 07/03/91 } & \multirow{5}{*}{$05 / 30 / 92$} & \multirow{5}{*}{332} & \multirow{5}{*}{16} & 0 & & & 1477 & & 919.3 \\
\hline & & & & & 6 & & 100 & 1145 & & 967.7 \\
\hline & & & & & 150 & 27 & 100 & 542 & & 957.9 \\
\hline & & & & & 292.3 & & 100 & 7 & & 943.1 \\
\hline & & & & & 321.3 & & 87.3 & 7 & 33.594 & 842.0 \\
\hline \multirow{5}{*}{14} & \multirow{5}{*}{$06 / 15 / 92$} & \multirow{5}{*}{$06 / 05 / 93$} & \multirow{5}{*}{355} & \multirow{5}{*}{26} & 0 & & & 1517 & & 888.9 \\
\hline & & & & & 6 & & 100 & 1178 & & 894.4 \\
\hline & & & & & 150 & 50 & 100 & 549 & & 854.8 \\
\hline & & & & & 290.1 & & 100 & 5 & & 841.4 \\
\hline & & & & & 331.3 & & 72.0 & 5 & 47.911 & 709.8 \\
\hline \multirow{5}{*}{15} & \multirow{5}{*}{ 07/01/93 } & \multirow{5}{*}{$06 / 04 / 94$} & \multirow{5}{*}{338} & & 0 & & & 1594 & & 806.6 \\
\hline & & & & & 6 & & 100 & 1243 & & 829.8 \\
\hline & & & & & 150 & 11 & 100 & 605 & & 810.6 \\
\hline & & & & & 301.9 & & 100 & 5 & & 804.0 \\
\hline & & & & & 326.7 & & 87.0 & 5 & 59.656 & 738.9 \\
\hline
\end{tabular}

${ }^{a}$ Sum of the actual down days and the difference between the actual cycle duration and effective full-power days.

Source: Ref. 48, p. 109. 
Table 92. Operating history data for Gösgen (ARIANE) samples GU3 and GU4

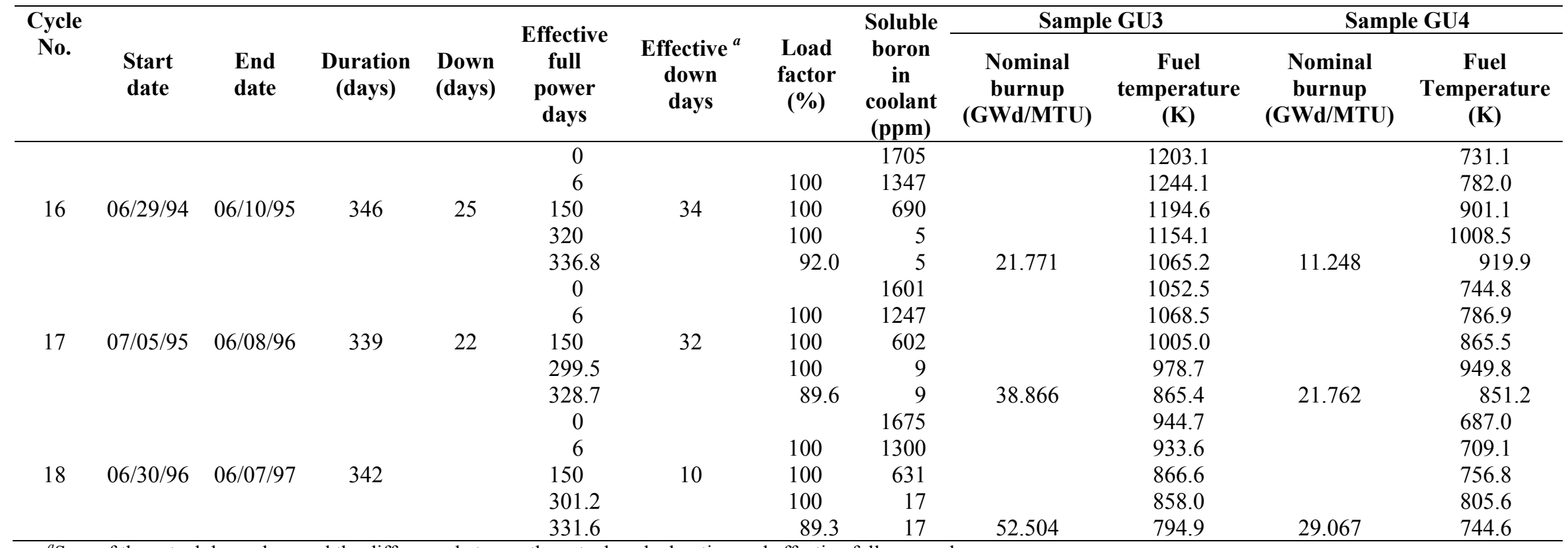

${ }^{a}$ Sum of the actual down days and the difference between the actual cycle duration and effective full-power days.

Source: Ref. 48, p. 138. 


\subsection{GKN II}

The measured sample was selected from a fuel rod, identified as M11, in assembly 419 that was irradiated in the GKN II PWR reactor between August 1993 and August 1996. The sample was cut from an axial location on the fuel rod between $105.5 \mathrm{~cm}$ and $108.5 \mathrm{~cm}$ from the top end of the rod, which is approximately $300 \mathrm{~cm}$ from the bottom of the active fuel region. The estimated burnup ${ }^{51}$ based on the measured ${ }^{137} \mathrm{Cs}$ gamma scan data was $54.095 \mathrm{GWd} / \mathrm{MTU}$.

The assembly had an $18 \times 18$ configuration, as illustrated in Fig. 20, with 300 fuel rods and 24 guide tubes. Twelve of the fuel rods contained $\mathrm{Gd}_{2} \mathrm{O}_{3}$ at $7.0 \mathrm{wt} \%$. The rods with $\mathrm{Gd}_{2} \mathrm{O}_{3}$ had an initial fuel enrichment of $2.6 \mathrm{wt} \%{ }^{235} \mathrm{U}$; the regular fuel rods had an enrichment of $3.8 \mathrm{wt} \%{ }^{235} \mathrm{U}$. The composition of uranium in the fresh fuel was obtained from Ref. 52.

Assembly design data are listed in Table 93. The content of soluble boron in moderator as a function of the irradiation time is listed in Table 94, along with the sample cumulative burnup at the end of each cycle as reported by the utility. ${ }^{50}$ The cycle duration and the sample cumulative burnup and average power values used in the calculations are shown in Table 95. The value for the burnup at the end of each cycle shown in Table 95 was obtained by normalizing the operator-based burnup data in Table 94 such that the sample final cumulative burnup corresponds to the reported value of $54.095 \mathrm{GWd} / \mathrm{MTU}$ based on the gamma scan (i.e., multiplying the burnup values in Table 94 by the ratio of 54.095 to 53.331, which is shown as total sample burnup in Table 94). The cycle average fuel and moderator temperatures presented in Table 96 were calculated based on a more detailed time-dependent data ${ }^{50}$ supplied by the utility for an axial location corresponding to the measured sample. Also shown in Table 96 are the moderator density data; they were calculated based on the moderator temperature by using temperature vs. pressure tabulated data ${ }^{58}$ corresponding to the operating system pressure of $158 \times 10^{5} \mathrm{~Pa}$. 

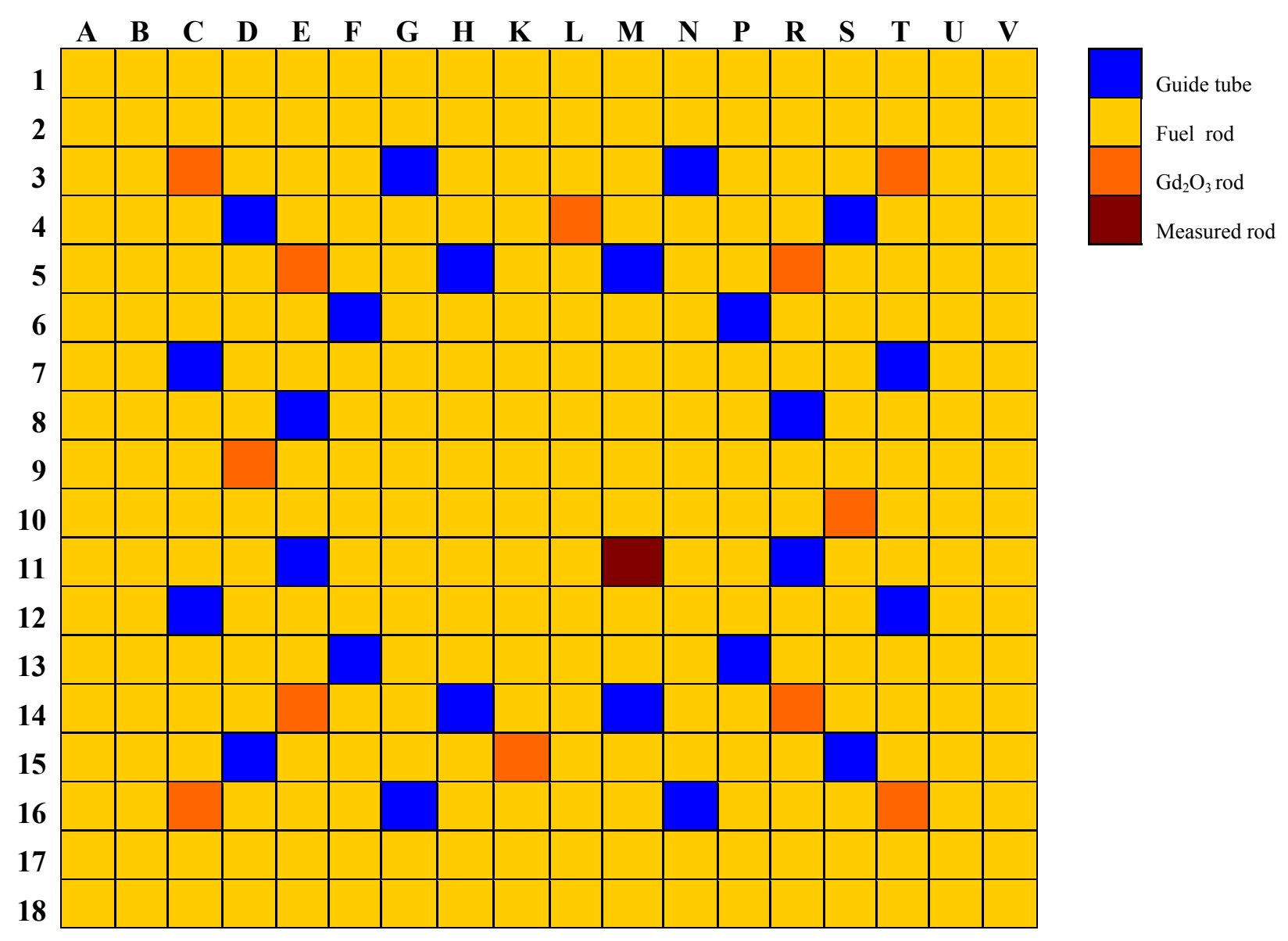

Fig. 20. Assembly layout for GKN II (REBUS) sample. (Source: Ref. 49, Sect. 1.1 and Fig. 1.1.) 
Table 93. Assembly design data for GKN II (REBUS) sample

\begin{tabular}{|c|c|}
\hline Parameter & Data \\
\hline \multicolumn{2}{|l|}{ Assembly and reactor data } \\
\hline Reactor & GKN II \\
\hline Operating pressure, $\mathrm{Pa}$ & $158 \times 10^{5}$ \\
\hline Lattice geometry & $18 \times 18$ \\
\hline Rod pitch, cm & 1.27 \\
\hline Number of fuel rods & 300 \\
\hline Number of guide tubes & 24 \\
\hline Active fuel rod length, ${ }^{a} \mathrm{~cm}$ & 390 \\
\hline Assembly pitch, cm & 23.116 \\
\hline \multicolumn{2}{|l|}{ Fuel rod data } \\
\hline Fuel material type & $\mathrm{UO}_{2}$ \\
\hline Fuel pellet density, $\mathrm{g} / \mathrm{cm}^{3}$ & 10.4 \\
\hline Enrichment, wt $\%{ }^{235} \mathrm{U}$ & $3.8(2.6)^{c}$ \\
\hline Sample location, ${ }^{b} \mathrm{~cm}$ & 303 \\
\hline Fuel pellet diameter, $\mathrm{cm}$ & 0.805 \\
\hline Fuel temperature, $\mathrm{K}$ & See Table 96 \\
\hline Clad material & Zircaloy-4 \\
\hline Clad inner diameter, $\mathrm{cm}$ & 0.822 \\
\hline Clad outer diameter, $\mathrm{cm}$ & 0.95 \\
\hline Average clad temperature, ${ }^{d} \mathrm{~K}$ & 619 \\
\hline Number of rods with $\mathrm{Gd}_{2} \mathrm{O}_{3}$ & 12 \\
\hline Density of fuel in $\mathrm{Gd}_{2} \mathrm{O}_{3}, \mathrm{~g} / \mathrm{cm}^{3}$ & 10.4 \\
\hline $\mathrm{Gd}_{2} \mathrm{O}_{3}$ content, wt $\%$ & 7.0 \\
\hline \multicolumn{2}{|l|}{$\mathrm{U}$ isotopic composition, ${ }^{e}$ wt $\%$} \\
\hline${ }^{234} \mathrm{U}$ & $0.036(0.0)^{c}$ \\
\hline${ }^{235} \mathrm{U}$ & $3.798(2.6)^{c}$ \\
\hline${ }^{236} \mathrm{U}$ & $0.0(0.0)^{c}$ \\
\hline${ }^{238} \mathrm{U}$ & $96.166(97.4)^{c}$ \\
\hline \multicolumn{2}{|l|}{ Moderator data } \\
\hline Moderator temperature, $\mathrm{K}$ & See Table 96 \\
\hline Moderator density, $\mathrm{g} / \mathrm{cm}^{3}$ & See Table 96 \\
\hline Soluble boron content, ppm & See Table 94 \\
\hline \multicolumn{2}{|l|}{ Guide tube data } \\
\hline Guide tube material $^{f}$ & Zircaloy-4 \\
\hline Inner diameter, cm & 1.110 \\
\hline Outer diameter, cm & 1.232 \\
\hline $\begin{array}{l}{ }^{a} \text { Ref. } 51 . \\
{ }^{b} \text { Relative to the bottom of the active fuel regio } \\
\text { segment (Ref. 53). } \\
{ }^{c} \text { Values in parentheses correspond to gadolinia } \\
{ }^{d} \text { Maximum clad temperature as given in Ref. } 5 \\
{ }^{e} \text { Initial (fresh fuel) values from Ref. } 53 \text {. } \\
{ }^{f} \text { Assumed the same as clad material. } \\
\text { Source: Ref. } 49 \text { unless otherwise noted. }\end{array}$ & g to center of the \\
\hline
\end{tabular}


Table 94. Operating history data for GKN II (REBUS) sample

\begin{tabular}{|c|c|c|c|c|}
\hline Cycle & $\begin{array}{c}\text { Cumulative } \\
\text { time } \\
\text { (days) }\end{array}$ & $\begin{array}{c}\text { Burn time } \\
\text { (days) }\end{array}$ & $\begin{array}{c}\text { Soluble }^{b} \\
\text { boron in } \\
\text { moderator } \\
(\mathrm{ppm})\end{array}$ & $\begin{array}{c}\text { Cumulative }^{a} \\
\text { burnup } \\
\text { (GWd/MTU) }\end{array}$ \\
\hline \multirow{12}{*}{5} & 6.0 & 6.0 & 965.6 & \\
\hline & 30.0 & 30.0 & 876.6 & \\
\hline & 60.0 & 60.0 & 783.2 & \\
\hline & 90.0 & 90.0 & 681.8 & \\
\hline & 120.0 & 120.0 & 583.2 & \\
\hline & 150.0 & 150.0 & 489.4 & \\
\hline & 180.0 & 180.0 & 400.9 & \\
\hline & 210.0 & 210.0 & 308.3 & \\
\hline & 240.0 & 240.0 & 206.9 & \\
\hline & 270.0 & 270.0 & 99.4 & \\
\hline & 295.4 & 295.4 & 10.0 & \\
\hline & 310.0 & 310.0 & 10.0 & 17.196 \\
\hline \multirow[t]{7}{*}{ Down } & 332.0 & & & \\
\hline & 338.0 & 316.0 & 1175.9 & \\
\hline & 362.0 & 340.0 & 1088.9 & \\
\hline & 392.0 & 370.0 & 998.8 & \\
\hline & 422.0 & 400.0 & 898.8 & \\
\hline & 452.0 & 430.0 & 800.2 & \\
\hline & 482.0 & 460.0 & 706.1 & \\
\hline \multirow[t]{8}{*}{6} & 512.0 & 490.0 & 617.3 & \\
\hline & 542.0 & 520.0 & 529.3 & \\
\hline & 572.0 & 580.0 & 432.0 & \\
\hline & 602.0 & 580.0 & 323.7 & \\
\hline & 632.0 & 610.0 & 212.4 & \\
\hline & 662.0 & 640.0 & 101.8 & \\
\hline & 687.0 & 665.0 & 10.0 & \\
\hline & 718.7 & 696.7 & 10.0 & 35.356 \\
\hline \multirow[t]{7}{*}{ Down } & 735.7 & & & \\
\hline & 741.7 & 702.7 & 1016.0 & \\
\hline & 765.7 & 726.7 & 926.5 & \\
\hline & 795.7 & 786.7 & 833.8 & \\
\hline & 825.7 & 766.7 & 732.3 & \\
\hline & 855.7 & 816.7 & 632.7 & \\
\hline & 885.7 & 846.7 & 537.4 & \\
\hline \multirow[t]{6}{*}{7} & 915.7 & 876.7 & 447.5 & \\
\hline & 945.7 & 906.7 & 355.7 & \\
\hline & 975.7 & 936.7 & 255.0 & \\
\hline & 1005.7 & 966.7 & 148.6 & \\
\hline & 1044.6 & 1005.6 & 7.8 & \\
\hline & 1083.6 & 1044.6 & 7.8 & 49.356 \\
\hline \multirow[t]{7}{*}{ Down } & 1098.6 & & & \\
\hline & 1104.6 & 1050.6 & 1228.9 & \\
\hline & 1128.6 & 1074.6 & 1119.9 & \\
\hline & 1158.6 & 1104.6 & 1001.3 & \\
\hline & 1188.6 & 1134.6 & 874.3 & \\
\hline & 1218.6 & 1164.6 & 749.2 & \\
\hline & 1248.6 & 1194.6 & 627.3 & \\
\hline \multirow[t]{6}{*}{8} & 1278.6 & 1224.6 & 509.1 & \\
\hline & 1308.6 & 1254.6 & 395.4 & \\
\hline & 1338.6 & 1284.6 & 282.6 & \\
\hline & 1368.6 & 1314.6 & 169.4 & \\
\hline & 1411.0 & 1357.0 & 11.9 & \\
\hline & 1445.4 & 1391.4 & 11.9 & 53.331 \\
\hline
\end{tabular}

\footnotetext{
${ }^{a}$ From beginning of cycle 5 based on operating data
}

${ }^{b}$ As provided in Ref. 49. 
Table 95. Cycle average power data for GKN II (REBUS) sample

\begin{tabular}{ccccc}
\hline Cycle \# & $\begin{array}{c}\text { Duration } \\
\text { (effective power days) }\end{array}$ & $\begin{array}{c}\text { Down } \\
\text { (days) }\end{array}$ & $\begin{array}{c}\text { Cumulative burnup } \\
\text { (GWd/MTU) }\end{array}$ & $\begin{array}{c}\text { Power }^{\boldsymbol{a}} \\
\text { (MW/MTU) }\end{array}$ \\
\hline 5 & 310.0 & 22 & 17.442 & 56.265 \\
6 & 386.7 & 17 & 35.862 & 47.634 \\
7 & 347.9 & 15 & 50.063 & 40.820 \\
8 & 346.8 & - & 54.095 & 11.626 \\
\hline${ }^{a}$ Derived from cumulative burnup and effective power days.
\end{tabular}

${ }^{a}$ Derived from cumulative burnup and effective power days.

Source: Ref. 49.

Table 96. Cycle average moderator and fuel data for GKN II (REBUS) sample

\begin{tabular}{|c|c|c|c|}
\hline Cycle \# & $\begin{array}{c}\text { Moderator } \\
\text { density }^{a} \\
\left(\mathrm{~g} / \mathrm{cm}^{3}\right)\end{array}$ & $\begin{array}{c}\text { Moderator } \\
\text { temperature }^{b} \\
(\mathrm{~K})\end{array}$ & $\begin{array}{c}\text { Fuel } \\
\text { temperature }^{b} \\
(\mathrm{~K}) \\
\end{array}$ \\
\hline 5 & 0.646 & 605.01 & 1018.04 \\
\hline 6 & 0.665 & 598.98 & 904.25 \\
\hline 7 & 0.681 & 593.34 & 819.69 \\
\hline 8 & 0.725 & 574.23 & 646.13 \\
\hline
\end{tabular}

${ }^{a}$ Values corresponding to moderator temperatures and operating system pressure

determined by interpolating steam data from Ref. 58 .

${ }^{b}$ Ref. 49.

\subsection{GÖSGEN: MALIBU PROGRAM}

A description of the assembly design and operational data for the Gösgen spent fuel samples selected for the MALIBU program and used in this validation study is available in DTN: MO1003MALIBUIP.001. 


\section{SCALE TWO-DIMENSIONAL DEPLETION CALCULATION METHOD}

This section describes the SCALE 2-D depletion computation method and the TRITON/NEWT models developed for the spent fuel samples evaluated in this report.

\subsection{METHOD DESCRIPTION}

The depletion computational method and the cross-section library being evaluated are the 2-D transport and depletion sequence TRITON/NEWT (T-DEPL) and 44GROUPNDF5 cross-section library, respectively, in the SCALE 5.1 (Ref. 1) code system. The SCALE 44GROUPNDF5 cross-section library is based on the Evaluated Nuclear Data File/B Version V (ENDF/B-V) library. The T-DEPL analysis sequence is one of the five sequences developed for the TRITON control module. ${ }^{2}$ It invokes SCALE functional modules for resonance processing (BONAMI and WORKER/CENTRM/PMC or BONAMI and NITAWL); 2-D discrete ordinates transport calculations (NEWT) ${ }^{3}$ burnup-dependent cross-section preparation (COUPLE) $;{ }^{91}$ and depletion calculations (ORIGEN-S). ${ }^{92}$ At each depletion step, the transport flux solution from NEWT is used to generate cross sections and assembly power distributions for the ORIGEN-S calculations; the isotopic composition data resulting from ORIGEN-S is employed in the subsequent transport calculation to obtain cross sections and power distributions for the next depletion step in an iterative manner throughout the irradiation history.

TRITON has the capability of simulating the depletion of multiple mixtures in a fuel assembly model. This is a very useful and powerful feature in a nuclide inventory analysis, as it allows a more appropriate representation of the local flux distribution and neutronic environment for a specific measured fuel rod in the assembly. The flux normalization in a TRITON calculation can be performed using as a basis the power in a specified mixture, the total power corresponding to multiple mixtures, or the assembly power. The first of the above-mentioned options permits specification of the burnup (power) in the measured sample, usually inferred from experimental measurements of burnup indicators (such as ${ }^{148} \mathrm{Nd}$ ).

\subsection{MODELING APPROACH}

The input data available for modeling the measured spent fuel samples considered in this study are described in Sect. 8. This section describes the general input format and additional input parameters that are specific to the TRITON/NEWT (T-DEPL) analysis sequence, such as input options and control parameters, which were consistently used in all input files.

\subsubsection{Input File Format for Depletion Calculations}

The general format of an input file for the T-DEPL analysis sequence is listed below and is followed by a description of the input data for the various data blocks identified by keywords.

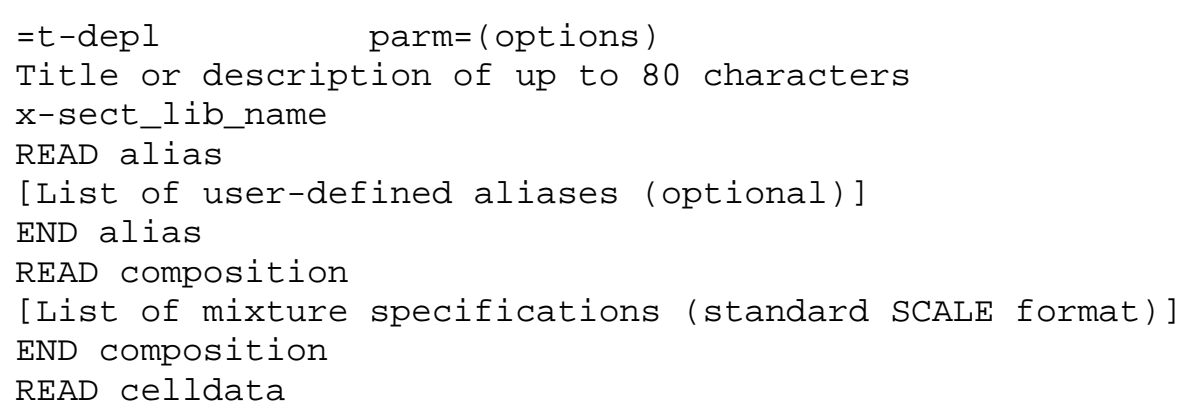




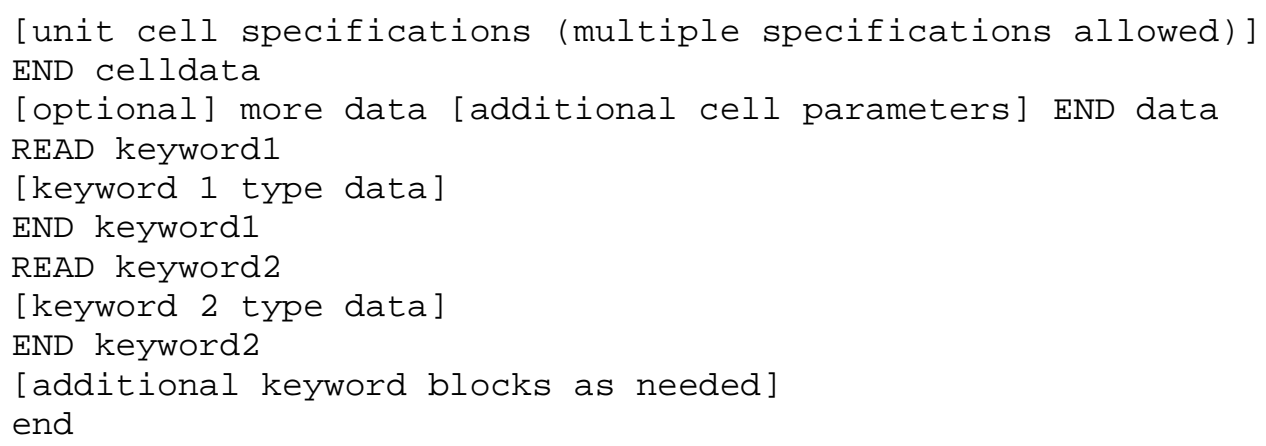

PARM

PARM control options: parm $=($ addnux $=3$, nitawl $)$

All the isotopes (232) for which cross sections data are available in the multigroup transport library used with NEWT were applied in updating cross sections for the ORIGEN-S fuel depletion calculation at each depletion step based on the flux solution from the transport calculation with NEWT.

BONAMI and NITAWL functional modules were invoked for cross-section processing.

Cross-section library name: 44groupndf5(SCALE 44GROUPNDF5 cross-section library based on the ENDF/B-V library)

\section{ALIAS}

Mixture aliases were used to associate multiple mixture IDs with a single alias.

\section{COMPOSITION}

The composition block provides standard composition mixture data for fresh fuel, cladding, moderator, neutron absorber, and structural materials. SCALE standard compositions were used for cladding and structural materials (zirc4 and/or ss304). The compositions for the other mixtures are documented in Sect. 8. Note that nitrogen rather than helium was used as the filling gas in the fuel rod gap in the calculations described in this document. Both $\mathrm{He}$ and $\mathrm{N}$ have no effect on the neutron spectrum.

\section{CELLDATA}

This data block provides unit cell data description including the type of lattice cell (latticecell squarepitch), fuel, gap, and clad radii, fuel rod pitch, and the corresponding material mixture numbers. Input data for the unit cell data block are documented in Sect. 8.

\section{BURNDATA}

Specific power, irradiation time, and downtime/cooling time data for this block are documented in Sect. 8. The number of cross-section libraries produced per cycle was selected such that the sample burnup per library is less than $3 \mathrm{GWd} / \mathrm{MTU}$. Burnup steps of $3 \mathrm{GWd} / \mathrm{MTU}$ are generally adequate to represent the cross section variations with burnup. ${ }^{93}$ 


\section{DEPLETION}

This data block specifies the mixtures to be depleted and the mixture that is used to normalize the input power. The mixtures to be depleted consist of fuel mixtures and the fixed absorber mixture such as BPR or control rod mixture, if applicable. The input power was normalized to the mixture in the fuel rod from which the sample was selected.

\section{TIMETABLE}

This data block specifies time-dependent material properties such as fuel temperature, soluble boron concentration in the moderator, or moderator density. TRITON applies linear interpolation to obtain these parameters within the time intervals.

OPUS

This data block provides a partial set of OPUS commands that can be used to control postprocessing of ORIGEN-S output binary files as part of the sequence of calculations. The input files requested OPUS tables providing nuclide concentrations in grams per MTU for the measured isotopes in the rod containing the measured sample.

\section{MODEL}

The MODEL data block provides assembly description data for NEWT calculations. In the models, the fuel rod that contained the measured sample and its nearest neighbor fuel rods were represented as individual geometry units, whereas the other fuel rods in the assembly were described using a single geometry unit. The model includes other assembly components for which data was available, such as guide and instrument tubes, fixed burnable absorber, or integral burnable absorber, as applicable. Assembly models used reflective boundary conditions for the four sides of the assembly because modeling data is usually unavailable for adjacent assemblies. Reflective boundary conditions are very good approximations to use in 2-D transport calculations for measured fuel rods selected from the inner assembly locations. However, these approximations may not be adequate for modeling the assembly that provided samples from outer assembly rods, such as the KWO assemblies BE124 and BE210. Note that the TRITON/NEWT models for the measured samples in the TMI-1 assembly NJ070G included information on the assembly surroundings.

\section{BOUNDARY}

The unit boundary for the pin cells defines a $4 \times 4$ rectangular grid.

\section{PARAMETER}

Default convergence control parameters were used to control spatial, angular, and eigenvalue convergence for the iterative phases of the solution process. 


\subsubsection{Fuel Mixture Modeling Simplifications}

Typical TRITON/NEWT models used in this validation study consist of individual depleting mixtures specified for the measured rod and its adjacent nearest-neighbor fuel rods with all other fuel rods in the assembly treated as a single depletion material with uniform composition. This modeling technique was employed to reduce the overall computer time while maintaining sufficient accuracy for the results. A sensitivity study for the Turkey Point sample D01_G9 ( 30 GWd/MTU burnup) showed that the relative differences between the isotopic concentration values obtained with detailed and simplified pin models are within $\pm 0.5 \%$ for all isotopes and within $\pm 0.3 \%$ for the burnup credit isotopes (see DVD/xls/input_data.xls, worksheet Turkey-Point). The results are summarized in Sect. 10.2.1, Table 107. Therefore, the uncertainty associated with fuel mixture modeling simplifications is expected to be significantly small.

\subsubsection{Modeling Approach for H. B. Robinson Assembly BO-5, Calvert Cliffs Assembly BT03, and TMI Assembly NJ05YU}

H. B. Robinson assembly BO-5, Calvert Cliffs assembly BT03, and TMI assembly NJ05YU were exposed to burnable poison rods during their first cycle of irradiation. The burnable poison rods were removed at the end of those cycles and the assemblies were irradiated for one or more subsequent cycles without being exposed to burnable poison rods. For these cases, separate TRITON models were used to represent a fuel assembly during irradiation cycles with and without burnable poison exposures. Fuel mixture compositions for an assembly containing burnable poison rods throughout the first cycle of irradiation were used as the initial fuel compositions at the beginning of the subsequent cycle(s). Because the heavy metal mass in the measured rod changes slightly due to depletion and because the power in TRITON is normalized to the heavy metal mass of the measured fuel rod at the BOC of each simulation cycle, the power values for the subsequent cycle(s) shown in the tables included in Sect. 8, which were determined using as a basis the heavy metal mass in the measured fuel rod for fresh fuel before the irradiation, were adjusted to obtain the measured sample burnup. A multiplying factor was determined as the ratio between the total heavy metal mass in the sample mixture at the beginning of the first irradiation cycle and the corresponding quantity at the end of the first irradiation cycle.

\subsection{TRITON/NEWT MODELING}

\subsubsection{Trino Vercellese}

The TRITON/NEWT models for assemblies 509-032, 509-049, and 509-069, as illustrated in Fig. 21 for assembly 509-069, represent a full square assembly with half of the cruciform assembly rods adjoining the upper left quadrant of the square assembly and use reflective boundary conditions to simulate the surrounding assembly environment. Assumptions were embedded into the model to simplify the geometric representation of a measured square assembly and surrounding assemblies because insufficient description of the surrounding assemblies was available in primary reference documents, including (1) initial enrichment and burnup values for the adjacent square assemblies and (2) the two empty lattice locations in a cruciform assembly knowing that a cruciform fuel assembly has 28 rod locations and contains 26 rods (see Sect. 8.1). In the current validation study, it was assumed that the 13 lattice positions surrounding the upper left quadrant of the square assembly illustrated in Sect. 8.1, Fig. 4, contain cruciform assembly fuel rods. The simplifying assumptions are deemed to have insignificant effects on the calculated isotopic compositions because the evaluated samples were obtained from inner assembly rods that were irradiated in either an asymptotic or intermediate (near water hole) neutron spectrum. ${ }^{12,13}$ Note that the model illustrated in Fig. 21 was also used for fuel rods 509-032-E11 and 509-069-L5, which were located approximately halfway between a control group and the center of the 
square assembly. The control group was inserted $30 \%$, or approximately $80 \mathrm{~cm}$, from the top during period 1 of cycle 1 , and each cruciform control rod was connected to a fuel bearing follower so that if a cruciform control rod were removed, a cruciform fuel assembly would raise into the fuel. Therefore, a geometric model including a control rod may be justified only for sample 509-032-E11-1, which had a rod axial location of $246.7 \mathrm{~cm}$. However, the 2-D assembly model illustrated in Fig. 21 adequately represents the irradiation environment for sample 509-032-E11-1 because fuel rod 509-032-E11 was located approximately halfway between the control group and the center of the square assembly where the irradiation spectrum was asymptotic.

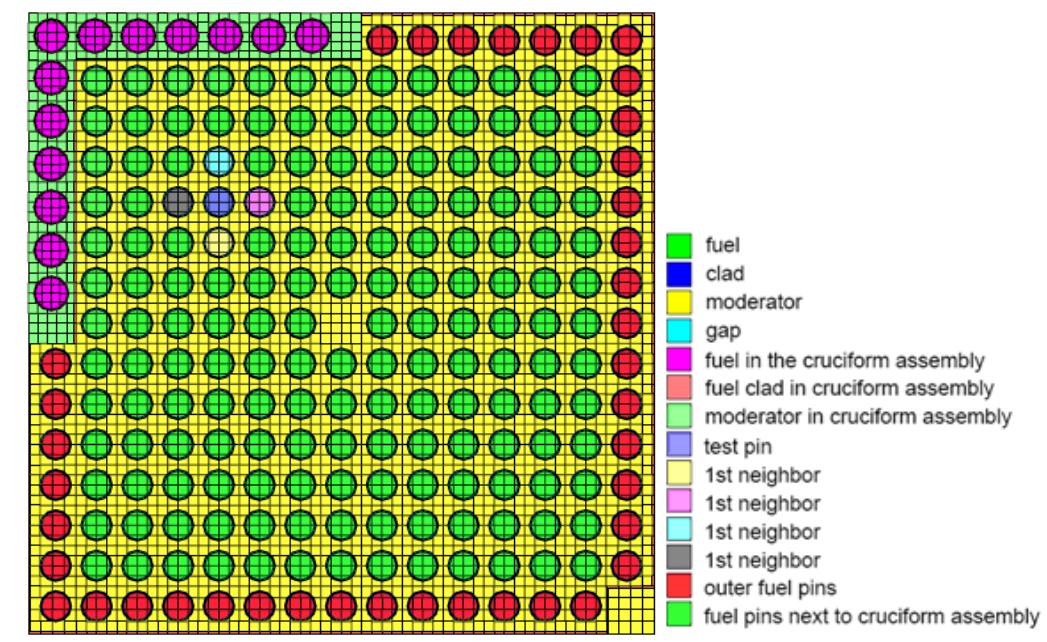

Fig. 21. TRITON/NEWT model for Trino Vercellese assembly 509-069, rod E11.

Assembly 509-104 was irradiated in a location at the core periphery, and assumptions were made for the outer core materials and their unavailable dimensions. The model for this assembly is shown in Fig. 22. A $2-\mathrm{cm}$ stainless steel core liner, $10-\mathrm{cm}$ borated water, and a void boundary condition were assumed for the core periphery. Reflective boundary conditions were used to represent the three adjoining assemblies. Note that neutron leakage at the core periphery has negligible effects on the measured rod since this rod was separated from the core periphery by 11 rows of rods. 


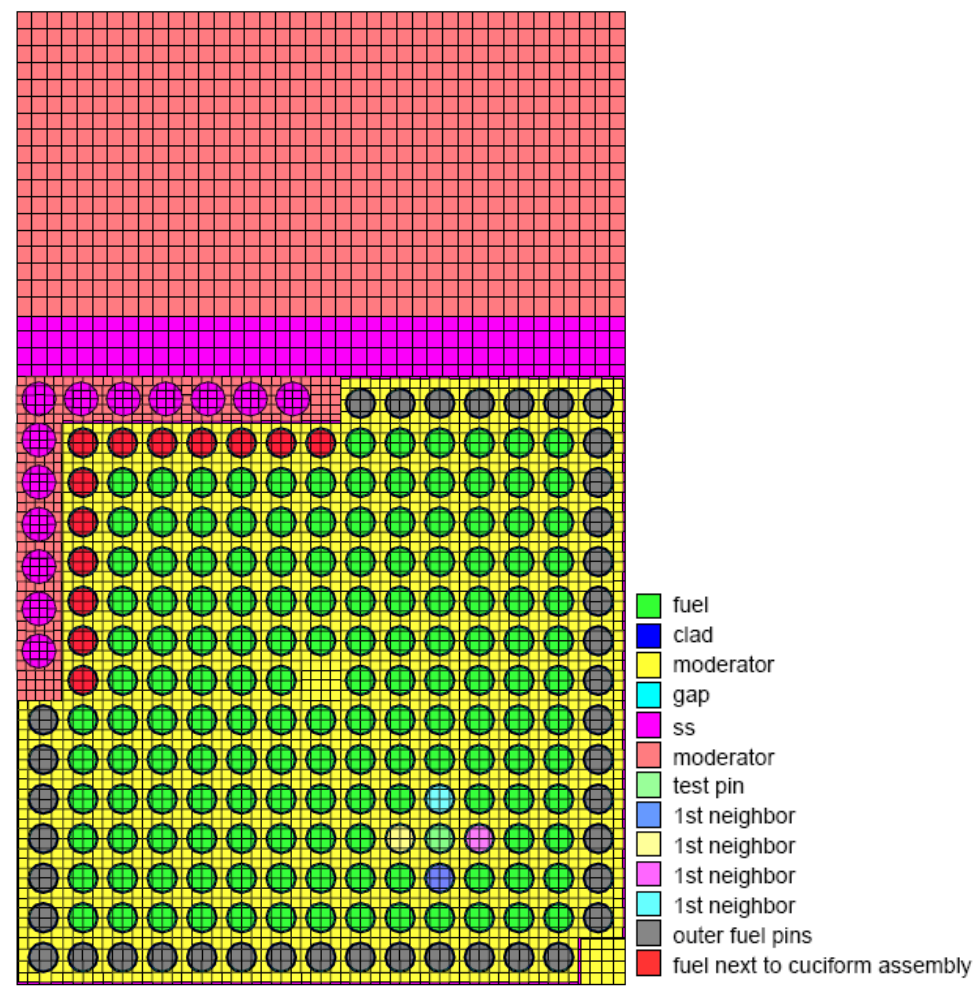

Fig. 22. TRITON/NEWT model for Trino Vercellese assembly 509-104, rod M11.

\subsubsection{Obrigheim}

In the TRITON/NEWT models for the KWO spent fuel samples, individual depleting mixtures were specified for the measured rod and its adjacent nearest-neighbor fuel rods. All other fuel rods were treated as a single depletion material with uniform composition. A full assembly model was developed for all KWO spent fuel samples from assemblies BE124 and BE210, as illustrated in Fig. 23 for assembly BE124, rod G7, whereas a one-quarter assembly model with a single fuel mixture was used for KWO spent fuel assemblies BE168, BE170, BE171, BE172, and BE176. Although a significant number of the evaluated Obrigheim rod samples were taken from assembly peripheral rods, reflective boundary conditions were specified in the TRITON calculations to simulate the assembly surrounding environment because the characteristics of the adjacent assemblies were not available in the primary reference documents (refer to Sect. 8.2 for a description of relevant modeling uncertainties). In addition, as illustrated in Fig. 7, assembly BE124 was irradiated at the reactor core edge during cycle 2, removed from the reactor during cycle 3 , and then irradiated for two more cycles at an inner core location. Therefore, one of the measured peripheral rods in assembly BE124 could have been located near the outer core moderator during cycle 2 of irradiation. The use of reflective boundary conditions for such a rod during cycle 2 is considered to result in small uncertainties in the calculated isotopic compositions. 


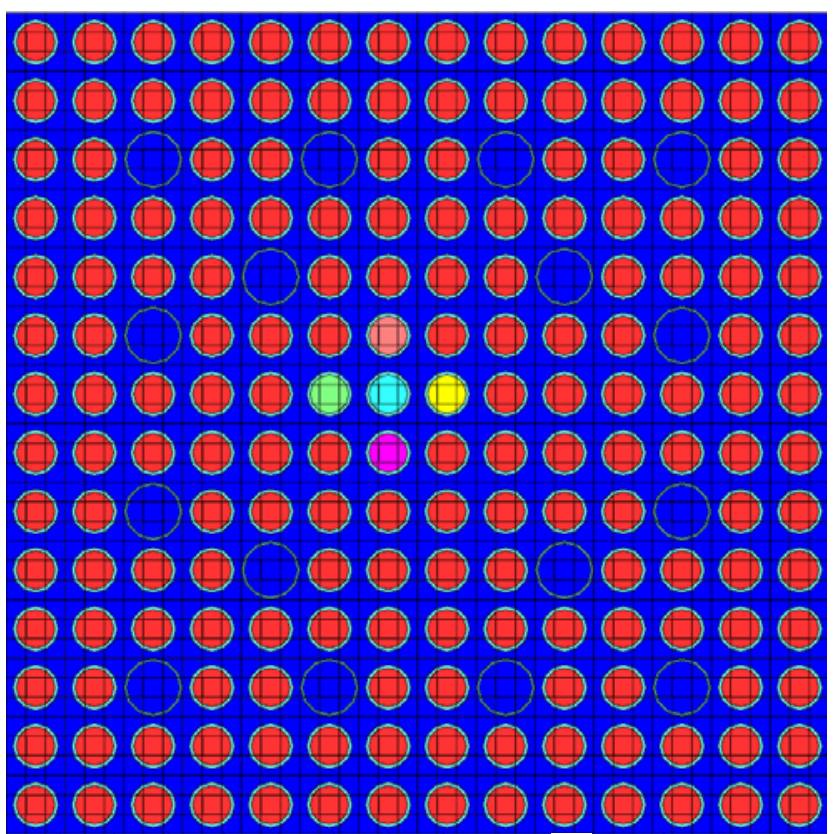

standard fuel rod $\square$ measured fuel rod $\square$ moderator

a nearest neighbor fuel rods of the measured rod

Fig. 23. TRITON/NEWT model for KWO assembly BE124, fuel rod G7.

\subsubsection{Turkey Point Unit 3}

The TRITON/NEWT models for the Turkey Point Unit 3 assemblies D01 and D04 consist of half of the assembly with reflective boundary conditions. The model for spent fuel samples from rod D01-G9, illustrated in Fig. 24, shows the measured rod and its nearest neighbors individually modeled and the other rods modeled as a single material mixture. 


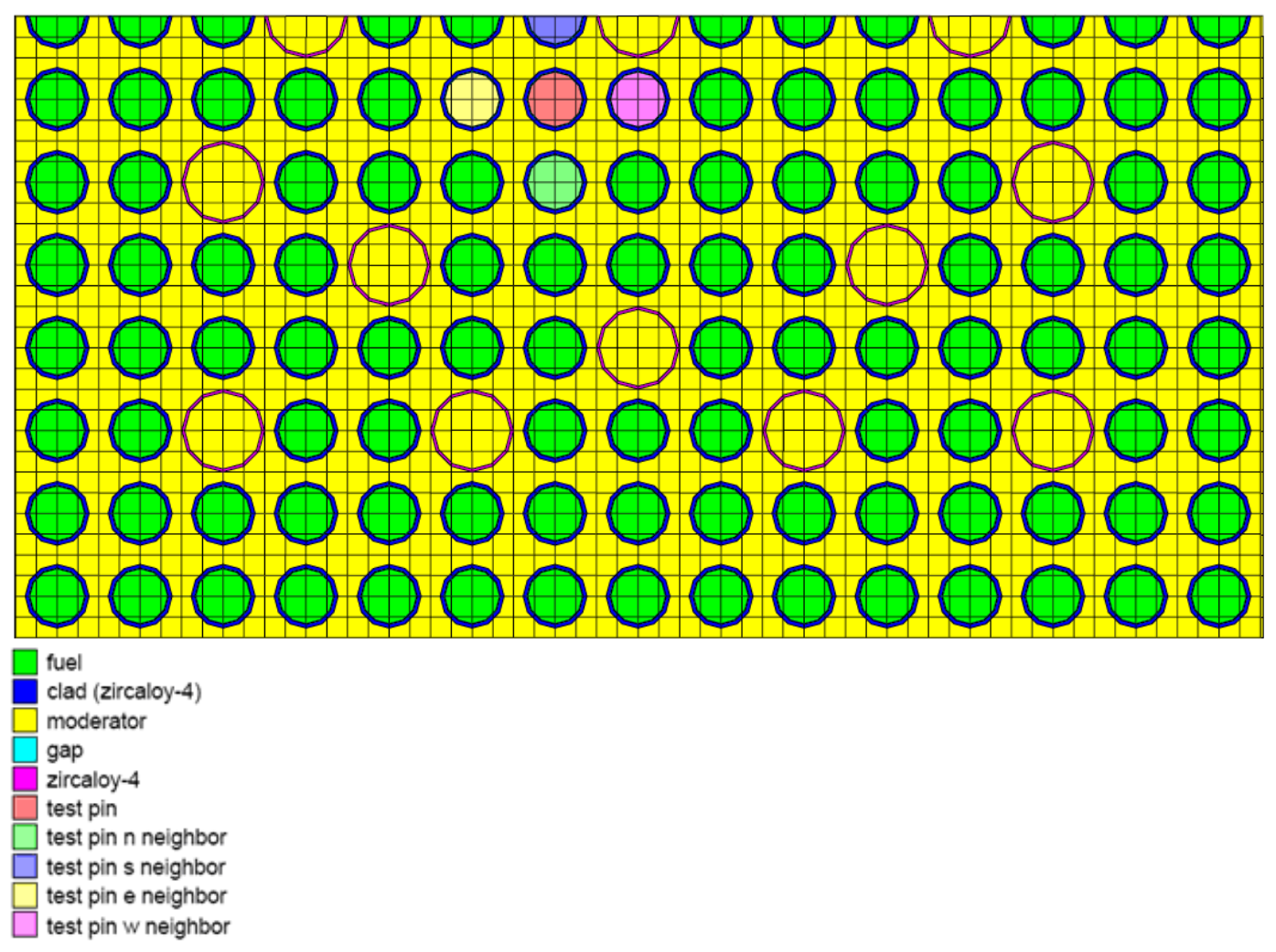

Fig. 24. TRITON/NEWT model for Turkey Point Unit 3 assembly D01, rod G9.

\subsubsection{H. B. Robinson Unit 2}

The TRITON/NEWT models for H. B. Robinson assembly BO-5 for cycles 1 and 2 of irradiation used the one-quarter assembly models illustrated in Fig. 25. Individual depleting mixtures were specified for the measured rod and its adjacent nearest-neighbor fuel rods, as well as for the burnable absorber material (for cycle 1 of irradiation only). All other fuel rods were treated as a single depletion material with uniform composition. It was assumed that the surrounding assemblies had the same enrichment and irradiation history as the measured assembly, so that reflective boundary conditions are applicable. This assumption has a negligible effect on the results of the calculations since the measured fuel rod had an inner assembly location.

The model shown in Fig. 25(a) provided the concentrations of nuclides in all depleted fuel mixtures at the end of cycle 1. These mixture concentrations served as input data for the second model, shown in Fig. 25(b), which was used to simulate the depletion of the assembly during cycle 2. Note that the burnable poison was removed when the average assembly burnup had reached 18,000 MWd/MTU (Ref. 27) and the burnup values of assembly BO-5 at the end of cycles 1 and 2 were 18.613 and $28.03 \mathrm{MWd} / \mathrm{MTU}$, respectively (Ref. 28). Therefore, the assembly model illustrated in Fig. 25(a) was also used to simulate the last $613 \mathrm{MWd} / \mathrm{MTU}$ burnup in cycle 1 . The impact of this modeling approximation on the accuracy of the calculation results is considered to be very small since the $613 \mathrm{MWd} / \mathrm{MTU}$ burnup represents approximately $2 \%$ of the total assembly burnup. 


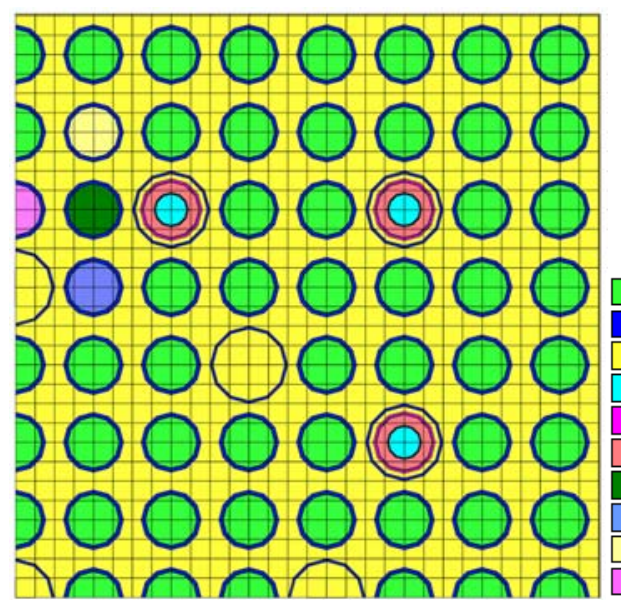

(a)

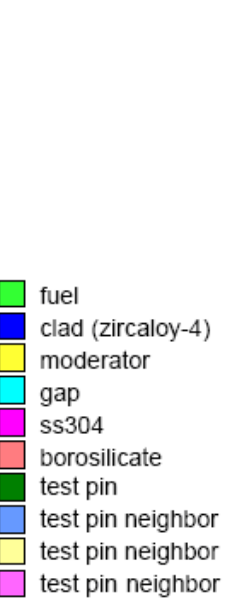

test pin neighbor

Fig. 25. TRITON/NEWT model for H. B. Robinson Unit 2 assembly BO-5: (a) for cycle 1 of irradiation; (b) for cycle 2 of irradiation.

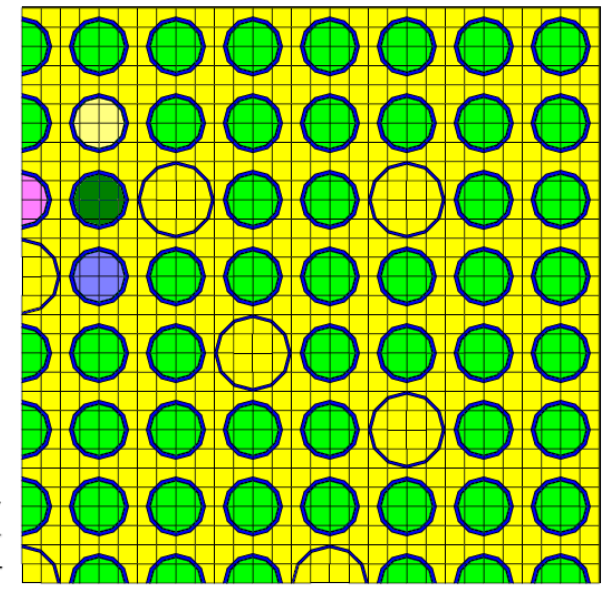

(b)

\subsubsection{Calvert Cliffs}

Half assembly models were used for the analysis of the nine measured fuel samples, as illustrated in Fig. 26, Fig. 27, and Fig. 28 for assemblies D047, D101, and BT03, respectively. Individual depleting mixtures were specified for the measured rod and its adjacent nearest-neighbor fuel rods, as well as for the burnable absorber materials. All other fuel rods were treated as a single depletion material with uniform composition. For samples from rod NBD107 of assembly BT03, two models were used: one for cycle 1, in which the assembly included burnable absorber rods (see Fig. 28), and one for cycles 2-4, where the absorber rods were not present (see Fig. 29). The first of these two models provided the concentrations of nuclides in all depleted fuel mixtures at the end of cycle 1; these data served as input data for the second model that simulated the depletion of the assembly during cycles 2 to 4 .

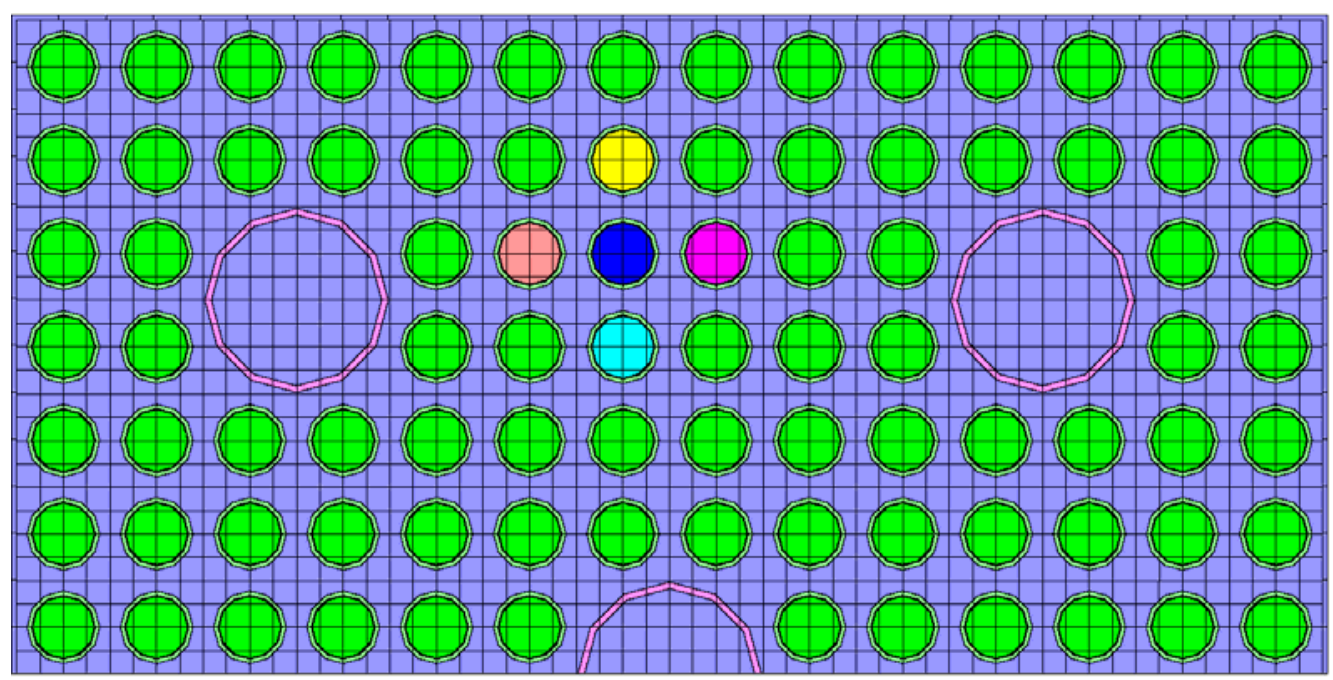

regular fuel pin $\square$ measured fuel pin $\square \square \square \quad$ nearest neighbors of measured fuel pin moderator

Fig. 26. TRITON/NEWT model for Calvert Cliffs samples from assembly D047. 


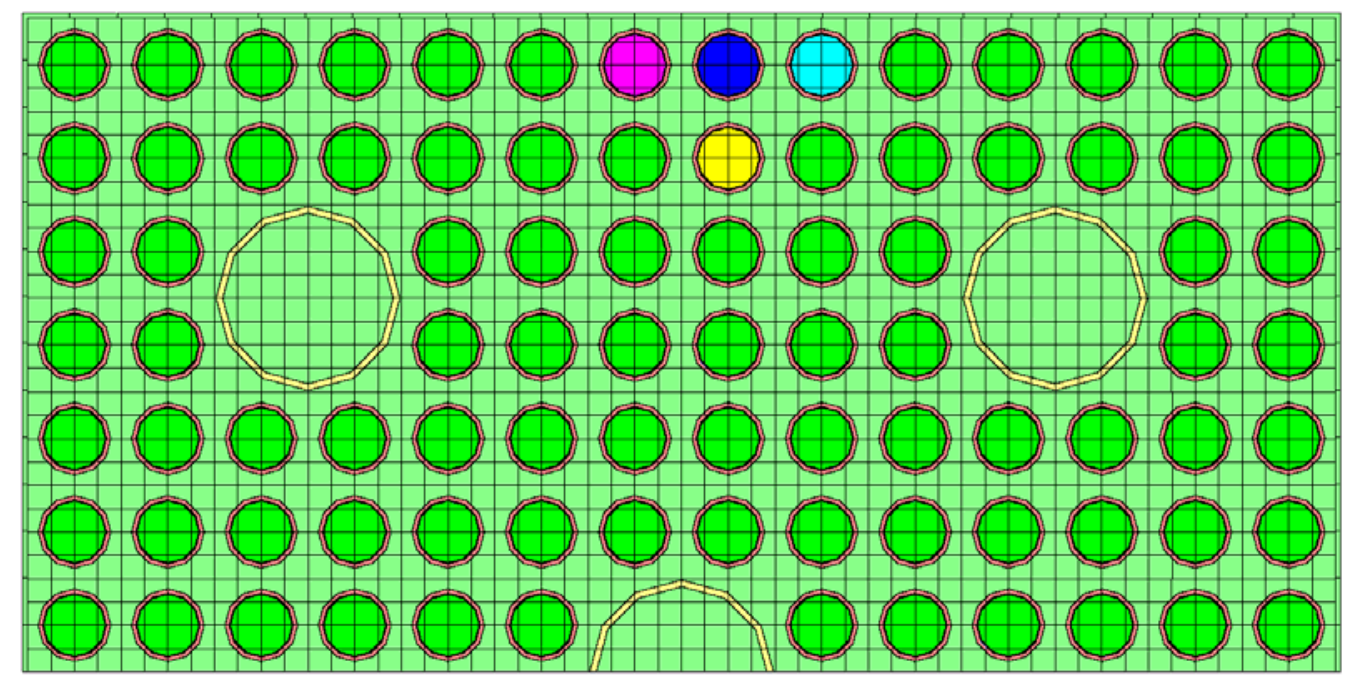

regular fuel pin $\square$ measured fuel pin $\square \square$ nearest neighbors of measured fuel pin guide tube moderator

Fig. 27. TRITON/NEWT model for Calvert Cliffs samples from assembly D101.

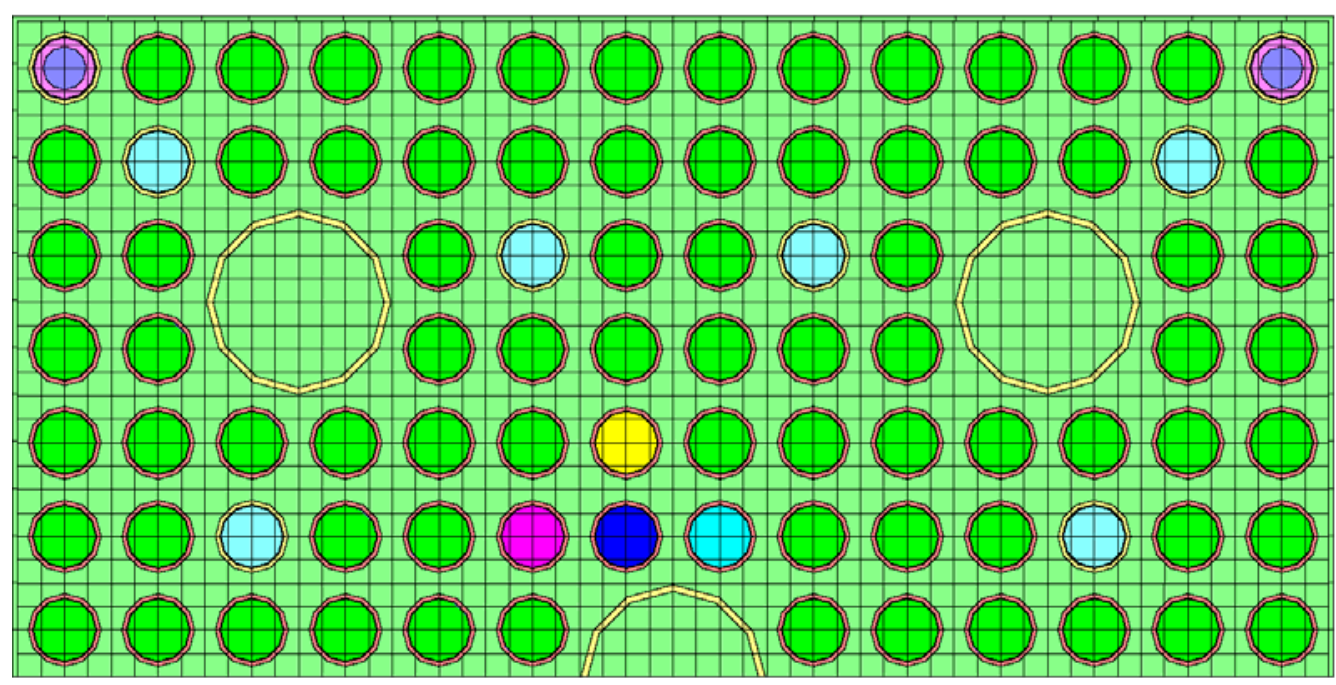

regular fuel pin $\square$ measured fuel pin $\square \square$ nearest neighbors of measured fuel pin guide tube moderator $\square$ gap in test rod $\square$ test rod material SS304 $\square$ BPR

Fig. 28. TRITON/NEWT model for Calvert Cliffs samples from assembly BT03, cycle 1. 


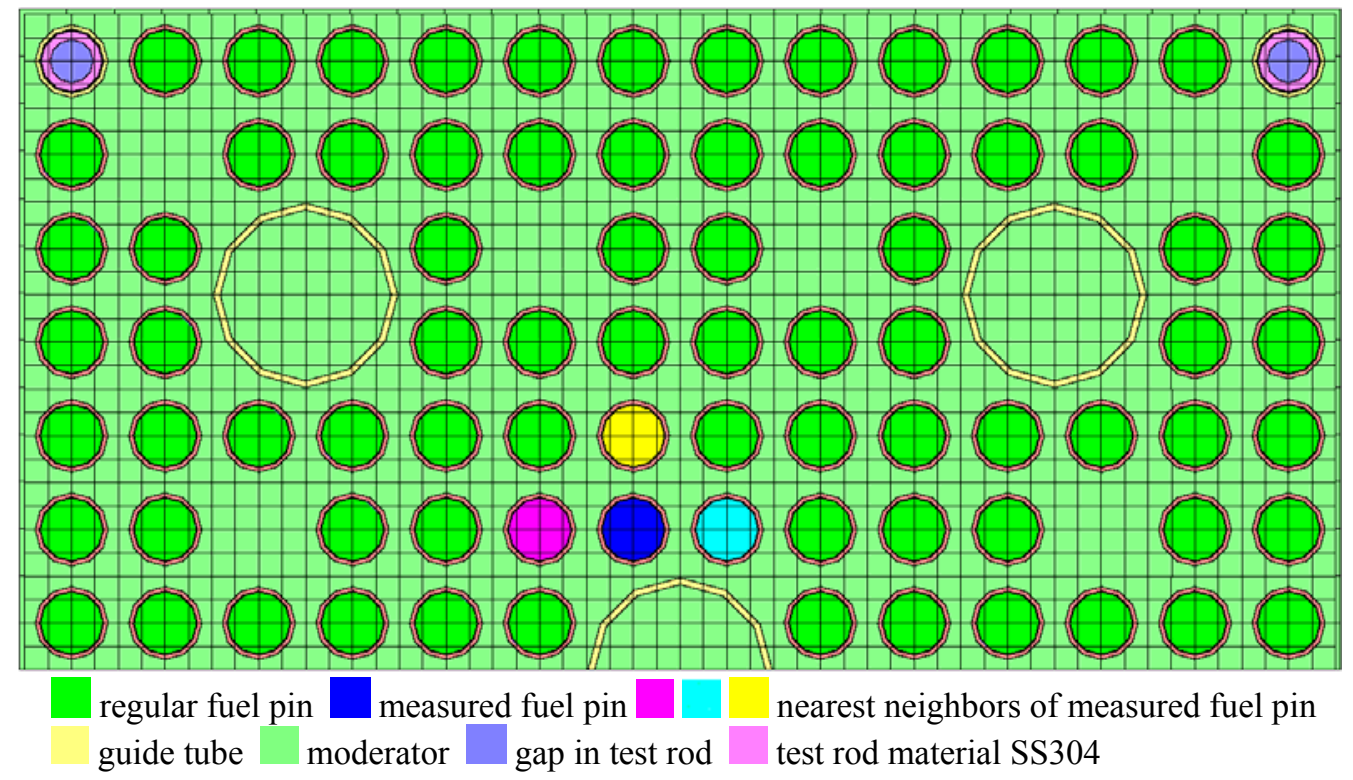

Fig. 29. TRITON/NEWT model for Calvert Cliffs samples from assembly BT03, cycles 2-4.

T-DEPL simulations were carried out for each sample. For samples from fuel rod MKP109, the available burnup and power data were slightly adjusted, in order to obtain a calculated ${ }^{148} \mathrm{Nd}$ concentration in agreement with the measured value. The calculated burnup values are 27.11,36.90, and 44.13 GWd/MTU for sample MKP109-LL, MKP109-CC, and MKP109-P, respectively. These values are slightly different from the available burnups ${ }^{30}$ of $27.35,37.12$, and $44.34 \mathrm{GWd} / \mathrm{MTU}$, respectively (see Table 70).

\subsubsection{Takahama Unit 3}

Fuel rod SF97, residing in assembly NT3G24, was simulated using a one-half assembly geometry model because the rod was located on a quarter-assembly symmetry axis. The models for fuel rods SF95 and SF96 from assembly NT3G23 used a one-quarter assembly model. The three models used for each measured rod are illustrated in Fig. 30 through Fig. 32. In each model, the measured fuel rod, as well as the fuel rods adjacent to it, was individually depleted. The moderator density and temperature values are provided in Table 77. The variation of the soluble boron in the moderator given in Table 79 was simulated through the use of the TIMETABLE input block in the TRITON input. Note that fuel rods SF95 and SF97 are located on the edge of the assembly and therefore possibly subjected to edge effects. However, as no information was available on the surrounding assemblies, these assemblies were not included in the model.

As mentioned previously, the sample reported burnups were normalized to the measured ${ }^{148} \mathrm{Nd}$ content. In the case of the samples from rod SF96, the simulation using the sample power (and burnup) in Table 77 yielded a calculated ${ }^{148} \mathrm{Nd}$ concentration that was within 4 to $10 \%$ less than the measured value, depending on the sample. This difference is much larger than the maximum 3\% error in burnup specified in the JAERI report. ${ }^{41}$ The sample burnup determination by JAERI was made using the ASTM E 321-79 standard method that estimates the burnup (in GWd/MTU units) by multiplying the value of the burnup rate $\left(\%\right.$ FIMA $=$ fission per initial metal atom in percent value that is based on the measured ${ }^{148} \mathrm{Nd}$ content) by a factor of $9.6 \pm 0.3$ (Ref. 74). However, derivation of this factor is based on a recoverable energy per fission (MeV/fission) value obtained for a system that is near critical. While this assumption is 
valid for a large-scale reactor system, it may not apply on a local level. For the case of a gadolinia-bearing rod or other poison rod the absorption rate may significantly exceed the fission rate. The capture reactions in gadolinium contribute prompt capture gamma-ray energy to the system that is not accounted for in the ASTM method, but may be accounted for in modern depletion computer codes (such as ORIGEN-S). The applicability of simplified methods for burnup determination needs to be carefully considered, particularly when applied to nonstandard type fuel.

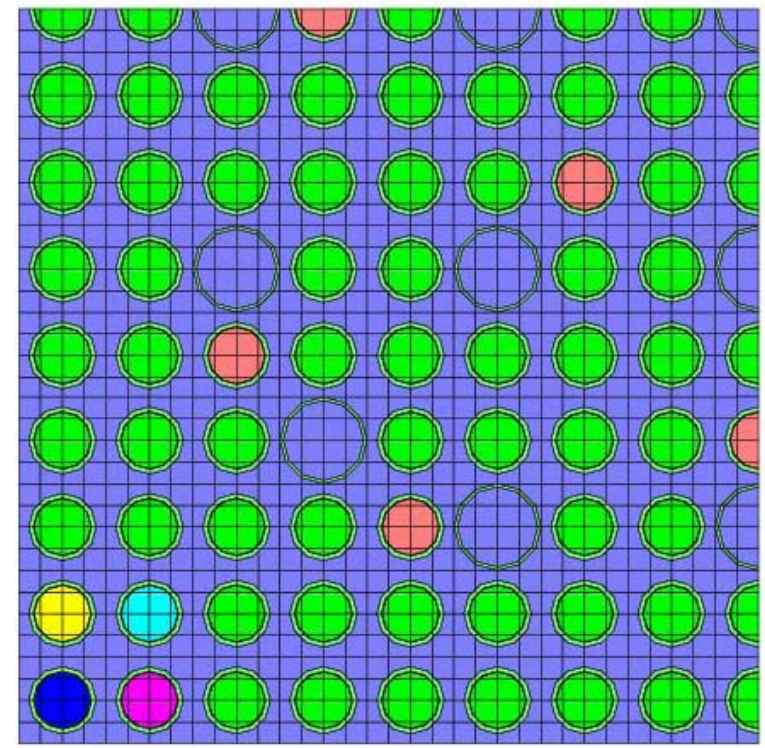

regular fuel pin $\square$ test fuel pin $\square$ neighbors of test fuel pin gadolinia fuel pin moderator

Fig. 30. TRITON/NEWT model for Takahama-3 SF95 spent fuel samples.

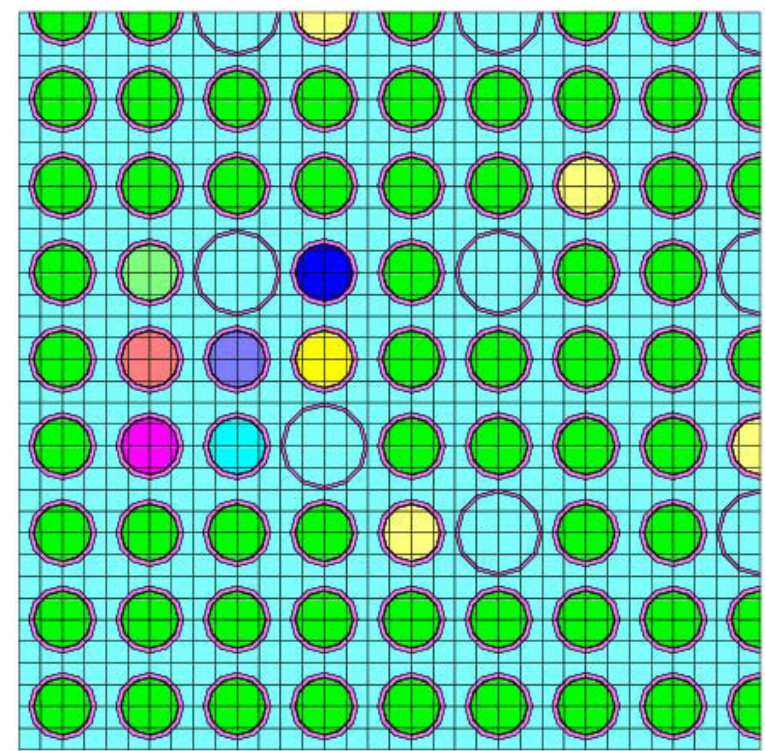

regular fuel pin test fuel pin gadolinia fuel pin moderator

Fig. 31. TRITON/NEWT model for Takahama-3 SF96 spent fuel samples. 


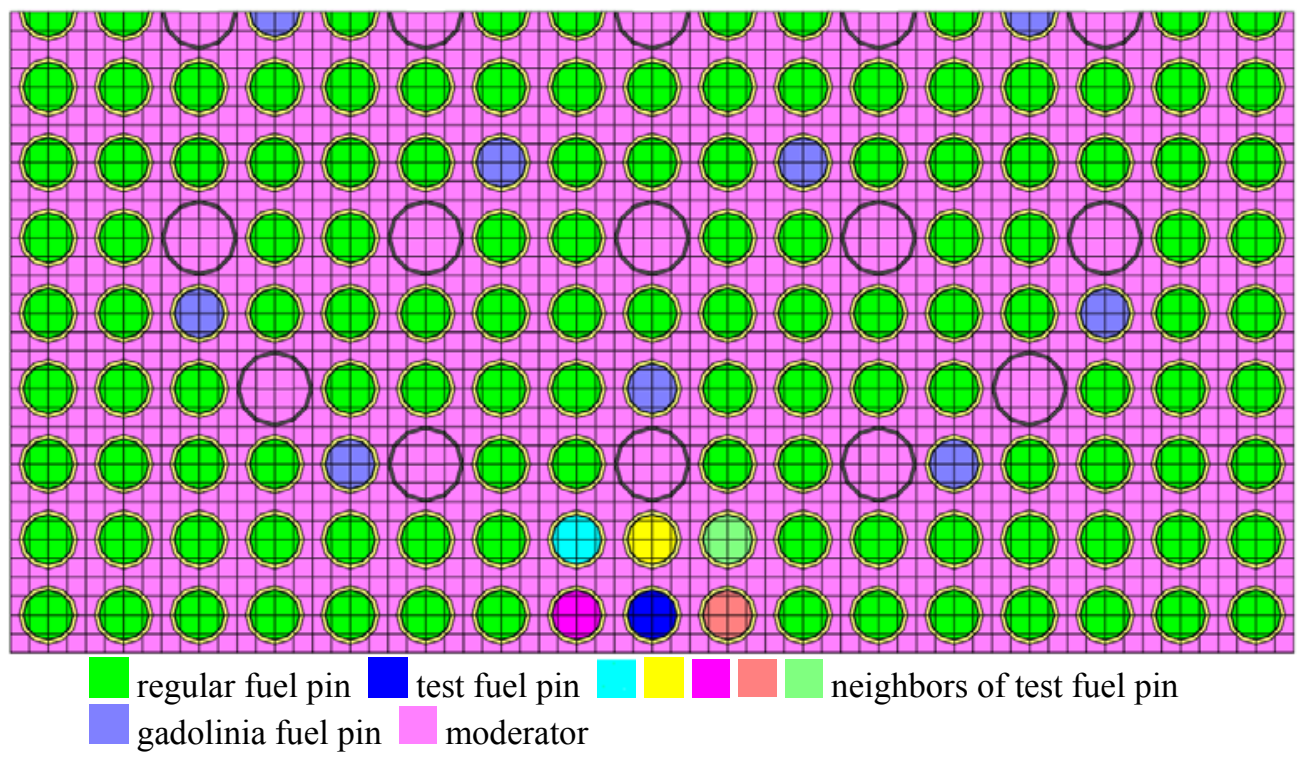

Fig. 32. TRITON/NEWT model for Takahama-3 SF97 spent fuel samples.

\subsubsection{TMI Unit 1}

Assembly NJ05YU that hosted the fuel rod H6 (see Fig. 16), from which 11 samples were selected, was irradiated in two consecutive cycles, cycle 9 and cycle 10. The BPRs present during cycle 9 were removed in cycle 10. Separate TRITON models were developed to accurately represent this change in the assembly geometry, as illustrated in Fig. 33. Given the symmetry and the location of rod H6 in assembly NJ05YU, the models for the analysis of samples selected from this rod represent only half of the assembly geometry, with a reflective boundary condition on the left side of the configuration and white boundary conditions on the other three bounding surfaces. The geometry and material data were used as given in Table 81, and the power data as provided in Table 82. Six fuel mixtures were specified: one corresponding to the measured rod, four to the nearest neighbor fuel rods, and one to the rest of the fuel rods in the assembly. At the end of the depletion simulation for cycle 9, the isotopic composition for each of these six fuel mixtures was extracted and used as input data in the model corresponding to cycle 10 (with no BPR present). A total of 232 nuclides present in the SCALE multigroup transport library, representing the main light elements, actinides, and fission products, were included to represent the fuel composition at the start of cycle 10. The variation of the soluble boron content in the coolant and of the temperature in fuel during irradiation, as given in Table 84 and Table 87, for samples from assemblies NJ05YU and NJ070G, respectively, was modeled through the use of the TIMETABLE input block in TRITON; ten burnup steps per cycle were used for depletion.

All three rods in assembly NJ070G, from which samples were selected for measurement, were edge rods located along one side of the assembly, with one of these rods placed at the corner of the assembly. The computational models used for the analysis of these samples include information on the assembly surroundings. The models for rods $\mathrm{O} 12$ and $\mathrm{O} 13$ are similar and include a quarter of assembly NJ070G and a quarter of the assembly surrounding it on the side on which the samples are located, as illustrated for rod $\mathrm{O} 12$ in Fig. 34. As observed in this figure, in order to better approximate the local environment, given the close proximity of the measured rod to the assembly boundary, the nearest neighboring rods were represented by using different mixtures; one of these neighboring rods is located in a different assembly. In the case of the corner rod O1, the TRITON model included a quarter of assembly NJ070G and a quarter of each of the three surrounding assemblies that share the same corner point with assembly 
NJ070G (refer to Table 89 for the characteristics of the surrounding assemblies). This model is illustrated in Fig. 35. TRITON calculations were also performed for the assembly from batch $11 \mathrm{C}$ adjoining the south side of assembly NJ070G (see Fig. 18) to simulate its irradiation during cycle 9. The fuel composition for this assembly calculated at the end of cycle 9 was used as the fuel composition at the beginning of cycle 10 for this assembly in the model illustrated in Fig. 35.

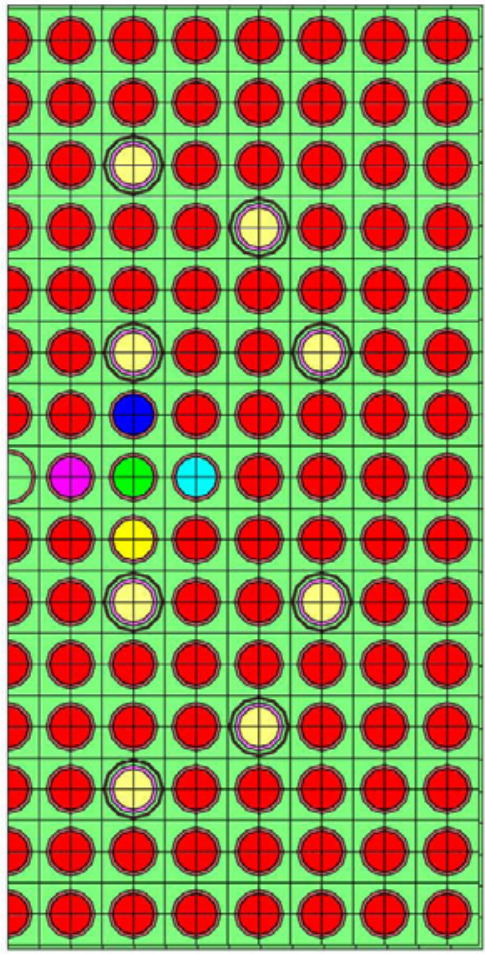

Cycle 9

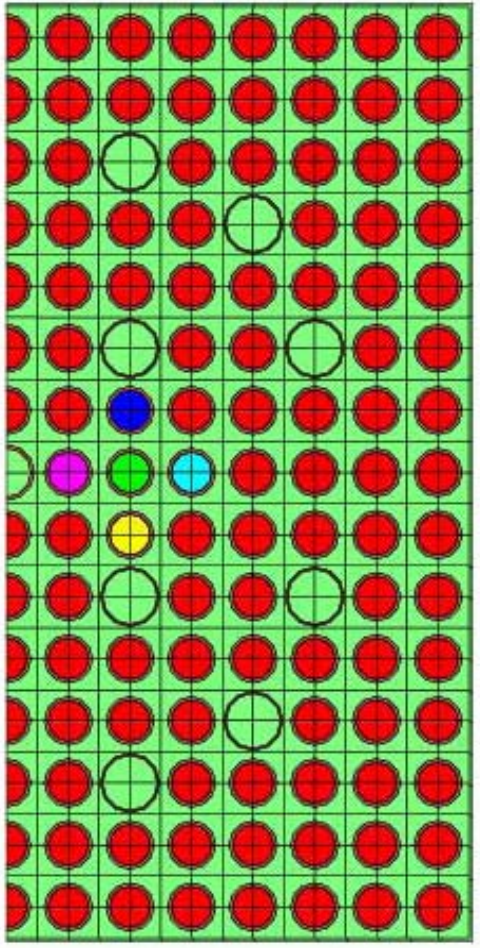

Cycle 10

regular fuel pin measured fuel pin $\mathrm{H} 6$ BPR absorber BPR clad

Fig. 33. TRITON/NEWT model for TMI-1 samples in assembly NJ05YU. 


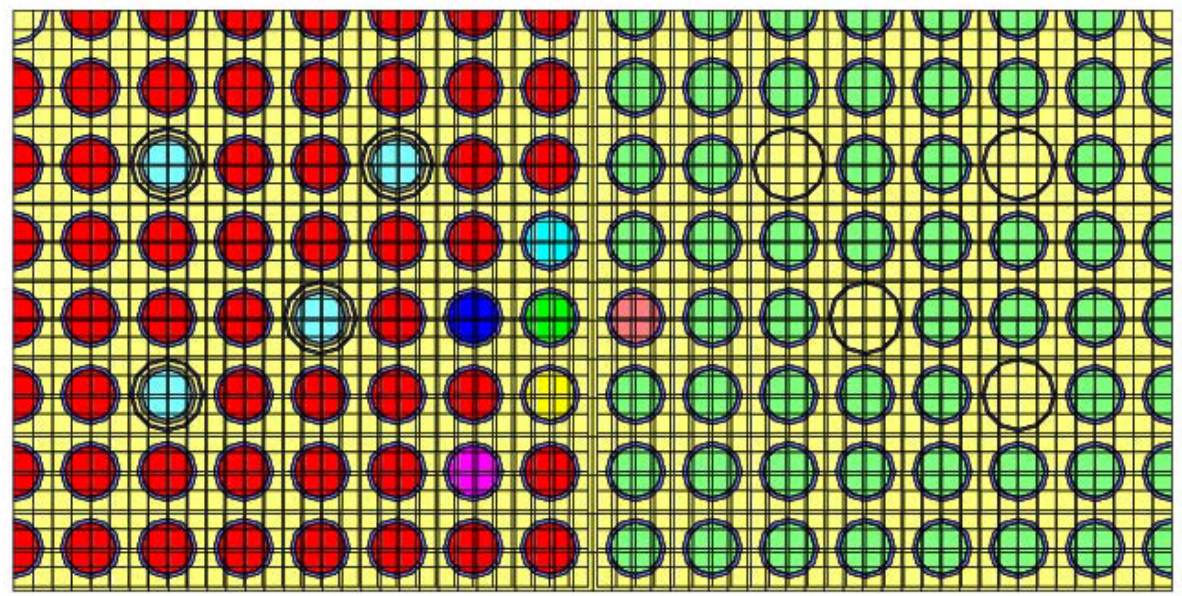

measured fuel pin $\mathrm{O} 12$ regular fuel pins in assembly NJ070G gadolinia fuel pin fuel pins in neighboring assembly moderator BPR absorber

Fig. 34. TRITON/NEWT model for TMI-1 samples in rod O12 of assembly NJ070G.

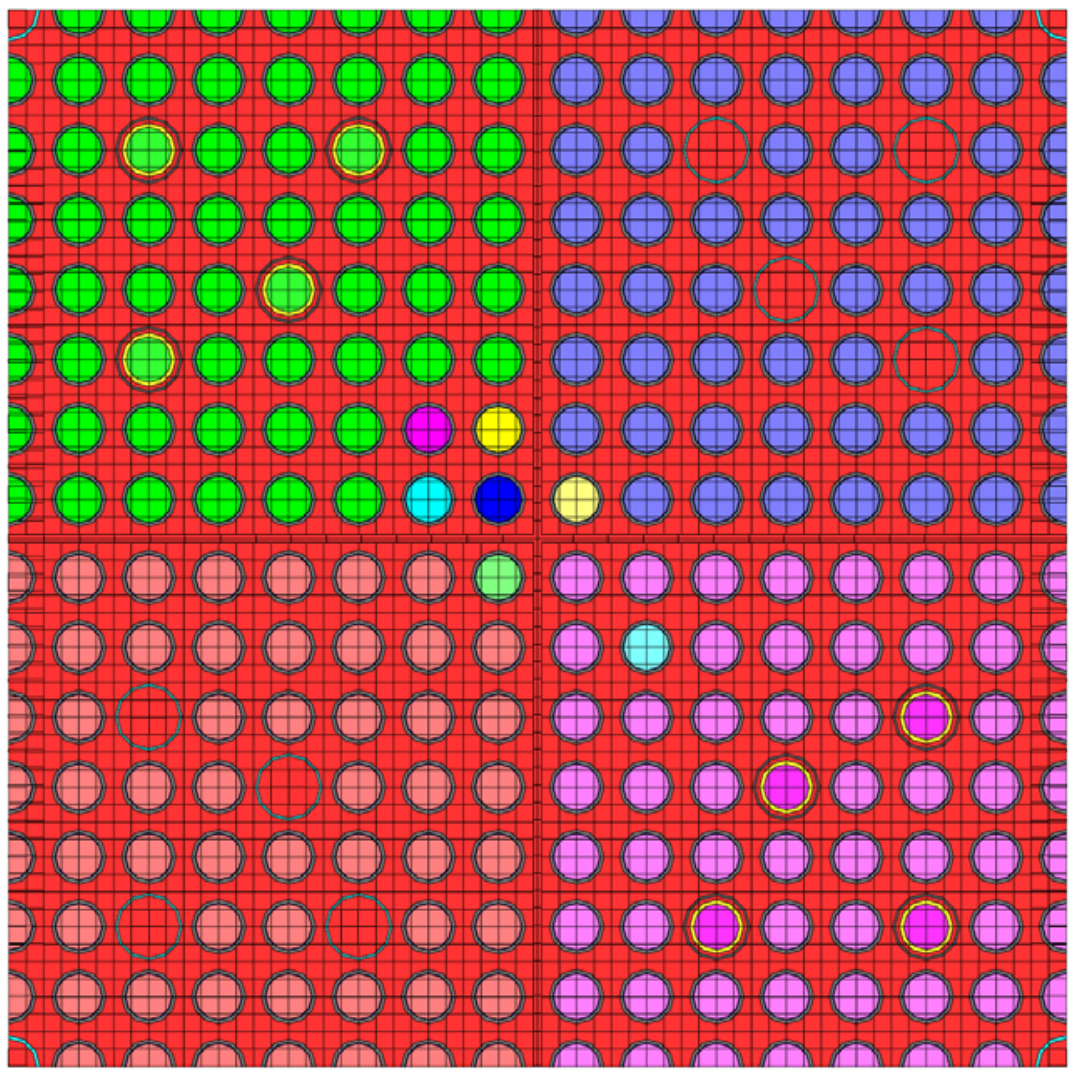

nj070g assy

measured pin

$\mathrm{n}$ pin neighbor

w pin neighbor

gd pin

s neighbor assy

s pin neighbor

e neighbor assy

e pin neighbor

se neighbor assy

se neighbor assy gd pin

clad

moderator

bpr abs

gap

bpr clad

bpr1 clad

guide tube

Fig. 35. TRITON/NEWT model for TMI-1 samples in rod O1 of assembly NJ070G. 


\subsubsection{Gösgen: ARIANE Program}

The analysis of sample GU1 was carried out by using a quarter assembly model of assembly 12-40, as shown in Fig. 36. The geometry, material, and burnup data used in the TRITON model were as given in Table 90 to Table 92. Replacement of some of the fuel rods during cycles 14 and 15 was not modeled because insufficient information on the configurations was available. However, the replacement rods were indicated to have burnup similar to that of the original rods, and not modeling the fuel rods reconfiguration was deemed to be of minor importance.

The depletion history of the fuel rod from which samples GU3 and GU4 were selected, including the reconstitution of the fuel assembly, was explicitly simulated with TRITON. One TRITON model, as illustrated in Fig. 37, was used to model the depletion of assembly 16-01 during cycles 16 and 17; individual depleting mixtures were used for the measured rod and its nearest neighbor fuel rods, whereas all other fuel rods in the assembly were treated as a single depletion material with uniform composition. The nuclide compositions for the measured rod and the average composition for the regular fuel rods in assembly 16-01 were saved at the end of the simulation for cycle 17 and used in the input file for simulating assembly 17-01 during cycle 18. The average composition for the regular fuel rods from assembly 16-01 was used as composition data for the three replacement rods that were, in addition to the measured rod, inserted in the rebuilt assembly 1701 at the beginning of cycle (BOC) 18 .

The TRITON model for assembly 17-01 is illustrated in Fig. 38. As mentioned in Section 8.8, it is known that the average burnup of assembly $17-01$ at BOC- 18 was about $20 \mathrm{GWd} / \mathrm{MTU}$. To determine the composition of the spent fuel for the 201 fuel rods in this assembly from the total of 205 rods, once the composition for the four replacement rods was calculated, an additional TRITON model was used to simulate the depletion of assembly 17-01 prior to the reconstitution. This model is similar to that illustrated in Fig. 37 but considered a single depletion mixture for all the fuel rods in the assembly; this mixture was depleted to a burnup of $20 \mathrm{GWd} / \mathrm{MTU}$ for sample GU3 and to a burnup of $9.71 \mathrm{GWd} / \mathrm{MTU}$ for sample GU4 (Ref. 48, Table 3.b), and the composition of the depletion mixture was saved to be used in the depletion model of assembly 17-01 during cycle 18 .

The sample burnups used in the code simulations were normalized to the measured ${ }^{148} \mathrm{Nd}$ concentration. The sample burnup values based on measured ${ }^{148} \mathrm{Nd}$ for samples GU1, GU3, and GU4 were 60.7, 53.2, and $31.1 \mathrm{GWd} / \mathrm{MTU}$, respectively. These burnups based on experimental data are in good agreement with the burnup values 59.7, 52.5, and 29.1 GWd/MTU from operator data. The burnup history data presented in Table 91 and Table 92 were adjusted by a constant factor to correspond to the measurementbased burnup. 


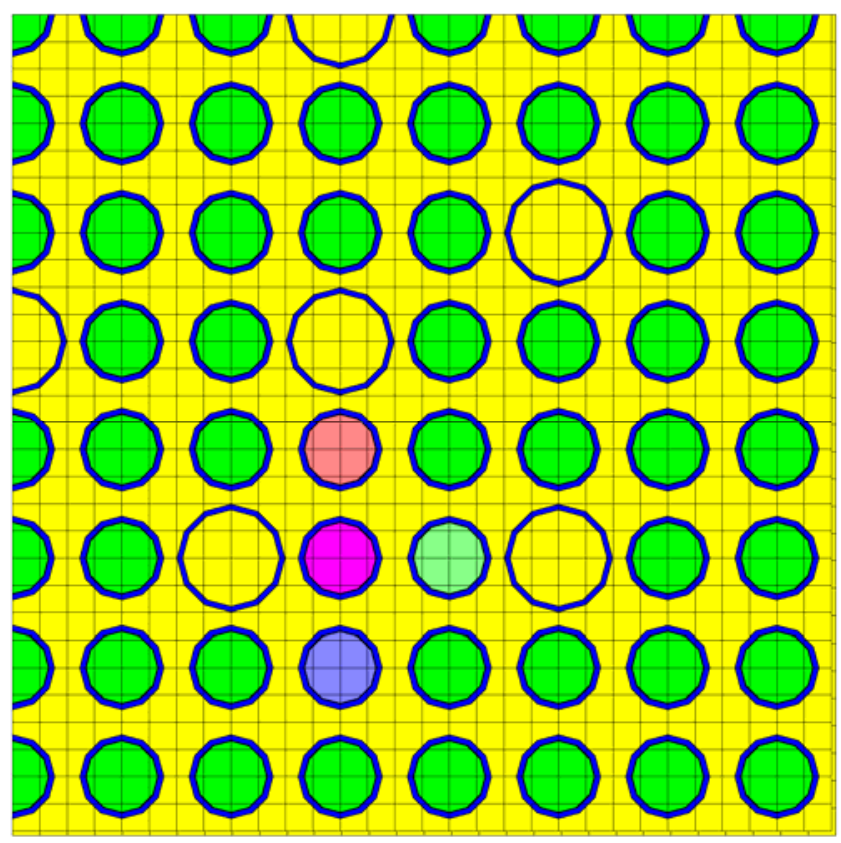

standard fuel rod $\square$ measured fuel rod $\_$moderator $\square$ nearest neighbors of measured fuel rod

Fig. 36. TRITON/NEWT assembly model for Gösgen (ARIANE) - sample GU1.

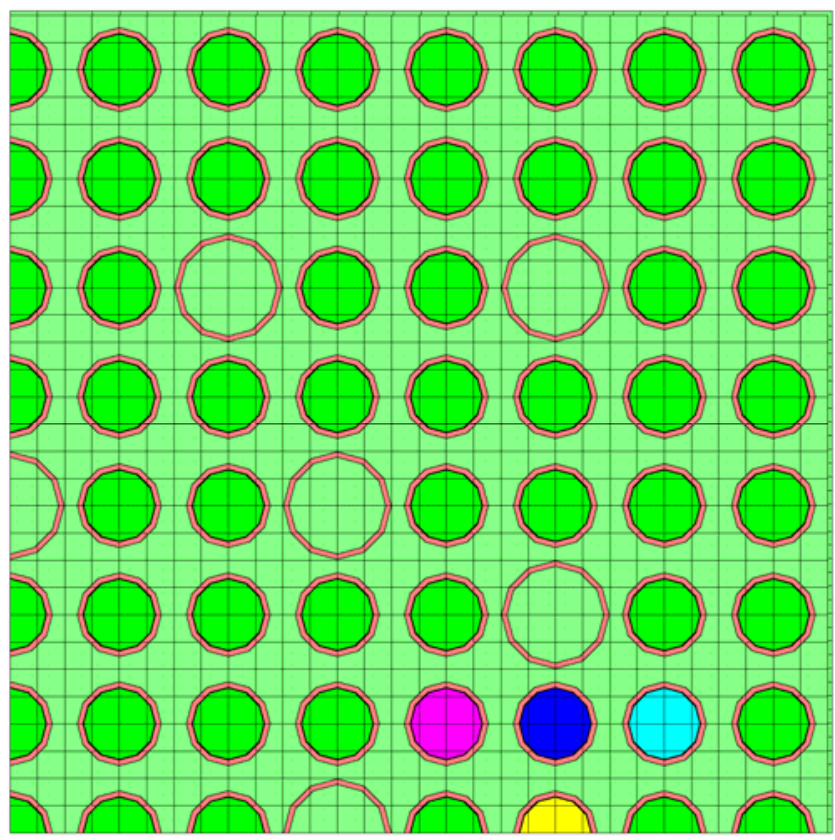

standard fuel rod $\square$ measured fuel rod $\square \square$ nearest neighbors of measured fuel rod $\square$ moderator

Fig. 37. TRITON/NEWT assembly model for Gösgen (ARIANE) - sample GU3/4, cycles 16 -17. 


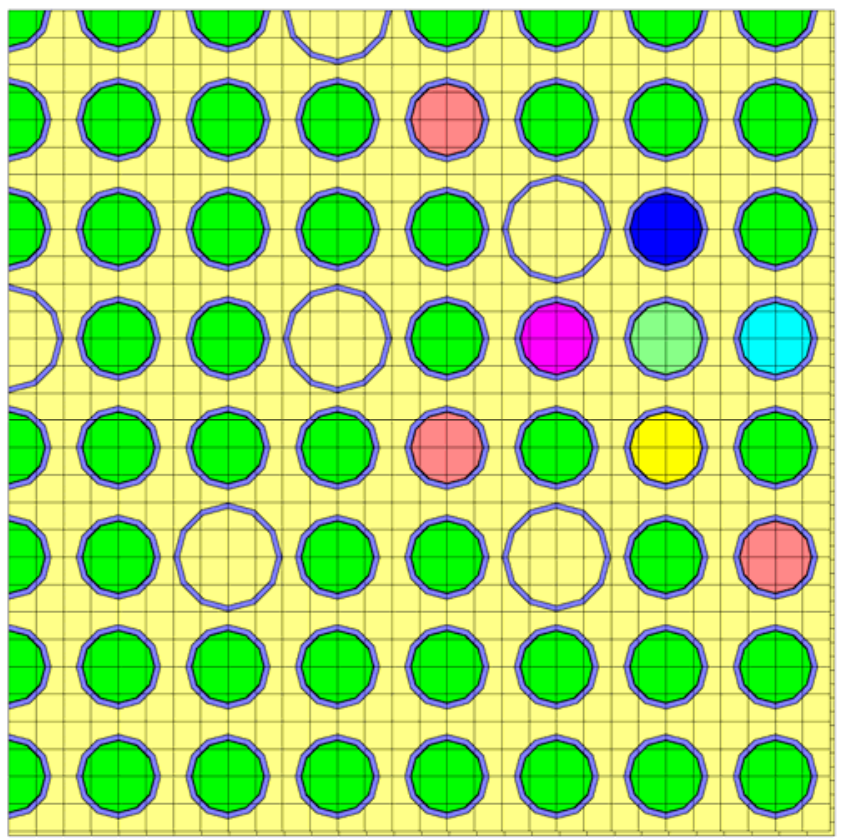

standard fuel rod measured fuel rod nearest neighbors of measured fuel rod moderator replacement rods from assembly 1601

Fig. 38. TRITON/NEWT assembly model for Gösgen (ARIANE) - sample GU3/4, cycle 18.

\subsubsection{GKN II}

The geometry of the $18 \times 18$ GKN II assembly 419 was modeled in full detail, as illustrated in Fig. 39 . White boundary conditions were used for the assembly bounding surfaces. As observed, there is a slight asymmetry in the assembly with respect to the placement of the gadolinia-bearing rods. The average power used in the simulations for each of the four irradiation cycles was taken from Table 94. The timedependent variation of the boron concentration in the moderator, as well as of the moderator density and fuel and moderator temperatures, as given in Table 94 and Table 96, were simulated through the TIMETABLE input block in the TRITON input. The use of the provided sample burnup based on the gamma scan, 54.095 GWd/MTU, yielded a calculated ${ }^{148} \mathrm{Nd}$ content consistent with the measured value. 


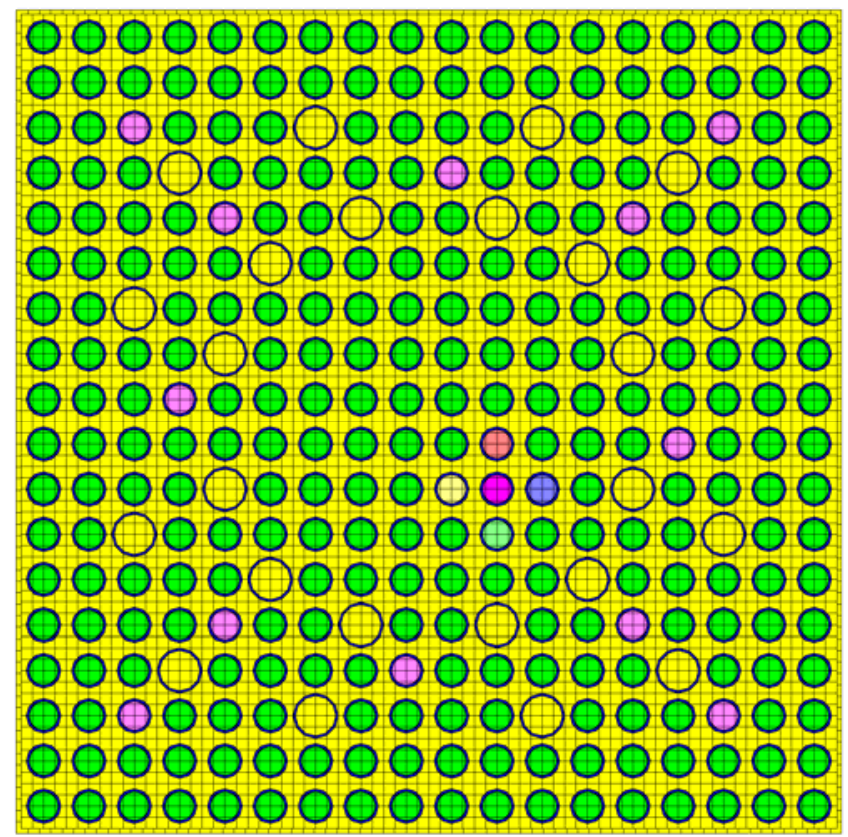

standard fuel rod nearest neighbors of measured rod moderator gadolinia fuel rod

Fig. 39. TRITON/NEWT assembly model for GKN II (REBUS) spent fuel sample. 



\section{CALCULATION RESULTS}

The current SCALE validation study evaluated 118 spent fuel samples from 37 fuel rods irradiated in nine PWR reactors, with sample initial enrichment varying from 2.453 to $4.657 \mathrm{wt} \%{ }^{235} \mathrm{U}$ and burnup varying from 7.2 to $70.4 \mathrm{GWd} / \mathrm{MTU}$ (refer to Table 4 for the evaluated samples). The calculation results, which are listed in the tables included in Section 10.1, are reported as the ratio of the experimental-to-calculated (E/C) isotopic concentrations. This ratio is suitable for use in the isotopic composition validation methodology because (1) it shows the significance of deviations between calculated and measured isotopic concentrations and (2) it can be applied directly as a multiplicative correction factor to spent fuel compositions used in criticality calculations employing burnup credit to determine the impact of isotopic composition bias and bias uncertainty on $k_{\text {eff. }}$ Graphical representations of the calculation results for the burnup-credit nuclides are presented in Appendix A.

\subsection{RESULTS OF THE T-DEPL CALCULATIONS}

The E/C ratios for Trino Vercellese, Obrigheim, Turkey Point, H. B. Robinson, Calvert Cliffs, Takahama, TMI, Gösgen (ARIANE), GKN, and Gösgen (MALIBU) spent fuel samples are listed in Table 97-Table 106 , respectively. The tables also present the percentage deviations of the $\mathrm{E} / \mathrm{C}$ values from unity, $\mathrm{E} / \mathrm{C}-1$ $(\%)$, to clearly indicate the significance of deviations between calculation and measurement isotopic concentrations. 
Table 97. SCALE calculation results for Trino Vercellese spent fuel samples

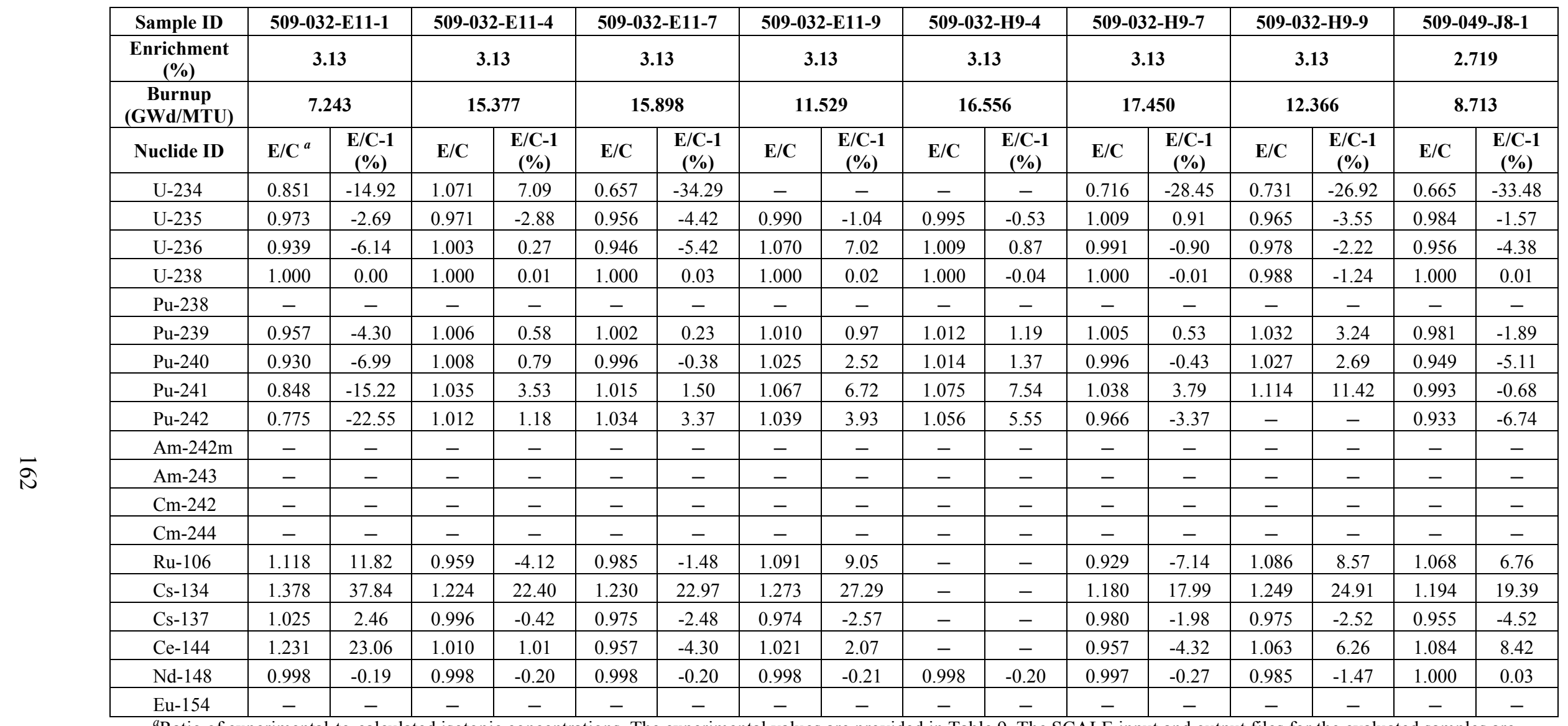

${ }^{a}$ Ratio of experimental-to-calculated isotopic concentrations. The experimental values are provided in Table 9. The SCALE input and output files for the evaluated samples are provided on the accompanying DVD (see Appendix B). 
Table 97. SCALE calculation results for Trino Vercellese spent fuel samples (continued)

\begin{tabular}{|c|c|c|c|c|c|c|c|c|c|c|c|c|c|c|c|c|}
\hline Sample ID & \multicolumn{2}{|c|}{ 509-049-J8-4 } & \multicolumn{2}{|c|}{ 509-049-J8-7 } & \multicolumn{2}{|c|}{ 509-049-J8-9 } & \multicolumn{2}{|c|}{ 509-049-L5-1 } & \multicolumn{2}{|c|}{ 509-049-L5-4 } & \multicolumn{2}{|c|}{ 509-049-L5-9 } & \multicolumn{2}{|c|}{ 509-104-M11-7 } & \multicolumn{2}{|c|}{ 509-069-E11-1 } \\
\hline $\begin{array}{c}\text { Enrichment } \\
(\%)\end{array}$ & \multicolumn{2}{|c|}{2.719} & \multicolumn{2}{|c|}{2.719} & \multicolumn{2}{|c|}{2.719} & \multicolumn{2}{|c|}{2.719} & \multicolumn{2}{|c|}{2.719} & \multicolumn{2}{|c|}{2.719} & \multicolumn{2}{|c|}{3.897} & \multicolumn{2}{|c|}{3.130} \\
\hline $\begin{array}{c}\text { Burnup } \\
\text { (GWd/MTU) }\end{array}$ & \multicolumn{2}{|c|}{14.770} & \multicolumn{2}{|c|}{15.193} & \multicolumn{2}{|c|}{11.127} & \multicolumn{2}{|c|}{7.822} & \multicolumn{2}{|c|}{14.323} & \multicolumn{2}{|c|}{10.187} & \multicolumn{2}{|c|}{12.042} & \multicolumn{2}{|c|}{12.859} \\
\hline Nuclide ID & $\mathrm{E} / \mathrm{C}^{a}$ & $\begin{array}{c}\text { E/C-1 } \\
(\%)\end{array}$ & $\mathbf{E} / \mathbf{C}$ & $\begin{array}{c}\text { E/C-1 } \\
(\%)\end{array}$ & E/C & $\begin{array}{c}\text { E/C-1 } \\
(\%)\end{array}$ & $\mathbf{E} / \mathbf{C}$ & $\begin{array}{c}\text { E/C-1 } \\
(\%)\end{array}$ & $\mathbf{E} / \mathbf{C}$ & $\begin{array}{c}\text { E/C-1 } \\
(\%)\end{array}$ & $\mathrm{E} / \mathrm{C}$ & $\begin{array}{c}\text { E/C-1 } \\
(\%)\end{array}$ & $\mathrm{E} / \mathrm{C}$ & $\begin{array}{c}\text { E/C-1 } \\
(\%)\end{array}$ & $\mathbf{E} / \mathbf{C}$ & $\begin{array}{c}\text { E/C-1 } \\
(\%)\end{array}$ \\
\hline U-234 & 0.712 & -28.83 & - & - & - & - & 0.620 & -37.98 & 0.775 & -22.45 & 0.772 & -22.80 & - & - & - & - \\
\hline U-235 & 0.951 & -4.92 & 0.971 & -2.87 & 0.983 & -1.72 & 1.004 & 0.43 & 0.995 & -0.51 & 0.983 & -1.67 & 0.988 & -1.22 & 0.998 & -0.25 \\
\hline $\mathrm{U}-236$ & 0.969 & -3.11 & 0.978 & -2.20 & 0.986 & -1.40 & 0.935 & -6.52 & 0.958 & -4.15 & 1.018 & 1.75 & 1.034 & 3.36 & 1.050 & 4.95 \\
\hline U-238 & 1.000 & 0.01 & 0.999 & -0.07 & 1.000 & 0.00 & 1.000 & 0.00 & 1.000 & -0.01 & 1.000 & -0.01 & 1.000 & -0.05 & 1.001 & 0.12 \\
\hline $\mathrm{Pu}-238$ & - & - & - & - & - & - & - & - & - & - & - & - & - & - & 1.055 & 5.50 \\
\hline $\mathrm{Pu}-239$ & 0.983 & -1.69 & 1.018 & 1.82 & 1.005 & 0.45 & 1.004 & 0.35 & 0.993 & -0.70 & 0.999 & -0.09 & 1.026 & 2.65 & 0.949 & -5.06 \\
\hline $\mathrm{Pu}-240$ & 1.013 & 1.27 & 1.024 & 2.44 & 1.016 & 1.57 & 0.995 & -0.54 & 1.005 & 0.49 & 1.023 & 2.34 & 1.057 & 5.73 & 0.943 & -5.66 \\
\hline $\mathrm{Pu}-241$ & 1.066 & 6.61 & 1.085 & 8.54 & 1.084 & 8.41 & 1.035 & 3.51 & 1.040 & 4.04 & 1.090 & 8.96 & 1.116 & 11.61 & 0.949 & -5.11 \\
\hline $\mathrm{Pu}-242$ & 1.095 & 9.46 & 1.080 & 7.97 & 1.063 & 6.30 & 1.010 & 0.98 & 1.000 & -0.05 & 1.063 & 6.29 & 1.119 & 11.93 & 0.931 & -6.87 \\
\hline Am-242m & - & - & - & - & - & - & - & - & - & - & - & - & - & - & 0.809 & -19.06 \\
\hline Am-243 & - & - & - & - & - & - & - & - & - & - & - & - & - & - & - & - \\
\hline $\mathrm{Cm}-242$ & - & - & - & - & - & - & - & - & - & - & - & - & - & - & 1.399 & 39.88 \\
\hline $\mathrm{Cm}-244$ & - & - & - & - & - & - & - & - & - & - & - & - & - & - & - & - \\
\hline $\mathrm{Ru}-106$ & 1.040 & 3.98 & - & - & - & - & 1.132 & 13.22 & 1.001 & 0.06 & 1.129 & 12.88 & - & - & - & - \\
\hline Cs- 134 & 1.237 & 23.73 & - & - & - & - & 1.245 & 24.49 & 1.198 & 19.79 & 1.285 & 28.45 & 1.297 & 29.68 & 1.260 & 25.96 \\
\hline Cs-137 & 0.994 & -0.60 & - & - & - & - & 1.000 & 0.00 & 0.990 & -0.96 & 1.030 & 3.03 & 0.999 & -0.10 & 1.002 & 0.16 \\
\hline $\mathrm{Ce}-144$ & 0.997 & -0.35 & - & - & - & - & 1.135 & 13.55 & 1.001 & 0.08 & 1.090 & 8.99 & 1.018 & 1.81 & - & - \\
\hline Nd-148 & 0.999 & -0.10 & 0.998 & -0.16 & 0.999 & -0.11 & - & - & 1.001 & 0.12 & 0.999 & -0.11 & 0.995 & -0.50 & - & - \\
\hline $\mathrm{Eu}-154$ & - & - & - & - & - & - & - & - & - & - & - & - & - & - & 1.224 & 22.35 \\
\hline
\end{tabular}

${ }^{a}$ Ratio of experimental-to-calculated isotopic concentrations. The experimental values are provided in Table 9. The SCALE input and output files for the evaluated samples are provided on the accompanying DVD (see Appendix B). 
Table 97. SCALE calculation results for Trino Vercellese spent fuel samples (continued)

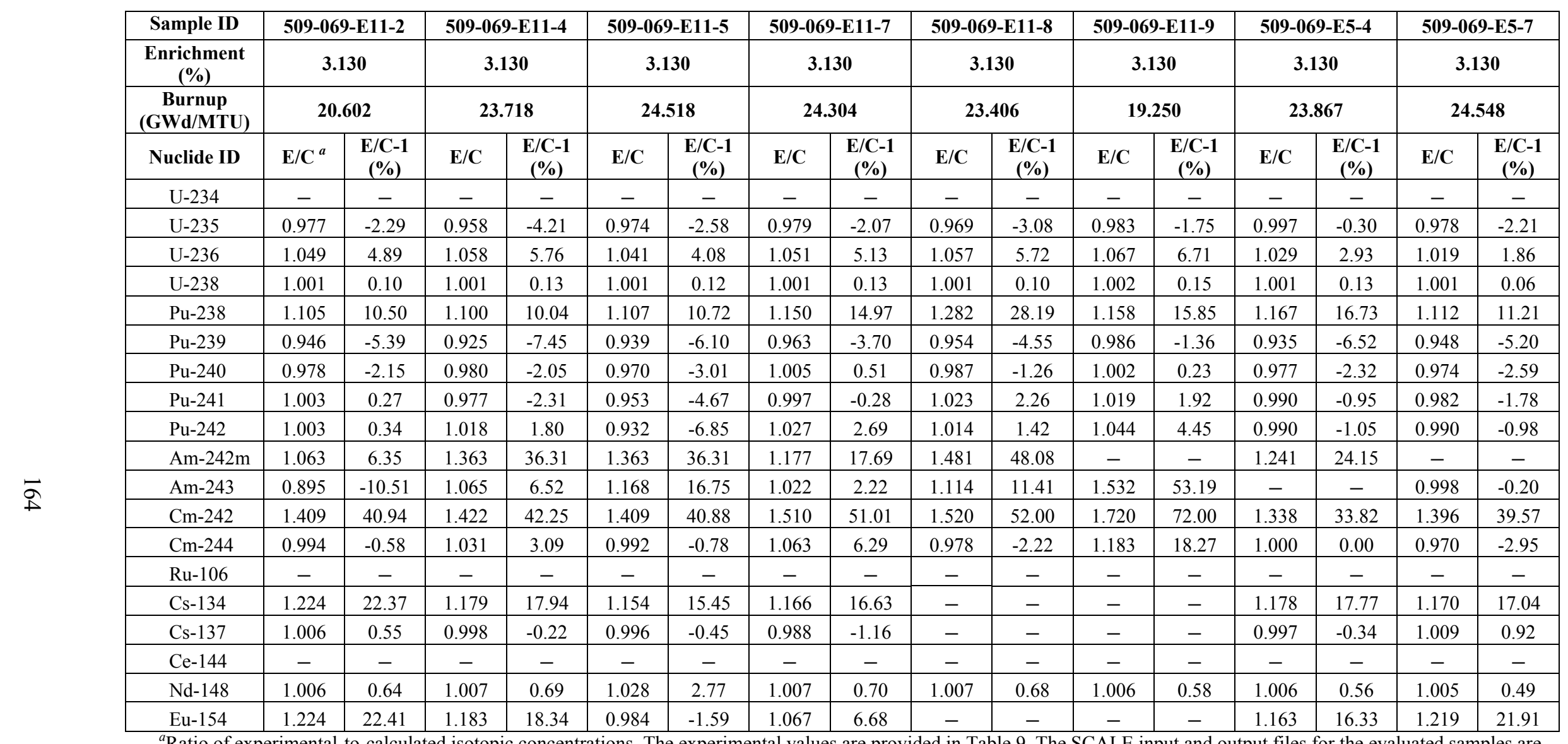

${ }^{a}$ Ratio of experimental-to-calculated isotopic concentrations. The experimental values are provided in Table 9. The SCALE input and output files for the evaluated samples are provided on the accompanying DVD (see Appendix B). 
Table 97. SCALE calculation results for Trino Vercellese spent fuel samples (continued)

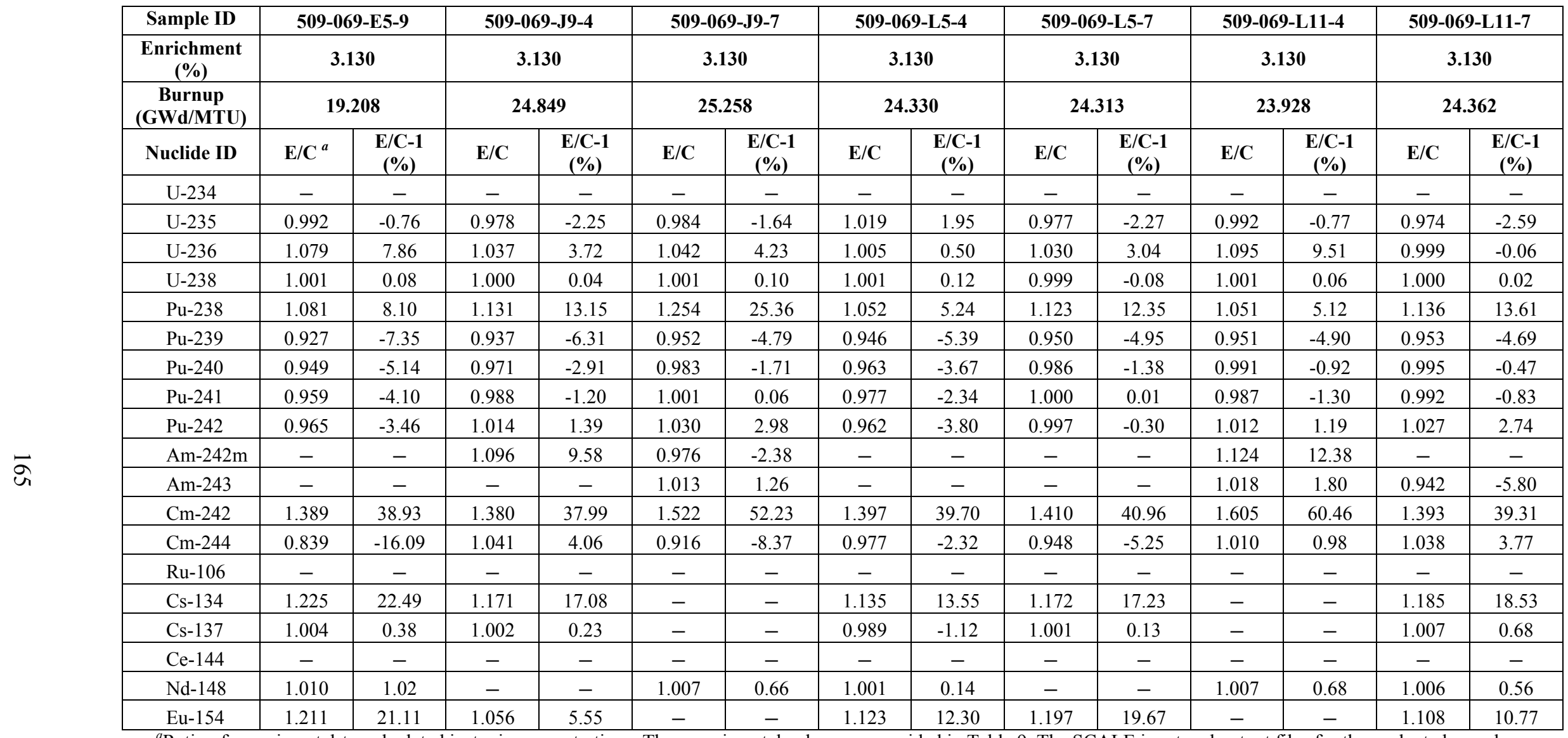

${ }^{a}$ Ratio of experimental-to-calculated isotopic concentrations. The experimental values are provided in Table 9. The SCALE input and output files for the evaluated samples are provided on the accompanying DVD (see Appendix B). 
Table 98. SCALE calculation results for Obrigheim spent fuel samples

\begin{tabular}{|c|c|c|c|c|c|c|c|c|c|c|c|c|c|c|c|c|}
\hline Sample ID & \multicolumn{2}{|c|}{ BE124.D1P1 } & \multicolumn{2}{|c|}{ BE124.D1P3 } & \multicolumn{2}{|c|}{ BE124.E3P1 } & \multicolumn{2}{|c|}{ BE124.E3P2 } & \multicolumn{2}{|c|}{ BE124.E3P3 } & \multicolumn{2}{|c|}{ BE124.E3P4 } & \multicolumn{2}{|c|}{ BE124.E3P5 } & \multicolumn{2}{|c|}{ BE124.G7P1 } \\
\hline $\begin{array}{c}\text { Enrichment } \\
(\%)\end{array}$ & \multicolumn{2}{|c|}{3.00} & \multicolumn{2}{|c|}{3.00} & \multicolumn{2}{|c|}{3.00} & \multicolumn{2}{|c|}{3.00} & \multicolumn{2}{|c|}{3.00} & \multicolumn{2}{|c|}{3.00} & \multicolumn{2}{|c|}{3.00} & \multicolumn{2}{|c|}{3.00} \\
\hline $\begin{array}{c}\text { Burnup } \\
\text { (GWd/MTU) }\end{array}$ & \multicolumn{2}{|c|}{21.17} & \multicolumn{2}{|c|}{33.75} & \multicolumn{2}{|c|}{20.18} & \multicolumn{2}{|c|}{29.35} & \multicolumn{2}{|c|}{36.26} & \multicolumn{2}{|c|}{30.92} & \multicolumn{2}{|c|}{22.86} & \multicolumn{2}{|c|}{17.13} \\
\hline Nuclide ID & $\mathrm{E} / \mathrm{C}^{a}$ & $\begin{array}{c}\text { E/C-1 } \\
(\%)\end{array}$ & E/C & $\begin{array}{c}\text { E/C-1 } \\
(\%)\end{array}$ & $\mathbf{E} / \mathbf{C}$ & $\begin{array}{c}\text { E/C-1 } \\
(\%)\end{array}$ & $\mathbf{E} / \mathbf{C}$ & $\begin{array}{c}\text { E/C-1 } \\
(\%)\end{array}$ & $\mathrm{E} / \mathrm{C}$ & $\begin{array}{c}\text { E/C-1 } \\
(\%)\end{array}$ & $\mathbf{E} / \mathbf{C}$ & $\begin{array}{c}\text { E/C-1 } \\
(\%)\end{array}$ & $\mathbf{E} / \mathbf{C}$ & $\begin{array}{c}\text { E/C-1 } \\
(\%)\end{array}$ & $\mathbf{E} / \mathbf{C}$ & $\begin{array}{c}\text { E/C-1 } \\
(\%)\end{array}$ \\
\hline U-235 & 1.116 & 11.63 & 1.012 & 1.18 & 1.017 & 1.66 & 1.065 & 6.52 & 1.080 & 8.03 & 1.002 & 0.20 & 1.047 & 4.70 & 1.032 & 3.16 \\
\hline $\mathrm{U}-236$ & 0.947 & -5.35 & 1.036 & 3.61 & 0.915 & -8.54 & 1.007 & 0.75 & 1.024 & 2.41 & 1.016 & 1.61 & 1.096 & 9.60 & 1.053 & 5.27 \\
\hline $\mathrm{U}-238$ & 1.000 & -0.05 & 1.001 & 0.14 & 1.001 & 0.12 & 0.993 & -0.68 & 1.001 & 0.09 & 1.001 & 0.06 & 1.000 & 0.01 & 1.000 & 0.04 \\
\hline $\mathrm{Pu}-238$ & 0.768 & -23.22 & 1.140 & 13.97 & 1.055 & 5.45 & 1.121 & 12.11 & 1.096 & 9.63 & 1.028 & 2.82 & 1.103 & 10.29 & 1.081 & 8.11 \\
\hline $\mathrm{Pu}-239$ & 0.925 & -7.51 & 0.940 & -6.01 & 0.983 & -1.66 & 0.972 & -2.82 & 0.952 & -4.82 & 0.984 & -1.61 & 0.992 & -0.75 & 0.968 & -3.17 \\
\hline $\mathrm{Pu}-240$ & 0.870 & -13.01 & 0.984 & -1.57 & 0.964 & -3.64 & 0.963 & -3.70 & 0.970 & -2.98 & 1.009 & 0.89 & 0.974 & -2.60 & 0.974 & -2.56 \\
\hline $\mathrm{Pu}-241$ & 0.816 & -18.38 & 0.971 & -2.92 & 0.929 & -7.13 & 0.964 & -3.57 & 0.954 & -4.62 & 1.005 & 0.48 & 1.000 & -0.03 & 0.978 & -2.19 \\
\hline $\mathrm{Pu}-242$ & 0.696 & -30.42 & 0.998 & -0.21 & 0.880 & -11.99 & 0.928 & -7.17 & 0.951 & -4.94 & 1.012 & 1.25 & 0.924 & -7.55 & 0.950 & -5.02 \\
\hline $\mathrm{Cm}-244$ & 0.606 & -39.42 & 0.986 & -1.45 & 0.801 & -19.85 & 0.780 & -22.05 & 0.931 & -6.92 & 1.029 & 2.91 & 0.935 & -6.50 & 0.810 & -19.05 \\
\hline Cs-137 & - & - & 0.974 & -2.61 & 0.956 & -4.37 & - & - & 0.962 & -3.80 & 0.982 & -1.82 & 0.976 & -2.35 & 0.979 & -2.09 \\
\hline
\end{tabular}

${ }^{a}$ Ratio of experimental-to-calculated isotopic concentrations. The experimental values are provided in Table 16. The SCALE input and output files for the evaluated samples are provided on the accompanying DVD (see Appendix B). 
Table 98. SCALE calculation results for Obrigheim spent fuel samples (continued)

\begin{tabular}{|c|c|c|c|c|c|c|c|c|c|c|c|c|c|c|}
\hline Sample ID & \multicolumn{2}{|c|}{ BE124.G7P2 } & \multicolumn{2}{|c|}{ BE124.G7P3 } & \multicolumn{2}{|c|}{ BE124.G7P4 } & \multicolumn{2}{|c|}{ BE124.G7P5 } & \multicolumn{2}{|c|}{ BE124.M14P1 } & \multicolumn{2}{|c|}{ BE124.M14P3 } & \multicolumn{2}{|c|}{ BE124.M14P4 } \\
\hline $\begin{array}{c}\text { Enrichment } \\
(\%)\end{array}$ & \multicolumn{2}{|c|}{3.00} & \multicolumn{2}{|c|}{3.00} & \multicolumn{2}{|c|}{3.00} & \multicolumn{2}{|c|}{3.00} & \multicolumn{2}{|c|}{3.00} & \multicolumn{2}{|c|}{3.00} & \multicolumn{2}{|c|}{3.00} \\
\hline $\begin{array}{c}\text { Burnup } \\
\text { (GWd/MTU) }\end{array}$ & \multicolumn{2}{|c|}{25.83} & \multicolumn{2}{|c|}{31.32} & \multicolumn{2}{|c|}{27.71} & \multicolumn{2}{|c|}{25.81} & \multicolumn{2}{|c|}{15.60} & \multicolumn{2}{|c|}{29.36} & \multicolumn{2}{|c|}{24.90} \\
\hline Nuclide ID & $\mathbf{E} / \mathbf{C}^{a}$ & $\begin{array}{c}\text { E/C-1 } \\
(\%)\end{array}$ & $\mathbf{E} / \mathbf{C}$ & $\begin{array}{c}\text { E/C-1 } \\
(\%)\end{array}$ & $\mathrm{E} / \mathrm{C}$ & $\begin{array}{c}\text { E/C-1 } \\
(\%)\end{array}$ & $\mathrm{E} / \mathrm{C}$ & $\begin{array}{c}\text { E/C-1 } \\
(\%)\end{array}$ & $\mathrm{E} / \mathrm{C}$ & $\begin{array}{c}\text { E/C-1 } \\
(\%)\end{array}$ & $\mathrm{E} / \mathrm{C}$ & $\begin{array}{c}\text { E/C-1 } \\
(\%)\end{array}$ & $\mathrm{E} / \mathrm{C}$ & $\begin{array}{c}\mathrm{E} / \mathrm{C}-1 \\
(\%)\end{array}$ \\
\hline U-235 & 1.087 & 8.67 & 0.974 & -2.59 & 1.077 & 7.70 & 0.986 & -1.36 & 0.997 & -0.30 & 1.035 & 3.54 & 0.974 & -2.62 \\
\hline U-236 & 1.097 & 9.69 & 1.039 & 3.87 & 1.119 & 11.94 & 1.029 & 2.88 & 1.046 & 4.60 & 1.025 & 2.50 & 1.047 & 4.66 \\
\hline U-238 & 1.000 & 0.02 & 1.001 & 0.09 & 1.000 & 0.00 & 1.000 & 0.02 & 1.000 & 0.02 & 1.001 & 0.10 & 1.000 & 0.03 \\
\hline $\mathrm{Pu}-238$ & 1.059 & 5.89 & 1.205 & 20.48 & 1.140 & 14.04 & 0.992 & -0.77 & 1.097 & 9.71 & 1.050 & 5.02 & 1.043 & 4.28 \\
\hline $\mathrm{Pu}-239$ & 0.940 & -5.97 & 0.945 & -5.53 & 0.960 & -4.00 & 0.975 & -2.52 & 0.946 & -5.43 & 0.964 & -3.57 & 0.969 & -3.07 \\
\hline $\mathrm{Pu}-240$ & 0.968 & -3.22 & 1.010 & 1.01 & 0.998 & -0.24 & 1.019 & 1.92 & 0.980 & -1.97 & 0.977 & -2.32 & 1.009 & 0.91 \\
\hline $\mathrm{Pu}-241$ & 0.959 & -4.11 & 0.975 & -2.52 & 0.991 & -0.87 & 1.013 & 1.29 & 0.953 & -4.68 & 0.970 & -3.01 & 1.012 & 1.24 \\
\hline $\mathrm{Pu}-242$ & 0.919 & -8.06 & 1.021 & 2.05 & 1.000 & -0.03 & 1.031 & 3.06 & 0.937 & -6.31 & 0.924 & -7.60 & 1.049 & 4.87 \\
\hline $\mathrm{Cm}-244$ & 0.980 & -2.04 & 1.137 & 13.73 & 1.102 & 10.23 & 0.983 & -1.67 & 1.323 & 32.28 & 0.973 & -2.69 & 0.980 & -1.98 \\
\hline Cs-137 & 0.952 & -4.75 & 0.994 & -0.61 & 0.978 & -2.17 & - & - & - & - & 0.972 & -2.82 & - & - \\
\hline
\end{tabular}

${ }^{a}$ Ratio of experimental-to-calculated isotopic concentrations. The experimental values are provided in Table 16. The SCALE input and output files for the evaluated samples are provided on the accompanying DVD (see Appendix B). 
Table 98. SCALE calculation results for Obrigheim spent fuel samples (continued)

\begin{tabular}{|c|c|c|c|c|c|c|c|c|c|c|c|c|c|c|}
\hline Sample ID & \multicolumn{2}{|c|}{ BE210.G14P31 } & \multicolumn{2}{|c|}{ BE210.G14P41 } & \multicolumn{2}{|c|}{ BE210.G14P51 } & \multicolumn{2}{|c|}{ BE210.G14P52 } & \multicolumn{2}{|c|}{ BE210.K14P1 } & \multicolumn{2}{|c|}{ BE210.K14P31 } & \multicolumn{2}{|c|}{ BE210.K14P41 } \\
\hline $\begin{array}{c}\text { Enrichment } \\
(\%)\end{array}$ & \multicolumn{2}{|c|}{2.83} & \multicolumn{2}{|c|}{2.83} & \multicolumn{2}{|c|}{2.83} & \multicolumn{2}{|c|}{2.83} & \multicolumn{2}{|c|}{2.83} & \multicolumn{2}{|c|}{2.83} & \multicolumn{2}{|c|}{2.83} \\
\hline $\begin{array}{c}\text { Burnup } \\
\text { (GWd/MTU) }\end{array}$ & \multicolumn{2}{|c|}{37.49} & \multicolumn{2}{|c|}{35.64} & \multicolumn{2}{|c|}{30.16} & \multicolumn{2}{|c|}{24.22} & \multicolumn{2}{|c|}{22.90} & \multicolumn{2}{|c|}{36.67} & \multicolumn{2}{|c|}{32.99} \\
\hline Nuclide ID & $\mathbf{E} / \mathbf{C}^{a}$ & $\begin{array}{c}\text { E/C-1 } \\
(\%)\end{array}$ & $\mathrm{E} / \mathrm{C}$ & $\begin{array}{c}\text { E/C-1 } \\
(\%)\end{array}$ & $\mathbf{E} / \mathbf{C}$ & $\begin{array}{c}\text { E/C-1 } \\
(\%)\end{array}$ & E/C & $\begin{array}{c}\text { E/C-1 } \\
(\%)\end{array}$ & $\mathrm{E} / \mathrm{C}$ & $\begin{array}{c}\text { E/C-1 } \\
(\%)\end{array}$ & $\mathrm{E} / \mathrm{C}$ & $\begin{array}{c}\text { E/C-1 } \\
(\%)\end{array}$ & $\mathbf{E} / \mathbf{C}$ & $\begin{array}{c}\text { E/C-1 } \\
(\%)\end{array}$ \\
\hline $\mathrm{U}-235$ & 0.980 & -1.99 & 0.900 & -9.96 & 0.862 & -13.85 & 0.918 & -8.21 & 0.997 & -0.28 & 0.968 & -3.19 & 0.800 & -20.04 \\
\hline $\mathrm{U}-236$ & 1.009 & 0.87 & 1.041 & 4.10 & 1.019 & 1.87 & 1.020 & 2.04 & 1.012 & 1.18 & 1.008 & 0.82 & 1.031 & 3.07 \\
\hline $\mathrm{U}-238$ & 1.001 & 0.13 & 1.003 & 0.28 & 1.003 & 0.32 & 1.003 & 0.27 & 0.998 & -0.20 & 1.002 & 0.19 & 1.002 & 0.19 \\
\hline $\mathrm{Pu}-238$ & 0.974 & -2.58 & 1.011 & 1.12 & 1.022 & 2.22 & 0.942 & -5.81 & 1.149 & 14.89 & 1.048 & 4.79 & 0.946 & -5.45 \\
\hline $\mathrm{Pu}-239$ & 0.882 & -11.82 & 0.838 & -16.21 & 0.848 & -15.19 & 0.867 & -13.33 & 0.987 & -1.25 & 0.913 & -8.68 & 0.871 & -12.95 \\
\hline $\mathrm{Pu}-240$ & 0.951 & -4.86 & 0.931 & -6.89 & 0.939 & -6.15 & 0.934 & -6.59 & 1.025 & 2.51 & 0.958 & -4.24 & 0.986 & -1.45 \\
\hline $\mathrm{Pu}-241$ & 0.935 & -6.52 & 0.873 & -12.72 & 0.907 & -9.28 & 0.902 & -9.84 & 1.072 & 7.23 & 0.946 & -5.41 & 0.935 & -6.46 \\
\hline $\mathrm{Pu}-242$ & 1.046 & 4.59 & 1.007 & 0.68 & 1.040 & 3.99 & 0.993 & -0.67 & 1.088 & 8.80 & 1.029 & 2.88 & 1.148 & 14.81 \\
\hline $\mathrm{Cm}-244$ & 0.902 & -9.77 & 0.960 & -3.98 & 0.926 & -7.39 & 0.793 & -20.67 & 1.110 & 11.01 & 0.986 & -1.43 & 0.911 & -8.90 \\
\hline Cs-137 & 0.993 & -0.68 & 0.983 & -1.73 & 1.003 & 0.31 & 0.993 & -0.72 & 0.981 & -1.85 & 0.967 & -3.32 & - & - \\
\hline
\end{tabular}

${ }^{a}$ Ratio of experimental-to-calculated isotopic concentrations. The experimental values are provided in Table 16. The SCALE input and output files for the evaluated samples are provided on the accompanying DVD (see Appendix B). 
Table 98. SCALE calculation results for Obrigheim spent fuel samples (continued)

\begin{tabular}{|c|c|c|c|c|c|c|c|c|c|c|}
\hline Sample ID & \multicolumn{2}{|c|}{ BE168 } & \multicolumn{2}{|c|}{ BE170 } & \multicolumn{2}{|c|}{ BE171 } & \multicolumn{2}{|c|}{ BE172 } & \multicolumn{2}{|c|}{ BE176 } \\
\hline Enrichment (\%) & \multicolumn{2}{|c|}{3.13} & \multicolumn{2}{|c|}{3.13} & \multicolumn{2}{|c|}{3.13} & \multicolumn{2}{|c|}{3.13} & \multicolumn{2}{|c|}{3.13} \\
\hline $\begin{array}{c}\text { Burnup } \\
\text { (GWd/MTU) }\end{array}$ & \multicolumn{2}{|c|}{29.350} & \multicolumn{2}{|c|}{27.005} & \multicolumn{2}{|c|}{28.655} & \multicolumn{2}{|c|}{27.890} & \multicolumn{2}{|c|}{28.755} \\
\hline Nuclide ID & $\mathrm{E} / \mathrm{C}^{a}$ & $\begin{array}{c}\text { E/C-1 } \\
(\%)\end{array}$ & $\mathbf{E} / \mathbf{C}$ & $\begin{array}{c}\text { E/C-1 } \\
(\%)\end{array}$ & $\mathbf{E} / \mathbf{C}$ & $\begin{array}{c}\text { E/C-1 } \\
(\%)\end{array}$ & $\mathbf{E} / \mathbf{C}$ & $\begin{array}{c}\text { E/C-1 } \\
(\%)\end{array}$ & $\mathbf{E} / \mathbf{C}$ & $\begin{array}{c}\text { E/C-1 } \\
(\%)\end{array}$ \\
\hline U-235 & 1.035 & 3.53 & 1.032 & 3.17 & 1.035 & 3.46 & 1.017 & 1.67 & 1.024 & 2.36 \\
\hline U-236 & 0.985 & -1.49 & 0.989 & -1.14 & 0.984 & -1.63 & 0.980 & -2.00 & 0.985 & -1.47 \\
\hline $\mathrm{U}-238$ & 1.000 & 0.02 & 1.000 & 0.03 & 1.000 & 0.03 & 1.001 & 0.07 & 1.000 & 0.04 \\
\hline $\mathrm{Pu}-238$ & 1.149 & 14.94 & 1.042 & 4.24 & 1.045 & 4.53 & 1.008 & 0.76 & 1.075 & 7.53 \\
\hline $\mathrm{Pu}-239$ & 0.993 & -0.70 & 0.980 & -2.01 & 0.981 & -1.89 & 0.960 & -4.02 & 0.982 & -1.82 \\
\hline $\mathrm{Pu}-240$ & 0.990 & -1.02 & 0.985 & -1.52 & 0.970 & -3.02 & 0.963 & -3.66 & 0.978 & -2.22 \\
\hline $\mathrm{Pu}-241$ & 1.053 & 5.25 & 1.049 & 4.89 & 1.036 & 3.56 & 1.019 & 1.87 & 1.048 & 4.79 \\
\hline $\mathrm{Pu}-242$ & 1.111 & 11.09 & 1.087 & 8.74 & 1.064 & 6.36 & 1.090 & 8.97 & 1.098 & 9.77 \\
\hline $\mathrm{Cm}-244$ & 1.124 & 12.42 & 1.178 & 17.79 & 1.141 & 14.06 & 1.155 & 15.54 & 1.182 & 18.20 \\
\hline Cs-137 & - & - & - & - & - & - & - & - & - & - \\
\hline
\end{tabular}

${ }^{a}$ Ratio of experimental-to-calculated isotopic concentrations. The experimental values are provided in Table 12. The SCALE input and output files for the evaluated samples are provided on the accompanying DVD (see Appendix B). 
Table 99. SCALE calculation results for Turkey Point Unit 3 spent fuel samples

\begin{tabular}{|c|c|c|c|c|c|c|c|c|c|c|}
\hline Sample ID & \multirow{2}{*}{\multicolumn{2}{|c|}{$\begin{array}{c}\text { D01.G9 } \\
2.556\end{array}$}} & \multirow{2}{*}{\multicolumn{2}{|c|}{$\begin{array}{c}\text { D01.G10 } \\
2.556\end{array}$}} & \multicolumn{2}{|c|}{ D01.H9 } & \multicolumn{2}{|c|}{ D04.G9 } & \multicolumn{2}{|c|}{ D04.G10 } \\
\hline Enrichment (\%) & & & & & & & & & & \\
\hline $\begin{array}{c}\text { Burnup } \\
\text { (GWd/MTU) }\end{array}$ & \multicolumn{2}{|c|}{30.72} & \multicolumn{2}{|c|}{30.51} & \multicolumn{2}{|c|}{31.56} & \multicolumn{2}{|c|}{31.26} & \multicolumn{2}{|c|}{31.31} \\
\hline Nuclide ID & $\mathbf{E} / \mathbf{C}^{a}$ & $\begin{array}{c}\text { E/C-1 } \\
(\%)\end{array}$ & $\mathrm{E} / \mathrm{C}$ & $\begin{array}{c}\text { E/C-1 } \\
(\%)\end{array}$ & $\mathbf{E} / \mathbf{C}$ & $\begin{array}{c}\text { E/C-1 } \\
(\%)\end{array}$ & $\mathrm{E} / \mathrm{C}$ & $\begin{array}{c}\text { E/C-1 } \\
(\%)\end{array}$ & $\mathrm{E} / \mathrm{C}$ & $\begin{array}{c}\text { E/C-1 } \\
(\%)\end{array}$ \\
\hline U-234 & 0.966 & -3.37 & 0.961 & -3.88 & 0.910 & -8.98 & 0.836 & -16.38 & 0.974 & -2.56 \\
\hline U-235 & 1.038 & 3.76 & 0.989 & -1.13 & 1.049 & 4.91 & 1.005 & 0.46 & 1.031 & 3.11 \\
\hline U-236 & 0.965 & -3.51 & 0.968 & -3.22 & 0.933 & -6.73 & 0.930 & -6.95 & 0.959 & -4.10 \\
\hline U-238 & 1.002 & 0.15 & 1.002 & 0.18 & 1.001 & 0.14 & 1.002 & 0.17 & 1.002 & 0.17 \\
\hline $\mathrm{Pu}-238$ & 1.019 & 1.93 & 1.036 & 3.56 & 1.025 & 2.54 & 1.004 & 0.35 & 0.992 & -0.81 \\
\hline $\mathrm{Pu}-239$ & 0.964 & -3.64 & 0.966 & -3.39 & 0.996 & -0.38 & 0.985 & -1.55 & 0.953 & -4.73 \\
\hline $\mathrm{Pu}-240$ & 0.970 & -2.98 & 0.987 & -1.27 & 0.966 & -3.42 & 0.979 & -2.12 & 0.961 & -3.93 \\
\hline $\mathrm{Pu}-241$ & 1.003 & 0.28 & 1.010 & 1.04 & 1.027 & 2.74 & 1.041 & 4.11 & 0.993 & -0.68 \\
\hline $\mathrm{Pu}-242$ & 0.937 & -6.32 & 0.988 & -1.20 & 0.956 & -4.41 & 0.967 & -3.31 & 0.934 & -6.62 \\
\hline Nd-148 & 0.982 & -1.76 & 0.982 & -1.82 & 0.983 & -1.73 & 0.982 & -1.76 & 0.982 & -1.82 \\
\hline
\end{tabular}

${ }^{a}$ Ratio of experimental-to-calculated isotopic concentrations. The experimental values are provided in Table 18. The SCALE input and output files for the evaluated samples are provided on the accompanying DVD (see Appendix B).

Table 100. SCALE calculation results for H. B. Robinson Unit 2 spent fuel samples

\begin{tabular}{|c|c|c|c|c|c|c|c|c|}
\hline Sample ID & \multicolumn{2}{|c|}{ N-9B-N } & \multicolumn{2}{|c|}{ N-9B-S } & \multicolumn{2}{|c|}{ N-9C-D } & \multicolumn{2}{|c|}{ N-9C-J } \\
\hline Enrichment (\%) & \multicolumn{2}{|c|}{2.561} & \multicolumn{2}{|c|}{2.561} & \multicolumn{2}{|c|}{2.561} & \multicolumn{2}{|c|}{2.561} \\
\hline $\begin{array}{c}\text { Burnup } \\
\text { (GWd/MTU) }\end{array}$ & \multicolumn{2}{|c|}{23.81} & \multicolumn{2}{|c|}{16.02} & \multicolumn{2}{|c|}{31.66} & \multicolumn{2}{|c|}{28.47} \\
\hline Nuclide ID & $\mathbf{E} / \mathbf{C}^{a}$ & $\begin{array}{c}\text { E/C-1 } \\
(\%)\end{array}$ & $\mathrm{E} / \mathrm{C}$ & $\begin{array}{c}\mathrm{E} / \mathrm{C}-1 \\
(\%)\end{array}$ & $\mathbf{E} / \mathbf{C}$ & $\begin{array}{c}\text { E/C-1 } \\
(\%)\end{array}$ & $\mathbf{E} / \mathbf{C}$ & $\begin{array}{c}\text { E/C-1 } \\
(\%)\end{array}$ \\
\hline U-234 & 0.991 & -0.92 & 0.992 & -0.79 & 0.890 & -10.99 & 0.915 & -8.46 \\
\hline U-235 & 1.004 & 0.36 & 0.997 & -0.34 & 0.980 & -1.97 & 1.065 & 6.47 \\
\hline U-236 & 1.020 & 1.95 & 1.019 & 1.89 & 0.995 & -0.52 & 0.976 & -2.42 \\
\hline $\mathrm{U}-238$ & 1.006 & 0.58 & 0.998 & -0.18 & 1.001 & 0.07 & 0.994 & -0.56 \\
\hline $\mathrm{Pu}-238$ & 1.153 & 15.32 & 1.145 & 14.54 & 1.110 & 11.00 & 1.215 & 21.49 \\
\hline $\mathrm{Pu}-239$ & 0.989 & -1.13 & 0.988 & -1.22 & 0.958 & -4.21 & 1.064 & 6.43 \\
\hline $\mathrm{Pu}-240$ & 0.984 & -1.59 & 0.974 & -2.60 & 0.961 & -3.94 & 0.980 & -2.04 \\
\hline $\mathrm{Pu}-241$ & 1.060 & 5.98 & 1.056 & 5.65 & 1.017 & 1.72 & 1.113 & 11.32 \\
\hline $\mathrm{Pu}-242$ & 1.020 & 1.97 & 0.998 & -0.22 & 0.997 & -0.35 & 0.982 & -1.80 \\
\hline Np-237 & 1.118 & 11.76 & 1.114 & 11.40 & 0.985 & -1.46 & 1.024 & 2.38 \\
\hline Tc-99 & 0.892 & -10.84 & 0.861 & -13.88 & 0.859 & -14.10 & 0.844 & -15.57 \\
\hline Cs-137 & 1.190 & 18.99 & 1.011 & 1.08 & 0.996 & -0.42 & 0.981 & -1.92 \\
\hline Nd-143 & 0.932 & -6.79 & 0.950 & -4.97 & 0.895 & -10.49 & 0.962 & -3.82 \\
\hline Nd-144 & 0.958 & -4.16 & 0.965 & -3.46 & 0.926 & -7.38 & 0.949 & -5.13 \\
\hline Nd-145 & 0.957 & -4.34 & 0.962 & -3.83 & 0.919 & -8.09 & 0.959 & -4.06 \\
\hline $\mathrm{Nd}-146$ & 0.958 & -4.24 & 0.958 & -4.19 & 0.911 & -8.91 & 0.956 & -4.44 \\
\hline Nd-148 & 0.987 & -1.33 & 0.976 & -2.41 & 0.934 & -6.64 & 0.979 & -2.14 \\
\hline Nd-150 & 0.979 & -2.05 & 0.967 & -3.31 & 0.927 & -7.33 & 0.978 & -2.17 \\
\hline
\end{tabular}

${ }^{a}$ Ratio of experimental-to-calculated isotopic concentrations. The experimental values are provided in Table 21. The SCALE input and output files for the evaluated samples are provided on the accompanying DVD (see Appendix B). 
Table 101. SCALE calculation results for Calvert Cliffs Unit 1 spent fuel samples

\begin{tabular}{|c|c|c|c|c|c|c|c|c|c|c|}
\hline Sample ID & \multicolumn{2}{|c|}{ 106-NBD107-GG } & \multicolumn{2}{|c|}{ 106-NBD107-MM } & \multicolumn{2}{|c|}{ 106-NBD107-Q } & \multicolumn{2}{|c|}{ 104-MKP109-CC } & \multicolumn{2}{|c|}{ 104-MKP109-LL } \\
\hline $\begin{array}{c}\text { Enrichment } \\
(\%)\end{array}$ & \multicolumn{2}{|c|}{2.453} & \multicolumn{2}{|c|}{2.453} & \multicolumn{2}{|c|}{2.453} & \multicolumn{2}{|c|}{3.038} & \multicolumn{2}{|c|}{3.038} \\
\hline $\begin{array}{c}\text { Burnup } \\
\text { (GWd/MTU) }\end{array}$ & \multicolumn{2}{|c|}{37.27} & \multicolumn{2}{|c|}{31.40} & \multicolumn{2}{|c|}{46.46} & \multicolumn{2}{|c|}{$36.90^{a}$} & \multicolumn{2}{|c|}{$27.11^{a}$} \\
\hline Nuclide ID & $E / C^{b}$ & $\begin{array}{c}\text { E/C-1 } \\
(\%)\end{array}$ & $\mathrm{E} / \mathrm{C}$ & $\begin{array}{c}\text { E/C-1 } \\
(\%)\end{array}$ & $\mathrm{E} / \mathrm{C}$ & $\begin{array}{c}\text { E/C-1 } \\
(\%)\end{array}$ & $\mathrm{E} / \mathrm{C}$ & $\begin{array}{c}\text { E/C-1 } \\
(\%)\end{array}$ & $\mathbf{E} / \mathbf{C}$ & $\begin{array}{c}\text { E/C-1 } \\
(\%)\end{array}$ \\
\hline U-234 & 1.187 & 18.74 & 1.310 & 30.95 & 0.796 & -20.36 & 1.027 & 2.72 & 1.014 & 1.41 \\
\hline $\mathrm{U}-235$ & 1.097 & 9.71 & 1.050 & 5.03 & 1.037 & 3.70 & 1.014 & 1.38 & 1.009 & 0.92 \\
\hline $\mathrm{U}-236$ & 1.005 & 0.51 & 0.983 & -1.73 & 0.999 & -0.14 & 0.976 & -2.41 & 0.979 & -2.06 \\
\hline $\mathrm{U}-238$ & 1.013 & 1.26 & 1.008 & 0.82 & 1.002 & 0.20 & 1.004 & 0.42 & 1.007 & 0.66 \\
\hline $\mathrm{Pu}-238$ & 1.116 & 11.58 & 1.118 & 11.82 & 1.130 & 13.00 & 1.078 & 7.84 & 1.103 & 10.25 \\
\hline $\mathrm{Pu}-239$ & 1.028 & 2.81 & 1.029 & 2.88 & 0.994 & -0.59 & 0.966 & -3.42 & 0.973 & -2.69 \\
\hline $\mathrm{Pu}-240$ & 0.994 & -0.60 & 0.992 & -0.84 & 0.987 & -1.29 & 0.989 & -1.15 & 0.992 & -0.85 \\
\hline $\mathrm{Pu}-241$ & 1.109 & 10.93 & 1.114 & 11.44 & 1.065 & 6.46 & 1.027 & 2.72 & 1.027 & 2.71 \\
\hline $\mathrm{Pu}-242$ & 1.052 & 5.19 & 1.055 & 5.52 & 1.068 & 6.79 & 0.999 & -0.07 & 1.003 & 0.34 \\
\hline Np-237 & 0.893 & -10.73 & 0.870 & -13.05 & 0.857 & -14.28 & 0.870 & -13.01 & 0.942 & -5.80 \\
\hline Am-241 & 1.233 & 23.31 & 1.098 & 9.83 & 1.671 & 67.14 & 1.113 & 11.30 & 1.049 & 4.85 \\
\hline Se-79 & 1.630 & 62.96 & 1.391 & 39.07 & 1.457 & 45.70 & 0.857 & -14.26 & 0.790 & -20.97 \\
\hline Sr-90 & 0.974 & -2.61 & 0.980 & -1.95 & 0.987 & -1.35 & 0.993 & -0.74 & 0.981 & -1.94 \\
\hline Tc-99 & 0.678 & -32.25 & 0.671 & -32.90 & 0.693 & -30.68 & 0.923 & -7.67 & 0.939 & -6.11 \\
\hline Rh-103 & 1.250 & 25.02 & - & - & - & - & - & - & - & - \\
\hline Sn-126 & 0.643 & -35.75 & 0.699 & -30.15 & 0.646 & -35.40 & 0.782 & -21.79 & 0.757 & -24.26 \\
\hline Cs-133 & - & - & - & - & - & - & 0.981 & -1.87 & 0.993 & -0.74 \\
\hline Cs-135 & 0.954 & -4.57 & 0.974 & -2.56 & 1.010 & 0.98 & 0.942 & -5.75 & 0.940 & -6.01 \\
\hline Cs-137 & 0.993 & -0.73 & 1.025 & 2.53 & 1.047 & 4.65 & 1.001 & 0.07 & 1.012 & 1.17 \\
\hline Nd-143 & 1.012 & 1.19 & - & - & - & - & 0.988 & -1.15 & 0.993 & -0.67 \\
\hline Nd-144 & 1.014 & 1.43 & - & - & - & - & 1.010 & 1.05 & 1.010 & 0.97 \\
\hline Nd-145 & 1.013 & 1.26 & - & - & - & - & 1.009 & 0.85 & 1.006 & 0.58 \\
\hline Nd-146 & 0.991 & -0.89 & - & - & - & - & 0.992 & -0.77 & 0.994 & -0.65 \\
\hline Nd-148 & 1.008 & 0.82 & - & - & - & - & 1.000 & -0.02 & 1.000 & -0.05 \\
\hline Nd-150 & - & - & - & - & - & - & 0.968 & -3.21 & 0.977 & -2.29 \\
\hline Sm-147 & 1.008 & 0.78 & - & - & - & - & 0.995 & -0.50 & 0.966 & -3.40 \\
\hline Sm-148 & 1.032 & 3.20 & - & - & - & - & 1.015 & 1.47 & 1.004 & 0.39 \\
\hline Sm-149 & - & - & - & - & - & - & - & - & - & - \\
\hline Sm- 150 & 0.973 & -2.75 & - & - & - & - & 0.926 & -7.41 & 0.940 & -6.04 \\
\hline $\mathrm{Sm}-151$ & 0.854 & -14.56 & - & - & - & - & 0.780 & -22.02 & 0.694 & -30.57 \\
\hline Sm-152 & 0.812 & -18.80 & - & - & - & - & 0.762 & -23.80 & 0.809 & -19.06 \\
\hline Sm-154 & 1.000 & 0.03 & - & - & - & - & 0.921 & -7.87 & 1.123 & 12.30 \\
\hline Eu-153 & 1.047 & 4.66 & - & - & - & - & 0.966 & -3.42 & 0.966 & -3.41 \\
\hline Eu-154 & 1.045 & 4.47 & - & - & - & - & 0.985 & -1.50 & 1.032 & 3.19 \\
\hline Eu-155 & 1.640 & 64.02 & - & - & - & - & 1.421 & 42.08 & 1.439 & 43.85 \\
\hline Gd-154 & 0.587 & -41.32 & - & - & - & - & 0.760 & -24.01 & 1.244 & 24.43 \\
\hline Gd-155 & 1.123 & 12.34 & - & - & - & - & 1.338 & 33.75 & 1.916 & 91.55 \\
\hline Gd-156 & 0.580 & -41.96 & - & - & - & - & 0.731 & -26.87 & 1.327 & 32.68 \\
\hline Gd-158 & 0.607 & -39.29 & - & - & - & - & 0.708 & -29.16 & 1.225 & 22.55 \\
\hline Gd-160 & 0.344 & -65.59 & - & - & - & - & - & - & 1.927 & 92.67 \\
\hline
\end{tabular}

${ }^{a}$ Burnup based on measured ${ }^{148} \mathrm{Nd}$.

${ }^{b}$ Ratio of experimental-to-calculated isotopic concentrations. The experimental values are provided in Table 28 and Table 29. The SCALE input and output files for the evaluated samples are provided on the accompanying DVD (see Appendix B). 
Table 101. SCALE calculation results for Calvert Cliffs Unit 1 spent fuel samples (continued)

\begin{tabular}{|c|c|c|c|c|c|c|c|c|}
\hline Sample ID & \multicolumn{2}{|c|}{ 104-MKP109-P } & \multicolumn{2}{|c|}{ 103-MLA098-BB } & \multicolumn{2}{|c|}{ 103-MLA098-JJ } & \multicolumn{2}{|c|}{ 103-MLA098-P } \\
\hline Enrichment (\%) & \multicolumn{2}{|c|}{3.038} & \multicolumn{2}{|c|}{2.72} & \multicolumn{2}{|c|}{2.72} & \multicolumn{2}{|c|}{2.72} \\
\hline $\begin{array}{c}\text { Burnup } \\
\text { (GWd/MTU) }\end{array}$ & \multicolumn{2}{|c|}{$44.13^{a}$} & \multicolumn{2}{|c|}{26.62} & \multicolumn{2}{|c|}{18.68} & \multicolumn{2}{|c|}{33.17} \\
\hline Nuclide ID & $\mathrm{E} / \mathbf{C}^{b}$ & $\begin{array}{c}\text { E/C-1 } \\
(\%)\end{array}$ & $E / C$ & $\begin{array}{c}\text { E/C-1 } \\
(\%)\end{array}$ & $\mathbf{E} / \mathbf{C}$ & $\begin{array}{c}\text { E/C-1 } \\
(\%)\end{array}$ & $\mathbf{E} / \mathbf{C}$ & $\begin{array}{c}\text { E/C-1 } \\
(\%)\end{array}$ \\
\hline U-234 & 0.977 & -2.27 & 0.873 & -12.65 & 0.892 & -10.77 & 0.958 & -4.20 \\
\hline U-235 & 0.992 & -0.81 & 1.003 & 0.26 & 0.995 & -0.49 & 0.954 & -4.55 \\
\hline U-236 & 0.982 & -1.80 & 1.019 & 1.88 & 1.023 & 2.33 & 1.025 & 2.49 \\
\hline U-238 & 1.002 & 0.23 & 1.017 & 1.74 & 1.012 & 1.24 & 1.010 & 1.01 \\
\hline $\mathrm{Pu}-238$ & 1.067 & 6.66 & 1.127 & 12.65 & 1.261 & 26.15 & 1.062 & 6.17 \\
\hline $\mathrm{Pu}-239$ & 0.939 & -6.10 & 0.976 & -2.37 & 0.989 & -1.15 & 0.919 & -8.14 \\
\hline $\mathrm{Pu}-240$ & 0.984 & -1.61 & 0.981 & -1.90 & 0.995 & -0.52 & 0.963 & -3.66 \\
\hline $\mathrm{Pu}-241$ & 1.005 & 0.45 & 1.053 & 5.30 & 1.079 & 7.89 & 1.001 & 0.05 \\
\hline $\mathrm{Pu}-242$ & 1.020 & 1.98 & 1.029 & 2.90 & 1.045 & 4.49 & 1.046 & 4.60 \\
\hline $\mathrm{Np}-237$ & 0.942 & -5.83 & 1.087 & 8.67 & 1.004 & 0.43 & 0.945 & -5.55 \\
\hline Am-241 & 1.088 & 8.79 & 1.038 & 3.85 & 1.062 & 6.22 & 1.016 & 1.56 \\
\hline Se-79 & 0.790 & -20.97 & 0.882 & -11.77 & 0.914 & -8.60 & 0.876 & -12.40 \\
\hline Sr-90 & 0.981 & -1.94 & 0.995 & -0.47 & 1.004 & 0.37 & 1.006 & 0.62 \\
\hline Tc-99 & 0.876 & -12.38 & 0.939 & -6.12 & 0.975 & -2.49 & 0.937 & -6.26 \\
\hline Rh-103 & - & - & - & - & - & - & - & - \\
\hline Sn-126 & 0.757 & -24.26 & 0.841 & -15.85 & 0.823 & -17.75 & 0.797 & -20.35 \\
\hline Cs-133 & 0.970 & -3.00 & - & - & - & - & - & - \\
\hline Cs-135 & 0.946 & -5.36 & 0.936 & -6.39 & 0.941 & -5.93 & 0.918 & -8.24 \\
\hline Cs-137 & 1.015 & 1.48 & 1.020 & 2.03 & 1.021 & 2.09 & 1.012 & 1.19 \\
\hline Nd-143 & 0.975 & -2.51 & - & - & - & - & - & - \\
\hline Nd-144 & 1.017 & 1.73 & - & - & - & - & - & - \\
\hline Nd-145 & 1.008 & 0.85 & - & - & - & - & - & - \\
\hline Nd-146 & 0.992 & -0.83 & - & - & - & - & - & - \\
\hline Nd-148 & 1.000 & -0.01 & - & - & - & - & - & - \\
\hline Nd-150 & 0.960 & -4.03 & - & - & - & - & - & - \\
\hline Sm-147 & 1.091 & 9.13 & - & - & - & - & - & - \\
\hline Sm-148 & 1.092 & 9.22 & - & - & - & - & - & - \\
\hline Sm-149 & - & - & - & - & - & - & - & - \\
\hline Sm-150 & 0.958 & -4.24 & - & - & - & - & - & - \\
\hline Sm-151 & 0.783 & -21.72 & - & - & - & - & - & - \\
\hline Sm-152 & 0.804 & -19.60 & - & - & - & - & - & - \\
\hline Sm-154 & 1.067 & 6.68 & - & - & - & - & - & - \\
\hline Eu-153 & 0.965 & -3.48 & - & - & - & - & - & - \\
\hline Eu-154 & 0.991 & -0.91 & - & - & - & - & - & - \\
\hline Eu-155 & 1.431 & 43.11 & - & - & - & - & - & - \\
\hline Gd-154 & 0.759 & -24.08 & - & - & - & - & - & - \\
\hline Gd-155 & 1.384 & 38.45 & - & - & - & - & - & - \\
\hline Gd-156 & 0.612 & -38.80 & - & - & - & - & - & - \\
\hline Gd-158 & 0.662 & -33.76 & - & - & - & - & - & - \\
\hline Gd-160 & - & - & - & - & - & - & - & - \\
\hline
\end{tabular}

${ }^{a}$ Burnup based on measured ${ }^{148} \mathrm{Nd}$.

${ }^{b}$ Ratio of experimental-to-calculated isotopic concentrations. The experimental values are provided in Table 26 and Table 28. The SCALE input and output files for the evaluated samples are provided on the accompanying DVD (see Appendix B). 
Table 102. SCALE calculation results for the Takahama Unit 3 spent fuel samples

\begin{tabular}{|c|c|c|c|c|c|c|c|c|c|c|}
\hline Sample ID & \multicolumn{2}{|c|}{ NT3G23.SF95-1 } & \multicolumn{2}{|c|}{ NT3G23.SF95-2 } & \multicolumn{2}{|c|}{ NT3G23.SF95-3 } & \multicolumn{2}{|c|}{ NT3G23.SF95-4 } & \multicolumn{2}{|c|}{ NT3G23.SF95-5 } \\
\hline $\begin{array}{c}\text { Enrichment } \\
(\%)\end{array}$ & \multicolumn{2}{|c|}{4.11} & \multicolumn{2}{|c|}{4.11} & \multicolumn{2}{|c|}{4.11} & \multicolumn{2}{|c|}{4.11} & \multicolumn{2}{|c|}{4.11} \\
\hline $\begin{array}{c}\text { Burnup } \\
\text { (GWd/MTU) }\end{array}$ & \multicolumn{2}{|c|}{14.18} & \multicolumn{2}{|c|}{24.46} & \multicolumn{2}{|c|}{35.68} & \multicolumn{2}{|c|}{37.01} & \multicolumn{2}{|c|}{30.45} \\
\hline Nuclide ID & $\mathrm{E} / \mathbf{C}^{a}$ & $\begin{array}{c}\text { E/C-1 } \\
(\%)\end{array}$ & $\mathbf{E} / \mathbf{C}$ & $\begin{array}{c}\text { E/C-1 } \\
(\%)\end{array}$ & $\mathbf{E} / \mathbf{C}$ & $\begin{array}{c}\text { E/C-1 } \\
(\%)\end{array}$ & $\mathbf{E} / \mathbf{C}$ & $\begin{array}{c}\text { E/C-1 } \\
(\%)\end{array}$ & $\mathbf{E} / \mathbf{C}$ & $\begin{array}{c}\text { E/C-1 } \\
(\%)\end{array}$ \\
\hline $\mathrm{U}-234$ & 0.913 & -8.73 & 1.015 & 1.50 & 0.794 & -20.64 & 0.803 & -19.72 & 1.089 & 8.94 \\
\hline U-235 & 0.986 & -1.37 & 0.974 & -2.55 & 0.973 & -2.73 & 0.968 & -3.19 & 0.977 & -2.30 \\
\hline U-236 & 1.002 & 0.18 & 1.016 & 1.58 & 0.999 & -0.07 & 1.000 & -0.03 & 1.011 & 1.05 \\
\hline $\mathrm{U}-238$ & 1.002 & 0.17 & 1.002 & 0.15 & 1.002 & 0.21 & 1.002 & 0.18 & 1.002 & 0.18 \\
\hline $\mathrm{Pu}-238$ & 0.943 & -5.69 & 1.035 & 3.54 & 0.945 & -5.48 & 0.944 & -5.56 & 0.980 & -2.02 \\
\hline $\mathrm{Pu}-239$ & 0.883 & -11.69 & 0.913 & -8.65 & 0.905 & -9.52 & 0.910 & -8.96 & 0.911 & -8.90 \\
\hline $\mathrm{Pu}-240$ & 0.944 & -5.62 & 0.960 & -4.05 & 0.930 & -6.99 & 0.925 & -7.54 & 0.932 & -6.79 \\
\hline $\mathrm{Pu}-241$ & 0.913 & -8.70 & 0.991 & -0.92 & 0.984 & -1.62 & 0.976 & -2.35 & 0.976 & -2.43 \\
\hline $\mathrm{Pu}-242$ & 0.907 & -9.28 & 0.996 & -0.42 & 1.002 & 0.21 & 0.989 & -1.07 & 0.971 & -2.87 \\
\hline Np-237 & - & - & - & - & - & - & - & - & - & - \\
\hline Am-241 & 1.088 & 8.80 & 0.808 & -19.21 & 0.805 & -19.52 & 0.585 & -41.52 & 0.842 & -15.80 \\
\hline Am-242m & 0.835 & -16.45 & 0.850 & -15.02 & 0.851 & -14.86 & 0.833 & -16.68 & 0.817 & -18.33 \\
\hline Am-243 & 0.769 & -23.09 & 0.814 & -18.58 & 0.814 & -18.58 & 0.795 & -20.52 & 0.808 & -19.16 \\
\hline $\mathrm{Cm}-242$ & 1.227 & 22.73 & 1.435 & 43.49 & 1.590 & 59.03 & 1.816 & 81.55 & 1.221 & 22.09 \\
\hline $\mathrm{Cm}-243$ & 1.114 & 11.45 & 1.234 & 23.41 & 1.108 & 10.83 & 1.138 & 13.80 & 1.265 & 26.52 \\
\hline $\mathrm{Cm}-244$ & 0.813 & -18.66 & 0.999 & -0.13 & 0.915 & -8.50 & 0.924 & -7.56 & 0.887 & -11.29 \\
\hline $\mathrm{Cm}-245$ & 0.943 & -5.65 & 1.267 & 26.74 & 1.146 & 14.56 & 1.211 & 21.09 & 1.166 & 16.58 \\
\hline $\mathrm{Cm}-246$ & 1.985 & 98.53 & 1.839 & 83.86 & 1.247 & 24.72 & 1.267 & 26.74 & 0.803 & -19.67 \\
\hline $\mathrm{Cm}-247$ & - & - & - & - & - & - & - & - & - & - \\
\hline $\mathrm{Ru}-106$ & 0.985 & -1.51 & 0.825 & -17.48 & 0.766 & -23.40 & 0.756 & -24.43 & 0.885 & -11.47 \\
\hline Sb-125 & 0.519 & -48.12 & 0.535 & -46.52 & 0.439 & -56.10 & 0.359 & -64.12 & 0.469 & -53.12 \\
\hline Cs-134 & 1.117 & 11.69 & 1.156 & 15.61 & 1.132 & 13.20 & 1.129 & 12.92 & 1.146 & 14.56 \\
\hline Cs-137 & 1.027 & 2.69 & 1.029 & 2.88 & 1.019 & 1.91 & 1.021 & 2.06 & 1.016 & 1.62 \\
\hline $\mathrm{Ce}-144$ & 1.031 & 3.10 & 1.017 & 1.72 & 1.046 & 4.60 & 0.952 & -4.81 & 1.015 & 1.53 \\
\hline Nd-142 & 1.261 & 26.07 & 1.074 & 7.42 & 1.170 & 17.01 & 1.136 & 13.57 & 1.057 & 5.72 \\
\hline Nd-143 & 1.030 & 2.98 & 1.018 & 1.79 & 1.015 & 1.51 & 1.006 & 0.58 & 1.013 & 1.34 \\
\hline Nd-144 & 1.011 & 1.13 & 1.015 & 1.50 & 1.007 & 0.66 & 1.043 & 4.30 & 1.014 & 1.40 \\
\hline Nd-145 & 1.006 & 0.61 & 1.001 & 0.07 & 1.002 & 0.19 & 0.995 & -0.48 & 0.998 & -0.18 \\
\hline Nd-146 & 0.983 & -1.71 & 0.980 & -2.00 & 0.978 & -2.17 & 0.978 & -2.25 & 0.978 & -2.24 \\
\hline Nd-148 & 1.001 & 0.08 & 1.000 & 0.04 & 1.001 & 0.06 & 1.000 & 0.04 & 1.001 & 0.05 \\
\hline Nd-150 & 1.013 & 1.29 & 0.993 & -0.68 & 0.998 & -0.18 & 0.995 & -0.50 & 0.988 & -1.18 \\
\hline Sm-147 & - & - & - & - & - & - & - & - & - & - \\
\hline Sm-148 & - & - & - & - & - & - & - & - & - & - \\
\hline Sm-149 & - & - & - & - & - & - & - & - & - & - \\
\hline Sm-150 & - & - & - & - & - & - & - & - & - & - \\
\hline Sm-151 & - & - & - & - & - & - & - & - & - & - \\
\hline Sm-152 & - & - & - & - & - & - & - & - & - & - \\
\hline Sm-154 & - & - & - & - & - & - & - & - & - & - \\
\hline Eu-154 & 0.958 & -4.24 & 0.994 & -0.60 & 0.951 & -4.89 & 0.979 & -2.14 & 0.975 & -2.47 \\
\hline
\end{tabular}

${ }^{a}$ Ratio of experimental-to-calculated isotopic concentrations. The experimental values are provided in Table 32. The SCALE input and output files for the evaluated samples are provided on the accompanying DVD (see Appendix B). 
Table 102. SCALE calculation results for the Takahama Unit 3 spent fuel samples (continued)

\begin{tabular}{|c|c|c|c|c|c|c|c|c|c|c|}
\hline Sample ID & \multicolumn{2}{|c|}{ NT3G23.SF96-1 } & \multicolumn{2}{|c|}{ NT3G23.SF96-2 } & \multicolumn{2}{|c|}{ NT3G23.SF96-3 } & \multicolumn{2}{|c|}{ NT3G23.SF96-4 } & \multicolumn{2}{|c|}{ NT3G23.SF96-5 } \\
\hline $\begin{array}{c}\text { Enrichment } \\
(\%)\end{array}$ & \multicolumn{2}{|c|}{2.63} & \multicolumn{2}{|c|}{2.63} & \multicolumn{2}{|c|}{2.63} & \multicolumn{2}{|c|}{2.63} & \multicolumn{2}{|c|}{2.63} \\
\hline $\begin{array}{c}\text { Burnup } \\
\text { (GWd/MTU) }\end{array}$ & \multicolumn{2}{|c|}{8.63} & \multicolumn{2}{|c|}{17.43} & \multicolumn{2}{|c|}{29.69} & \multicolumn{2}{|c|}{30.41} & \multicolumn{2}{|c|}{25.42} \\
\hline Nuclide ID & $\mathbf{E} / \mathbf{C}^{a}$ & $\begin{array}{c}\text { E/C-1 } \\
(\%)\end{array}$ & E/C & $\begin{array}{c}\text { E/C-1 } \\
(\%)\end{array}$ & $\mathbf{E} / \mathbf{C}$ & $\begin{array}{c}\text { E/C-1 } \\
(\%)\end{array}$ & $\mathbf{E} / \mathbf{C}$ & $\begin{array}{c}\text { E/C-1 } \\
(\%)\end{array}$ & $\mathbf{E} / \mathbf{C}$ & $\begin{array}{c}\text { E/C-1 } \\
(\%)\end{array}$ \\
\hline $\mathrm{U}-234$ & 1.080 & 8.05 & 1.059 & 5.92 & 1.080 & 8.05 & 1.086 & 8.62 & 1.071 & 7.11 \\
\hline U-235 & 0.986 & -1.42 & 0.991 & -0.90 & 0.988 & -1.22 & 0.980 & -1.98 & 0.997 & -0.32 \\
\hline U-236 & 1.015 & 1.51 & 1.015 & 1.48 & 1.005 & 0.48 & 1.009 & 0.92 & 1.004 & 0.39 \\
\hline U-238 & 1.001 & 0.14 & 1.001 & 0.10 & 1.001 & 0.12 & 1.001 & 0.11 & 1.001 & 0.08 \\
\hline $\mathrm{Pu}-238$ & 0.850 & -14.97 & 1.046 & 4.56 & 1.031 & 3.05 & 1.066 & 6.58 & 1.010 & 1.01 \\
\hline $\mathrm{Pu}-239$ & 0.825 & -17.51 & 0.964 & -3.58 & 0.974 & -2.57 & 0.985 & -1.52 & 0.974 & -2.65 \\
\hline $\mathrm{Pu}-240$ & 0.881 & -11.86 & 0.941 & -5.92 & 0.935 & -6.52 & 0.945 & -5.53 & 0.922 & -7.77 \\
\hline $\mathrm{Pu}-241$ & 0.802 & -19.76 & 0.996 & -0.37 & 1.000 & 0.02 & 1.013 & 1.33 & 0.990 & -1.00 \\
\hline $\mathrm{Pu}-242$ & 0.820 & -18.01 & 0.962 & -3.81 & 0.974 & -2.65 & 0.987 & -1.27 & 0.939 & -6.05 \\
\hline Np-237 & 0.742 & -25.80 & 0.696 & -30.37 & 0.604 & -39.64 & 0.628 & -37.20 & 0.658 & -34.24 \\
\hline Am-241 & 0.605 & -39.45 & 0.711 & -28.88 & 0.795 & -20.52 & 0.898 & -10.19 & 0.699 & -30.06 \\
\hline Am-242m & 0.782 & -21.78 & 0.951 & -4.92 & 0.836 & -16.36 & 0.956 & -4.43 & 0.934 & -6.64 \\
\hline Am-243 & 0.609 & -39.09 & 0.810 & -19.04 & 0.815 & -18.55 & 0.850 & -14.99 & 0.783 & -21.68 \\
\hline $\mathrm{Cm}-242$ & 1.006 & 0.60 & 1.269 & 26.94 & 1.254 & 25.39 & 1.281 & 28.14 & 1.207 & 20.74 \\
\hline $\mathrm{Cm}-243$ & - & - & - & - & - & - & - & - & - & - \\
\hline $\mathrm{Cm}-244$ & 0.674 & -32.58 & 0.955 & -4.47 & 0.948 & -5.17 & 0.998 & -0.21 & 0.897 & -10.31 \\
\hline $\mathrm{Cm}-245$ & - & - & - & - & - & - & - & - & - & - \\
\hline $\mathrm{Cm}-246$ & - & - & - & - & - & - & - & - & - & - \\
\hline $\mathrm{Cm}-247$ & - & - & - & - & - & - & - & - & - & - \\
\hline $\mathrm{Ru}-106$ & 0.783 & -21.69 & 0.658 & -34.25 & 0.735 & -26.54 & 0.661 & -33.88 & 0.890 & -10.98 \\
\hline $\mathrm{Sb}-125$ & 0.762 & -23.82 & 0.656 & -34.39 & 0.457 & -54.25 & 0.568 & -43.15 & 0.558 & -44.20 \\
\hline Cs-134 & 0.955 & -4.53 & 1.084 & 8.42 & 1.042 & 4.24 & 1.061 & 6.07 & 1.033 & 3.30 \\
\hline Cs-137 & 0.962 & -3.85 & 0.968 & -3.22 & 0.951 & -4.89 & 0.959 & -4.07 & 0.938 & -6.24 \\
\hline Ce-144 & 0.991 & -0.86 & 0.948 & -5.18 & 0.865 & -13.55 & 0.866 & -13.39 & 0.925 & -7.46 \\
\hline Nd-142 & - & - & - & - & - & - & - & - & - & - \\
\hline Nd-143 & 1.033 & 3.35 & 1.024 & 2.45 & 1.020 & 2.02 & 1.016 & 1.57 & 1.031 & 3.11 \\
\hline Nd-144 & 1.059 & 5.86 & 1.056 & 5.60 & 1.104 & 10.44 & 1.088 & 8.79 & 1.067 & 6.73 \\
\hline Nd-145 & 1.001 & 0.12 & 0.994 & -0.60 & 0.994 & -0.64 & 0.989 & -1.07 & 0.997 & -0.27 \\
\hline Nd-146 & 1.001 & 0.08 & 0.996 & -0.37 & 0.993 & -0.67 & 0.993 & -0.66 & 0.996 & -0.40 \\
\hline Nd-148 & 0.992 & -0.82 & 0.999 & -0.15 & 1.000 & -0.05 & 1.000 & -0.03 & 0.999 & -0.06 \\
\hline Nd-150 & 0.986 & -1.44 & 0.993 & -0.66 & 0.988 & -1.24 & 0.988 & -1.22 & 0.984 & -1.62 \\
\hline $\mathrm{Sm}-147$ & - & - & - & - & - & - & - & - & - & - \\
\hline Sm-148 & - & - & - & - & - & - & - & - & - & - \\
\hline Sm-149 & - & - & - & - & - & - & - & - & - & - \\
\hline Sm-150 & - & - & - & - & - & - & - & - & - & - \\
\hline Sm-151 & - & - & - & - & - & - & - & - & - & - \\
\hline Sm-152 & - & - & - & - & - & - & - & - & - & - \\
\hline Sm-154 & - & - & - & - & - & - & - & - & - & - \\
\hline Eu-154 & 0.966 & -3.40 & 1.035 & 3.52 & 0.934 & -6.61 & 0.944 & -5.62 & 0.937 & -6.31 \\
\hline
\end{tabular}

${ }^{a}$ Ratio of experimental-to-calculated isotopic concentrations. The experimental values are provided in Table 33. The SCALE input and output files for the evaluated samples are provided on the accompanying DVD (see Appendix B). 
Table 102. SCALE calculation results for the Takahama Unit 3 spent fuel samples (continued)

\begin{tabular}{|c|c|c|c|c|c|c|}
\hline Sample ID & \multicolumn{2}{|c|}{ NT3G24.SF97-1 } & \multicolumn{2}{|c|}{ NT3G24.SF97-2 } & \multicolumn{2}{|c|}{ NT3G24.SF97-3 } \\
\hline Enrichment (\%) & \multicolumn{2}{|c|}{4.11} & \multicolumn{2}{|c|}{4.11} & \multicolumn{2}{|c|}{4.11} \\
\hline $\begin{array}{c}\text { Burnup } \\
\text { (GWd/MTU) }\end{array}$ & \multicolumn{2}{|c|}{17.39} & \multicolumn{2}{|c|}{30.48} & \multicolumn{2}{|c|}{42.10} \\
\hline Nuclide ID & $\mathbf{E} / \mathbf{C}^{a}$ & $\begin{array}{c}\mathrm{E} / \mathrm{C}-1 \\
(\%) \\
\end{array}$ & $\mathrm{E} / \mathrm{C}$ & $\begin{array}{c}\text { E/C-1 } \\
(\%)\end{array}$ & $\mathbf{E} / \mathbf{C}$ & $\begin{array}{c}\text { E/C-1 } \\
(\%)\end{array}$ \\
\hline U-234 & 0.936 & -6.42 & 0.909 & -9.15 & 0.935 & -6.52 \\
\hline $\mathrm{U}-235$ & 0.959 & -4.11 & 0.983 & -1.69 & 0.979 & -2.09 \\
\hline U-236 & 1.002 & 0.19 & 1.007 & 0.73 & 1.004 & 0.39 \\
\hline $\mathrm{U}-238$ & 1.003 & 0.27 & 1.001 & 0.09 & 1.001 & 0.08 \\
\hline $\mathrm{Pu}-238$ & 0.793 & -20.72 & 1.082 & 8.21 & 1.088 & 8.84 \\
\hline $\mathrm{Pu}-239$ & 0.759 & -24.10 & 0.952 & -4.81 & 0.947 & -5.33 \\
\hline $\mathrm{Pu}-240$ & 0.886 & -11.36 & 0.938 & -6.16 & 0.925 & -7.49 \\
\hline $\mathrm{Pu}-241$ & 0.786 & -21.41 & 1.033 & 3.26 & 1.022 & 2.25 \\
\hline $\mathrm{Pu}-242$ & 0.850 & -14.96 & 1.011 & 1.12 & 1.017 & 1.73 \\
\hline $\mathrm{Np}-237$ & 0.822 & -17.80 & 0.991 & -0.86 & 0.963 & -3.74 \\
\hline Am-241 & 0.587 & -41.31 & 0.777 & -22.28 & 0.778 & -22.19 \\
\hline Am-242m & 0.488 & -51.19 & 0.800 & -19.96 & 0.845 & -15.51 \\
\hline Am-243 & 0.604 & -39.61 & 0.894 & -10.60 & 0.887 & -11.25 \\
\hline $\mathrm{Cm}-242$ & 0.875 & -12.48 & 1.065 & 6.47 & 0.983 & -1.67 \\
\hline $\mathrm{Cm}-243$ & 0.822 & -17.81 & 1.263 & 26.33 & 1.219 & 21.86 \\
\hline $\mathrm{Cm}-244$ & 0.586 & -41.40 & 1.068 & 6.85 & 1.056 & 5.55 \\
\hline $\mathrm{Cm}-245$ & 0.621 & -37.90 & 1.473 & 47.34 & 1.456 & 45.62 \\
\hline $\mathrm{Cm}-246$ & 0.771 & -22.87 & 15.748 & $1,474.80$ & 1.551 & 55.13 \\
\hline $\mathrm{Cm}-247$ & - & - & 1.581 & 58.13 & 1.513 & 51.33 \\
\hline $\mathrm{Ru}-106$ & 1.094 & 9.45 & 1.060 & 5.99 & 1.022 & 2.18 \\
\hline Sb-125 & 0.776 & -22.39 & 0.824 & -17.57 & 0.543 & -45.73 \\
\hline Cs-134 & 1.095 & 9.46 & 1.268 & 26.76 & 1.218 & 21.77 \\
\hline Cs-137 & 1.039 & 3.89 & 1.032 & 3.21 & 1.029 & 2.89 \\
\hline Ce-144 & 1.234 & 23.43 & 1.122 & 12.22 & 1.028 & 2.77 \\
\hline Nd-142 & - & - & - & - & - & - \\
\hline Nd-143 & 1.011 & 1.07 & 1.003 & 0.32 & 0.998 & -0.22 \\
\hline Nd-144 & 0.987 & -1.34 & 0.998 & -0.24 & 1.026 & 2.57 \\
\hline Nd-145 & 1.012 & 1.17 & 0.994 & -0.61 & 0.993 & -0.73 \\
\hline Nd-146 & 0.994 & -0.61 & 0.995 & -0.54 & 0.994 & -0.62 \\
\hline Nd-148 & 1.000 & -0.01 & 1.000 & -0.05 & 1.000 & -0.04 \\
\hline Nd-150 & 0.976 & -2.43 & 0.990 & -1.00 & 0.986 & -1.36 \\
\hline Sm-147 & 1.036 & 3.62 & 0.998 & -0.21 & 1.017 & 1.74 \\
\hline Sm-148 & 0.874 & -12.63 & 1.058 & 5.76 & 1.109 & 10.91 \\
\hline Sm-149 & 0.939 & -6.08 & 1.049 & 4.85 & 0.981 & -1.87 \\
\hline Sm-150 & 0.974 & -2.62 & 0.976 & -2.36 & 0.974 & -2.58 \\
\hline Sm-151 & 0.664 & -33.62 & 0.772 & -22.77 & 0.749 & -25.11 \\
\hline $\mathrm{Sm}-152$ & 0.949 & -5.05 & 0.820 & -17.95 & 0.779 & -22.07 \\
\hline Sm-154 & 0.986 & -1.41 & 1.008 & 0.83 & 0.999 & -0.09 \\
\hline Eu-154 & 0.857 & -14.27 & 1.050 & 4.98 & 0.996 & -0.37 \\
\hline
\end{tabular}


Table 102. SCALE calculation results for the Takahama Unit 3 spent fuel samples (continued)

\begin{tabular}{|c|c|c|c|c|c|c|}
\hline Sample ID & \multicolumn{2}{|c|}{ NT3G24.SF97-4 } & \multicolumn{2}{|c|}{ NT3G24.SF97-5 } & \multicolumn{2}{|c|}{ NT3G24.SF97-6 } \\
\hline Enrichment (\%) & \multicolumn{2}{|c|}{4.11} & \multicolumn{2}{|c|}{4.11} & \multicolumn{2}{|c|}{4.11} \\
\hline BU (GWd/MTU) & \multicolumn{2}{|c|}{47.07} & \multicolumn{2}{|c|}{47.26} & \multicolumn{2}{|c|}{40.85} \\
\hline Nuclide ID & $\mathbf{E} / \mathbf{C}^{a}$ & $\begin{array}{c}\text { E/C-1 } \\
(\%)\end{array}$ & $\mathrm{E} / \mathrm{C}$ & $\begin{array}{c}\mathrm{E} / \mathrm{C}-1 \\
(\%)\end{array}$ & $\mathrm{E} / \mathrm{C}$ & $\begin{array}{c}\text { E/C-1 } \\
(\%)\end{array}$ \\
\hline $\mathrm{U}-234$ & 0.939 & -6.11 & 0.933 & -6.71 & 0.924 & -7.62 \\
\hline $\mathrm{U}-235$ & 0.977 & -2.29 & 0.989 & -1.13 & 0.978 & -2.16 \\
\hline $\mathrm{U}-236$ & 1.005 & 0.48 & 1.004 & 0.38 & 1.007 & 0.72 \\
\hline $\mathrm{U}-238$ & 1.001 & 0.07 & 1.000 & 0.04 & 1.001 & 0.12 \\
\hline $\mathrm{Pu}-238$ & 1.115 & 11.47 & 1.142 & 14.23 & 1.069 & 6.89 \\
\hline Pu-239 & 0.954 & -4.63 & 0.977 & -2.27 & 0.940 & -6.04 \\
\hline $\mathrm{Pu}-240$ & 0.932 & -6.78 & 0.936 & -6.40 & 0.923 & -7.70 \\
\hline $\mathrm{Pu}-241$ & 1.025 & 2.50 & 1.050 & 5.01 & 1.008 & 0.80 \\
\hline $\mathrm{Pu}-242$ & 1.024 & 2.42 & 1.029 & 2.90 & 1.004 & 0.39 \\
\hline $\mathrm{Np}-237$ & 0.984 & -1.60 & 1.015 & 1.45 & 1.000 & 0.00 \\
\hline Am-241 & 0.862 & -13.85 & 0.900 & -9.99 & 0.753 & -24.69 \\
\hline Am-242m & 0.933 & -6.72 & 0.977 & -2.26 & 0.835 & -16.51 \\
\hline Am-243 & 0.901 & -9.92 & 0.916 & -8.39 & 0.861 & -13.88 \\
\hline $\mathrm{Cm}-242$ & 0.932 & -6.83 & 0.884 & -11.61 & 0.971 & -2.87 \\
\hline $\mathrm{Cm}-243$ & 1.217 & 21.67 & 1.257 & 25.66 & 1.208 & 20.79 \\
\hline $\mathrm{Cm}-244$ & 1.074 & 7.39 & 1.103 & 10.34 & 1.003 & 0.26 \\
\hline $\mathrm{Cm}-245$ & 1.496 & 49.63 & 1.568 & 56.76 & 1.340 & 33.98 \\
\hline $\mathrm{Cm}-246$ & 1.625 & 62.47 & 1.691 & 69.06 & 1.490 & 49.01 \\
\hline $\mathrm{Cm}-247$ & 1.567 & 56.72 & 1.628 & 62.79 & 1.541 & 54.08 \\
\hline Ru-106 & 0.919 & -8.05 & 0.552 & -44.82 & 1.167 & 16.73 \\
\hline Sb-125 & 0.585 & -41.54 & 0.720 & -28.03 & 0.520 & -47.95 \\
\hline Cs-134 & 1.173 & 17.34 & 1.181 & 18.13 & 1.189 & 18.86 \\
\hline Cs-137 & 1.018 & 1.75 & 1.020 & 1.98 & 1.025 & 2.47 \\
\hline $\mathrm{Ce}-144$ & 0.941 & -5.90 & 0.934 & -6.58 & 1.047 & 4.70 \\
\hline Nd-142 & - & - & - & - & - & - \\
\hline $\mathrm{Nd}-143$ & 0.991 & -0.87 & 1.001 & 0.05 & 0.995 & -0.48 \\
\hline Nd-144 & 1.042 & 4.24 & 1.047 & 4.72 & 1.024 & 2.40 \\
\hline Nd-145 & 0.989 & -1.15 & 0.989 & -1.09 & 0.991 & -0.89 \\
\hline $\mathrm{Nd}-146$ & 0.992 & -0.77 & 0.994 & -0.63 & 0.988 & -1.18 \\
\hline $\mathrm{Nd}-148$ & 0.999 & -0.06 & 1.000 & -0.04 & 0.994 & -0.57 \\
\hline $\mathrm{Nd}-150$ & 0.986 & -1.39 & 0.984 & -1.57 & 0.977 & -2.32 \\
\hline Sm-147 & 1.029 & 2.88 & 1.023 & 2.32 & 1.009 & 0.88 \\
\hline Sm-148 & 1.143 & 14.32 & 1.156 & 15.62 & 1.085 & 8.47 \\
\hline Sm-149 & 0.901 & -9.89 & 0.899 & -10.13 & 0.982 & -1.79 \\
\hline Sm-150 & 0.975 & -2.53 & 0.981 & -1.87 & 0.957 & -4.25 \\
\hline Sm-151 & 0.755 & -24.52 & 0.786 & -21.45 & 0.747 & -25.30 \\
\hline Sm-152 & 0.769 & -23.14 & 0.772 & -22.80 & 0.794 & -20.61 \\
\hline Sm-154 & 1.000 & 0.01 & 1.009 & 0.91 & 0.986 & -1.35 \\
\hline Eu-154 & 0.987 & -1.32 & 1.002 & 0.20 & 0.978 & -2.21 \\
\hline
\end{tabular}

${ }^{a}$ Ratio of experimental-to-calculated isotopic concentrations. The experimental values are provided in Table 34. The SCALE input and output files for the evaluated samples are provided on the accompanying DVD (see Appendix B). 
Table 103. SCALE calculation results for the TMI Unit 1 spent fuel samples

\begin{tabular}{|c|c|c|c|c|c|c|c|c|c|c|}
\hline Sample ID & \multicolumn{2}{|c|}{ NJ05YU.A1B } & \multicolumn{2}{|c|}{ NJ05YU.A2 } & \multicolumn{2}{|c|}{ NJ05YU.B1B } & \multicolumn{2}{|c|}{ NJ05YU.B2 } & \multicolumn{2}{|c|}{ NJ05YU.B3J } \\
\hline $\begin{array}{c}\text { Enrichment } \\
(\%)\end{array}$ & \multicolumn{2}{|c|}{4.013} & \multicolumn{2}{|c|}{4.013} & \multicolumn{2}{|c|}{4.013} & \multicolumn{2}{|c|}{4.013} & \multicolumn{2}{|c|}{4.013} \\
\hline $\begin{array}{c}\text { Burnup } \\
\text { (GWd/MTU) }\end{array}$ & \multicolumn{2}{|c|}{44.8} & \multicolumn{2}{|c|}{50.6} & \multicolumn{2}{|c|}{54.5} & \multicolumn{2}{|c|}{50.1} & \multicolumn{2}{|c|}{$\mathbf{5 3 . 0}$} \\
\hline Nuclide ID & $\mathrm{E} / \mathrm{C}^{a}$ & $\begin{array}{c}\text { E/C-1 } \\
(\%)\end{array}$ & $\mathbf{E} / \mathbf{C}$ & $\begin{array}{c}\text { E/C-1 } \\
(\%)\end{array}$ & $\mathbf{E} / \mathbf{C}$ & $\begin{array}{c}\text { E/C-1 } \\
(\%)\end{array}$ & $\mathrm{E} / \mathrm{C}$ & $\begin{array}{c}\text { E/C-1 } \\
(\%)\end{array}$ & $\mathbf{E} / \mathbf{C}$ & $\begin{array}{c}\text { E/C-1 } \\
(\%)\end{array}$ \\
\hline U-234 & 0.955 & -4.54 & 0.987 & -1.35 & 0.999 & -0.08 & 0.957 & -4.31 & 0.956 & -4.41 \\
\hline U-235 & 1.014 & 1.39 & 0.939 & -6.08 & 1.101 & 10.12 & 0.894 & -10.61 & 1.010 & 0.96 \\
\hline $\mathrm{U}-236$ & 0.952 & -4.79 & 0.990 & -1.01 & 0.959 & -4.14 & 0.976 & -2.45 & 0.973 & -2.70 \\
\hline $\mathrm{U}-238$ & 1.002 & 0.16 & 1.002 & 0.15 & 1.002 & 0.17 & 1.002 & 0.22 & 1.001 & 0.14 \\
\hline $\mathrm{Pu}-238$ & 1.502 & 50.15 & 1.011 & 1.07 & 1.071 & 7.08 & 0.908 & -9.19 & 1.056 & 5.62 \\
\hline $\mathrm{Pu}-239$ & 0.867 & -13.26 & 0.901 & -9.90 & 0.845 & -15.52 & 0.882 & -11.83 & 0.860 & -13.99 \\
\hline $\mathrm{Pu}-240$ & 0.836 & -16.44 & 0.908 & -9.17 & 0.814 & -18.59 & 0.894 & -10.56 & 0.841 & -15.89 \\
\hline $\mathrm{Pu}-241$ & 0.968 & -3.17 & 0.918 & -8.22 & 0.942 & -5.82 & 0.935 & -6.53 & 0.975 & -2.49 \\
\hline $\mathrm{Pu}-242$ & 0.900 & -10.02 & 0.959 & -4.06 & 0.868 & -13.17 & 0.971 & -2.92 & 1.053 & 5.27 \\
\hline $\mathrm{Np}-237$ & 0.965 & -3.53 & 0.968 & -3.18 & 0.901 & -9.92 & 0.970 & -3.02 & 0.940 & -5.96 \\
\hline Am-241 & 0.922 & -7.82 & 1.018 & 1.84 & 0.665 & -33.45 & 1.139 & 13.88 & 1.211 & 21.07 \\
\hline $\mathrm{Am}-242 \mathrm{~m}$ & - & - & - & - & - & - & - & - & 0.959 & -4.14 \\
\hline Am-243 & 0.660 & -34.03 & 0.954 & -4.60 & 0.630 & -37.05 & 0.981 & -1.88 & 0.702 & -29.83 \\
\hline $\mathrm{Cm}-242$ & - & - & - & - & - & - & - & - & - & - \\
\hline $\mathrm{Cm}-243$ & - & - & - & - & - & - & - & - & - & - \\
\hline $\mathrm{Cm}-244$ & - & - & - & - & - & - & - & - & - & - \\
\hline $\mathrm{Cm}-245$ & - & - & - & - & - & - & - & - & - & - \\
\hline Mo-95 & 1.031 & 3.10 & 1.005 & 0.55 & 0.977 & -2.26 & 1.023 & 2.29 & 0.975 & -2.53 \\
\hline Tc-99 & 1.339 & 33.88 & 0.924 & -7.65 & 1.062 & 6.18 & 0.940 & -5.98 & 1.026 & 2.56 \\
\hline $\mathrm{Ru}-101$ & 1.058 & 5.81 & 0.976 & -2.43 & 0.935 & -6.50 & 1.025 & 2.51 & 0.947 & -5.33 \\
\hline Rh-103 & 0.965 & -3.51 & 0.918 & -8.20 & 0.883 & -11.70 & 0.938 & -6.17 & 0.892 & -10.80 \\
\hline Ag-109 & 0.490 & -50.99 & 0.482 & -51.76 & 0.321 & -67.88 & 0.432 & -56.80 & 0.592 & -40.82 \\
\hline Cs-134 & - & - & - & - & - & - & - & - & - & - \\
\hline Cs-137 & 1.145 & 14.52 & 1.026 & 2.58 & 0.987 & -1.31 & 1.027 & 2.66 & 1.000 & -0.01 \\
\hline Nd-143 & 0.951 & -4.89 & 0.870 & -12.99 & 0.961 & -3.86 & 0.914 & -8.61 & 0.954 & -4.62 \\
\hline Nd-145 & 0.959 & -4.06 & 0.905 & -9.49 & 0.965 & -3.52 & 0.942 & -5.82 & 0.975 & -2.48 \\
\hline Nd-146 & - & - & - & - & - & - & - & - & - & - \\
\hline Nd-148 & 0.982 & -1.85 & 0.985 & -1.54 & 0.985 & -1.46 & 0.984 & -1.63 & 0.984 & -1.56 \\
\hline Nd-150 & - & - & - & - & - & - & - & - & - & - \\
\hline Sm-147 & 0.900 & -10.02 & 0.885 & -11.50 & 0.992 & -0.76 & 0.836 & -16.35 & 0.965 & -3.52 \\
\hline Sm-149 & 0.812 & -18.79 & 0.984 & -1.59 & 0.857 & -14.30 & 0.854 & -14.55 & 0.805 & -19.52 \\
\hline Sm-150 & 0.907 & -9.31 & 0.831 & -16.90 & 0.959 & -4.10 & 0.843 & -15.67 & 0.956 & -4.38 \\
\hline Sm-151 & 0.734 & -26.60 & 0.661 & -33.88 & 0.757 & -24.26 & 0.701 & -29.90 & 0.771 & -22.90 \\
\hline Sm-152 & 0.736 & -26.37 & 0.726 & -27.38 & 0.748 & -25.23 & 0.719 & -28.14 & 0.752 & -24.76 \\
\hline Eu-151 & 0.985 & -1.50 & 1.885 & 88.45 & 0.760 & -23.97 & 1.677 & 67.67 & 1.034 & 3.36 \\
\hline Eu-153 & 0.917 & -8.33 & 0.919 & -8.10 & 0.917 & -8.29 & 0.911 & -8.93 & 0.934 & -6.57 \\
\hline Eu-155 & 2.545 & 154.55 & 2.125 & 112.50 & 2.945 & 194.48 & 2.202 & 120.23 & 2.048 & 104.76 \\
\hline Gd-155 & 2.047 & 104.69 & 1.496 & 49.57 & 1.876 & 87.60 & 1.899 & 89.92 & 2.030 & 102.97 \\
\hline
\end{tabular}

${ }^{a}$ Ratio of experimental-to-calculated isotopic concentrations. The experimental values are provided in Table 37. The SCALE input and output files for the evaluated samples are provided on the accompanying DVD (see Appendix B). 
Table 103. SCALE calculation results for the TMI Unit 1 spent fuel samples (continued)

\begin{tabular}{|c|c|c|c|c|c|c|c|c|c|c|}
\hline Sample ID & \multicolumn{2}{|c|}{ NJ05YU.C1 } & \multicolumn{2}{|c|}{ NJ05YU.C2B } & \multicolumn{2}{|c|}{ NJ05YU.C3 } & \multicolumn{2}{|c|}{ NJ05YU.D1A2 } & \multicolumn{2}{|c|}{ NJ05YU.D1A4 } \\
\hline $\begin{array}{c}\text { Enrichment } \\
(\%)\end{array}$ & \multicolumn{2}{|c|}{4.013} & \multicolumn{2}{|c|}{4.013} & \multicolumn{2}{|c|}{4.013} & \multicolumn{2}{|c|}{4.013} & \multicolumn{2}{|c|}{4.013} \\
\hline $\begin{array}{c}\text { Burnup } \\
\text { (GWd/MTU) }\end{array}$ & \multicolumn{2}{|c|}{50.2} & \multicolumn{2}{|c|}{52.6} & \multicolumn{2}{|c|}{51.3} & \multicolumn{2}{|c|}{55.7} & \multicolumn{2}{|c|}{50.5} \\
\hline Nuclide ID & $\mathrm{E} / \mathrm{C}^{a}$ & $\begin{array}{c}\text { E/C-1 } \\
(\%)\end{array}$ & $\mathbf{E} / \mathbf{C}$ & $\begin{array}{c}\text { E/C-1 } \\
(\%)\end{array}$ & $\mathbf{E} / \mathbf{C}$ & $\begin{array}{c}\text { E/C-1 } \\
(\%)\end{array}$ & $\mathbf{E} / \mathbf{C}$ & $\begin{array}{c}\text { E/C-1 } \\
(\%)\end{array}$ & $\mathrm{E} / \mathrm{C}$ & $\begin{array}{c}\text { E/C-1 } \\
(\%)\end{array}$ \\
\hline $\mathrm{U}-234$ & 1.017 & 1.72 & 0.938 & -6.17 & 0.964 & -3.60 & 1.044 & 4.40 & 0.998 & -0.18 \\
\hline U-235 & 0.926 & -7.39 & 0.979 & -2.13 & 0.939 & -6.10 & 1.230 & 23.04 & 1.055 & 5.53 \\
\hline U-236 & 0.987 & -1.26 & 0.926 & -7.37 & 0.957 & -4.32 & 0.964 & -3.60 & 0.967 & -3.34 \\
\hline $\mathrm{U}-238$ & 1.002 & 0.20 & 1.003 & 0.26 & 1.002 & 0.19 & 1.001 & 0.07 & 1.001 & 0.12 \\
\hline $\mathrm{Pu}-238$ & 0.928 & -7.19 & 1.205 & 20.55 & 0.688 & -31.18 & 0.893 & -10.71 & 1.045 & 4.54 \\
\hline $\mathrm{Pu}-239$ & 0.873 & -12.72 & 0.816 & -18.41 & 0.910 & -8.99 & 0.878 & -12.22 & 0.859 & -14.06 \\
\hline $\mathrm{Pu}-240$ & 0.892 & -10.78 & 0.802 & -19.77 & 0.915 & -8.49 & 0.820 & -18.01 & 0.842 & -15.81 \\
\hline $\mathrm{Pu}-241$ & 0.932 & -6.84 & 0.927 & -7.32 & 0.925 & -7.52 & 0.981 & -1.94 & 0.999 & -0.10 \\
\hline $\mathrm{Pu}-242$ & 0.955 & -4.48 & 0.904 & -9.59 & 0.938 & -6.23 & 0.844 & -15.60 & 0.990 & -0.98 \\
\hline $\mathrm{Np}-237$ & 0.971 & -2.86 & 0.908 & -9.22 & 0.930 & -6.99 & 0.879 & -12.14 & 0.932 & -6.76 \\
\hline Am-241 & 1.220 & 22.03 & 1.177 & 17.74 & 0.990 & -0.97 & 0.750 & -25.03 & 1.221 & 22.15 \\
\hline Am-242m & - & - & 1.194 & 19.41 & - & - & 0.430 & -56.99 & 0.586 & -41.41 \\
\hline Am-243 & 0.933 & -6.74 & 0.659 & -34.14 & 0.888 & -11.24 & 0.597 & -40.30 & 0.687 & -31.30 \\
\hline $\mathrm{Cm}-242$ & - & - & - & - & - & - & - & - & - & - \\
\hline $\mathrm{Cm}-243$ & - & - & - & - & - & - & - & - & - & - \\
\hline $\mathrm{Cm}-244$ & - & - & - & - & - & - & - & - & - & - \\
\hline $\mathrm{Cm}-245$ & - & - & - & - & - & - & - & - & - & - \\
\hline Mo-95 & 0.998 & -0.21 & 0.960 & -4.01 & 0.897 & -10.34 & 0.929 & -7.08 & 0.984 & -1.58 \\
\hline Tc-99 & 0.932 & -6.85 & 1.126 & 12.61 & 0.875 & -12.52 & 0.904 & -9.58 & 1.022 & 2.18 \\
\hline $\mathrm{Ru}-101$ & 0.992 & -0.80 & 0.955 & -4.47 & 0.855 & -14.47 & 0.872 & -12.76 & 0.931 & -6.95 \\
\hline Rh-103 & 0.918 & -8.19 & 0.885 & -11.47 & 0.803 & -19.69 & 0.854 & -14.58 & 0.890 & -10.97 \\
\hline Ag-109 & 0.435 & -56.48 & 0.499 & -50.07 & 0.731 & -26.95 & 0.326 & -67.39 & 0.681 & -31.91 \\
\hline Cs-134 & - & - & - & - & - & - & - & - & - & - \\
\hline Cs-137 & 1.062 & 6.19 & 1.025 & 2.50 & 0.975 & -2.52 & 0.843 & -15.74 & 1.001 & 0.05 \\
\hline Nd-143 & 0.888 & -11.20 & 0.923 & -7.70 & 0.860 & -13.96 & 0.968 & -3.25 & 0.974 & -2.59 \\
\hline Nd-145 & 0.933 & -6.72 & 0.946 & -5.40 & 0.917 & -8.33 & 0.968 & -3.25 & 0.995 & -0.55 \\
\hline Nd-146 & - & - & - & - & - & - & - & - & - & - \\
\hline Nd-148 & 0.983 & -1.72 & 0.985 & -1.51 & 0.984 & -1.61 & 0.986 & -1.40 & 0.982 & -1.75 \\
\hline Nd-150 & - & - & - & - & - & - & - & - & - & - \\
\hline Sm-147 & 0.845 & -15.54 & 0.894 & -10.59 & 0.818 & -18.20 & 0.982 & -1.76 & 0.928 & -7.25 \\
\hline Sm-149 & 0.812 & -18.81 & 0.848 & -15.24 & 0.747 & -25.33 & 0.927 & -7.32 & 0.878 & -12.18 \\
\hline Sm-150 & 0.859 & -14.10 & 0.892 & -10.77 & 0.792 & -20.78 & 0.906 & -9.37 & 0.918 & -8.22 \\
\hline Sm-151 & 0.631 & -36.95 & 0.674 & -32.58 & 0.643 & -35.70 & 0.754 & -24.63 & 0.710 & -29.00 \\
\hline Sm-152 & 0.705 & -29.49 & 0.697 & -30.27 & 0.685 & -31.48 & 0.731 & -26.86 & 0.744 & -25.60 \\
\hline Eu-151 & 1.399 & 39.92 & 0.941 & -5.89 & 1.756 & 75.62 & 0.850 & -14.95 & 0.885 & -11.50 \\
\hline Eu-153 & 0.907 & -9.25 & 0.886 & -11.36 & 0.850 & -15.01 & 0.910 & -8.97 & 0.940 & -6.03 \\
\hline Eu-155 & 2.387 & 138.71 & 1.991 & 99.12 & 2.063 & 106.34 & 1.810 & 81.03 & 2.666 & 166.62 \\
\hline Gd-155 & 1.830 & 83.02 & 1.845 & 84.48 & 1.867 & 86.71 & 1.844 & 84.37 & 2.882 & 188.15 \\
\hline
\end{tabular}

${ }^{a}$ Ratio of experimental-to-calculated isotopic concentrations. The experimental values are provided in Table 37. The SCALE input and output files for the evaluated samples are provided on the accompanying DVD (see Appendix B). 
Table 103. SCALE calculation results for the TMI Unit 1 spent fuel samples (continued)

\begin{tabular}{|c|c|c|c|c|c|c|c|c|c|c|}
\hline Sample ID & \multicolumn{2}{|c|}{ NJ05YU.D2 } & \multicolumn{2}{|c|}{ NJ070G.012S4 } & \multicolumn{2}{|c|}{ NJ070G.012S5 } & \multicolumn{2}{|c|}{ NJ070G.012S6 } & \multicolumn{2}{|c|}{ NJ070G.013S7 } \\
\hline $\begin{array}{c}\text { Enrichment } \\
(\%)\end{array}$ & \multicolumn{2}{|c|}{4.013} & \multicolumn{2}{|c|}{4.657} & \multicolumn{2}{|c|}{4.657} & \multicolumn{2}{|c|}{4.657} & \multicolumn{2}{|c|}{4.657} \\
\hline $\begin{array}{c}\text { Burnup } \\
\text { (GWd/MTU) }\end{array}$ & \multicolumn{2}{|c|}{44.8} & \multicolumn{2}{|c|}{23.7} & \multicolumn{2}{|c|}{26.5} & \multicolumn{2}{|c|}{24.0} & \multicolumn{2}{|c|}{22.8} \\
\hline Nuclide ID & $\mathrm{E} / \mathrm{C}^{a}$ & $\begin{array}{c}\text { E/C-1 } \\
(\%)\end{array}$ & $\mathbf{E} / \mathbf{C}$ & $\begin{array}{c}\text { E/C-1 } \\
(\%)\end{array}$ & $\mathbf{E} / \mathbf{C}$ & $\begin{array}{c}\text { E/C-1 } \\
(\%)\end{array}$ & $\mathrm{E} / \mathrm{C}$ & $\begin{array}{c}\text { E/C-1 } \\
(\%)\end{array}$ & $\mathrm{E} / \mathrm{C}$ & $\begin{array}{c}\text { E/C-1 } \\
(\%) \\
\end{array}$ \\
\hline $\mathrm{U}-234$ & 0.916 & -8.39 & 1.003 & 0.30 & 0.982 & -1.84 & 0.993 & -0.67 & 1.019 & 1.91 \\
\hline U-235 & 0.823 & -17.70 & 0.972 & -2.76 & 0.970 & -2.98 & 0.984 & -1.59 & 0.954 & -4.61 \\
\hline U-236 & 0.995 & -0.48 & 1.036 & 3.59 & 1.029 & 2.85 & 1.044 & 4.42 & 1.044 & 4.41 \\
\hline $\mathrm{U}-238$ & 1.003 & 0.28 & 1.001 & 0.07 & 1.001 & 0.06 & 0.999 & -0.06 & 1.000 & 0.03 \\
\hline $\mathrm{Pu}-238$ & 1.131 & 13.06 & 1.172 & 17.15 & 1.189 & 18.87 & 1.305 & 30.46 & 1.240 & 24.00 \\
\hline $\mathrm{Pu}-239$ & 0.859 & -14.08 & 0.973 & -2.71 & 0.990 & -1.04 & 1.039 & 3.86 & 0.983 & -1.69 \\
\hline $\mathrm{Pu}-240$ & 0.932 & -6.80 & 1.001 & 0.15 & 1.023 & 2.28 & 1.046 & 4.56 & 1.033 & 3.32 \\
\hline $\mathrm{Pu}-241$ & 0.946 & -5.36 & 1.052 & 5.22 & 1.086 & 8.61 & 1.136 & 13.63 & 1.099 & 9.94 \\
\hline $\mathrm{Pu}-242$ & 1.059 & 5.86 & 1.087 & 8.71 & 1.106 & 10.64 & 1.141 & 14.14 & 1.173 & 17.25 \\
\hline $\mathrm{Np}-237$ & 1.041 & 4.08 & 1.073 & 7.27 & 1.018 & 1.76 & 1.088 & 8.79 & 1.056 & 5.55 \\
\hline Am-241 & 1.181 & 18.13 & 1.092 & 9.21 & 1.061 & 6.13 & 0.908 & -9.18 & 1.080 & 7.96 \\
\hline Am-242m & - & - & 1.084 & 8.45 & 1.057 & 5.69 & 0.948 & -5.22 & 1.032 & 3.23 \\
\hline Am-243 & 0.990 & -1.02 & 0.967 & -3.34 & 0.998 & -0.24 & 0.838 & -16.21 & 1.058 & 5.76 \\
\hline $\mathrm{Cm}-242$ & - & - & 1.635 & 63.48 & 1.441 & 44.13 & 1.270 & 27.05 & 1.403 & 40.33 \\
\hline $\mathrm{Cm}-243$ & - & - & 1.386 & 38.61 & 1.456 & 45.59 & 1.309 & 30.93 & 1.517 & 51.73 \\
\hline $\mathrm{Cm}-244$ & - & - & 1.165 & 16.46 & 1.216 & 21.57 & 1.088 & 8.84 & 1.303 & 30.28 \\
\hline $\mathrm{Cm}-245$ & - & - & 1.690 & 68.98 & 1.815 & 81.55 & 1.779 & 77.86 & 1.940 & 94.04 \\
\hline Mo-95 & 0.916 & -8.37 & - & - & - & - & - & - & - & - \\
\hline Tc-99 & 0.923 & -7.68 & - & - & - & - & - & - & - & - \\
\hline $\mathrm{Ru}-101$ & 0.900 & -9.98 & - & - & - & - & - & - & - & - \\
\hline Rh-103 & 0.830 & -17.00 & - & - & - & - & - & - & - & - \\
\hline Ag-109 & 0.441 & -55.91 & - & - & - & - & - & - & - & - \\
\hline Cs-134 & - & - & 1.264 & 26.35 & 1.282 & 28.20 & 1.330 & 32.96 & 1.336 & 33.55 \\
\hline Cs-137 & 1.061 & 6.06 & 1.038 & 3.83 & 1.041 & 4.10 & 1.040 & 4.00 & 1.080 & 7.97 \\
\hline Nd-143 & 0.868 & -13.16 & 0.974 & -2.61 & 0.968 & -3.22 & 0.981 & -1.86 & 0.991 & -0.89 \\
\hline Nd-145 & 0.938 & -6.19 & 0.980 & -1.96 & 0.973 & -2.68 & 0.981 & -1.89 & 1.000 & 0.05 \\
\hline Nd-146 & - & - & 0.988 & -1.20 & 0.986 & -1.40 & 0.999 & -0.08 & 1.013 & 1.29 \\
\hline Nd-148 & 0.982 & -1.81 & 0.992 & -0.80 & 0.989 & -1.06 & 1.002 & 0.24 & 1.017 & 1.68 \\
\hline Nd-150 & - & - & 0.986 & -1.44 & 0.987 & -1.28 & 1.004 & 0.43 & 1.019 & 1.87 \\
\hline Sm-147 & 0.847 & -15.34 & 1.049 & 4.87 & 1.019 & 1.94 & 1.036 & 3.56 & 1.031 & 3.10 \\
\hline Sm-149 & 0.769 & -23.14 & 0.871 & -12.86 & 0.873 & -12.71 & 0.948 & -5.23 & 0.868 & -13.25 \\
\hline Sm-150 & 0.882 & -11.75 & 0.979 & -2.07 & 0.980 & -2.01 & 0.990 & -0.98 & 1.001 & 0.12 \\
\hline Sm-151 & 0.654 & -34.56 & 0.788 & -21.21 & 0.799 & -20.13 & 0.851 & -14.88 & 0.785 & -21.50 \\
\hline Sm-152 & 0.740 & -26.03 & 0.874 & -12.61 & 0.848 & -15.23 & 0.848 & -15.17 & 0.892 & -10.83 \\
\hline Eu-151 & 1.466 & 46.59 & 0.839 & -16.11 & 0.775 & -22.53 & 0.897 & -10.33 & 0.760 & -24.03 \\
\hline Eu-153 & 0.972 & -2.83 & 1.085 & 8.49 & 1.072 & 7.15 & 1.097 & 9.66 & 1.111 & 11.06 \\
\hline Eu-155 & 2.412 & 141.18 & - & - & - & - & - & - & - & - \\
\hline Gd-155 & 1.897 & 89.72 & 1.716 & 71.58 & 1.659 & 65.93 & 1.893 & 89.25 & 1.674 & 67.37 \\
\hline
\end{tabular}

${ }^{a}$ Ratio of experimental-to-calculated isotopic concentrations. The experimental values are provided in Table 37 and Table

39. The SCALE input and output files for the evaluated samples are provided on the accompanying DVD (see Appendix B). 
Table 103. SCALE calculation results for the TMI Unit 1 spent fuel samples (continued)

\begin{tabular}{|c|c|c|c|c|c|c|c|c|}
\hline Sample ID & \multicolumn{2}{|c|}{ NJ070G.013S8 } & \multicolumn{2}{|c|}{ NJ070G.01S1 } & \multicolumn{2}{|c|}{ NJ070G.01S2 } & \multicolumn{2}{|c|}{ NJ070G.01S3 } \\
\hline Enrichment (\%) & \multicolumn{2}{|c|}{4.657} & \multicolumn{2}{|c|}{4.657} & \multicolumn{2}{|c|}{4.657} & \multicolumn{2}{|c|}{4.657} \\
\hline $\begin{array}{c}\text { Burnup } \\
\text { (GWd/MTU) }\end{array}$ & \multicolumn{2}{|c|}{26.3} & \multicolumn{2}{|c|}{25.8} & \multicolumn{2}{|c|}{29.917} & \multicolumn{2}{|c|}{26.7} \\
\hline Nuclide ID & $\mathbf{E} / \mathbf{C}^{a}$ & $\begin{array}{c}\text { E/C-1 } \\
(\%)\end{array}$ & $\mathrm{E} / \mathrm{C}$ & $\begin{array}{c}\text { E/C-1 } \\
(\%)\end{array}$ & E/C & $\begin{array}{c}\text { E/C-1 } \\
(\%)\end{array}$ & $\mathrm{E} / \mathrm{C}$ & $\begin{array}{c}\mathrm{E} / \mathrm{C}-1 \\
(\%)\end{array}$ \\
\hline $\mathrm{U}-234$ & 0.998 & -0.24 & 1.008 & 0.81 & 0.996 & -0.35 & 0.989 & -1.10 \\
\hline $\mathrm{U}-235$ & 0.968 & -3.21 & 0.973 & -2.74 & 0.949 & -5.13 & 0.971 & -2.91 \\
\hline U-236 & 1.025 & 2.52 & 1.028 & 2.82 & 1.028 & 2.76 & 1.033 & 3.31 \\
\hline $\mathrm{U}-238$ & 1.001 & 0.08 & 1.001 & 0.11 & 1.001 & 0.14 & 1.000 & -0.01 \\
\hline $\mathrm{Pu}-238$ & 1.194 & 19.35 & 1.122 & 12.17 & 1.120 & 12.04 & 1.240 & 23.97 \\
\hline $\mathrm{Pu}-239$ & 0.970 & -2.95 & 0.962 & -3.78 & 0.901 & -9.91 & 0.986 & -1.43 \\
\hline $\mathrm{Pu}-240$ & 1.013 & 1.29 & 0.990 & -1.04 & 1.001 & 0.08 & 1.044 & 4.45 \\
\hline $\mathrm{Pu}-241$ & 1.072 & 7.24 & 1.043 & 4.31 & 1.029 & 2.88 & 1.113 & 11.31 \\
\hline $\mathrm{Pu}-242$ & 1.105 & 10.45 & 1.066 & 6.58 & 1.134 & 13.38 & 1.169 & 16.88 \\
\hline $\mathrm{Np}-237$ & 1.024 & 2.38 & 0.966 & -3.42 & 0.987 & -1.27 & 1.049 & 4.90 \\
\hline Am-241 & 1.041 & 4.07 & 0.744 & -25.57 & 0.881 & -11.92 & 0.990 & -0.96 \\
\hline $\mathrm{Am}-242 \mathrm{~m}$ & 1.026 & 2.64 & 0.762 & -23.84 & 0.804 & -19.61 & 0.934 & -6.57 \\
\hline Am-243 & 0.983 & -1.75 & 0.646 & -35.37 & 0.843 & -15.65 & 0.907 & -9.27 \\
\hline $\mathrm{Cm}-242$ & 1.523 & 52.29 & 1.116 & 11.63 & 1.635 & 63.54 & 1.451 & 45.09 \\
\hline $\mathrm{Cm}-243$ & 1.404 & 40.40 & 0.922 & -7.84 & 1.164 & 16.35 & 1.383 & 38.29 \\
\hline $\mathrm{Cm}-244$ & 1.189 & 18.90 & 0.744 & -25.61 & 0.994 & -0.61 & 1.121 & 12.10 \\
\hline $\mathrm{Cm}-245$ & 1.776 & 77.63 & 1.049 & 4.93 & 1.328 & 32.82 & 1.694 & 69.43 \\
\hline Mo-95 & - & - & - & - & - & - & - & - \\
\hline Tc-99 & - & - & - & - & - & - & - & - \\
\hline $\mathrm{Ru}-101$ & - & - & - & - & - & - & - & - \\
\hline Rh-103 & - & - & - & - & - & - & - & - \\
\hline Ag-109 & - & - & - & - & - & - & - & - \\
\hline Cs-134 & 1.300 & 30.03 & 1.224 & 22.43 & 1.244 & 24.40 & 1.295 & 29.52 \\
\hline Cs-137 & 1.060 & 5.96 & 1.022 & 2.24 & 1.078 & 7.80 & 1.048 & 4.76 \\
\hline Nd-143 & 0.968 & -3.22 & 0.965 & -3.50 & 0.966 & -3.37 & 0.976 & -2.42 \\
\hline Nd-145 & 0.975 & -2.48 & 0.974 & -2.56 & 0.984 & -1.62 & 0.982 & -1.79 \\
\hline Nd-146 & 0.987 & -1.27 & 0.981 & -1.89 & 0.991 & -0.94 & 0.996 & -0.37 \\
\hline Nd-148 & 0.991 & -0.90 & 0.989 & -1.15 & 0.999 & -0.07 & 1.003 & 0.34 \\
\hline Nd-150 & 0.988 & -1.18 & 0.987 & -1.32 & 0.995 & -0.50 & 1.006 & 0.62 \\
\hline Sm-147 & 1.015 & 1.47 & 1.048 & 4.80 & 1.042 & 4.24 & 1.052 & 5.16 \\
\hline Sm-149 & 0.870 & -13.02 & 0.856 & -14.36 & 0.827 & -17.33 & 0.918 & -8.16 \\
\hline Sm-150 & 0.977 & -2.32 & 0.966 & -3.40 & 0.979 & -2.06 & 0.993 & -0.68 \\
\hline Sm-151 & 0.800 & -20.02 & 0.769 & -23.08 & 0.756 & -24.44 & 0.805 & -19.53 \\
\hline Sm-152 & 0.847 & -15.32 & 0.860 & -13.99 & 0.872 & -12.77 & 0.867 & -13.26 \\
\hline Eu-151 & 0.771 & -22.90 & 0.807 & -19.29 & 0.715 & -28.55 & 0.830 & -17.02 \\
\hline Eu-153 & 1.078 & 7.80 & 1.048 & 4.80 & 1.051 & 5.13 & 1.074 & 7.44 \\
\hline Eu-155 & - & - & - & - & - & - & - & - \\
\hline Gd-155 & 1.692 & 69.19 & 1.811 & 81.14 & 1.563 & 56.26 & 1.922 & 92.19 \\
\hline
\end{tabular}

${ }^{a}$ Ratio of experimental-to-calculated isotopic concentrations. The experimental values are provided in Table 39. The SCALE input and output files for the evaluated samples are provided on the accompanying DVD (see Appendix B). 
Table 104. SCALE calculation results for Gösgen (ARIANE) spent fuel samples

\begin{tabular}{|c|c|c|c|c|c|c|}
\hline Sample ID & \multicolumn{2}{|c|}{ 1240.GU1 } & \multicolumn{2}{|c|}{ 1701.GU3 } & \multicolumn{2}{|c|}{ 1701.GU4 } \\
\hline Enrichment (\%) & \multicolumn{2}{|c|}{3.5} & \multicolumn{2}{|c|}{4.1} & \multicolumn{2}{|c|}{4.1} \\
\hline Burnup $^{a}$ (GWd/MTU) & \multicolumn{2}{|c|}{60.7} & \multicolumn{2}{|c|}{53.2} & \multicolumn{2}{|c|}{31.1} \\
\hline Nuclide ID & $E / C^{b}$ & $\begin{array}{c}\text { E/C-1 } \\
(\%)\end{array}$ & $\mathbf{E} / \mathbf{C}$ & $\begin{array}{c}\text { E/C-1 } \\
(\%)\end{array}$ & $\mathrm{E} / \mathrm{C}$ & $\begin{array}{c}\text { E/C-1 } \\
(\%)\end{array}$ \\
\hline U-234 & 0.863 & -13.70 & 0.734 & -26.62 & 0.708 & -29.19 \\
\hline $\mathrm{U}-235$ & 0.960 & -4.01 & 1.045 & 4.47 & 0.999 & -0.11 \\
\hline U-236 & 0.995 & -0.52 & 0.999 & -0.11 & 0.998 & -0.18 \\
\hline U-238 & 1.003 & 0.34 & 1.008 & 0.79 & 1.005 & 0.54 \\
\hline $\mathrm{Pu}-238$ & 1.024 & 2.44 & 1.028 & 2.82 & 1.026 & 2.62 \\
\hline $\mathrm{Pu}-239$ & 0.948 & -5.25 & 0.984 & -1.56 & 0.955 & -4.46 \\
\hline $\mathrm{Pu}-240$ & 0.973 & -2.69 & 0.952 & -4.75 & 0.968 & -3.21 \\
\hline $\mathrm{Pu}-241$ & 1.002 & 0.20 & 1.038 & 3.80 & 1.027 & 2.69 \\
\hline $\mathrm{Pu}-242$ & 1.033 & 3.25 & 0.987 & -1.31 & 0.993 & -0.73 \\
\hline $\mathrm{Np}-237$ & - & - & 1.089 & 8.93 & 1.371 & 37.10 \\
\hline Am-241 & 0.923 & -7.66 & 0.888 & -11.18 & 1.032 & 3.18 \\
\hline Am-242m & 0.669 & -33.11 & 0.845 & -15.50 & - & - \\
\hline Am-243 & 0.851 & -14.90 & 0.798 & -20.22 & 0.814 & -18.60 \\
\hline $\mathrm{Cm}-242$ & 1.187 & 18.71 & 1.257 & 25.69 & - & - \\
\hline $\mathrm{Cm}-243$ & 0.330 & -66.97 & 0.792 & -20.82 & - & - \\
\hline $\mathrm{Cm}-244$ & 0.981 & -1.87 & 1.028 & 2.80 & 1.144 & 14.36 \\
\hline $\mathrm{Cm}-245$ & 1.254 & 25.44 & 1.605 & 60.51 & 1.547 & 54.70 \\
\hline $\mathrm{Cm}-246$ & 1.579 & 57.90 & 1.484 & 48.39 & - & - \\
\hline Mo-95 & 1.061 & 6.10 & 1.011 & 1.09 & 1.011 & 1.07 \\
\hline Tc-99 & 0.941 & -5.86 & 0.917 & -8.30 & 0.979 & -2.10 \\
\hline Rh-103 & 0.899 & -10.14 & 0.784 & -21.55 & 1.003 & 0.33 \\
\hline Ru-101 & 0.917 & -8.31 & 0.977 & -2.33 & 1.014 & 1.38 \\
\hline Ru-106 & 0.910 & -8.98 & 1.124 & 12.36 & 1.169 & 16.89 \\
\hline Ag-109 & 0.457 & -54.25 & 0.926 & -7.43 & - & - \\
\hline Sb-125 & 0.680 & -32.01 & 0.604 & -39.61 & - & - \\
\hline Cs-133 & 0.928 & -7.24 & 0.949 & -5.11 & 0.969 & -3.11 \\
\hline Cs-134 & 1.067 & 6.70 & 1.088 & 8.80 & 1.110 & 11.05 \\
\hline Cs-135 & 0.984 & -1.58 & 0.983 & -1.67 & 0.916 & -8.39 \\
\hline Cs-137 & 0.990 & -0.98 & 0.959 & -4.14 & 0.917 & -8.32 \\
\hline Ce-144 & 1.002 & 0.21 & 0.945 & -5.53 & 0.957 & -4.31 \\
\hline $\mathrm{Nd}-142$ & 0.955 & -4.49 & 0.922 & -7.77 & 0.844 & -15.57 \\
\hline Nd-143 & 0.936 & -6.45 & 0.971 & -2.92 & 1.021 & 2.06 \\
\hline Nd-144 & 0.994 & -0.59 & 0.980 & -1.96 & 1.041 & 4.14 \\
\hline $\mathrm{Nd}-145$ & 0.976 & -2.44 & 0.982 & -1.84 & 1.008 & 0.78 \\
\hline Nd-146 & 0.974 & -2.58 & 0.984 & -1.57 & 1.002 & 0.23 \\
\hline Nd-148 & 1.000 & -0.04 & 0.998 & -0.20 & 1.002 & 0.17 \\
\hline $\mathrm{Nd}-150$ & 0.990 & -0.96 & 0.986 & -1.42 & 0.981 & -1.87 \\
\hline
\end{tabular}

${ }^{a}$ Burnup based on measured ${ }^{148} \mathrm{Nd}$.

${ }^{b}$ Ratio of experimental-to-calculated isotopic concentrations. The experimental values are provided in Table 42. The SCALE input and output files for the evaluated samples are provided on the accompanying DVD (see Appendix B). 
Table 104. SCALE calculation results for Gösgen (ARIANE) spent fuel samples (continued)

\begin{tabular}{|c|c|c|c|c|c|c|}
\hline Sample ID & \multicolumn{2}{|c|}{ 1240.GU1 } & \multicolumn{2}{|c|}{ 1701.GU3 } & \multicolumn{2}{|c|}{ 1701.GU4 } \\
\hline Enrichment (\%) & \multicolumn{2}{|c|}{3.5} & \multicolumn{2}{|c|}{4.1} & \multicolumn{2}{|c|}{4.1} \\
\hline Burnup $^{a}$ (GWd/MTU) & \multicolumn{2}{|c|}{60.7} & \multicolumn{2}{|c|}{53.2} & \multicolumn{2}{|c|}{31.1} \\
\hline Nuclide ID & $E / C^{b}$ & $\begin{array}{c}\text { E/C-1 } \\
(\%)\end{array}$ & $\mathrm{E} / \mathrm{C}$ & $\begin{array}{c}\text { E/C-1 } \\
(\%)\end{array}$ & $\mathbf{E} / \mathbf{C}$ & $\begin{array}{c}\text { E/C-1 } \\
(\%)\end{array}$ \\
\hline Pm-147 & 1.549 & 54.87 & 0.909 & -9.14 & 1.099 & 9.94 \\
\hline Sm-147 & 1.059 & 5.89 & 0.979 & -2.07 & 0.935 & -6.49 \\
\hline $\mathrm{Sm}-148$ & 1.131 & 13.07 & 1.129 & 12.94 & 1.035 & 3.53 \\
\hline Sm-149 & 0.984 & -1.61 & 0.797 & -20.31 & 0.932 & -6.80 \\
\hline $\mathrm{Sm}-150$ & 0.948 & -5.15 & 0.908 & -9.16 & 0.909 & -9.12 \\
\hline Sm-151 & 0.744 & -25.61 & 0.720 & -28.00 & 0.738 & -26.16 \\
\hline Sm-152 & 0.792 & -20.77 & 0.712 & -28.81 & 0.782 & -21.79 \\
\hline Sm-154 & 1.023 & 2.27 & 0.922 & -7.77 & 0.901 & -9.93 \\
\hline Eu-151 & 1.745 & 74.46 & 1.218 & 21.80 & - & - \\
\hline Eu-153 & 0.900 & -10.02 & 0.933 & -6.73 & 0.967 & -3.28 \\
\hline Eu-154 & 0.845 & -15.52 & 0.985 & -1.48 & 0.949 & -5.07 \\
\hline Eu-155 & 1.416 & 41.60 & 1.541 & 54.08 & 1.490 & 49.03 \\
\hline Gd-155 & 1.285 & 28.50 & 1.240 & 23.99 & 2.055 & 105.51 \\
\hline
\end{tabular}

${ }^{a}$ Burnup based on measured ${ }^{148} \mathrm{Nd}$.

${ }^{b}$ Ratio of experimental-to-calculated isotopic concentrations. The experimental values are provided in Table 42. The SCALE input and output files for the evaluated samples are provided on the accompanying DVD (see Appendix B). 
Table 105. SCALE calculation results for GKN II (REBUS) spent fuel sample

\begin{tabular}{|c|c|c|}
\hline Sample ID & \multicolumn{2}{|c|}{ 419.M11 } \\
\hline Enrichment (\%) & \multicolumn{2}{|c|}{3.8} \\
\hline Burnup (GWd/MTU) & \multicolumn{2}{|c|}{54.095} \\
\hline Nuclide ID & $\mathrm{E} / \mathrm{C}^{a}$ & $\begin{array}{c}\mathrm{E} / \mathrm{C}-1 \\
(\%)\end{array}$ \\
\hline U-234 & 0.837 & -16.26 \\
\hline U-235 & 0.960 & -4.01 \\
\hline U-236 & 1.009 & 0.92 \\
\hline $\mathrm{U}-238$ & 1.003 & 0.27 \\
\hline $\mathrm{Pu}-238$ & 1.085 & 8.45 \\
\hline Pu-239 & 0.923 & -7.69 \\
\hline $\mathrm{Pu}-240$ & 0.970 & -2.97 \\
\hline $\mathrm{Pu}-241$ & 0.993 & -0.68 \\
\hline $\mathrm{Pu}-242$ & 1.024 & 2.43 \\
\hline $\mathrm{Np}-237$ & 0.789 & -21.09 \\
\hline Am-241 & 0.777 & -22.30 \\
\hline $\mathrm{Am}-242 \mathrm{~m}$ & 0.786 & -21.36 \\
\hline Am-243 & 0.728 & -27.17 \\
\hline $\mathrm{Cm}-242$ & 0.791 & -20.94 \\
\hline $\mathrm{Cm}-243$ & 1.087 & 8.73 \\
\hline $\mathrm{Cm}-244$ & 1.066 & 6.63 \\
\hline $\mathrm{Cm}-245$ & 1.463 & 46.34 \\
\hline Mo-95 & 0.900 & -9.99 \\
\hline Тc-99 & 1.026 & 2.55 \\
\hline Ru-101 & 0.769 & -23.14 \\
\hline Rh-103 & 0.813 & -18.66 \\
\hline Ag-109 & 0.760 & -24.01 \\
\hline Pd-105 & 0.633 & -36.73 \\
\hline Pd-108 & 0.626 & -37.36 \\
\hline Cs-133 & 0.929 & -7.12 \\
\hline Cs-135 & 0.960 & -4.03 \\
\hline Cs-137 & 1.016 & 1.59 \\
\hline $\mathrm{Ce}-144$ & 1.042 & 4.15 \\
\hline Nd-142 & 1.091 & 9.07 \\
\hline Nd-143 & 0.962 & -3.77 \\
\hline Nd-144 & 1.016 & 1.60 \\
\hline Nd-145 & 0.993 & -0.65 \\
\hline Nd-146 & 0.992 & -0.80 \\
\hline Nd-148 & 1.000 & -0.01 \\
\hline Nd-150 & 0.981 & -1.92 \\
\hline Sm-147 & 1.053 & 5.31 \\
\hline Sm-148 & 1.161 & 16.11 \\
\hline Sm-149 & 0.953 & -4.68 \\
\hline $\mathrm{Sm}-150$ & 0.980 & -1.96 \\
\hline $\mathrm{Sm}-151$ & 0.732 & -26.82 \\
\hline Sm-152 & 0.770 & -22.95 \\
\hline Sm-154 & 1.018 & 1.80 \\
\hline $\mathrm{Eu}-153$ & 0.939 & -6.08 \\
\hline Eu-154 & 0.907 & -9.34 \\
\hline Eu-155 & 1.735 & 73.45 \\
\hline Gd-155 & 1.435 & 43.47 \\
\hline
\end{tabular}

${ }^{a}$ Ratio of experimental-to-calculated isotopic concentrations. The experimental values are provided in Table 45. The SCALE input and output files for the evaluated samples are provided on the accompanying DVD (see Appendix B). 
Table 106. SCALE calculation results for Gösgen (MALIBU) spent fuel samples

\begin{tabular}{|c|c|c|c|c|c|c|}
\hline Sample ID & \multicolumn{2}{|c|}{ 1901.GGU1 } & \multicolumn{2}{|c|}{ 1964.GGU2-1 } & \multicolumn{2}{|c|}{ 1964.GGU2-2 } \\
\hline Enrichment (\%) & \multicolumn{2}{|c|}{4.3} & \multicolumn{2}{|c|}{4.3} & \multicolumn{2}{|c|}{4.3} \\
\hline $\begin{array}{c}\text { Burnup }^{a} \\
(\text { GWd/MTU) }\end{array}$ & \multicolumn{2}{|c|}{70.35} & \multicolumn{2}{|c|}{$\mathbf{5 0 . 8 0}$} & \multicolumn{2}{|c|}{46.00} \\
\hline Nuclide ID & $E / C^{b}$ & $\begin{array}{c}\text { E/C-1 } \\
(\%)\end{array}$ & $E / C$ & $\begin{array}{c}\text { E/C-1 } \\
(\%)\end{array}$ & $\mathrm{E} / \mathrm{C}$ & $\begin{array}{c}\mathrm{E} / \mathrm{C}-1 \\
(\%)\end{array}$ \\
\hline $\mathrm{U}-234$ & 1.005 & 0.51 & 0.996 & -0.42 & 0.968 & -3.19 \\
\hline $\mathrm{U}-235$ & 1.026 & 2.55 & 1.070 & 7.03 & 0.998 & -0.22 \\
\hline U-236 & 1.022 & 2.16 & 0.996 & -0.39 & 0.989 & -1.10 \\
\hline $\mathrm{U}-238$ & 1.014 & 1.42 & 1.001 & 0.09 & 0.990 & -1.00 \\
\hline $\mathrm{Pu}-238$ & 1.047 & 4.66 & 1.113 & 11.31 & 1.116 & 11.61 \\
\hline $\mathrm{Pu}-239$ & 0.952 & -4.83 & 1.044 & 4.43 & 1.003 & 0.33 \\
\hline $\mathrm{Pu}-240$ & 0.972 & -2.85 & 0.983 & -1.68 & 0.967 & -3.31 \\
\hline $\mathrm{Pu}-241$ & 1.024 & 2.38 & 1.071 & 7.14 & 1.068 & 6.81 \\
\hline $\mathrm{Pu}-242$ & 1.048 & 4.81 & 0.993 & -0.74 & 1.018 & 1.84 \\
\hline $\mathrm{Np}-237$ & 0.971 & -2.92 & 0.931 & -6.91 & 0.909 & -9.11 \\
\hline Am-241 & 1.091 & 9.13 & 1.120 & 12.01 & 0.881 & -11.86 \\
\hline Am-242m & 0.774 & -22.62 & 1.209 & 20.88 & 0.772 & -22.77 \\
\hline Am-243 & 0.971 & -2.86 & 0.930 & -7.01 & 0.765 & -23.48 \\
\hline $\mathrm{Cm}-242$ & 1.121 & 12.12 & - & - & 1.269 & 26.90 \\
\hline $\mathrm{Cm}-243$ & 1.187 & 18.69 & - & - & 1.067 & 6.75 \\
\hline $\mathrm{Cm}-244$ & 1.068 & 6.77 & 1.015 & 1.51 & 1.100 & 10.04 \\
\hline $\mathrm{Cm}-245$ & 1.381 & 38.08 & 1.417 & 41.70 & 1.508 & 50.78 \\
\hline $\mathrm{Cm}-246$ & 1.591 & 59.11 & 1.408 & 40.79 & 1.515 & 51.54 \\
\hline Mo-95 & 0.996 & -0.44 & 1.096 & 9.59 & 1.007 & 0.75 \\
\hline Tc-99 & 0.841 & -15.90 & 0.854 & -14.55 & 1.026 & 2.59 \\
\hline $\mathrm{Ru}-101$ & 0.937 & -6.33 & 1.039 & 3.91 & 0.996 & -0.45 \\
\hline Ru-106 & 0.889 & -11.13 & 1.108 & 10.82 & 0.894 & -10.61 \\
\hline Rh-103 & 0.927 & -7.32 & 1.033 & 3.28 & 0.972 & -2.85 \\
\hline Ag-109 & 0.371 & -62.92 & 0.420 & -57.97 & 0.997 & -0.32 \\
\hline Sb-125 & - & - & - & - & - & - \\
\hline Cs-133 & - & - & - & - & - & - \\
\hline Cs-134 & 0.612 & -38.82 & 0.865 & -13.53 & 0.722 & -27.82 \\
\hline Cs-135 & 0.961 & -3.89 & 0.962 & -3.78 & 0.960 & -3.98 \\
\hline Cs-137 & 1.130 & 13.02 & 1.166 & 16.65 & 1.179 & 17.92 \\
\hline $\mathrm{Ce}-144$ & 1.017 & 1.69 & 1.029 & 2.92 & 1.004 & 0.41 \\
\hline Nd-142 & 1.005 & 0.48 & 0.999 & -0.09 & 1.003 & 0.33 \\
\hline Nd-143 & 1.067 & 6.73 & 1.089 & 8.87 & 1.088 & 8.75 \\
\hline Nd-144 & 0.981 & -1.88 & 0.923 & -7.74 & 1.152 & 15.22 \\
\hline $\mathrm{Nd}-145$ & 0.978 & -2.19 & 0.955 & -4.47 & 1.137 & 13.68 \\
\hline Nd-146 & 0.992 & -0.81 & 1.026 & 2.63 & 0.967 & -3.25 \\
\hline $\mathrm{Nd}-148$ & 1.046 & 4.59 & 1.028 & 2.77 & 0.988 & -1.18 \\
\hline $\mathrm{Nd}-150$ & 1.033 & 3.28 & 1.025 & 2.52 & 0.976 & -2.45 \\
\hline
\end{tabular}

${ }^{a}$ Based on measured data for burnup indicators fission products ${ }^{148} \mathrm{Nd}$ and ${ }^{137} \mathrm{Cs}$.

${ }^{b}$ Ratio of experimental-to-calculated isotopic concentrations. The SCALE input and output files for the evaluated samples are provided on the accompanying DVD (see Appendix B). 
Table 106. SCALE calculation results for Gösgen (MALIBU) spent fuel samples (continued)

\begin{tabular}{|c|c|c|c|c|c|c|}
\hline Sample ID & \multicolumn{2}{|c|}{ 1901.GGU1 } & \multicolumn{2}{|c|}{ 1964.GGU2-1 } & \multicolumn{2}{|c|}{ 1964.GGU2-2 } \\
\hline Enrichment (\%) & \multicolumn{2}{|c|}{4.3} & \multicolumn{2}{|c|}{4.3} & \multicolumn{2}{|c|}{4.3} \\
\hline $\begin{array}{c}\text { Burnup }^{a} \\
(\mathbf{G W d} / \mathbf{M T U})\end{array}$ & \multicolumn{2}{|c|}{70.3} & \multicolumn{2}{|c|}{50.8} & \multicolumn{2}{|c|}{46.0} \\
\hline Nuclide ID & $\mathrm{E} / \mathbf{C}^{a}$ & $\begin{array}{c}\text { E/C-1 } \\
(\%)\end{array}$ & $\mathbf{E} / \mathbf{C}$ & $\begin{array}{c}\text { E/C-1 } \\
(\%)\end{array}$ & $\mathrm{E} / \mathrm{C}$ & $\begin{array}{c}\mathrm{E} / \mathrm{C}-1 \\
(\%)\end{array}$ \\
\hline Pm-147 & 1.131 & 13.11 & 1.063 & 6.28 & 1.026 & 2.65 \\
\hline Sm-147 & 1.260 & 25.98 & 1.142 & 14.18 & 1.086 & 8.62 \\
\hline Sm-148 & 0.871 & -12.88 & 0.920 & -7.97 & 0.900 & -9.98 \\
\hline Sm-149 & 1.041 & 4.08 & 1.000 & 0.04 & 0.957 & -4.29 \\
\hline Sm-150 & 0.761 & -23.89 & 0.831 & -16.90 & 0.796 & -20.36 \\
\hline Sm-151 & 0.797 & -20.33 & 0.803 & -19.66 & 0.778 & -22.25 \\
\hline Sm-152 & 1.050 & 5.02 & 1.030 & 3.02 & 1.073 & 7.26 \\
\hline Sm-154 & 0.696 & -30.44 & - & - & 0.894 & -10.56 \\
\hline Eu-151 & 0.918 & -8.21 & 0.960 & -3.98 & 0.965 & -3.47 \\
\hline Eu-153 & 0.897 & -10.34 & 1.011 & 1.06 & 1.018 & 1.79 \\
\hline Eu-154 & 1.327 & 32.68 & 1.416 & 41.62 & 1.631 & 63.08 \\
\hline Eu-155 & 1.296 & 29.55 & 1.355 & 35.52 & 1.614 & 61.37 \\
\hline Gd-155 & 1.131 & 13.11 & 1.063 & 6.28 & 1.026 & 2.65 \\
\hline
\end{tabular}

${ }^{a}$ Based on measured data for burnup indicators fission products ${ }^{148} \mathrm{Nd}$ and ${ }^{137} \mathrm{Cs}$.

${ }^{b}$ Ratio of experimental-to-calculated isotopic concentrations. The SCALE input and output files for the evaluated samples are provided on the accompanying DVD (see Appendix B).

\subsection{SENSITIVITY CALCULATIONS}

Sensitivity calculations were performed to evaluate the effects of a series of modeling assumptions used in this validation study on the calculated isotopic compositions. The results of the sensitivity study are tabulated in this section.

\subsubsection{Assembly Model Simplifications}

As described in Sect. 9.2.2, a typical TRITON/NEWT calculation model used in this validation study consists of individual depleting mixtures specified for the measured rod and its adjacent nearest-neighbor fuel rods with all other fuel rods in the assembly treated as a single depletion material with uniform composition. This simplified assembly model was used in place of a detailed assembly model that would specify individual depleting mixtures for all the pins included in the assembly model. Calculations using detailed and simplified assembly pin models for Turkey Point spent fuel sample D01-G9 were performed and the isotopic compositions in the measured sample, in $\mathrm{g} / \mathrm{gU}_{\text {initial }}$, are summarized in Table 107 . As seen in the table, the isotopic compositions differ within $\pm 0.5 \%$ for all isotopes of interest. 
Table 107. Comparison between isotopic compositions obtained with detailed and simplified lattice pin model

\begin{tabular}{|c|c|c|c|c|c|c|c|}
\hline $\begin{array}{c}\text { Model } \\
\text { characteristic }\end{array}$ & Detailed & Simplified & & $\begin{array}{c}\text { Model } \\
\text { characteristic }\end{array}$ & Detailed & Simplified & \\
\hline Isotope & $\mathbf{g} / \mathbf{g} \mathbf{U}_{\text {initial }}$ & $\mathbf{g} / \mathbf{g} \mathbf{U}_{\text {initial }}$ & $\begin{array}{c}\text { Rel. diff. } \\
(\%)\end{array}$ & Isotope & $\mathrm{g} / \mathrm{g} \mathbf{U}_{\text {initial }}$ & $\mathbf{g} / \mathbf{g} \mathbf{U}_{\text {initial }}$ & $\begin{array}{l}\text { Rel. diff. } \\
\text { (\%) }\end{array}$ \\
\hline U-234 & $1.35 \mathrm{E}-04$ & $1.34 \mathrm{E}-04$ & 0.08 & Nd-148 & $3.40 \mathrm{E}-04$ & $3.40 \mathrm{E}-04$ & 0.00 \\
\hline U-235 & $5.59 \mathrm{E}-03$ & $5.58 \mathrm{E}-03$ & 0.20 & Cs-137 & $1.07 \mathrm{E}-03$ & $1.07 \mathrm{E}-03$ & 0.00 \\
\hline U-236 & $3.35 \mathrm{E}-03$ & $3.35 \mathrm{E}-03$ & -0.02 & Sm-147 & $1.51 \mathrm{E}-04$ & $1.51 \mathrm{E}-04$ & 0.07 \\
\hline U-238 & $9.49 \mathrm{E}-01$ & $9.49 \mathrm{E}-01$ & -0.01 & Sm-149 & $3.21 \mathrm{E}-06$ & $3.21 \mathrm{E}-06$ & -0.08 \\
\hline $\mathrm{Pu}-238$ & $1.34 \mathrm{E}-04$ & $1.34 \mathrm{E}-04$ & -0.19 & Sm-150 & $2.73 \mathrm{E}-04$ & $2.73 \mathrm{E}-04$ & -0.04 \\
\hline $\mathrm{Pu}-239$ & $5.05 \mathrm{E}-03$ & $5.04 \mathrm{E}-03$ & 0.12 & Sm-151 & $1.25 \mathrm{E}-05$ & $1.25 \mathrm{E}-05$ & -0.12 \\
\hline $\mathrm{Pu}-240$ & $2.36 \mathrm{E}-03$ & $2.36 \mathrm{E}-03$ & 0.09 & Sm-152 & $1.25 \mathrm{E}-04$ & $1.25 \mathrm{E}-04$ & 0.12 \\
\hline $\mathrm{Pu}-241$ & $1.07 \mathrm{E}-03$ & $1.07 \mathrm{E}-03$ & 0.24 & Eu-151 & $2.58 \mathrm{E}-07$ & $2.59 \mathrm{E}-07$ & -0.10 \\
\hline $\mathrm{Pu}-242$ & $5.47 \mathrm{E}-04$ & $5.45 \mathrm{E}-04$ & 0.28 & Eu-153 & $1.11 \mathrm{E}-04$ & $1.11 \mathrm{E}-04$ & 0.00 \\
\hline Np-237 & $3.67 \mathrm{E}-04$ & $3.67 \mathrm{E}-04$ & -0.07 & Eu-155 & $3.60 \mathrm{E}-06$ & $3.59 \mathrm{E}-06$ & 0.13 \\
\hline Am-241 & $1.76 \mathrm{E}-04$ & $1.76 \mathrm{E}-04$ & 0.17 & Gd-155 & $1.68 \mathrm{E}-06$ & $1.67 \mathrm{E}-06$ & 0.12 \\
\hline Am-242m & $6.86 \mathrm{E}-07$ & $6.88 \mathrm{E}-07$ & -0.28 & Mo-95 & $6.92 \mathrm{E}-04$ & $6.92 \mathrm{E}-04$ & 0.00 \\
\hline Am-243 & $1.12 \mathrm{E}-04$ & $1.12 \mathrm{E}-04$ & -0.09 & Tc-99 & $7.45 \mathrm{E}-04$ & 7.44E-04 & 0.04 \\
\hline $\mathrm{Cm}-242$ & $2.53 \mathrm{E}-07$ & $2.52 \mathrm{E}-07$ & 0.10 & Ru-101 & 7.34E-04 & 7.34E-04 & 0.06 \\
\hline $\mathrm{Cm}-244$ & $2.83 \mathrm{E}-05$ & $2.85 \mathrm{E}-05$ & -0.45 & Ru-106 & $2.93 \mathrm{E}-05$ & $2.92 \mathrm{E}-05$ & 0.30 \\
\hline Nd-143 & $7.11 \mathrm{E}-04$ & $7.11 \mathrm{E}-04$ & 0.06 & Rh-103 & $4.71 \mathrm{E}-04$ & $4.70 \mathrm{E}-04$ & 0.17 \\
\hline Nd-145 & $6.18 \mathrm{E}-04$ & $6.17 \mathrm{E}-04$ & 0.03 & Ag-109 & $8.02 \mathrm{E}-05$ & $8.00 \mathrm{E}-05$ & 0.25 \\
\hline
\end{tabular}

\subsubsection{Trino Vercellese Fuel Density Sensitivity Calculations}

The mass density value for the Trino Vercellese fuel was derived using various fuel mass data, as described in Sect. 8.1 (see Table 49). A mass density value of $10.353 \mathrm{~g} / \mathrm{cm}^{3}$ was obtained for assemblies $509-049,509-032$, and $509-104$ by averaging $10.3529 \mathrm{~g} / \mathrm{cm}^{3}$, which is the fuel density based on the $\mathrm{UO}_{2}$ mass in a square assembly $(353.81 \mathrm{~kg})$ in Ref. 12 , Table 2 , and $10.3531 \mathrm{~g} / \mathrm{cm}^{3}$, which is the fuel density based on the $\mathrm{UO}_{2}$ mass in all 112 square assemblies for Cycle $2(39,626 \mathrm{~kg})$ in Ref. 13, Table 2. The fuel density of $10.353 \mathrm{~g} / \mathrm{cm}^{3}$ was used to obtain the E/C values presented in Sect. 10.1. The fuel density based on the total $\mathrm{UO}_{2}$ mass $(42,321 \mathrm{~kg})$ in 120 square fuel assemblies for Cycle 1 provided in Ref. 12, Table 2, is $10.3198 \mathrm{~g} / \mathrm{cm}^{3}$. Depletion calculations using a fuel mass density of $10.3198 \mathrm{~g} / \mathrm{cm}^{3}$ were also performed, and the results of the calculations for selected samples are described in this section. A comparison between isotopic concentration, in $\mathrm{g} / \mathrm{g} \mathrm{U}_{\text {initial }}$, obtained for the fuel density values of 10.353 and $10.3198 \mathrm{~g} / \mathrm{cm}^{3}$ is presented in Table 108 for selected Trino Vercellese spent fuel samples. As seen in the table, the $0.32 \%$ decrease in fuel density resulted in an approximately $0.5 \%$ increase in ${ }^{244} \mathrm{Cm}$ mass; $0.3 \%$ increase in ${ }^{238} \mathrm{Pu},{ }^{242 \mathrm{~m}} \mathrm{Am}$, and ${ }^{243} \mathrm{Am}$ mass; and $0.15 \%$ increase in ${ }^{239} \mathrm{Pu},{ }^{241} \mathrm{Pu},{ }^{242} \mathrm{Pu}$, and ${ }^{241} \mathrm{Am}$ mass. The uranium isotopes were practically unaffected by the fuel density change. 
Table 108. Fuel density sensitivity calculation results for Trino Vercellese spent fuel samples

\begin{tabular}{|c|c|c|c|c|c|c|c|c|c|}
\hline Sample & \multicolumn{3}{|c|}{ 509-104-M11-7 } & \multicolumn{3}{|c|}{ 509-049-L5-1 } & \multicolumn{3}{|c|}{ 509-032-H9-9 } \\
\hline $\begin{array}{c}\text { Fuel } \\
\text { density } \\
\left(\mathbf{g} / \mathbf{c m}^{3}\right)\end{array}$ & 10.353 & 10.3198 & & 10.353 & 10.3198 & & 10.353 & 10.3198 & \\
\hline Isotope & g/g $U_{\text {initial }}$ & g/g $U_{\text {initial }}$ & $\begin{array}{l}\text { Rel. } \\
\text { diff. } \\
(\%)\end{array}$ & $\mathrm{g} / \mathrm{g} \mathbf{U}_{\text {initial }}$ & $\mathbf{g} / g \mathbf{U}_{\text {initial }}$ & $\begin{array}{l}\text { Rel. } \\
\text { diff. } \\
(\%)\end{array}$ & $g / g U_{\text {initial }}$ & $\mathrm{g} / \mathrm{g} \mathbf{U}_{\text {initial }}$ & $\begin{array}{l}\text { Rel. } \\
\text { diff. } \\
\text { (\%) }\end{array}$ \\
\hline U-234 & $2.93 \mathrm{E}-04$ & $2.93 \mathrm{E}-04$ & 0.00 & $2.08 \mathrm{E}-04$ & $2.08 \mathrm{E}-04$ & -0.01 & $2.29 \mathrm{E}-04$ & $2.29 \mathrm{E}-04$ & -0.02 \\
\hline U-235 & $2.70 \mathrm{E}-02$ & $2.70 \mathrm{E}-02$ & 0.00 & $1.96 \mathrm{E}-02$ & $1.96 \mathrm{E}-02$ & 0.01 & $1.96 \mathrm{E}-02$ & $1.96 \mathrm{E}-02$ & 0.01 \\
\hline U-236 & $2.46 \mathrm{E}-03$ & $2.46 \mathrm{E}-03$ & 0.00 & $1.53 \mathrm{E}-03$ & $1.53 \mathrm{E}-03$ & 0.02 & $2.26 \mathrm{E}-03$ & $2.26 \mathrm{E}-03$ & 0.08 \\
\hline U-238 & $9.52 \mathrm{E}-01$ & $9.52 \mathrm{E}-01$ & 0.00 & $9.66 \mathrm{E}-01$ & $9.66 \mathrm{E}-01$ & 0.00 & $9.59 \mathrm{E}-01$ & $9.59 \mathrm{E}-01$ & 0.00 \\
\hline $\mathrm{Pu}-238$ & $1.43 \mathrm{E}-05$ & $1.43 \mathrm{E}-05$ & 0.26 & $6.69 \mathrm{E}-06$ & $6.67 \mathrm{E}-06$ & 0.24 & $1.54 \mathrm{E}-05$ & $1.53 \mathrm{E}-05$ & 0.24 \\
\hline $\mathrm{Pu}-239$ & $4.47 \mathrm{E}-03$ & $4.46 \mathrm{E}-03$ & 0.09 & $3.60 \mathrm{E}-03$ & $3.59 \mathrm{E}-03$ & 0.10 & $4.31 \mathrm{E}-03$ & $4.30 \mathrm{E}-03$ & 0.13 \\
\hline $\mathrm{Pu}-240$ & $6.78 \mathrm{E}-04$ & $6.77 \mathrm{E}-04$ & 0.03 & $5.18 \mathrm{E}-04$ & $5.18 \mathrm{E}-04$ & 0.02 & $8.12 \mathrm{E}-04$ & $8.12 \mathrm{E}-04$ & 0.03 \\
\hline $\mathrm{Pu}-241$ & $3.11 \mathrm{E}-04$ & $3.11 \mathrm{E}-04$ & 0.13 & $1.97 \mathrm{E}-04$ & $1.97 \mathrm{E}-04$ & 0.15 & $3.67 \mathrm{E}-04$ & $3.67 \mathrm{E}-04$ & 0.16 \\
\hline $\mathrm{Pu}-242$ & $2.73 \mathrm{E}-05$ & $2.73 \mathrm{E}-05$ & 0.15 & $1.52 \mathrm{E}-05$ & $1.52 \mathrm{E}-05$ & 0.11 & $4.20 \mathrm{E}-05$ & $4.20 \mathrm{E}-05$ & 0.08 \\
\hline Am-241 & $8.15 \mathrm{E}-06$ & $8.13 \mathrm{E}-06$ & 0.15 & $4.98 \mathrm{E}-06$ & $4.97 \mathrm{E}-06$ & 0.16 & $9.15 \mathrm{E}-06$ & $9.14 \mathrm{E}-06$ & 0.12 \\
\hline Am-242m & $1.25 \mathrm{E}-07$ & $1.25 \mathrm{E}-07$ & 0.25 & 7.09E-08 & 7.07E-08 & 0.26 & $1.48 \mathrm{E}-07$ & $1.48 \mathrm{E}-07$ & 0.22 \\
\hline Am-243 & $1.96 \mathrm{E}-06$ & $1.95 \mathrm{E}-06$ & 0.30 & $8.29 \mathrm{E}-07$ & $8.27 \mathrm{E}-07$ & 0.30 & $3.22 \mathrm{E}-06$ & $3.21 \mathrm{E}-06$ & 0.25 \\
\hline $\mathrm{Cm}-242$ & $7.03 \mathrm{E}-07$ & $7.01 \mathrm{E}-07$ & 0.21 & $3.83 \mathrm{E}-07$ & $3.82 \mathrm{E}-07$ & 0.21 & $1.03 \mathrm{E}-06$ & $1.03 \mathrm{E}-06$ & 0.17 \\
\hline $\mathrm{Cm}-244$ & $1.62 \mathrm{E}-07$ & $1.61 \mathrm{E}-07$ & 0.48 & $5.28 \mathrm{E}-08$ & $5.25 \mathrm{E}-08$ & 0.48 & $2.90 \mathrm{E}-07$ & $2.89 \mathrm{E}-07$ & 0.44 \\
\hline $\mathrm{Ru}-106$ & $3.97 \mathrm{E}-05$ & $3.97 \mathrm{E}-05$ & 0.10 & $2.75 \mathrm{E}-05$ & $2.75 \mathrm{E}-05$ & 0.06 & $4.65 \mathrm{E}-05$ & $4.65 \mathrm{E}-05$ & 0.03 \\
\hline Cs-134 & $1.63 \mathrm{E}-05$ & $1.62 \mathrm{E}-05$ & 0.13 & $8.40 \mathrm{E}-06$ & $8.39 \mathrm{E}-06$ & 0.11 & $1.83 \mathrm{E}-05$ & $1.83 \mathrm{E}-05$ & 0.11 \\
\hline Cs-137 & 4.49E-04 & $4.49 \mathrm{E}-04$ & 0.00 & $2.91 \mathrm{E}-04$ & $2.91 \mathrm{E}-04$ & -0.02 & $4.61 \mathrm{E}-04$ & $4.61 \mathrm{E}-04$ & -0.02 \\
\hline Ce-144 & $1.78 \mathrm{E}-04$ & $1.78 \mathrm{E}-04$ & 0.00 & $1.17 \mathrm{E}-04$ & $1.17 \mathrm{E}-04$ & -0.02 & $1.84 \mathrm{E}-04$ & $1.84 \mathrm{E}-04$ & -0.01 \\
\hline Nd-148 & $1.36 \mathrm{E}-04$ & $1.36 \mathrm{E}-04$ & 0.00 & $8.79 \mathrm{E}-05$ & $8.79 \mathrm{E}-05$ & 0.00 & $1.39 \mathrm{E}-04$ & $1.39 \mathrm{E}-04$ & -0.01 \\
\hline Eu-154 & $3.23 \mathrm{E}-06$ & $3.23 \mathrm{E}-06$ & 0.19 & $1.65 \mathrm{E}-06$ & $1.65 \mathrm{E}-06$ & 0.18 & $3.63 \mathrm{E}-06$ & $3.63 \mathrm{E}-06$ & 0.16 \\
\hline
\end{tabular}

Source: TRITON/NEWT input and output files are provided in DVD/TrinoVercellese/sen-fuelden. The relative difference values were obtained in DVD/xls/input_data.xls, worksheet Trino.

\subsubsection{Trino Vercellese Fuel Temperature Sensitivity Calculations}

Effective fuel temperature data for the measured Trino Vercellese samples were not available in the primary experimental reports, and the effective fuel temperature data for the Yankee Rowe PWR, which had a similar assembly design, were used in the depletion calculations (see Table 51). To evaluate the magnitude of the uncertainty in the calculated isotopic concentrations due to the uncertainty associated with the effective fuel temperature values used, calculations were performed for Trino Vercellese samples 509-032-E11-4 (15.377 GWd/MTU) and 509-069-E11-5 (24.518 MTU) in which the applicable Yankee Rowe effective fuel temperature values were increased by $10 \%$. As seen in Table 109, the relative percent differences between the isotopic concentrations obtained with the Yankee Rowe temperature values and the isotopic concentrations obtained with the perturbed temperature values were less than $1 \%$ for all isotopes of interest. The sensitivity calculation results suggest that the uncertainty in the fuel temperature data used for the Trino Vercellese samples will likely impact the calculated ${ }^{239} \mathrm{Pu},{ }^{241} \mathrm{Pu},{ }^{241} \mathrm{Am}$, and ${ }^{242 \mathrm{~m}} \mathrm{Am}$ isotopic concentrations. 
Table 109. Fuel temperature sensitivity calculation results for Trino Vercellese spent fuel samples

\begin{tabular}{|c|c|c|c|c|c|c|}
\hline \multirow{3}{*}{$\begin{array}{c}\text { Sample } \\
\begin{array}{c}\text { Fuel } \\
\text { temperature }\end{array} \\
\text { Nuclide }\end{array}$} & \multicolumn{3}{|c|}{ 509-032-E11-4 } & \multicolumn{3}{|c|}{ 509-069-E11-5 } \\
\hline & \multirow{2}{*}{$\frac{\text { Nominal }^{a}}{\mathrm{~g} / \mathrm{g} U_{\text {initial }}}$} & \multicolumn{2}{|c|}{ Perturbed $^{b}$} & \multirow{2}{*}{$\frac{\text { Nominal }^{a}}{\text { g/g } U_{\text {initial }}}$} & \multicolumn{2}{|c|}{ Perturbed $^{b}$} \\
\hline & & $\mathbf{g} / \mathbf{g} \mathbf{U}_{\text {initial }}$ & $\begin{array}{c}\text { Rel. diff. } \\
(\%)\end{array}$ & & $\mathrm{g} / \mathrm{g} \mathbf{U}_{\text {initial }}$ & $\begin{array}{c}\text { Rel. diff. } \\
(\%)\end{array}$ \\
\hline U-234 & $2.16 \mathrm{E}-04$ & $2.16 \mathrm{E}-04$ & -0.02 & $1.85 \mathrm{E}-04$ & $1.85 \mathrm{E}-04$ & -0.06 \\
\hline U-235 & $1.78 \mathrm{E}-02$ & $1.78 \mathrm{E}-02$ & -0.15 & $1.26 \mathrm{E}-02$ & $1.26 \mathrm{E}-02$ & -0.28 \\
\hline U-236 & $2.63 \mathrm{E}-03$ & $2.63 \mathrm{E}-03$ & 0.08 & $3.48 \mathrm{E}-03$ & $3.47 \mathrm{E}-03$ & 0.13 \\
\hline U-238 & $9.56 \mathrm{E}-01$ & $9.56 \mathrm{E}-01$ & 0.00 & $9.48 \mathrm{E}-01$ & $9.48 \mathrm{E}-01$ & 0.02 \\
\hline $\mathrm{Pu}-238$ & $2.92 \mathrm{E}-05$ & $2.92 \mathrm{E}-05$ & 0.08 & $1.06 \mathrm{E}-04$ & $1.06 \mathrm{E}-04$ & -0.11 \\
\hline $\mathrm{Pu}-239$ & $5.24 \mathrm{E}-03$ & $5.28 \mathrm{E}-03$ & -0.93 & $6.40 \mathrm{E}-03$ & $6.47 \mathrm{E}-03$ & -1.01 \\
\hline $\mathrm{Pu}-240$ & $1.11 \mathrm{E}-03$ & $1.11 \mathrm{E}-03$ & -0.26 & $1.85 \mathrm{E}-03$ & $1.85 \mathrm{E}-03$ & -0.13 \\
\hline $\mathrm{Pu}-241$ & $5.93 \mathrm{E}-04$ & $5.98 \mathrm{E}-04$ & -0.86 & $1.09 \mathrm{E}-03$ & $1.10 \mathrm{E}-03$ & -0.79 \\
\hline $\mathrm{Pu}-242$ & $8.33 \mathrm{E}-05$ & $8.36 \mathrm{E}-05$ & -0.45 & $2.58 \mathrm{E}-04$ & $2.58 \mathrm{E}-04$ & -0.17 \\
\hline Am-241 & $1.48 \mathrm{E}-05$ & $1.49 \mathrm{E}-05$ & -0.95 & $8.49 \mathrm{E}-05$ & $8.56 \mathrm{E}-05$ & -0.92 \\
\hline Am-242m & $2.76 \mathrm{E}-07$ & $2.78 \mathrm{E}-07$ & -0.97 & $2.04 \mathrm{E}-06$ & $2.06 \mathrm{E}-06$ & -1.16 \\
\hline Am-243 & $8.96 \mathrm{E}-06$ & $9.00 \mathrm{E}-06$ & -0.47 & $4.71 \mathrm{E}-05$ & $4.72 \mathrm{E}-05$ & -0.28 \\
\hline $\mathrm{Cm}-242$ & $2.16 \mathrm{E}-06$ & $2.18 \mathrm{E}-06$ & -0.54 & $1.83 \mathrm{E}-05$ & $1.84 \mathrm{E}-05$ & -0.44 \\
\hline $\mathrm{Cm}-244$ & $1.11 \mathrm{E}-06$ & $1.12 \mathrm{E}-06$ & -0.32 & $1.00 \mathrm{E}-05$ & $1.00 \mathrm{E}-05$ & 0.02 \\
\hline Ru-106 & $6.69 \mathrm{E}-05$ & $6.72 \mathrm{E}-05$ & -0.33 & $7.44 \mathrm{E}-05$ & $7.46 \mathrm{E}-05$ & -0.24 \\
\hline Cs-134 & $2.94 \mathrm{E}-05$ & $2.94 \mathrm{E}-05$ & 0.15 & $5.28 \mathrm{E}-05$ & $5.26 \mathrm{E}-05$ & 0.21 \\
\hline Cs-137 & $5.72 \mathrm{E}-04$ & $5.72 \mathrm{E}-04$ & 0.00 & $8.61 \mathrm{E}-04$ & $8.61 \mathrm{E}-04$ & 0.00 \\
\hline Ce-144 & $2.23 \mathrm{E}-04$ & $2.22 \mathrm{E}-04$ & 0.10 & $1.60 \mathrm{E}-04$ & $1.60 \mathrm{E}-04$ & 0.07 \\
\hline Nd-148 & $1.72 \mathrm{E}-04$ & $1.72 \mathrm{E}-04$ & 0.01 & $2.73 \mathrm{E}-04$ & $2.73 \mathrm{E}-04$ & 0.08 \\
\hline Eu-154 & $6.19 \mathrm{E}-06$ & $6.19 \mathrm{E}-06$ & 0.00 & $1.53 \mathrm{E}-05$ & $1.53 \mathrm{E}-05$ & 0.00 \\
\hline
\end{tabular}

${ }^{\mathrm{a}}$ Results obtained with the effective fuel temperature values presented in Table 51.

${ }^{\mathrm{b}}$ The perturbed fuel temperatures were $1.1 \times$ the effective fuel temperature values presented in Table 51 .

Source: TRITON/NEWT input and output files are provided in DVD/TrinoVercellese/sen-fueltemp. The relative difference values were obtained in DVD/xls/input_data.xls, worksheet Trino.

\subsection{GRAPHICAL REPRESENTATIONS OF E/C VALUES FOR THE BURNUP CREDIT ISOTOPES}

The graphs illustrated in Figs. A-1 through A-28, Appendix A, show the ratio of the experimental-tocalculated isotopic concentrations as a function of sample burnup for the burnup-credit nuclides (refer to Sect. 6.1 for the list of burnup-credit nuclides). The error bar for each data point shown in the graphs represents one standard deviation from the $\mathrm{E} / \mathrm{C}$ value and is entirely based on the reported experimental uncertainties for the burnup-credit isotopes (see Sect. 7). 


\section{SUMMARY}

This calculation report provides an evaluation of radiochemically assayed data for 118 spent fuel samples obtained from low-, moderate-, and high-burnup spent fuel assemblies from the following nine PWRs: Trino Vercellese, Kernkraftwerk Obrigheim, Turkey Point Unit 3, H. B. Robinson Unit 2, Calvert Cliffs Unit 1, Three Mile Island Unit 1, Takahama Unit 3, Gösgen, and GKN II. The initial enrichment and burnup of the evaluated spent fuel samples vary from 2.453 to $4.657 \mathrm{wt} \%{ }^{235} \mathrm{U}$ and from 7.2 to 70.4 $\mathrm{GWd} / \mathrm{MTU}$, respectively. Most of the measured spent fuel samples have been selected from typical $\mathrm{UO}_{2}$ assemblies; however, spent fuel samples from assemblies containing burnable poison rods and from gadolinia rods are also included in the current evaluation. The number of the isotopes with measured concentrations varies depending on the experimental program. The earlier experimental programs provided measurement data for the uranium and plutonium isotopes mainly, whereas the more recent experimental programs provided measurement data for up to 50 isotopes, including actinide and fission product isotopes relevant to burnup credit.

The documentation of the evaluated data and calculations performed is very comprehensive in the current report. Section 6 of the report describes the measurement methods used by each experimental program, the reported measured isotopic concentrations, sample burnup values, and measurement uncertainties. The input parameters for use in 2-D depletion and decay calculations are documented in Sect. 8, whereas a series of assumptions employed in determining some of the input parameters for calculations are described in Sect. 5. The TRITON/NEWT models developed for performing calculations for the evaluated spent fuel samples are described in Sect. 9. The results of the calculations are provided as the ratio of experimental-to-calculated isotopic concentrations in the tables included in Sect. 10.1 and may directly be used in subsequent criticality safety analyses employing burnup credit. Graphical representations of the $\mathrm{E} / \mathrm{C}$ values are provided in Appendix A to support qualitative evaluations of the results. All the electronic files consisting of MS Excel spreadsheet applications and SCALE 5.1 input and output files that were generated are provided on the DVD that accompanies this report; a listing of the files included on the DVD is given in Appendix B. 



\section{REFERENCES}

1. SCALE: A Modular Code System for Performing Standardized Computer Analyses for Licensing Evaluations, ORNL/TM-2005/39, Version 5.1, Vols. I-III, November 2006. Available from Radiation Safety Information Computational Center at Oak Ridge National Laboratory as CCC-732.

2. M. D. DeHart, “TRITON: A Two-Dimensional Transport and Depletion Module for Characterization of Spent Nuclear Fuel," Vol. I, Book 3, Sect. T1 in SCALE: A Modular Code System for Performing Standardized Computer Analyses for Licensing Evaluations, ORNL/TM-2005/39, Version 5.1, Vols. I-III, November 2006. Available from Radiation Safety Information Computational Center at Oak Ridge National Laboratory as CCC-732.

3. M. D. DeHart, "NEWT: A New Transport Algorithm for Two-Dimensional Discrete Ordinates Analysis in Non-Orthogonal Geometries," Vol. II, Book 4, Sect. F21 in SCALE: A Modular Code System for Performing Standardized Computer Analyses for Licensing Evaluations, ORNL/TM-2005/39, Version 5.1, Vols. I-III, November 2006. Available from Radiation Safety Information Computational Center at Oak Ridge National Laboratory as CCC-732.

4. S. M. Bowman, M. E. Dunn, D. F. Hollenbach, and W. C. Jordan "SCALE Cross-Section Libraries," Vol. III, Sect. M4 in SCALE: A Modular Code System for Performing Standardized Computer Analyses for Licensing Evaluations, ORNL/TM-2005/39, Version 5.1, Vols. I-III, November 2006. Available from Radiation Safety Information Computational Center at Oak Ridge National Laboratory as CCC-732.

5. Test Plan for: Isotopic Validation for Postclosure Criticality of Commercial Spent Nuclear Fuel, TP-OCRWM-LL-ORNL-02 Rev. 00, CN 01.

6. Calculation Packages, ORNL OCRW-19.1, Revision 03, CN 00.

7. Scientific Investigations, ORNL OCRW-21.0, Revision 03, CN 00.

8. Control of the Electronic Management of Data, ORNL-OCRW-23.0, Revision 01, CN 01.

9. Software Control, ORNL-OCRW-19.0, Revision 06, CN 00.

10. SCALE-YMP Software Verification Report for Linux_2, ORNL OCRW-SQA-011, Revision 03, CN 00.

11. "Standard Review Plan for Dry Cask Storage Systems," NUREG-1536, U.S. Nuclear Regulatory Commission, Washington, DC (1997).

12. A. Bresesti, M. Bresesti, and S. Facchetti, Post-Irradiation Analysis of Trino Vercellese Reactor Fuel Elements, EUR-4909, Joint Nuclear Research Centre Ispra and Karlsruhe Establishments, 1972.

13. P. Barbero, G. Bidoglio, and M. Bresesti, Post-Irradiation Examination of the Fuel Discharged from the Trino Vercellese Reactor after the 2nd Irradiation Cycle, EUR-5605, Joint Research Centre Ispra and Karlsruhe Establishments, 1977. 
14. S. Guardini and G. Guzzi, Benchmark: Reference Data on Post-Irradiation Analyses of Light Water Reactor Fuel Samples. A Review of 12 Years' Experience: Results Obtained and Their Characterization, EUR-7879, Commission of the European Communities, Luxembourg, 1983.

15. P. Barbero, G. Bidoglio, A. Caldiroli, F. Daniele, R. DeMeester, R. Ernstberger, S. Facchetti, A. Frigo, S. Guardini, G. Guzzi, P. Hansen, L. Lezzoli, L. Koch, W. Konrad, L. Mammarella, F. Mannone, A. Marell, A. Schurenkamper, P. R. Trincherini, and R. Wellum, Post Irradiation Analysis of the Obrigheim PWR Spent Fuel, EUR 6589en, Commission of the European Communities, Joint Research Center, Ispra Establishment, Italy. Also published in European Appl. Res. Rept. -Nucl. Sci. Technol. 2(1), 129-177 (1980).

16. U. Hesse, Verification of the OREST (HAMMER-ORIGEN) Depletion Program System Using PostIrradiation Analyses of Fuel Assemblies 168, 170, 171, and 176 from the Obrigheim Reactor, ORNL-TR-88/20, GRS-A-962, Oak Ridge National Laboratory, Oak Ridge, Tenn., 1984.

17. U. Fisher and H. W. Wiese, Improved and Consistent Determination of the Nuclear Inventory of Spent PWR Fuel on the Basis of Cell-Burnup Methods Using KORIGEN, ORNL-TR-5043 (translated from the German report KfK 3014, Institute for Neutron Physics and Reactor Technology, Reprocessing and Waste Treatment Project, Karlsruhe Nuclear Research Center, 1983), Oak Ridge National Laboratory, Oak Ridge, Tenn.

18. “Obrigheim," sections in Nuclear Power Experience, Plant Description, and Histories, Vol. PWR-1, pp. 1-10, Aug 1974, p. 1, Dec 1983, and p. 2, Jun 1985.

19. D. Gupta et al., Safeguarding Fissile Material Flow at Strategic Points in Power Reactors, KFK 803, Kernforschungszentrum Karlsruhe, February 1969.

20. Brennelement-Daten für das Project KWO, A1C-1309011-1, private communication with J. C. Neuber, AREVA NP GmbH, Dept. NEEA-G, Germany, September 15, 2008.

21. S. D. Atkin, Destructive Examination of 3-Cycle LWR Fuel Rods from Turkey Point Unit 3 for the Climax - Spent Fuel Test, HEDL-TME 80-89, Hanford Engineering Development Laboratory, June 1981.

22. E. M. Green, Spent Fuel Data for Waste Storage Programs, HEDL-TME 79-20, Hanford Engineering Development Laboratory, September 1980.

23. J. C. Ryman et al., Fuel Inventory and Afterheat Power Studies of Uranium-Fueled Pressurized Water Reactor Fuel Assemblies Using the SAS2 and ORIGEN-S Modules of SCALE with an ENDF/B-V Updated Cross Section Library, NUREG/CR-2397 (ORNL/CSD-90), prepared for the U.S. Nuclear Regulatory Commission by Oak Ridge National Laboratory, September 1982.

24. M. D. DeHart and O. W. Hermann, An Extension of the Validation of SCALE (SAS2H) Isotopic Predictions for PWR Spent Fuel, ORNL/TM-13317, Oak Ridge National Laboratory, Oak Ridge, Tenn., September 1996.

25. F. Schmittroth, G. J. Neely, and J. C. Krogness, A Comparison of Measured and Calculated Decay Heat for Spent Fuel Near 2.5 Years Cooling Time, TC-1759, Hanford Engineering Development Laboratory, August 1980. 
26. J. O. Barner, Characterization of LWR Spent Fuel MCC-Approved Testing Material - ATM-101, PNL-5109, Rev. 1, Pacific Northwest Laboratory, 1985.

27. Letter, O. Ozer of Electric Power Research Institute to W. B. Lowenstein and B. A. Zolotar, "EPRI-CELL Test Calculations of Isotopes as a Function of Burnup," April 1976.

28. P. E. MacDonald, "Transmittal of CPL Assembly BO5 Axial Flux Measurements - MacD-67-75," Aeroject Nuclear Company, Inc., Idaho, September 11, 1975.

29. "Robinson 2," Sections in Nuclear Power Experience, Plant Description, and Histories, Vol. PWR-1, p. 5, May 1972, and p. 1, September 1975.

30. R. J. Guenther, D. E. Blahnik, T. K. Campbell, U. P. Jenquin, J. E. Mendel, L. E. Thomas, and C. K. Thornhill, Characterization of Spent Fuel Approved Testing Material-ATM-103, Pacific Northwest Laboratory, PNL-5109-103 (UC-70), April 1988.

31. R. J. Guenther, D. E. Blahnik, U. P. Jenquin, J. E. Mendel, L. E. Thomas, and C. K. Thornhill, Characterization of Spent Fuel Approved Testing Material-ATM-104, Pacific Northwest Laboratory, PNL-5109-104 (UC-802), December 1991.

32. R. J. Guenther, D. E. Blahnik, T. K. Campbell, U. P. Jenquin, J. E. Mendel, and C. K. Thornhill, Characterization of Spent Fuel Approved Testing Material-ATM-106, Pacific Northwest Laboratory, PNL-5109-106 (UC-70), October 1988.

33. M. C. Brady-Raap and R. J. Talbert, Compilation of Radiochemical Analyses of Spent Nuclear Fuel Samples, PNL-13677, Pacific Northwest National Laboratory, Richland, WA, September 2001.

34. S. R. Bierman and R. J. Talbert, Benchmark Data for Validating Irradiated Fuel Compositions Used in Criticality Calculations, PNL-10045, Pacific Northwest Laboratory, October 1994.

35. S. R. Bierman, "Spent Reactor Fuel Benchmark Composition Data for Code Validation," Proceedings of International Conference on Nuclear Criticality Safety, Oxford, United Kingdom, September 1991.

36. SFCOMPO - Spent Fuel Isotopic Composition Database, operated by the NEA Nuclear Science Division under the supervision of the Working Party on Nuclear Criticality Safety, Nuclear Energy Agency web site: http://www.nea.fr/html/science/wpncs/sfcompo/.

37. A. A. Rimski-Korsakov, A. V. Stepanov, A. D. Kirikov, Radiochemical Analysis of Spent Reactor Fuel Sample, 1993; A. A. Rimski-Korsakov, T. P. Makarova, V. M. Alexandruk, B. N. Beljaev, V. D. Domkin, and A. V. Lovtsus, Radiochemical Analysis of Spent Reactor Fuel Samples, April 1995; A. V. Stepanov, L. S. Buljanitsa, P. A. Galtzev, and A. B. Bogorodizkii, Radiochemical Analysis of Spent Reactor Fuel Sample 87-108, March 1996; A. V. Stepanov, T. P. Makarova, V. M. Alexandruk, T. A. Demjanova, B. N. Beljaev, V. D. Domkin, and A. V. Lovtsus, Radiochemical Analysis of Spent Reactor Fuel Samples: Report on the Results of Determination of Rare Earth Isotopic Abundances, April 1996; reports of the European Analytical Services, Inc., representing the V. G. Khlopin Radium Institute, St. Petersburg, Russia. Information and data are reproduced in PNL-13677, September 2001. 
38. O. W. Hermann, S. M. Bowman, M. C. Brady, and C. V. Parks, Validation of the SCALE System for PWR Spent Fuel Isotopic Composition Analyses, ORNL/TM-12667, Oak Ridge National Laboratory, Oak Ridge, Tenn., March 1995.

39. M. Rahimi, E. Fuentes, D. Lancaster, Isotopic and Criticality Validation for PWR Actinide-only Burnup Credit, DOE/RW-0497, Office of Civilian Radioactive Waste Management, May 1997.

40. J. W. Roddy, H. C. Claiborne, R. C. Ashline, P. J. Johnson, and B. T. Rhyne, Physical and Decay Characteristics of Commercial LWR Spent Fuel, ORNL/TM-9591/V1, Oak Ridge National Laboratory, Oak Ridge, Tenn., October 1985.

41. Y. Nakahara, Y. Suyama, and T. Suzaki, Technical Development on Burnup Credit for Spent LWR Fuels, JAERI-Tech 2000-071 (ORNL/TR-2001/01), English Translation, Oak Ridge National Laboratory, Oak Ridge, Tenn. (2002).

42. K. Suyama, H. Mochizuki, and Y. Nakahara, "Revised Burnup Code System SWAT: Description and Validation Using Postirradiation Examination Data." Nucl. Technol. 138, 97-110 (2002).

43. Y. Nakahara, K. Suyama, J. Inagawa, R. Nagaishi, S. Kurosawa, N. Kohno, M. Onuki, and H. Mochizuki, "Nuclide Composition Benchmark Data Set for Verifying Burnup Codes on Spent Light Water Reactor Fuels," Nucl. Technol. 137, 111-126 (2002).

44. S. F. Wolf, D. L. Bowers, and J. C. Cunnane, Analysis of Spent Nuclear Fuel Samples from Three Mile Island and Quad Cities Reactors: Final Report, Argonne National Laboratory, Argonne, Ill., November 2000.

45. R. D. Reager, R. B. Adamson, and K. W. Edsinger, TRW Yucca Mountain Project Test Report, Phase I and 2, Ref. TRW Purchase Order No. A09112CC8A, General Electric Nuclear Energy (1999).

46. Summary Report of Commercial Reactor Criticality Data for Three Mile Island Unit 1, TDR-UDC-NU-000004 Rev 01, Bechtel SAIC Company, Las Vegas, Nev. (2001).

47. Three Mile Island Unit 1 Radiochemical Assay Comparisons to SAS2H Calculations, CAL-UDC-NU-000011, Rev A, Bechtel SAIC Company, Las Vegas, Nev. (2002).

48. ARIANE International Programme-Final Report, ORNL/SUB/97-XSV750-1, Oak Ridge National Laboratory, Oak Ridge, Tenn., May 2003.

49. REBUS International Program-Reactivity Tests for a Direct Evaluation of the Burnup Credit on Selected Irradiated LWR Fuel Bundles, Fuel Irradiation History Report, SCK-CEN, Belgonucleaire, RE 2002/18, Rev. B, June 2005.

50. REBUS International Program-Reactivity Tests for a Direct Evaluation of the Burnup Credit on Selected Irradiated LWR Fuel Bundles, Destructive Radiochemical Spent Fuel Characterization of a PWR $\mathrm{UO}_{2}$ Fuel Sample, SCK-CEN, Belgonucleaire, RE 2005/35, Rev. A, May 2006.

51. REBUS International Program-Reactivity Tests for a Direct Evaluation of the Burnup Credit on Selected Irradiated LWR Fuel Bundles, Gamma Spectroscopy PIE on Irradiated GKN II Fuel Rods, SCK-CEN, Belgonucleaire, RE 2004/29, December 2004. 
52. REBUS International Program-Reactivity Tests for a Direct Evaluation of the Burnup Credit on Selected Irradiated LWR Fuel Bundles, VENUS Fuel Characterization Report, SCK-CEN, Belgonucleaire, RE 2001/13, Rev. C, May 2006.

53. REBUS International Program-Reactivity Tests for a Direct Evaluation of the Burnup Credit on Selected Irradiated LWR Fuel Bundles, Final Report, SCK-CEN, Belgonucleaire, RE 2005/37, February 2006.

54. MALIBU Program, Radiochemical Analysis of MOX and UOX LWR Fuels Irradiated to High Burnup, Final Report on the Basic Scope, MA 2006/11, December 2007.

55. MALIBU Program, Radiochemical Analysis of MOX and UOX LWR Fuels Irradiated to High Burnup, Irradiation Data Report, MA 2003/05, Rev. D, December 2007.

56. 1998 World Nuclear Industry Handbook, Nuclear Engineering International (1998).

57. 2004 World Nuclear Industry Handbook, edited by Nuclear Engineering International (2005).

58. L. Haar, J. S. Gallagher, and G. S. Kell, NBS/NRC Steam Tables: Thermodynamic and Transport Properties and Computer Programs for Vapor and Liquid States of Water in SI Units, Taylor \& Francis, Levittown, PA, 1984.

59. Evaluated Nuclear Structure Data File-a computer file of evaluated experimental nuclear structure data maintained by the National Nuclear Data Center, Brookhaven National Laboratory (file as of January 2005).

60. Nuclear Data Sheets - Elsevier B.V., Amsterdam. Evaluations published by mass number for $A=21$ to 294. See page ii of any issue for the index to A-chains. See also Energy Levels of A = 21-44 Nuclei (VII), P. M. Endt, Nuclear Physics A521, 1 (1990). Supplement, Nuclear Physics A633, 1 (1998).

61. Nuclear Physics - North Holland Publishing Co., Amsterdam - Evaluations for A $=3$ to 20 .

62. G. Audi, A. H. Wapstra, and C. Thibault, The AME2003 atomic mass evaluation-(II) Tables, graphs and references, Nuclear Physics A729, 337-676 (2003).

63. J. R. Parrington, H. D. Knox, S. L. Breneman, E. M. Baum, and F. Feiner. Nuclides and Isotopes, Chart of the Nuclides. 15th Edition. San Jose, California: General Electric Company and KAPL, Inc, 1996.

64. O. W. Hermann, C. V. Parks, and J. P. Renier, Technical Support for a Proposed Decay Heat Guide Using SAS2H/ORIGEN-S Data, NUREG/CR-5625 (ORNL/TM-2005/39), prepared for the U.S. Nuclear Regulatory Commission by Oak Ridge National Laboratory, July 1994.

65. J. R. Lamarsh and A. J. Baratta, Introduction to Nuclear Engineering ( $3^{\text {rd }}$ Edition).

66. W. J. M. de Kruijf and A. J. Janssen, "The Effective Fuel Temperature to be Used for Calculating Resonance Absorption in a ${ }^{238} \mathrm{UO}_{2}$ Lump with a Nonuniform Temperature Profile," Nucl. Sci. Eng. 123, 121-135 (1996). 
67. I. C. Gauld and O. W. Herman "SAS2: A Coupled One-Dimensional Depletion and Shielding Analysis Module," Vol. I, Book 3, Sect. S2 in SCALE: A Modular Code System for Performing Standardized Computer Analyses for Licensing Evaluations, ORNL/TM-2005/39, Version 5.1, Vols. I-III, November 2006. Available from Radiation Safety Information Computational Center at Oak Ridge National Laboratory as CCC-732.

68. Disposal Criticality Analysis Methodology Topical Report, YMP/TR-004Q, Rev. 02, Yucca Mountain Site Characterization Project, Las Vegas, Nevada (2003).

69. Calculation of Isotopic Bias and Uncertainty for PWR Spent Nuclear Fuel, CAL-DSU-NU-000001 Rev A, Bechtel SAIC Company, Las Vegas, Nev. (2002).

70. O. W. Hermann, M. D. DeHart, and B. D. Murhpy, Evaluation of Measured LWR Spent Fuel Composition Data for Use in Code Validation-End-User Manual, Oak Ridge National Laboratory Report ORNL/M-6121, February 1998.

71. D. Boulanger, M. Lippens, L. Mertens, J. Basselier, and B. Lance, "High Burnup PWR and BWR MOX Fuel Performance: A Review of BELGONUCLEAIRE Recent Experimental Programs," ANS International Meeting on LWR Fuel Performance, Orlando, FL, USA, September 19-22, 2004.

72. P. Baeten, P. D'hondt, L. Sannen, D. Marloye, B. Lance, A. Renard and J. Basselier, "The REBUS Experimental Programme for Burn-up Credit," ICNC 2003-7th Int. Conf. on Nuclear Criticality Safety Tokai Mura, Japan, October 19-24, 2003.

73. CSNF Loading Curve Sensitivity Analysis, ANL-EBS-NU-000010 REV 00, Sandia National Laboratories, Las Vegas, Nev., February 2008.

74. American Society for Testing and Materials Standard Method E 321-96 (Reapproved 2005), "Standard Test Method for Atom Percent Fission in Uranium and Plutonium Fuel (Neodymium148 Method)," (2005).

75. J. S. Kim, Y. S. Jeon, K. S. Choi, B. C. Song, S. H. Han, and W. H. Kim, "Burnup Measurement of Spent U3Si/A1 Fuel by Chemical Methods Using Neodymium Isotope Monitors," J. Korean Nucl. Soc. 33(4), 375-385, August 1002.

76. K. Suyama, H. Mochizuki, "Corrections to the ${ }^{148}$ Nd Method of Evaluation of Burnup for the PIE Samples from Mihama-3 and Genkai-1 Reactors," Annals of Nuclear Energy.

77. J. Tuli, Nuclear Wallet Cards $7^{\text {th }}$ Edition, National Nuclear Data Center, Brookhaven National Laboratory, Upton, NY (2005).

78. American Society for Testing and Materials Standard Method E 267-90(2001), "Standard Test Method for Uranium and Plutonium Concentrations and Isotopic Abundances" (withdrawn 2006).

79. Department of Energy, "Energy Information Administration," Form RW-859, Nuclear Fuel Data (2002).

80. W. B. Wilson, R. J. LaBauve, and T. R. England, "Spent LWR Fuel Inventory Benchmarks, in Applied Nuclear Data Research and Development," April 1, 1982-September 30, 1982, Los Alamos National Laboratory, LA-9647-PR, pp. 75-88, 1982. 
81. American Society for Testing and Materials Standard Method E 692-00, "Standard Test Method for Determining the Content of Cesium-137 in Irradiated Nuclear Fuels by High-Resolution Gamma-Ray Spectral Analysis" (2000).

82. M. D. DeHart, M. C. Brady and C. V. Parks, OECD/NEA Burnup Credit Calculational Criticality Benchmark Phase I-B Results, NEA/NSC/DOC(96)-06, ORNL-6901, Oak Ridge National Laboratory, Oak Ridge, Tenn., June 1996.

83. TMI-1 Cycle 10 Fuel Rod Failures - Volume 1: Root Cause Failure Evaluations, EPRI Report TR-108784-V1, 1998.

84. Trino Vercellese Nuclear Power Plant Research Program for the Development of Closed-Cycle Water Reactor Technology, Commission of the European Communities EUR 4827 (1973).

85. J. B. Melehan, Yankee Core Evaluation Program Final Report, WCAP-3017-6094, Westinghouse Electric Corp., 1971.

86. L. M. Petrie, P. B. Fox, and K. Lucius "Standard Composition Library," Vol. III, Sect. M8 in SCALE: A Modular Code System for Performing Standardized Computer Analyses for Licensing Evaluations, ORNL/TM-2005/39, Version 5.1, Vols. I-III, November 2006. Available from Radiation Safety Information Computational Center at Oak Ridge National Laboratory as CCC732 .

87. Calculation of Isotopic Bias and Uncertainty for PWR Spent Nuclear Fuel, CAL-DSU-NU-000001 REV A, Las Vegas, Nev.: Bechtel SAIC Company, 2002.

88. Department of Energy, "Energy Information Administration," Form RW-859, Nuclear Fuel Data (2002).

89. CRC Depletion Calculations for McGuire Unit 1. B00000000-01717-0210-00003 REV 00. Las Vegas, CRWMS M\&O, 1998.

90. C. E. Sanders and I. C. Gauld, Isotopic Analysis of High-Burnup PWR Spent Fuel Samples from the Takahama-3 Reactor, NUREG/CR-6798 (ORNL/TM-2001/259), Oak Ridge National Laboratory, Oak Ridge, Tenn., January 2003.

91. I. C. Gauld and O. W. Hermann, "COUPLE: SCALE System Module to Process ProblemDependent Cross Sections and Neutron Spectral Data for ORIGEN-S Analyses," Vol. II, Book 1, Sect. F6 in SCALE: A Modular Code System for Performing Standardized Computer Analyses for Licensing Evaluations, ORNL/TM-2005/39, Version 5.1, Vols. I-III, November 2006. Available from Radiation Safety Information Computational Center at Oak Ridge National Laboratory as CCC-732.

92. I. C. Gauld, O. W. Hermann, and R. M. Westfall, "ORIGEN-S: SCALE System Module to Calculate Fuel Depletion, Actinide Transmutation, Fission Product Buildup and Decay, and Associated Radiation Source Terms," Vol. II, Book 1, Sect. F7 in SCALE: A Modular Code System for Performing Standardized Computer Analyses for Licensing Evaluations, ORNL/TM-2005/39, Version 5.1, Vols. I-III, November 2006. Available from Radiation Safety Information Computational Center at Oak Ridge National Laboratory as CCC-732. 
93. I. C. Gauld, S. M. Bowman, and J. E. Horwedel, "ORIGEN-ARP: Automatic Rapid Processing for Spent Fuel Depletion, Decay, and Source Term Analysis," Vol. I, Book 2, Sect. D1 in SCALE: A Modular Code System for Performing Standardized Computer Analyses for Licensing Evaluations, ORNL/TM-2005/39, Version 5.1, Vols. I-III, November 2006. Available from Radiation Safety Information Computational Center at Oak Ridge National Laboratory as CCC-732. 
APPENDIX A:

GRAPHICAL REPRESENTATION OF THE RATIO OF EXPERIMENTAL-TO-CALCULATED ISOTOPIC CONCENTRATION

AS A FUNCTION OF BURNUP FOR ISOTOPES RELEVANT TO BURNUP CREDIT 



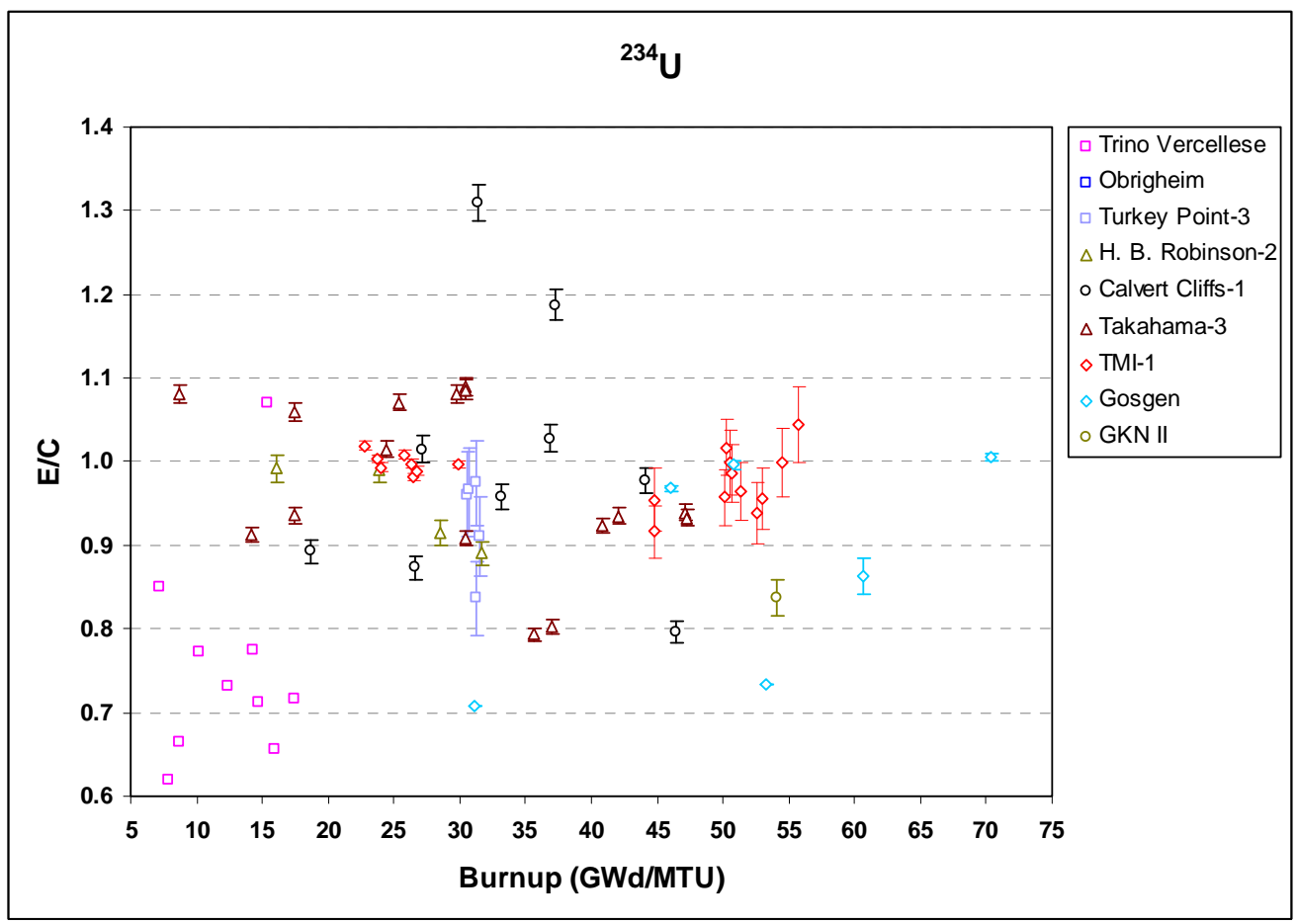

Fig. A.1. Ratio of experimental-to-calculated (E/C) ${ }^{234} \mathrm{U}$ concentration versus sample burnup. The error bars show the one-sigma measurement uncertainty.

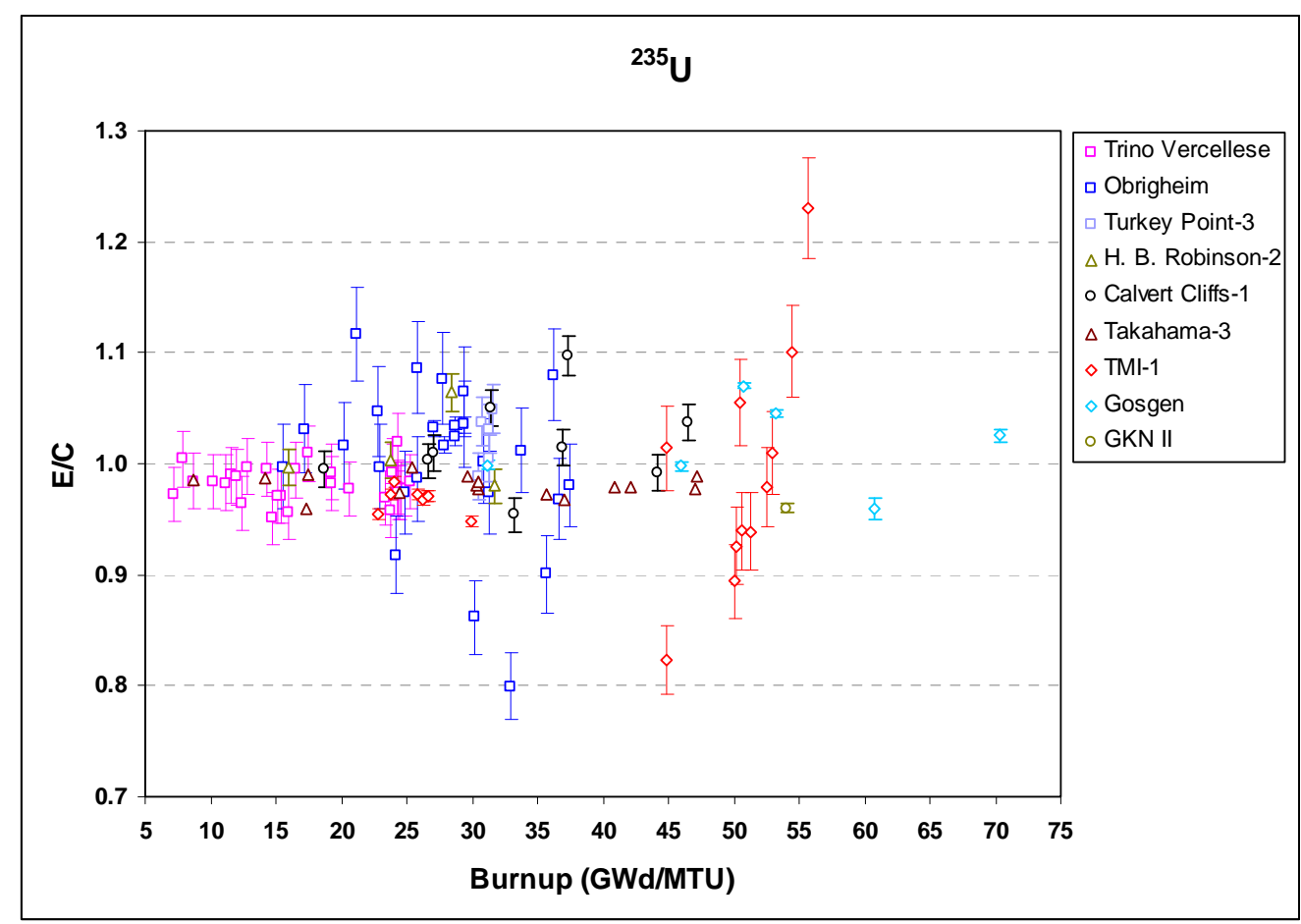

Fig. A.2. Ratio of experimental-to-calculated $(E / C){ }^{235} \mathrm{U}$ concentration versus sample burnup. The error bars show the one-sigma measurement uncertainty. 


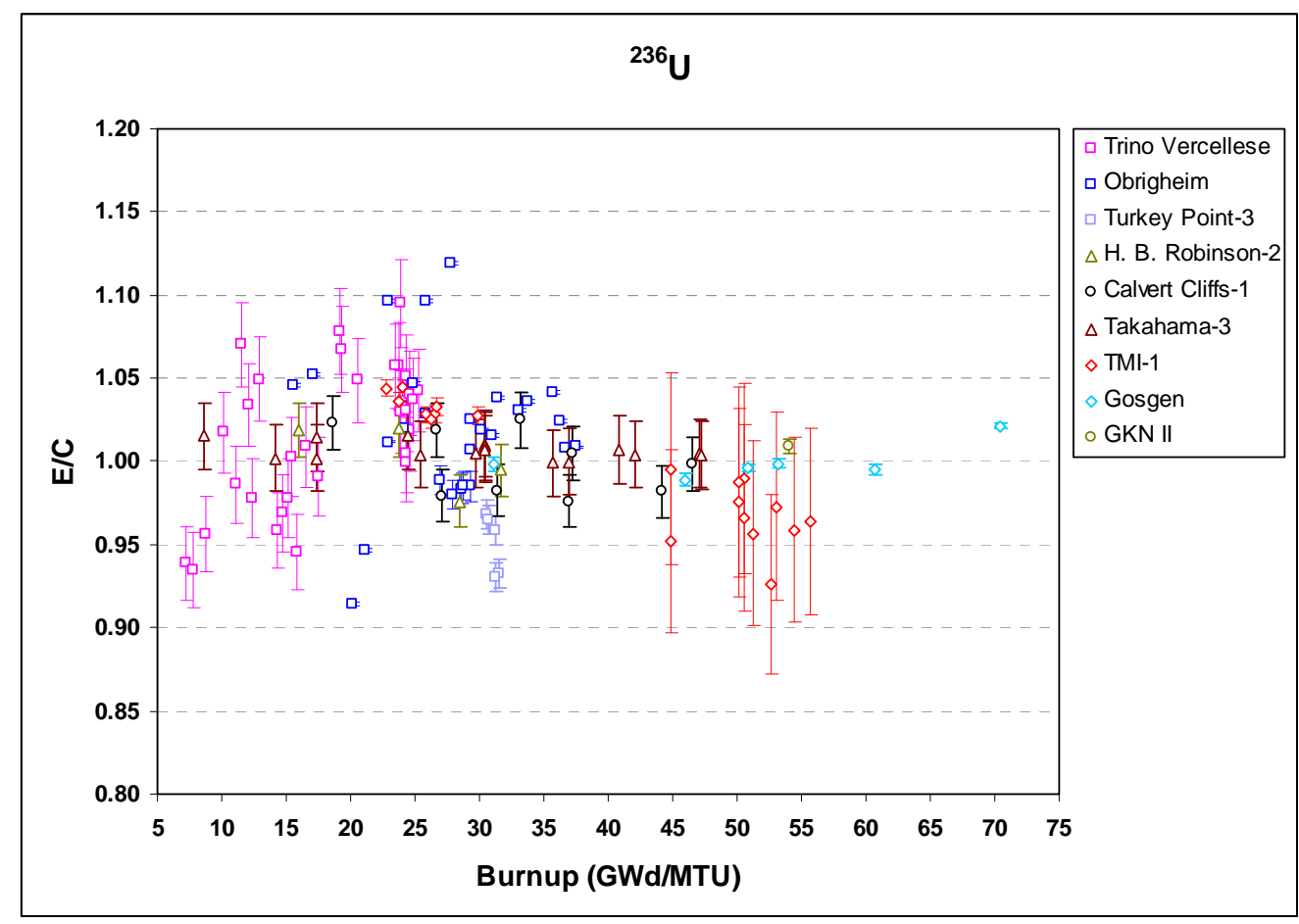

Fig. A.3. Ratio of experimental-to-calculated $(E / C){ }^{236} \mathrm{U}$ concentration versus sample burnup. The error bars show the one-sigma measurement uncertainty.

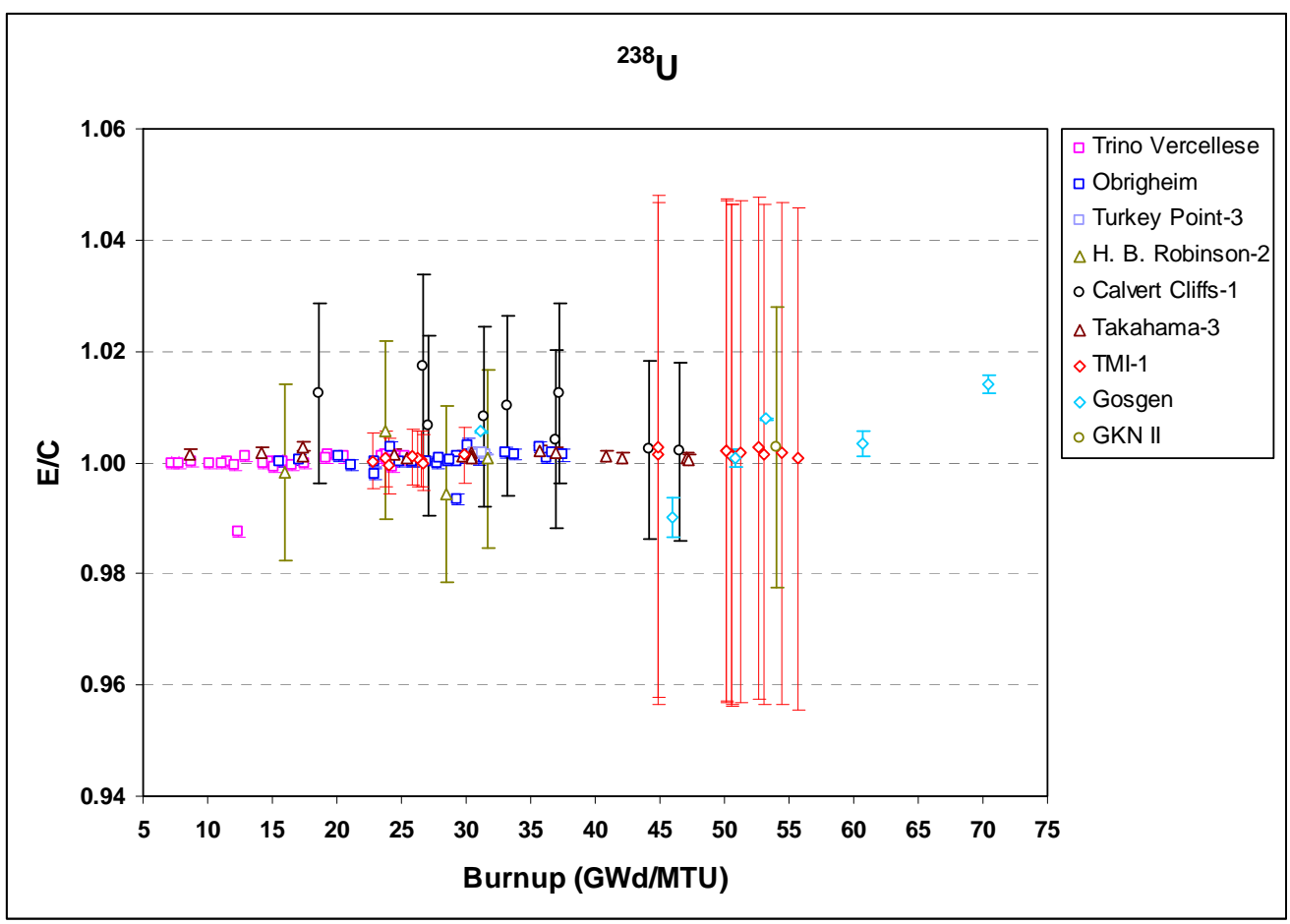

Fig. A.4. Ratio of experimental-to-calculated $(\mathrm{E} / \mathrm{C}){ }^{238} \mathrm{U}$ concentration versus sample burnup. The error bars show the one-sigma measurement uncertainty. 


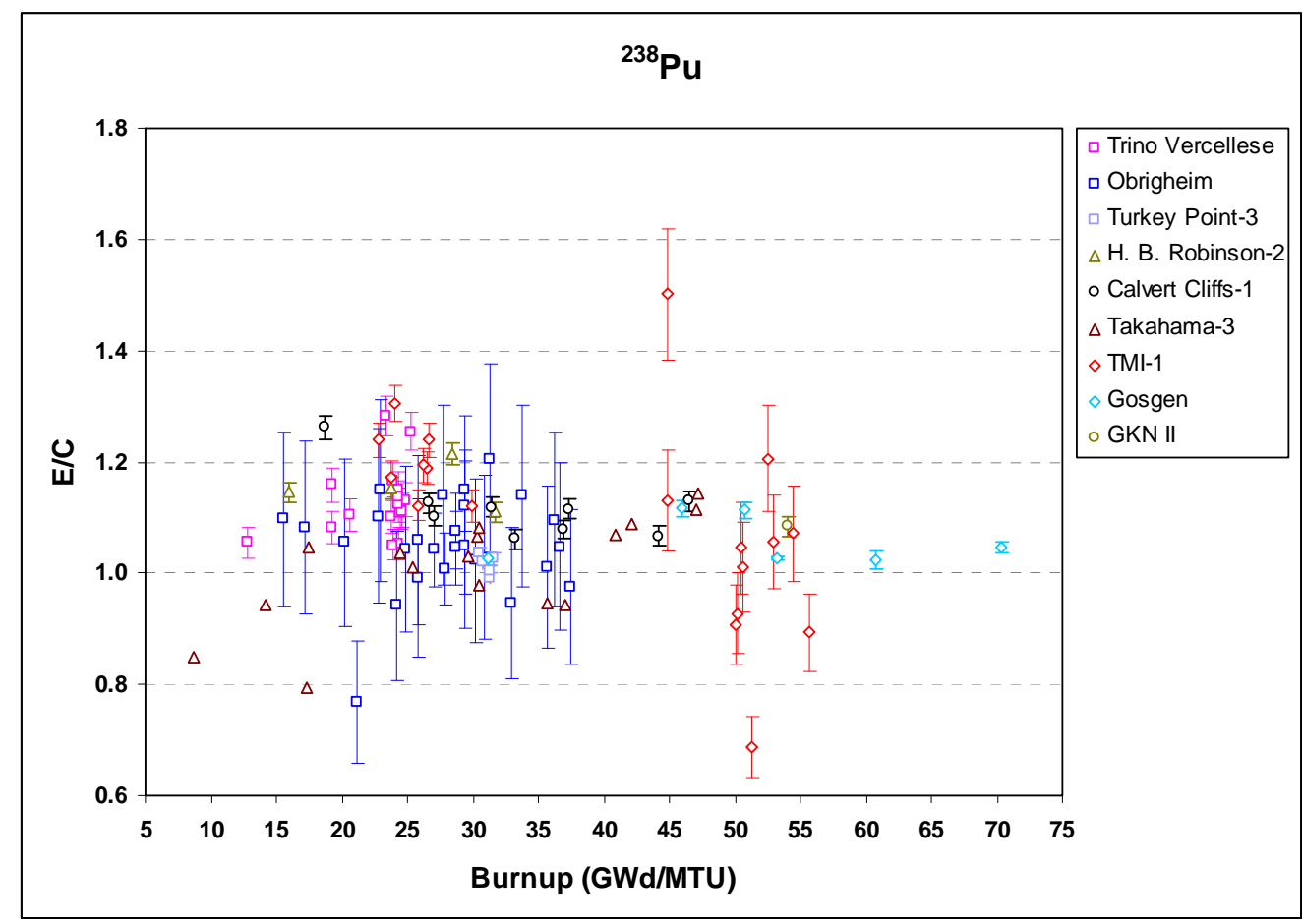

Fig. A.5. Ratio of experimental-to-calculated $(\mathrm{E} / \mathrm{C}){ }^{238} \mathrm{Pu}$ concentration versus sample burnup. The error bars show the one-sigma measurement uncertainty.

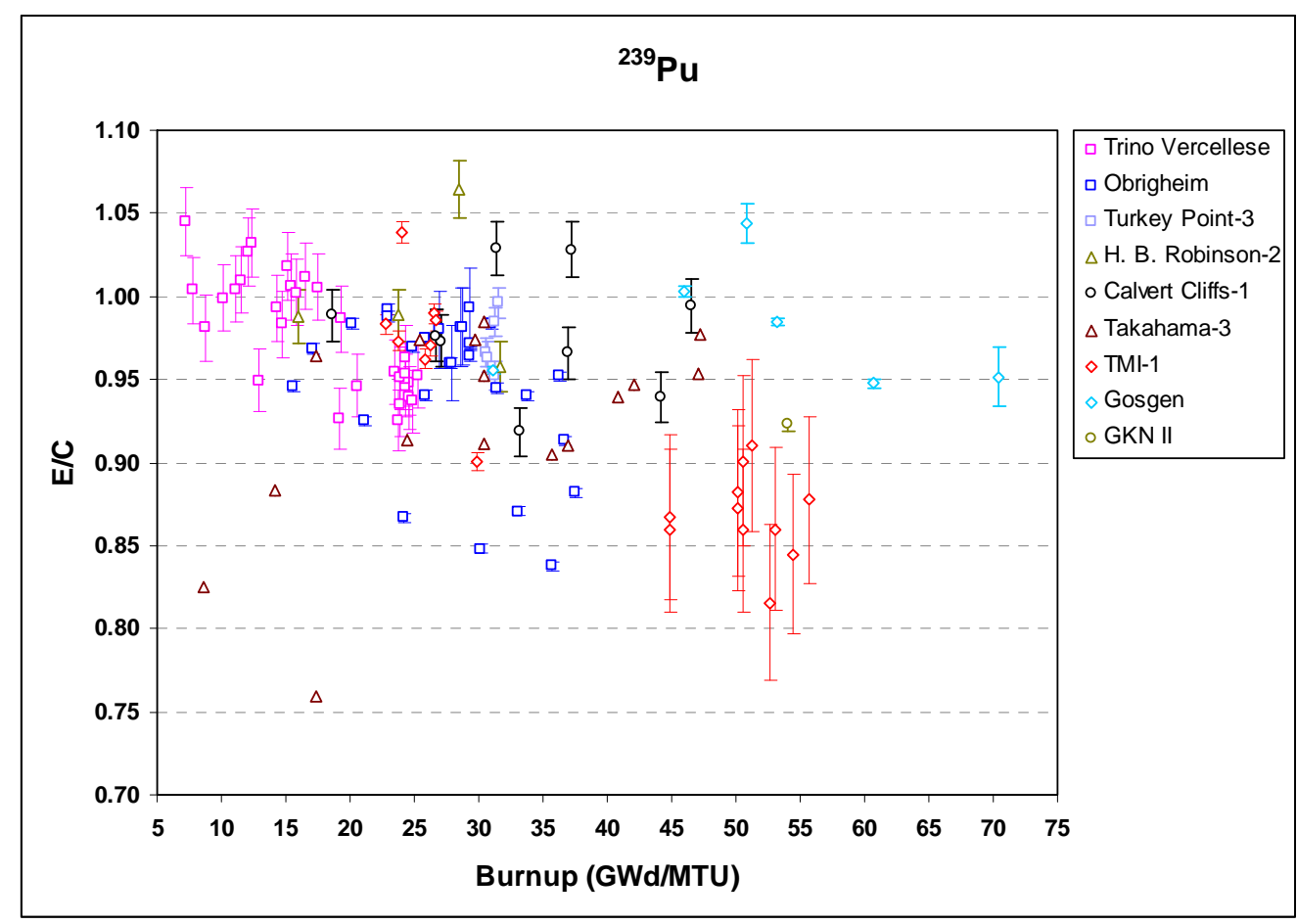

Fig. A.6. Ratio of experimental-to-calculated $(\mathrm{E} / \mathrm{C}){ }^{239} \mathrm{Pu}$ concentration versus sample burnup. The error bars show the one-sigma measurement uncertainty. 


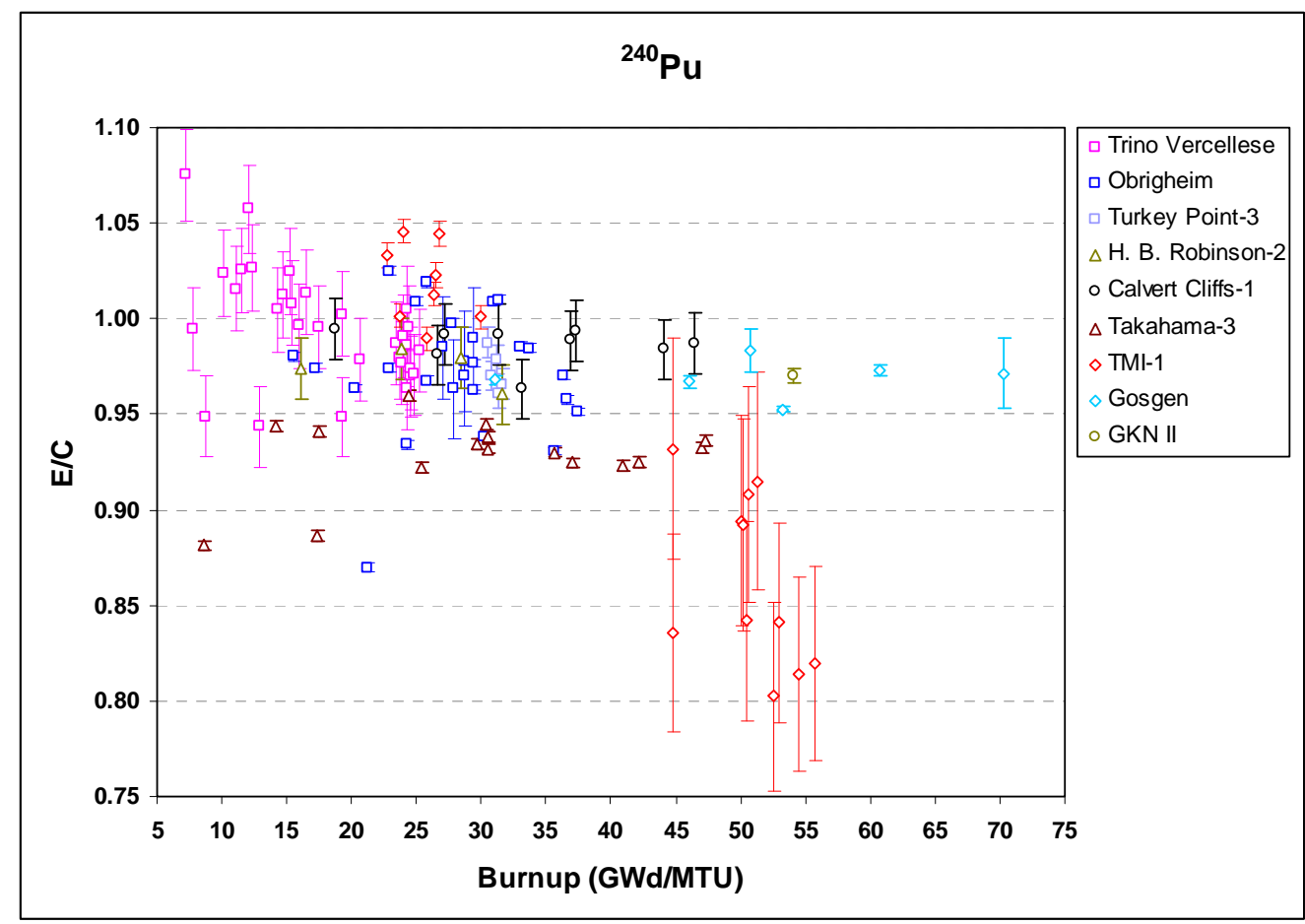

Fig. A.7. Ratio of experimental-to-calculated (E/C) ${ }^{240} \mathrm{Pu}$ concentration versus sample burnup. The error bars show the one-sigma measurement uncertainty.

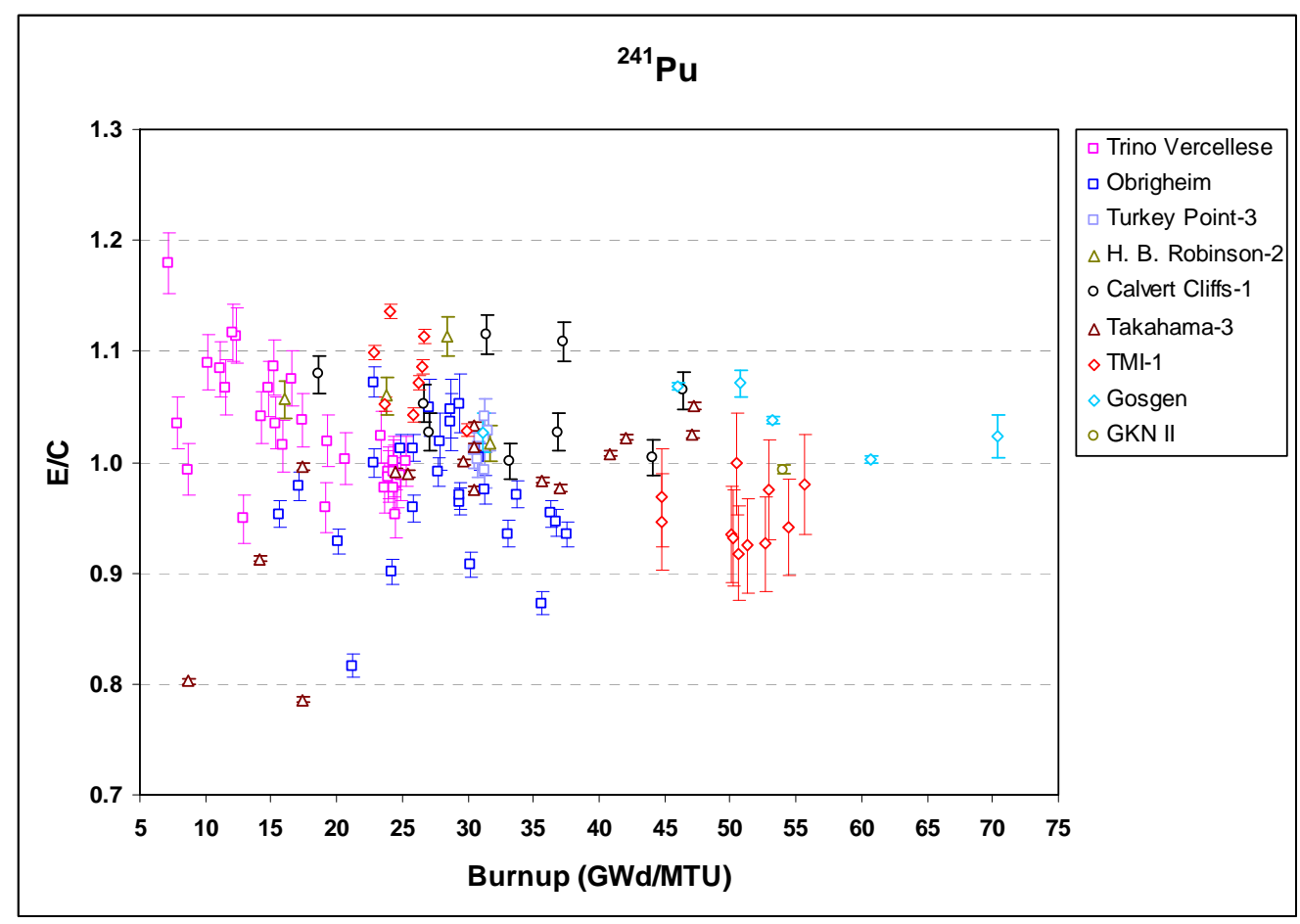

Fig. A.8. Ratio of experimental-to-calculated (E/C) ${ }^{241} \mathrm{Pu}$ concentration versus sample burnup. The error bars show the one-sigma measurement uncertainty. 


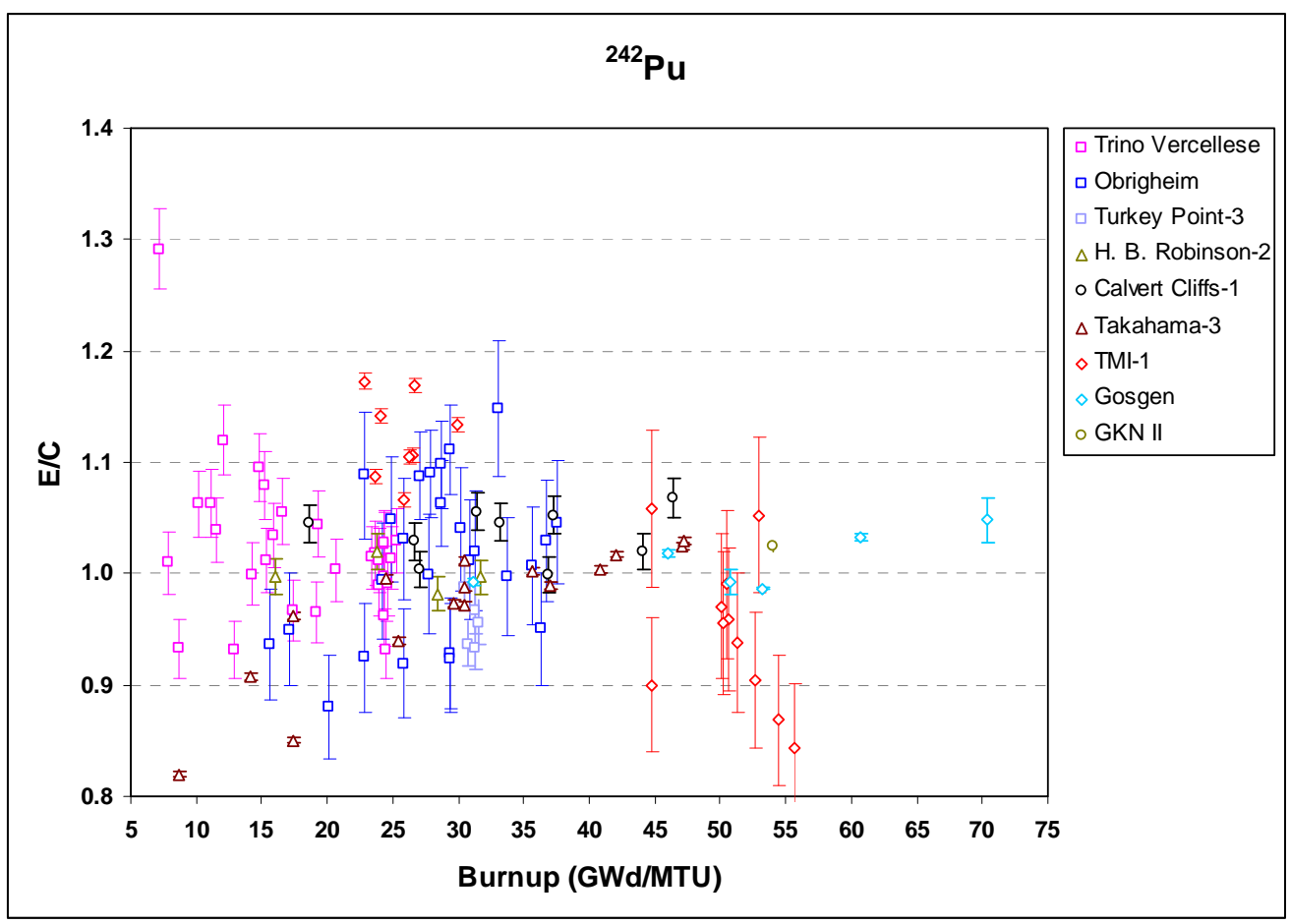

Fig. A.9. Ratio of experimental-to-calculated $(\mathrm{E} / \mathrm{C})^{242} \mathrm{Pu}$ concentration versus sample burnup. The error bars show the one-sigma measurement uncertainty.

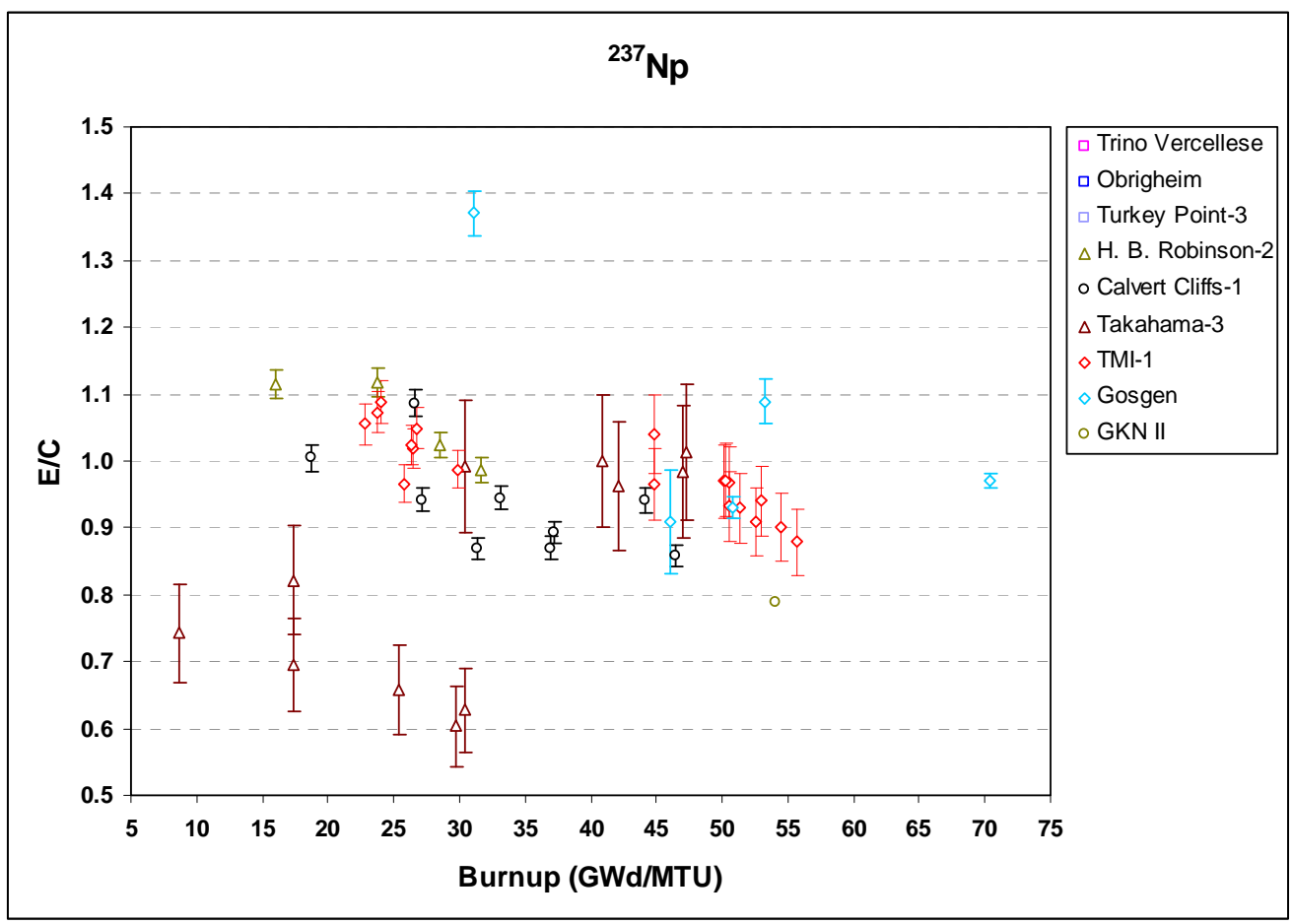

Fig. A.10. Ratio of experimental-to-calculated (E/C) ${ }^{237} \mathrm{~Np}$ concentration versus sample burnup. The error bars show the one-sigma measurement uncertainty. 


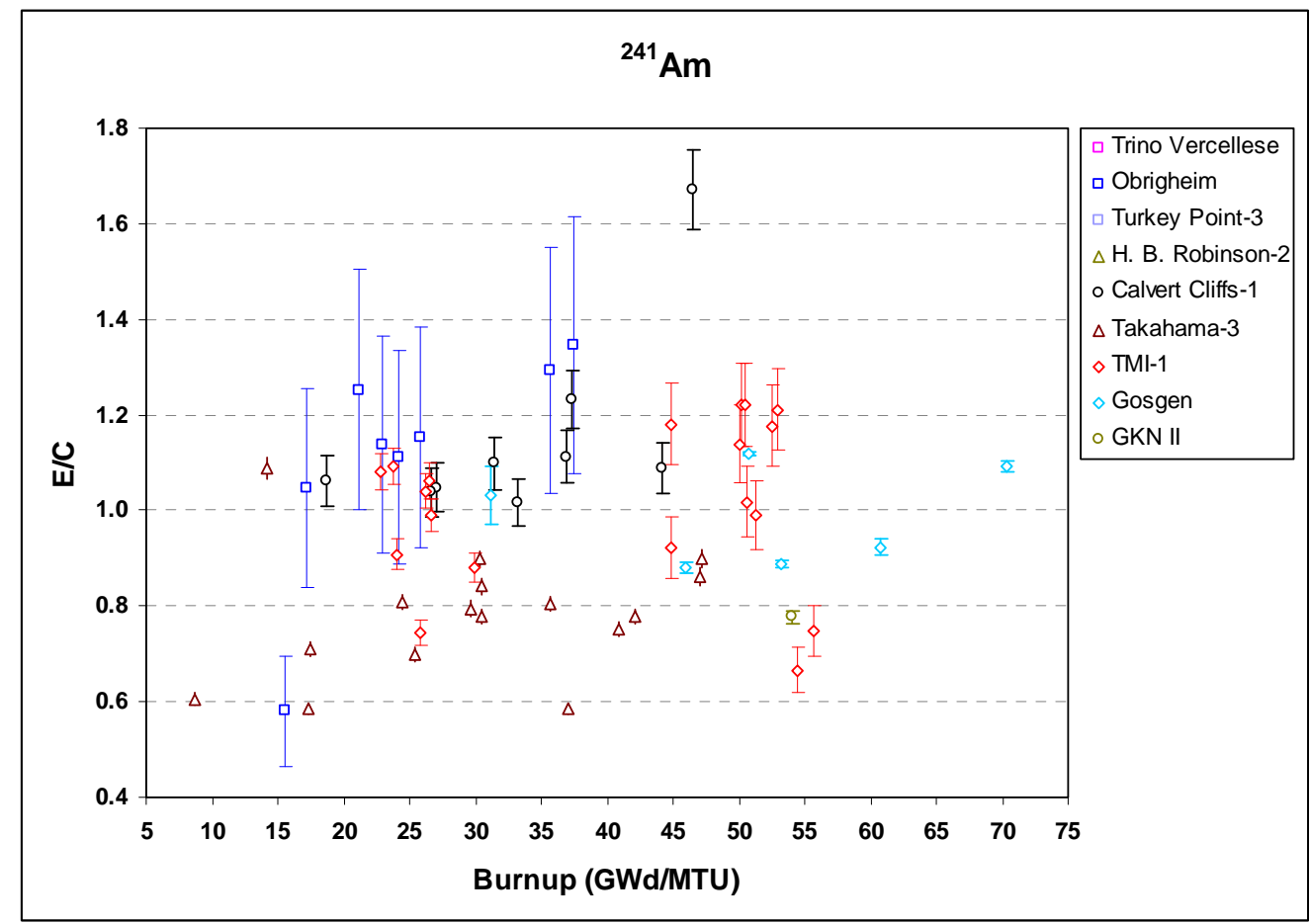

Fig. A.11. Ratio of experimental-to-calculated (E/C) ${ }^{241} \mathrm{Am}$ concentration versus sample burnup. The error bars show the one-sigma measurement uncertainty.

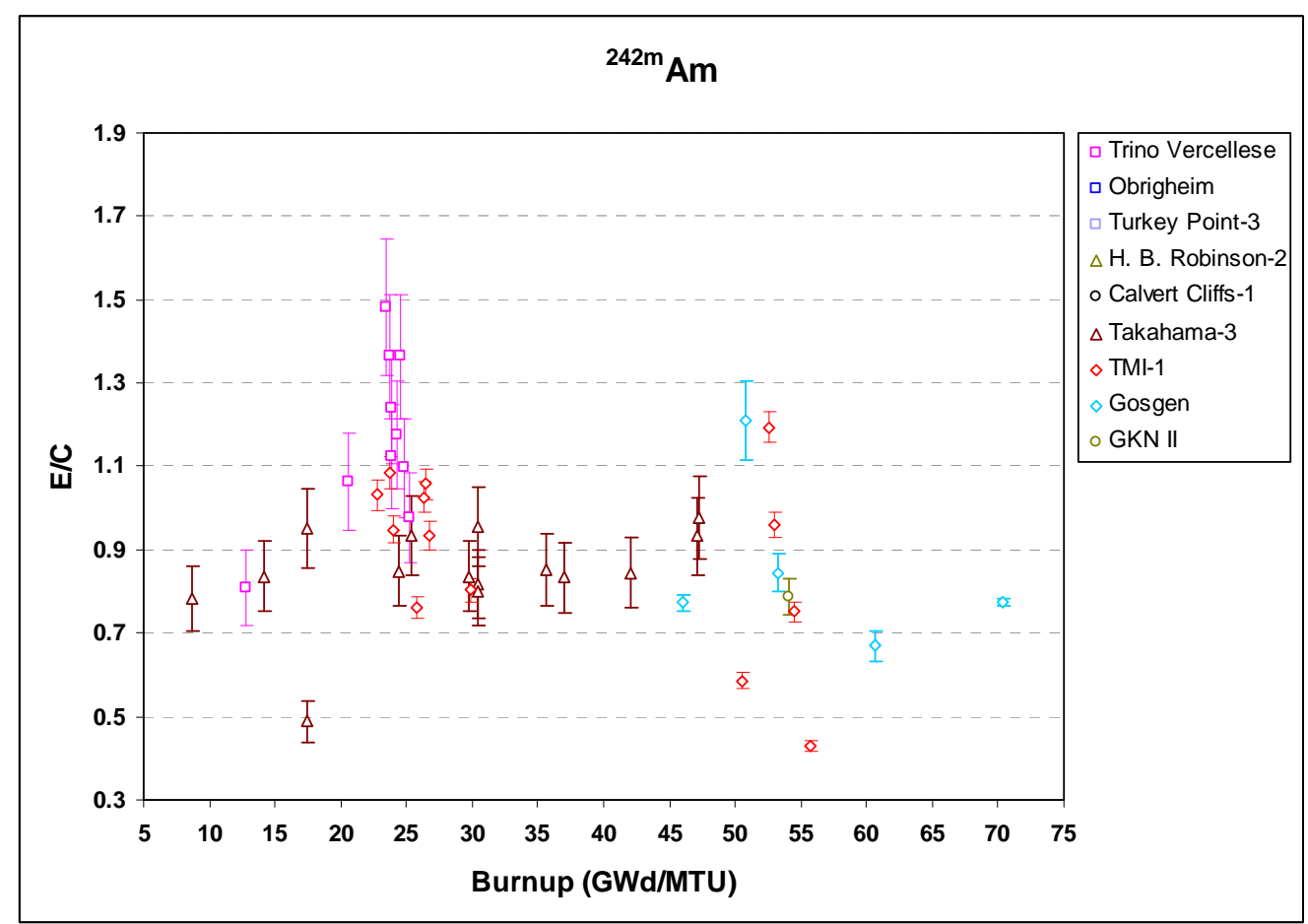

Fig. A.12. Ratio of experimental-to-calculated (E/C) ${ }^{242 \mathrm{~m}}$ Am concentration versus sample burnup. The error bars show the one-sigma measurement uncertainty. 


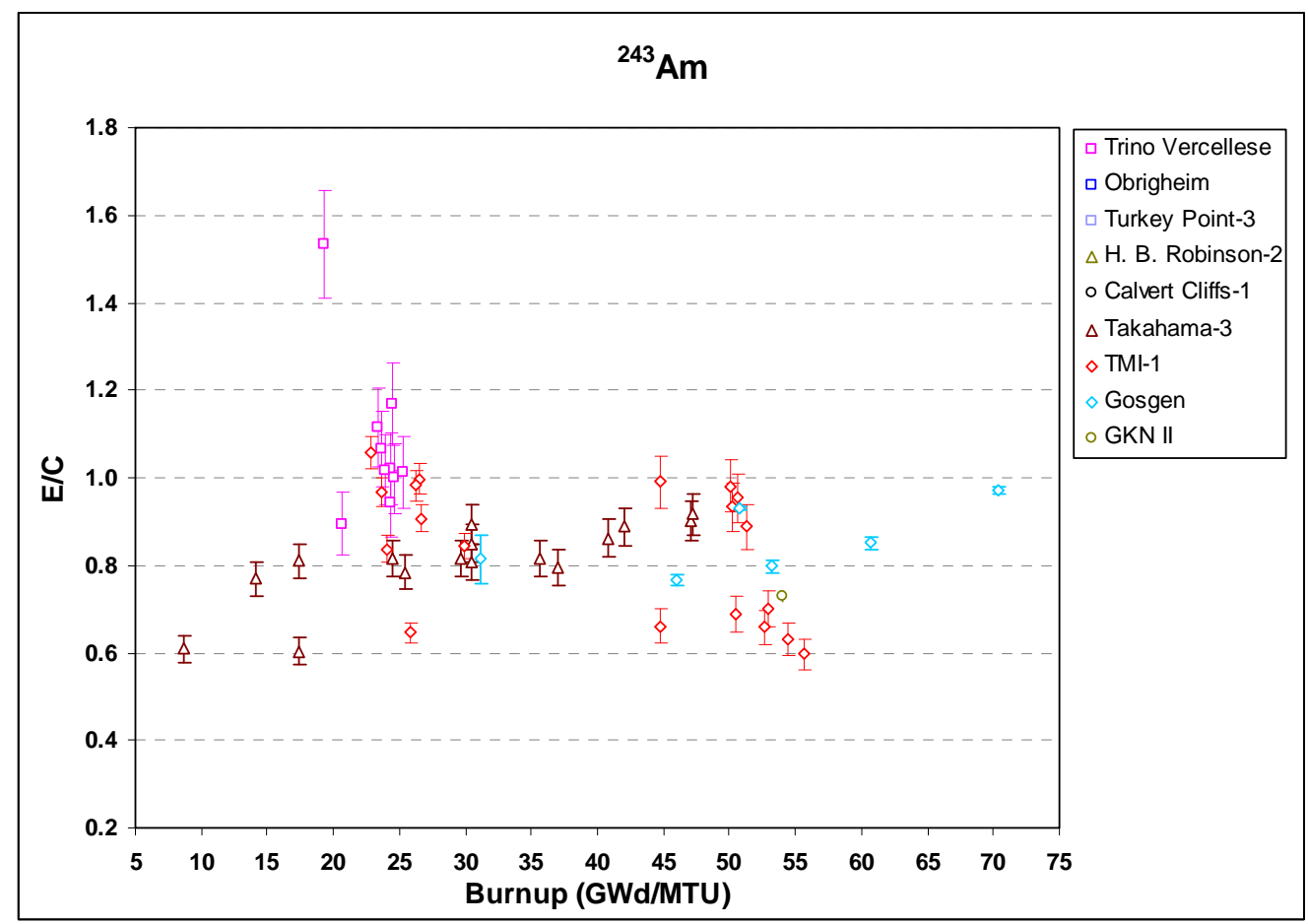

Fig. A.13. Ratio of experimental-to-calculated $(\mathrm{E} / \mathrm{C}){ }^{243} \mathrm{Am}$ concentration versus sample burnup. The error bars show the one-sigma measurement uncertainty.

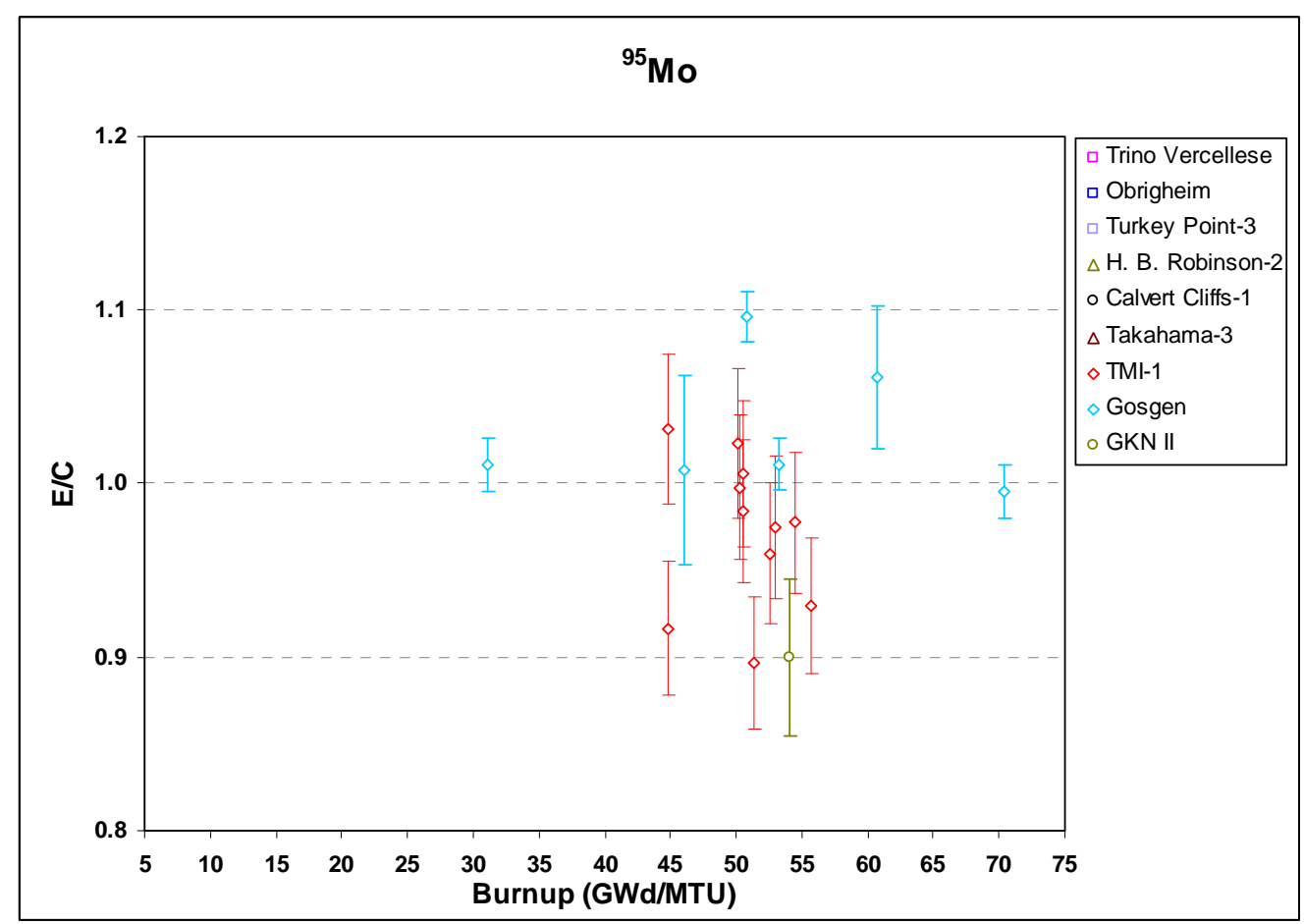

Fig. A.14. Ratio of experimental-to-calculated (E/C) ${ }^{95} \mathrm{Mo}$ concentration versus sample burnup. The error bars show the one-sigma measurement uncertainty. 


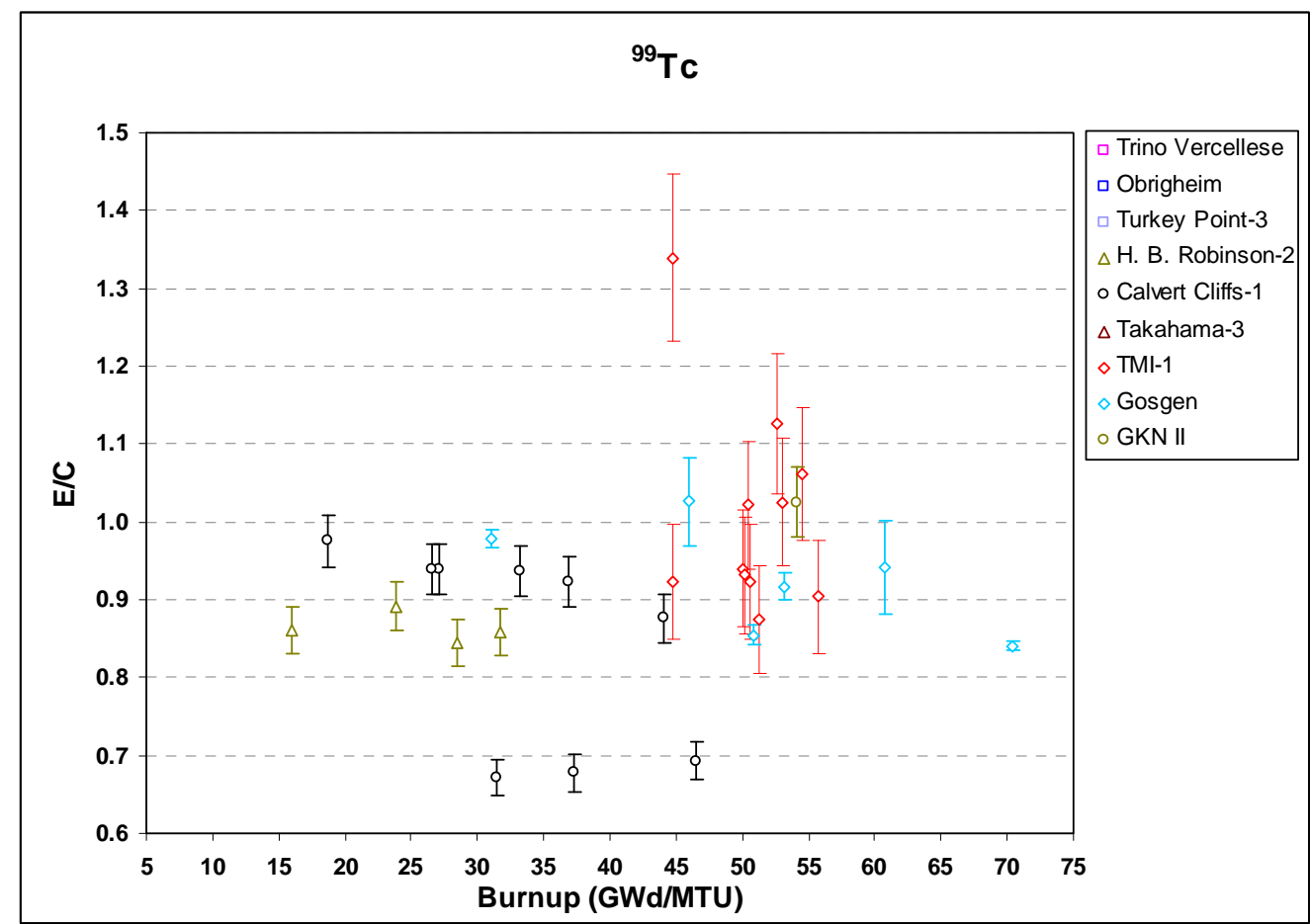

Fig. A.15. Ratio of experimental-to-calculated $(\mathrm{E} / \mathrm{C})^{99} \mathrm{Tc}$ concentration versus sample burnup. The error bars show the one-sigma measurement uncertainty.

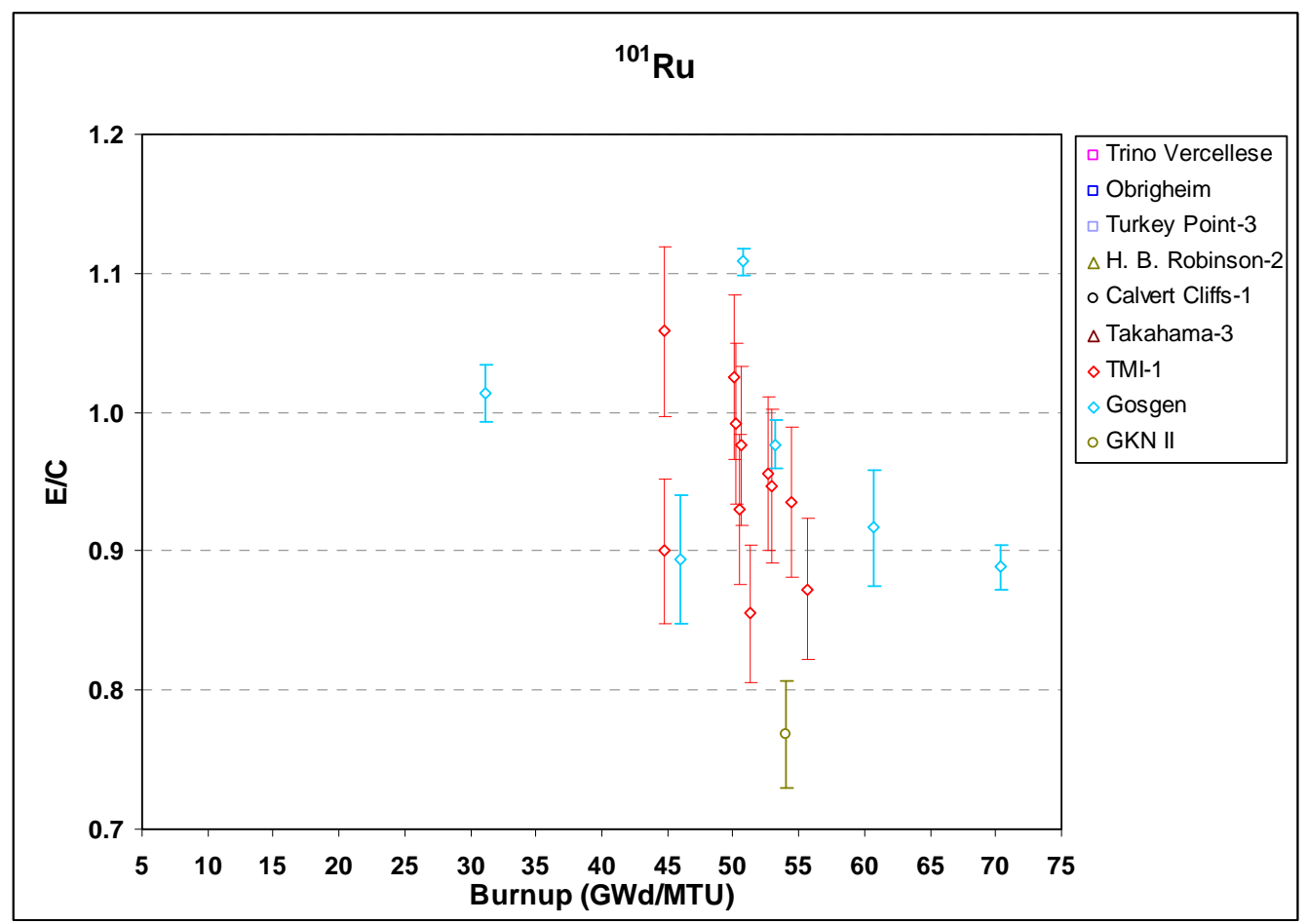

Fig. A.16. Ratio of experimental-to-calculated $(\mathrm{E} / \mathrm{C}){ }^{101} \mathrm{Ru}$ concentration versus sample burnup. The error bars show the one-sigma measurement uncertainty. 


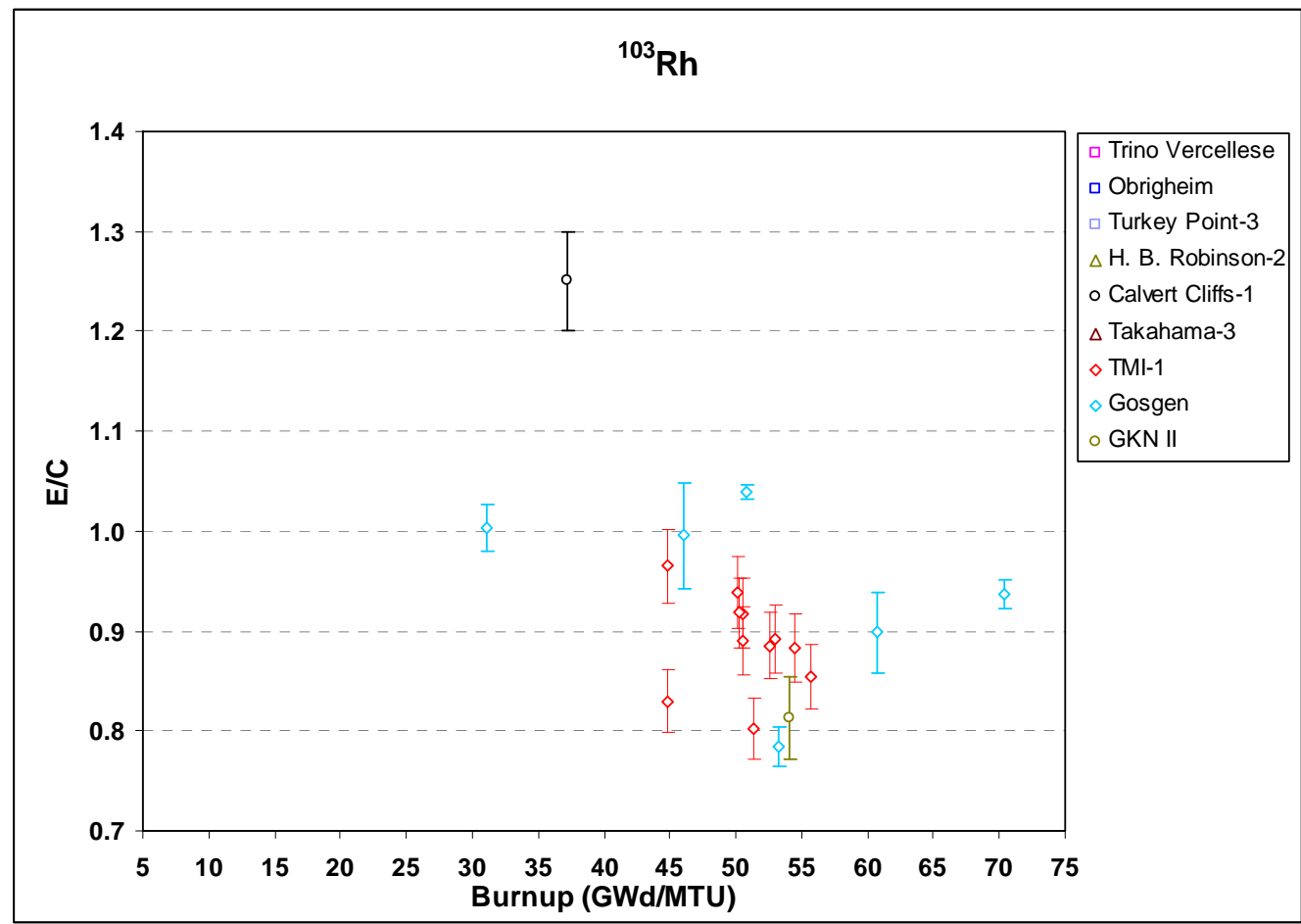

Fig. A.17. Ratio of experimental-to-calculated $(\mathrm{E} / \mathrm{C}){ }^{103} \mathrm{Rh}$ concentration versus sample burnup. The error bars show the one-sigma measurement uncertainty.

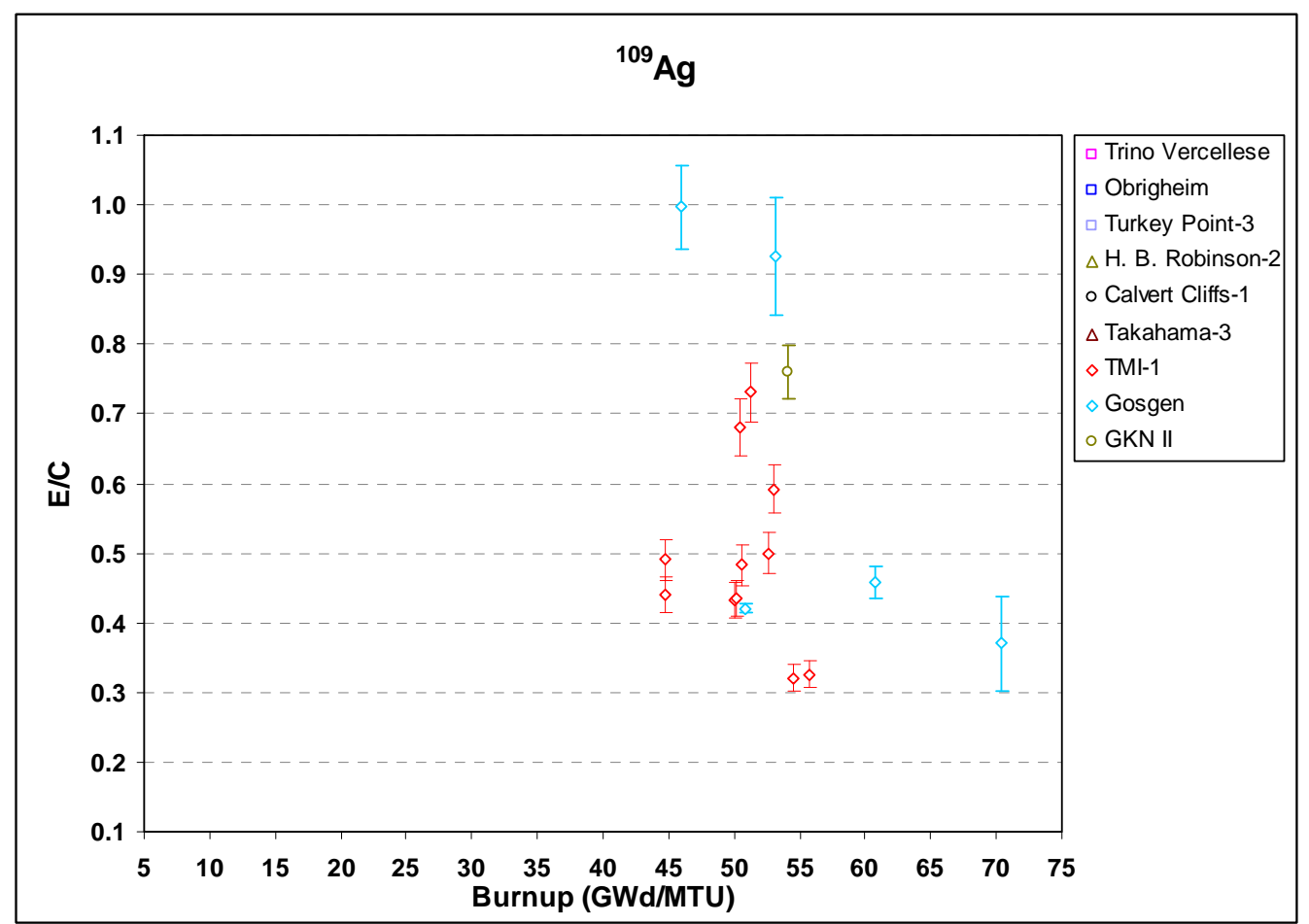

Fig. A.18. Ratio of experimental-to-calculated (E/C) ${ }^{109} \mathrm{Ag}$ concentration versus sample burnup. The error bars show the one-sigma measurement uncertainty. 


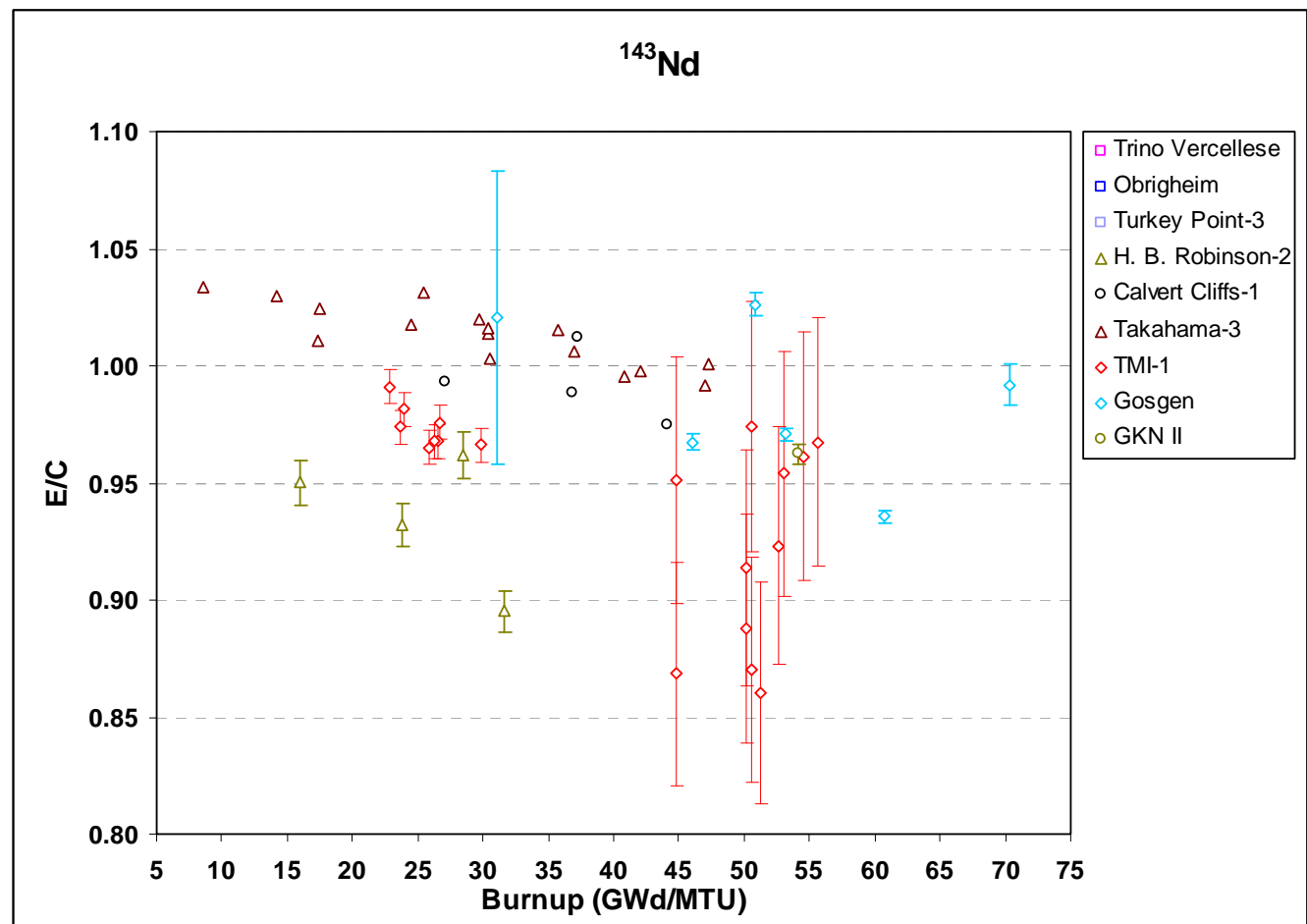

Fig. A.19. Ratio of experimental-to-calculated $(\mathrm{E} / \mathrm{C}){ }^{143} \mathrm{Nd}$ concentration versus sample burnup. The error bars show the one-sigma measurement uncertainty.

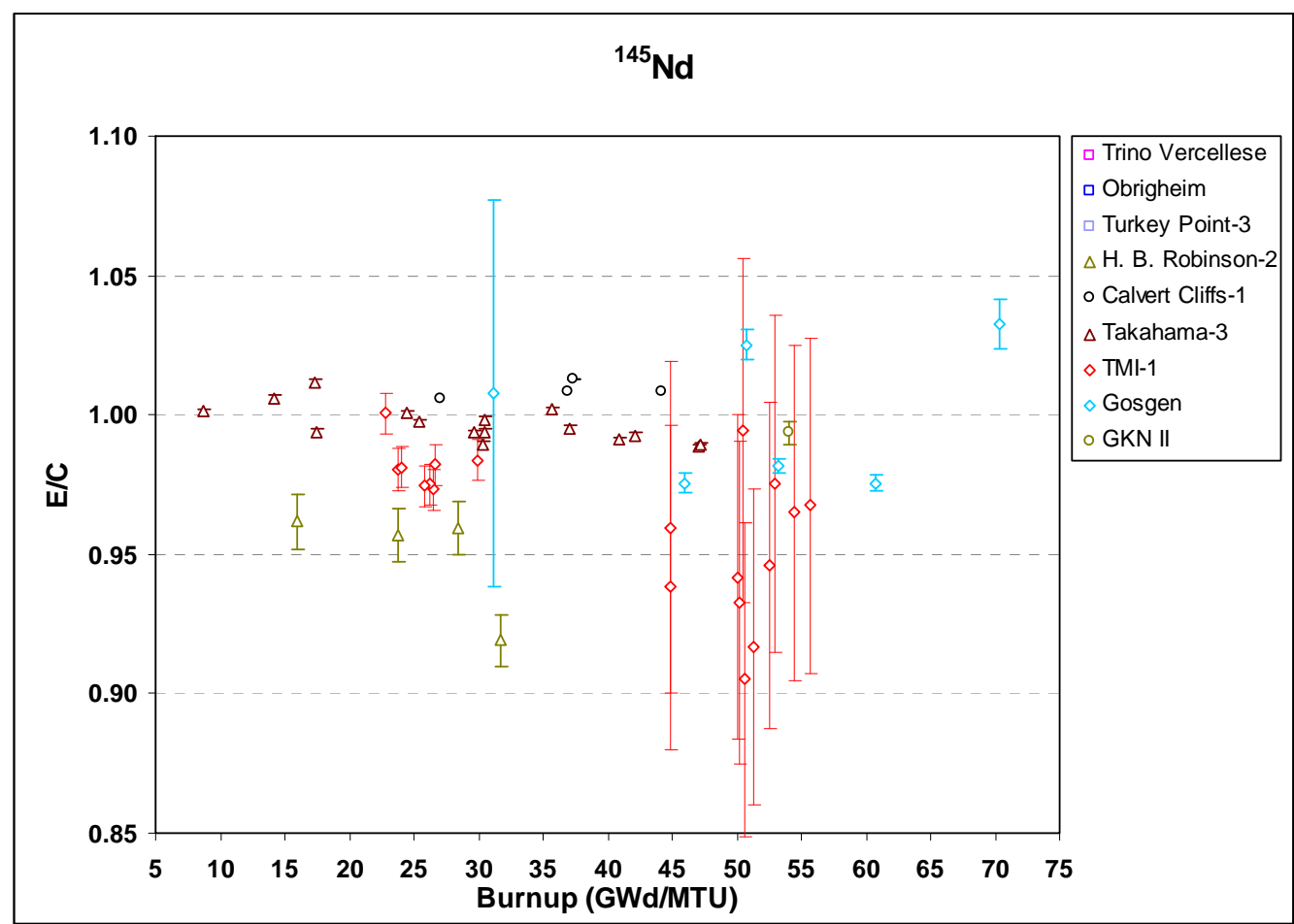

Fig. A.20. Ratio of experimental-to-calculated $(\mathrm{E} / \mathrm{C}){ }^{145} \mathrm{Nd}$ concentration versus sample burnup. The error bars show the one-sigma measurement uncertainty. 


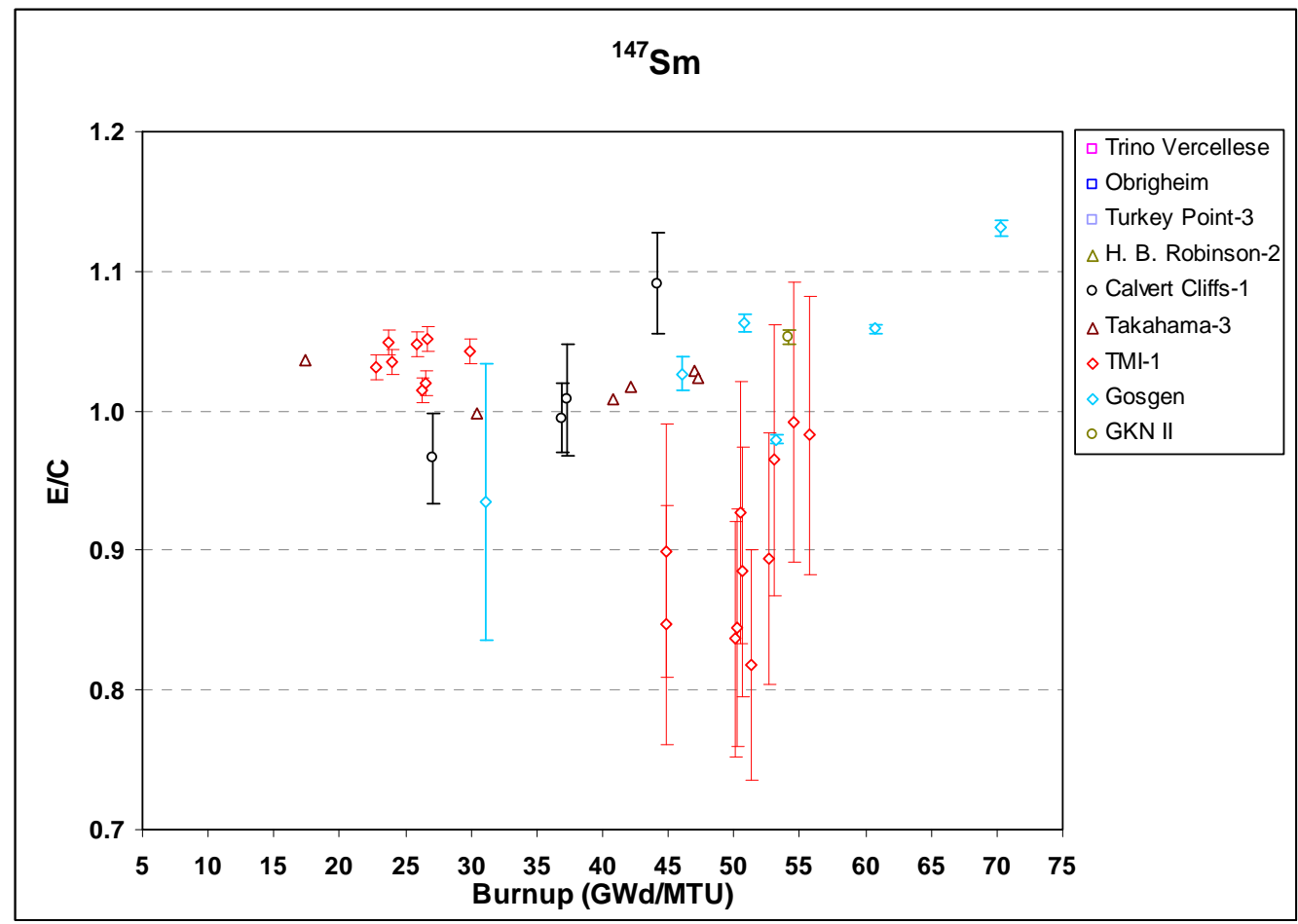

Fig. A.21. Ratio of experimental-to-calculated $(\mathrm{E} / \mathrm{C}){ }^{147} \mathrm{Sm}$ concentration versus sample burnup. The error bars show the one-sigma measurement uncertainty.

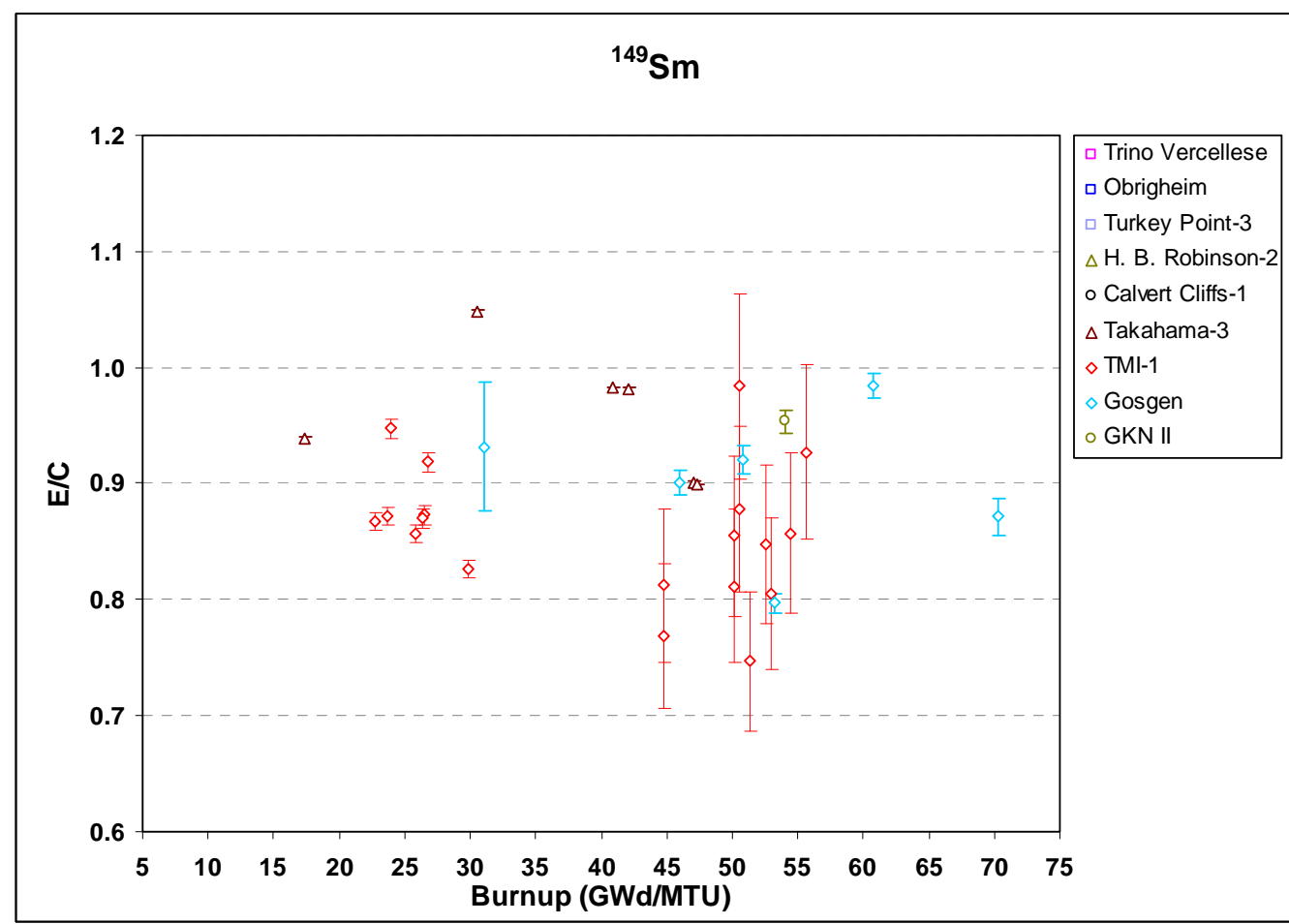

Fig. A.22. Ratio of experimental-to-calculated (E/C) ${ }^{149} \mathrm{Sm}$ concentration versus sample burnup. The error bars show the one-sigma measurement uncertainty. 


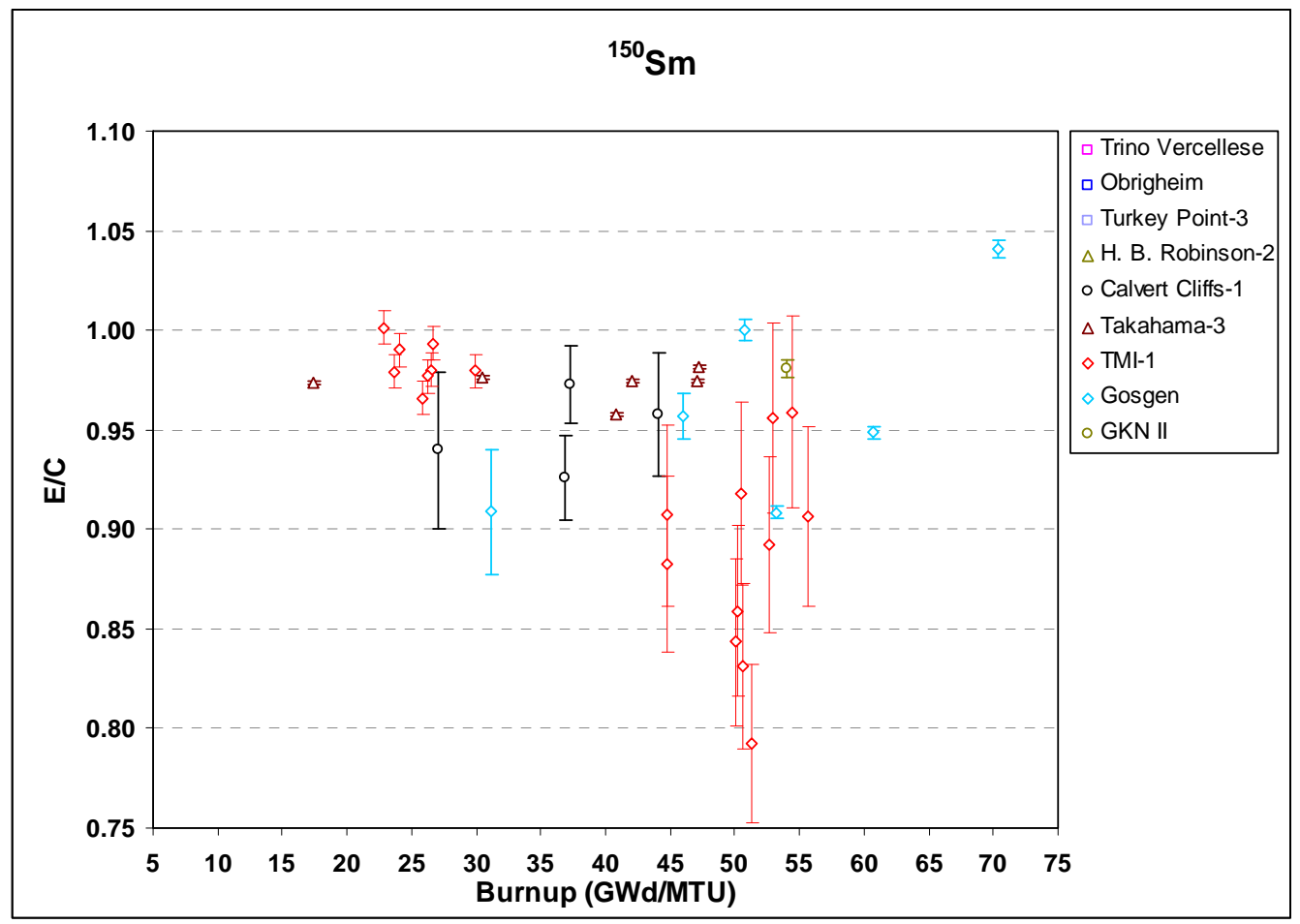

Fig. A.23. Ratio of experimental-to-calculated (E/C) ${ }^{150} \mathrm{Sm}$ concentration versus sample burnup. The error bars show the one-sigma measurement uncertainty.

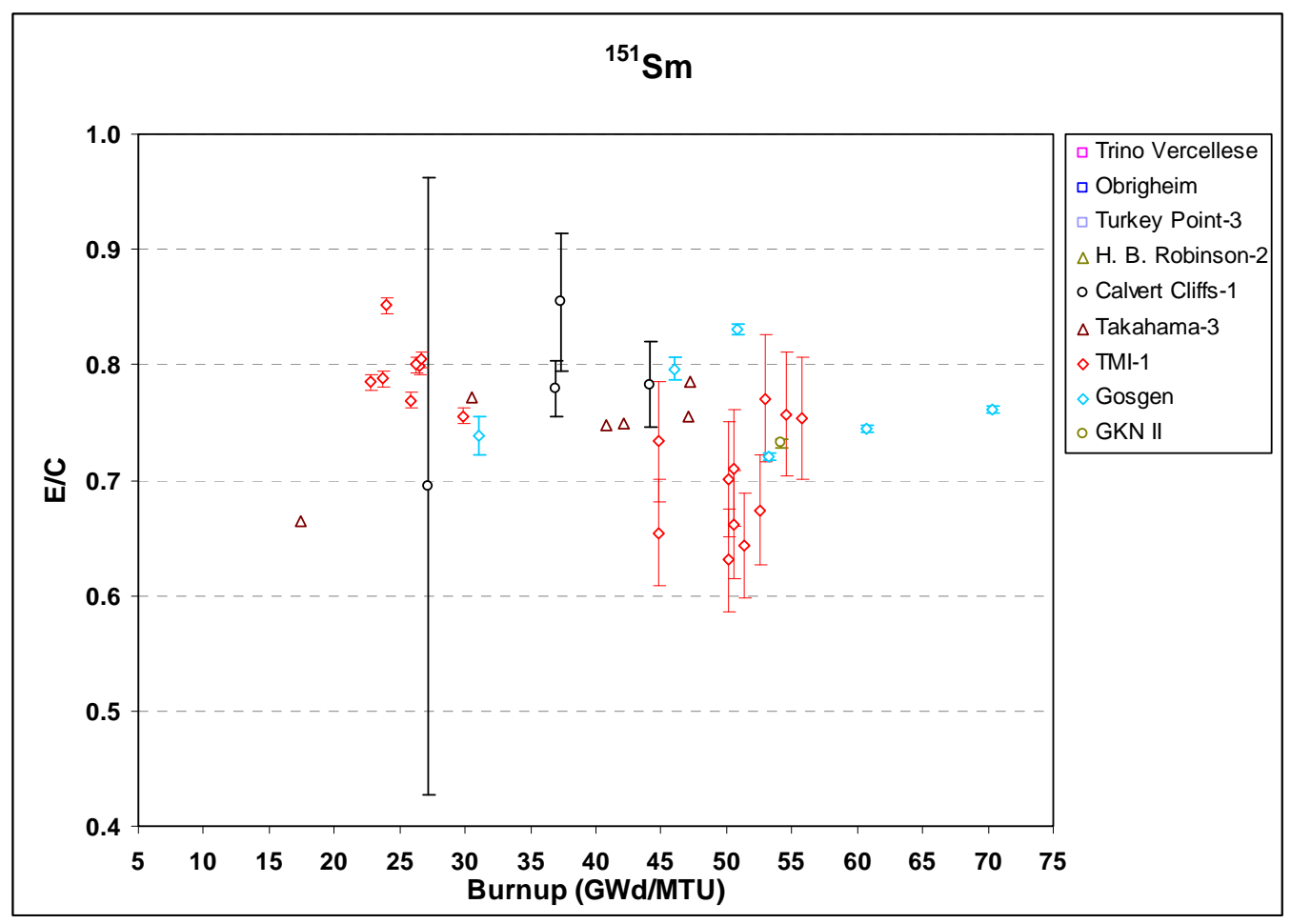

Fig. A.24. Ratio of experimental-to-calculated (E/C) ${ }^{151} \mathrm{Sm}$ concentration versus sample burnup. The error bars show the one-sigma measurement uncertainty. 


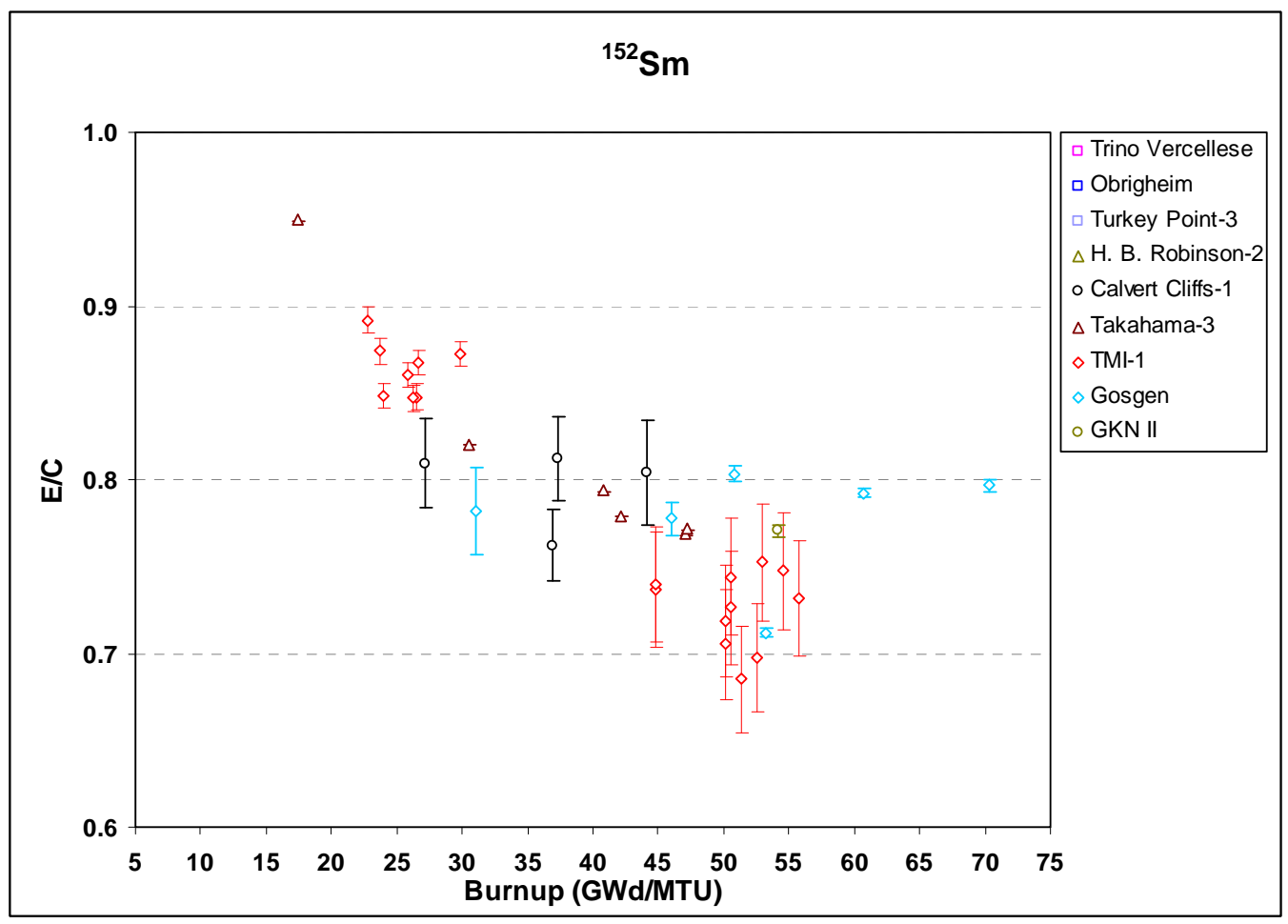

Fig. A.25. Ratio of experimental-to-calculated $(\mathrm{E} / \mathrm{C}){ }^{152} \mathrm{Sm}$ concentration versus sample burnup. The error bars show the one-sigma measurement uncertainty.

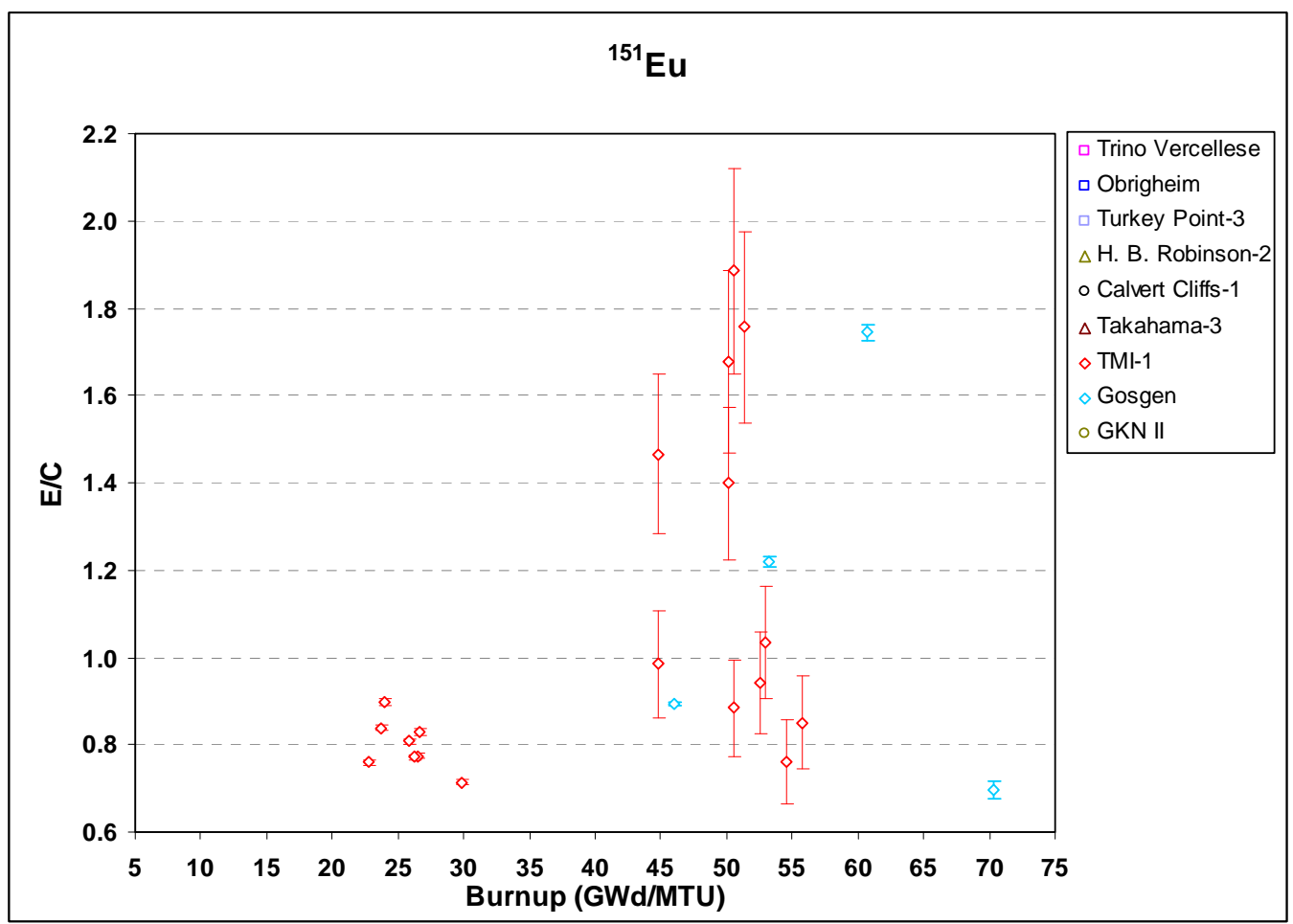

Fig. A.26. Ratio of experimental-to-calculated (E/C) ${ }^{151}$ Eu concentration versus sample burnup. The error bars show the one-sigma measurement uncertainty. 


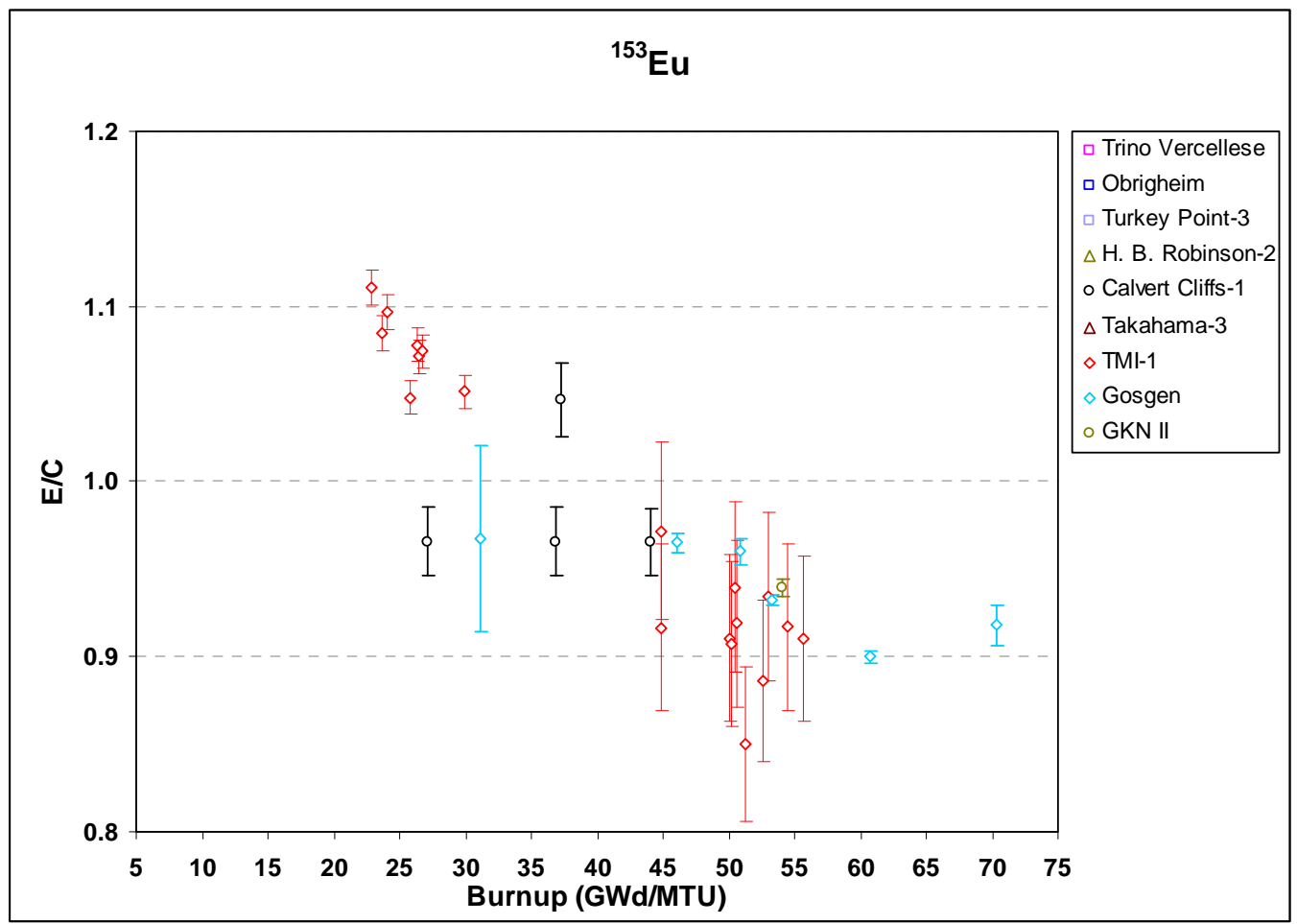

Fig. A.27. Ratio of experimental-to-calculated (E/C) ${ }^{153} \mathrm{Eu}$ concentration versus sample burnup. The error bars show the one-sigma measurement uncertainty.

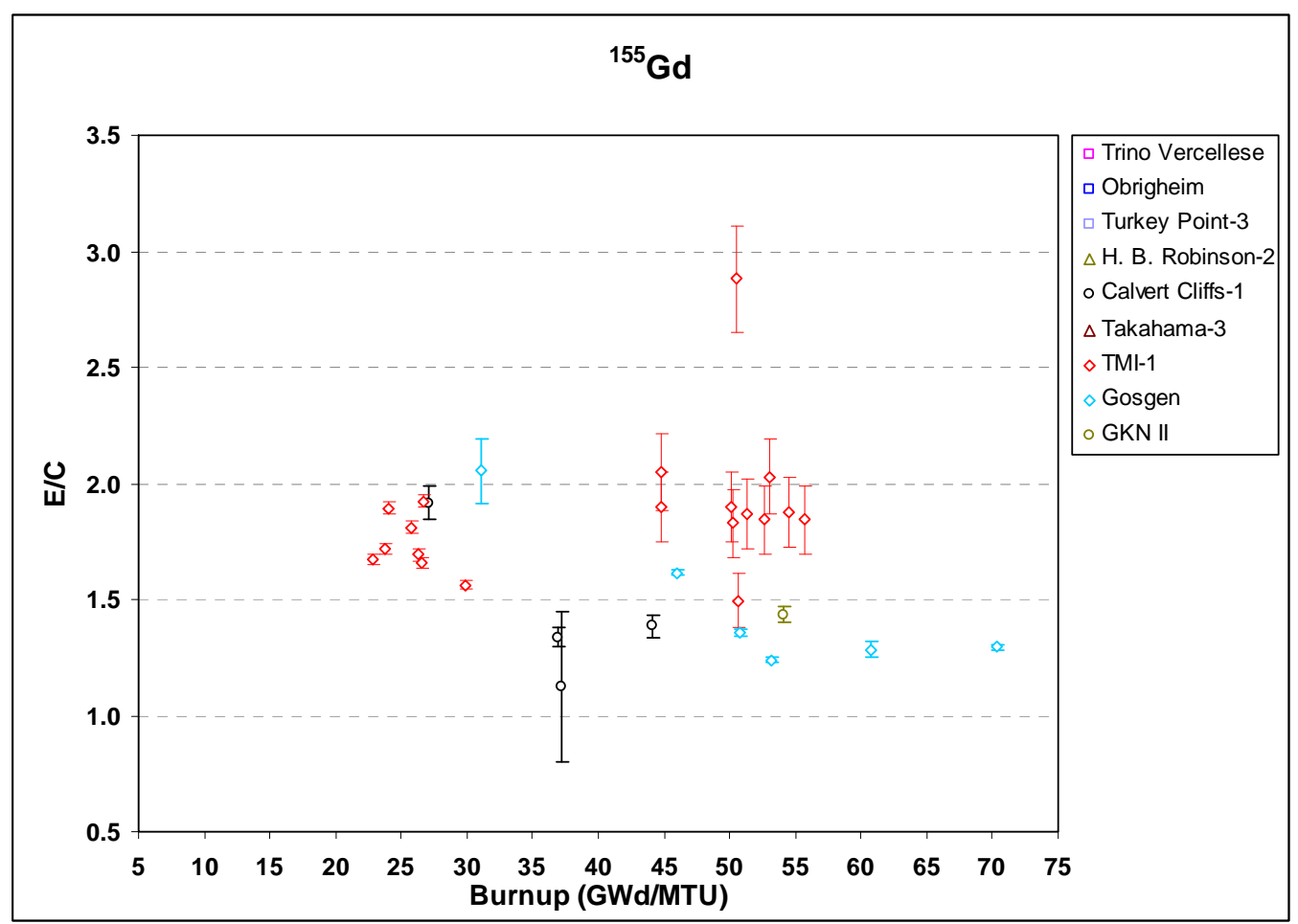

Fig. A.28. Ratio of experimental-to-calculated $(\mathrm{E} / \mathrm{C}){ }^{155} \mathrm{Gd}$ concentration versus sample burnup. The error bars show the one-sigma measurement uncertainty. 
APPENDIX B:

ELECTRONIC DATA SPECIFICATIONS 

This appendix contains a listing and description of the files contained in the Digital Versatile/Video Discs (DVD+R format) that are attached to the calculation report SCALE 5.1 Predictions of PWR Spent Nuclear Fuel Isotopic Compositions. The operating system used to create the electronic data on the DVDs was Microsoft Windows XP Professional, Version 2002. The files stored on the electronic media contain zipped archives consisting of SCALE input and output files (text format) and Microsoft Excel files, which were created using standard Windows XP compress capabilities. The following process controls for storage and protection of electronic data apply.

Medium: $\quad$ DVD

Conditions: $\quad$ Fireproof cabinet kept at ambient temperature

Location: $\quad$ OCRWM QA Records, currently stored in Building 5700, Room H330

Retention Time: Lifetime

Security: $\quad$ Fireproof cabinet is locked

Access: $\quad$ Project manager and records custodian only

The attributes of the electronic files are as follows:

\begin{tabular}{|c|c|c|c|c|c|}
\hline File name & $\begin{array}{c}\text { Size (bytes) } \\
\text { (on disk) }\end{array}$ & Number of files & File date $^{b}$ & File time & Description \\
\hline \multicolumn{6}{|c|}{ DVD } \\
\hline xls.zip & $1,929,216$ & 19 & $3 / 29 / 2010$ & 11:02:54 am & $\begin{array}{l}\text { Archive containing all Microsoft Excel } \\
\text { files used in this calculation }\end{array}$ \\
\hline CalvertCliffs.zip & $163,706,880$ & 213 & $3 / 22 / 2010$ & $3: 41: 07 \mathrm{pm}$ & $\begin{array}{l}\text { Archive containing SCALE depletion and } \\
\text { decay files for the Calvert Cliffs spent fuel } \\
\text { samples }\end{array}$ \\
\hline GKN_Rebus.zip & $23,313,432$ & 30 & $3 / 22 / 2010$ & $3: 28: 42 \mathrm{pm}$ & $\begin{array}{l}\text { Archive containing SCALE depletion and } \\
\text { decay files for the GKN II spent fuel } \\
\text { samples }\end{array}$ \\
\hline Gosgen_Ariane.zip & $126,485,528$ & 209 & $3 / 25 / 2010$ & 5:29:03 pm & $\begin{array}{l}\text { Archive containing SCALE depletion and } \\
\text { decay files for the Gösgen (ARIANE } \\
\text { Program) spent fuel samples }\end{array}$ \\
\hline HBRobinson.zip & $57,681,920$ & 56 & $3 / 22 / 2010$ & 1:31:09 pm & $\begin{array}{l}\text { Archive containing SCALE depletion and } \\
\text { decay files for the H.B. Robinson Unit } 2 \\
\text { spent fuel samples }\end{array}$ \\
\hline Obrigheim.zip & $215,351,296$ & 127 & $3 / 22 / 2010$ & $1: 28: 11 \mathrm{pm}$ & $\begin{array}{l}\text { Archive containing SCALE depletion and } \\
\text { decay files for the Obrigheim spent fuel } \\
\text { samples }\end{array}$ \\
\hline Takahama.zip & $430,202,880$ & 208 & $3 / 22 / 2010$ & $2: 47: 56 \mathrm{pm}$ & $\begin{array}{l}\text { Archive containing SCALE depletion and } \\
\text { decay files for the Takahama Unit } 3 \text { spent } \\
\text { fuel samples }\end{array}$ \\
\hline TMI1.zip & $251,276,312$ & 394 & $3 / 22 / 2010$ & $3: 02: 34 \mathrm{pm}$ & $\begin{array}{l}\text { Archive containing SCALE depletion and } \\
\text { decay files for the TMI Unit } 1 \text { spent fuel } \\
\text { samples }\end{array}$ \\
\hline TrinoVercellese.zip & $380,110,848$ & 141 & $3 / 22 / 2010$ & $9: 55: 23 \mathrm{am}$ & $\begin{array}{l}\text { Archive containing SCALE depletion and } \\
\text { decay files for the Trino Vercellese spent } \\
\text { fuel samples }\end{array}$ \\
\hline TurkeyPoint.zip & $76,744,704$ & 27 & $3 / 22 / 2010$ & 10:03:16 am & $\begin{array}{l}\text { Archive containing SCALE depletion and } \\
\text { decay files for the Turkey Point Unit } 3 \\
\text { spent fuel samples }\end{array}$ \\
\hline \multicolumn{6}{|c|}{ DVDr $^{a}$} \\
\hline Gosgen_Malibu.zip & $122,482,688$ & 84 & $3 / 22 / 2010$ & $3: 35: 03 \mathrm{pm}$ & $\begin{array}{l}\text { Archive containing SCALE depletion and } \\
\text { decay files for the Gösgen (MALIBU } \\
\text { Program) spent fuel samples }\end{array}$ \\
\hline
\end{tabular}

${ }^{a}$ Restricted Contract Data (MALIBU Experimental Program).

${ }^{b}$ All DVDs were created on March 29, 2010, by G. Radulescu. 